RICARDO VICTALINO DE OLIVEIRA

\title{
A ABERTURA DO ESTADO \\ CONSTITUCIONAL BRASILEIRO AO DIREITO INTERNACIONAL
}

Tese de Doutorado em Direito do Estado

Orientadora: Professora Doutora Fernanda Dias Menezes de Almeida

Faculdade de Direito da Universidade de São Paulo

São Paulo

2014 
RICARDO VICTALINO DE OLIVEIRA

\section{A ABERTURA DO ESTADO \\ CONSTITUCIONAL BRASILEIRO AO DIREITO INTERNACIONAL}

Tese de Doutorado apresentada no Departamento de Direito do Estado da Faculdade de Direito da Universidade de São Paulo, como requisito parcial para a obtenção do título de Doutor em Direito do Estado.

Orientadora: Professora Doutora Fernanda Dias Menezes de Almeida

São Paulo 
"Não podemos nos conformar com o status quo; nosso desafio é construir uma ordem constitucional que seja mais justa e livre em comparação àquela que nos foi legada".

BRUCE ACKERMAN (Nós, o Povo Soberano: Fundamentos do Direito Constitucional, Belo Horizonte, Del Rey, 2006, p. 6) 
Para a Professora Fernanda Dias Menezes de Almeida, não apenas por ser a melhor orientadora que um aluno poderia ter, mas, principalmente, por ter tornado tudo diferente em minha vida. 


\section{AGRADECIMENTOS}

Prefiro correr o risco do exagero ao da negligência em relação às muitas pessoas que contribuíram para que este trabalho se tornasse possível. Por isso, estes agradecimentos serão longos, e, mesmo assim, muitos nomes serão esquecidos por mim. Peço que se sentirem igualmente lembrados àqueles que, porventura não encontrem seus nomes aqui. Estas palavras apenas exemplificam a imensa gratidão que tenho por todos que, de diferentes modos, contribuíram para que eu concluísse a elaboração desta tese de doutorado.

Em primeiro lugar, agradeço à Professora Fernanda Dias Menezes de Almeida. Meu maior exemplo de docente e de compromisso acadêmico. Além do profundo conhecimento de Direito Constitucional, que ela jamais negligencia aos seus alunos, a atenção e o zelo com que conduziu minha orientação permitiram que prosseguisse com segurança até a versão final do trabalho. Faço questão de registrar que, em diversas ocasiões, fui recebido por ela aos domingos e feriados, a fim de discutirmos os pontos controvertidos da tese. Além de indicar excelentes obras para minha pesquisa, ela também me ajudou a consolidar as ideias que eu, muitas vezes, acreditava não fazerem sentido. Dizer "obrigado" é pouco para tudo o que ela fez por mim. Ela realmente transformou minha vida. Justamente por isso, dediquei-lhe este trabalho.

Aos Professores Roger Stieffelmann Leal e Manoel Gonçalves Ferreira FILHO, presentes em minha banca de qualificação, momento em que prestaram excelentes contribuições ao desenvolvimento do trabalho, externo minha gratidão. Impressionei-me com a precisão das observações e das indicações bibliográficas que fizeram. Em poucos minutos de arguição, eles convenceram-me de que era necessário reestruturar praticamente tudo o que pensava naquela época. Sem suas valiosas indicações de leitura, a conclusão desta tese teria sido tarefa muito mais complicada. Espero, apesar de todo o auxílio recebido, não ter desapontado ambos com a versão final do trabalho.

Durante os anos de meu doutorado, tive a oportunidade de trabalhar no Governo Federal em Brasília. Foram talvez os meses mais intensos que vivi, já que não abandonei minhas atividades docentes em São Paulo e no Rio de Janeiro no período. Também foram os meses em que mais pude aprender sobre o funcionamento das instituições deste país e, sobretudo, compartilhar conhecimento com exímios acadêmicos que servem ao Poder Público brasileiro. Em especial, agradeço a LuCIANA LEAL BRAYNER, minha colega de 
doutorado que, mesmo durante os últimos meses da elaboração de sua tese, dedicou-me atenção para ministrar uma verdadeira aula sobre acordos administrativos internacionais. MARCELO D. VARELLA, reconhecido internacionalista, fez-me sugestões de vários autores estrangeiros dedicados ao Direito Internacional, os quais, sinceramente, eu nunca teria tido condições de, sozinho, alcançar. MaUritÂnia Bogus Pereira, tornou-se exemplo de companheirismo e de como as pessoas podem se ajudar mutuamente para que os trabalhos, por mais desafiadores que pareçam, sejam concluídos com qualidade e eficiência. Por fim, meu amigo de longa data, Daniel Gustavo Falcão Pimentel dos Reis, também doutorando, foi uma pessoa fundamental durante todo este doutorado; cursamos juntos os créditos, trocamos muitas ideias sobre nossas pesquisas e, sobretudo, compartilhamos as angústias que uma tese causa em seus autores. Sem dúvida, este trabalho tem muito de cada uma das pessoas mencionadas acima.

Registro minha imensa gratidão ao grande amigo e professorJoÃo DANIEL LIMA DE ALMEIDA, queconseguiu a proeza de fazer que eu encarasse com disciplina, pela primeira vez na vida, o desafio de estudar Direito Internacional. Foi depois de uma conversa em um dia chuvoso no Centro de São Paulo, com a oferta de "onze contos de rés". Estou certo de que, sem sua ousadia de confiar as aulas da disciplina a mim, eu jamais teria tido coragem de desenvolver uma tese que abordasse o universo das relações internacionais.

Embora o faça todos os dias e em todas as oportunidades que encontro, vou agradecer, mais uma vez, àqueles que, mesmo não sendo acadêmicos, deram-me apoio para que tudo (na verdade, sei bem, só mais uma etapa) "chegasse ao fim". Meus pais, NILCE E SÔNIA, por serem os maiores paradigmas de como vencer os muitos e aparentemente insuperáveis obstáculos que a vida nos coloca. Meus irmãos, RAFAEL e ANA CAROLINA, com que eu conto e sei que sempre posso contar "para o que der e vier". Minha avó Assumpta, figura sublime e fonte inesgotável de amor. Meus tios, Sílvio, SirLEne e ORIDES, que, do jeito deles, sempre me deram proteção e apoio para prosseguir.

Não posso esquecer ainda aqueles que, mesmo não sendo a minha família, no fundo, sei que o são. As pessoas mais próximas, que me mostraram que a maravilhosa São Paulo não era tão grande como eu imaginava ser, quando, em 2001, deixei minha cidadezinha de sete mil habitantes no interior do Estado para cursar a graduação na Faculdade de Direito do Largo de São Francisco. Amo-os profundamente e eles sabem disso. FÁBIO LOLI, exemplo de autocontrole e de segurança, que sempre me demonstra o quanto é importante não desistir daquilo que verdadeiramente queremos para nossas vidas. MÁRCIA STAMATO, por ter sido a primeira responsável por eu ter abraçado a Academia 
como projeto de vida e por ser minha grande incentivadora (a pessoa que, como sempre digo, "acredita mais em mim do que eu mesmo"). VANESSA Alves VIEIRA, a amiga mais incrível e humana que as Arcadas do Largo de São Francisco me trouxeram. PAUlo Henrique De Oliveira, exemplar estudioso de Direito, quem sabe exatamente o que eu penso, mas sempre faz tudo ao inverso, só para me ver evoluir como pessoa. RoDRIGO ISHIDA, por ser o único e o inconfundível RODRIGO ISHIDA! VENCESLAU COELHO, o amigo de todas as horas e que sempre apoia tudo o que eu faço. DióGENEs BATISTA, que, além de ser o meu médico preferido, é a pessoa a quem sempre recorro para ouvir os conselhos mais sensatos de que preciso. MARIA HELOÍsA PORCEL, que usucapiu meu coração sem nunca ter tido justo título para isso. PRISCILLA NEGREIROS, que consegue ser minha cópia fiel em quase tudo o que faz: se não é minha alma gêmea, passou muito perto de ser. IVo YONAMINE, de quem esta tese me fez ficar mais próximo e a quem aprendi admirar ainda mais, não apenas como amigo, mas também como profissional. E WALLACE FERNANDES, aquele que, ainda que não admita isso, é sim "paulistano de coração".

É tarefa impossível listar o nome de todos os meus alunos a quem sou grato por conviver e por aprender com eles muito mais do que posso ensiná-los. Em todo caso, agradeço a todos na pessoa de GUILHERME DE ABRANCHES QUINTÃO, meu antigo aluno que é, atualmente, diplomata brasileiro. Tenho um especial respeito por esse ex-aluno, porque foi ele quem, após dirigir-me em aula inúmeras perguntas que envolviam o Direito Constitucional Internacional, fez-me perceber a importância desse tema. Em 2010, quando ele me indagava e eu quase nunca encontrava respostas para seus questionamentos, ficou claro o quanto a relação entre Constituição e Direito Internacional precisava ser aprofundada.

Nesta lista que parece não ter fim, consigno ainda minha gratidão a MÁRCIA AlONSO e William ShaKuRAmaCHI, meus professores de inglês que me ajudaram na compreensão de grande parte da bibliografia usada no trabalho. Também agradeço a ISA Stamato, Artur Lascala e Bruno ImPARAto pela ajuda com a organização dos fichamentos e das traduções que embasaram o trabalho. E aClaudia Simionato, minha revisora de confiança, meu muito obrigado. 


\section{SUMÁRIO}

OBSERVAÇÕES INICIAIS......................................................................................... 1

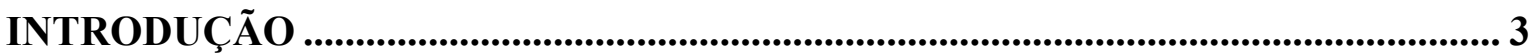

1. CONSTITUCIONALISMO CONTEMPORÂNEO E ADENSAMENTO DO DIREITO INTERNACIONAL .................................................................................9

1.1. Internacionalização das Constituições e Estagnação da Concepção Internacionalista

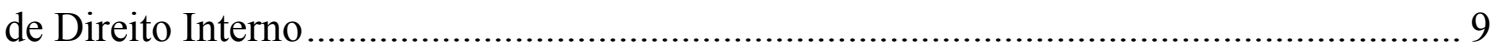

1.1.1. Convergência Temática e Aproximação dos Sistemas Normativos Interno e

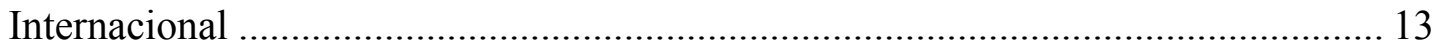

1.1.2. Estado Constitucional e Ordem Internacional ……………………………....... 17

1.2. Globalização e Reconstrução do Conceito de Soberania............................................ 20

1.2.1. Efeitos da Globalização nos Sistemas Jurídicos Interno e Internacional.......... 22

1.2.2. Forças que Incidem na Reformulação da Soberania ......................................... 26

1.2.2.1.Estado de Direito e Limitação da Soberania Interna ...................................... 28

1.2.2.2. Direito Internacional e Limitação da Soberania Externa............................... 29

1.3. Abertura dos Estados Nacionais ao Direito Internacional e Transformações do

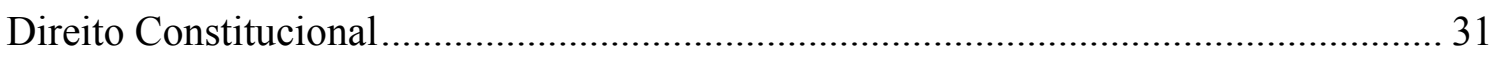

1.3.1. Novas Feições Constitucionais Decorrentes da Multiplicação de Fontes

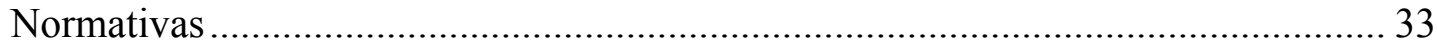

1.3.2. O Imprescindível Situar Internacional do Estado Constitucional..................... 38

1.4. O Diálogo entre o Nacional e o Externo como Mecanismo de Fortalecimento dos Sistemas Jurídicos Interno e Internacional ................................................................... 41

1.4.1. A Superação das Concepções Monista e Dualista Sobre a Relação Entre Direito Interno e Direito Internacional ................................................................. 44

1.4.2. A Emergência do Direito Comum ................................................................. 49

2. A EVOLUÇÃo do PROCESSO de ABERTURA dO ESTAdO BRASILEIRO AO DIREITO INTERNACIONAL ................................................................................ 54

2.1. O Direito Constitucional Internacional: Nem Direito Constitucional, nem Direito Internacional (na Verdade, um Pouco de Cada) ........................................................... 54

2.2. Relações Internacionais e Direito Constitucional Brasileiro ...................................... 59

2.2.1. Breve Histórico das Relações Exteriores no Constitucionalismo Pátrio .......... 61

2.3. O Tratamento da Questão Internacional na Constituição de 1988 ............................. 69 
2.3.1. A Inovação Oriunda da Positivação dos Princípios Constitucionais das

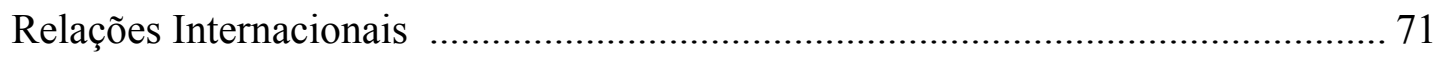

2.3.2. Integração Econômica, Política, Social e Cultural dos Povos da América

Latina e a Afirmação Institucional do Mercosul....................................................... 77

2.4. Emenda Constitucional $n^{\circ} 45 / 2004$ e Intensificação do Compromisso do Estado

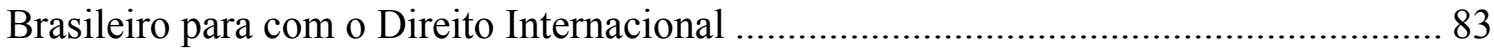

2.4.1. O Reconhecimento da Jurisdição do Tribunal Penal Internacional ................. 85

2.4.2. O Incidente de Deslocamento de Competência .............................................. 92

\section{O PRINCÍPIO DA SEPARAÇÃO DOS PODERES E DIREITO} INTERNACIONAL.................................................................................................98

3.1. Princípio da Separação dos Poderes e o Regime de Corresponsabilidade na Efetivação das Normas Internacionais........................................................................ 98

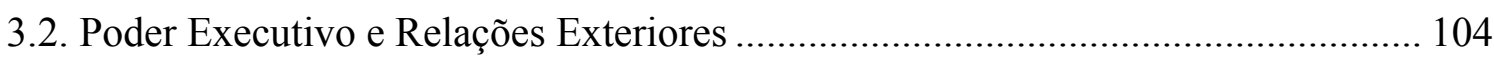

3.2.1. O Déficit Democrático na Produção da Normativa Internacional ................. 109

3.3. O Papel do Poder Legislativo em Matéria de Relações Exteriores ......................... 114

3.3.1. Denúncia de Tratados e Participação do Congresso Nacional........................ 119

3.3.2. Parlamento do Mercosul e a Democratização (Possível) do Processo de

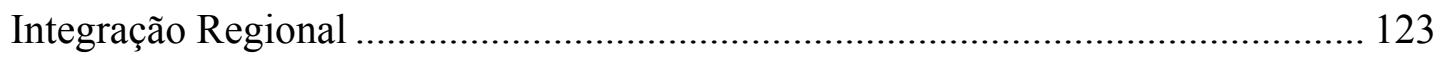

3.4. Poder Judiciário e Aplicação do Direito Internacional ........................................... 127

3.4.1. O Diálogo das Cortes e a Margem de Apreciação Nacional .......................... 130

4. APLICAÇÃO DO DIREITO INTERNACIONAL NA ORDEM JURÍDICA

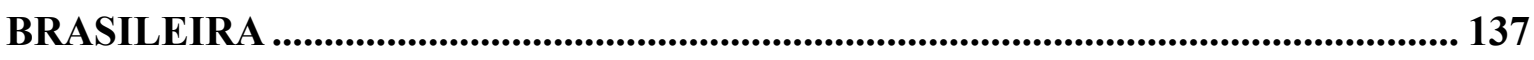

4.1. Pluralidade Normativa e Entrelaçamento do Ordenamento Nacional com o Direito

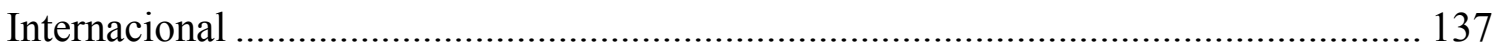

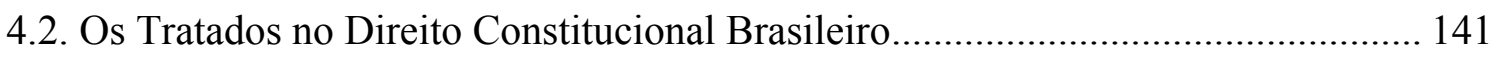

4.2.1. A Processualística de Internalização dos Tratados Internacionais ................ 143

4.2.1.1.As Etapas Necessárias para Transpor ao Sistema Jurídico Brasileiro os

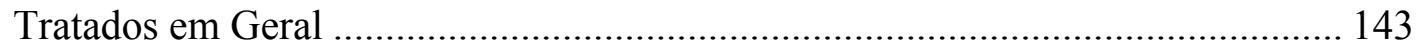

4.2.1.2.A Problemática Doutrinária Sobre as Fases de Incorporação dos Tratados de

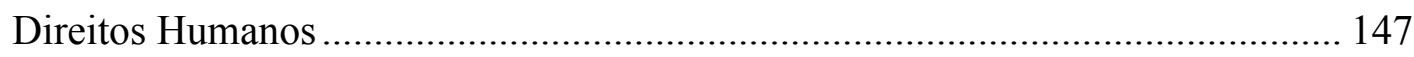

4.2.2. A Hierarquia Normativa dos Tratados Incorporados ao Ordenamento Jurídico Pátrio

4.2.2.1.O Recurso Extraordinário no 80.004 e a Equiparação dos Tratados à Lei Ordinária Federal

4.2.2.2.A Emenda Constitucional $n^{0} 45 / 2004$ e a Possibilidade de Inclusão de Tratados de Direitos Humanos no Bloco de Constitucionalidade. 
4.2.2.3.O Recurso Extraordinário $n^{\circ} 466.343$ e a Afirmação da Supralegalidade Inerente aos Tratados Protetivos dos Direitos Humanos em Geral ...................... 167

4.3. A Aplicação do Costume Internacional no Ordenamento Jurídico Interno ............. 174

4.4. A Execução Interna das Decisões e Resoluções Emanadas das Organizações Internacionais

5. FEDERALISMO E RELAÇÕES INTERNACIONAIS: A ATUAÇÃO EXTERIOR DOS ENTES FEDERADOS.

5.1. O Protagonismo dos Entes Federados em Matéria de Relacionamentos com o Mundo Exterior

5.1.1. A Ascensão do Conceito de Paradiplomacia e de Figuras Afins.... 193

5.2. Natureza Jurídica dos Atos e Acordos Decorrentes das Ações Externas das Unidades Autônomas

5.2.1. Atos e Acordos Paradiplomáticos e Direito Internacional............................ 203

5.2.2. Atos e Acordos Paradiplomáticos e Direito Interno ..................................... 211

5.3. Federação Brasileira e Relações Externas Empreendidas pelos Entes Federados.. 218

5.3.1. A Competência para Manter Relações com Estados Estrangeiros, Participar de Organizações Internacionais e Figurar como Parte em Tratados Internacionais .... 218

5.3.2. A Competência para Celebrar Convênios Administrativos Internacionais ... 222

5.3.3. A Competência para Realizar Operações Externas de Natureza Financeira . 230

CONCLUSÃO

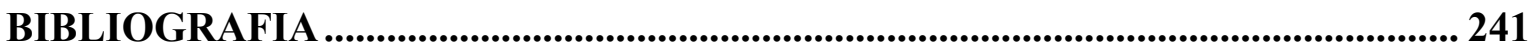

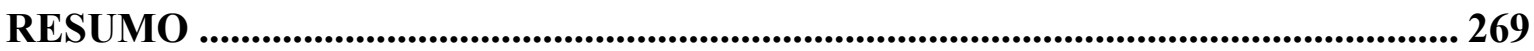

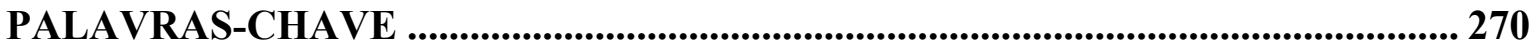

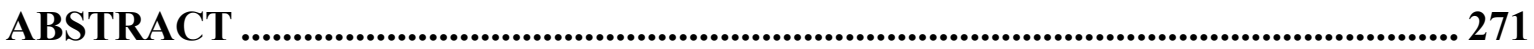

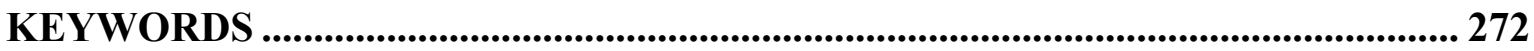

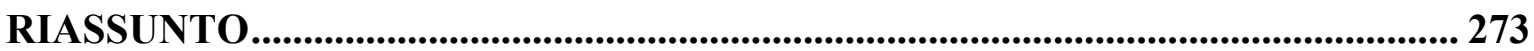

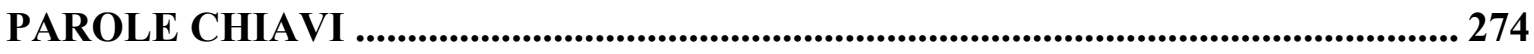




\section{OBSERVAÇÕES INICIAIS}

Com o objetivo de aumentar a clareza e de proporcionar uma leitura facilitada e não cansativa do texto confeccionado, informa-se que, na composição do presente trabalho, as citações literais, empregadas a partir da consulta de obras de autores estrangeiros, não traduzidas para língua portuguesa, foram vertidas para o nosso vernáculo por meio de tradução livre, pela qual o autor assume total responsabilidade. Além disso, os excertos retirados de obras nacionais pesquisadas, cuja ortografia se mostrava arcaica, foram adaptados a fim de se adequarem às orientações ortográficas atualmente adotadas pelos gramáticos.

No que tange à redação desenvolvida, deve-se anotar que, visando à delimitação de conceitos - bem como à padronização do texto -, os termos Direito Internacional e Direito das Gentes são utilizados para aludir ao conjunto de prescrições normativas que compõem a ordem jurídica objeto de estudo do Direito Internacional Público, a qual, consoante sedimentado entendimento doutrinário, abarca diversas fontes normativas, a saber: tratados, costumes internacionais, princípios gerais do Direito, atos unilaterais e decisões tomadas no âmbito das organizações internacionais ${ }^{1}$.

Cabe pontuar também que o emprego das expressões Federação, Estado federal, entes federados e unidades federativas tem como referência os Estados territorialmente compostos e suas partes integrantes ${ }^{2}$. Buscam, assim, retratar não somente a forma federativa de Estado, mas também as estruturas político-administrativas existentes no seio do Estado regional e do Estado autonômico, motivo pelo qual os termos em questão são reiteradas vezes adotados como sinônimos.

Ainda no tocante ao federalismo, houve a opção de aplicar, indistintamente, as expressões paradiplomacia, diplomacia federativa, política externa federativa, microdiplomacia regional, cooperação técnica internacional e diplomacia de múltiplas camadas para tratar das ações exteriores patrocinadas pelas unidades autônomas que compõem os Estados de estrutura territorial composta. Assinale-se, desde já, que o objetivo de fixar o sentido dessas atividades é evitar confusão com as práticas diplomáticas

${ }^{1}$ Cf. Francisco RezeK, Direito Internacional Público: Curso Elementar, 14 a ed., São Paulo, Saraiva, 2013, p. 33.

${ }^{2}$ Cf. Sobre a descentralização territorial do poder, consultar MANOEL GonÇALVES FerREIRA FILHO, Princípios Fundamentais do Direito Constitucional, 2a ed., São Paulo, Saraiva, 2010, pp. 286-290. 
tradicionais, cuja execução compete aos agentes do governo central, quando a União atua como representante do Estado soberano, tomado em sua completude.

Por último, esclarece-se que o conceito de constitucionalismo é empregado sob a perspectiva do movimento iniciado depois da promulgação da Constituição dos Estados Unidos, em 1787, e que se seguiu como fenômeno político-jurídico em grande parte dos países do mundo, resultando na adoção de numerosos textos constitucionais como mecanismos de organização e de limitação do poder do Estado ${ }^{3}$.

\footnotetext{
${ }^{3}$ Cf. PaOlo BISCARETTI Di RufFì, Introducción al Derecho Constitucional Comparado y 1988-1990. Un Trienio de Profundas Transformaciones Constitucionales en Occidente, en la URSS y en los Estados Socialistas del Este Europeo, México, Fondo de Cultura Económica, 1996, pp. 503-505 e DALMO DE ABREU Dallari,A Constituição na Vida dos Povos: Da Idade Média ao Século XXI, $2^{\mathrm{a}}$ ed., Saraiva, São Paulo, 2013, pp. 351-355.
} 


\section{INTRODUÇÃO}

A obra Curso de Direito Internacional Público, de Jorge Miranda, lançada em maio de 2002, veio acompanhada de uma interessante nota: “o autor não é especialista de Direito Internacional Público. Todavia, não pode ser indiferente ao influxo cada vez maior que ele exerce sobre a ordem jurídica interna, mormente sobre o Direito Constitucional, e à necessidade de compreensão dos seus principais institutos". O registro de um dos maiores constitucionalistas da atualidade reflete não apenas o cuidado e o zelo pela produção acadêmica desse exímio e consagrado pesquisador. Representa, sem dúvida, muito mais que isso. Prova sensibilidade em relação a um fenômeno que transforma o constitucionalismo do presente e que, apesar de ser cada vez mais visível, pouco é estudado e, menos ainda, compreendido. A observação em destaque evidencia que, caso o Estado ignore as normas internacionais que também o vinculam interna e externamente, será impossível entender - e até aplicar - o Direito Constitucional em sua plenitude.

A tendência de internacionalização das Constituições retrata o fenômeno por meio do qual um número expressivo de textos constitucionais passa a reconhecer a densidade jurídica das relações exteriores e, por conseguinte, a adotar variados mecanismos com o objetivo de incrementar a execução, no plano doméstico, da normativa internacional. Sem abandonarem a supremacia que lhe é característica, as Constituições - especialmente aquelas elaboradas depois da Segunda Guerra Mundial - iniciaram um lento e gradual processo de abertura ao Direito Internacional, o que resulta em impactos significativos em alguns conceitos basilares do constitucionalismo. A confluência entre ambas as ordens jurídicas, ditada notadamente pelas forças da globalização, obriga, assim, a reformular os tradicionais conceitos do Direito Constitucional, além de desencadear o surgimento de inovações que, hoje, já fazem parte do sistema constitucional de vários países.

A extraordinária multiplicação dos entrecruzamentos entre Direito Constitucional e Direito das Gentes requer estudos que ultrapassem as clássicas propostas de explicar a relação entre esses dois sistemas normativos com base em concepções teóricas do dualismo e do monismo. A criação de normas internacionais cujo conteúdo aborde temas que, durante muito tempo, figuraram como matérias exclusivas do Direito Interno, ao mesmo tempo em que aumenta a proteção de determinados bens jurídicos, ocasiona a identidade normativa entre os mandamentos que compõem as duas ordens jurídicas em questão, impondo, assim, a necessidade de estabelecer permanentes diálogos entre os 
sistemas normativos. É preciso aproximar os estudiosos dessas duas áreas - os quais, não raro, embora se ocupando de analisar a mesma problemática, parecem vislumbrar mundos estranhamente diversos e frequentemente inconciliáveis.

$\mathrm{O}$ processo de abertura das Constituições às relações internacionais implica avanços tanto no Direito Constitucional quanto no Direito Internacional. Por certo, o fato de, cada vez mais, existirem ordenamentos jurídicos internos estruturados de modo a reconhecer a importância das normas provenientes do Direito das Gentes conduz à construção de ambientes domésticos em que os órgãos estatais se apresentam não somente dispostos a observar a normativa internacional, mas obrigados a assim proceder porque o Direito Internacional torna-se importante para a concretização da própria Constituição. Sob esse prisma, a Constituição - que se mantém como norma fundante dos ordenamentos nacionais - é tida como ferramenta que busca fomentar a projeção exterior do Estado, haja vista que, além de se ocupar da organização e da limitação interna do poder estatal, também cuida de estabelecer diretrizes para os Poderes nacionais atuarem nos processos de criação e de execução dos mandamentos exteriores.

A compreensão desse novo perfil do Estado requer investigações que vão além do universo do Direito Interno de cada país. Ganha relevo, assim, a proposta de Estado Constitucional Cooperativo, idealizada por PETER HÄBERLE, autor cuja obra influenciou, em grande medida, a confecção desta tese. Com amparo na teoria desenvolvida por HÄBERLE, é possível encontrar normas plasmadas em várias Constituições que certificam a opção feita pelos respectivos constituintes de inserir os Estados no espaço internacional. Isso, consequentemente, torna os ordenamentos nacionais permeáveis ao Direito das Gentes, em especial no que respeita a temas em que há visível identidade entre os comandos internos e internacionais, como é o caso dos direitos humanos. Ressoa, portanto, a certeza de que essa aproximação entre ordens jurídicas, por ser algo inacabado e altamente influenciável por fatores internacionais globais e regionais, permite que as Constituições assimilem novas diretrizes normativas até o limite da preservação dos valores e dos interesses nacionais.

Com efeito, a permeabilidade do Direito Constitucional ao Direito Internacional deflagra a necessidade de ajustar normas constitucionais encarregadas de disciplinar, por exemplo, a relação harmônica entre os Poderes do Estado, tendo em vista que o controle recíproco entre Executivo, Legislativo e Judiciário deve também ser materializado no campo das ações exteriores. Em igual sentido, a aplicação interna de uma série de 
comandos internacionais - os quais não se restringem apenas aos tratados - exige definições por parte dos ordenamentos nacionais quanto à forma de internalizar esses mandamentos e de eventualmente controlá-los, caso ocorra incompatibilidade com os preceitos da Lei Maior. Por fim, a forma de Estado também demonstra mudanças, sobretudo em Estados compostos, pois os entes subnacionais, mesmo impedidos de criar normas internacionais, passam a atuar no terreno das relações exteriores para solucionar problemas transfronteiriços mediante acordos de índole administrativo-material.

Desse modo, temas muito caros ao constitucionalismo são submetidos aos influxos do progressivo adensamento jurídico das relações internacionais, bem como do aumento da participação dos países em organismos internacionais que, em muitas situações, tomam decisões revestidas de caráter normativo visando proporcionar patamares mínimos de coexistência e de cooperação entre os povos. Diante da complexidade erigida desse quadro fático, é pertinente esclarecer que a análise do contexto brasileiro, com base em elementos que retratam a tendência de internacionalização de nossa ordem constitucional, delimita o projeto acadêmico que norteou a elaboração do presente trabalho. Tentou-se, na medida do possível, demonstrar de que forma o Direito Constitucional pátrio tem disciplinado a necessidade de integrar o Estado nacional no universo das relações exteriores, tecendo-se, para tanto, ponderações sobre os preceitos da Constituição Federal de 1988 que mais se destacam nesse mister.

Apesar da interdisciplinaridade imanente ao tema, o enfoque foi concentrado na apreciação dos institutos atrelados ao Direito Constitucional pátrio que guardam relação com o desenvolvimento das relações internacionais. Não se trata, pois, de um trabalho que tem a pretensão de analisar com detalhes os conceitos que servem de substrato ao Direito Internacional, o que, talvez, faça que um internacionalista dedicado exclusivamente ao estudo do Direito das Gentes estranhe algumas das abordagens que serão aqui realizadas. Fixadas as coordenadas gerais que guiaram a elaboração deste trabalho, passa-se a apresentar, resumidamente, as matérias tratadas e os objetivos mirados nos cinco capítulos que o integram.

Assim, o primeiro capítulo cuida da imprescindibilidade de situar internacionalmente o Estado Constitucional. São analisadas as mudanças advindas da contemporaneidade que, ao tornarem rarefeitas as fronteiras entre interno e o externo, alteraram tradicionais conceitos do Estado - em especial a soberania, que teve de se adaptar a uma nova realidade de crescentes interconexões entre sujeitos do Direito 
Internacional. Também se aborda o surgimento de mecanismos que podem auxiliar a solução de impasses decorrentes desse cenário, a exemplo do diálogo entre as fontes normativas e da emergência do conceito de Direito Comum. Em suma, neste capítulo, prima-se por delimitar as consequências de maior amplitude, derivadas da intersecção entre Constituição e Direito Internacional, buscando-se, com isso, facilitar a compreensão dos capítulos subsequentes.

A evolução das relações exteriores na história do constitucionalismo brasileiro representa o assunto desenvolvido no segundo capítulo da tese. Nesta parte do trabalho, dedica-se atenção destacada às normas inseridas na Constituição vigente para viabilizar o processo de abertura ao Direito Internacional, notadamente aos princípios fundamentais previstos no art. $4^{\circ}$ da Lei Maior para orientar a atuação dos órgãos estatais no desempenho das relações exteriores. As contribuições prestadas pelo constituinte reformador ao aperfeiçoamento da matéria foram referenciadas por meio da análise das normas introduzidas no cenário constitucional pátrio pela Emenda Constitucional no $45 / 2004$, que reconheceu a jurisdição de Tribunal Penal Internacional a cuja criação o país tenha manifestado adesão e, ainda, previu o instituto do incidente de deslocamento de competência de processos da justiça estadual para a justiça federal como medida para assegurar o cumprimento, no contexto interno, dos tratados internacionais de direitos humanos.

O capítulo de número três é dedicado ao estudo dos reflexos causados pelo incremento das interações entre os Estados à operacionalização do princípio constitucional da separação dos poderes do Estado. Explora-se, neste ponto da tese, os instrumentos que a Constituição Federal oferece para que seja possível transpor, para o plano das relações exteriores, o controle recíproco entre os Poderes, imprescindível para que as ações governamentais sejam empreendidas com responsabilidade política e em consonância aos princípios democráticos. É, ainda, assinalada a relevância de os Poderes Executivo, Legislativo e Judiciário empreenderem ações concertadas a fim de garantir que as normas internacionais que vinculam o Estado pátrio possam ser executadas internamente dentro de padrões satisfatórios de eficácia, haja vista que o constituinte nacional parece ter criado condições para se edificar um regime de corresponsabilidade entre os Poderes na promoção dos interesses nacionais para além de nossas fronteiras, notadamente quando a edição de tratados se mostra como medida indicada para tanto. 
O penúltimo capítulo (capítulo quatro) refere-se aos aspectos constitucionais que influenciam a aplicação interna das diferentes espécies de normas do Direito Internacional. Espaço especial é reservado à análise do processo de internalização dos tratados e convenções, notadamente aqueles cujo tema verse sobre direitos humanos e que podem vir a apresentar, no ordenamento interno, equivalência de emenda constitucional. Questões acerca da decisão de submeter esses tratados de direitos humanos ao procedimento específico de votação estatuído no art. $5^{\circ}, \S 3^{\circ}$, da Carta Magna, bem como as discussões em torno da denúncia dos mesmos e dos impactos que seu surgimento causou no ordenamento brasileiro constituem o mote de considerável parte do capítulo. A aplicação interna dos costumes internacionais e das decisões emitidas por organismos internacionais completam os assuntos desenvolvidos.

Por derradeiro, o capítulo cinco apresenta as implicações constitucionais que acompanham o fortalecimento das ações exteriores praticadas pelos entes federados brasileiros, atividade que recebeu a denominação doutrinária de paradiplomacia. Após uma exposição genérica acerca do panorama atual no qual se desenvolve uma série de acordos transfronteiriços entre unidades autônomas alocadas em Federações diferentes, são analisados os aspectos jurídicos ligados à natureza desses ajustes e aos fundamentos constitucionais que os justificam. Ainda são feitas considerações a fim de esclarecer que a atuação externa dos governos subnacionais não enseja a criação de tratados internacionais, haja vista que estes apenas podem surgir por meio do consentimento dos sujeitos de Direito Internacional Público, condição essa que os entes autônomos não ostentam.

Com base nessa estrutura, buscou-se elaborar um trabalho que conseguisse evidenciar que as transformações vivenciadas no cenário internacional desencadearam significativas alterações no Direito Constitucional. Sem dúvida, a maior articulação entre os sujeitos integrantes da sociedade internacional e a proliferação de normas jurídicas nesse segmento foram percebidas pelo constituinte brasileiro, que, sem abandonar a centralidade da Constituição para a organização do Estado, introduziu normas no texto constitucional que permitissem alinhar o país a esse quadro de valorização das relações exteriores. A existência de inquietantes dúvidas acerca da compatibilidade de vários institutos e diversas normas do Direito das Gentes em relação à Constituição pátria - as quais, embora tenham sido tratadas nesta tese, continuam sem respostas - aponta para a relevância do tema e convida à reflexão, pois a conciliação das divergências por meio do 
diálogo entre os sistemas jurídicos importará ganhos para ambas as ordens que, muitas vezes, parecem contrapor-se. 


\title{
1. CONSTITUCIONALISMO CONTEMPORÂNEO ADENSAMENTO DO DIREITO INTERNACIONAL
}

\begin{abstract}
"Repensar o Estado em suas relações externas à luz do atual Direito Internacional não é diferente de pensar o Estado em sua dimensão interna à luz do Direito Constitucional".
\end{abstract}

LUIGI FERRAJOLI ${ }^{4}$

\subsection{Internacionalização das Constituições e Estagnação da Concepção Internacionalista de Direito Interno}

"Do ponto de vista do Direito Internacional e deste Tribunal, as leis internas são meros fatos que expressam a vontade e constituem a atividade dos Estados" ${ }^{\text {. }}$ A frase, proferida no ano de 1926 pela extinta Corte Permanente de Justiça Internacional, na ocasião do julgamento do caso que ficou conhecido como Certos Interesses Alemães na Silésia Superior Polonesa, tornou-se um famoso axioma entre os internacionalistas e foi projetada ao longo do tempo como a principal referência da forma como o Direito Internacional percebe o Direito Interno ${ }^{6}$. Mais do que reduzir os atos normativos nacionais a um dado desprovido de juridicidade, o entendimento firmado em um momento histórico muito diverso do atual contribuiu para que a ciência do Direito Internacional se desenvolvesse ao largo da realidade jurídica vivenciada por expressivo número de países.

Assim, durante todo o século XX, consolidou-se na jurisprudência internacional a concepção de que as normas domésticas constituíam meras provas de condutas imputáveis aos Estados transgressores do Direito das Gentes ${ }^{7}$. A orientação em destaque figura como o principal embasamento para um princípio propagado por parcela expressiva dos cultores do Direito Internacional: a premissa da preeminência das normas exteriores diante da normativa nacional ${ }^{8}$. Na prática, isso significa que, "para o Direito Internacional, os atos

\footnotetext{
${ }^{4}$ A Soberania no Mundo Moderno: Nascimento e Crise do Estado, $2^{\mathrm{a}}$ ed., Martins Fontes, 2007, p. 46.

${ }^{5}$ PCIJ, Série A, $n^{\circ} 7$, p. 19, decisão disponível no endereço eletrônico $w w w$.icj-cij.org.

${ }^{6} \mathrm{O}$ art. 27 da Convenção de Viena sobre o Direito dos Tratados de 1969 alinha-se a essa diretriz ao estabelecer que "uma parte não pode invocar as disposições de seu Direito Interno para justificar o inadimplemento de um tratado".

${ }^{7}$ A expressão Direito das Gentes, empregada como sucedâneo do termo Direito Internacional, é definida por MONTESQUIEU como "fundado sobre o princípio de que as nações devem fazer umas às outras, reciprocamente, na paz, a maior soma de bem possível, e também na guerra, a menor soma de mal possível; e isto, sem prejudicar, entretanto, os seus verdadeiros interesses" (Do Espírito das Leis: Vol. 1, Rio de Janeiro, Nova Fronteira, 2012, p. 30).

${ }^{8}$ Entre outros, apresentam esse ponto de vista Malcolm N. SHaW, Direito Internacional, São Paulo, Martins Fontes, 2010, pp. 104-107; IAN Brownlie, Princípios de Direito Internacional Público, Lisboa, Fundação Calouste Gulbenkian, 1997, pp. 51-53; CESÁREO GuTIÉRREZ EsPADA, Derecho Internacional Publico, Editorial Trotta, Madrid, 1995, pp. 624-626; MARIO FALCÃO ESPALTER, Ensayo sobre la Influencia del
} 
normativos internos (leis, atos administrativos e mesmo decisões judiciais) são expressões da vontade de um Estado, que devem ser compatíveis com seus engajamentos internacionais anteriores, sob pena de ser o Estado responsabilizado internacionalmente"

Apesar de reconhecer que o Direito Interno não passa de um simples fato para o Direito Internacional, Celso D. De Albuquerque Mello grifa que esse dado "não significa que o DIP ignore o Direito Interno, sendo de se recordar que os princípios gerais do direito são fontes do DIP, bem como o Direito Interno pode servir de prova para a existência de um costume internacional" ${ }^{\text {10 }}$. Há que se convir que a ressalva apresentada pelo autor não deixa de retratar uma concepção altamente contaminada pela perspectiva de que o Direito Internacional, ainda que considere esporadicamente aspectos jurídicos das normas internas, teria condições de se desenvolver de forma isolada, independentemente de quaisquer diálogos com os ordenamentos nacionais. E é justamente esse tipo de posicionamento que a abertura das Constituições ao mundo exterior, ocorrida com destaque desde 1945, demonstra ter superado.

A excelência do Direito das Gentes, segundo afirmam Hildebrando AcCioly, G. E. do Nascimentoe Silva e Paulo Borba Casella, seria decorrência da necessidade de preservar as bases da convivência internacional, ou seja, resultado da preocupação com a funcionalidade e a harmonia dos relacionamentos travados pelos seus sujeitos ${ }^{11}$. Entretanto, ao se focar unicamente nas relações externas para defender a ideia da irrelevância do ordenamento nacional na concretização da eficácia do Direito Internacional, os responsáveis por aplicar estas normas parecem incorrer na errônea e perigosa tese da exaltação de uma ordem jurídica ao preço da destruição da outra ${ }^{12}$. A segmentação entre ambas as áreas do Direito Público carece de sentido, uma vez que, nos termos destacados por Boris Mirkine-Guetzévitch, “o Direito Internacional e o Direito

Derecho Internacional en el Derecho Constitucional: Historia y Doctrina, Montevideo, Peña \& Cia, 1938, pp. 413-414.

${ }^{9}$ André De CARVAlho RAmos, Responsabilidade Internacional por Violação de Direitos Humanos: seus Elementos, a Reparação Devida e Sanções Possíveis: Teoria e Prática do Direito Internacional, Rio de Janeiro, Renovar, 2004, p. 132. Sobre o tema, PAUlo EMÍlio VAUTHIER BORGES DE MACEDO registra ainda que "uma das regras mais aceitas de Direito Internacional, que remonta ao caso Alabama de 1876, é a de que as disposições de Direito Nacional não podem prevalecer sobre a de um tratado. Ao contrário, a parte de um tratado se obriga a assegurar que os seus órgãos de Direito Interno executem as previsões ali dispostas. Essa concepção se aplica até mesmo se as normas internas tiverem status constitucional" (Comentários ao Artigo 27, in Direito dos Tratados: Comentários à Convenção de Viena sobre o Direito dos Tratados (1969), Aziz Tuffi Saliba (org.), Belo Horizonte, Arraes, 2011, p. 191).

${ }^{10}$ Curso de Direito Internacional Público, vol. 1, $11^{\mathrm{a}}$ ed., Rio de Janeiro, Renovar, 1997, p. 109.

${ }^{11}$ Cf. Manual de Direito Internacional Público, $17^{\mathrm{a}}$ ed., São Paulo, Saraiva, 2009, p. 211.

${ }^{12}$ Cf. Vicente Marotta Rangel, Os Conflitos entre o Direito Interno e os Tratados Internacionais, in Ciências Econômicas e Sociais, vol. 3, jul. 1968, p. 59. 
Nacional são dois aspectos da mesma realidade histórica e social; ambos são o resultado do mesmo processo histórico; a regra internacional impõe obrigações, mas a execução destas requer regras constitucionais" ${ }^{\prime 13}$.

Tem-se, pois, como certo que a jurisprudência internacional moldou o posicionamento referido para impedir que os Estados nacionais buscassem, em seus respectivos ordenamentos jurídicos, fundamentos e estratégias que os isentassem da responsabilidade internacional decorrente de violação da normativa exterior ${ }^{14}$. É preciso advertir que essa forma de compreender a interação entre os dois segmentos jurídicos deve ficar adstrita à apuração da responsabilidade internacional, uma vez que, caso as escusas jurídicas lastreadas em disposições internas fossem aceitas, o Direito Internacional jamais teria conseguido afirmar sua obrigatoriedade, tampouco contaria com um número expressivo de órgãos jurisdicionais habilitados a zelar pela aplicação de suas disposições. O fato desse salutar objetivo no campo da responsabilidade ter sido alcançado não pode, entretanto, justificar o surgimento de teorias que pregam a absoluta irrelevância do Direito Interno para o Direito das Gentes, porque, além disso não refletir a realidade, impede o surgimento de profícuos diálogos entre ambas as ordens jurídicas, o que, sem dúvida, prejudica o desenvolvimento dos dois sistemas normativos.

O Direito Interno tem, portanto, repercussão expressiva para além de suas fronteiras e, por isso, deve-se considerá-lo no processo de elaboração dos arranjos jurídicos da sociedade internacional, de forma "que se tem por superada, ou, pelo menos, desprezada a visão que se admitira, anteriormente, de serem as normas internas ou internacionais meros fatos uns em relação aos outros" ${ }^{\prime 15}$. A referência da Constituição no terreno das relações externas deriva não apenas do fato de que o texto constitucional é peça fundamental para assegurar a soberania e a independência dos Estados, mas, sobretudo, por ser este

\footnotetext{
${ }^{13}$ Derecho Constitucional Internacional, Madrid, Editorial Reus, s. a., p. 474.

${ }^{14}$ Cite-se ANDRÉ DE CARVAlHo RAMOS, cujas considerações indicam que "a jurisprudência internacional determinou que a responsabilidade internacional do Estado é um princípio geral do Direito Internacional. Para citar algumas decisões judiciais, vê-se que, no caso do S.S. Wimbledon, decidiu a então existente Corte Permanente de Justiça Internacional que o descumprimento de uma obrigação internacional gerava a obrigação de efetuar reparação, o que, para a Corte, constituía-se em um princípio de Direito Internacional. A Corte Permanente de Justiça Internacional consagrou esse princípio na análise dos fatos envolvendo a Fábrica de Chorzów, determinando que o Estado deve, na máxima extensão possível, eliminar todas as consequências de um ato ilegal e restabelecer a situação que existiria, com toda probabilidade, caso o citado ato não houvesse sido realizado" (Responsabilidade Internacional do Estado por Violação de Direitos Humanos, in Revista CEJ, n 29, abr./jun. 2005, p. 54).

${ }^{15}$ CÁRmen Lúcia Antunes Rocha, O Direito Constitucional Perante o Direito Internacional Atual, in Direito Constitucional em Evolução: Perspectivas, Paulo Gomes Pimentel Júnior (coord.), Curitiba, Juruá, 2006, p. 99.
} 
documento o pressuposto da própria capacidade internacional estatal ${ }^{16}$. Adotar, sem maiores reflexões, o dogma do primado do Direito Internacional pode conduzir à criação de um indesejável conjunto de mandamentos internacionais ineficazes porque desconectados da realidade social, política e humana que cada Estado encarna, a qual se reflete e se consolida nas normas constitucionais ${ }^{17}$.

A verdade é que, consoante atesta Peter HäBerle, “o Estado Constitucional e o Direito Internacional transformam-se em conjunto. O Direito Constitucional não começa onde cessa o Direito Internacional. Também não é válido o contrário, ou seja, o Direito Internacional não termina onde começa o Direito Constitucional. Os cruzamentos e as ações recíprocas são por demais intensivas para que se dê a esta forma externa de complementariedade uma ideia exata" ${ }^{18}$. Há, portanto, um claro e progressivo entrelaçamento entre as ordens jurídicas dirigido não pela preocupação de definir a hierarquia de um tipo de norma sobre o outro, mas pela verificação de uma salutar identidade de matérias objeto de normatização.

Em abono, JORGE MiRANDA observa que "conceitos nascidos no campo do Direito constitucional irradiam para o Direito das Gentes, assim como, reciprocamente, as adstrições provenientes da inserção dos Estados na vida jurídico-internacional se projetam sobre as Constituições a começar pelas relações entre ordem interna e ordem internacional" ${ }^{\prime 19}$. No atual cenário mundial tanto o constitucionalismo quanto o Direito Internacional têm estado sob forte pressão e, por isso, tornam-se insuscetíveis de sobreviver em suas formas clássicas, compreendidas pelos estudiosos, na maior parte das vezes, como universos que tratam de temas totalmente incomunicáveis. A globalização jurídica, que dita a construção de identidade normativa entre os sistemas, "é hoje um pressuposto do Estado e não simples consequência de uma estatização incompleta"20.

Ao se considerar o regime das fontes normativas sob a ótica da participação do Estado na crescente complexidade das relações internacionais, fica patente o processo de internacionalização das Constituições. Influenciados pelas cambiantes mudanças na configuração da sociedade internacional, os ordenamentos nacionais têm absorvido as repercussões erigidas do aumento, na seara das interações exteriores, da "amplitude do

\footnotetext{
${ }^{16}$ Cf. Santi Romano, Princípios de Direito Constitucional Comparado, São Paulo, Revista dos Tribunais, 1977, p. 11.

${ }^{17}$ Cf. Vicente Marotta Rangel, Os Conflitos entre, Ob. cit., p. 59.

${ }^{18}$ Estado Constitucional Cooperativo, Rio de Janeiro, Renovar, 2007, pp. 11-12.

${ }^{19}$ Direito Constitucional e Direito Internacional, in Revista do Advogado, ano 23, no 73, nov. 2003, p. 90.

${ }^{20}$ Miguel AzPitarte SAnchéz, La Función de la Constitución en el Contexto Contemporáneo, in Revista de Derecho Constitucional Europeo, ano 6, nº 12, jul./dez. 2009, p. 172.
} 
poder de vincular o Estado, o que concede às autoridades nacionais uma área de ação cada vez maior, seja pela simplificação dos processos de conclusão dos tratados internacionais, seja pelo incremento do emprego de instrumentos não convencionais no âmbito das relações exteriores" ${ }^{21}$. A diretriz que desponta no constitucionalismo do presente é a de que o Direito das Gentes complementa e auxilia os sistemas normativos dos Estados, o que torna sem sentido arcaicas ideias sobre a contraposição entre ambas as ordens, pois as normas jurídicas, no fundo, têm se ocupando de instituir mandamentos com o fito de proteger idênticos fins e valores jurídicos, não obstante sua fonte de criação seja doméstica ou não.

\subsubsection{Convergência Temática e Aproximação dos Sistemas Normativos Interno e Internacional}

Embora as transformações vividas depois do fim da Segunda Guerra Mundial potencializarem a fertilização cruzada de conteúdos disciplinados pelo corpo normativo nacional e externo, cabe pontuar que as preocupações ligadas à interpenetração dessas normas não é novidade que data desse período. Em 1890, VINCENTO MiCELI, atento ao problema, asseverou que, "do ponto de vista dinâmico, no que diz respeito à lógica da evolução, somos levados à conclusão, com alguma certeza, de que o desenvolvimento do Direito Internacional deve ser, obrigatoriamente, precedido de um conjunto de fatos relevantes que ocasionam uma crescente afinidade na composição e na organização dos Estados nacionais, ambiente onde as normas internacionais são aplicadas. Sem aumentar a afinidade das partes, a evolução do Direito Internacional não poderia jamais acontecer, faltar-lhe-ia um fundamento sólido, haja vista que inexistiriam condições de ser formado o definitivo substrato da consciência jurídica internacional" ${ }^{\prime 22}$.

As contribuições que poderiam ser prestadas pelo Direito Constitucional ao desenvolvimento das relações internacionais, também foram objeto de estudo, em 1904, por Francesco GiUseppe BAgLiati. Segundo registrado à época, a afirmação e o aperfeiçoamento do Direito das Gentes dependeriam de elementos fornecidos pelas Constituições, o que certificava, por óbvio, a necessidade de aproximação entre esses dois compartimentos jurídicos, já que a visão de que os dois conjuntos normativos deveriam

\footnotetext{
${ }^{21}$ HÉLÈne TOURARD,L'Internationalisation des Constitutions Nationales, Paris, Librairie Générale de Droit et de Jurisprudence, 2000, p. 18.

${ }^{22}$ Lo Stato e La Nazione nei Rapporti fra il Diritto Costituzionale e il Diritto Internazionale, Firenze, Cellini, 1890 , pp. 265-266.
} 
crescer dentro de um regime de colaboração mútua parecia fortalecer a ambos ${ }^{23}$. Percebese, pois, que, na virada do século XIX e nos primeiros anos do século XX - quando, paradoxalmente, as ordens nacionais eram marcantemente fechadas às regras externas, e 0 Direito Internacional cuidava com ênfase de assuntos que não eram caros ao constitucionalismo $^{24}$-, não era raro encontrar registros de internacionalistas sensíveis ao papel a ser ocupado pelo Direito Constitucional na evolução da normativa internacional.

Interessa registrar, mais recentemente, autores que, com base em novos argumentos que explicam o estágio em curso dos relacionamentos entre as nações, voltaram a defender a inexistência de oposição entre esses dois regimes jurídicos. Nesse compasso, OTÁviO Augusto Drummond CANÇAdo Trindade proclama que a "influência do constitucionalismo no Direito Internacional é evidente na internacionalização dos direitos fundamentais $" 25$. Ponto de vista que recebe o endosso de JÜRGEN HABERMAS, para quem "a conjugação da Carta das Nações Unidas com a Declaração de Direitos Humanos de 1948 representa, no plano principiológico, uma ruptura revolucionária, porque fez a comunidade internacional obrigar-se a cumprir em todo o mundo princípios constitucionais que, até então, somente eram concretizados no interior dos Estados nacionais" ${ }^{26}$.

Compreende CRISTINA QUEIROZ que a aproximação sistêmica entre ordens jurídicas denota um processo de mudanças conceituais que transformarão as duas disciplinas que estão em sua base: o Direito Constitucional e o Direito Internacional. O aparecimento de um Direito Internacional constitucionalmente orientado, tende a transformar o conjunto de normas internacionais de um mero Direito de coordenação para um Direito constitutivo dos princípios ordenadores básicos da sociedade internacional. Assim, os Estados conservarão sua autonomia constitucional, porém tendem a apresentar maior permeabilidade em relação à normativa exterior, ao passo que o Direito das Gentes passará

\footnotetext{
${ }^{23}$ Diritto Internazionale e Diritto Costituzionale, vol. I - Lo Stato e la Societá Internazionale, Torino, Fratelli Bocca, 1904, p. 6.

${ }^{24}$ ANTONIO CASSESE elucida que, "nessa época, o Direito Internacional limitava-se a disciplinar as relações diplomáticas entre os Estados, a estipular tratados, a assegurar o respeito recíproco dos agentes diplomáticos e de outros órgãos estatais envolvidos na gestão dos afazeres internacionais, a viabilizar a proteção diplomática e judicial dos seus nacionais no estrangeiro, ao uso do mar, e a passagem do direito de paz ao direito de guerra e ao direito de neutralidade. Nesse contexto, o Direito Internacional inspirou-se em princípios liberais, do laissez faire, laissez passer, deixando, por isso, de intervir nos afazeres internos de cada Estado, e, em geral, adotando um comportamento permissivo no confronto dos Estados soberanos. Tais características do Direito Internacional respondem, em parte, porque, nesse período da história, os ordenamentos estatais nacionais tiveram pouca necessidade de incorporar as normas jurídicas internacionais" (L'Apertura degli Ordinamenti Statali all'Ordinamento della Comunità Internazionale, Editoriale Scientifica, 2009, pp. 9-10).

${ }^{25}$ A Carta das Nações Unidas: Uma Leitura Constitucional, Belo Horizonte, Del Rey, 2012, p. 39.

${ }^{26}$ El Derecho Internacional en la Transición Hacia un Escenario Posnacional, Barcelona e Buenos Aires, Centro de Cultura Contemporánea de Barcelona e Katz Editores, 2008, pp. 19-20.
} 
a refletir escopos que se identificam com os objetivos constitucionais. Essa dinâmica de interação entre os sistemas permitirá reforçar a sintonia entre ambos os conjuntos normativos, visto que potencializa a identidade de matérias entre as normas que os compõem $^{27}$.

Junte-se a estas últimas propostas a leitura do fenômeno da convergência normativa apresentada por MARCELO NEVES, sob o nome de transconstitucionalismo. Os sinais desse movimento podem, segundo o estudioso, ser aferidos por meio do ascendente envolvimento dos tribunais constitucionais em assuntos pertinentes aos direitos humanos ou à delimitação do poder do Estado, em especial quando envolvem causas que ultrapassam o campo de validade específico do ordenamento interno; e, no sentido inverso, mediante a incorporação de matérias tipicamente constitucionais na pauta de decisões de órgãos internacionais que passam a ter a pretensão de decidir com caráter vinculante e imediato para os Estados e seus cidadãos ${ }^{28}$. Em síntese, pugna pelo reconhecimento de que - sem os riscos da exacerbação do internacionalismo ou de um descontrolado supranacionalismo, nem com as limitações decorrentes do emprego de soluções exclusivamente locais - as diversas ordens jurídicas precisam combinar-se harmoniosamente para a resolução dos problemas jurídico-constitucionais mais complexos, como algumas das discussões que atualmente circundam os direitos humanos e a organização legítima do poder ${ }^{29}$.

Independentemente da teoria que se prefira para explicar esse fato, é certo que acontecimentos históricos e políticos desenrolados no último século ocasionaram a substituição do conceito estatal de soberania lastreado em uma ordem jurídica hermética, "por um modelo de interdependências e de cooperação internacional entre Estados. Com uma organização progressiva da comunidade internacional, as instituições supranacionais podem receber a competência de estipular regras de vinculação intraestatal, de regular de forma vinculante as relações entre os Estados e, para além disso, podem obter o poder de

\footnotetext{
${ }^{27}$ Cf. CRISTINA QueIROZ, Direito Constitucional Internacional, Ob. cit., p. 106. Averbe-se que essa proposta indica um certo grau de congruência com o modo de AFONSO ARINOS DE MELO FrANCO compreender o fenômeno jurídico em questão, haja vista que esse estudioso considerava adequado cindir a relação estabelecida entre normativa interna e ordem jurídica internacional em duas etapas, a saber: "na primeira fase, a tendência era de trazer para o Direito Interno alguns princípios de Direito Externo: era a internacionalização do Direito Constitucional. Hoje visa-se dar ao Direito Externo uma estabilidade que se traduz, inclusive, na criação de órgãos permanentes, que, não sendo superestados, procuram indubitavelmente, imitar, na estrutura e no funcionamento, as Constituições estatais. Define-se, desta forma, o período a que chamamos de constitucionalização do Direito Internacional" (Curso de Direito Constitucional Brasileiro, Vol. I: Teoria Geral, Rio de Janeiro, Forense, 1958, p. 206).

${ }^{28}$ Cf.Transconstitucionalismo, São Paulo, Martins Fontes, 2009, pp. 132-133.

${ }^{29}$ Cf. Idem, p. 297.
} 
impor essas regras de forma segura" ${ }^{30}$. De tal sorte, a partir de 1920, engenhos constitucionais passaram a introduzir nas Constituições esquemas voltados a compatibilizar as relações entre o ordenamento interno e o Direito das Gentes, o que fez que a maior parte dos Estados adquirisse um perfil decididamente internacionalista ${ }^{31}$.

Os quadros normativos das Constituições, conforme sublinha MaTTIAS KUMM, costumam abrigar ferramentas habilitadas a orientar os poderes do Estado no processo de criação de normas internacionais de forma segura, isto é, em atenção "tanto aos seus respectivos compromissos constitucionais quanto às crescentes exigências do sistema de internacional" ${ }^{32}$. Infere-se, portanto, que, diferentemente da orientação sedimentada desde 1926 pela decisão judiciária que abre este capítulo, o Direito Constitucional não enveredou por tratar o conjunto de normas internacionais como algo sem relevância. Ao contrário, as Constituições da atualidade indicam um grau de permeabilidade ao exterior jamais experimentado, que tem ocasionado "a afirmação do Direito Internacional como Direito do próprio país e o reconhecimento de alguns de seus princípios ou regras como medida de justiça, vinculativa da própria ordem jurídica interna" ${ }^{33}$.

Com efeito, o término da Segunda Guerra Mundial foi responsável por mudanças marcantes nas Constituições e no conjunto de atos ordenadores da sociedade internacional. Pode-se dizer que o contexto que emergiu determinou que os tradicionais pontos fundantes do Direito das Gentes instaurados no século XVII ${ }^{34}$ acabassem submetidos a um intenso processo de diluição, materializado na perda do protagonismo estatal e na crescente aparição de novos atores supra e transnacionais no universo das relações exteriores ${ }^{35}$. Hoje, normas internacionais não constituem mais uma esfera de Direito rigidamente separada e distinta do mundo jurídico dos ordenamentos estatais, sobretudo porque o Direito

\footnotetext{
${ }^{30}$ Reinhold ZipPelius, Introdução ao Estudo do Direito, Belo Horizonte, Del Rey, 2006, pp. 25-26.

${ }^{31}$ Cf. Antonio La Pergola, Poder Exterior y Estado de Derecho:El Constitucionalista Ante el Derecho Internacional,Salamanca, Ediciones Universidad Salamanca, 1987, p. 13.

${ }^{32}$ Democratic Constitucionalism Encounters International Law: Terms of Engagement, in The Migration of Constitutional Ideas, Sujit Choudhry (ed.), Cambridge, Cambridge University Press, 2006, p. 291.

${ }^{33}$ J. J. Gomes CAnotilho, Direito Constitucional e Teoria da Constituição, $7^{a}$ ed., Coimbra, Almedina, 2003, p. 369.

${ }^{34}$ NgUYen Quoc Dinh, PATRick Daillier e Alain Pelletpontuam que os Tratados de Vestfália, celebrados em 1648, "assentam os primeiros elementos de um 'direito público europeu'. A soberania e a igualdade dos Estados são reconhecidas como princípios fundamentais das relações internacionais. Para a resolução de problemas comuns, prevê-se o recurso ao processo do tratado fundado no acordo dos Estados participantes. Além disso, cria-se um mecanismo para assegurar a manutenção da nova ordem europeia. [...] Juridicamente, os Tratados de Vestfália podem ser considerados como o ponto de partida de toda a evolução do Direito Internacional contemporâneo" (Direito Internacional Público, $2^{\mathrm{a}}$ ed., Lisboa, Fundação Calouste Gulbenkian, 2003, p. 53). Ver também Alberto do Amaral Júnior, Curso de Direito Internacional Público, $4^{\mathrm{a}}$ ed., São Paulo, Atlas, 2013, pp. 29-34.

${ }^{35}$ Cf. Alfonso de Julios-Campuzano, Constitucionalismo em Tempos de Globalização, Porto Alegre, Livraria do Advogado, 2009, p. 58.
} 
Internacional, ao efetuar incursões importantes sobre temáticas que sempre foram objeto de normatização pelos sistemas internos, causou impactos notáveis sobre estes, condicionando-os e também contribuindo para modelar seu funcionamento ${ }^{36}$.

Vale registrar, nessa altura, a advertência formulada por GERSON DE BRITTO MELLO Boson acerca de que "os assuntos de interesse de ambas as ordens, a nacional e internacional, não podem ser regulados rigidamente por nenhuma delas. Ao contrário, devem comportar certa maleabilidade, por serem fronteiriços na distribuição das competências materiais" ${ }^{37}$.O diálogo entre as ordens normativas interna e internacional é não apenas possível, mas desejável em se tratando dos temas em questão, já que enseja a ampliação conjunta dos dois compartimentos normativos, munindo-os, não raro, de instrumentais impossíveis de serem imaginados sob a perspectiva restrita de somente um dos sistemas.

Caso houvesse apenas previsões constitucionais no tratamento dos assuntos mencionados, ter-se-ia de conceber, no mínimo, a edificação de uma espécie de Federação mundial, alicerçada em um único documento que assumiria a forma de uma Constituição global, ideia deveras incerta de acontecer. Em outro sentido, se somente o Direito das Gentes se ocupasse de estabelecer essa normativa, seria preciso assumir o risco de entregar ao sistema internacional - carente de uma estrutura orgânica que cuide da elaboração e da aplicação de suas normas - o encargo de zelar pelo cumprimento dos comandos normativos criados. Os riscos de abraçar uma ou outra solução, isoladamente, são elevados, pois é provável que causaria a perda de uma série de conquistas do constitucionalismo solidificadas ao longo da história, do mesmo modo que prejudicaria o advento de melhorias nos dois sistemas jurídicos, especialmente no que se refere a matérias em que as normas internacionais não podem prescindir das Constituições para serem integralmente eficazes.

\subsubsection{Estado Constitucional e Ordem Internacional}

Influenciadas pelas transformações decorrentes da normatização internacional de temas, até então, reservados ao domínio exclusivo das normas internas, a maioria das Constituições editadas na última metade do século XX descerraram, em diferentes

\footnotetext{
${ }^{36} \mathrm{Cf}$. Antonio CASSESE, L'Apertura degli, Ob. cit., pp. 27-28.

${ }^{37}$ Conceituação Jurídica da Soberania do Estado, in Direito Constitucional: Teoria Geral do Estado (Coleção Doutrinas Essenciais, vol. 2), Clèmerson Merlin Clève e Luís Roberto Barroso (org.) São Paulo, Revista dos Tribunais, 2011, p. 303.
} 
intensidades, suas portas para a sociedade internacional. Como observa PATRICE GÉLARD, a internacionalização do Direito Constitucional tem várias explicações, e a mais considerável está ligada aos impactos originados da tendência de internacionalização dos Direitos do Homem ${ }^{38}$, medida que causou a humanização do Direito das Gentes e o alargamento da noção de sujeito internacional, criando, ainda, terreno propício para que ambas as ordens jurídicas pudessem entabular entendimentos reciprocamente construtivos. Ainda que as causas desse movimento sejam múltiplas e nem todas tenham, até agora, sido reveladas, o fato é que a identidade das matérias tratadas pelas atos jurídicos internos e exteriores torna obsoletos os esforços teóricos para fundamentar a primazia de um conjunto de normas em relação ao outro.

As dissonâncias doutrinárias que ainda persistem entre os estudiosos do Direito Interno e o Direito das Gentes provam que "os discursos nacionais e internacionais sobre as Constituições e o constitucionalismo estão visivelmente desconectados" ${ }^{\text {"39 }}$. Esse dado é preocupante, na medida em que a normatividade da Constituição é resultado de um processo histórico longo, uma construção dos povos ocidentais que tornou possível a convivência pacífica, respeitosa em relação ao pluralismo e garantidora dos direitos e das liberdades. Assim é que os internacionalistas mais tradicionais que ignoram solenemente o Direito Constitucional, além de exprimirem descompasso com a realidade, contribuem para que Direito Internacional não edifique um plexo normativo que seria, sem dúvida, mais ajustado às necessidades e possibilidades constitucionais dos Estados - e, por conseguinte, cumprido de maneira mais significativa pelas autoridades nacionais.

Colocado em termos diversos, o que se pretende explicitar é que, se os constitucionalistas tivessem seguido à risca a instrução estabelecida pela Corte Permanente de Justiça Internacional no precedente Certos Interesses Alemães na Silésia Superior Polonesa, tanto o Direito Interno quanto o Direito Internacional teriam conformações muito distintas da que se verifica nos dias correntes. Por certo, as Constituições estariam, agora, padecendo de um grave anacronismo e dificilmente poderiam guiar $\mathrm{o}$

\footnotetext{
${ }^{38}$ As Transformações do Direito Constitucional na Sociedade Contemporânea, in Revista da Faculdade de Direito das Faculdades Metropolitanas Unidas, nº 15, ano 10, jan./jun. 1996, p. 37.

${ }^{39}$ Anne Peters, Constitucionalismo Compensatório: Las Funciones y el Potencial de las Normas y Estruturas Internacionales, in La Constitucionalización de la Comunidade Internacional, Anne Peters, Mariano J. Aznar e Ignacio Gutiérrez (ed.), Valencia, Tirant lo Blanch, 2010, p. 238. Compartilha de idêntica impressão Flávia PiOVESAN, que assevera que "os estudiosos do Direito Constitucional não se arriscam no campo do Direito Internacional, e, por sua vez, os que se dedicam a esse Direito também não se aventuram no plano constitucional. Ao invés do diálogo e da interação, prevalecem o divórcio e o silêncio. Isso se faz problemático especialmente quando os dois campos do Direito revelam o mesmo objeto e a mesma preocupação" (Direitos Humanos e o Direito Constitucional Internacional, $11^{\mathrm{a}}$ ed., São Paulo, Saraiva, 2010, pp. 17-18).
} 
funcionamento dos Estados em um cenário marcado pelo fortalecimento da globalização. O Direito Internacional, por sua vez, não teria obtido êxito em se aperfeiçoar a patamares tão expressivos apenas com base na afirmação jurisprudencial de sua superioridade, tampouco haveria existido condições propícias para ampliar a abrangência das normas internacionais.

Não é difícil compreender o espanto com que muitos constitucionalistas e os próprios cidadãos assistem a um processo que, por não ter chegado ao fim, relativiza e questiona a normatividade da Constituição em prol do surgimento de uma ordem internacional onipotente ${ }^{40}$. Sem dúvida, a internacionalização do Direito Constitucional deve ser tomada como um movimento que enaltece a importância crescente dos acontecimentos exteriores, tanto para a vida privada como para a ação do Estado, motivo pelo qual os textos constitucionais passam a se ocupar de disciplinar assuntos que, antes, eram objeto de atenção exclusiva do Direito das Gentes. No entanto, a aproximação entre os dois sistemas normativos não pode resultar no extermínio das bases em que o Direito Constitucional se assenta, já que, sem Constituições que organizem e limitem o aparato estatal, o Direito Internacional perde sua razão de ser, porque é impossível aplicá-lo satisfatoriamente na ausência de órgãos nacionais habilitados para tanto.

O entusiasmo cosmopolita do Direito Internacional, não obstante permita o alargamento das pautas das normativas de que tratam os comandos exteriores, pode resultar na total ineficácia de alguns mandamentos internacionais criados em dissonância com as reais possibilidades de execução ofertadas pelas estruturas constitucionais. A proposta (nem sempre sustentável) da superioridade hierárquica das normas exteriores pode causar a debilidade das prescrições internacionais, sobretudo quando estas, no âmbito interno, contrariarem Constituições rígidas. A simbiose entre as ordens interna e internacional evidencia-se como a chave para assegurar a coexistência e o mútuo aprimoramento das prescrições que condicionam os vários quadrantes da vida pública e privada atuais.

São, com certeza, irreais construções teóricas que defendem a viabilidade de o Direito Internacional regular, sozinho, todas as matérias que julgar importantes, retirandoas, por completo, se preciso for, da competência estatal. A concretização desse tipo de tese conduziria o Direito das Gentes à autodestruição, uma vez que o sistema jurídico

${ }^{40}$ Cf. Francisco BAlaguer CAllejón, La Constitucionalización de la Unión Europea y la Articulación de los Ordenamientos Europeo y Estatal, in El Constitucionalismo em la Crisis del Estado Social, Miguel Ángel García Herrera (org.), Bilbao, Servicio Editorial de la Universidad del Pais Vasco, 1997, p. 601. 
internacional pressupõe ordens jurídicas estatais que se autodeterminam, pois são os sistemas nacionais que cumprem, na maior parte das vezes, as prescrições e decisões produzidas pelo Direito Internacional. Caso as normas exteriores pudessem intervir no terreno nacional a ponto de tornar impossível que os Estados nacionais se autoorganizassem para atender seus valores, suas tradições e suas peculiaridades locais, estarse-ia diante de um inexequível Estado planetário, o qual teria todos os povos como súditos e cujas decisões políticas seriam tomadas sem que seus destinatários pudessem participar dentro dos parâmetros democráticos ${ }^{41}$.

Firme na crença de que "sem o Direito Constitucional seria impossível a execução das regras do Direito Internacional"42, a análise de como as Constituições nacionais têm-se amoldado para assegurar o cumprimento de normas exteriores criadas em uma profusão até então desconhecida passa a figurar como necessária e impostergável. Mais do que uma visão panorâmica sobre o tema, devem ser realçados os mecanismos contidos na Constituição Federal do Brasil de 1988 e que impulsionam a inserção do constitucionalismo pátrio nesse ambiente de progressiva internacionalização do Direito. E, porque, sem nenhuma dúvida, procede a afirmação de CLÈMERSON MERLIN CLÈVE no sentido de que "o Direito Internacional e o Direito Constitucional brasileiro precisam fazer amizade"43, é que o tema da abertura do nosso Estado ao Direito das Gentes merece ser estudado sob a perspectiva das Constituições.

\subsection{Globalização e Reconstrução do Conceito de Soberania}

A globalização é um processo que pode ser descrito em muitas facetas; não representa um estado final ${ }^{44}$. Manifestado sobretudo como fenômeno econômico, que de modo progressivo também se difundiu para outras esferas da atividade humana, o impulso globalizante deflagrou um vigoroso processo de transformações, capacitado, em um longo prazo, a modificar radicalmente a estrutura estatal assentada desde o Tratado de Vestfália. Como consequência, a acentuação da dependência da economia interna em relação à

\footnotetext{
${ }^{41}$ Cf. Gerson de Britto Mello Boson, Conceituação Jurídica da Soberania do Estado, in Direito Constitucional: Teoria Geral do Estado (Coleção Doutrinas Essenciais, vol. 2), Clèmerson Merlin Clève e Luís Roberto Barroso (org.), Ob. cit., pp. 303-304.

${ }^{42}$ Boris MiRkINE-GuETZÉVITCH, Derecho Constitucional Internacional, Ob. cit., p. 474.

${ }^{43}$ Direito Constitucional, Novos Paradigmas, Constituição Global e Processos de Integração, in Revista da Academia Brasileira de Direito Constitucional, no 5, 2004, p. 231.

${ }^{44}$ Cf. JÜrgen Habermas, A Constelação Pós-Nacional: Ensaios Políticos, São Paulo, Littera Mundi, 2001, p. 84.
} 
economia mundial e o aparecimento de redes cada vez mais amplas de conexões entre os variados sujeitos tornaram praticamente impossível separar o que é definido como assunto nacional e o que é de interesse externo ${ }^{45}$.

Nessa direção, pondera ANTHONY GIDDES que a globalização traduz-se essencialmente em um processo de alongamento, "na medida em que as modalidades de conexão entre diferentes regiões ou contextos sociais se enredam através da superfície da terra como um todo"46. As novas variáveis econômicas, políticas e sociais provenientes do mundo globalizado implodem os pilares fundamentais sobre os quais se erigiu o pensamento jurídico ocidental, desafiando o jurista a reexaminar os institutos e conceitos que formam o seu instrumental técnico sob inovadoras perspectivas, despindo-se de preconceitos e dogmas ${ }^{47}$. A aparição de problemas globais demanda esforços igualmente globais e, em meio a essa situação, claudicante e dinâmica, os Estados são obrigados a transpor suas fronteiras para fazer valer seus interesses e reafirmar constantemente sua soberania.

Os Estados e as Constituições nacionais são colocados sob prova de diferentes modos: os problemas globais forçam os Estados a cooperarem no seio de organizações internacionais e a se vincularem a uma série de tratados bilaterais e multilaterais. Paralelamente, funções governamentais típicas, como a garantia da segurança humana, a liberdade e a igualdade são, em parte, transferidas para instâncias intergovernamentais ou supranacionais. Há, ainda, o surgimento de atores não estatais, que praticam relações múltiplas no âmbito nacional e transnacional. $\mathrm{O}$ resultado de todo esse conjunto redunda na convicção de que o atendimento regular das matérias de interesse público passa, ultimamente, para mais além dos confins constitucionais dos Estados ${ }^{48}$.

Da maneira como apresentada, a globalização assume contornos de uma constante que se espraia em numerosos campos, abarcando, até mesmo, os aspectos institucionais do Estado. Os vetores que prevalecem induzem a forte interdependência entre as nações e a abertura dos órgãos nacionais ao exterior, até o grau de se tornar inviável a decisão que poderia ser tomada soberanamente por um Estado de isolar-se do restante dos seus

\footnotetext{
${ }^{45}$ Cf. Konrad Hesse, Temas Fundamentais do Direito Constitucional: Textos Selecionados e Traduzidos por Carlos dos Santos Almeida, Gilmar Ferreira Mendes e Inocêncio Mártires Coelho, São Paulo, Saraiva, 2009, pp. 19-20.

${ }^{46}$ As Consequências da Modernidade, São Paulo, Editora UNESP, 1991, p. 69.

${ }^{47}$ Cf. Daniel Sarmento, Constituição e Globalização: A Crise dos Paradigmas do Direito Constitucional, in Revista de Direito Administrativo, vol. 215, jan./mar. 1999, p. 20.

${ }^{48}$ Cf. AnNe Peters, Constitucionalismo Compensatório: Las Funciones y el Potencial de las Normas y Estruturas Internacionales, in La Constitucionalización de la Comunidade Internacional, Anne Peters, Mariano J. Aznar e Ignacio Gutiérrez (ed.), Ob. cit., pp. 209-210.
} 
congêneres e demais atores que atuam no cenário internacional. Para fazer frente a um conjunto de circunstâncias notadamente econômicas, os Estados tendem a integrar-se em regiões ou blocos econômicos e a constituir acordos e instituições multinacionais responsáveis por cuidar das inevitáveis interconexões, o que, certamente, reduz a margem de controle de suas fronteiras, em virtude do incremento da liberdade de circulação de pessoas, serviços e capitais, além do poder de alcance descomunal dos meios de comunicação $^{49}$.

\subsubsection{Efeitos da Globalização nos Sistemas Jurídicos Interno e Internacional}

Produto da globalização, há um sensível esvaziamento das estruturas jurídicas estatais, o que causa o reenquadramento da própria ordem constitucional, haja vista que esta, na contramão do que acontecia no passado, fica desprovida de força normativa suficiente para disciplinar todas as conflitivas interações dos diferentes subsistemas sociais. A gradativa interdependência entre os processos sociais, produtivos e financeiros força, pois, a aparição de singulares formas de juridicidade transnacional e internacional, que interseccionam com o modelo clássico de juridicidade estatal, impactando-o profundamente. ALFONSO DE JULIOS-CAMPUZANO registra que "a Constituição fica, assim, aprisionada pela emergência de um paradigma jurídico global que torna incontrolável o processo econômico: a regulação dos mercados se afasta do âmbito público estatal e se desloca até âmbitos privados inacessíveis ao controle do poder estatal" ${ }^{, 50}$.

Diante desse contexto, JÜRGEN HABERMAS concentra sua análise em três aspectos que revelam exaurimento do poder do Estado nacional, a saber: "a perda da capacidade de controle, o crescente déficit de legitimação nos processos decisórios e a incapacidade, cada vez maior, de fornecer serviços de organização e de condução eficazes do ponto de vista da legitimação" ${ }^{51}$. Essas questões, quando transpostas para o plano jurídico, indicam o desaparecimento (ou, ao menos, a dissipação) de limites das áreas de influência do Direito Interno e do Direito Internacional, ao mesmo tempo em que tornam a desenvoltura para lidar com os reiterados cruzamentos entre ambos os sistemas normativos um predicado imprescindível colocado aos juristas de hoje ${ }^{52}$. É tamanha a importância dos pontos

49 Cf. Clicerio Coello Garcés, El Estado Democrático Postnacional: Dimensiones Actuales del Principio de Soberanía y Ciudadanía, Valencia, Tirant lo Blanch, 2013, pp. 32-34.

${ }^{50}$ Constitucionalismo em Tempos, Ob. cit., pp. 59-60.

${ }^{51}$ Cf. Era das Transições, Rio de Janeiro, Tempo Brasileiro, 2003, p. 106.

${ }^{52}$ Cf. Miguel Carbonell, Globalización y Derecho: Siete Tesis, in Globalización y Derechos Humanos, Luís T. Díaz Müller (coord.), Universidad Nacional Autónoma de México, México, 2003, pp. 11-12. 
destacados pelo autor para a compreensão dos reflexos da globalização nas estruturas nacionais dos Estados, que se passa, na sequência, a examiná-los, mesmo que superficialmente, com o objetivo de melhor entendê-los.

Em primeiro lugar, a parcial perda da soberania estatal revela, entre outros dados, não estar mais o Estado em condições de proteger, por si só, seus cidadãos contra os efeitos externos de decisões que são tomadas por outros atores, bem como contra as reações em cadeia de certos processos que têm sua origem fora de suas fronteiras ${ }^{53}$. É fato que as forças da globalização não podem suprimir as ordens jurídicas estatais, entretanto, torna-se imprescindível que as atividades legislativa e jurisdicional desempenhadas pelos Estados nacionais estejam em sintonia com atos normativos provenientes de outros sujeitos que não o próprio Estado ${ }^{54}$. Cabe reconhecer que uma das contribuições positivas creditadas à globalização refere-se ao fortalecimento do Direito Internacional, sobretudo no que respeita aos direitos humanos, o que apenas se tornou viável graças à transformação da sociedade internacional de um simples somatório de nações em um autêntico espaço de convivência e comunhão entre os povos, orientado pela busca do bem comum da humanidade ${ }^{55}$.

Mais um aspecto a se destacar é a ausência de legitimação democrática na sistemática de funcionamento de vários dos processos decisórios que resultaram da globalização ${ }^{56}$. Estar-se-á, segundo HABERMAS, diante de uma conjuntura de déficit de legitimação, quando o círculo dos que participam de decisões democráticas não coincide exatamente com o círculo dos atingidos por essas decisões, e isso ocorre inegavelmente na celebração de tratados intergovernamentais e na edição de resoluções vinculantes por parte de organismos internacionais ${ }^{57}$. De tal sorte, quanto mais frequentes e volumosas forem as matérias objeto de normatização mediante negociações interestatais, mais decisões tendem a serem subtraídas de instrumentos de formação democrática de opinião e de vontade popular.

\footnotetext{
${ }^{53}$ Cf. JÜrgen Habermas, Era das Transições, Ob. cit., p. 107.

${ }^{54}$ Cf. Alessandro Pizzorusso, La Produzione Normativa in Tempi di Globalizzazione, Torino, G. Giappicheli Editore, 2008, pp. 15-16.

${ }^{55}$ Cf. Gonzalo Aguilar Cavallo, La Internacionalización del Derecho Constitucional, in Estudos Constitucionais, $\mathrm{n}^{\circ}$ 1, ano 5, 2007, p. 248.

${ }^{56} \mathrm{NICO}$ KRISCH adverte que, não obstante estar crescendo em importância, o Direito Internacional apresenta problemas em sua base de legitimidade, porque apenas o consentimento ofertado pelos Estados não é ser suficiente para tanto; com isso, as normas internacionais revestem-se da natureza de um conjunto formalista e antidemocrático de prescrições, passando a reclamar uma base mais sólida e espessa de fundamentação, indissociável da participação popular (Beyond Constitutionalism: The Pluralism Structure of Posnational Law, Oxford, Oxford University Press, 2010, pp. 3-4).

${ }^{57}$ Cf. Era das Transições, Ob. cit., pp. 107-108.
} 
O terceiro dado que ocupa o centro da discussão é a redução da capacidade de intervenção do Estado nacional como promotor de eficientes políticas sociais. Em outras palavras, as condições da concorrência global pelas praças de investimento e os altos custos dos salário incentivam a busca de racionalização do capital privado, o que faz os governos nacionais perderem a capacidade de esgotar os recursos fiscais da economia local, deixando de estimular o crescimento nacional e, assim, perdendo o controle sobre o principal componente de sua legitimação. As políticas de taxação da demanda adotadas pelas autoridades governamentais nacionais podem ter terríveis efeitos externos sobre o circuito da economia nacional, uma vez que as bolsas internacionais assumiram a tarefa de avaliar as decisões econômicas traçadas pelos Estados ${ }^{58}$.

A confluência das forças mencionadas corroeu a tradicional visão de soberania estatal, responsável por guiar a inserção do Estado nacional no âmbito da sociedade internacional. Os maciços abalos causados pelo avanço da globalização obrigou que fossem remodelados os elementos que definem o poder soberano, de modo que, em termos práticos, não mais se pode entendê-lo com base no dogma idealizado por JEAN BODIN, ou seja, como o atributoresponsável por garantir o "poder absoluto e perpétuo de uma República" "59 . A noção de soberania está em transição, busca arranjos viáveis para que não seja um empecilho aos movimentos de integração supranacional; ao mesmo tempo, emite sinais contundentes de que os direitos fundamentais devem ser alçados à categoria de limites ao exercício das atribuições que lhes são próprias ${ }^{60}$.

A recomposição dos elementos informadores da soberania é consequência da emergência, no plano externo, desse ambiente marcado pela integração política, econômica e social em níveis altamente acentuados, do qual decorre a expansão do sistema de Direito Internacional Público. Esse dado jamais poderá ser interpretado como rejeição do primado da soberania ou uma possível tendência de abandono da soberania como peça basilar na estruturação política do mundo ${ }^{61}$. Sem embaraços, pode-se dizer que "o antigo conceito de soberania absoluta do Estado - e de seu poder de dispor como bem entender dentro de suas

\footnotetext{
${ }^{58}$ Cf. JÜrgen Habermas, Era das Transições, Ob. cit., pp. 108-109.

${ }^{59}$ Os Seis Livros da República: Livro Primeiro, São Paulo, Ícone, 2011, p. 195.

${ }^{60}$ Cf. JAVIER GARCía ROCA, La Interpretación Constitucional de una Declaración Internacional, el Convenio Europeo de Derechos Humanos, y Bases para una Globalización de los Derechos, in Revista Iberoamericana de Derecho Procesal Constitucional, $\mathrm{n}^{\circ}$ 5, 2006, p. 169.

${ }^{61}$ Cf. Pedro B. A. DAllari, Constituição e Tratados Internacionais, São Paulo, Saraiva, 2003, p. 3. Igual juízo é externado por MANOEl GonÇAlves FerReIRA FILHo, O Futuro do Estado, in Revista da Escola Paulista da Magistratura, n $^{\circ}$ 4, nov./jun. 1998, p. 94; e ENRIQUE RICARDO LEWANDOWSKI,Globalização, Regionalização e Soberania, São Paulo, Juarez de Oliveira, 2004, p. 295.
} 
fronteiras - foi superado pela evolução da ordem internacional, cada vez mais integrada com as ordens nacionais e com valores consagrados pela humanidade como um todo"

Averbe-se, por oportuno, que a construção de um prenunciado Estado mundial, como resultado dos novos quadrantes da soberania, não passa de uma miragem teórica incompatível com as possibilidades concretas de serem extraídas do concerto entre os Estados nacionais. Sobre o tema, MANOEL GonçALVES FERREIRA FiLHo esclarece que a expressão usualmente empregada é, todavia, enganadora, porque um Estado mundial, caso venha remotamente a se formar, seria uma forma política nova, que pouco se ajusta ao tipo Estado no sentido restrito da palavra ${ }^{63}$. Não é demais relembrar que a sociedade internacional não é um todo ligado por um sistema jurídico unitário; é formada por uma pluralidade de Estados, com ordens jurídicas próprias e que decidem com independência, dentro de seus respectivos âmbitos de soberania, como ocorrerá a aplicação interna das normas internacionais ${ }^{64}$.

Ainda acerca da tese de um arranjo que venha a se revestir da natureza de Estado mundial, JORGE MIRANDA adota posição de enfática contrariedade a esse desiderato. Entende que há muitos obstáculos intransponíveis para sua materialização, a exemplo das grosseiras desigualdades factuais entre as nações; da diversidade dos sistemas constitucionais e de culturas políticas vigentes em cada Estado; da diversidade cultural, religiosa e política entre os povos; além da incerteza quanto ao viés democrático e compromissado com a liberdade e o pluralismo que venha a apresentar. Também adverte que um provável Estado global dificilmente garantiria a observância dos postulados democráticos, porquanto tenderia a se transmutar em um diretório dos grandes e poderosos Estados, contrariando toda a axiologia da igualdade soberana ${ }^{65}$.

Independentemente dos rumos que o fenômeno da globalização venha a ditar aos Estados nacionais, constitui circunstância aclarada que a profusão de normas internacionais impõe que os ordenamentos internos não sejam refratários ao cumprimento dos comandos

\footnotetext{
${ }^{62}$ José CARlos de Magalhães, O Supremo Tribunal Federal e o Direito Internacional: uma Análise Crítica, Porto Alegre, Livraria do Advogado, 2000, p. 62.

${ }^{63}$ Cf. Manoel Gonçalves Ferreira Filho, O Estado no Limiar do Novo Século, in Revista de Direito Administrativo, vol. 217, jul./set. 199, p. 84.

${ }^{64}$ Cf. Christian Hillgruber, La Integración del Derecho Internacional y del Derecho de la Unión Europea en el Ordenamiento Constitucional Alemán, in Revista de Derecho Constitucional Europeo, $\mathrm{n}^{\circ} 1$, jan./jun. 2004, p. 137. Filia-se a essa percepção MiREILlE DELMAS-MARTY, ao assinalar que "a futura ordem mundial não anuncia, sem dúvida, o advento de uma visão federal do mundo, mas mais provavelmente uma combinação de diversos modelos, nacional, internacional, transnacional e supranacional" (La Refondation des Pouvoirs: Les Forces Imaginantes du Droit (III), Paris, Éditions du Seuil, 2007, p. 55).

${ }^{65}$ Cf. Jorge Miranda, Democracia e Constituição para lá do Estado, in Revista da Faculdade de Direito da Universidade de Lisboa, vol. 51, nº 1 e 2, p. 39.
} 
advindos do exterior. O Direito das Gentes avança seu âmbito de incidência e permite que novas abordagens sejam experimentadas no universo político e jurídico dos Estados, o que converge para a conclusão de que "a criação do Direito Internacional representa um paradoxo, na medida em que, sendo fruto da soberania, esta se vai esgotando à medida em que o gera" ${ }^{\prime 66}$. Desse modo, mostra-se impossível compreender a soberania sob um ponto de vista estritamente estático, porque, mais do que nunca, esse conceito merece uma análise consentânea com seu nítido caráter evolutivo.

\subsubsection{Forças que Incidem na Reformulação da Soberania}

Ao longo de toda a história moderna, a soberania sempre foi tida como um conceito que, embora inquestionavelmente reconhecido, nunca conseguiu ser objeto de uma definição uniforme e pacífica ${ }^{67}$. Se, no passado, defini-la já era tarefa complicada e sujeita a ampla divergência, agora, a globalização da economia, a pluralidade dos sistemas de controle social e a proliferação das fontes normativas transformaram esse encargo em missão ainda mais delicada, sobretudo se for feita com fulcro no resgate das ideias clássicas sobre o tema. O significado de soberania deve ser reconstruído porque os paradigmas definidores das estruturas políticas e jurídicas essenciais dos Estados passam por um intenso e sem precedentes processo de refundação.

Predomina o senso teórico comum de que, em aspectos gerais, a soberania “equivale a uma moeda de duas faces: uma correspondendo ao conceito de supremacia e outra à ideia de independência" ${ }^{\circ}$. É que, no plano interno, as leis e as determinações elaboradas pelo Estado vigoram sem contraste dentro de seu território, isentas de limites em qualquer outro poder, haja vista que a soberania encarna um poder de decisão, em última instância, respaldado no monopólio da coação legal. Já na seara internacional, esse conceito revela a ausência de vínculos de subordinação ou de dependência do Estado nas relações interestatais que venha a empreender, considerando que a sociedade internacional é pautada pela igualdade das soberanias.

A realidade dos dias de hoje comprova, entretanto, que o Estado enfrenta forças internas e externas que deflagram questionamentos severos sobre a aptidão do tipo estatal

\footnotetext{
${ }^{66}$ Luiz Olavo BAPtista, ALCA - Notas sobre o Impacto da ALCA sobre o Sistema Jurídico Brasileiro, in Alca e Mercosul: Riscos e Oportunidades para o Brasil, Samuel Pinheiro Guimarães (org.), Brasília, IPRI e FUNAG, 1999, p. 200.

${ }^{67}$ Cf. DAlmo De Abreu Dallari, Elementos de Teoria Geral do Estado, 28 a ed., São Paulo, Saraiva, 2009, p. 74.

${ }^{68}$ ENRIQUE RICARDO LEWANDOWSKI, Globalização, Regionalização e, Ob. cit., pp. 234-235.
} 
definido pelos padrões de Vestfália para lidar com exigências impostas pela perda de governabilidade sentida nos planos local, regional, transnacional e global. Conforme apura Cristina QUeIROZ,o Direito Constitucional e o Direito Internacional clássicos construíram seus institutos elementares com base no paradigma do Estado nacional de substrato territorial. Esse parâmetro pende para a perda de sustentabilidade, quer pelo prisma do Direito das Gentes, quer pela ótica das próprias Constituições, uma vez que as normas internacionais denotam considerável grau de desenvolvimento e tornam os Estados altamente interdependentes, enquanto o constitucionalismo abandonou a figura do Estado como seu objeto central e fez dos direitos fundamentais seu "núcleo duro"69.

Nesse compasso, após detido estudo, LuIGI FERRAJOLI traz incisivas observações que fortalecem a percepção de que os pressupostos e as características da soberania, seja no âmbito interno, seja na dimensão externa, não mais subsistem em suas feições tradicionais. O desenvolvimento do Estado de Direito dissolveu a ideia seiscentista de que, dentro dos limites territoriais do Estado, o soberano era titular de um poder incontrastável e sem limites; concomitantemente, o notório fortalecimento das interações exteriores fez emergir um sistema de normas internacionais tidas como cogentes ou imperativas (jus cogens), porque vinculam os Estados nacionais imediatamente e sem a exigência de aquiescência dos mesmos. As inovações nos contornos da soberania trouxeram consigo a ascensão de novos sujeitos no Direito Internacional: além dos Estados, os indivíduos e os povos também passaram a ter subjetividade jurídica e, por conseguinte, direitos e obrigações internacionalmente exigíveis ${ }^{70}$.

\footnotetext{
${ }^{69} \mathrm{Cf}$. Direito Constitucional Internacional, Ob. cit., p. 12.

${ }^{70}$ Cf. Luigi Ferrajoli, A Soberania no Mundo Contemporâneo: Nascimento e Crise do Estado Nacional, $2^{\mathrm{a}}$ ed., São Paulo, Martins Fontes, 2007, pp. 41-42. No que é atinente ao enquadramento dos indivíduos como integrantes da sociedade internacional, preconiza ALAIN PELLET que "não são somente sujeitos ativos do Direito Internacional. Eles tornaram-se também sujeitos 'passivos', no sentido de que eles não são apenas destinatários, às vezes diretos, da norma de Direito Internacional [...] mas também que eles podem ser chamados a responder, no plano internacional, pela violação de algumas dessas regras. Essa evolução se desenhou desde o Tratado de Versalhes, concretizada em 1945 e 1946 com a criação e os julgamentos dos Tribunais Militares Internacionais de Nuremberg e de Tóquio, afirmou-se com a instituição dos Tribunais Penais ad hoc para a ex-Iugoslávia e Ruanda e, a partir de julho de 2002, ficou definitivamente consolidada pela criação do Tribunal Penal Internacional" (As Novas Tendências do Direito Internacional: Aspectos "Macrojurídicos", in O Brasil e os Novos Desafios do Direito Internacional, Leonardo Nemer Caldeia Brant (coord.), Rio de Janeiro, Forense, 2004,pp. 6-7).
} 


\subsubsection{Estado de Direito e Limitação da Soberania Interna}

O reconhecimento de direitos fundamentais em sucessivas Constituições da contemporaneidade mudou a estrutura interna dos Estados e alterou substancialmente a noção de soberania interna. De fato, ao se instituírem, no universo público, normas referentes à divisão dos poderes, ao princípio de legalidade e às limitações do poder impostas pelos direitos de proteção da pessoa humana, ocorreu a limitação do poder soberano, o que, em última análise, indica graus expressivos de negação do antigo pensamento que se tinha acerca da soberania interna ${ }^{71}$. Graças a essas conquistas, a relação entre Estado e indivíduos deixou, gradativamente, de ser uma relação entre soberano e súditos, para se conformar como uma ligação entre dois sujeitos, ambos dotados de limitações e prerrogativas preestabelecidas ${ }^{72}$.

Como o objetivo de todo Estado de Direito e de suas instituições básicas centra-se na pretensão de lograr uma suficiente garantia e segurança jurídica no que concerne aos direitos fundamentais, o elemento essencial do sistema de legitimidade em que o Estado se apoia hoje é justamente o respeito a esses direitos ${ }^{73}$. Desse modo, a delimitação do espaço interno onde a soberania é exercida não pode ser dissociada da verificação do completo respeito, por parte das autoridades estatais, da gama dos direitos em destaque, sob pena do indesejável resgate da ideia há muito abandonada de poder absoluto do Estado na definição dos rumos das esferas política e social. "Portanto, o regime do Estado de Direito se estabelece no interesse dos cidadãos e tem por finalidade especial preservá-los e defendêlos contra a arbitrariedade das autoridades estatais" 74 .

Assevera ANTONIO ENRIQUe PÉREZ LuÑo que“um dos problemas mais importantes, senão o principal, da teoria jurídico-política reside na conciliação entre os direitos dos particulares e a soberania do Estado" 75 . Dessa feita, a doutrina dos direitos fundamentais ocupa posição de extrema importância na composição do Estado de Direito, tendo em vista que ela é responsável por articular as exigências, aparentemente, antagônicas de liberdade individual, de um lado, e de imperatividade da lei criada pelo poder soberano, de outro. A

\footnotetext{
${ }^{71}$ Consoante EliAS DIAS, as características imprescindíveis de um autêntico Estado de Direito podem ser elencadas nas seguintes notas: “a) império da lei: a lei como expressão da vontade geral; b) separação de Poderes: Legislativo, Executivo e Judiciário; c) legalidade da Administração: regulação por lei e controle judicial; d) direitos e liberdades fundamentais: garantia jurídico-formal e realização material" (Estado de Derecho y Sociedad Democratica, Madrid, Cuadernos para el Dialogo, 1966, p. 18).

${ }^{72}$ Idem, p. 28.

${ }^{73}$ Cf. Elias Diaz, Estado de Derecho, Ob. cit., p. 25.

${ }^{74}$ R. CARré De Malberg, Teoría General del Estado, $2^{a}$ ed., México, Facultad de Derecho/UNAM e Fondo de Cultura Económica, 2001, p. 450.

${ }^{75}$ Derechos Humanos, Estado de Derecho y Constitución, $10^{\mathrm{a}}$ ed., Madrid, Tecnos, 2010, p. 218.
} 
compatibilização de ambos os pontos demanda que se compreenda a lei como produto da vontade popular geral, direcionada a garantir os direitos fundamentais, o que, consequentemente, significa abandonar qualquer inclinação a usá-la como ferramenta do arbítrio estatal $^{76}$.

Essas reflexões ancoram a ilação de que o reconhecimento generalizado dos direitos fundamentais transformou-os em inequívocos limites à soberania do Estado ${ }^{77}$. A indissolúvel ligação entre esses direitos e soberania fica muito clara no contexto do Estado Constitucional de Direito, principalmente porque o constitucionalismo se encarregou de, ao longo da história, estatuir em textos escritos uma variedade daqueles direitos segundo a influência de condicionantes históricos, políticos, sociais e econômicos permitia. Os direitos fundamentais transmutam-se em valores perenes compartilhados pela sociedade, na qual o poder constituinte manifesta sua atividade, de forma a tornar toda essa carga axiológica um dos principais conteúdos incrustados nas decisões do poder constituinte responsáveis por criar os textos constitucionais que organizam os órgãos estatais e tomam os aludidos direitos como nortes à atuação do Estado ${ }^{78}$.

\subsubsection{Direito Internacional e Limitação da Soberania Externa}

No que respeita ao espaço internacional, impende situar que os Estados não mais conduzem suas ações externas buscando a defesa contra inimigos externos. Em definitivo, o contexto mundial globalizado fez desaparecer o modelo de sociedade de nações difundido à época de Vestfália, lastreado na presença de um reduzido número de sujeitos internacionais, com raro compartilhamento de valores comuns e no qual havia autorização para o uso de violência bélica na tutela de direitos e interesses próprios ${ }^{79}$. Existe, pois, um evidente descolamento de propósito em insistir na conceituação da soberania exterior como um predicado que orienta os Estados a se comportarem de modo atomizado, totalmente livre e, mesmo, com a faculdade de jamais se vincular a mandamentos internacionais, caso assim deseje.

\footnotetext{
${ }^{76}$ Idem, ibidem.

${ }^{77}$ Cf. Manoel Gonçalves Ferreira Filho, Tendências do Direito Constitucional Contemporâneo, in Lições de Direito Constitucional em Homenagem ao Jurista Celso Bastos, André Ramos Tavares, Gilmar Ferreira Mendes e Ives Gandra da Silva Martins (coord.), São Paulo, Saraiva, 2005, p. 938.

${ }^{78}$ Cf. Alejandro SaIz ARnaiz, La Apertura Constitucional al Derecho Internacional y Europeu de los Derechos Humanos. El Artículo 10.2 de la Constitución Española, Madrid, Consejo General del Poder Judicial, 1999, p. 35.

${ }^{79}$ Cf. Antonio CASSESE, L'Apertura degli, Ob. cit., pp. 7-8.
} 
A soberania exterior do Estado, esquadrinhada para justificar a defesa contra inimigos externos, requer uma reconstrução capaz de adaptar esse conceito às necessidades atuais. $\mathrm{O}$ aumento exponencial das interdependências que adstringem as nações produziu uma séria crise de legitimação desse sistema de soberanias formalmente iguais, mas que, na prática, acaba dando azo a drásticas situações de desigualdade e inaceitáveis relações assimétricas entre países ricos e pobres. O Direito Internacional produzido a par da tradicional ideia de soberania faz da sociedade internacional, segundo LUIGI FERRAJOLI, "um sistema que não parece ser tolerável, a longo prazo, pelos próprios ordenamentos políticos dos países avançados" ${ }^{80}$, já que a ordem externa não consegue refletir a identidade e a legitimação democráticas que, internamente, foram cimentadas pelo constitucionalismo.

Considerar a existência de um Direito Internacional geral imperativo (jus cogens), oponível a todos os Estados, autonomamente em relação à aceitação ou participação dos mesmos no processo formador dessas normas, é um fato que ganhou curso nos últimos tempos $^{81}$. A propósito, explicita J. J. GOMES CANOTILHO que "as relações internacionais devem ser cada vez mais relações reguladas em termos de direito e de justiça, convertendo-se o Direito Internacional numa indubitável ordem imperativa, à qual não falta um núcleo material duro - o jus cogens internacional - vertebrador quer da 'política e relações internacionais' quer da própria construção constitucional interna" ${ }^{82}$. Ao abandonar-se a lógica de que o Direito das Gentes não era senão um conjunto de normas de autocontenção, que os Estados impunham a si mesmos, houve o reconhecimento de que há limites objetivos à vontade estatal, o que importou rever a acepção comumente empregada acerca do conceito de soberania.

A extensão da subjetividade internacional do Estado soberano restou profundamente alterada pelo advento de organizações internacionais supranacionais e intergovernamentais, a exemplo da ONU, FMI, União Europeia e Mercosul. Destacam-se, nos dias correntes, os papéis estratégicos que essas instituições ocupam na tomada de

\footnotetext{
${ }^{80}$ A Soberania no, Ob. cit., p. 48.

${ }^{81}$ Cf. Salem Hikmat Nasser, Jus Cogens: Ainda Esse Desconhecido, in Revista Direito FGV, vol. 1, $\mathrm{n}^{\circ} 2$, jun./dez. 2005, p. 162. Confirma essa impressão FÁBIO KONDER COMPARATO, ao afirmar que, "no plano internacional, ninguém mais contesta o princípio da supremacia absoluta de Direito Internacional geral (jus cogens). A Convenção de Viena sobre o Direito dos Tratados de 1969, em seu art. 53, declara nulo o tratado cujas disposições estejam em conflito com uma norma imperativa de Direito Internacional geral, definida como 'uma norma aceita e reconhecida pela comunidade internacional dos Estados em seu conjunto, como norma da qual nenhuma derrogação é permitida e que só pode ser modificada por nova norma de Direito Internacional geral da mesma natureza" (A Afirmação Histórica dos Direitos Humanos, 8 a ed., São Paulo, Saraiva, 2013, p. 75).

${ }^{82}$ Direito Constitucional e, Ob. cit., p. 1370.
} 
decisões sobre matérias que, no passado, dependiam exclusivamente da vontade estatal defesa militar, controle da economia, política monetária, proteção dos direitos humanos, dentre outros ${ }^{83}$. Considerando-se que "a prática das organizações internacionais não tem permitido que os Estados determinem por si mesmos os assuntos pertencentes ao seu domínio exclusivo" ${ }^{84}$, passa a ser tarefa de extrema dificuldade definir, por meio do exercício da soberania estatal, os domínios em que as autoridades nacionais podem atuar livres de interferências exógenas.

A soberania não perfaz, sob nenhum prisma, um conceito absoluto e imutável. Ao contrário, em virtude de ter sido formada sob a influência de causas históricas específicas, a definição de soberania, bem como dos valores que consagra, é marcada pela relatividade, uma vez que as construções teóricas humanas, por mais bem elaboradas que sejam, não conseguem refletir com perfeição a realidade permanente ${ }^{85}$. De fato, a roupagem ilimitada da soberania que informava o Estado absolutista passou a ser cada vez mais inadequada na proporção em que as forças da globalização e da interdependência adquiriram robustez e tornaram as fronteiras territoriais menos significativas, diminuindo, por consequência, o controle governamental sobre assuntos que figuravam como sendo de trato exclusivo da ordem doméstica $^{86}$.

\subsection{Abertura dos Estados Nacionais ao Direito Internacional e Transformações do Direito Constitucional}

A tendência atual do Direito Constitucional para regular de forma mais ampla e precisa a relação entre Estado e Direito Internacional constitui o ponto de partida do movimento de internacionalização das Constituições. Na verdade, o Direito Internacional somente consegue desenvolver sua influência sobre as normas constitucionais porque estas têm encartado disposições normativas voltadas ao reconhecimento da importância dos mandamentos advindos das relações exteriores. Nessa direção, HÉLÈNE TOURARD sublinha

\footnotetext{
${ }^{83}$ Cf. Luigi Ferrajoli, A Soberania no, Ob. cit., pp. 47-49.

${ }^{84}$ Antônio Augusto CAnÇADo TRIndade, Direito das Organizações Internacionais, 4 a ed., Belo Horizonte, Del Rey, 2009, p. 135.

${ }^{85}$ Cf. Eduardo Felipe PÉrez Matias, A Humanidade e suas Fronteiras: Do Estado Soberano à Sociedade Global, São Paulo, Paz e Terra, 2005, pp. 32-33. Idêntico entendimento é compartilhado por A. MACHADO PAUPERIO, para quem "a soberania do Estado não pode ser estática: tem de ser dinâmica, no sentido de se tornar capaz de se adaptar à variedade de circunstâncias que se abrem, constantemente, na vida dos povos" (O Conceito Polêmico de Soberania, $2^{\mathrm{a}}$ ed., Rio de Janeiro, Forense, 1958, p. 205).

${ }^{86}$ Cf. Jack Goldsmith e Daryl Levinson, Law for States: International Law, Constitutional Law, Public Law, in Harvad Law Review, vol. 122, nº 7, mai. 2009, p. 1842.
} 
que a internacionalização não é um novo estágio da relação entre Direito Interno e Direito Internacional; representa um processo de duas vias, que, por um lado, permite definir o tratamento que os Estados darão ao Direito Internacional; e, por outro, resulta na crescente assimilação de padrões internacionais no seio das Constituições ${ }^{87}$.

A abertura dos Estados ao exterior marca a superação de uma fase em que Estados nacionais se fechavam sobre si mesmos, tendo em vista que prevalecia a concepção de soberania sem limites, tida como um elemento teórico que informava o arcabouço estatal ${ }^{88}$. A impossibilidade de disciplinar com precisão fenômenos que ultrapassam as respectivas fronteiras, aliada à convicção de que a observância aos direitos humanos não pode depender diretamente de oscilações provocadas pelo exercício da soberania estatal, preparou o terreno para que as Constituições franqueassem às normas decorrentes de tratados ou emanadas de organizações internacionais a regulação de inúmeras matérias ${ }^{89}$. O compartilhamento de prescrições normativas, embora altere as tradicionais propriedades do Direito Público, resulta benéfico tanto para o Direito Internacional, que passa a ter suas normas aplicadas com inédita intensidade pelas autoridades nacionais, quanto para o Direito Constitucional, que se vale de salutares influências externas para o aperfeiçoamento do ordenamento interno.

O panorama que se descortina obriga o constitucionalismo a não ignorar o avanço da influência das normas internacionais no esboço de um pretenso ambiente de governança global. Por conseguinte, apresenta-se como razoável incluir nas reflexões referentes ao tema governabilidade outras variantes que ultrapassam as abordagens usuais relacionadas ao alcance das Constituições e do processo político-decisório nacionais. Somam-se a este dado os efeitos da globalização, a qual impõe sérios desafios aos poderes estatais, notadamente no tocante à perda do domínio sobre as forças que influem na economia nacional e à deterioração da capacidade governamental de formular e implementar políticas públicas que assegurem a eficácia dos direitos fundamentais ${ }^{90}$.

\footnotetext{
${ }^{87}$ Cf. L'Internationalisation des, Ob. cit., pp. 11-12.

${ }^{88}$ IgNACIO GutiÉRrez GutiÉRrez, De la Constitución del Estado al Derecho Constitucional para la Comunidad Internacional, in La Constitucionalización de la Comunidad Internacional, Anne Peters, Mariano J. Aznar e Ignacio Gutiérrez (ed.), Ob. cit., p. 41.

${ }^{89}$ Cf. Elival Da Silva Ramos, Os Tratados sobre Direitos Humanos no Direito Constitucional Brasileiro Pós-Emenda Constitucional 45/04, in O STF e o Direito Internacional dos Direitos Humanos, Alberto do Amaral Júnior e Liliana Lyra Jubilut (org.), São Paulo, Quartier Latin, 2009, pp. 146-147.

${ }^{90}$ Cf. Daniel Sarmento, Direitos Sociais e Globalização: Limites Éticos-Jurídicos ao Realinhamento Constitucional, in Revista de Direito Administrativo, vol. 223, jan./mar. 2001, pp. 153-154.
} 


\subsubsection{Novas Feições Constitucionais Decorrentes da Multiplicação de Fontes Normativas}

A erosão do dogma da soberania ilimitada vem, indissociavelmente, acompanhada de profundas mudanças para a organização dos Estados e para teoria da Constituição. Uma delas - a mais significativa para o universo do Direito - é que deixa de existir o monopólio estatal na produção de normas jurídicas, em função do surgimento de centros de poder alternativos e concorrentes com o Estado operantes em dimensões não circunscritas ao território estatal $^{91}$. O possível colapso da capacidade reguladora da lei, o retorno ao papel criativo da jurisdição, a perda da unidade e coerência entre as fontes normativas e, ainda, a convivência e a superposição de diversos ordenamentos concorrentes, são diferentes frentes que evidenciam a importância de se repensar as funções ocupadas pelos Estados e pelas Constituição nacionais no contexto contemporâneo ${ }^{92}$.

As mudanças em questão convergem para a necessidade de "não de entender a Constituição como um edifício concreto, como algo acabado e concluído, mas sim de conceber o Direito Constitucional como um conjunto de materiais de construção com os

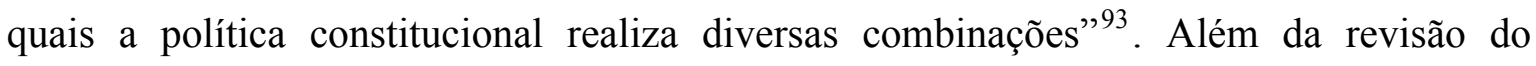
conceito de soberania, isso implica abraçar o entendimento de que valores e princípios plasmados nos textos constitucionais devem coexistir com atos normativos pertencentes a segmentos diversos. Consoante preconiza Gustavo Zagrebelsky, a unidade do ordenamento nacional e sua integração com outros sistemas normativos dependem de práticas condizentes com o respeito da base pluralista que dimana do meio social e da relativização dos vetores constitucionais, de modo a possibilitar o convívio destes com as demais normas nem sempre elaboradas pelo legislador pátrio ${ }^{94}$.

Caso o constitucionalista permaneça preso às construções seculares, sem, todavia, tomar referência das mudanças ocorridas na história recente quanto à função do Direito

\footnotetext{
${ }^{91}$ Cf. Gullherme Peña de Moraes, Readequação Constitucional do Estado Moderno: Transformações do Conceito de Estado no Direito Constitucional do Limiar do Século XXI, Rio de Janeiro, Lumen Juris, 2006, p. 61.

92 Cf. Luigi Ferrajoli, Pasado y Futuro del Estado de Derecho, in Revista Internacional de Filosofía Política, $\mathrm{n}^{\mathrm{o}}$ 17, 2001,p. 35. Averbe-se que esse fenômeno jurídico é sintetizado de forma muito clara por MiREILlE DELMAS-MARTY no trecho apresentado a seguir: "Com a proliferação, a diversificação e a dispersão de fontes, o monopólio do Estado é, com efeito, questionado em suas principais formas: o Estadocentro é atingido pela descentralização das fontes; o Estado-esfera pública por sua privatização; por fim e sobretudo, o Estado-nação, expressão da soberania de uma comunidade feita de interesses imbricados e de aspirações idênticas, é ameaçado pela internacionalização do Direito" (Le Pluralisme Ordonné: Les Forces Imaginantes du Droit (II), Paris, Éditions du Seuil, 2006, p. 225).

${ }^{93}$ Alfonso de Julios-CAMPuZANo, Constitucionalismo em Tempos, Ob. cit., pp. 45-46.

${ }^{94}$ El Derecho Dúctil. Lei, Derechos, Justicia, Madrid, Editorial Trotta, 2011, p. 14.
} 
Constitucional em relação aos demais campos que integram a ordem jurídica, certamente não compreenderá o quão complexa se tornou a tarefa de ordenar e limitar os poderes do Estado por meio de um texto escrito. Antes, as Constituições, fundadas no conceito de soberania ilimitada, firmaram-se como incontrastáveis, na medida em que corporificavam um conjunto de mandamentos absolutos ${ }^{95}$. Agora, em razão de radicais transformações na estrutura da sociedade internacional e na organização interna dos Estados, o Direito Constitucional corre o risco de se tornar um "direito de restos", tal qual adverte J. J. GoMES CANOTILHO $^{96}$.

As atuais sociedades pluralistas, complexas e com múltiplos centros de criação do Direito, impõem que a unidade, a coerência e a hierarquia do ordenamento não podem ser concebidas como pressuposto de partida, mas sim como uma meta a se alcançar pela ciência jurídica. No Estado Constitucional do presente, existe uma heterogeneidade de fatores e instâncias sociais que influem na produção normativa, considerando que a atividade legiferante é pulverizada em diversos centros dos quais emanam os comandos normativos. Esse quadro aponta para um sistema jurídico cujos postulados básicos reclamam do intérprete da Constituição uma atitude aberta e que seja capaz de extrair novas possibilidades e novo planejamento jurídicos, o que faz da hermenêutica constitucional não um processo orientado por categorias fechadas e estáticas, mas algo dinâmico e que permita compatibilizar o constitucionalismo aos novos desafios que vão surgindo $^{97}$.

Em definitivo, a teoria liberal de Constituição, idealizada na Europa a partir das revoluções liberais do século XVIII e que, ao sepultar o absolutismo, foi crucial na arquitetura dos componentes do Estado contemporâneo, já não basta para atender às necessidades colocadas pelo contexto caracterizado pela globalização e pela crise dos

\footnotetext{
${ }^{95}$ Cf. J. H. Meirelles TeIXeIRA, Curso de Direito Constitucional, Rio de Janeiro, Forense Universitária, 1991, pp. 14-15; e Santi Romano, Princípios de Direito, Ob. cit., p. 10.

96 Cf. "Brancosos" e Interconstitucionalidade: Itinerários dos Discursos sobre a Historicidade Constitucional, $2^{\mathrm{a}}$ ed., Coimbra, 2008, pp. 184-185. O autor consigna que o Direito Constitucional, caso continue a ser entendimento nos parâmetros tradicionais, estará no limite da sua integridade, haja vista que, nos dias correntes, já se apresenta como um "direito do resto do Estado, depois da transferência de competências e atribuições deste, a favor de organizações supranacionais (União Europeia, Mercosul). Direito do resto do 'nacionalismo jurídico', depois das consistentes e persistentes internacionalização e globalização terem reduzido o Estado a um simples 'herói do local'. 'Direito dos restos da auto-regulação', depois de os esquemas regulatórios haverem mostrado a eficácia superior da auto-regulação privada e corporativa relativamente à programática estatal. 'Direito dos restos das regionalizações', depois de as várias manifestações dos 'estados complexos' (federais, regionais) exigirem a inclusão de outros entes, quase soberanos, nos espaços unitarizantes da soberania estatal” (Idem, p. 185).

${ }^{97}$ Cf. Antonio EnriQue Pérez Luño, Perspectivas e Tendências Atuais do Estado Constitucional, Porto Alegre, Livraria do Advogado, 2012, p. 55.
} 
tradicionais paradigmas. A Constituição não pode continuar ser vista somente como um documento escrito que "imprime no Estado a reta organização, a qual deverá impedir o abuso, isto é, a violação pelos órgãos estatais dos direitos do homem"98, porque está inserida em meio a um processo no qual perde a sua centralidade na regulação da vida social. É necessário agregar novo significado à Constituição e, por conseguinte, ao Direito Constitucional; "torná-lo um direito reflexivo mais apto a fornecer sugestões para o político do que a traçar autoritativamente regras normativas da política"99.

LOUIS FAVOREU endossa essa constatação, ao advertir que relevantes e aceleradas transformações impregnaram novas feições ao Direito Constitucional, de forma que seu conteúdo "não pode mais ser ensinado neste fim do século XX, como ele era ensinado, não somente no século XIX e no início do século XX, mas também como há uma vintena de anos" ${ }^{\prime 100}$. Obviamente, as forças que impuseram essas alterações não desapareceram nos dias atuais e tendem a continuar a operar seus efeitos, haja vista que toda essa mutação se inscreveu em um contexto internacional que possibilitou definir a verdadeira dimensão das Constituições. Conclui-se, assim, que o movimento constitucional - iniciado em um momento em que o vetor predominante era conter o poder dos governantes mediante a “elaboração de um texto constitucional, que estabelecesse, então, normas jurídicas superiores no concernente à organização, divisão, controle e limitação do poder político" "101 - precisa ser repensado de forma a permitir a construção de sistemas constitucionais que ultrapassem esse propósito.

Qualquer releitura acerca das funções e tarefas do Direito Constitucional com o objetivo de ajustá-lo às exigências colocadas pela contemporaneidade passa,

\footnotetext{
${ }^{98}$ Manoel Gonçalves Ferreira Filho, Estado de Direito e Constituição, $4^{\mathrm{a}}$ ed., Saraiva, São Paulo, 2009, p. 19.

${ }^{99}$ J. J. Gomes CANOTILHO, “Brancosos" e Interconstitucionalidade, Ob. cit., p. 186.

${ }^{100}$ A Evolução e a Mutação do Direito Constitucional Francês, in Direito Constitucional: Estudos em Homenagem a Manoel Gonçalves Ferreira Filho, Sérgio Resende de Barros e Fernando Aurelio Zilveti (org.), São Paulo, Dialética, 1999, p. 215. Há uma multiplicidade de causas que condicionam o referido processo de alteração do perfil das Constituições, entretanto, o autor destacou alguns desses fatores, a saber: (i) a dessacralização da lei: a lei não está mais no centro do sistema normativo, em virtude de o nazismo ter provado que o legislador nacional é falível e pode trazer danos irreparáveis a todos; (ii) a expansão das Constituições e do constitucionalismo: devido ao fenômeno da descolonização que fez elevar o número de Estados no mundo, houve a multiplicação dos textos constitucionais e esse movimento provocou a modernização de inúmeros institutos constitucionais; (iii) a difusão da ideologia dos direitos do homem por meio da edição de documentos internacionais: a Declaração Universal dos Direitos do Homem de 1948 e a Convenção Europeia dos Direitos do Homem de 1950, entre outros atos, colocaram a proteção do indivíduo em primeiro plano e, com isso, modificaram profundamente as perspectivas de organização do poder; (iv) o aparecimento da justiça constitucional como ferramenta fundamental de organização do Estado: os sistemas constitucionais passaram cada vez mais a considerar a justiça constitucional como fator decisivo no controle das atividades estatais (Cf. Idem, ibidem).

${ }^{101}$ Celso Ribeiro Bastos, Curso de Direito Constitucional, 22a ed., São Paulo, Malheiros, 2010, p. 152.
} 
indubitavelmente, pela análise das influências que o processo de internacionalização dos direitos ocasionou no seio dos ordenamentos nacionais. Em uma visão bastante interessante, KEVIN FERDINAND NDJIMBA consigna que mencionado processo trouxe uma espécie de revalorização da Constituição, pois expôs a importância do constitucionalismo para que as relações exteriores possam ocorrer dentro de parâmetros que viabilizem a criação de normas internacionais adequadas. A internacionalização das Constituições encarna, de tal sorte, a tendência de ajustar o Direito Constitucional, assegurando que as normas constitucionais mantenham a qualidade de mandamentos fundamentais, mesmo quando concorrem com vários outros instrumentos normativos cuja criação nem sempre coincide com a atuação dos órgãos estatais ${ }^{102}$.

É esperado, hoje, que a Constituição seja mais do que um documento que certifique o ocaso do despotismo em decorrência da cristalização de governos jurídica e politicamente limitados e empenhados no respeito aos direitos fundamentais reconhecidos aos indivíduos abrigados no território do Estado. Como, em escala florescente, os regimes absolutistas perdem forças e apoiadores e deixam de ser admitidos como aceitáveis, há notáveis indicativos de que os valores da racionalização do poder e da prevalência dos direitos da pessoa humana passam a estar, pelo menos no Ocidente, permanentemente incluídos no substrato do sentimento constitucional ${ }^{103}$. A expansão do Direito Constitucional para mais longe das aspirações liberais do século XVIII é inevitável, e o sentimento constitucional vivido neste momento dá conta de que "o Estado se desenvolve também em uma comunidade internacional cada vez mais determinada pelo prefixo 'inter', isto é, interdependente, inter-relacionada, interconectada, com interações"104.

Chega-se, portanto, ao momento de explorar a funcionalidade das Constituições, haja vista que sua tradicional concepção carece de conteúdo normativo suficiente para regular e ordenar todos os fenômenos políticos e sociais relevantes que permeiam o conjunto estatal na atualidade. A realidade do mundo mostra que a capacidade de o texto constitucional assegurar, sozinho, a unidade de comunidades políticas nacionais altamente

\footnotetext{
${ }^{102}$ Cf. L'Internationalisation des Constitutions et la Revalorisation du Droit Constitutionnel des Etats, in Politeia, $\mathrm{n}^{\circ}$ 22, dez. 2012, pp. 413-416.

${ }^{103} \mathrm{O}$ conceito de sentimento constitucional é sintetizado por PABLO LUCAS VERDÚ no seguinte trecho: "A princípio, o sentimento constitucional consiste na adesão interna às normas e instituições fundamentais de um pais, experimentada com intensidade mais ou menos consciente porque estima-se (sem que seja necessário um conhecimento exato de suas peculiaridades e funcionamento) que são boas e convenientes para a integração, manutenção e desenvolvimento de uma justa convivência" (O Sentimento Constitucional: Aproximação ao Estudo do Sentir Constitucional como Modo de Integração Política, Rio de Janeiro, Forense, 2004, p. 75).

${ }^{104}$ GonZalo Aguilar Cavallo, La Internacionalización del, Ob. cit., p. 248.
} 
complexas e interdependentes não consegue mais ser defendida nem mesmo no plano teórico $^{105}$. Evidencia-se, portanto, que a Constituição precisa ser compreendida como mais um dos elementos materialmente constitucionais que se projetam sobre a organização do Estado e da sociedade, admitindo que ela não tem condições de assumir o papel de único centro do qual germina a multiplicidade dos comandos normativos vinculantes, pois o poder nacional há muito não mais decide isoladamente de que forma ocorrerá a ordenação dos variados setores que interferem na governabilidade ${ }^{106}$.

Ao que tudo indica, a ideia de Constituição total, tal qual ventilada por PINTO FERrEIRA, deixou de ser possível, uma vez que a Constituição não é mais o único instrumento no qual se "processa a integração dialética dos vários conteúdos da vida coletiva na unidade de uma ordenação fundamental e suprema"107. Diferentemente de outrora, quando o código constitucional apresentava, "na sua complexidade intrínseca, aspectos econômicos, sociológicos, jurídicos e filosóficos, a fim de abranger o seu conceito em uma perspectiva unitária" ${ }^{108}$, agora é aclarada - sobretudo quando se considera a produção normativa de uma gama de órgãos internacionais - a impossibilidade de toda atividade legiferante ser comandada diretamente pelas prescrições constitucionais ${ }^{109}$. Essa conclusão não se mostra, em absoluto, contrária à inabalável principiologia da supremacia da Lei Maior, haja vista que, diante da proliferação de centros de produção normativa, a

\footnotetext{
${ }^{105}$ Esse complexo contexto no qual o constitucionalismo deve se alocar é objeto de análise porJOSÉ CARLOS FRANCISCO, que demonstra sensibilidade ao apontar uma visão integrada por múltiplas variantes que forçam a uma redefiniçãodos antigos dogmas e construções teóricas que balizaram a atuação do poder estatal no passado.Assevera o estudioso que, "em face de tantas dúvidas e crises, há, pelo menos, algumas certezas resultantes da internacionalização, tais como a globalização da economia (expressa na multinacionalização das empresas, na flexibilização do processo produtivo e na eliminação relativa de barreiras alfandegárias, o que se reflete em diversos acordos firmados no contexto da Organização Mundial do Comércio), a desconcentração do aparelho estatal (com a desformalização, deslegalização da área social e a agencialização), a internacionalização do Estado (com o fortalecimento de organismos internacionais), a necessidade de políticas públicas internacionais, e a expansão do Direito não estatal (cuja natureza mercatória visa harmonizar as relações em face do pluralismo de ordenamentos nacionais)" (Estado Democrático de Direito, Politicas Públicas e Novos Modelos de Governanças Internacionais, in Direito Constitucional, Estado de Direito e Democracia: Homenagem ao Prof. Manoel Gonçalves Ferreira Filho, Carlos Bastide Horbach, Fernando Dias Menezes de Almeida, José Levi Mello do Amaral Júnior e Roger Stiefelmann Leal (coord.), São Paulo, Quartier Latin, 2011, pp. 429-430).

${ }^{106}$ Cf. Miguel AzPitARTe SÁNCHEZ, La Función de,Ob. cit., p. 189.

${ }^{107}$ Princípios Gerais do Direito Constitucional Moderno, tomo I, $2^{\mathrm{a}}$ ed., Rio de Janeiro, José Konfino, 1951, p. 64.

${ }^{108}$ J. H. MeIRELles TeiXeIRA, Curso de Direito, Ob. cit., p. 77.

${ }^{109}$ JORGE MiRANDA, em sintonia, averba que "todo Direito Internacional - geral ou comum, convencional e derivado de organizações internacionais e entidades afins - vigora ou tende a vigorar (com técnicas diversas) diretamente na ordem interna; e vigora mesmo que as Constituições não o digam. $\mathrm{O}$ alargamento das matérias objeto de normas internacionais e a emanação de muitas que só fazem sentido enquanto aplicáveis na ordem interna, o papel crescente das organizações internacionais e a irrupção do indivíduo como sujeito ativo ou passivo implicam uma integração sistemática cada vez mais estreita entre Direito estadual e Direito das Gentes" (Direito Constitucional e Direito, Ob. cit., p. 90).
} 
Constituição assume o papel de "centro sobre o qual tudo deve convergir, e não como centro do qual tudo deriva por irradiação através da soberania do Estado em que se apoia" 110 .

\subsubsection{O Imprescindível Situar Internacional do Estado Constitucional}

A dimensão constitucional do Estado não pode fugir do desafio de equacionar, no mínimo, três variantes delicadas, quais sejam: a reconfiguração do conceito de soberania estatal, o aumento de fontes criadoras do Direito e a manutenção do papel garantidor das Constituições nacionais. Não é sem motivo, portanto, que Luigi FerRAJOLI, depois de considerar o cenário colocado, conclui que "a única alternativa ao declínio do Estado de Direito é a promoção de uma integração jurídica e institucional, complementando a integração econômica e política, hoje, já irreversível" ${ }^{111}$. Em outras palavras, o desenvolvimento da normativa internacional torna compreensível a impossibilidade de abandonar-se o tratamento constitucional de matérias ligadas às relações exteriores, e, ademais, dita a tendência do aumento progressivo da inclusão no Direito Constitucional de uma gama de debates e mecanismos antes totalmente estranhos ao estudo desta disciplina jurídica.

O entroncamento do Direito Constitucional e do Direito das Gentes desperta, em geral, duas atitudes entre os juristas. Conforme explica DANIEL SARMENTO, a primeira é adotada por aqueles que, talvez por medo do desconhecido, negam as transformações, pugnando pela conservação dos institutos jurídicos tradicionais, congelados no tempo, como se eles vigorassem em um mundo etéreo e pudessem resistir olimpicamente às mutações que sacodem as sociedades; a segunda, reflete o vício oposto, mediante a pretensão arrogante de erigir novas categorias conceituais do nada, desconstruindo todo o saber jurídico sedimentado ao longo de séculos, como se ele fosse de nenhuma valia ${ }^{112}$. Acredita-se, contudo, que, entre esses extremos, "é possível buscar o ponto de equilíbrio, no qual, por um lado, se reconheça a necessidade da reformulação de ideias e conceitos da ortodoxia constitucional, para torná-los mais compatíveis com a realidade contemporânea, mas, por outro, não se abandone, em nome de modismos estéreis e fúteis, os valores humanitários que inspiraram o advento e a evolução do constitucionalismo"113.

\footnotetext{
${ }^{110}$ Guilherme PeÑa de Moraes, Readequação Constitucional do, Ob. cit., pp. 62-63.

${ }^{111}$ Pasado y Futuro, Ob. cit., p. 38. Ver ainda MARCos Augusto MALISKA, Estado e Século XXI: A Integração Supranacional sob a Ótica do Direito Constitucional, Rio de Janeiro, Renovar, 2006, pp. 71-74.

112 Cf. Constituição e Globalização, Ob. cit., p. 20.

${ }^{113}$ Idem, ibidem.
} 
A aquisição de consciência nessa seara deriva, por certo, do movimento de adensamento de juridicidade dos comandos exteriores, o que transformou substancialmente a natureza dessas normas: deixaram de ser apenas um conjunto de mandamentos orquestrados a fim de assegurar a coexistência pacífica entre Estados para revelarem-se efetivo instrumento de cooperação entre as nações e, em certos casos, até referencial para a auto-organização dos Estados nacionais. Por isso, não é desprovido de fundamento que, "no campo do Direito Constitucional, podem ser antevistas tendências que apontam para a relativização da segmentada divisão entre o interno e o externo, em benefício de uma

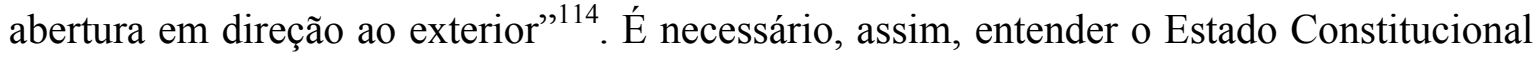
contemporâneo como internacionalmente situado e, por conseguinte, atrelado à normativa criada no seio das relações firmadas pelos sujeitos que conferem vida ao Direito Internacional .

Em igual rumo, J. J. Gomes CANOTILHo enfatiza que, em seu atual estágio, o Estado Democrático de Direito está associado às normas jurídicas interestatais, já que "os limites jurídicos impostos aos Estados advêm também, em medida crescente, de princípios e regras jurídicas internacionais. Estes princípios e regras estão, em grande número, recebidos ou incorporados no Direito Interno fazendo parte of the law of the land [...]. Nenhum Estado pode permanecer out, isto é, fora da comunidade internacional. Por isso, ele deve submeter-se às normas de Direito Internacional quer nas relações internacionais quer no próprio atuar interno. A doutrina mais recente acentua mesmo a amizade e a abertura ao Direito Internacional como uma das dimensões caracterizadoras do Estado de Direito" 115 .

Em razão da imprescindibilidade de analisar o enquadramento dos Estados nacionais no contexto da sociedade internacional de agora, adquire envergadura a proposição teórica exposta por PETER HÄBERLE responsável por trazer as linhas que conformam o chamado Estado Constitucional Cooperativo. Compreender a organização do Estado e a própria Constituição sob esse prisma pode ser o caminho a percorrer na tentativa de balancear as forças que sempre emperraram a harmonização entre os sistemas jurídicos interno e internacional. Com efeito, o vetor principal dessa teoria aponta para uma visível tentativa de superar a infrutífera discussão a respeito da hierarquização entre ambos os conjuntos normativos, conforme esclarece o trecho que segue: "o Estado

\footnotetext{
${ }^{114}$ Peter HäBerle, El Estado Constitucional, México, Universidad Nacional Autonóma de México, 2003, p. 73.

${ }^{115}$ Direito Constitucional e, Ob. cit., p. 232.
} 
Constitucional Cooperativo não conhece alternativas de uma 'primazia' do Direito Constitucional ou do Direito Internacional; ele considera tão seriamente o observado efeito recíproco entre as relações externas ou Direito Internacional, e a ordem constitucional interna (nacional), que partes do Direito Internacional e do Direito Constitucional interno crescem juntas num todo" ${ }^{\prime 16}$.

A consequência prática da adoção dos parâmetros apresentados por HÄBERLE aponta para a edificação de uma visão conjuntamente pensada pelos Estados Constitucionais e as relações internacionais. Converge-se, de tal sorte, para um horizonte em que "a ideologia do monopólio estatal das fontes jurídicas torna-se estranha ao Estado constitucional quando ele muda para o Estado Constitucional Cooperativo. Ele não mais exige monopólio na legislação e interpretação: ele se abre - de forma escalonada - a procedimentos internacionais ou de Direito Internacional de legislação, e a processos de interpretação" ${ }^{117}$. É precisamente essa abertura escalonada, a fim de permitir que cada Estado molde o processo de aproximação com o mundo externo com segurança e responsabilidade, que certifica o papel de importância fundamental que as Constituições assumem nesse complicado processo conciliatório.

A experiência cotidiana da crescente interdependência em uma sociedade mundial tomada por um grau acentuado de complexidade modifica a percepção que os Estados nacionais têm de si mesmos. Os Estados, cuja soberania, antes, fazia deles sujeitos livres para tomar suas decisões com plena independência, "vão aprendendo novos papéis: o de participantes em redes transnacionais que se adaptam às obrigações funcionais da cooperação, mas também o de membros de organizações internacionais que se vinculam mediante compromissos e expectativas normativas" ${ }^{118}$. Nessa toada, as autoridades nacionais e os cidadãos são induzidos a aprender que não mais vivem insulados dentro de limites territoriais das fronteiras geográficas, pois ocupam, agora, a posição de membros de comunidades políticas cujos contornos extrapolam as áreas fronteiriças nacionais.

Tornar as Constituições permeáveis ao mundo exterior é, portanto, um dado inquestionável, e esse impulso determina que a limitação dos poderes do Estado, com base no Direito Internacional, assuma o papel de diretriz consagrada constitucionalmente ${ }^{119}$. Como a globalização e os efeitos dela decorrentes estão a forçar mudanças no perfil do

\footnotetext{
${ }^{116}$ Estado Constitucional Cooperativo, Ob. cit., p. 12.

${ }^{117}$ Idem, p. 61.

${ }^{118}$ JÜRGEN HABERMAS, El Derecho Internacional, Ob. cit., pp. 37-38.

${ }^{119}$ Cf. Alejandro Saiz Arnaiz, La Apertura Constitucional, Ob. cit., p. 53.
} 
Estado - a alteração da sua feição clássica, soberana e fechada, para fornecer-lhe uma roupagem atualizada, internacionalmente adstrito às prescrições normativas externas -, caberá ao Direito Constitucional promover a aderência entre os valores que dirigem, desde outrora, o constitucionalismo moderno com nova e inconclusa axiologia que se avista ${ }^{120}$. Nada mais natural quando se lembra que o regime constitucional está em permanente evolução, o que significa que Constituição "sofre constante evolução, decorrente da ampliação e da variação inevitáveis das incumbências do Estado moderno" ${ }^{\text {"121 }}$.

\subsection{O Diálogo entre o Nacional e o Externo como Mecanismo de Fortalecimento dos Sistemas Jurídicos Interno e Internacional}

Ante o relatado até esse ponto, são inegáveis a profundidade e a precisão da conclusão aportada por KONRAD HESSE de que "a evolução do Estado desde sua concepção tradicional como soberano, nacional, relativamente hermético, para o atual, internacionalmente imbricado e supranacionalmente vinculado, corresponde à perda da primazia e do valor e importância que até muito tempo teve sua Constituição" ${ }^{\text {122 }}$. A constatação em apreço não significa que a Constituição deixará de ser instrumento essencial para o Estado, tampouco pode ser tomada como um provável prenúncio de que a relevância dos textos constitucionais desaparecerá em um cenário futuro. Ao contrário, representa motivo vigoroso para que o constitucionalismo se alinhe aos novos paradigmas decorrentes da globalização e do alargamento do escopo do Direito Internacional, a fim de que o Direito Constitucional permaneça como o braço do ordenamento que congrega a decisão política fundamental que cimenta todo o sistema jurídico interno.

Embora seja difícil acreditar que um arranjo político-jurídico venha a substituir o desenho que retrata a sociedade internacional como uma constelação de Estados nacionais, a reformulação de alguns dos traços característicos dos Estados é uma necessidade premente. O processo de entrelaçamento dessas ordens jurídicas decorre de um fenômeno jurídico muito mais complexo, cuja característica de maior relevo é uma espécie de

\footnotetext{
${ }^{120}$ A propósito, DIETER GRIMM esclarece que "uma Constituição terá um efeito de integração somente se incorporar um sistema de valores e aspirações fundamentais da sociedade, e se a sociedade perceber que sua Constituição reflete precisamente tais valores com os quais se identificam e que são a fonte de sua especificidade" (Integration by Constitution, in International Journal of Constitutional Law, vol. 3, 2005, p. 199).

${ }^{121}$ Afonso Arinos de Melo Franco, Direito Constitucional: Teoria da Constituição; As Constituições do Brasil, Rio de Janeiro, Forense, 1976, p. 111.

${ }^{122}$ Temas Fundamentais de, Ob. cit., p. 21.
} 
"retroalimentação, em que as mudanças da realidade geram novas formulações e modelos concretos que, por sua vez, geram novas mudanças" ${ }^{\prime 23}$. Depreende-se, assim, que a globalização, o fortalecimento do Direito das Gentes e a mitigação da soberania não tendem a fazer do Estado uma construção descartável, até porque, segundo VICENTE MAROTTA RANGEL, “a existência do Estado precede, aliás, no tempo à própria ordem internacional e continua a afirmar-se concretamente, embora com cerceamentos, no estágio atual de evolução do Direito e da sociedade"124.

A materialização da vertente internacionalista em uma série de Constituições nacionais, sobretudo naquelas mais recentes, não pode dispensar o papel dos Estados para que se efetivem os objetivos e as promessas que orientam o processo de convergência aludido. $\mathrm{O}$ fortalecimento dos comandos internacionais não se corporifica à margem ou sobre o universo estatal ${ }^{125}$, nem pode ser interpretado como um estágio que antecede o esgotamento da magnitude do texto constitucional. Reflete, em verdade, um novo momento do Direito Constitucional, no qual existe maturidade suficiente para aceitar que “a pluralidade dos princípios não pode ser concebida como um conjunto de contradições a serem eliminadas com decisões seletivas e simplificadoras"126.

Cumpre apreciar a tessitura encontrada com o norte nos modelos contemporâneos, o que permitirá ultrapassar a premissa de oposição do Direito Interno face o Direito Internacional, bem como a ideia de sociedade mundial disposta somente como um conglomerado de Estados soberanos dispostos a brigar pelos próprios interesses. Do contrário, haverá o risco de padecer do vício que MireILle Delmas-MARTY denomina de “incompletude das ideias", na medida em que a globalização reclama refundar e adaptar o conceito de Estado a novas condições que capacitem as estruturas de poder para adequar-se a horizontes já vislumbrados e outros que, invariavelmente, surgirão com o desenrolar do processo de aproximação dos povos e dos governos. A título de exemplo, cite-se a manifesta superposição de cidadanias (nacional, regional, mundial), resultando na participação simultânea do indivíduo em várias comunidades políticas, aspecto que

\footnotetext{
${ }^{123}$ Estêvão FERreIRA COUTO, A Relação entre o Interno e o Internacional: Concepções Cambiantes de Soberania, Doutrina e Jurisprudência dos Tribunais Superiores no Brasil, Rio de Janeiro, Renovar, 2003, p. 175.

${ }^{124}$ Os Conflitos entre, Ob. cit., p. 59.

${ }^{125}$ Cf. Antonio Remiro Brotons, La Accion Exterior del Estado, Madrid, Editorial Tecnos S.A., 1984, pp. 19-20.

126 Gustavo Zagrebelsky,Estado Constitucional, in Direito Constitucional, Estado de Direito e Democracia: Homenagem ao Prof. Manoel Gonçalves Ferreira Filho, Carlos Bastide Horbach, Fernando Dias Menezes de Almeida, José Levi Mello do Amaral Júnior e Roger Stiefelmann Leal (coord.), Ob. cit., p. 309.
} 
constitui prova esclarecedora de que as concepções tradicionais não permitem entender a completude do funcionamento dos diversos segmentos em que a cidadania toma forma nos dias correntes ${ }^{127}$.

Por tudo o que foi dito até aqui, ressoa a certeza de que a diferença entre o plano constitucional e exterior, que marcou de forma indelével as teorizações que se formaram ao longo do século XX sobre o tema, sucumbiu na entremistura que atualmente é provocada por um grupo plural de fontes normativas nacionais e internacionais, bem como pelos consensos produzidos por instituições ou organismos internacionais ${ }^{128}$. Razão que assiste, portanto, a Celso D. De Albuquerque Mello, quando este proclama que "o Direito Interno e o Direito Internacional estão unidos de tal modo que fica extremamente difícil distingui-los" ${ }^{129}$. Novas abordagens devem ser feitas, incentivando-se principalmente diálogos permanentes entre ambos os sistemas normativos, a fim de possibilitar a extração, tanto dos institutos internos quanto dos internacionais, de novas ferramentas adequadas para nortear as relações entre a vasta gama de sujeitos de direito, muitos deles dotados de personalidade jurídica no âmbito nacional, internacional e transnacional, de forma simultânea.

Como aconteceu com os progressos aferidos na tutela dos direitos humanos, o crescimento das ligações recíprocas entre Direito Constitucional e normativa internacional trará benefícios generalizados para o universo jurídico como um todo. Foi, de fato, essa aproximação sistêmica que favoreceu a construção de sistemas internacionais de fomento e de guarda dos direitos humanos após 1945, aparelhados, até mesmo, com Cortes especializadas aptas a condenar Estados recalcitrantes a reparar os danos causados; ao mesmo tempo em que, em caminho inverso, o Direito Constitucional ocidental desenvolveu nova feição, calcado nos princípios voltados à concretização do valor da dignidade humana. Os esforços em reformular o tratamento dispensado aos direitos da pessoa humana deu azo ao surgimento do quadro descrito por FLÁviA PIOVESAN como

\footnotetext{
${ }^{127}$ Cf. La Refondation des, Ob. cit., pp. 112-113.

${ }^{128}$ Cf. JÂNia MARIA Lopes SAldanha e SAdi Flores MAChado, O Papel da Jurisdição na Efetivação dos Direitos Humanos: O Cosmopolitismo para Além do Constitucional e do Internacional a Partir do Diálogo entre Têmis, Marco Pólo e o Barão Cosme de Rondó, in O Novo Constitucionalismo na Era Pós-Positivista: Homenagem a Paulo Bonavides, Lenice S. Moreira de Moura (org.), São Paulo, Saraiva, 2009, p. 160.

${ }^{129}$ A Revisão do Direito Internacional na Constituição de 1988, in Revista de Ciências Sociais, Rio de Janeiro, v. 1, n.1, 1995, p. 75.
} 
“internacionalização do Direito Constitucional somado ao processo de constitucionalização do Direito Internacional" ${ }^{\prime 130}$.

O aperfeiçoamento mútuo e contínuo das ordens jurídicas interna e internacional, operacionalizado pela conjugação dos mandamentos que as integram, indica ser a proposta adequada para orientar a composição de entendimentos no que tange à controvertida relação entre Direito Interno e Direito das Gentes. Essa impressão adquire substância sobretudo quando é pensada sob o influxo de que "não apenas se deseja que as conquistas se projetem no Direito Internacional para que estas alicercem, fortaleçam e protejam os direitos humanos nos diferentes Estados, mas, igualmente, deseja-se que as conquistas que os povos dos diferentes Estados realizem no espaço regional reflitam-se no cenário internacional, de tal modo que haja uma conjugação de valores, princípios e experiências jurídicas que se complementem e se aprofundem para a melhoria do ser humano em qualquer parte do planeta"131 . Fica claro, portanto, que desenvolver formas de proporcionar a aplicação integral de normas jurídicas, independentemente de a criação destas ser resultado da ação de órgãos nacionais ou exteriores, é o caminho a percorrer na missão de evoluir em assuntos que, há muito, opõem a doutrina e carecem de respostas convincentes.

\subsubsection{A Superação das Concepções Monista e Dualista Sobre a Relação Entre Direito Interno e Direito Internacional}

A convivência entre normas jurídicas nacionais e internacionais tem sido compreendida, em geral, sob o enfoque de uma disputa fundamentada na premissa de que a harmonia entre essas duas ordens será obtida pelo equacionamento da competição que, virtualmente, existiria entre elas. A maioria dos estudos produzidos acerca do assunto perfilha a tese de que a interação entre ambos os sistemas normativos, invariavelmente, resultará em desacordos que devem ser sanados por meio de teses que entendam a interface entre os referidos mandamentos mediante a definição de uma superioridade relativa ou da imprescindibilidade de transformar os comandos exteriores em normas internas, para que aqueles possam ser adotados pelos órgãos estatais. Essas concepções, polarizadas na famosa dicotomia monismo versus dualismo, embora tenham ocupado exaustivamente os acadêmicos que se lançaram na investigação desse tema, pouco contribuíram para a

\footnotetext{
${ }^{130}$ Hierarquia dos Tratados Internacionais de Proteção dos Direitos Humanos Jurisprudência do STF, in $O$ STF e o Direito Internacional dos Direitos Humanos, Alberto do Amaral Junior e Liliana Lyra Jubilut (org.), Ob. cit., p. 145

${ }^{131}$ CÁRMEN LÚCIA ANTUNEs RochA, O Constitucionalismo Contemporâneo e a Instrumentalização para a Eficácia dos Direitos Fundamentais, in Revista de Direito Público, nº 16, 1996, p. 49.
} 
resolução da problemática, muito em razão da constatação de que o relacionamento em referência tornou-se destacadamente mais simbiótico do que conflitivo ${ }^{132}$.

O inigualável entrosamento entre os sujeitos do Direito Internacional alcançado e a própria multiplicação daqueles que detêm subjetividade para atuar no âmbito exterior, em especial com o aparecimento de variadas organizações internacionais, propiciaram maior sintonia entre os Estados em direção às práticas coordenadas e cooperativas na consecução de seus interesses nacionais e transnacionais. Por consequência, ocorreu o incremento significativo na produção da normativa internacional, o que foi acompanhado da ampliação dos escopos tutelados por essa ordem jurídica, do afrouxamento de sua ligação com o consentimento estatal como único fundamento de validade e existência e, ainda, do reforço dos mecanismos de aplicação compulsória de suas prescrições. A necessidade de execução interna da maior parte dos comandos jurídicos criados externamente expôs a habilidade e as deficiências de cada sistema constitucional em lidar com esses novos paradigmas, servindo ainda para explicitar a inaptidão das teorias monista e dualista para o enfrentamento da matéria.

Antes de qualquer incursão em análises de cunho prospectivo, interessa apresentar os pontos de apoio dessas duas correntes de entendimento que dominaram as discussões sobre os possíveis tratamentos da articulação entre as ordens jurídicas doméstica e internacional $^{133}$. Grife-se que a preferência de um Estado em adotar a vertente monista ou a dualista revela, em linhas gerais, a decisão do poder constituinte respectivo em entender o Direito Nacional e o Direito das Gentes como "dois ordenamentos independentes, estanques, ou dois ramos do mesmo sistema jurídico"134. O constitucionalismo ascende, pois, como peça crucial na apuração das características tanto do monismo quanto do dualismo já que, no fundo, como assinalou Fernanda DiAs Menezes DE AlmeidA, “a

\footnotetext{
${ }^{132}$ Cf. Hilary Charlesworth, Madelaine Chiam, Devika Hovell e George Williams, International Law and National Law: Fluid State, in The Fluid State: International Law and National Legal Systems, Hilary Charlesworth, Madelaine Chiam, Devika Hovell e George Williams (ed.), Sydney, The Federation Press, 2005, p. 16.

${ }^{133}$ A respeito das delimitação conceitual do monismo e dualismo, consultar: CELSO D. DE ALBUQUERQUE Mello, Curso de Direito Internacional Público, vol. 1, Ob. cit., pp. 103-125; JOAQuim DA Silva CunHA e Maria da Assunção do VAle Pereira, Manual de Direito Internacional Público, $2^{\mathrm{a}}$ ed., Coimbra, Almedina, 2004, pp. 89-99; ANTONIO CASSESE, International Law, $2^{\text {a }}$ ed., New York, Oxford, 2005, pp. 213237; Marco ANTÔNIO CORRÊA MonteIro, Tratados Internacionais de Direitos Humanos e Direito Interno, São Paulo, Saraiva, 2011, pp. 23-65; AnTEnor MAdrugA, Constituição Brasileira de 1988: Monista ou Dualista?, in Revista de Informação Legislativa, ano 45, $\mathrm{n}^{\circ}$ 179, jul./set. 2008, pp. 135-140; e GUSTAVO Binenbojm, Monismo e Dualismo no Brasil: Uma Dicotomia Afinal Irrelevante, in Revista Forense, vol. 350, abr./jun. 2000, pp. 39-48.

${ }^{134}$ Hildebrando Accioly, G. E. do Nascimento e Silva e Paulo Borba Casella, Manual de Direito, Ob. cit., p. 211.
} 
forma de recepcionar-se o tratado no ordenamento jurídico interno (seja por incorporação automática, seja por incorporação intermediada) não é determinada pelas normas internacionais e sim por decisão do próprio Estado signatário. Dirá este, de preferência na respectiva Constituição, como se devem conduzir as coisas" ${ }^{\text {,135. }}$.

Os teóricos atrelados ao dualismo difundiram a ideia de que a ordem nacional e o sistema internacional são, cada qual, um conjunto de normas independentes e absolutamente distintos, sendo preciso submeter os mandamentos exteriores a um processo formal de internalização, o qual pode se identificar com o processo legislativo exigido para edição de lei (dualismo radical) ou para elaboração de atos normativos procedimentalmente mais simples (dualismo moderado). A noção de duplicidade de sistemas é produto da obra de HeINRICH TRIEPEL, adepto do ponto de vista de que, "se existe um Direito Internacional, ele deve governar outras relações não abarcadas pelo Direito Interno"136. A falta de identidade material entre as normas internas e externas fazia impensável integrar essas ordens jurídicas, de modo que o dualismo seria a resposta prestada pelas Constituições ao Direito Internacional Público, criado entre o século XIX e início do século XX, quando as normas exteriores tinham natureza eminentemente contratual, na medida em que se destinavam tão somente a fixar regras políticas de convivência entre os Estados soberanos, como aquelas voltadas ao estabelecimento de acordos de delimitação de fronteiras e de alianças militares ofensivas e defensivas ${ }^{137}$.

De outra banda, imbuído da crença de que "somente pode dar conta da realidade jurídica uma teoria que, reconhecendo desde logo a possibilidade de conflitos entre o Direito Internacional e o Direito Interno, adverte que tais conflitos não têm caráter definitivo e encontram sua solução na unidade do sistema jurídico" ${ }^{138}$, ALFRED

\footnotetext{
${ }^{135}$ A Incorporação dos Tratados Internacionais ao Ordenamento Jurídico Brasileiro. Análise do Tema à Luz do Direito Constitucional, in Revista do Advogado, Ano 23, nº 73, nov. 2003, p. 50. Na mesma direção, José CARLOS DE MAGALHÃESaduz que a polêmica entre dualistas e monistas pode ser considerada ultrapassada, "uma vez que a questão se cinge ao exame da Constituição do país e dos mecanismos por ela adotados para a celebração e ratificação dos tratados. Trata-se, assim, de matéria constitucional, mais do que internacional, devendo-se sempre examinar a Constituição para se verificar a constitucionalidade de um tratado e, assim, sua regularidade perante a ordem interna”, conforme anota (O Supremo Tribunal, Ob. cit., p. 18).

${ }^{136}$ Droit International et Droit Interne, Paris e Oxford, A. Pédone e Oxford, 1920, p. 22. DiONISIO ANZILOTTI, em abono, justifica a relevância do dualismo nas premissas subsequentes: "[...] a) não pode existir normas internacionais emanadas conforme os padrões internos ou normas internas criadas sob o padrão fundamental da norma internacional b) as normas internacionais não podem interferir na força obrigatória das normas internas e vice-versa; c) não é possível haver um conflito, literalmente, entre Direito Internacional e Direito Interno, d) que o Direito Internacional pode remeter para o Direito Interno e, ainda assim, continuará sendo Direito Internacional" (Cours de Droit International, Paris, Panthéon-Assas, 1999, pp. 51-52).

${ }^{137}$ Cf. Pedro B. A. DAllari, Constituição e Tratados, Ob. cit.,p. 9.

${ }^{138}$ Derecho Internacional Publico, $5^{\mathrm{a}}$ ed., Madrid, Aguilar, 1969, p. 65.
} 
VERDROSSexpõe o ponto fulcral da corrente monista. Essa teoria preconiza a total integração entre as ordens jurídicas interna e externa - o que, por conseguinte, implica considerar a norma doméstica e internacional como pertencentes a um único ordenamento -, havendo, ademais, possibilidade de optar-se, em situações de antinomia, pela prevalência dos mandamentos nacionais (monismo nacionalista) ou das prescrições exteriores (monismo internacionalista). Ainda que esta concepção seja sintomática da nota de que "nada, hoje, escapa ao furor normativo internacional, que possui normas que abrangem todos os ramos do Direito Interno"139, o monismo encontra grande dificuldade para provar a unicidade sistêmica do Direito, haja vista que o fato de ser Constituição nacional a responsável por adotá-lo, por si só, é um forte reflexo da dualidade de ordens jurídicas $^{140}$.

A compreensão dos fenômenos ligados à interação entre ordem jurídica nacional e sistema normativo internacional requer o emprego de recursos que ultrapassam as concepções teóricas do monismo e do dualismo. Isso porque, segundo explica MIREILLE Delmas-Marty, nas relações entre o Direito Interno e o Direito Internacional, o monismo, ao supor uma ordem jurídica global à qual todas as outras estariam subordinadas, reflete um quadro utópico que dificilmente poderá se concretizar. $\mathrm{O}$ dualismo, por sua vez, propugnando a existência de ordens jurídicas separadas e independentes, apega-se, inversamente, a uma ideia de separação radical entre as normativas nacional e exterior, o que impede que todos os fenômenos que acompanham internacionalização do Direito possam ser integrados ao raciocínio jurídico necessário para explicar a complexidade do tema em apreço ${ }^{141}$.

Independentemente do posicionamento que se venha a escolher, "sucede, porém, que o Direito Internacional somente se integra à ordem jurídica estatal por meio de filtragem realizada pela correspondente Constituição, vale dizer, essa incorporação se dá nas condições, limites e efeitos estabelecidos pelos sistemas constitucionais estaduais"142. Não há que se cogitar, sob nenhum prisma, confusão entre os ordenamentos normativos; passa a ser interessante pensar em desenlaces condizentes com um contexto de recíprocas

\footnotetext{
${ }^{139}$ André De Carvalho Ramos, Pluralidade das Ordens Jurídicas: A Relação do Direito Brasileiro com o Direito Internacional, Curitiba, Juruá, 2012, p. 15.

140 Cf. MATTIAS KUMM, Democratic Constitucionalism Encounters International Law: Terms of Engagement, in The Migration of Constitutional Ideas, Sujit Choudhry (ed.),Ob. cit., p. 258.

${ }^{141}$ Cf. Études Juridiques Comparatives et Internalisation du Droit (Leçons Inaugurales du Collège de France), Paris, Collège de France e Fayard, 2003, p. 41.

${ }^{142}$ Elival da Silva Ramos, Os Tratados sobre Direitos Humanos no Direito Constitucional Brasileiro PósEmenda Constitucional 45/04, in O STF e o Direito Internacional dos Direitos Humanos, Alberto do Amaral Júnior e Liliana Lyra Jubilut (org.), Ob. cit., pp. 155-156.
} 
influências e interpenetrações entre ambas as ordens jurídicas, marcado pela cooperação e ausência de hierarquia ${ }^{143}$. São aguardados, com isso, avanços no tema que foi diagnosticado por GUIDO FERnANDO SILVA SOARES de "verdadeiro caos na doutrina dos internacionalistas brasileiros, que não se entendem entre si, em especial no que se refere ao monismo e ao dualismo, nem com alguns constitucionalistas, aferrados a um nacionalismo de certa forma ultrapassado, ou em descompasso com os fenômenos da globalização a que o país, quer queiram, quer não, se encontra submetido"144.

As propostas de separação ou de oposição entre os compartimentos interno e externo são uma consequência direta do conceito - que deixou de prevalecer - de soberania ilimitada. A ampliação do objeto de normatização do Direito das Gentes somada a uma nova configuração da figura estatal, que passa a ser visualizada como parte de uma sociedade internacional que comunga de alguns valores universais e cuja infringência não é admitida, impõem-se ao Estado contemporâneo como demanda de readequar as formas de processamento do intercâmbio entre os dois campos normativos ${ }^{145}$. Diante do "pluralismo de ordens jurídicas que tornou obsoleta a polêmica dualismo x monismo"146, sobressai a impressão de que relativizar as antigas concepções encarregadas de explicar a matéria não é uma ousadia perigosa e desaconselhável, mas uma necessidade incontornável.

Combinar os dois universos normativos referidos (sem que se tenha de escolher qual terá maior ou menor relevância jurídica, já que complementares nos dias de hoje) e sobrepujar ideias incompletas e dessincronizadas quanto à aplicação interna de prescrições jurídicas exteriores não dependem da opção soberana de filiar-se à orientação monista ou dualista $^{147}$. Essas tarefas condicionam-se pela "ideia de uma interação que não acarreta forçosamente o desaparecimento de todas as hierarquias, mas, antes, o enredamento delas,

\footnotetext{
${ }^{143}$ Cf. Ignacio Gutiérrez GutiÉRrez, De la Constitución del Estado al Derecho Constitucional para la Comunidad Internacional, in La Constitucionalización de la Comunidad Internacional, Anne Peters, Mariano J. Aznar e Ignacio Gutiérrez (ed.), Ob. cit., pp. 32-33.

${ }^{144}$ Curso de Direito Internacional Público, vol. 1, São Paulo, Atlas, 2002, p. 225.

${ }^{145}$ Cf. ESTÊVÃo Ferreira CoUTO, A Relação entre, Ob. cit., pp. 166-167.

${ }^{146}$ Luiz Olavo Baptista, ALCA - Notas sobre o Impacto da ALCA sobre o Sistema Jurídico Brasileiro, in Alca e Mercosul: Riscos e Oportunidades para o Brasil, Samuel Pinheiro Guimarães (org.), Ob. cit., p. 201.

${ }^{147}$ Sob esse influxo, vale realçar a observação de OCTAVIO IANNI de que, em fins do século XX, "verifica-se que as ciências sociais estão sendo desafiadas a interpretar novas realidades e a reinterpretar realidades que já haviam sido explicas e compreendidas. Na medida em que o objeto se modifica qualitativamente, e não apenas em termos quantitativos, reabre-se o problema da reconstrução de conceitos, categorias, leis e interpretações. Além das novas realidades, as anteriores se recolocam em novos moldes, outro contexto histórico, diferente contraponto entre singularidade e universalidade" (A Sociedade Global, 11 ${ }^{\mathrm{a}}$ ed., Rio de Janeiro, Civilização Brasileira, 2003, p. 170).
} 
e, por isso mesmo, o aparecimento de novos modos de geração do Direito" ${ }^{148}$. A conveniência de revisitar os dogmas que orientarão as propostas que podem ser idealizadas para responder aos desafios do agora é fortalecida pela conclusão de que, "sobre a questão global da relação entre o Direito Interno e o Direito Internacional, as construções teóricas provavelmente contribuíram em grande medida para obscurecer a realidade", como assinalado por IAN BROWNLIE ${ }^{149}$.

\subsubsection{A Emergência do Direito Comum}

A dicotomia entre dualistas e monistas remanesce como indício de que os estudiosos pressupõem que há, de um lado, o Direito Interno, e, de outro, o Direito Internacional; e que nos encontramos ora em um, ora em outro, mas nunca nos dois ao mesmo tempo - e, menos ainda, em nenhum deles. Ocorre, todavia, que tal diretriz não se coaduna com as disposições encartadas nas Constituições, nem com a prática internacional adotada pelos Estados, uma vez que é incapaz de compreender a realidade não condensada nos esforços doutrinários lastreados em ideias que se prendem à possibilidade de segmentar ou não essas ordens jurídicas ${ }^{150}$. Mais significativo do que definir se o Direito Interno e o Direito das Gentes compõem um ou dois sistemas normativos e as implicações que se pode extrair da opção que prevalecer, é perquirir sobre a decantação de valores que influem igualmente em ambos os ordenamentos e, dessa maneira, evidencia que "a internacionalização do Direito levaria a destacar, a partir das instituições específicas de cada país, alguns princípios constituintes de um Direito Comum com vocação universal" $" 151$.

Nesse sentido, afirma PETER HÄBerle que o alargamento da cooperação entre as nações provoca o surgimento de um efetivo Direito Comum, cujo conteúdo pertence aos dois planos normativos entrelaçados e não hierarquizados e reflete a junção de identidades entre ordem estatal e ordenamento internacional, com o escopo de proteger os mesmos bens jurídicos ${ }^{152}$. Ilustra esse movimento a preocupação de interpretar normas constitucionais em harmonia com a Declaração Universal de Direitos Humanos da ONU e tratados internacionais, tal qual consta no art. 10, $\mathrm{n}^{\mathrm{o}} 2$, da Constituição Espanhola da

\footnotetext{
${ }^{148}$ Mireille Delmas-Marty, Por um Direito Comum, São Paulo, Martins Fontes, 2004, p. 98.

${ }^{149}$ Princípios de Direito, Ob. cit., pp. 67-68.

${ }^{150}$ Elisabeth Zoller, Aspects Internationaux du Droit Constitutionnel: Contribution à la Théorie de la Fédération d'Etats, in Recueil des Cours, n 294, 2003, p. 54.

${ }^{151}$ HÉLÈnE TOURARD, L'Internationalisation des, Ob. cit., pp. 5-6.

${ }^{152}$ Sobre o conceito de Direito Comum na obra de HÄBERLE, consultar Estado Constitucional Cooperativo, Ob. cit., pp. 63-70.
} 
$1978^{153}$ e no art. 16, no 2, da Constituição da República Portuguesa de $1976^{154}$. Adquire relevância, portanto, construir entendimentos convergentes, na esteira do que se processou com os direitos fundamentais, que foram alçados à posição de "um sistema de valores objetivos dotados de uma unidade de sentido e que representam a suprema expressão da ordem axiológica das nossas sociedades, assim como também da comunidade internacional a que pertencemos" $" 155$.

Embora a concepção de normas comuns pareça se avolumar em torno dos direitos humanos, se houver soma de esforços entre os sujeitos do Direito Internacional - o que contempla, destacadamente, os Estados nacionais que precisarão de órgãos nacionais alinhados ao fenômeno jurídico em comento -, é certo que o Direito Comum aumentará expressivamente seu repertório temático. A propósito, CÁRMEN LÚCIA ANTUNES RochA enfatiza que duas influências diretas parecem dar suporte ao que acontece: a primeira corresponde à ampliação e à fusão dos compartimentos normativos interno e externo, aumentando-lhes a eficácia e permitindo que ambos saiam reforçados no que há de comum e complementados naquilo em que guardam diferença. A outra força liga-se às consequências da integração econômica e política operada por organizações internacionais como a União Europeia e o Mercosul, cuja solidificação demanda a edição de normas no plano internacional acompanhada de ações domésticas, para que os mandamentos jurídicos tenham concretude ${ }^{156}$.

A interconexão sistêmica que transforma o Estado constitucional denota inegável compromisso do constitucionalismo em atender às imposições colocadas pela urgência de um mundo interdependente e em contínua mutação ${ }^{157}$. Os desafios da ordem internacional não podem ficar à margem da própria dinâmica dos acontecimentos jurídicos e políticos das democracias contemporâneas, daí por que os aspectos adjacentes ao conceito de Direito Comum indicam que a renovação do Direito Constitucional é uma ferramenta

\footnotetext{
153 “Art. 10 [...] 2. As normas relativas aos direitos fundamentais e às liberdades que a Constituição reconhece devem ser interpretadas em conformidade com a Declaração Universal de Direitos Humanos e os tratados e acordos internacionais sobre as mesmas matérias ratificados pela Espanha".

154 “Art. 16. [...] 2. Os preceitos constitucionais e legais relativos aos direitos fundamentais devem ser interpretados e integrados de harmonia com a Declaração Universal dos Direitos do Homem”.

${ }^{155}$ Antonio-EnRIQUe PÉREZ LuÑo,Dogmática de los Derechos Fundamentales y Transformaciones del Sistema Constitucional, in Teoria y Realidade Constitucional, $\mathrm{n}^{\circ}$ 20, 2007, p. 500.

${ }^{156}$ O Direito Constitucional Perante o Direito Internacional Atual, in Direito Constitucional em Evolução: Perspectivas, Paulo Gomes Pimentel Júnior (coord.),Ob. cit., p. 99.

${ }^{157}$ Com efeito, a importância da calibração entre as ordens jurídicas tendo como ponto de equilíbrio o Direito Comum é reforçada pela advertência de MIREILLE DELMAS-MARTY a respeito de que "a integração mundial permanecerá, de fato, caótica enquanto a globalização se traduzir na adoção de normas e de instituições sem relação com o universalismo de valores" (Le Pluralisme Ordonné: Les Forces Imaginantes du Droit (II), Paris, Éditions du Seuil, 2006, p. 189).
} 
efetiva na missão "de salvar a fratura entre o mundo enquanto globalidade e o Estado de Direito como modelo organizativo em nível de Estado-nação" ${ }^{158}$. Por essa via, a delimitação dos conteúdos que ocupam os constitucionalistas transcende os tópicos estritamente nacionais, já que a organização e o funcionamento das instituições internas, cada vez mais, devem adequar-se aos valores preconizados tanto pelos Estados, que mantêm a autoridade soberana e suas singularidades, quanto pela sociedade internacional, que faz da cooperação fator de progresso de todo o concerto internacional ${ }^{159}$.

Essa tendência pode ser provada pelo surgimento de alguns direitos voltados à proteção do homem, notadamente aqueles que ficaram conhecidos no seio do constitucionalismo como direitos fundamentais de terceira dimensão ${ }^{160}$. Explica MANOEL GONÇALVES FerReIRA FilHo que "na segunda metade do século passado, o avanço na identificação dos direitos fundamentais, se deu no plano internacional, em tratados e deliberações de instituições internacionais. É o caso dos direitos de solidariedade, como o direito ao meio ambiente, direitos estes que justificam se fale numa 'terceira geração' dos direitos fundamentais" ${ }^{\prime 161}$. Sobressai a apuração histórica de que essa categoria de direitos com a finalidade de proteger a pessoa humana primeiro foi, primeiramente, difundida no terreno externo, tendo encontrado ambiente propício para consolidação na atuação das organizações internacionais. Acabou sendo recebida pelo Direito Constitucional positivo somente em um segundo momento, o que ocorreu no seio das Constituições elaboradas a partir de 1945.

Dessa forma, tem-se que o estabelecimento de conteúdos comuns para as diferentes esferas normativas está amparado no pensamento de que a interação entre ordens jurídicas não acarreta forçosamente o desaparecimento de todas as hierarquias, mas, antes, o

\footnotetext{
${ }^{158}$ Alfonso de Julios-CAMPUZANO, Constitucionalismo em Tempos, Ob. cit., p. 105.

${ }^{159}$ Confirma essa orientaçãoArTur CORTEZ BonifÁCIO, que estatui que o Direito Constitucional deve ser referenciado numa escala global, o que, consoante anotou, "significa trazer ao ambiente jurídico interno um sistema normativo centrado, minimamente, na convergência internacional, motivado pelos ideais democráticos, de solidariedade e paz, mediante o reconhecimento, nesse sentido, de normas imperativas em favor da dignidade humana. Também, por outro lado, visa-se projetar os valores internos da Constituição às relações internacionais. Na confluência entre os sistemas interno e internacional, objetivamos a garantia da efetividade dos direitos fundamentais, por considerá-los pautas comuns, realidades com o mesmo fundamento material, mediante o estabelecimento de uma dupla proteção: internamente, a Justiça Constitucional; externamente, no contexto do Sistema Global das Nações Unidas, o Sistema Interamericano de Proteção dos Direitos Humanos, da Organização dos Estados Americanos, sob a tutela jurídica da Convenção Americana dos Direitos Humanos, de 1969" (O Direito Constitucional Internacional e a Proteção dos Direitos Fundamentais, São Paulo, Método, 2008, p. 29).

${ }^{160}$ Sobre a evolução histórica dos direitos fundamentais e a teoria das gerações desses direitos, ver INGO Wolfgang Sarlet, A Eficácia dos Direitos Fundamentais: Uma Teoria Geral dos Direitos Fundamentais na Perspectiva Constitucional, $11^{\mathrm{a}}$ ed., Porto Alegre, Livraria do Advogado, 2012, pp. 45-57.

${ }^{161}$ Constitucionalismo e Direito Natural: Uma Relação Inelidivel, in Revista Brasileira de Direito Constitucional, $\mathrm{n}^{\mathrm{o}}$ 6, jul./dez. 2005, pp. 651-652.
} 
enredamento delas, e, por isso mesmo, o aparecimento de novas fórmulas de geração do Direito. "Modos novos e diferentes uns dos outros conforme o enredamento ocorra entre sistemas autônomos e não hierarquizados, que criam hierarquias 'alternativas' que estabelecem certa continuidade no ponto em que o processo normativo estava interrompido, ou se desenvolve a partir de sistemas já hierarquizados, ou parcialmente hierarquizados, tendo o efeito de inverter os níveis normativos ao fazer o nível inferior participar da determinação das normas de nível superior e favorecendo assim o

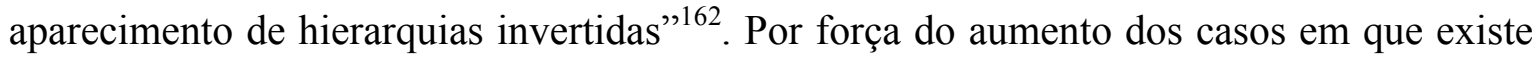
coincidência material entre os comandos jurídicos, vêm à tona outras maneiras de apreciar a relação entre Direito Interno e Direito das Gentes, o que causa o fortalecimento das proposições doutrinárias que pregam a necessidade de superar os inférteis debates ecoados pelos dualistas e monistas.

À proporção que cresce a cooperação entre os Estados, mais favoráveis tornam-se as condições para o desenvolvimento do Direito Comum. O panorama de agora demonstra, com certeza, que um considerável número de normas, processos, competências e objetivos típicos do Direito Internacional já se impregnaram nos conteúdos consagrados pelas Constituições, o que favorece sobremaneira a identificação de normas de Direito cooperativo que a comparação constitucional deve continuar a especificar. Cumpre destacar que o processo de lapidação do Direito comum de cooperação precisa ser desenvolvido tanto quanto a competência jurisdicional das Constituições avançar ${ }^{163}$, o que pode ocorrer mediante adoção de novas e atualizadas Constituições, reforma constitucional ou, ainda, emprego de métodos de exegese ${ }^{164}$.

O movimento consistente na ascensão de normas para proteger bens jurídicos comuns e induzir o alcance de metas igualmente compartilhadas entre os povos não deixa de ser um resgate da visão universalista do Direito. As condições são, de fato, as mais propícias para que se realizem incursões nessa área, propiciando, de certo modo, que o universalismo jurídico ressurja "hoje não mais como crença num eterno Direito natural,

\footnotetext{
${ }^{162}$ Mireille Delmas-Marty, Por um Direito Comum, São Paulo, Martins Fontes, 2004, p. 98.

163 Cf. Peter HäBerle, Estado Constitucional Cooperativo, Ob. cit., pp. 63-64.

${ }^{164}$ SAMANTHA RIBEIRO MEYER-PFLUG apresenta esclarecedora relação entre o processo de abertura das Constituições ao Direito Internacional e o surgimento do Direito Comum. Como explicitou a autora, "é possível identificar três elementos responsáveis pela internacionalização do Direito Constitucional, quais sejam, os próprios textos das Constituições dos Estados, as teorias formuladas pela doutrina e as sentenças constitucionais. Tais elementos demonstram o grau de evolução da internacionalização do Direito Constitucional interno, na busca de um Direito Comum" (A Internacionalização do Direito Constitucional Brasileiro, in Direito Constitucional Internacional dos Direitos Humanos, Alexandre Coutinho Pagliarini e Dimitri Dimoulis (org.), Belo Horizonte, Fórum, 2012, p. 279).
} 
mas como vontade de construir um Direito positivo único, que recolha em unidade todos os Direitos positivos existentes e que seja produto não da natureza, mas da história, e esteja não no início do desenvolvimento social e histórico (como o Direito natural e o estado de natureza), mas no fim" ${ }^{\text {165 }}$. Em termos práticos, esse é o período em que a humanidade encontrou mais instrumentos para criar aquilo que IMMANUEL KANT idealizou como um Direito cosmopolita, isto é, uma espécie de "complemento necessário de código não escrito, tanto do Direito político como do Direito das Gentes, num Direito Público da humanidade em geral e, assim, um complemento da paz perpétua, em cuja contínua aproximação é possível encontrar-se só sob esta condição" ${ }^{\text {"166 }}$.

O caráter permanentemente inacabado da construção do Direito Comum instiga o estudo de como as ordens constitucionais têm cuidado da tendência - que parece irreversível - de abertura ao mundo exterior ${ }^{167}$. Longe de abordar esse tema em seu aspecto geral, os próximos capítulos procurarão traçar o perfil dos mecanismos albergados na Constituição brasileira de 1988, que podem servir para compatibilizar a inserção do Estado nacional num ambiente marcado pelo surgimento de novos e desafiadores parâmetros de organização e limitação dos poderes estatais. Para tanto, buscar-se-á inspiração nas ideias de Horst DipPEL, em especial na percepção de que "a história do constitucionalismo moderno desvia-se assim deliberadamente dos caminhos trilhados pela história constitucional nacional para investir numa perspectiva global. Os documentos necessários a essa nova abordagem estão disponíveis; tudo aquilo de que necessitam é de uma nova leitura, que possibilitará um conjunto vasto de novas perspectivas"168 e a obtenção de ganhos reais para os dois sistemas jurídicos aqui focados.

\footnotetext{
${ }^{165}$ Norberto BobBio, Teoria do Ordenamento Jurídico, $2^{\mathrm{a}}$ ed., São Paulo, Edipro, 2014, p. 154.

${ }^{166}$ A Paz Perpétua: Um Projeto Filosófico, Covilhã, Universidade da Beira Interior, 2008, p. 22.

${ }^{167}$ Confere maior vigor a essa impressão o pensamento de PINTO FERREIRA, cujo teor apregoa que "nenhum Estado pode fugir a relações com outros países estrangeiros. O mundo se encontra hoje de tal maneira interpenetrado que as nações se empenham em manter relações umas com as outras, para isso celebrando tratados e convenções conducentes à boa realização da vida em comum" (Comentários à Constituição Brasileira-Vol. 2: Arts. 22 a 53, São Paulo, Saraiva, 1989, p. 547).

${ }^{168}$ História do Constitucionalismo Moderno, Lisboa, Fundação Calouste Gulbernkian, 2007, p. 35.
} 


\title{
2. A EVOLUÇÃO DO PROCESSO DE ABERTURA DO ESTADO BRASILEIRO AO DIREITO INTERNACIONAL
}

\begin{abstract}
“A Carta de 1988 é a primeira Constituição brasileira a elencar o princípio da prevalência dos direitos humanos, como princípio fundamental a reger o Estado nas relações internacionais. $\mathrm{Na}$ realidade, trata-se da primeira Constituição brasileira a consagrar um universo de princípios para guiar o Brasil no cenário internacional, fixando valores a orientar a agenda internacional do Brasil - iniciativa sem paralelo nas experiências constitucionais anteriores".
\end{abstract}

FLÁVIA PIOVESAN ${ }^{169}$

\subsection{O Direito Constitucional Internacional: Nem Direito Constitucional, nem Direito Internacional (na Verdade, um Pouco de Cada)}

Transcorridos quase dois séculos desde a publicação da primeira versão da obra $A$ Democracia da América, os reflexos derivados da interconexão entre democracia e relações exteriores - não apreciados, em 1835, por ALEXIS DE TOCQUEVILLE - podem ser analisados com considerável margem de segurança no momento atual. Com efeito, nos cenários político e jurídico do século XIX, mostrava-se difícil saber quais habilidades desenvolveria a democracia na condução dos negócios externos, motivo pelo qual ToCQUEVILLE advertiu que, sobre esse ponto, tanto os adversários quanto os amigos da democracia deveriam deixar em suspenso o julgamento que fariam ${ }^{170}$. É patente, hoje, que a expansão generalizada da democracia no interior dos Estados representa fator determinante para a consolidação de "um internacionalismo de vocação pacífica, pois existe uma homologia entre as práticas democráticas de lidar com os conflitos e a democracia concebida como um processo contínuo de diálogo e negociação"171.

A solidificação das bases nacionais que sustentam o regime democrático, além de ter propiciado o desenvolvimento de uma infinidade de institutos constitucionais relacionados predominantemente ao contexto interno dos Estados, também ressoou relevantes impactos na condução das relações internacionais pelos governos orientados por

\footnotetext{
${ }^{169}$ Direitos Humanos e, Ob. cit., p. 37.

${ }^{170}$ Cf. A Democracia na América - Livro I: Leis e Costumes de Certas Leis e Certos Costumes Políticos que Foram Naturalmente Sugeridos aos Americanos por seu Estado Social Democrático, 2a ed., São Paulo, Martins Fontes, 2005, p. 266.

${ }^{171}$ Celso LAfer, Prefácio do Livro Constituição e Relações Exteriores de Pedro B. A. Dallari, Ob. cit., p. XVI.
} 
esse regime ${ }^{172}$. Nessa quadra, há de se admitir que a força das normas internacionais não é a mesma no Estado democrático e no Estado despótico, uma vez que a estrutura jurídica estatal orientada pelos postulados da democracia se opõe à violação do Direito das Gentes ${ }^{173}$. Por certo, desde a Revolução Francesa, quando a Assembleia Nacional obteve autorização constitucional para atuar no controle das relações internacionais, tem-se um quadro de lenta e gradativa evolução da matéria, responsável por viabilizar o incremento das interações entre os países com doses de responsabilidade política e segurança jurídica $^{174}$.

A participação do povo, mesmo que indiretamente, na tomada de decisões que orientam as ações exteriores do Estado, bem como o estabelecimento de princípios constitucionais declaradamente direcionados a reger as relações internacionais, denotam o quão importante é a Constituição para a sociedade internacional e para o Direito das Gentes $^{175}$. Acerca da aproximação de ambas as esferas jurídicas, CÁRMEN LÚCIA ANTUNES Rocha enuncia que "o Direito Constitucional, como o Direito Internacional, dota-se de conteúdo essencialmente político. Ora, à medida que o político (e a política) nacional aproxima-se, cinge-se, soma-se, coordena-se, cada vez mais, com o político (e a política) internacional, em que as decisões em um plano repercutem, imediatamente, no outro, é certo que o direito interno, e, aí, basicamente, o Constitucional, e o Direito Internacional passam a constituir feições mais próximas da matéria jurídica, a qual busca, fundamentalmente, a unidade para maior eficácia e segurança" ${ }^{176}$.

Verifica-se, pois, em especial no século XX, expressivo progresso na inserção de normas nas Constituições com o objetivo claro de possibilitar a observância pelas autoridades nacionais de prescrições no âmbito do Direito Internacional. Esse avanço é explicitado por ALEJANDRO SAIZ ARNAIZ, para quem os comandos constitucionais encarregados de tratar de temas relativos às relações exteriores deixaram de se limitar apenas às questões da guerra e dos tratados internacionais para abarcar também “critérios

\footnotetext{
${ }^{172}$ Com efeito, afirma MANOEL GonÇALVES FERREIRA Filho que "ninguém contestará, hoje, ser a democracia o princípio de atribuição do Poder adotado pelo constitucionalismo. Na verdade, vigora atualmente a crença da simbiose entre constitucionalismo e democracia, democracia e constitucionalismo. Assim, o estabelecimento de Constituição é visto como o mesmo que instituição da democracia e a instituição da democracia passa pela adoção da Constituição" (Princípios Fundamentais do Direito Constitucional: O Estado da Questão no Início do Século XXI, em Face do Direito Comparado e, Particularmente, do Direito Positivo Brasileiro, 2a ed., São Paulo, Saraiva, 2010, p. 43).

${ }^{173}$ Cf. Boris Mirkine-GuetZÉvitch, Derecho Constitucional Internacional, Ob. cit., p. 120.

${ }^{174}$ Cf. Celso D. De AlbuQuerque Mello, A Revisão do, Ob. cit., p. 78.

${ }^{175} \mathrm{Cf}$. ANTONIO REMIRO BROTONS, La Accion Exterior, Ob. cit., pp. 13-15.

${ }^{176}$ Constituição, Soberania e Mercosul, in Revista de Informação Legislativa, no 139, ano 35, jul./set. 1998, p. 290.
} 
orientadores das relações entre o Direito Internacional e o Direito Interno, assim como fórmulas constitucionais que tornaram possível a participação do Estado em organizações supranacionais, concretizando, em cada caso, os perfis e os limites desse engajamento" ${ }^{" 177}$. Em igual direção, despontou ainda "a construção e consolidação de um autêntico Direito Constitucional Internacional dos direitos humanos, resultado da interpretação cada vez maior entre os direitos fundamentais constitucionais e os direitos humanos dos instrumentos jurídicos internacionais" ${ }^{, 178}$.

Esse entrelaçamento, cada vez mais acentuado, entre Constituição e Direito das Gentes resultou na aparição de "normas constitucionais de alcance internacional que devem ser analisadas em cada caso procurando compatibilizar os dois ramos da Ciência Jurídica" ${ }^{179}$. Diante desse fato, parcela da doutrina vislumbrou a possibilidade de reconhecer a existência de novo campo de estudo do Direito: o assim denominado Direito Constitucional Internacional. Idealizado pioneiramente por BORIS MIRKINE-GUETZÉVITCH, nos primeiros anos da década de 1930, essa matéria seria composta por um conjunto de disposições constitucionais destinadas a produzir efeitos jurídicos no contexto exterior e, com isso, viabilizar a consecução da paz entre os Estados soberanos. Não seria, portanto, Direito Internacional, já que sua fonte normativa, por excelência, era a Constituição ${ }^{180}$.

O Direito Constitucional Internacional corresponderia ao "ramo do Direito em que se dá a intercessão entre o Direito Constitucional Interno e o Direito Constitucional Internacional. Assenta, pois, numa das dicotomias - Direito Interno (ou seja, Direito Nacional) e Direito Externo (isto é, Direito Internacional) - de que é tão fértil a ciência jurídica moderna" ${ }^{181}$. Haveria, desse modo, um núcleo material mínimo a ser desenvolvido pelo Direito Constitucional Internacional, cuja abrangência incidiria sobre aspectos da conclusão de tratados, da declaração de guerra, da celebração de paz, da recepção de

\footnotetext{
${ }^{177}$ La Apertura Constitucional, Ob. cit., p. 47.

178 IngO Wolfgang SARLet, Os Direitos Fundamentais, a Reforma do Judiciário e os Tratados Internacionais de Direitos Humanos Notas em Torno dos $\$ \S 2^{\circ}$ e $3^{\circ}$ do art. $5^{\circ}$ da Constituição de 1988, in Revista da AJURIS, n 102, ano 32, pp. 192-193.

${ }^{179}$ Celso D. De Albuquerque Mello, Direito Constitucional Internacional: Uma Introdução, Rio de Janeiro, Renovar, 1994, p. 32.

${ }^{180} \mathrm{Cf}$. Derecho Constitucional Internacional, Ob. cit., p. 470. No mesmo sentido, anotam VICENTE MAROTTA RANGEL que "o chamado Direito Constitucional Internacional demonstra, como reiteradamente ensinou Mirkine-Guetzévitch, que a técnica da liberdade e a técnica da paz se unem e se completam. E revela, por outro lado, que toda constituição estatal concorre para a realização da unidade do sistema jurídico universal" (Os Conflitos entre, Ob. cit., p. 30); e CELSO LAFER que "a delimitação da 'razão-de-Estado' e da discricionariedade do poder no plano externo, através de princípios constitucionais, é uma contribuição para a paz que resulta do aprofundamento democrático" (Prefácio do Livro Constituição e Relações Exteriores de Pedro B. A. Dallari, Ob. cit., p. XVI).

${ }^{181}$ José Souto MAIOR BorgeS, Curso de Direito Comunitário, 2a ed., São Paulo, Saraiva, 2009, p. 107.
} 
normas internacionais, do controle parlamentar da política externa, entre outros temas. Assuntos esses que interessam, em igual proporção, às duas áreas jurídicas mencionadas. Isso justifica a conclusão de que não se pode dizer que o Direito Constitucional Internacional tenha um objeto e método próprios ou que seja um ramo autônomo da Ciência Jurídica, já que não passa de uma divisão do Direito Constitucional, a exemplo do que ocorre com o Direito Constitucional Tributário ${ }^{182}$.

A melhor forma de enquadrar o Direito Constitucional Internacional é, sem dúvida, alocando-o "nos 'confins' do Direito Constitucional e do Direito Internacional, o que significa que qualquer especialista nestas matérias pode versá-la. Contudo, é de se observar que o maior número de obras sobre ele tem sido publicado por internacionalistas" ${ }^{\text {"183 }}$. A ausência de um número significativo de obras e estudos jurídicos com ênfase em apreciar o Direito Constitucional Internacional sob a perspectiva do constitucionalismo serve, pois, para atestar a relevância científica da proposta central do presente trabalho. Consoante LOUIS HENKIN, as relações exteriores não podem ser compreendidas somente à luz da Constituição isolada, mas não devem ser entendidas sem ela, pois o texto constitucional molda as instituições e as ações que determinam essas relações ${ }^{184}$.

O caráter interdisciplinar do Direito Constitucional Internacional demanda a utilização de instrumentos metodológicos diversos dos tradicionais a fim de que se compatibilizem as imbricadas relações entre Direito Interno (Constitucional) e o Direito Externo (Internacional) ${ }^{185}$. Por esse motivo, na linha de entendimento defendida por Flávia Piovesan, é de se concordar com a proposta de classificar os estudos ligados à temática como não sendo puramente de Direito Constitucional ou de Direito Internacional, pois seu objeto alcança uma complexidade disciplinar resultante de uma matéria inovadora, que é propriamente o Direito Constitucional Internacional ${ }^{186}$. Não se trata,

\footnotetext{
${ }^{182}$ Cf. Celso D. De Albuquerque Mello, Direito Constitucional Internacional, Ob. cit., p. 31.

${ }^{183}$ Celso D. De AlbuQuerque Mello, A Revisão do, Ob. cit., pp. 75-76.

${ }^{184}$ Cf. Foreign Affairs and the Constitution, Nova Iorque e Londres, W. W. Norton \& Company, 2007, p. 7. Reforça essa impressão PEDRo B. A. DALLARI, ao grifar que "não se pode ignorar a relevância das normas constitucionais que explicitamente tratam das relações exteriores de um país. De um lado, porque, ao fixarem competências para os distintos organismos, poderes e esferas do Estado, podem contribuir, considerando-se a evolução de sistemas cada vez mais complexos de gestão pública, para uma reversão da percepção desfocada dos paradigmas das relações exteriores de um país, que os retrata enquanto decorrência automática da política externa governamental, pois instituições não necessariamente vinculadas a esta última, como o parlamento, passam a ter maiores atribuições em torno de questões internacionais. De outro lado, porque, ao fixarem princípios, as normas constitucionais estabelecem a primazia de valores que não deixam de permear não só a retórica, mas a própria materialização dos atos decorrentes da política externa" (Constituição $e$ Relações Exteriores, São Paulo, Saraiva, 1994, p. 18).

${ }^{185}$ José Souto Maior Borges, Curso de Direito, Ob. cit., p. 108.

${ }^{186}$ Cf. Direitos Humanos e o Direito, Ob. cit., p. 17.
} 
entretanto, de setor do conhecimento jurídico dotado de autonomia e absolutamente desprendido do Direito Interno e do Direito das Gentes, haja vista que se tem exatamente o contrário: uma área do conhecimento em que os pontos de conexão entre normas constitucionais e normas internacionais são tão fortes e consistentes, que se torna impossível dissociá-las.

O estudo da problemática em análise representa tarefa de inquestionável dificuldade, pois "não há um Direito Constitucional Internacional claramente delimitado e com normas próprias de interpretação, ou ainda com um conteúdo preciso. Pelo contrário, tudo vai depender do grau de internacionalização dos diferentes setores da vida social"187. Não obstante os delicados pontos de inflexão que acompanham a matéria, a relevância do Direito Constitucional Internacional vem alcançando patamares cada vez mais elevados em virtude da necessidade de estruturar o Estado nacional para que seja possível sua cooperação com outros Estados, comunidades de Estados e organizações internacionais. A abertura do Estado ao internacionalismo confirma as percepções teóricas do Direito Constitucional Internacional, na medida em que as Constituições passam a desenvolver processos, competências e estruturas internas hábeis a viabilizar a execução de ações estatais na seara internacional.

Os efeitos concretos desse movimento refletem-se nas disposições constitucionais, que passam a ter feições inéditas e a consagrar instrumentos jamais experimentados pelo constitucionalismo. Em termos práticos, é possível pensar na superação das diferenças entre o externo e o nacional, no anacronismo da ideologia da impermeabilidade da ordem jurídica interna e, ainda, na insustentabilidade do monopólio estatal das fontes do Direito $^{188}$. Nessa órbita, ainda que seja crescente a interpenetração sistêmica entre diferentes ordens jurídicas, cabe advertir que a tendência de abrigar, nos textos constitucionais, mandamentos que favoreçam processos de cooperação e integração na esfera internacional não autoriza, no entanto, realizar interpretações que desconsiderem os demais princípios constitucionais, porque a Constituição - como núcleo da estrutura jurídica que é - mantém-se como o cerne da legitimidade da ordem estatal ${ }^{189}$.

\footnotetext{
${ }^{187}$ Celso D. De Albuquerque Mello, Direito Constitucional Internacional, Ob. cit., pp. 2-3. No mesmo sentido, consultar IRINEU Strenger,O Direito Internacional na Constituição, in Direito Internacional: Teoria Geral (Coleção Doutrinas Essenciais, vol. 1), Luiz Olavo Baptista e Valerio de Oliveira Mazzuoli (org.), São Paulo, Revista dos Tribunais, 2012, p. 1051.

${ }^{188}$ Cf. Peter HäBerle, Estado Constitucional Cooperativo, Ob. cit., p. 47.

${ }^{189}$ Cf. Marcos Augusto Maliska, Estado e Século, Ob. cit., p. 206.
} 
Anote-se, ademais, que a técnica de constitucionalização das normas de origem internacional eleva os níveis de eficácia do Direito das Gentes. Isso acontece porque a transformação de normas exteriores em comandos constitucionais fornece-lhes, no universo interno dos Estados, máxima força normativa, o que acaba sendo decisivo para a aplicação da normativa internacional pelos órgãos internos ${ }^{190}$. Mais do que uma opção política estatal, o processo descrito denota a assunção de uma consciência pelos Estados nacionais de que "o mundo de hoje é composto de círculos sociais simultâneos $e$ justapostos, com as suas legislações simultaneamente em vigor e em possíveis contatos, interpenetrações e entrechoques" ${ }^{191}$, sendo preciso encontrar soluções para que a concorrência legislativa seja motivo não de impasses, mas de maior proteção daquelas matérias protegidas por mais de uma ordem jurídica.

Efetuadas essas considerações de ordem geral, em que se pretendeu aclarar que o Direito Constitucional Internacional requer uma análise integrada, cuja compreensão delimite aspectos característicos tanto do Direito Constitucional quanto do Direito das Gentes $^{192}$, cabe, agora, aprofundar seu estudo, a fim de investigar os preceitos de maior destaque na Constituição Federal de 1988 para as relações exteriores. Nessa empreitada, não se pode perder de vista que "essas normas variam de uma Constituição para outra, isto é, entre os Estados, bem como dentro do próprio Estado cada Constituição de acordo com o momento histórico, que inclui ou elimina determinadas normas"193. Por assim ser, o processo de abertura da República Federativa do Brasil à ordem internacional deve contar com uma investigação que, além de abarcar o texto vigente, apresente a evolução histórica do tema ao longo das Constituições nacionais, pois, desse modo, serão mais visíveis os importantes avanços introduzidos pela última Lei Fundamental promulgada no país.

\subsection{Relações Internacionais e Direito Constitucional Brasileiro}

A expansão axiológica do conteúdo das normas jurídicas também se verifica na atual Constituição do Brasil, cujo conteúdo, além de transparecer maior disposição para

\footnotetext{
${ }^{190}$ Cf. KeVIn FERDINAND NDJimBA, L'Internationalisation des, Ob. cit., p. 421.

${ }^{191}$ Pontes de Miranda, Comentários à Constituição da República dos E. U. do Brasil, Tomo I: Artigos 1103, Rio de Janeiro, Guanabara, 1937, p. 162.

192 Estatui a respeito JOSÉ SOUTO MAIOR BORGES que "a abordagem do Direito Constitucional Internacional se inclina diretamente sobre um objeto do conhecimento inconfundível com o Direito Constitucional nacional e com o Direito Internacional e só apreensível pela conjugação de ambos" (Curso de Direito, Ob. cit., p. 108).

${ }^{193}$ Celso D. De Albuquerque Mello, Direito Constitucional Internacional, Ob. cit., p. 4.
} 
dialogar com o Direito Internacional, retrata também a passagem política do regime interno autoritário-militar para a democracia ${ }^{194}$. Em verdade, por força de raízes que remetem aos múltiplos vetores apresentados no capítulo anterior e que obrigam o Estado nacional a remodelar o conceito de soberania para responder aos imperativos advindos da globalização e do sensível aumento dos centros de criação dos comandos normativos, "a abertura à normação internacional passa a ser elemento caracterizador da ordem constitucional contemporânea" ${ }^{195}$. A identificação dos elementos de abertura e de cooperação com o mundo exterior como marcas da conformação do Estado nacional projeta-se em iniciativas de integração interestatal e obriga o Direito Constitucional e a Teoria do Estado a se adaptarem esse novo ambiente ${ }^{196}$.

O ampliação do tratamento constitucional das relações exteriores significou implicações na elaboração das Constituições e tem ensejado novas possibilidades de interpretar os textos constitucionais já editados. À medida que se promove a constitucionalização de princípios típicos do internacionalismo, abandona-se a tradição de o Direito Constitucional reduzir os assuntos internacionais apenas à fixação de competências entre os diferentes poderes do Estado para atuarem nas instâncias externas e ao modo de recepcionar a normativa exterior ${ }^{197}$. A natureza constitucional, agora impregnada a comandos que antes ficavam circunscritos ao Direito das Gentes, interfere na exegese da Constituição, ao mesmo tempo em que potencializa o controle político pelo Parlamento e o controle jurídico pelo Poder Judiciário da ação externa do Estado.

Os efeitos que afloram da abertura internacional do Estado não se restringem aos aspectos acima ressaltados. Em complemento, J. J. Gomes CANOTILHO enxerga outras quatro significativas dimensões resultantes da aceitação, por parte das Constituições, do Estado inscrito em uma sociedade internacional onde a interdependência fática e jurídica é consequência incontornável. Em resumo, o autor enuncia que a aludida abertura pressupõe: (i) o abandono da pretensão de ter na Constituição um esquema exclusivo e totalizante de ordenação; (ii) a afirmação do Direito das Gentes como conjunto de mandamentos próprios do país e a previsão de princípios ou regras internacionais orientando o sistema normativo interno; (iii) a indispensabilidade de os poderes públicos constitucionalmente competentes tomarem participação ativa na solução de problemas internacionais (nas organizações

\footnotetext{
${ }^{194}$ Cf. Celso Lafer, A Internacionalização dos Direitos Humanos: Constituição, Racismo e Relações Internacionais, Barueri, Manole, 2005, p. 13.

${ }^{195}$ Flávia Piovesan, Direitos Humanos e o Direito, Ob. cit., p. 54.

${ }^{196}$ Cf. Marcos Augusto Maliska, Estado e Século, Ob. cit., p. 209.

${ }^{197}$ Pedro B. A. Dallari, Constituição e Relações, Ob. cit., pp. 16-17.
} 
internacionais, na defesa da paz e segurança exteriores e no respeito aos direitos humanos); (iv) uma base antropológica amiga de todos os homens e de todos os povos, a exemplo do compromisso estatal de promover o princípio da dignidade da pessoa humana ${ }^{198}$.

A transposição desses sinais indicativos para o contexto constitucional brasileiro, embora possa ensejar alguma divergência a respeito do grau de abertura da Lei Maior vigente em relação ao Direito Internacional, certifica que, em linhas gerais, esta é a Constituição que mais se ocupou da disciplina da permeabilidade do ordenamento pátrio ao Direito das Gentes. Muitas foram as causas (internas e externas) responsáveis por isso, mas o fato é que a obra do constituinte, ainda que possa ter albergado, na essência, os elementos necessários para enfrentar os desafios ínsitos à aludida abertura, requer o permanente aprimoramento das fórmulas e instrumentos que acomodem as demandas impostas pelas forças internacionais ao Estado nacional ${ }^{199}$. Antes, porém, de adentrar o estudo das normas da Constituição de 1988 que provam a afirmação aqui consignada, convém realizar uma incursão na história do Direito Constitucional brasileiro para traçar, mesmo que superficialmente, a evolução do tratamento das relações internacionais em nossa experiência constitucionalista.

\subsubsection{Breve Histórico das Relações Exteriores no Constitucionalismo Pátrio}

De acordo com HéLÈnE TOURARD,"pode-se classificar os Estados em duas categorias diferentes: os Estados receptivos a esta nova distribuição das tarefas e os Estados que lhe opõem maior resistência. A separação entre essas duas categorias depende claramente da data na qual a Constituição foi redigida. Assim, os Estados que têm uma Constituição relativamente antiga adotam uma atitude desconfiada para com o Direito Internacional e reservam grande liberdade de atuação ao Poder Legislativo interno. As Constituições mais recentes, no entanto, demonstram notável vontade de compatibilizar os

\footnotetext{
${ }^{198}$ Direito Constitucional e, Ob. cit., pp. 368-370.

199 Avulta, nesse ponto, o papel desempenhado pelo método científico-espiritual de hermenêutica constitucional, referido por GILMAR FERREIRA MENDES, INOCÊNCIO MÁRTIRES COELHO e PAUlO GUSTAVO GONET BRANCO por meio da advertência de que o intérprete não encare a Constituição como um momento estático e permanente da vida do Estado, "e sim como algo dinâmico, que se renova continuamente, a compasso das transformações, igualmente constantes, da própria realidade que as suas normas intentam regular" (Curso de Direito Constitucional, $5^{\mathrm{a}}$ ed., São Paulo, Saraiva, 2010, p. 166). Também chancela esse posicionamento MARIA GARCIA, ao enfatizar que a Constituição "deverá permanecer incompleta e inacabada, por ser a vida que pretende formar vida histórica e, enquanto tal, submetida a mudanças históricas. Se a Constituição quer fazer possível a solução das múltiplas situações críticas historicamente mutantes, seu conteúdo terá de permanecer necessariamente 'aberto no tempo" (Fundamentalidade e Direitos Fundamentais: $O \S 2^{\circ}$ do Art. $5^{\circ}$ da CF/1988. Direitos Humanos e Garantias Fundamentais, in Revista de Direito Constitucional e Internacional, nº 67, ano 17, abr./jun. 2009, p. 255).
} 
mandamentos internacionais com as normas nacionais, reconhecendo, de tal sorte, a estreita ligação entre os sistemas jurídicos interno e internacional”200. Essa constatação, mesmo amparada em um desdobramento lógico da evolução do Direito Constitucional e do Direito Internacional, apresenta-se como útil para ajudar a entender por que existe, ao longo do tempo, uma trajetória ascendente no número e na intensidade de previsões constitucionais sobre relações exteriores.

Aprioristicamente, é interessante apresentar os registros genéricos que podem ser depreendidos da análise histórica da temática internacionalista no decorrer das várias Constituições adotadas pelo Brasil. Observa-se que "o Império cuidou da independência e da preservação da unidade nacional e que a República, tendo consolidado as fronteiras nacionais, afirmou a vocação pacífica do país, reconhecendo progressivamente a importância da cooperação internacional para a preservação da paz"201. Já no tocante à dinâmica interna dos tratados e convenções internacionais, JOÃO GRANDINO RODAS assinala que o exame dos textos constitucionais republicanos demonstra "de um lado, a existência de poucos artigos sobre o assunto e, de outro, grande semelhança formal entre os dispositivos das várias Cartas Magnas"202.

Vale esclarecer que, neste Capítulo, terão prioridade as normas constitucionais relacionadas aos aspectos exteriores da unidade nacional, da manutenção da paz e da solução de controvérsias. A opção se justifica porque o Capítulo 4 será integralmente dedicado à aplicação das normas internacionais no Direito brasileiro, o que exigirá uma investigação mais criteriosa acerca da internalização dos tratados, inclusive ao longo das sucessivas Leis Fundamentais que tiveram vigência no país. Visualiza-se, assim, na Constituição do Império de 1824 , já em seu art. $1^{\text {o203 }}$, a acentuada preocupação de zelar pela "manutenção e defesa da sua existência nacional, livre e soberana. Ela confirma esse dever em seu art. 145, chamando todos os brasileiros às armas para sustentar e fazer

\footnotetext{
${ }^{200}$ L'Internationalisation des, Ob. cit., p. 131. No mesmo sentido, PATRICE GÉLARD informa que "raras são as Constituições que não definem o conceito de Estado em vistas do Direito Internacional. A partir dessa afirmação, de respeito ao Direito Internacional Público, iremos ter geralmente nas Constituições modernas, uma definição de relações de Direito Interno com o Direito Internacional, principalmente quanto ao valor dos tratados, das convenções internacionais" (As Transformações do, Ob. cit., pp. 40-41).

${ }^{201}$ Celso Lafer, Prefácio do Livro Constituição e Relações Exteriores de Pedro B. A. Dallari, Ob. cit., pp. XVII-XVIII.

${ }^{202}$ A Constituinte e os Tratados Internacionais, in Direito Internacional Público: Teoria Geral (Coleção Doutrinas Essenciais, vol. 1), Luiz Olavo Baptista e Valerio de Oliveira Mazzuoli (org.), São Paulo, Revista dos Tribunais, 2012, p. 261.

203 “Art. $1^{\circ}$. O Império do Brasil é a associação política de todos os cidadãos brasileiros. Eles formam uma nação livre, e independente, que não admite com qualquer outra laço de união, ou federação, que se oponha à sua Independência”.
} 
respeitar a independência da pátria" ${ }^{204}$. Seja em razão da rudimentar e inexpressiva rede de interações internacionais existente no século XIX, seja por causa da preocupação de evitar o retrocesso quanto à independência recém-conquistada, a primeira Constituição brasileira não continha nenhum dispositivo que permitisse a ativa inserção do Estado nacional no campo das relações exteriores, haja vista que, à época, figurava como "vértice maior da política externa brasileira a afirmação da independência nacional"205.

Não obstante inexistir no Pacto Fundamental de 1824 comandos constitucionais que obrigassem o Brasil a utilizar a arbitragem para resolver seus conflitos no mundo exterior, há indícios de que essa já era uma prática reiterada do Estado nacional. Agreguem-se, nessa direção, as informações colhidas da obra de JoÃo PANDIÁ CAlogeras, as quais certificam que, “com a abdicação de D. Pedro I, o influxo das ideias, dos alvos e da política portuguesa ia ficando atenuado: não seria mais o imperialismo o motor da expansão nacional por territórios estrangeiros. As Regências e D. Pedro II adotavam, como base invariável, de sua ação internacional a norma uti possidetis, para limites, o sentimento fraternal para com as Repúblicas sul-americanas e o arbitramento como remédios para solver todas as questões litigiosas" ${ }^{206}$. Não é demais recordar, nesse contexto, que o envolvimento do Brasil no conflito armado na Bacia do Prata teve como fator determinante a agressiva política externa de Solano López, líder paraguaio que, em 1864, resolveu invadir a Província brasileira do Mato Grosso ${ }^{207}$.

O advento da primeira Constituição Republicana foi crucial para a introdução de importantes diretrizes ao constitucionalismo pátrio que regeriam a atuação externa do Brasil na posteridade. A edição da Lei Maior de 1891 - certamente influenciada pelas incontáveis perdas humanas e econômicas que o país sofreu no quinquênio em que a Guerra do Paraguai se desenvolveu - trouxe a proibição de guerras de conquista (art. 88$)^{208}$ e o estímulo à arbitragem como engenho de solução dos litígios internacionais (art. 34, $\mathrm{n}^{\mathrm{o}}$

\footnotetext{
${ }^{204}$ José Antônio Pimenta Bueno, Direito Público Brasileiro e Análise da Constituição do Império (Coleção Formadores de Opinião), São Paulo, Editora 34, 2002, p. 79. A propósito, o dispositivo aludido preceituava: "Art. 145. Todos os brasileiros são obrigados a pegar em armas, para sustentar a Independência e integridade do Império, e defendê-lo dos seus inimigos externos, ou internos".

${ }^{205}$ Flávia Piovesan, Artigo $4^{\circ}$, in Comentários à Constituição Federal de 1988, Paulo Bonavides, Jorge Miranda e Walber de Moura Agra (coord.), Rio de Janeiro, Forense, 2009, p. 40.

${ }^{206}$ Formação Histórica do Brasil, Rio de Janeiro, Pimenta de Mello \& C., 1930, pp. 401-402.

${ }^{207}$ Para uma visão panorâmica das relações internacionais do Brasil na época em que eclodiu a Guerra do Paraguai, consultar JoÃo DANIEl LIMA DE AlmeIDA, História do Brasil, Brasília, FUNAG, 2013, pp. 237242.

208 “Art. 88. Os Estados Unidos do Brasil, em caso algum, se empenharão em guerra de conquista, direta ou indiretamente, por si ou em aliança com outra nação".
} 
$\left.11^{\circ}\right)^{209}$, refletindo, assim, as salutares influências do republicanismo para a promoção da paz no âmbito externo ${ }^{210}$. Sublinhe-se a ocorrência, nesse período, de um significativo fato histórico notado por WALDEMAR MARTINS FERREIRA: ter sido o Brasil o primeiro país do mundo a inscrever em sua Constituição o princípio de que, sob nenhuma circunstância, se empenharia em guerra de conquista, direta ou indiretamente, por si ou em aliança com outra nação ${ }^{211}$.

Findada a República Velha, a Constituição de 1934, elaborada em momento histórico em que as relações internacionais já tomavam dimensões mais densas ${ }^{212}$, antecedeu aos progressos na ordem internacional no que concerne à proibição do uso da força $^{213}$. Muito antes da vedação geral ao emprego da guerra como meio de solucionar controvérsias entre Estados (o que seria concretizado somente em 1945, a partir da adoção da Carta da ONU) ${ }^{214}$, o art. $4^{\circ}$ da Carta Magna brasileira promulgada em $1934^{215}$ inovou ao estatuir que o Brasil apenas declararia guerra se não coubesse ou malograsse o recurso do arbitramento. Tem-se, desse modo, forte indicativo de que o republicanismo nacional foi decisivo para consolidar o pacifismo como autêntico princípio a guiar a atuação exterior da República Federativa do Brasil em suas mais variadas formas de interação com os sujeitos reconhecidos pelo Direito das Gentes.

209 “Art. 34. Compete privativamente ao Congresso Nacional: [...] 11 ${ }^{\circ}$ ) autorizar o governo a declarar guerra, se não tiver lugar ou malograr-se o recurso do arbitramento, e a fazer a paz".

${ }^{210}$ Cf. Celso LAfer, Prefácio do Livro Constituição e Relações Exteriores de Pedro B. A. Dallari, Ob. cit., p. XVI.

${ }^{211}$ Cf. História do Direito Constitucional Brasileiro, São Paulo, Max Limonad, 1954, p. 205.

${ }^{212}$ PAUlo Borba CASElla esclarece que o marco inicial de uma nova fase das relações e das normas internacionais foi a celebração, em 1919, do Tratado de Versalhes, o qual, a despeito de ter contribuído para a ocorrência da Segunda Guerra Mundial, criou condições para que houvesse o surgimento do "Direito Internacional de cooperação, que sucederia aos séculos precedentes de Direito Internacional de mera coexistência e mútua abstenção" (Tratado de Versalhes na História do Direito Internacional, São Paulo, Quartier Latin, 2007, p. 17).

${ }^{213}$ WaLdemar MARTins FerReira, História do Direito, Ob. cit., p. 205.

${ }^{214}$ No que diz respeito à evolução da proibição da guerra no Direito das Gentes, assevera CELSO D. DE AlBUQUERQUe MELlo que "no século XX passa a existir um repúdio não só à guerra, mas a utilização da força de um modo geral. O Pacto da Liga das Nações não proibiu propriamente o uso da força. Ele apenas obrigava os Estados litigantes a, antes de iniciarem uma guerra, tentarem uma solução pacífica do conflito, sendo o caso submetido a uma decisão arbitral, ou judiciária, ou levada ao Conselho da SDN. A guerra, ou qualquer outra medida coercitiva, só poderia ser iniciada após três meses da decisão arbitral ou judiciária, ou ainda, do relatório do Conselho. É a 'moratória da guerra'. A renúncia à guerra surgiu com o Pacto BriandKellogg, assinado em 1928, em Paris, por quinze Estados, sendo que às vésperas da 2a Guerra Mundial ele contava com 63 Estados. [...] Esse Pacto, apesar da sua grande importância na evolução do DI, contém algumas falhas. Entre elas, podemos mencionar que ele não previu sanções para aqueles que o violassem, bem como não interditou o uso da força, nos casos em que não houvesse guerra. [...] Como se pode verificar, alguns textos anteriores à Carta da ONU não proíbem apenas o recurso à guerra, mas o recurso à força de modo genérico. O Pacto de Briand-Kellogg serviu de base nos julgamentos de Nuremberg e Tóquio para acusar os criminosos de crimes contra a paz" (Curso de Direito Internacional Público, vol. 2, $11^{\mathrm{a}}$ ed., Rio de Janeiro, Renovar, 1997, pp. 1299-1300).

215 “Art. 4․ O Brasil só declarará guerra se não couber ou malograr-se o recurso do arbitramento; e não se empenhará jamais em guerra de conquista, direta ou indiretamente, por si ou em aliança com outra nação". 
A Carta Política de 1937 outorgada em meio à tessitura institucional do Estado Novo significou lamentável irrupção na tendência do constitucionalismo pátrio em primar pelas soluções pacíficas de litígios entre Estados e de proibir explicitamente a realização de guerras de conquista. Os parcos dispositivos constitucionais que cuidam das relações exteriores na referida Constituição retratam o tenso clima político interna $\mathrm{e}$ internacionalmente vivido naquele momento ${ }^{216}$. Cabe consignar que o art. $4^{\mathrm{o}}$ do texto original $^{217}$ continha previsão de que novas porções territoriais poderiam ser acrescidas ao território brasileiro, desde que isso se processasse em consonância com as regras do Direito Internacional; bem como que a Lei Constitucional $\mathrm{n}^{\circ}$ 09/1945 buscou aumentar ainda mais o poder do Chefe do Executivo reformando o art. 75 da Lei Maior ${ }^{218}$ para autorizar que, discricionariamente, essa autoridade decidisse sobre a execução provisória de tratados internacionais antes, entretanto, de submetê-los ao referendo congressual.

Em 1946, o advento da Constituição foi acompanhado do claro resgate da tradição republicana. Trata-se da tendência presente nos textos de 1891 e 1934, contrária às guerras de conquista e favorável à compulsoriedade do emprego da arbitragem e de outros meios pacíficos de solução de conflitos interestatais. As normas agasalhadas nessa Constituição têm notável repercussão no engajamento do Brasil no cenário internacional erigido após o término da Segunda Guerra Mundial, pois essa Lei Maior possibilitou que toda a principiologia republicana referida fosse cristalizada no sistema jurídico pátrio ${ }^{219}$. Um dado que não pode ser ignorado é o de que, ao disciplinar a resolução de controvérsias, a Lei Fundamental referida determinou a cooperação do Brasil com órgão internacional de segurança de que participasse $\left(\operatorname{art} .4^{\circ}\right)^{220}$, o que foi interpretado por CELSO LAFER como ato

\footnotetext{
${ }^{216}$ Cf. Celso Lafer, Prefácio do Livro Constituição e Relações Exteriores de Pedro B. A. Dallari, Ob. cit., p. XVII.

217 “Art. $4^{\circ}$. O território federal compreende os territórios dos Estados e os diretamente administrados pela União, podendo acrescer com novos territórios que a ele venham a incorporar-se por aquisição, conforme as regras do Direito Internacional”.

218 "Art. 75. Compete privativamente ao Presidente da República: [...] r) determinar que entrem provisoriamente em execução, antes de aprovados pelo Parlamento, os tratados ou convenções internacionais, se a isso o aconselharem os interesses do país".

${ }^{219}$ Cf. Waldemar Martins Ferreira, História do Direito, Ob. cit., p. 205. Em igual norte: PaUlo Bonavides, Curso de Direito Constitucional, 25 ed., São Paulo, Malheiros, 2010, p. 47; e FlÁviA Piovesan, Artigo $4^{\circ}$, in Comentários à Constituição Federal de 1988, Paulo Bonavides, Jorge Miranda e Walber de Moura Agra (coord.), Ob. cit., pp. 40-41.

220 “Art. $4^{\circ}$. O Brasil só recorrerá à guerra, se não couber ou se malograr o recurso ao arbitramento ou aos meios pacíficos de solução do conflito, regulados por órgão internacional de segurança, de que participe; e em caso nenhum se empenhará em guerra de conquista, direta ou indiretamente, por si ou em aliança com outro Estado".
} 
de reconhecimento, ainda que implícito, do relevante papel a ser desempenhado pela então recém-criada Organização das Nações Unidas ${ }^{221}$.

No mesmo sentido, os compromissos do Estado nacional em promover a defesa da paz, de repudiar a guerra e de exigir a utilização de meios pacíficos de solução de controvérsias foram reiterados pela Constituição de 1967 (art. $\left.7^{\circ}\right)^{222}$, mandamento que não foi objeto de modificação pela Emenda Constitucional $n^{\circ} 1 / 1969^{223}$. Sobressai a maior amplitude redacional apresentada por essa Constituição, uma vez que são perceptíveis alterações que, sem abandonar os postulados republicanos, fazem transparecer a intenção do constituinte em não deslocar o Estado brasileiro das vertentes que orientavam as ações exteriores. As mudanças verificadas compreendem dois aspectos, conforme indicado a seguir: ( $i$ ) alusão nominal às negociações diretas para resolver litígios que surgissem no terreno das relações exteriores; (ii) previsão de que o Brasil cooperaria com todos os organismos internacionais em que figurasse como parte - e não mais somente com as organizações voltadas à questão da segurança - na obtenção de soluções para eventuais conflitos.

Identificadas as mudanças operadas pelo constituinte de 1967, intenta-se esclarecer quais fatores condicionaram sua ocorrência. Sob essa perspectiva, vale registrar que, ao comentar as prescrições da Carta de 1967, PEDRo B. A. DALlari aduz que a consagração específica das negociações diretas (além dos outros meios já previstos em 1946) como ferramenta para a solução de conflitos internacionais decorreu da intensificação das relações exteriores bilaterais e multilaterais, tendência que, ao que tudo indica, não se desfez com ruptura da ordem jurídica e constitucional em $1964^{224}$. Quanto à maior receptividade da ordem constitucional em prol da atuação das organizações internacionais como instâncias para o apaziguamento de disputas, isso deriva, em grande parte, do fato de

\footnotetext{
${ }^{221}$ Cf. Prefácio do Livro Constituição e Relações Exteriores de Pedro B. A. Dallari, Ob. cit., p. XVII.

222 "Art. $7^{\circ}$. Os conflitos internacionais deverão ser resolvidos por negociações diretas, arbitragem e outros meios pacíficos, com a cooperação dos organismos internacionais de que o Brasil participe. Parágrafo único. É vedada a guerra de conquista".

${ }^{223}$ Convém pontuar a observação de PONTES DE MIRANDA a respeito de uma alteração provocada pela Emenda Constitucional $n^{\circ} 1 / 1969$ a respeito de tema afeito às relações exteriores. Esclarece o autor que, na redação do texto constitucional de 1967, "no então art. 47, parágrafo único, dizia-se que o Poder Executivo tinha o prazo de quinze dias, após a assinatura, para enviar ao Congresso Nacional, 'os tratados celebrados pelo Presidente da República'. O remetente podia ser a Secretaria da Presidência da República, ou o Ministro das Relações Exteriores, ou o corpo ou funcionário público que tivesse tal função. O prazo era preclusivo. Expirado o prazo, só havia, para o Presidente da República, o caminho de assinar outro tratado, para que fosse enviado. A Emenda Constitucional n. 1, de 17 de outubro de 1969, retirou o parágrafo único do então art. 47" (Comentários à Constituição de 1967, Tomo III (Arts. 32-117), 2a ed., São Paulo, Revista dos Tribunais, 1970, pp. 114-115).

${ }^{224}$ Cf. Constituição e Relações, Ob. cit.,pp. 54-55.
} 
que, entre 1946 a 1967, o Brasil aderiu a 18 dessas organizações (número muito representativo, sobretudo quando se toma nota de que, no interregno de 1920 a 1999, o país passou a fazer parte de um total de 40 desses organismos de cooperação internacional) ${ }^{225}$.

Interessa ainda mencionar a exegese feita por MANOEL GonÇALVES FERREIRA FILHO a respeito da extensão do disposto no art. $7^{\circ}$ da Lei Maior de 1967. Trata-se da percepção de que, embora esta Constituição tenha repetido os propósitos pacifistas da tradição nacional, o texto confeccionado acabou se afastando da orientação enunciada no Pacto Republicano de 1946. Por meio do cotejo entre ambos os textos constitucionais mencionados, conforme expõe o autor, é possível depreender que a Constituição de 1967 não mais exigiria que o país, primeiro, recorresse aos meios pacíficos de solução de conflitos internacionais para, apenas num segundo momento, restando infrutíferos esses meios, a guerra se tornasse uma opção válida. A técnica constitucional adotada na década de 1960 teria como fulcro a ideia de que não mais seria necessário aguardar o insucesso dos mecanismos pacíficos de solução para que se decidisse empregar a força nas relações exteriores $^{226}$.

Embora seja indiscutível a importância acadêmica do posicionamento tomado por FERREIRA FILHO, principalmente quando se recorda do momento histórico no qual os comentários foram tecidos, cumpre reconhecer que esse ponto de vista acabou sendo infirmado pelas práticas adotadas pelo governo brasileiro para conduzir seus negócios exteriores durante os anos de vigência da Lei Maior de 1967. Ademais, vale assinalar que, se o país tivesse abraçado a interpretação aqui analisada, teria incorrido em patente contrariedade ao disposto na Carta de São Francisco, documento que, além de criar as Nações Unidas em 1945, também se encarregou, a teor do que estabelece seu art. $2^{\circ}$, $\S$ $4^{\text {o227 }}$, da proscrição da guerra e de fenômenos variantes. Também restaria configurado lamentável retrocesso político e jurídico, pois o Estado entraria na contramão das práticas de composição das dissensões exteriores e, ainda, no desvio de sua trajetória histórica de cooperar com organismos internacionais de segurança.

${ }^{225}$ Cf. Ricardo Seitenfus,Manual das Organizações Internacionais, $5^{\text {a }}$ ed., Porto Alegre, Livraria do Advogado, 2008, pp. 365-366.

${ }^{226}$ Comentários à Constituição Brasileira, $6^{a}$ ed., São Paulo, Saraiva, 1986, pp. 66-67.

227 "Art. $2^{\circ}$. [...] $\S 4^{\circ}$. Os membros deverão abster-se nas suas relações internacionais de recorrer à ameaça ou ao uso da força, quer seja contra a integridade territorial ou a independência política de um Estado, quer seja de qualquer outro modo incompatível com os objetivos das Nações Unidas". 
Todo esse percurso trilhado pelo constitucionalismo tem seu auge com a promulgação da Constituição Federal de 1988, muito em virtude da onda redemocratizante que tomou conta do cenário nacional após a derrocada do regime político implantado em 1964. Para além da manutenção da antiga preocupação vivida no Império acerca da independência nacional e da não intervenção, endossaram-se os ideais republicanos voltados à defesa da paz e à solução pacífica das controvérsias, tendo sido ainda consagradas extraordinárias inovações no plano das relações internacionais. Com efeito, texto constitucional vigente realçou uma orientação internacionalista jamais vista em nosso constitucionalismo, o que se traduz na adoção dos princípios da prevalência dos direitos humanos, da autodeterminação dos povos, do repúdio ao terrorismo e ao racismo, e da cooperação entre os povos para o progresso da humanidade e da concessão de asilo político (art. $4^{\circ}$, incisos II, III, VIII, IX e X) ${ }^{228}$ como autênticos guias das ações concluídas pelo Brasil, seja na esfera interna ou externa, e que causem algum impacto internacional ${ }^{229}$.

Sem dúvida, as contribuições aportadas ao universo das relações exteriores com a formulação e a consolidação da atual ordem constitucional não se esgotam nos pontos assinalados acima. Justamente por esse motivo, após ter sido apresentada uma visão geral da temática ao longo das Constituições nacionais que já vigeram no país, faz-se necessário apreciar com maior detalhamento as normas constantes na Lei Maior atual - inclusive aquelas introduzidas no sistema constitucional mediante reforma - para que se possa ter uma noção confiável da dimensão da abertura ao Direito Internacional permitida pela Constituição. Para tanto, identificar-se-ão os mandamentos constitucionais que viabilizam a inclusão do Brasil na sociedade internacional, mediante o mapeamento das principais normas, competências, objetivos e conteúdos típicos do Direito das Gentes que já se encontram amalgamados aos preceitos da Magna Carta, modelando o Estado nacional em sintonia com normas que, inicialmente, se impuseram no terreno do internacionalismo.

\footnotetext{
228 “Art. 4 $4^{\text {A }}$ República Federativa do Brasil rege-se nas suas relações internacionais pelos seguintes princípios: [...] II - prevalência dos direitos humanos; III - autodeterminação dos povos; [...] VIII - repúdio ao terrorismo e ao racismo; IX - cooperação entre os povos para o progresso da humanidade; X - concessão de asilo político".

${ }^{229}$ Cf. Flávia Piovesan, Artigo $4^{\circ}$, in Comentários à Constituição Federal de 1988, Paulo Bonavides, Jorge Miranda e Walber de Moura Agra (coord.), Rio de Janeiro, Forense, 2009, p. 41.
} 


\subsection{O Tratamento da Questão Internacional na Constituição de 1988}

Do sucinto escorço histórico apresentado, depreende-se que o tema das relações internacionais sempre esteve presente nos textos constitucionais brasileiros. Ao analisar a temática, CARMen Tiburcio e Luís Roberto BARroso sentenciam "que os dispositivos encontrados até 1988 são frutos antes de fatores pontuais do que da preocupação do constituinte em regulamentar e estabelecer fins para as relações exteriores do país. Ademais, é visível a vagarosidade com a qual as sucessivas Constituições incorporaram novos princípios" ${ }^{230}$. Também ganha destaque, nessa matéria, a conclusão de CELSO Ribeiro Bastos e IVEs Gandra Martins no sentido de que "o nosso Direito anterior era silente sobre a exata inserção do Brasil no contexto do Direito Internacional" ${ }^{, 231}$, o que pode ser a principal causa da crônica escassez doutrinária sobre o assunto entre os constitucionalistas pátrios.

$\mathrm{O}$ acentuado laconismo no tratamento que as Constituições brasileiras reservam às relações exteriores permite extrair, pelo menos, duas outras conclusões. A primeira é a de que, em perspectiva centrada exclusivamente na comparação com as pretéritas Leis Fundamentais do país, o texto promulgado em 1988 trouxe, de fato, relevantes progressos às relações exteriores, pois inaugurou mandamentos que orientam a atuação dos poderes estatais sobre a matéria e, sobretudo, enalteceu o papel dos direitos humanos. O segundo ponto que se infere decorre da inevitável comparação da Constituição nacional a Constituições estrangeiras, o que, não raro, resulta em argumentos de que o constituinte brasileiro atuou timidamente, deixando de solucionar tormentosas questões para a condução dos assuntos internacionais (que, inclusive, já eram conhecidas do meio jurídico nacional em 1987-1988), a exemplo da hierarquia dos tratados incorporados ao ordenamento interno.

Nesse compasso, Paulo Roberto de Almeida, depois de analisar a redação empregada no texto constitucional de 1988, enfatiza que as disposições jurídicas referentes à condução e à implementação das relações exteriores comparecem de forma bastante discreta na versão promulgada. Isso torna a concisão normativa, refletida nessa escassa presença terminológica, dado que se sobreleva como primeira constatação da análise empreendida. Consoante o autor, o assunto foi disciplinado esparsamente, por comandos principiológicos destinados a guiar as relações internacionais e mediante menções à

\footnotetext{
${ }^{230}$ Direito Constitucional Internacional, Rio de Janeiro, Renovar, 2013, p. 7.

${ }^{231}$ Comentários à Constituição do Brasil (Promulgada em 5 de Outubro de 1988), vol. 1: PréConstitucionalismo. O Estado. Constituição. Arts. $1^{o}$ ao $4^{o}$, São Paulo, Saraiva, 1988, p. 450.
} 
expressão tratados internacionais com vistas a fixar as competências atribuídas aos Poderes Legislativo, Executivo e Judiciário. As razões indicadas para o aparente acanhamento do constituinte sobre a matéria seriam a especificidade do tema e seu reduzido impacto em termos de realizações concretas ${ }^{232}$.

Ainda que haja muito de verdade na afirmação de que as questões internacionais “ingressam na história constitucional brasileira como preocupação secundária, subordinada a interesses circunstanciais do país" ${ }^{\text {233 }}$, parece insustentável desacreditar na intenção do constituinte de alinhavar o Estado à tendência de internacionalização das Constituições contemporâneas. Pode ser que a técnica empregada para essa finalidade não tenha sido a mais perfeita, já que alguns aspectos muito importantes sobre a matéria ficaram sem respostas explícitas no texto constitucional, mas isso não pode servir de pretexto para usar a Lei Maior para impedir a acomodação dos interesses que conduzem à aproximação entre as ordens jurídicas nacional e internacional. Os desdobramentos subsequentes à promulgação do texto constitucional provam essa percepção, até porque a expressiva atividade do constituinte derivado reformador e da jurisprudência do Supremo Tribunal Federal com vistas a estimular o engajamento do Brasil nas relações exteriores evidenciam essa diretriz.

Na medida em que a Constituição passa a justificar as ações internacionais das autoridades nacionais, a ideia de que "os Estados que participam de uma negociação devem estar conscientes dos respectivos dispositivos constitucionais e tomar as medidas necessárias para que não sejam ignorados os preceitos estabelecidos nos tratados"234 adquire força e contribui decisivamente para a construção de institutos jurídicos que fomentam o diálogo entre o Direito Interno e o Direito Internacional. Grife-se, ainda, que, depois de 1988, o Brasil reconheceu a jurisdição de várias instâncias internacionais de controle, como a Corte Interamericana de Direitos Humanos, o Tribunal Penal Internacional, Comitês diversos de tratados internacionais de direitos humanos, o Órgão de Solução de Controvérsias da Organização Mundial do Comércio, o Tribunal Permanente de Revisão do Mercosul, o que representa prova irrefutável dos sensíveis avanços que a

${ }^{232}$ Cf. As Relações Internacionais na Ordem Constitucional, in Revista de Informação Legislativa, $\mathrm{n}^{\mathrm{o}} 101$, ano 26, jan./mar. 1989, pp. 50-51.

${ }^{233}$ Carmen Tiburcio e Luís Roberto Barroso,Direito Constitucional Internacional, Rio de Janeiro, Renovar, 2013, pp. 7-8.

234 PaUlo Hamilton SIQUeIRA JÚNIOR, Tratados Internacionais de Direitos Humanos, in Direito Internacional: Direito Internacional dos Direitos Humanos (Coleção Doutrinas Essenciais, vol. 3), Luiz Olavo Baptista e Valerio de Oliveira Mazzuoli (org.), São Paulo, Revista dos Tribunais, 2012, p. 515. 
matéria alcançou ${ }^{235}$. Tudo isso pode ser considerado como sólidos indicativos da predisposição de o Estado brasileiro se engajar continuamente no ambiente externo, sem, no entanto, fazer com que isso determine o enfraquecimento de sua Constituição, a qual é uma imprescindível ferramenta para justificar, ao menos na esfera do Direito Público Interno, todas as ações e medidas adotados pelo país nessa órbita.

Confere crédito a esse ponto de vista a observação lançada por PETER HÄBERLE de que "o Estado Constitucional Cooperativo ainda não é um objetivo alcançado, ele se encontra 'a caminho'. Objetivo dessas linhas é conduzi-lo (e mantê-lo) adiante no caminho, torná-lo 'possibilidade' para a 'realidade",236. Nessa senda, é possível inferir que a irreversibilidade do tratamento constitucional da matéria de relações exteriores implica, por certo, a inevitabilidade de introduzir na Constituição brasileira - à semelhança do que vem ocorrendo com outros sistemas constitucionais - os temas internacionais que forem sendo realçados em virtude do acentuado desenvolvimento da integração entre os Estados soberanos $^{237}$. É, sob essa alentadora e desafiante perspectiva, que se inicia a análise das normas plasmadas na Constituição de 1988 responsáveis por exprimirem maior significado para o desenvolvimento das relações exteriores. Cumpre, desde já, advertir que os capítulos seguintes deverão ser considerados como complementares a este, pois especificam as implicações decorrentes da permeabilidade do Direito Constitucional ao Direito das Gentes nos campos da separação dos poderes, da aplicação das normas internacionais pelas autoridades pátrias e da forma federativa de Estado.

\subsubsection{A Inovação Oriunda da Positivação dos Princípios Constitucionais das Relações Internacionais}

Proclamado como o preceito mais representativo de quão amistosa a Constituição brasileira é para com o mundo externo, o art. $4^{\circ}$, segundo a concepção de CELSO LAFER, certifica a eleição da "abertura ao Direito Internacional como uma das dimensões caracterizadoras do Estado Democrático de Direito"238. Inspirado no art. $7^{\circ}$ da Constituição

\footnotetext{
${ }^{235}$ Cf. André de Carvalho Ramos, A Interpretação Internacional dos Direitos Humanos: Choque ou Diálogo com o Supremo Tribunal Federal, in Novos Caminhos do Direito no Século XXI: Direito Internacional, Filosofia Jurídica e Política, Dogmática Jurídica e Direitos Fundamentais: Uma Homenagem a Celso Lafer, $2^{\mathrm{a}}$ ed., Luiz Olavo Baptista e Tercio Sampaio Ferraz Junior (coord.), Curitiba, Juruá, 2013, p. 313.

${ }^{236}$ Estado Constitucional Cooperativo, Ob. cit., p. 70.

${ }^{237}$ Cf. Pedro B. A. Dallari, Constituição e Relações, Ob. cit., p. 201.

${ }^{238}$ A Internacionalização dos, Ob. cit., p. 14. Com efeito, o autor proclama que "o art. $4^{\circ}$ da Constituição de 1988 é indicativo desta abertura, pois os princípios nele positivados estão próximos dos que basicamente regem, de acordo com o Direito Internacional Público, ex vi do art. $2^{\circ}$ da Carta da ONU, a comunidade
} 
portuguesa de $1976^{239}$, esse dispositivo foi recebido como um progresso sem precedentes nos textos constitucionais anteriores, tendo em vista que nunca antes o constitucionalismo brasileiro tinha contado com a "sistematização de paradigmas que devem reger as relações exteriores do Brasil” ${ }^{240}$. É importante, assim, que a interpretação do dispositivo constitucional em comento seja empreendida com base na ideia de que a Lei Maior não pode ser compreendida em sua integridade por meio de técnicas de hermenêutica que a isolem das demais ordens jurídicas, porquanto o Direito Constitucional "não funciona como um recipiente hermético, mas nutre-se do contato renovado e reafirmado incessantemente com outras disciplinas, jurídicas ou não"241.

Em franca reafirmação da axiologia instituída em seu Preâmbulo, o art. $4^{\circ}$ do Pacto Fundamental de 1988 delineia os parâmetros que o Brasil deverá primar, interna e internacionalmente, pela busca de soluções pacíficas de suas controvérsias. Em verdade, os incisos desse dispositivo especificam quais vetores irão nortear o desempenho das atividades exteriores e as ações governamentais domésticas que forem efetivadas pelo Estado. Reflete-se, pois, a clara preocupação do constituinte originário em não impor obstáculos à adoção pelo Brasil dos mandamentos de matriz internacional responsáveis por assegurar a coexistência e a cooperação entre soberanias e por orientar o surgimento de regras comuns para a convivência harmônica entre os povos. Interessa esclarecer, nesse

internacional. [...] O art. $4^{\circ}$ aponta, assim, para a complementariedade entre o Direito Internacional Público e indica a irradiação de conceitos elaborados no âmbito do Direito das Gentes no plano do Direito Público Interno" (Ibidem).

239 “Art. $7^{\circ}$. Relações Internacionais. 1. Portugal rege-se nas relações internacionais pelos princípios da independência nacional, do respeito dos direitos do homem, dos direitos dos povos, da igualdade entre os Estados, da solução pacífica dos conflitos internacionais, da não ingerência nos assuntos internos dos outros Estados e da cooperação com todos os outros povos para a emancipação e o progresso da humanidade. 2. Portugal preconiza a abolição do imperialismo, do colonialismo e de quaisquer outras formas de agressão, domínio e exploração nas relações entre os povos, bem como o desarmamento geral, simultâneo e controlado, a dissolução dos blocos político-militares e o estabelecimento de um sistema de segurança coletiva, com vista à criação de uma ordem internacional capaz de assegurar a paz e a justiça nas relações entre os povos.3. Portugal reconhece o direito dos povos à autodeterminação e independência e ao desenvolvimento, bem como o direito à insurreição contra todas as formas de opressão. 4. Portugal mantém laços privilegiados de amizade e cooperação com os países de língua portuguesa.5. Portugal empenha-se no reforço da identidade europeia e no fortalecimento da ação dos Estados europeus a favor da democracia, da paz, do progresso económico e da justiça nas relações entre os povos.6. Portugal pode, em condições de reciprocidade, com respeito pelos princípios fundamentais do Estado de direito democrático e pelo princípio da subsidiariedade e tendo em vista a realização da coesão econômica, social e territorial, de um espaço de liberdade, segurança e justiça e a definição e execução de uma política externa, de segurança e de defesa comuns, convencionar o exercício, em comum, em cooperação ou pelas instituições da União, dos poderes necessários à construção e aprofundamento da união europeia.7. Portugal pode, tendo em vista a realização de uma justiça internacional que promova o respeito pelos direitos da pessoa humana e dos povos, aceitar a jurisdição do Tribunal Penal Internacional, nas condições de complementaridade e demais termos estabelecidos no Estatuto de Roma".

${ }^{240}$ Pedro B. A. Dallari, Constituição e Relações, Ob. cit., p. 153.

${ }^{241}$ YASMine El Boustani-BeAUVINON, Externalisation ou Circulation $d u$ Droit Constitutionnel?, in Politeia, no 22, dez. 2012, p. 497. 
assunto, que a concretização da inevitável integração sistêmica não implica a supressão das identidades nacionais, pois o fortalecimento de uma ordem global democrática, ao contrário, promoverá a preservação da diversidade que desponta entre os vários elementos formadores da sociedade internacional ${ }^{242}$.

Não é absurdo enxergar nos princípios constitucionais que regem as relações internacionais o mesmo propósito que levou a Constituição da República Federal Alemã de 1949 a prever uma "cláusula constitucional aberta" em seu art. 24, n $1^{243}$. Ainda que o texto constitucional brasileiro tenha sido confeccionado com redação menos explícita acerca do tema, as ponderações feitas por MARIA GARCIA no que concerne à extensão da sobredita prescrição constitucional germânica são passíveis de aproveitamento na definição da razão de ser do art. $4^{\circ}$ de nossa Constituição. A propósito, consignou a estudiosa que o comando destacado encerra "cláusula possibilitadora de um elo permanente (ainda que não definitivo) entre a ordem interna (soberania) e a ordem externa, permitindo canais de comunicação e consenso determinantes de práticas diretas e imediatas, em determinadas circunstâncias" 244 .

Outro dado que deve ser devidamente esclarecido é a constatação de que, "ao estabelecer diretrizes e linhas básicas, a Constituição não detém a pretensão da completude. A incompletude da Carta aponta para sua abertura, o que permite a flexibilidade necessária ao contínuo desenvolvimento político" ${ }^{, 245}$. Sob esse influxo, cabe amainar, portanto, eventuais ambiguidades que identificadas na atividade de interpretação dos incisos arrolados no art. $4^{\circ}$ da Carta Magna, como aquela notada por MANOEL GonÇALVES FERREIRA FILHO, sob a forma de aspirações nitidamente divergentes, e que contrapõe, de um lado, uma vertente nacionalista apegada às ideias de independência nacional (inciso I), de não intervenção (inciso II), de igualdade entre os Estados (inciso V); e, de outra banda, um impulso internacionalista, consistente no enaltecimento da prevalência dos direitos humanos (inciso II), da autodeterminação dos povos (inciso III), do repúdio ao terrorismo e ao racismo (inciso VIII) ${ }^{246}$.

Tudo isso aponta para não mais ser possível ignorar "a superposição de normas nacionais, regionais e mundiais, nem a abundância de instituições e de juízes nacionais e

${ }^{242}$ Cf. Marcos Augusto Maliska, Estado e Século, Ob. cit., p. 206.

243 "Art. 24. [...]. 1. A Federação pode transferir direitos de soberania para organizações interestatais, por meio de lei".

${ }^{244}$ Limites da Ciência: A Dignidade da Pessoa Humana: A Ética da Responsabilidade, São Paulo, Revista dos Tribunais, 2004, p. 314.

${ }^{245}$ Flávia Piovesan, Direitos Humanos e o Direito, Ob. cit., p. 56.

${ }^{246}$ Cf. Comentários à Constituição Brasileira de 1988, Vol. 1, 2 ${ }^{\mathrm{a}}$ ed., São Paulo, Saraiva, 1997, p. 21. 
internacionais, com competências aumentadas. Essas novas realidades fazem com que o Direito evolua na direção de sistemas interativos, complexos e fortemente instáveis. Mais do que um defeito do Direito, esse dado reflete, talvez, uma mutação, uma transformação da própria concepção de ordem jurídica" ${ }^{247}$. Tem-se, portanto, que a Constituição brasileira não é avessa aos valores cultuados pela sociedade internacional, os quais se apresentam sob a égide de princípios jurídicos que vinculam, indistintamente, todos os Poderes constituídos do Estado nacional. Lembre-se, por oportuno, que os princípios "exercem uma ação imediata enquanto diretamente aplicáveis ou diretamente capazes de conformar as relações político-constitucionais. E exercem também uma ação mediata tanto num plano integrativo e construtivo como num plano essencialmente prospectivo" ${ }^{248}$.

Impende, nesse compasso, acreditar que os princípios consignados pelo art. $4^{\circ}$ da Lei Maior se dirigem aos órgãos públicos e entidades administrativas em geral, sendo irrelevante o fato de estarem alocados no campo estrutural do Poder Executivo, Legislativo ou Judiciário. Embora o compartilhamento de competências para a prática das mais diversas ações ligadas às relações internacionais figure como tema central do próximo Capítulo deste trabalho, é preciso antecipar a concepção de corresponsabilidade entre as instituições nacionais para desmistificar a posição seguida por parcela da doutrina. Sob essa orientação, encontra-se, por exemplo, MARCO ANTÔNIO CORRÊA MONTEIRO, defensor da ideia de que a incidência das prescrições do art. $4^{\circ}$ da Constituição pesa "mais diretamente sobre o Presidente da República, a quem o texto constitucional, em seu art. 84, VII, determinou 'manter relações com Estados estrangeiros e acreditar seus representantes diplomáticos" "249 . No fundo, a noção aqui esgrimida é a de que o constitucionalismo pátrio buscou efetivamente abandonar os escudos (muito usuais no passado) contra o que é visto como intrusão do Direito Internacional no ordenamento doméstico, sem, no entanto, ocasionar a perda das prerrogativas estatais soberanas que são próprias da independência nacional.

Como "decisões políticas fundamentais concretizadas em normas conformadoras do sistema constitucional positivo" ${ }^{, 250}$, os princípios que regem as relações internacionais assumem, ainda, o contorno de típicas normas promocionais, de modo a corporificarem

\footnotetext{
${ }^{247}$ Mireille Delmas-Marty, Études Juridiques Comparatives, Ob. cit., p. 13.

${ }^{248}$ Jorge Miranda, Manual de Direito Constitucional - Tomo II: Constituição, $6{ }^{\mathrm{a}}$ ed., Coimbra, Coimbra Editora, 2007, p. 267.

${ }^{249}$ Tratados Internacionais de, Ob. cit., p. 97.

${ }^{250}$ José Afonso DA Silva, Curso de Direito Constitucional Positivo, 32a ed., São Paulo, Malheiros, 2009 , p. 93.
} 
instrumentos indutores de mudanças e transformações na sociedade, o que, por óbvio, exige que sua concretização aconteça pela atuação concertada de todas as instâncias do poder estatal ${ }^{251}$. Em virtude dessa percepção, aporta-se como razoável a proposta que vislumbra a aplicação dos fundamentos e objetivos fundamentais da República Federativa do Brasil - definidos, respectivamente, pelos art. $1^{0^{252}}$ e art. $3^{0253}$ da Lei Maior - tanto nas relações domésticas quanto nas relações exteriores, sob pena de violação de todo o arcabouço constitucional engendrado na Constituição ${ }^{254}$. Nesse quadrante, os valores jurídicos da dignidade, justiça, liberdade, igualdade e solidariedade projetam-se também sobre as relações exteriores, e, mesmo não literalmente elencados no art. $4^{\mathrm{o}}$ da Lei Fundamental, devem ser adotados como pontos cardeais nesse campo de atuação estatal ${ }^{255}$.

Para fortalecer essas impressões, basta imaginar o quão relevante o princípio da prevalência dos direitos humanos apresenta-se hoje para o tema da organização dos Poderes na Constituição. Por oportuno, AlBerto do AmARAL JÚNior e LiLianA LYRA JUBILUT preconizam que a efetividade da proteção interna das normas internacionais de direitos humanos deve-se materializar "a partir de uma perspectiva ampla, uma vez que as três esferas de poder têm atribuições nessa área. Ou seja, de modo simplificado, pode-se aferir que o Executivo - ao assinar tratados internacionais acerca da matéria e atuar mediante a execução de políticas públicas -, o Legislativo - ao aprovar os tratados assinados e ao criar leis internas (que podem ou não se adequar à normativa internacional e, desta forma, podem ensejar violação do Direito Internacional no caso da não adequação)

\footnotetext{
${ }^{251}$ Fundada na teoria de NORBERTO BOBBIO, projeta-se a noção de que as normas promocionais trazem em seu bojo prescrições de encorajamento a fim de fomentar condutas sociais devidas, o que, quando é voluntariamente acatado por seus destinatários, permite obter uma sanção premial perante o Poder Público que editou esse comando. Além disso, interessa admitir que as normas promocionais ensejam substanciais alterações no meio social, visto que, nos termos registrados por BoBBIo, "é notória a importância que têm, para uma análise funcional da sociedade, as categorias de conservação e da mudança. Considerando agora as medidas de desencorajamento e as de encorajamento de um ponto de vista funcional, o essencial a se destacar é que as primeiras são utilizadas predominantemente com o objetivo da conservação social e as segundas, com o objetivo da mudança" (Da Estrutura à Função: Novos Estudos de Teoria do Direito, Barueri, Manole, 2007, p. 19).

252 “Art. 1'. A República Federativa do Brasil, formada pela união indissolúvel dos Estados e Municípios e do Distrito Federal, constitui-se em Estado Democrático de Direito e tem como fundamentos: I - a soberania; II - a cidadania; III - a dignidade da pessoa humana; IV - os valores sociais do trabalho e da livre iniciativa; V - o pluralismo político".

253 “Art. 3". Constituem objetivos fundamentais da República Federativa do Brasil: I - construir uma sociedade livre, justa e solidária; II - garantir o desenvolvimento nacional; III - erradicar a pobreza e a marginalização e reduzir as desigualdades sociais e regionais; IV - promover o bem de todos, sem preconceitos de origem, raça, sexo, cor, idade e quaisquer outras formas de discriminação".

${ }^{254}$ Cf. MAURILIo CASAS MAIA, A Cooperação Solidária e a Desigualdade Compensadora como Mandamento Constitucional Brasileiro e Imperativo do Direito Internacional do Desenvolvimento, in Revista de Direito Constitucional e Internacional, ano 20, vol. 79, abr./jun. 2012, p. 338.

${ }^{255}$ Idem, ibidem.
} 
- e o Judiciário - ao assegurar a efetividade do cumprimento das normas -, atuam de modo a efetivar as obrigações internacionais assumidas pelo Brasil",256.

Especialmente no que diz respeito à proteção da pessoa humana é possível vislumbrar um quadro em que os direitos internacionalmente consagrados desempenham um efeito prismático, isto é, projetam-se em feixes de valores consagrados pela comunidade, os quais imantam os princípios e regras integradores do sistema constitucional, estendendo-se até o último dos seus dispositivos ${ }^{257}$. Em complemento, CELSO LAFER atenta que a "interpretação e aplicação dos princípios do art. $4^{\circ}$, tem, além de sua dimensão jurídica, uma nítida dimensão política que o diferencia de outros princípios gerais positivados pela Constituição de 1988. Com efeito, os preceitos do art. $4^{\circ}$ referem-se à realidade internacional e não à ordem interna. Por isso, na sua aplicação, é necessário ter sempre presente o ângulo externo, ou seja, os fatos e os valores presentes em cada situação concreta, em função da descentralização do poder no sistema internacional, que torna a correspondência entre as normas e a realidade internacional sempre problemática"258.

Por derradeiro, é oportuno sublinhar que, apesar da importância de cada um dos princípios listados no rol do art. $4^{\mathrm{o}}$ da Lei Maior, a presente tese não tem o escopo de definir a amplitude desses mandamentos constitucionais, motivo pelo qual não serão tecidas considerações nesse sentido. $\mathrm{O}$ que se pretende, de fato, é situar a elevada função reservada a essas normas na estruturação do Estado nacional e no desenvolvimento das tarefas que o texto constitucional repartiu entre os órgãos estatais. Em outras palavras, buscou-se assentar a diretriz de que a redemocratização do Brasil provocou alterações que suplantam a indiscutível participação popular na definição dos rumos da política do país e o valor angular atribuído aos direitos humanos para pautar as deliberações do Poder Público. A adoção de uma Constituição que consagra preceitos como os princípios em análise também significou a implantação de um sistema constitucional aberto, por meio do qual o Brasil se mostra receptivo às influências externas e habilitado a agregar à ordem

\footnotetext{
${ }^{256}$ O Direito Internacional dos Direitos Humanos e o Supremo Tribunal Federal, in $O$ STF e o Direito Internacional dos Direitos Humanos, Alberto do Amaral Júnior e Liliana Lyra Jubilut (org.), São Paulo, Quartier Latin, 2009, p. 38.

${ }^{257}$ Cf. Maria Garcia, O Efeito Prismático dos Direitos Humanos: A Expressão Circular do Homem Vitruviano e os Direitos Humanos das Vitimas, in Revista Mestrado em Direito, $\mathrm{n}^{\mathrm{o}}$ 1, ano 8, jan./ jun. 2008, p. 260.

${ }^{258}$ A Internacionalização dos, Ob. cit., p. 28.
} 
jurídica nacional mandamentos internacionais indispensáveis para que a arquitetura idealizada pelo constituinte alcance sua plenitude ${ }^{259}$.

\subsubsection{Integração Econômica, Politica, Social e Cultural dos Povos da América Latina}

\section{e a Afirmação Institucional do Mercosul}

$\mathrm{Na}$ América Latina, o movimento generalizado de mudanças em prol da democracia criou condições propícias à efetivação de processos de integração internacional, que, entre outros eventos, levaram à formação do Mercosul em 1991 com a elaboração do Tratado de Assunção. Inicialmente criado, em 1994, apenas com característica de zona de livre comércio e de união aduaneira, para as quais se associaram Brasil, Argentina, Uruguai e Paraguai, o advento do Protocolo de Ouro Preto converteu-o em uma organização internacional voltada à integração econômica, social, política e cultural da região. Resultaram dessa mudança no perfil institucional do bloco transformações mais profundas na execução das relações exteriores pelos Estados envolvidos, o que torna patente que, caso não existisse no atual constitucionalismo latinoamericano uma tendência de aproximação entre os universos governamentais interno e externo, dificilmente o Mercosul teria se tornado realidade, mesmo refletindo um processo de integração regional muito mais tímido do que o vivenciado na Europa ${ }^{260}$.

Nessa perspectiva de adensamento no processo integracionista, a norma do parágrafo único do art. $4^{\circ}$ da Constituição de $1988^{261}$ tem proeminência na participação do Estado brasileiro na integração regional operada com o surgimento de estruturas

\footnotetext{
${ }^{259}$ Corrobora esse ponto de vista ANDRÉ RAMOS TAVARES, cuja lição prega que "o sistema constitucional, contudo, não é definitivo, fechado, pois se encontra em constante evolução, tendo em vista o contato com a realidade social, o que ocorre especialmente pelos valores albergados constitucionalmente" (Principios Fundamentais na Constituição de 1988: Estudo de sua Evolução em 20 anos, in Constituição Federal: Avanços, Contribuições e Modificações no Processo Democrático Brasileiro, Ives Gandra Martins e Francisco Rezek (coord.), São Paulo, Revista dos Tribunais e Centro de Extensão Universitária (CEU), 2008, p. 14)

${ }^{260}$ Cf. Pedro B. A. Dallari, Constituição e Tratados, Ob. cit.,p. 25. Em abono, esclarece AlBerto DO AMARAL JÚNIOR que "a criação do Mercosul não pode ser imaginada fora dos marcos jurídicos e políticos surgidos com a redemocratização dos países latino-americanos. A complexidade da criação de um Mercado Comum entre economias com características diversas exige negociação contínua e capacidade de diálogo. A discussão em torno da institucionalidade e da elaboração dos macromodelos jurídicos do Mercosul não se pode restringir às esferas governamentais" (As Instituições do Mercosul, in Direito Internacional: Direito Internacional dos Direitos Humanos (Coleção Doutrinas Essenciais, vol. 3), Luiz Olavo Baptista e Valerio de Oliveira Mazzuoli (org.), São Paulo, Revista dos Tribunais, 2012, p. 438).

261 “Art. $4^{\circ}$. [...] Parágrafo único. A República Federativa do Brasil buscará a integração econômica, política, social e cultural dos povos da América Latina, visando à formação de uma comunidade latino-americana de nações".
} 
internacionais. Não obstante sua natureza programática ${ }^{262}$, coube a esse comando constitucional justificar, perante a ordem interna, os esforços governamentais realizados pelo país para viabilizar não somente a criação, mas também o desenvolvimento da normativa e dos órgãos integrantes do Mercado Comum do Sul. Assim, consoante destaca MARIA GARCIA, visualiza-se no Mercosul um importante mecanismo adotado para potencializar a construção de uma ordem internacional baseada no consenso e na cooperação $^{263}$.

A análise do preceito constitucional em destaque consubstancia-se em norma-fim, uma vez que "não expressa um suporte fático, extrafinalístico, que atue como seu pressuposto de aplicabilidade. Nele caracteriza-se a finalidade buscada pela normaprincípio: integração econômica, política, social e cultural da República Federativa do Brasil na comunidade latino-americana de nações - por exemplo, o Mercosul ou organismo internacional que o substitua, com mais avançado grau de integração comunitária" ${ }^{264}$. Sob esse enfoque, cabe reconhecer que o mandamento insculpido no texto constitucional somente "predetermina a integração latino-americana como um fim alvejado pela Federação brasileira, sem a indicação dos meios para obtê-lo, quaisquer meios para esse desiderato estão autorizados constitucionalmente. Assim, são autorizados tratados internacionais, como o Tratado de Assunção, protocolos internacionais, como o de Ouro Preto, leis internas que, à base da reciprocidade, isentem as importações e exportações" 265 .

É importante advertir que os Estados envolvidos no projeto do Mercado Comum do Sul não acolheram, sob nenhuma forma, a estrutura da supranacionalidade, haja vista a natureza de organismo intergovernamental que caracteriza o bloco regional. Esse dado é de alta relevância porque afasta da órbita do Mercosul a ideia de que haveria um verdadeiro Direito Comunitário sendo produzido nas instâncias intergovernamentais encarregadas de fomentar a integração no Cone Sul. Desse modo, tem-se que as normas provenientes dos órgãos regionais ou de entendimentos entre Estados-partes do Mercosul constituem "uma ordem jurídica particular de Direito Internacional Público (DIP). Tal ordem pode ser

\footnotetext{
${ }^{262} \mathrm{O}$ caráter programático desse dispositivo ficou assentado no seguinte acórdão julgado pelo STF: CR n ${ }^{\circ}$ 8.279-AgR, Rel. Min. CELSO DE MELlO, Ementa, julgamento 17/06/1998, DJ 10/08/2000, decisão disponível no endereço eletrônico $w w w . s t f . j u s . b r$.

${ }^{263}$ A Integração dos Estados - O Brasil no Mercosul: Implicações e Abrangências na Ordem Interna e Internacional, in Revista de Direito Constitucional e Internacional, $\mathrm{n}^{\mathrm{o}}$ 35, ano 9, abr./jun. 2001, p. 23.

${ }^{264}$ José Souto Maior Borges, Curso de Direito, Ob. cit., p. 226.

${ }^{265}$ Idem, p. 228.
} 
denominada 'Direito Internacional Público regional', ou 'Direito da Integração",266. Já a expressão Direito Comunitário é pertinente em relação ao conjunto normativo produzido na experiência regional europeia.

Por não ser enquadrada como mandamentos comunitários, a normativa atrelada ao Mercosul não goza de preeminência diante das Constituições nacionais, tampouco pode ser aplicada sem que haja a ultimação dos processos internos de incorporação exigidos pelos sistemas constitucionais dos Estados, considerados cada qual em sua singularidade ${ }^{267}$. Diferentemente do que acontece no âmbito da União Europeia, no Mercosul, os Estados não delegaram parcela de suas competências aos órgãos responsáveis por efetivar a integração regional, pois faltam, no bloco regional sul-americano, órgãos políticos que podem sobrepor suas decisões às vontades dos governos nacionais. Sem dúvida, para que as estruturas intergovernamentais do Mercado Comum do Sul cedam espaço para a supranacionalidade, será necessário criar condições para que se materialize uma radical evolução institucional, o que não pode ser feito sem amplas alterações no quadro constitucional dos Estados ${ }^{268}$.

A aplicação dos comandos jurídicos oriundos dos tratados e órgãos do Mercosul requer a soma de esforços cooperativos por parte dos Estados interconectados no bloco, tendo em vista o teor de dois artigos previstos no Protocolo de Outro Preto. O primeiro deles é o art. $42^{269}$, que admite a necessidade de incorporação das normas regionais aos ordenamentos de cada um dos países, obedecendo-se ao que dispuser o Direito Interno

\footnotetext{
${ }^{266}$ OtÁvio Augusto Drummond Cançado Trindade, A Incorporação das Normas do Mercosul ao Direito Brasileiro e a Segurança Jurídica Regional, in Novas Perspectivas do Direito Internacional Contemporâneo, Carlos Alberto Menezes Direito, Antônio Augusto Cançado Trindade e Antônio Celso Alves Pereira (coord.), Renovar, Rio de Janeiro, 2008, p. 236. Nessa mesma direção, Luiz OlAVo BAPTISTA é categórico ao defender o afastamento da "ideia falsa de que o Mercosul tem alguma forma de Direito Comunitário. Isso não ocorreu até hoje. O que há são normas de Direito Internacional Público, destinadas a promover a integração econômica de uma região" (A Aplicação das Normas do Mercosul no Brasil, in Revista de Direito do Mercosul, $\mathrm{n}^{\circ}$ 5, ano 2, 1998, p. 28).

${ }^{267}$ No que tange à relação entre Constituição de 1988 e normas exteriores provenientes do Mercosul, ANDRÉ DE CARVAlHo RAmos explica que "não há, na visão do Supremo Tribunal Federal, qualquer dispositivo constitucional que estabeleça tratamento privilegiado ao processo de recepção de atos, acordos, protocolos ou tratados celebrados pelo Brasil no âmbito do Mercosul. Assim, até que seja realizada uma alteração da Constituição que explicite de que modo tais normas devem ser tratadas, a vigência interna dos acordos mercosulinos continuará sujeita ao mesmo tratamento normativo que a Constituição brasileira impõe ao Direito Internacional convencional" (Direitos Humanos na Integração Econômica: Análise Comparativa da Proteção de Direitos Humanos e Conflitos Jurisdicionais na União Europeia e Mercosul, Rio de Janeiro, Renovar, 2008, p. 293).

${ }^{268}$ Cf. Manoel Gonçalves Ferreira Filho, Aspectos do Direito Constitucional Contemporâneo, São Paulo, Saraiva, 2003, p. 26.

269 “Art. 42. As normas emanadas dos órgãos do Mercosul previstos no Artigo 2 deste Protocolo terão caráter obrigatório e deverão, quando necessário, ser incorporadas aos ordenamentos jurídicos nacionais mediante os procedimentos previstos pela legislação de cada país".
} 
desses Estados. Em complemento, destaca-se o preceito do art. $40^{270}$, que adota a reciprocidade no tratamento das questões internacionais como parâmetro indissociável do Mercosul, já que institui o dever de vigência simultânea dessas normas, garantindo-se que os membros do bloco passem a cumprir os mandamentos regionais somente quando existirem reais condições de execução por todos os Estados envolvidos no processo de integração.

Vale asseverar que a manifesta abertura das ordens constitucionais aos processos de integração não pode, em nenhuma hipótese, levar ao abandono - ainda que parcial - das Constituições nacionais. Isso significa que eventuais normas internacionais criadas com esse propósito serão, decerto, rechaçadas em virtude de ofenderem a dinâmica da interação entre o interno e o externo nesse campo. Cite-se o exemplo do que aconteceu com a União Europeia, em que se pretendeu, em 2004, incorporar um espírito constitucional ao bloco por meio da edição do Tratado de Roma, que previa normas sobre repartição das competências comunitárias entre os vários órgãos da União Europeia, sobre delimitação das áreas de atuação dos Estados-partes, além da definição de um política externa comum, envolvendo defesa, segurança e cooperação internacional. A expectativa era de que a assim denominada Constituição Europeia fosse promulgada a partir de 2006, após concluída a ratificação por todos os Estados, todavia, essa ideia foi abandonada quando os cidadãos franceses e holandeses, em referendos organizados pelos governos de ambos os países, posicionaram-se contrariamente à ratificação do Tratado de Roma ${ }^{271}$.

Ainda sobre a pretensa adoção de normas regionais que poderiam ocupar o papel reservado às Constituições, cumpre observar que a necessidade de prévia alteração dos textos constitucionais nacionais para que esses projetos possam ter eficácia é um claro sinal de que as convenções internacionais criadas para favorecer a integração não são equivalentes às Constituições. Segundo JORGE MIRANDA, se a normativa editada para potencializar as competências dos blocos regionais pudesse substituir as normas constitucionais típicas, aquela, uma vez aprovada e vigente, impor-se-ia automaticamente e

270 “Art. 40. A fim de garantir a vigência simultânea nos Estados-partes das normas emanadas dos órgãos do Mercosul previstos no Artigo 2 deste Protocolo, deverá ser observado o seguinte procedimento: i) Uma vez aprovada a norma, os Estados-partes adotarão as medidas necessárias para a sua incorporação ao ordenamento jurídico nacional e comunicarão as mesmas à Secretaria Administrativa do Mercosul; ii) Quando todos os Estados-partes tiverem informado sua incorporação aos respectivos ordenamentos jurídicos internos, a Secretaria Administrativa do Mercosul comunicará o fato a cada Estado-parte; iii) As normas entrarão em vigor simultaneamente nos Estados-partes 30 dias após a data da comunicação efetuada pela Secretaria Administrativa do Mercosul, nos termos do item anterior. Com esse objetivo, os Estados-partes, dentro do prazo acima, darão publicidade do início da vigência das referidas normas por intermédio de seus respectivos diários oficiais".

${ }^{271}$ Cf. Alberto do Amaral Júnior, Curso de Direito, Ob. cit., p. 488. 
prevaleceria sobre as Constituições, as quais teriam sua inconsistência declarada por contradizer norma de grau superior. Fortalece, pois, essa constatação o fato de que, depois do fracasso do Tratado de Roma, a União Europeia ter adotado em 2007 o Tratado de Lisboa, documento que reconheceu expressamente, em seu art. $3^{\circ}-\mathrm{A}^{272}$, o respeito à identidade nacional dos Estados nacionais refletida nas estruturas políticas e constitucionais de cada um deles ${ }^{273}$.

Avulta o significado de que, seja no Mercosul ou na União Europeia, a integração regional deve respeitar as diversidades que marcam os países engajados no processo de aproximação e de adoção de mandamentos jurídicos comuns. Não se pretende, desse modo, operar a uniformização dos grupos sociais ou a unificação das culturas, acarretandose o esfacelamento das individualidades nacionais em proveito de interesses econômicos e comerciais, sem qualquer compromisso com as reais necessidades apresentadas pelos diferentes Estados que participam dos concertos regionais. Nessa toada, "a comunhão de Estados ou a integração de Estados não pode significar a supressão, a eliminação ou a simples extinção das diferenças dos povos e de suas culturas, pois elas devem se somar para acrescentar e se constituir objeto da união", como anota CÁRMEN LÚCIA ANTUNES ROCHA $^{274}$.

Entendimento contrário poderia determinar que a formação de blocos regionais enfraquecesse, de modo trágico, os Estados até seu completo aniquilamento. Seria uma contradição quanto aos impulsos de integração internacional, já que o motivo principal que leva ao surgimento dos blocos é o de fortalecer os Estados nacionais que se agregam para vencer desafios impossíveis de serem enfrentados, caso permanecessem isolados uns dos outros. A diversidade entre os países mantém-se respeitada no terreno do Mercosul, já que seu nítido caráter intergovernamental impede que os órgãos criados para fomentar o processo integracionista ditem normas e decisões oponíveis aos Estados quando não houver seu consentimento em adotá-las. Ademais, outro fator que prova a ausência de padronização nos sistemas normativos nacionais é a maneira de incorporar a normativa regional: enquanto, no Brasil e no Uruguai, a ausência de disposições constitucionais sobre

\footnotetext{
272 "Art. $3^{\circ}$-A. A União respeita a igualdade dos Estados-membros perante os tratados, bem como a respectiva identidade nacional, refletida nas estruturas políticas e constitucionais fundamentais de cada um deles, incluindo no que se refere à autonomia local e regional. A União respeita as funções essenciais do Estado, nomeadamente as que se destinam a garantir a integridade territorial, a manter a ordem pública e a salvaguardar a segurança nacional. Em especial, a segurança nacional continua a ser da exclusiva responsabilidade de cada Estado-membro".

${ }^{273}$ Cf. Democracia e Constituição, Ob. cit., pp. 45-46.

${ }^{274}$ Constituição, Soberania e, Ob. cit., p. 299.
} 
o status dos tratados relacionados ao Mercosul não permite que lhes seja reconhecida posição de destaque na legislação nacional ${ }^{275}$, as Constituições do Paraguai (art. $\left.9^{\circ}\right)^{276}$ e da Argentina (art. 75, $\left.\mathrm{n}^{\mathrm{o}} 24\right)^{277}$ admitem expressamente estatura privilegiada às normas regionais.

Ademais, mirando-se no foco central deste trabalho, cabe admitir que a integração que toma forma com o desenvolvimento do Mercosul demanda das instituições do Estado brasileiro comprometimento na efetivação das iniciativas de cooperação internacional regional, fato que confere destaque à estruturação constitucional dos Estados que se interrelacionam no bloco. Nessa senda, OtÁvio Augusto Drummond CAnçAdo Trindade atenta que, apesar de o Mercosul ter sido constituído em virtude de uma iniciativa tomada essencialmente pelo Poder Executivo, “o Legislativo e o Judiciário assumem papéis vitais para o êxito do empreendimento. Ao Congresso Nacional compete participar do procedimento de manifestação da vontade do país mediante a aprovação de compromissos internacionais. Aos tribunais cabe preservar direitos subjetivos tendo em vista a existência de atos internacionais que obrigam o Estado brasileiro e que produzem efeitos na esfera individual"278. Como será enfatizado com mais detalhes no próximo Capítulo, é inegável que a afirmação do Mercado Comum do Sul representa um novo foro para a criação e a aplicação do Direito Internacional, tendo, assim, ampliado significativamente as competências desempenhadas pelos Poderes constituídos dos Estados-partes nesse processo integracionista.

Aclara-se, desse modo, que as Constituições nacionais não podem ser simplesmente vistas pelas instâncias regionais como um fato, sem nenhuma expressividade para a produção de normas internacionais. O quadro formado no Mercosul, em que existe a

\footnotetext{
${ }^{275}$ Elucida RAÚl GRANILLO OCAMPO que o art. $6^{\circ}, \mathrm{n}^{\mathrm{o}} 2^{\mathrm{o}}$, da Constituição do Uruguai - cuja redação prevê que "A República procurará a integração social e econômica dos Estados latino-americanos, especialmente no que se refere à defesa de seus produtos e matérias-primas. Da mesma forma, buscará a efetiva complementação dos serviços públicos" - consagra um comando programático que nada trata da hierarquia dos tratados de integração regional, deixando à jurisprudência a tarefa de preencher essa lacuna, o que vem sendo feito pelo pronunciamento no sentido de que essas convenções são, no contexto do ordenamento uruguaio, equivalentes à legislação nacional (Cf. Direito Internacional Público da Integração, Rio de Janeiro, Elsevier, 2009, pp. 82-85).

276 “Art. 9. A República do Paraguai, em condições de igualdade com outros Estados, admite uma ordem jurídica supranacional que garanta a vigência dos direitos humanos, da paz, da justiça, da cooperação e do desenvolvimento político, econômico, social e cultural".

277 “Art. 75. [...] 24. Corresponde ao Congresso, aprovar tratados de integração que deleguem competências e jurisdição a organizações supraestatais em condições de reciprocidade e igualdade, e que respeitem a ordem democrática e os direitos humanos. As normas ditadas em sua consequência têm hierarquia superior às leis".

${ }^{278}$ A Incorporação das Normas do Mercosul ao Direito Brasileiro e a Segurança Jurídica Regional, in Novas Perspectivas do Direito Internacional Contemporâneo, Carlos Alberto Menezes Direito, Antônio Augusto Cançado Trindade e Antônio Celso Alves Pereira (coord.), Ob. cit., p. 230.
} 
necessidade de internalização da normativa regional, bem como a multiplicidade de previsões constitucionais acerca de como proceder nessa missão, indicam uma sensível valorização das Leis Fundamentais dos países envolvidos. Não se trata, pois, de defender que as disposições constitucionais são, no presente, suscetíveis, por si sós, de produzir efeitos concretos no plano externo, já que persiste incólume a diretriz enunciada pela jurisprudência internacional de que um Estado não deve invocar frente a outro Estado suas normas internas para subtrair-se das obrigações que lhe impõe o Direito das Gentes. Em verdade, o que se presencia é um movimento no qual a internacionalização das Constituições acaba por ampliar a importância de reconhecer o lugar particular dos preceitos constitucionais como ferramentas imprescindíveis para a efetivação das normas exteriores $^{279}$.

\subsection{Emenda Constitucional $n^{0} 45 / 2004$ e Intensificação do Compromisso do Estado Brasileiro para com o Direito Internacional}

Ao considerar em perspectiva panorâmica as Constituições vigentes na América Latina, ERNESTO J. REY CARO concluiu que o conceito de soberania estatal marcante em toda a filosofia político-constitucional do século XIX conduziu à adoção de textos constitucionais nessa região que dificilmente poderiam dar guarida a interpretações muito dispostas a aceitar as incontroláveis influencias exteriores. Em virtude desse fato, vários foram os Estados que, a fim de não serem excluídos do avanço e do aprofundamento da internacionalização do Direito, tiveram de introduzir modificações em suas respectivas Cartas Magnas ${ }^{280}$. Inclusive em países que adotaram, no final do século XX, textos constitucionais já com notável disposição de considerar o valor jurídico dos mandamentos internacionais - como é o caso do Brasil -, as tradições e influências do passado não permitiram que o constituinte originário conseguisse idealizar fórmulas e arranjos jurídicos perfeitamente ajustáveis às exigências impostas pela progressiva abertura das nações ao Direito das Gentes.

Conclui-se, desse modo, que coube ao poder de reforma das Constituições instituir formas habilitadas a compatibilizar as ordens jurídicas internas aos reclamos decorrentes da maior projeção alcançada pelos mandamentos exteriores. No caso brasileiro, a Emenda

\footnotetext{
${ }^{279}$ Cf. FERdinAND NDJIMBA, L'Internationalisation des, Ob. cit., p. 420.

${ }^{280} \mathrm{Cf}$. Los Tratados Internacionales en el Ordenamiento Jurídico Argentino. Consideraciones sobre la Reforma Constitucional, in Anuario Argentino de Derecho Internacional, Vol. VI, 1994-1995, pp. 209-238.
} 
Constitucional $n^{o} 45 / 2004$, que adicionou os $\S \S 3^{\circ}$ e $4^{\circ}$ ao art. $5^{\text {o281 }}$, além do $\S 5^{\circ}$ ao art. $109^{282}$, ambos da Carta Magna, confirma a relevância da interconexão entre sistemas normativos. Essa alteração contribuiu, notadamente, à abertura do Estado brasileiro para o Direito das Gentes, especialmente por ter munido a União de competências que lhe faltavam para lidar com a responsabilidade internacional do Estado nacional. Com efeito, no plano externo, é a União que responde pelas hipóteses de violação das obrigações internacionais em matérias a cujo cumprimento o Brasil se comprometeu juridicamente, daí o amplo significado dos novos elementos constitucionais introduzidos pela referida emenda ${ }^{283}$.

Não obstante outras mudanças ditadas pela Emenda Constitucional $n^{\mathrm{o}} 45 / 2004$ também tenham impactado o campo das relações exteriores - como a alteração de competência para homologar sentenças estrangeiras e conceder exequatur de cartas rogatórias, que deixou de figurar no rol de atribuições do Supremo Tribunal Federal para integrar as competências originárias do Superior Tribunal de Justiça (art. 105, inciso I, alínea "i”) ${ }^{284}$ - este trabalho irá se concentrar no estudo das três alterações mencionadas no parágrafo anterior, pois são elas que guardam maior proximidade com a problemática da interação entre Constituição e Direito Internacional Público. Dessa forma, informa-se que os reflexos causados em nosso Direito Constitucional como consequência da introdução do $\S 3^{\circ}$ ao art. $5^{\circ}$ da Lei Maior serão abordados no Capítulo 4 (Item 4.2.2.2), parte do trabalho dedicada exclusivamente às questões suscitadas pela aplicação das normas internacionais no Direito brasileiro. Restam a este capítulo, portanto, analisar os aspectos constitucionais que podem ser depreendidos da submissão do Brasil a Tribunal Penal Internacional, órgão a cuja criação o país aderiu, bem como a introdução, no âmbito do Poder Judiciário nacional, do denominado incidente de deslocamento de competência (IDC).

\footnotetext{
281 “Art. $5^{\circ}[\ldots] \S 3^{\circ}$ Os tratados e convenções internacionais sobre direitos humanos que forem aprovados, em cada Casa do Congresso Nacional, em dois turnos, por três quintos dos votos dos respectivos membros, serão equivalentes às emendas constitucionais. $\S 4^{\circ} \mathrm{O}$ Brasil se submete à jurisdição de Tribunal Penal Internacional a cuja criação tenha manifestado adesão".

282 “Art. 109. [...] § $5^{\circ}$ Nas hipóteses de grave violação de direitos humanos, o Procurador-Geral da República, com a finalidade de assegurar o cumprimento de obrigações decorrentes de tratados internacionais de direitos humanos dos quais o Brasil seja parte, poderá suscitar, perante o Superior Tribunal de Justiça, em qualquer fase do inquérito ou processo, incidente de deslocamento de competência para a Justiça Federal".

${ }^{283}$ Cf. CELSO LAFER, A Internacionalização dos Direitos, Ob. cit., p. 18.

284 “Art. 105. Compete ao Superior Tribunal de Justiça: I - processar e julgar, originariamente: [...] i) a homologação de sentenças estrangeiras e a concessão de exequatur às cartas rogatórias”.
} 


\subsubsection{O Reconhecimento da Jurisdição de Tribunal Penal Internacional}

A criação de uma Corte Internacional Penal permanente, sediada em Haia e com competência para julgar indivíduos que tenham cometidos ilícitos penais, além de confirmar a subjetividade internacional da pessoa humana - que, agora, passa a ocupar a posição de ré em processos criminais internacionais -, concretiza a ideia esposada por Hans Kelsen, logo após o encerramento da Segunda Guerra Mundial, de que "um dos meios mais eficazes de impedir a guerra e garantir a paz internacional é a criação de regras que estabeleçam a responsabilidade individual das pessoas que, como membros do governo, tenham violado o Direito Internacional recorrendo à provocação da guerra" ${ }^{\text {285 }}$. O Estatuto de Roma, ao institucionalizar o Tribunal Penal Internacional (TPI), confirma, pois, o movimento interestatal de combate a crimes cuja gravidade viole os próprios fundamentos da sociedade internacional, refletindo, por certo, um esforço dos Estados para coibir fatos internacionais que podem desestabilizar todo o conjunto de relações exteriores hoje existente ${ }^{286}$. O surgimento desse Tribunal atesta ainda a importância de se ter um Direito Internacional Penal verdadeiramente efetivo, habilitado a responsabilizar criminalmente aqueles que, independentemente da condição política ou do posto governamental ocupado no interior dos Estados, tomem decisões e executem ações que violem as normas mais elementares sobre a coexistência entre os povos ${ }^{287}$.

Os elevados propósitos que motivaram a criação do Tribunal Penal Internacional não impediram, entretanto, que, em alguns países, surgissem dificuldades de

\footnotetext{
${ }^{285}$ La Paz por Medio del Derecho, Madrid, Editorial Trotta, 2008, p. 91.

${ }^{286}$ Cf. Celso LAfer, A Reconstrução dos Direitos Humanos: Um Diálogo com o Pensamento de Hannah Arendt, São Paulo, Companhia das Letras, 1988, p. 169.

${ }^{287}$ ClÁUdia PERrone-Moisés leciona que o marco principal da História do Direito Internacional Penal é o pós-1945, mais precisamente o estabelecimento dos Tribunais de Nuremberg e Tóquio. Sobre o tema, assinala a estudiosa que "os horrores da guerra, o ineditismo dos campos de concentração e os requintes de crueldade utilizados haviam predisposto a comunidade internacional a não aceitar que os crimes cometidos ficassem sem julgamento. Fundando-se nessa convicção, com base na Declaração de Moscou de 1943, firmada por Roosevelt, Churchill e Stalin, os governos aliados, antes do final da guerra, estabelecem que os criminosos cujos crimes tivessem localização geográfica definida deveriam ser julgados no país onde os crimes foram cometidos. Já quanto aos crimes sem localização geográfica precisa, cujas ações estendiam suas consequências por todo o continente europeu, deveriam ser julgados de acordo com o que seria posteriormente definido. [...] No entanto, somente em 1989, por iniciativa de Trinidad e Tobago junto à Assembleia Geral da ONU, é que ocorreu a retomada dos trabalhos para a criação de um Tribunal Penal Internacional (Antecedentes Históricos do Estabelecimento do Tribunal Penal Internacional, in Revista da Faculdade de Direito da USP, vol. 98, 2003, pp. 575-577). Convém registrar ainda que, nos anos de 1993 e 1994 o Conselho de Segurança da ONU editou as Resoluções no 808 e n ${ }^{\circ}$ 955, criando, respectivamente, dois Tribunais Internacionais Ad Hoc: o primeiro para processar e julgar as sérias violações do Direito Internacional Humanitário cometidas no território da antiga Iugoslávia desde 1991, e o segundo para promover a responsabilização penal daqueles que cometeram transgressões aos mesmos direitos, porém no território de Ruanda e nos países vizinhos na constância do ano de 1994 (Cf. FERNANDA FLORENTINO FERnANDeZ Jankov, Direito Internacional Penal: Mecanismo de Implementação do Tribunal Penal Internacional, São Paulo, Saraiva, 2009, pp. 27-29).
} 
compatibilização do Estatuto de Roma com as Constituições nacionais, impasse que acabou explicitando a permeabilidade de diversos Estados em relação ao Direito Internacional. Quanto a esse fato, na esteira do que aponta GEORGE RODRIGO BANDEIRA GALINDO, é possível visualizar três grandes posturas adotadas pelas ordens jurídicas nacionais. A primeira "foi a dos Estados que exigiram mudanças para compatibilizar o tratado com a Constituição interna. França, Irlanda, Portugal, México, Colômbia, Luxemburgo, Alemanha e Romênia, por exemplo, podem ser inseridos nesse grupo. Uma segunda postura foi a dos Estados que concluíram que seus textos constitucionais poderiam ser interpretados de maneira compatível com o Estatuto de Roma. Algumas vezes, esse processo interpretativo chegou até às Cortes Constitucionais, que se pronunciaram favoravelmente ao tratado. Exemplos: Costa Rica, Dinamarca, Equador, Noruega, Espanha, Guatemala e Venezuela. Finalmente, houve Estados que consideraram impossível a compatibilidade do Estatuto de Roma com seus respectivos textos constitucionais, o que lhes impediria sua ratificação, como o caso dos Estados Unidos embora considerações constitucionais não sejam as únicas que impedem a ratificação, pois há também motivações políticas" 288 .

Note-se que a Emenda Constitucional no 45/2004, ao ampliar a extensão normativa do art. $5^{\circ}$ da Carta Magna por meio da inclusão do $\S 4^{\circ}$, situou o Brasil no universo do primeiro grupo de países. Tem-se, assim, evidente prova de que a República Federativa do Brasil inclina-se a adotar novas concepções sobre o Estado, a soberania nacional e a convivência entre as nações, já que tem consentido manifestamente no tocante às competências de Cortes Internacionais e demais instrumentos voltados à aplicação dos comandos pertencentes ao Direito das Gentes ${ }^{289}$. Essa constatação deve ser realçada quando se trata do reconhecimento da jurisdição do Tribunal Penal Internacional, pois esse órgão judiciário internacional tem a missão de zelar pela observância de normas que tutelam valores muito caros para todos os povos, sendo certo que, em última análise, as normas internacionais penais evidenciam não somente a humanidade como vítima, mas também como um valor a ser protegido ${ }^{290}$.

\footnotetext{
${ }^{288}$ Art. $5^{\circ}$, $4^{\circ}$, in Comentários à Constituição do Brasil, J. J. Gomes Canotilho, Gilmar Ferreira Mendes, Ingo Wolfgang Sarlet, Lenio Streck e Léo Ferreira Leoncy (coord.), São Paulo, Saraiva e Almedina, 2013, p. 525 .

${ }^{289}$ Cf. MARIA GARCIA, Limites da Ciência, Ob. cit., p. 295.

${ }^{290}$ Cf. Mireille Delmas-Marty, Vers Une Communauté de Valeurs?: Les Forces Imaginantes du Droit (IV), Paris, Éditons du Seuil, 2011, p. 331.
} 
É pertinente esclarecer que o Tribunal Penal Internacional é orientado pelo princípio da complementariedade, o que, em termos genéricos, impõe que a atuação desse órgão internacional não anteceda as ações de persecução criminal passíveis de serem efetuadas no plano dos sistemas judiciais internos. Para que a Corte Internacional exerça suas competências, é exigido o preenchimento de uma série de requisitos atinentes à admissibilidade, centrados, em especial, na questão do esgotamento dos recursos internos, embora aqui com um sentido mais amplo do que aquele previsto nos Estatutos das Cortes Europeia e Americana de Direitos Humanos. Da maneira como foi estruturada a jurisdição do TPI permite-se, portanto, a atuação dessa instância internacional sempre que um Estado não esteja disposto a proceder à investigação dos fatos, ou não possa fazê-lo, ou, ainda, na hipótese de que esteja em curso procedimento interno conduzido de forma displicente ${ }^{291}$.

Apresentadas essas ponderações relativas ao funcionamento do jurisdição do Tribunal Penal Internacional, fica claro que a submissão do Estado brasileiro a essa Corte, consoante a redação estampada no $\S 4^{\circ}$ do art. $5^{\circ}$ de nossa Constituição, não resulta, sob nenhum ponto de vista, na ideia de hierarquização jurisdicional, com eventual superioridade da justiça internacional sobre a interna. Na realidade, o que ocorre é a permissão da atuação supletiva do TPI em casos especialmente designados, desde que observada a desídia ou a inépcia do Poder Judiciário brasileiro ${ }^{292}$. É forçoso reconhecer que "as disposições de complementariedade do Estatuto buscam consagrar um alto grau de deferência aos processos nacionais e proporcionar respeito considerável aos atores estatais, considerando os possíveis cenários de conflito constitucional. [...] Múltiplas oportunidades existem para salvaguardar o primado dos Tribunais nacionais. A complementariedade fornece, desse modo, uma cláusula de escape de potenciais dificuldades constitucionais, desde que o Estado investigue ou processe os transgressores" ${ }^{293}$.

Tendo em vista o exposto, conclui ClÁUdIA PERrone-Moisés que, caso o Estado, no âmbito das obrigações que assumiu com o Estatuto de Roma, não estiver preparado para desempenhar sua competência, deverá, como consequência lógica, admitir a competência do Tribunal Penal Internacional, não constituindo essa atuação externa uma ingerência. A

\footnotetext{
${ }^{291}$ Cf. Silvia SteIneR, Tribunal Penal Internacional, in Direito Internacional: Direito Internacional dos Direitos Humanos (Coleção Doutrinas Essenciais, vol. 3), Luiz Olavo Baptista e Valerio de Oliveira Mazzuoli (org.), pp. 1033-1034.

${ }^{292}$ Cf. Luiz Alexandre Cruz Ferreira e Maria Cristina Vidotte Blanco Tárrega, Reforma do Poder Judiciário e Direitos Humanos, in Reforma do Judiciário: Primeiros Ensaios Críticos Sobre a EC $n$. 45/2004, Teresa Arruda Alvim Wambier, Luiz Rodrigues Wambier, Luiz Manoel Gomes Junior e outros (coord.), São Paulo, Revista dos Tribunais, 2005, p. 457.

${ }^{293}$ Helen DufFy, National Constitutional Compatibility and the International Criminal Court, in Duke Journal of Comparative \& International Law, vol. 11, 2000, pp. 18-19.
} 
ação do TPI será revestida, destarte, da forma de uma atividade que, na relação dialética de complementariedade estabelecida entre os sistemas jurídicos interno e internacional, mostra-se necessária e justificável para a manutenção da ordem internacional. Em uma visão prospectiva, é possível antever um fortalecimento das ordens internas, pois a atuação complementar da jurisdição internacional poderá constituir meio hábil de pressionar os Estados a promoverem o adensamento de suas legislações nacionais, bem como aparatos repressivos para assegurar que os casos não cheguem ao crivo da Corte instalada em Haia $^{294}$.

Parece certo que, em um contexto constitucional tal qual o encontrado presentemente no Brasil, o estágio de abertura do nosso Direito Interno ao Direito das Gentes fornece respaldo jurídico para a participação do Estado no concerto internacional responsável pela criação e pelo funcionamento de um órgão internacional da conformação do TPI, o que fica mais claro ainda com a evocação da norma do art. $7^{\circ}$ do Ato das Disposições Constitucionais Transitórias (ADCT) ${ }^{295}$. Com esteio na obra de ANDRÉ DE CARVALHO RAMOS, infere-se que "este artigo dispõe que o Brasil deve favorecer a criação de um tribunal internacional de direitos humanos. Logo, a interpretação que se tem deste dispositivo é que não podemos utilizar a própria Constituição para obstruir o funcionamento do Tribunal Penal Internacional, tribunal este criado justamente para combater graves violações de direitos humanos" ${ }^{296}$. A edição de uma emenda constitucional voltada a admitir a jurisdição do TPI pretendeu, assim, exterminar quaisquer objeções derivadas da ratificação do Estatuto de Roma pela República Federativa do Brasil, fato que constitui emblemático compromisso do Estado em incrementar sua disposição de cooperar no campo das relações exteriores.

O fato de existirem, desde a promulgação da Constituição vigente, fundamentos para justificar a vinculação do Brasil ao Tribunal Penal Internacional, não impediu o surgimento de uma série de questionamentos doutrinários quanto à constitucionalidade do Estatuto de Roma, em especial a respeito de dois pontos bem delimitados: a entrega de brasileiros natos ao TPI e a previsão de prisão perpétua como uma das medidas punitivas

\footnotetext{
${ }^{294}$ Cf.O Principio da Complementariedade no Estatuto do Tribunal Penal Internacional e a Soberania Contemporânea, in Revista de Política Externa, vol. 8, n 4, mar./mai. 2000, p. 7. Averbe-se que, em complemento, MireILlE DELMAS-MARTY observa que "a complementariedade não tem apenas a vantagem política de preservar a soberania nacional; ela apresenta também vantagens práticas, ao permitir que se evite o entupimento das jurisdições internacionais" (Vers Une Communauté, Ob. cit., p. 133).

295 “Art. $7^{\circ}$. O Brasil propugnará pela formação de um tribunal internacional dos direitos humanos".

${ }^{296}$ Processo Internacional de Direitos Humanos, $3^{\mathrm{a}}$ ed., São Paulo, Saraiva, 2013, p. 314. Em igual direção: CElso LAFER, A Internacionalização dos, Ob. cit., p. 15.
} 
passíveis de aplicação aos processados, previstos, respectivamente, no art. $89^{297}$ e $77^{298}$ do Estatuto de Roma. Informe-se, desde já, que, durante o procedimento de incorporação desse tratado à ordem jurídica pátria, não foi cogitada a hipótese de o Estado brasileiro apor reservas a esses dispositivos porque o art. 120 do Estatuto $^{299}$, categoricamente, proibiu o emprego desse expediente. Por serem os argumentos lançados contra ambos os institutos ligados a dispositivos da Constituição de 1988, essa discussão traz consigo reflexões que muito interessam ao Direito Constitucional, o que certifica o interesse para o tema central deste estudo.

No que concerne à entrega de brasileiros natos, a interpretação pela compatibilidade entre um diploma internacional de direitos humanos (que é o caso do Estatuto de Roma, como vimos) e a Constituição leva à diferenciação entre a extradição e $\mathrm{o}$ ato de entrega (surrender). De fato, o art. 102 do tratado constitutivo do TPI $^{300}$ apresenta expressa diferenciação entre os institutos da extradição e do ato de entrega. A extradição é termo reservado ao ato de cooperação judicial penal entre Estados soberanos, ao passo que a entrega ou o surrender diz respeito a mecanismo relacionado ao caso específico de cumprimento de ordem de organização internacional de proteção de direitos humanos, como é o caso do Tribunal Penal Internacional ${ }^{301}$.

\footnotetext{
297 “Art. 89. Entrega de Pessoas ao Tribunal 1. O Tribunal poderá dirigir um pedido de detenção e entrega de uma pessoa, instruído com os documentos comprovativos referidos no artigo 91, a qualquer Estado em cujo território essa pessoa se possa encontrar, e solicitar a cooperação desse Estado na detenção e entrega da pessoa em causa. Os Estados Partes darão satisfação aos pedidos de detenção e de entrega em conformidade com o presente Capítulo e com os procedimentos previstos nos respectivos direitos internos".

298 “Art. 77. Penas Aplicáveis. 1. Sem prejuízo do disposto no artigo 110, o Tribunal pode impor à pessoa condenada por um dos crimes previstos no artigo $5^{\circ}$ do presente Estatuto uma das seguintes penas: a) Pena de prisão por um número determinado de anos, até ao limite máximo de 30 anos; ou b) Pena de prisão perpétua, se o elevado grau de ilicitude do fato e as condições pessoais do condenado o justificarem".

299 “Art. 120. Reservas. Não são admitidas reservas a este Estatuto".

300 “Art. 102. Termos Usados. Para os fins do presente Estatuto: a) Por 'entrega', entende-se a entrega de uma pessoa por um Estado ao Tribunal nos termos do presente Estatuto. b) Por 'extradição', entende-se a entrega de uma pessoa por um Estado a outro Estado conforme previsto em um tratado, em uma convenção ou no direito interno".

${ }^{301}$ Cf. André De CARVAlho Ramos, Processo Internacional de, Ob. cit., p. 313. Ainda sobre a definição de extradição e de entrega, GÖRAN SLUITER estatui que as diferenças não se resumem a uma questão meramente terminológica. Ambos os conceitos se referem à transferência pelo Estado de criminosos para outra jurisdição criminal. A distinção vital entre os dois termos consiste na verificação de que a entrega aplica-se ao TPI, enquanto a extradição diz respeito a persecução e cumprimento de sentenças individuais em outros Estados. A proposta desta distinção é a de assegurar que as normas tradicionais sobre extradição não sejam aplicáveis, mutatis mutandis, no regime especial da entrega. A aplicação dos comandos normativos da extradição causaria numerosos obstáculos para a eficácia de mandados de prisão de criminosos de guerra. Por essa razão, o Estatuto de Roma e o Regulamento da Corte evitaram conscientemente empregar o termo 'extradição', substituindo-o pelas palavras 'transferência' e 'entrega' (Cf. The Surrender of War Criminals to the International Criminal Court, in Loyola of Los Angeles International and Comparative Law Review, vol. 25, 2003, pp. 607-608). Ver também CARMEN TIBURCIO, AEC $n^{\circ} 45$ e Temas de Direito Internacional, in Reforma do Judiciário: Primeiros Ensaios Críticos Sobre a EC n. 45/2004, Teresa Arruda Alvim Wambier,
} 
Com lastro na análise histórica de uma série de Constituições, Helen DufFY defende que, no momento da elaboração da maioria das proibições constitucionais acerca da extradição, os Estados contemplaram apenas a cooperação horizontal entre os tribunais nacionais, e não a cooperação vertical com um tribunal internacional. Como o TPI não é um tribunal estrangeiro - mas sim uma Corte internacional -, as proibições constitucionais contra a extradição não lhe são aplicáveis. A distinção substancial entre extradição e entrega diz respeito, portanto, às particularidades das relações estabelecidas entre um Estado e o TPI e entre dois Estados. O TPI é produto dos Estados. A maioria dos Estados participou das negociações legais e da elaboração de documentos complementares detalhados que definem os elementos constitutivos dos crimes dentro da jurisdição do Tribunal e seu Regulamento Processual. Esse envolvimento estatal persiste em momento posterior à ratificação, porque os Estados se tornam membros da Assembleia dos Estadospartes e, desse modo, compartilham a responsabilidade de, entre outros pontos, cuidar da gestão do Tribunal, lidando com situações de não cooperação por outros Estados-partes, com a nomeação e destituição dos juízes e do Procurador ${ }^{302}$.

Ao cuidar do assunto sob a ótica do constitucionalismo brasileiro, FERNANDA FLORENTINO FERNANDEZ JANKOV grifa que atual "Constituição provavelmente não previu o surrender, pois se trata de instituto posterior a sua elaboração e aprovação, haja vista o sistema protetivo adotado em relação à extradição especialmente em relação aos nacionais" $"$. Cabe esclarecer que idêntico entendimento pode ser depreendido do teor do despacho proferido pelo Ministro CELSO DE Mello, em 17 de julho de 2009, em sede da Petição $n^{\circ} 4.625-1$, relacionada à ordem de entrega expedida pelo Tribunal Penal Internacional em face do Presidente de Sudão, Omar al-Bashir. Na decisão, foi

Luiz Rodrigues Wambier, Luiz Manoel Gomes Junior e outros (coord.), São Paulo, Revista dos Tribunais, 2005 , p. 128.

${ }^{302}$ Cf. National Constitutional Compatibility, Ob. cit., p. 22. Sobre a cooperação internacional em matéria criminal, HERVÉ ASCENSIO explica que “até um período recente, as regras do Direito Internacional Penal eram destinadas principalmente a reger a cooperação entre os Estados de uma maneira que poderia ser qualificada de 'horizontal'. Desta forma, várias convenções definem as infrações, como tráfico internacional de entorpecentes e certos atos terroristas. Mas, nesta construção, o objetivo permanece a transposição para os Direitos Nacionais, de maneira a facilitar a repressão pelas ordens jurídicas internas. Estas convenções procuram também facilitar a extradição, melhorar a cooperação entre sistemas jurídicos nacionais e a estender a competência das jurisdições nacionais. Este fato de modo algum coloca em evidência a estrutura interestatal do sistema internacional, mas se inscreve, ao contrário, em uma abordagem clássica de cooperação entre Estados. Entretanto, depois do fim da Guerra Fria, o Direito Internacional Penal se desenvolveu em uma direção radicalmente diferente, recorrendo a uma construção qualificada de 'vertical'. As relações de Direito que a caracterizam não são mais relações entre Estados, mas relações entre indivíduos no interior dos Estados e a comunidade internacional em seu conjunto" ( $O$ Desenvolvimento do Direito Internacional Penal, in O Brasil e os Novos Desafios do Direito Internacional, Leonardo Nemer Caldeia Brant (coord.), Ob. cit.,pp. 265-266).

${ }^{303}$ Direito Internacional Penal, Ob. cit., p. 292. 
sedimentado pelo magistrado que as características da entrega convergem para uma forma autônoma de cooperação judiciária internacional, indubitavelmente distinta do instituto da extradição, o que impede estender à primeira as limitações constitucionais previstas no Pacto Fundamental para a segunda ${ }^{304}$.

Quanto à pena de prisão perpétua, o fato de a jurisprudência do Supremo Tribunal Federal ter sido consolidada no sentido de, no pleito extradicional, ser necessário o Estado requerente assumir o compromisso de comutá-la em pena privativa de liberdade não superior a trinta $\operatorname{anos}^{305}$ não implica obstáculo à efetivação do ato de entrega que venha a ser determinada pelo Tribunal Penal Internacional. Cabe asseverar que, no caso da entrega, a exigência da comutação de pena não tem cabimento por duas razões: em primeiro lugar, porque o próprio Estatuto de Roma traz previsão quanto à hipótese de revisão da pena, após vinte e cinco anos de cumprimento (art. 110) ${ }^{306}$. Em segundo lugar, está claro que essa vedação à extradição foi construída pelo STF para impedir que a cooperação entre Estados fosse realizada fora de determinados padrões de respeito a direitos humanos (no caso, pena excessiva), o que impede estender o entendimento em análise ao TPI, cuja função básica é justamente a de proteger os direitos humanos pela punição daqueles que violaram valores essenciais da sociedade internacional ${ }^{307}$.

Diante do exposto, há que se convir que a ideia sustentada por MARCos Augusto MALISKA, no sentido de o Estado nacional cumprir a ordem de surrender, sob a condição de que a Corte Internacional Penal aplique ao réu somente a pena de prisão por, no máximo, trinta anos mostra-se inadequada ${ }^{308}$. Esse debate, não obstante permaneça em

\footnotetext{
${ }^{304}$ Consultar: STF, Pet no 4625, Despacho do Min. Celso De Mello, Informativo do STF $\mathrm{n}^{\mathrm{o}} 554$, de 03/08/2009, documento disponível no endereço eletrônico www.stf.jus.br.

${ }^{305}$ As decisões da Corte Constitucional brasileira a respeito da matéria podem ser sintetizadas da seguinte forma: "A extradição somente será deferida pelo Supremo Tribunal Federal, tratando-se de fatos delituosos puníveis com prisão perpétua, se o Estado requerente assumir, formalmente, quanto a ela, perante o Governo brasileiro, o compromisso de comutá-la em pena não superior à duração máxima admitida na lei penal do Brasil (CP, art. 75), eis que os pedidos extradicionais - considerado o que dispõe o art. 5', XLVII, 'b' da Constituição da República, que veda as sanções penais de caráter perpétuo - estão necessariamente sujeitos à autoridade hierárquico-normativa da Lei Fundamental brasileira. Doutrina. Novo entendimento derivado da revisão, pelo Supremo Tribunal Federal, de sua jurisprudência em tema de extradição passiva" (STF, Ext. N ${ }^{\circ}$ 855, Rel. Min. Celso DE MEllo, Ementa, julgamento 26/08/2004, DJ 01/07/2005, decisão disponível no endereço eletrônico www.stf.jus.br.

306 “Art. 110. Reexame pelo Tribunal da Questão de Redução de Pena [...] 3. Quando a pessoa já tiver cumprido dois terços da pena, ou 25 anos de prisão em caso de pena de prisão perpétua, o Tribunal reexaminará a pena para determinar se haverá lugar a sua redução. Tal reexame só será efetuado transcorrido o período acima referido".

${ }^{307}$ Cf. ANDRÉ De CARVAlHo Ramos, Processo Internacional de, Ob. cit.,p. 315.

${ }^{308}$ A propósito, aduz o autor que "a Constituição brasileira, de fato, proíbe a pena de prisão perpétua, que está prevista no Tratado de Roma. Nesse ponto o tratado é questionável, pois o princípio da humanidade das penas não permite que a justiça humana faça uso, nas punições, da mesma irracionalidade do criminoso. De qualquer modo, certo é que a Constituição brasileira vincula somente seus aplicadores (Justiça brasileira,
} 
aberto no Direito Constitucional brasileiro, pois não se tem notícia de pronunciamento específico da Corte Máxima do país sobre a controvérsia, conduz-nos aos mesmos pontos de inflexão já enfrentados quando detalhadas as diferenças entre extradição e entrega. É caso, portanto, de aplicação do secular axioma de que "os fatos de igual natureza devem ser regulados de modo idêntico"309.

Em arremate, os avanços advindos para proteger os direitos humanos com o surgimento do Tribunal Penal Internacional não podem esbarrar no argumento de que o tratado que criou esse órgão judicial internacional apresenta ponto de incongruências quando confrontado com a Constituição Federal de 1988. A relevância de assegurar o engajamento do Brasil no combate dos crimes internacionais que ofendem valores cultuados pelo conjunto de Estados não viabiliza apenas o respeito aos direitos humanos cuja prevalência é reconhecida como um dos princípios constitucionais que devem nortear as ações exteriores do Estado (art. 4\%, inciso II). Implica, também, zelar pela "efetivação dos dispositivos contidos nos art. $5^{\circ}, \S 4^{\circ}$ da Lex Mater (redação inserida pela EC n ${ }^{\circ}$ 45/2004), bem como no art. $7^{\circ}$ do ADCT"310, mandamentos constitucionais esses que devem ser interpretados em harmonia com o restante da Constituição. Além disso, Mireille Delmas-MARTy indica outro motivo para incentivar os países a aceitarem a atuação do Tribunal Penal Internacional, qual seja,o caráter especializado dessa Corte, ao mesmo tempo em que facilita a progressiva internacionalização do Direito, contribui para que ocorra uma lenta harmonização das regras penais nacionais, coibindo, assim, práticas internas de ausência de normatização para combater atentados aos valores mais caros à humanidade como um todo ${ }^{311}$.

\subsubsection{O Incidente do Deslocamento de Competência}

Com o objetivo de proporcionar maior proteção aos direitos humanos no âmbito interno, a Emenda Constitucional no 45/2004 introduziu outra novidade ao constitucionalismo pátrio: o chamado incidente de deslocamento de competência (IDC)

autoridades públicas brasileiras etc.), não os organismos internacionais. O máximo que o Brasil pode fazer, no momento de entregar o preso ao Tribunal, será, tal como o Supremo Tribunal Federal já faz nas extradições, condicionar a entrega à não aplicação da pena de ergástulo (prisão perpétua)" (Estado e Século, Ob. cit., pp. 188-189).

${ }^{309}$ Carlos MaXimiliano, Hermenêutica e Aplicação do Direito, $19^{\mathrm{a}}$ ed., Rio de Janeiro, Forense, 2009, p. 171.

${ }^{310}$ EvÂNio Moura, O Tribunal Penal Internacional e o Direito Interno: A Necessária Distinção entre Extradição e Entrega de Nacional, in Direito Internacional: Direito Internacional dos Direitos Humanos (Coleção Doutrinas Essenciais, vol. 3), Luiz Olavo Baptista e Valerio de Oliveira Mazzuoli (org.), Ob. cit., p. 742 .

${ }^{311}$ Cf. La Refondation des, Ob. cit., p. 50. 
gravado na disposição do art. 109, $\S 5^{\circ}$, da Carta Magna. A importância desse mecanismo jurídico aumenta na proporção em que o país se enreda nos sistemas internacionais protetivos dos direitos humanos, mediante o reconhecimento da competência de órgãos internacionais habilitados a cuidar do monitoramento e, em casos extremos, realizar condenações dos Estados que transgridam essa normativa.

Busca o incidente tornar viável "uma ampliação qualitativa da proteção dos direitos humanos, conferindo-se meios ao ente central para realizar, diretamente, a resposta judicial a casos de grave violação dos compromissos internacionais assumidos pelo Brasil. Ao reconhecer a função de garante da concreção dos direitos humanos atribuída à União, matiza o instrumento a ideia de atribuir-lhe o papel de, diretamente, investigar e decidir lides que tenham como objeto situações concretas de desrespeito à dignidade humana"312. A essência do instituto está em permitir que o poder central impeça que o desapego à defesa e à promoção dos direitos humanos por unidades federadas locais e regionais provoque condenações internacionais imputáveis à República Federativa do Brasil e suportadas pela União, haja vista que, como restará detalhado no Capítulo 5 (Item 5.3.1), as condenações de Cortes Internacionais jamais alcançam as unidades autônomas.

Faculta-se, de tal sorte, ao Procurador-Geral da República, diante de grave violação das convenções internacionais que versem sobre direitos humanos, apresentar perante o Superior Tribunal de Justiça, a qualquer momento, pedido para que esse Tribunal Superior decida pela transferência de inquérito ou processo em curso nos órgãos judiciários estaduais para a Justiça Federal competente. Objetivou-se, pois, com a adição do $\S 5^{\circ}$ ao art. 109 da Lei Maior, criar uma habilidosa ferramenta que permitisse, no terreno da organização político-administrativa do Estado nacional, identificar os casos concretos em curso junto ao Judiciário estadual, cuja seriedade e iminência de futuras condenações internacionais motivadas pela inaptidão das instituições brasileiras recomendassem a atuação da União. A análise pormenorizada do funcionamento do IDC revela toda a complexidade que há em redistribuir feitos judiciais para órgãos judiciários pertencentes a categorias diversas de entes autônomos, sobretudo porque seus reflexos vão além do incremento nos índices de observância interna dos tratados internacionais, pois também tocam em temas como o respeito à autonomia federativa, aos direitos e garantias processuais do acusado e, ainda, o plexo de regras constitucionais responsáveis por assegurar a autonomia e independência do Poder Judiciário.

${ }^{312}$ Ubiratan Cazetta, Direitos Humanos e Federalismo: O Incidente de Deslocamento de Competência, São Paulo, Atlas, 2009, p. 92. 
Ao listar os benefícios sistêmicos que podem ser extraídos da adoção do incidente de deslocamento de competência pela ordem jurídica pátria, FLÁVIA PIOVESAN leciona que a federalização dos crimes de direitos humanos traz quatro contribuições muito substanciais à proteção desses direitos, a saber: $(i)$ assegura maior proteção à vítima e fortalece o combate à impunidade, pois os ofendidos passam a contar com as instâncias federais se houver falha ou inércia da Justiça estadual; (ii) amplia e dissemina a responsabilidade internacional em matéria de direitos humanos entre os diversos entes federados, em especial sensibiliza as unidades estaduais no tocante à tarefa que lhes cabe para a efetivação da gama de direitos da pessoa humana, já que a omissão ou falta de atenção para com a matéria pode incitar a atuação dos órgãos judiciários federais; (iii) fortalece, no contexto brasileiro, a responsabilidade da União em relação aos direitos humanos, o que contribui para a superação do paradoxo de o ente central ser externamente responsável pela observância desses direitos, mas se encontrar, no plano nacional, despido de competências para investigar, processar e julgar esses ilícitos; (iv) aperfeiçoa as ferramentas de responsabilidade interna em face das graves violações dos direitos humanos, haja vista que pode induzir a melhoria das instituições judiciárias estaduais para a deficitária atuação destas não venha ensejar o deslocamento da competência para as instâncias federais julgarem casos que envolvem o descumprimento dos direitos da pessoa humana ${ }^{313}$.

Em que pese o instituto jurídico em apreço ser, sob a ótica do Direito Internacional, um grande avanço que potencializa a concretização interna dos direitos humanos, significando, ainda, para o Direito Constitucional, uma nova e expressiva ferramenta de abertura ao exterior, há questionamentos doutrinários sobre a constitucionalidade do mesmo. De fato, não existem precedentes do Supremo Tribunal Federal atestando eventuais impropriedades da norma constitucional derivada inscrita no $\S 5^{\circ}$, do art. 109 da Constituição de $1988^{314}$, o que não depõe contra a importância desses posicionamentos

\footnotetext{
${ }^{313}$ Cf. Reforma do Judiciário e Direitos Humanos, in Reforma do Judiciário: Analisada e Comentada, André Ramos Tavares, Pedro Lenza e Pietro de Jesús Lora Alarcón (coord.), São Paulo, Método, 2005, pp. 79-81. Gustavo HenRIQUe Righi IVAHY BADARÓ acrescenta que "as causas relativas a direitos humanos e as hipóteses de grave violação não dizem respeito apenas ao processo penal visando a punição por cometimentos de crimes, podendo ser aplicadas no caso de processos civis que tenham tal tema como objeto. Inclui-se em tal competência qualquer causa que tenha por objeto direitos humanos que tenham sido gravemente violados" (A Garantia do Juiz Natural e o Incidente de Deslocamento de Competência para a Justiça Federal, em Caso de Grave Violação de Direitos Humanos, in Questões Relevantes do Direito Penal e Processual Penal, Fernando Gentil Gizzi de Almeida Pedroso e Roberto Victor Pereira Ribeiro (org.), Porto Alegre, Lex Magister, 2012, p. 294).

${ }^{314}$ Registre-se que há notícias da impugnação do dispositivo referido por meio de duas Ações Diretas de Inconstitucionalidade, a ADI n 3.486 e a ADI n 3.493, propostas, respectivamente, pela Associação dos
} 
divergentes. Isso porque as reflexões deflagradas pelos autores que enxergam eventuais máculas de inconstitucionalidade nesta parte da Emenda Constitucional no 45/2004, caso não confirmadas pelos órgãos encarregados de defender a supremacia da Constituição, certamente ajudam a melhor compreender a extensão e a própria natureza do instituto que ocupa a posição de objeto da discordância.

Nesse compasso, Ingo Wolfgang SARlet, Leonardo Furian e Tiago FENSTERSEIFER esposam a tese de que "a instituição do deslocamento de competência constitui, já por si só, pelo menos uma efetiva ameaça ao núcleo essencial do princípio federativo e, portanto, equivale à sua tendencial abolição"315. Também cumpre consignar que Gustavo HenRIQue Righi IVAHY BADARó considera que o incidente, na forma como foi disciplinado, viola a garantia do juiz natural, enquanto direito ao juiz competente determinado por lei (art. $5^{\circ}$, inciso LIII) ${ }^{316}$, a qual constitui cláusula pétrea, principalmente em virtude da utilização de critérios vagos e indeterminados no tocante à definição da hipótese de alteração da competência ("grave violação dos direitos humanos") e de deixar à discricionariedade de apenas um único legitimado sua propositura ${ }^{317}$. Os argumentos lançados não deixam de ser interessantes, mas enfrentá-los de modo satisfatório desviaria por completo o foco deste trabalho, sobretudo porque a profundidade das discussões a serem empreendidas demandaria, com certeza, a confecção de um trabalho monográfico específico que trate do assunto.

Assim sendo, opta-se por reafirmar que o IDC, ao menos no que tange ao aspecto finalístico, está em consonância com a tendência de internacionalização das Constituições, o que deve ser contabilizado como importante fator para atestar a constitucionalidade do instituto. Não se está defendendo, aqui, que o instituto dispense aclaramentos e definições mais objetivas, o que pode ser feito em especial pela jurisprudência do Superior Tribunal de Justiça, que é o único órgão competente para processar e julgar o pleito de deslocamento apresentado pelo Chefe do Ministério Público da União. Em caráter excepcional, é igualmente possível que decisões da Suprema Corte brasileira a respeito da

Magistrados Brasileiros (AMB) e Associação Nacional dos Magistrados Estaduais (ANAMAGES), estando ambas, até o momento, aguardando julgamento definitivo.

${ }^{315}$ A Reforma (ou Deforma?) do Judiciário e a Assim Denominada "Federalização" dos Crimes Contra os Direitos Humanos: Proteção ou Violação de Princípios e Direitos Fundamentais, in Revista Eletrônica de Direito Público, no 4, jan./fev. 2006, p. 22.

316 “Art. $5^{\circ}[\ldots]$ LIII - ninguém será processado nem sentenciado senão pela autoridade competente".

${ }^{317}$ Cf. A Garantia do Juiz Natural e o Incidente de Deslocamento de Competência para a Justiça Federal, em Caso de Grave Violação de Direitos Humanos, in Questões Relevantes do Direito Penal e Processual Penal, Fernando Gentil Gizzi de Almeida Pedroso e Roberto Victor Pereira Ribeiro (org.), Ob. cit., p. 297. 
precisa extensão normativa do comando albergado no art. $109, \S 5^{\circ}$, da Lei Fundamental também cumpram esse papel.

A jurisprudência do Superior Tribunal de Justiça já apresenta sinais de que pode, realmente, servir para solucionar os pontos de inflexão que podem ser levantados com a operacionalização do incidente. Esse dado é comprovado, por exemplo, com o acórdão lavrado em 2005, na ocasião do julgamento do IDC $\mathrm{n}^{\circ} 1$, quando a Corte esclareceu que “aparente incompatibilidade do IDC, criado pela Emenda Constitucional no 45/2004, com qualquer outro princípio constitucional ou com a sistemática processual em vigor deve ser resolvida aplicando-se os princípios da proporcionalidade e da razoabilidade" ${ }^{\natural 18}$. No mesmo aresto - que teve como pano de fundo a fixação da competência para julgar os envolvidos no homicídio da missionária Dorothy Stang, ocorrido no Estado do Pará também ficou assentada outra fulcral diretriz: a exigência de que, além do princípio da proporcionalidade, o deferimento da ordem para alterar a competência está condicionado à demonstração concreta de risco de descumprimento de obrigações decorrentes de tratados internacionais de que o Brasil seja parte, resultante da inércia, negligência, falta de vontade política ou de condições reais do Estado-membro, mediante suas próprias instituições, proceder à devida persecução penal; não bastando, para tanto, a verificação de comoção nacional ou de pressão da opinião pública interna e internacional em torno do ilícito ${ }^{319}$.

Vale ainda fazer referência ao pronunciamento do Superior Tribunal de Justiça, em 2010, no julgamento do IDC $\mathrm{n}^{\mathrm{o}} 2$ (caso Manoel Bezerra de Mattos Neto, assassinado no Estado da Paraíba por grupos de extermínio que atuam na divisa deste Estado com o Estado de Pernambuco). O acórdão publicado, além de ser o único precedente em que houve o acolhimento do pedido de deslocamento competencial, evidencia a confirmação dos parâmetros hermenêuticos fixados no julgado do IDC $\mathrm{n}^{\circ} 1$, ao mesmo tempo em que certifica a notável sensibilidade do STJ em relação ao tratamento do princípio federativo, que poderia restar violado com a decisão. $\mathrm{Na}$ ementa há sinais muito consistentes de que o Tribunal realmente perquiriu acerca da incapacidade das instâncias estaduais em oferecer respostas efetivas ao ocorrido, porque há menção expressa à reconhecida limitação e precariedade dos órgãos locais de apuração do crime e também à existência de um "quase pronunciamento uníssono em favor do deslocamento de competência para a Justiça Federal, dentre eles, com especial relevo: o Ministro da Justiça; o Governador do Estado

\footnotetext{
${ }^{318}$ STJ, IDC n ${ }^{\circ}$ 1, Rel. Min. ARNALDo Esteves Lima, Ementa, julgamento 07/06/2005, DJ 10/10/2005, decisão disponível no endereço eletrônico www.stj.jus.br.

${ }^{319}$ Cf. Idem.
} 
da Paraíba; a Secretaria Executiva de Justiça de Direitos Humanos; a Ordem dos Advogados do Brasil; a Procuradoria-Geral de Justiça do Ministério Público do Estado da Paraíba"320.

É oportuno, pois, encerrar o presente Capítulo tratando justamente do incidente de deslocamento de competência. Esse instrumento pode perfeitamente ser considerado como síntese elucidativa do que já se desenvolveu neste trabalho e de outros aspectos que serão abordados logo na sequência. Inicialmente, é preciso concordar que o deslocamento de competência entre esferas judiciárias nacionais atesta que a identidade material entre normas jurídicas internas e internacionais, mais do que fomentar a emergência de um Direito Comum, obriga os Estados nacionais a adotar medidas eficientes em prol da permeabilidade ao Direito das Gentes, sendo as normas relativas aos direitos humanos as mais beneficiadas por esse fenômeno jurídico. Também se apresenta como indicativo de que a internacionalização das Constituições, ao consagrar no texto constitucional valores e mandamentos cuja gênese remonta às relações exteriores, impõe a todos os Poderes estatais a necessidade de atuarem como garantidores de valores jurídicos que, no passado, dificilmente constituíam objetos dos atos que praticavam.

Sob esse enfoque, o incidente de deslocamento de competência atribui a duas instituições nacionais - o Poder Judiciário e o Ministério Público - o encargo de evitar que a República Federativa do Brasil sofra condenações em Cortes internacionais decorrentes da desídia interna na efetivação de tratados e convenções voltados à proteção do ser humano. Tamanho é o alargamento de atribuições dos Poderes estatais no campo do internacionalismo que o próximo Capítulo irá explorar esse quadro que se vem descortinando e, como consequência, causando impactos no funcionamento do mecanismo de freios e contrapesos, tão caro ao Direito Constitucional contemporâneo. Em verdade, tudo indica que o progressivo entrelaçamento entre as ordens internacional e estatais desemboca na "necessidade de superação do tratamento provinciano de problemas constitucionais pelos Estados, sem que isso nos leve à crença na ultima ratio do Direito Internacional Público: não só aqueles, mas também este pode equivocar-se quando confrontado com questões constitucionais, inclusive com problemas de direitos humanos" ${ }^{321}$, daí o porque se insiste na imprescindibilidade da construção de um permanente diálogo entre ambos os universos jurídicos.

${ }^{320}$ STJ, IDC $\mathrm{n}^{\circ}$ 2, Rel. Min. LAURITA VAZ, Ementa, julgamento 27/10/2010, DJ 22/11/2010, decisão disponível no endereço eletrônico www.stj.jus.br.

${ }^{321}$ Marcelo NeVes, Transconstitucionalismo, Ob. cit., p. 151. 


\section{O PRINCÍPIO DA SEPARAÇÃO DOS PODERES E DIREITO INTERNACIONAL}

"O Estado recebe direitos da sociedade internacional. Porém, a execução de um tratado ocorre por obra dos órgãos do Estado, os quais devem obedecer as regras do Direito Constitucional".

BORIS MIRKINE-GUETZÉVITCH ${ }^{322}$

\subsection{Princípio da Separação dos Poderes e o Regime de Corresponsabilidade na Efetivação das Normas Internacionais}

O constitucionalismo é uma inovação relativamente recente na história das instituições políticas, tendo surgido no último quarto do século XVIII, com as revoluções nas colônias britânicas da América do Norte e, depois, na França. Alcançou seu ápice no século XX, o que se comprova, segundo DIETER GRIMM, pelo fato de que, na atualidade, "apenas uma parcela ínfima dos quase 200 Estados no mundo permanece sem uma Constituição" ${ }^{\$ 23}$. Lastreado em valores que se difundiram rapidamente pelo mundo - como os postulados da democracia, da separação de poderes e dos direitos e garantias fundamentais -, esse movimento possibilitou que a maioria dos Estados lograsse êxito em se auto-organizarem, o que permitiu aos países avanços institucionais que se refletiram tanto no cenário nacional, quanto internacionalmente. Hoje, o Estado nacional compartilha seu poder com uma gama de atores não estatais, a maioria deles organizações internacionais que são criadas e passam a funcionar com base em arranjos jurídicos e políticos nem sempre expressamente reconhecidos como válidos pelas Constituições nacionais.

Não se trata, pois, de um quadro em que as normas constitucionais são violadas pelas prescrições oriundas do Direito Internacional, mas de casos em que é possível identificar lacunas entre os comandos consagrados nas Constituições e a realidade operada no âmbito das relações exteriores. Embora esse deslocamento entre norma e fato não seja um problema inédito e insolúvel para o Direito ${ }^{324}$, há de se reconhecer que o

\footnotetext{
${ }^{322}$ Derecho Constitucional Internacional, Ob. cit., p. 224.

${ }^{323}$ The Achievement of Constitutionalism and Its Prospects in a Changed World, in The Twilight of Constitutionalism?, Petra Dobner e Martin Loughlin (Org.), Oxford, Oxford University Press, 2010, p. 3.

${ }^{324}$ Recorde-se que, de acordo com a teoria de MigUEL REALE, a norma jurídica resulta de fatos ordenados conforme distintos valores, sendo, portanto, integrada por uma estrutura tridimensional, em que fatos e valores interagem dialeticamente. $O$ excerto que segue sintetiza essa concepção: “[...] o termo 'tridimensional' só pode ser compreendido rigorosamente como traduzindo um processo dialético, no qual o elemento normativo integra em si e supera a correlação fático-axiológica, podendo a norma, por sua vez,
} 
aprofundamento desses pontos de distorção pode minar o potencial do Direito Constitucional para disciplinar os aspectos de maior importância para a vida pública e para regular o exercício do poder político no raio territorial onde a Constituição vigora ${ }^{325}$. E, ainda que exista verdadeiro consenso quanto aos benefícios advindos do adensamento do Direito das Gentes à coexistência e à cooperação interestatal, e, de forma mais notável, à proteção da pessoa humana, JÜRGEN HABERMAS não deixa de pontuar que a transferência de competências antes desempenhadas exclusivamente pelas instâncias nacionais para órgãos internacionais vem acompanhada de um fenômeno preocupante: a formação de "vazios de legitimação"326.

Corrobora esse ponto de vista ROBERT A. DAHL, que, depois de analisar o processo de tomada de decisões dentro das organizações internacionais, concluiu que esses organismos "não são e nem tendem a ser democráticos" ${ }^{\text {"327 }}$. Adverte, porém, o autor que isso não significa que as organizações em tela sejam indesejáveis, uma vez que aumentam, a cada dia, as evidências de que elas são necessárias para atender a muitas das necessidades humanas, sobretudo para solucionar os delicados problemas transnacionais que se avolumam com a globalização ${ }^{328}$. $\mathrm{O}$ avanço das tarefas executadas por organismos intergovernamentais e supranacionais, bem como a convicção já externada por uma série de Constituições acerca da impossibilidade de o Estado soberano fechar-se para o Direito Internacional, impõe ao constitucionalismo o desafio de, conservando-se sua essência e seus dogmas, adaptar-se às múltiplas transformações ditadas pelo internacionalização das Constituições.

Sob essa perspectiva, as teorias tradicionais do Direito Constitucional, forjadas em um momento histórico e político muito diferente do presente, acabam tendo de ser revisitadas e recebem ajustes a fim de se adaptarem ao complexo contexto erigido no século XXI. Além da criação de normas constitucionais originárias ${ }^{329}$, também sofrem

converter-se em fato, em um ulterior momento do processo, mas somente com referência e em função de uma integração normativa determinada por novas exigências axiológicas e novas intercorrências fáticas" (Teoria Tridimensional do Direito, $2^{a}$ ed., São Paulo, Saraiva, 1979, p. 77).

${ }^{325}$ Cf.DIETER GRIMM,The Achievement of Constitutionalism and Its Prospects in a Changed World, in The Twilight of Constitutionalism?, Petra Dobner e Martin Loughlin (Org.), Ob. cit., pp. 3-4.

${ }^{326}$ Cf. A Constelação Pós-Nacional, Ob. cit., p. 91.

${ }^{327}$ Can International Organizations be Democratic? A Skeptic's View, inDemocracy Edges, Ian Schapiro e Hacker-Cordón (org.), Cambridge, Cambridge University Press, 1999, p. 32.

${ }^{328} \mathrm{Cf}$. Idem, Ibidem.

${ }^{329}$ Cite-se o exemplo de J. J. Gomes CANOTILHO, patrocinadorda teoria denominada de constitucionalismo global, que propagada a ideia de ampla adoção dos seguintes vetores internacionais no universo do Direito Constitucional: "(1) alicerçamento do sistema jurídico-político internacional não apenas no clássicoparadigma das relações horizontais entre Estados (paradigma hobbesiano/westfalliano) mas no novo paradigma centrado nas relações Estado/povo (as populações dos próprios Estados); (2) emergência de um 
remodelações, para que não se tornem barreiras à inserção dos Estados em uma sociedade internacional marcada pela rarefação das fronteiras entre o interno e o exterior, o princípio da separação dos poderes e, até mesmo, a forma federativa de Estado. Em virtude da envergadura que a separação de poderes representa para a arquitetura do Estado constitucional e do fato de sua correta aplicação ser determinante para não apenas impulsionar o movimento de abertura dos sistemas constitucionais, mas, sobretudo, para compatibilizar as tensões que podem surgir entre as duas ordens jurídicas referidas, é que se passa agora a tratar dos reflexos sentidos na conformação desse princípio constitucional de primeira importância por força da crescente permeabilidade da Constituição à normativa internacional.

Vale sublinhar que, como ocorre com a competência para interpretar e aplicar o Direito Interno, o texto constitucional não confere apenas a um Poder constituído estatal a tarefa de executar o Direito Internacional. Essa missão surge como incidente necessário para o exercício das diversas atribuições estipuladas ao Executivo, Legislativo e Judiciário. Assim, é de se convir que, na esfera doméstica, a interpretação e a concretização do Direito das Gentes não deixam de ser funções relacionadas à lógica imanente ao princípio constitucional da separação dos poderes. Na prática, essa ilação permite afirmar que todos os Poderes podem exercer, no limite de suas áreas de atuação constitucionalmente demarcadas, funções de controle importantes para o exercício dessa mesma competência pelos congêneres, o que faz do mecanismo de checks and balances uma ferramenta vital para o desenvolvimento das relações exteriores ${ }^{330}$.

Ganha destaque, nessa órbita, a necessidade de elaboração de Constituições que demonstrem sensibilidade com a questão internacional, porque é exatamente esse documento jurídico o meio essencial para fazer que o Estado possa desenvolver, com segurança, as imprescindíveis relações com os demais sujeitos internacionais. Enfatize-se que, perante a sociedade internacional, o Estado não se apresenta compartimentalizado nos diferentes Poderes pelos quais exerce suas ações que tenham relevância externas, motivo

jus cogens internacional materialmente informado por valores, princípios e regras universais progressivamente plasmados em declarações e documentos internacionais; (3) tendencial elevação da dignidade humana a pressuposto ineliminável de todos os constitucionalismos" (Direito Constitucional e, Ob. cit., p. 1370). Caminham na mesma direção: Jorge Miranda, Direito Constitucional e, Ob. cit., p. 90; Mauricio IVÁn Del TORO Huerta,La Apertura Constitucional al Derecho Internacional de los Derechos Humanos en la Era de la Mundialización y sus Consecuencias en la Práctica Judicial, in Boletín Mexicano de Derecho Comparado, n 112, ano 38, 2005, pp. 357-358; e HuMBERTo NogueIRA AlCALÁ, Los Limites del Poder Constituyente y el Control de Constitucionalidad de las Reformas Constitucionales en Chile, in Estudios Constitucionales, ano 4, n 2, 2006, pp. 443-445.

${ }^{330} \mathrm{Cf}$. Michael StOKes PAULSEN, The Constitutional Power to Interpret International Law, in The Yale Law Journal, vol. 118, 2009, pp. 1807-1808. 
pelo qual é recomendável que as previsões constitucionais deixem bem aclarado o regime de corresponsabilidade entre todos os órgãos públicos na execução dos mandamentos exteriores. O Estado é um só; e, por isso mesmo, os atos com repercussão internacional que editar, independentemente de terem sido objeto de manifestação do Executivo, Legislativo ou Judiciário, sempre podem acarretar-lhe responsabilidade internacional ${ }^{331}$.

Ademais, é de se reconhecer que o fato de a competência material para executar tarefas internacionais constituir matéria tipicamente reservada ao Poder Executivo não impediu que a atual conformação da ordem constitucional brasileira compartilhasse responsabilidades pelo sucesso das ações do Estado nesse setor. Mesmo não exercendo os atos materiais que concretizam o poder exterior do país, os Poderes Legislativo e Judiciário podem, perfeitamente, adotar medidas que contribuam para a execução, no terreno doméstico, das normas e projetos com os quais o Brasil se vincula externamente. Fortalece essa linha de entendimento a manifestação do Ministro JoAQuim BARBOSA, no voto que proferiu no julgamento da $\operatorname{ADI} \mathrm{n}^{\mathrm{o}} 1625$, de cujo teor se extrai que "o atual texto constitucional - ao estabelecer de maneira sistemática, pela primeira vez na história constitucional, princípios que regem as relações exteriores do Brasil (art. $4^{\circ}$ ) -, teria reforçado o papel do Parlamento em matéria de política exterior. Cumpriria a todos os Poderes, e não só ao Executivo, portanto, zelar por tais princípios, bem como fiscalizar a atuação da política externa"332.

Nessa direção, observa-se que a explícita afirmação, em textos constitucionais, de propósitos e princípios inspiradores do comportamento internacional dos Estados atua como interessante fator de contenção de excessos na condução dos negócios exteriores que poderiam ser praticados pelo Poder Executivo. A existência de normas versando sobre esse assunto nas Constituições significa marcos jurídicos que reforçam a possibilidade de controle político por parte do Parlamento sobre a atividade exterior, visto que permite identificar condutas contrárias aos valores inspiradores do Direito Internacional, os quais, agora, seguem consagrados nas Cartas Magnas de diversos países. Em igual medida, abrese caminho para que o Poder Judiciário realize controle de constitucionalidade com a finalidade de assegurar que esses princípios, originados no Direito das Gentes, possam ser

\footnotetext{
${ }^{331}$ Cf.José CARlos de MagalhãEs, O Supremo Tribunal, Ob. cit., p. 61.

${ }^{332} \mathrm{STF}$, ADI n ${ }^{\circ} 1625-\mathrm{DF}$, Relator Min. MAURícIO CORRÊA, Voto do Min. JOAQUIM BARBOSA, Informativo do $S T F n^{\circ} 549$, de 01/06/2009, documento disponível no endereço eletrônico www.stf.jus.br.
} 
cumpridos internamente pelos órgãos estatais, em virtude de figurarem como normas constitucionais $^{333}$.

É inegável que a maior penetração do Direito Internacional nas ordens constitucionais ocasiona alterações de institutos que foram regidos, durante séculos, puramente pelo Direito Constitucional. Consoante a percepção de HÉLÈNE TOURARD, esse dado alcança com maior intensidade "as relações entre os Poderes Públicos e as relações entre estes últimos e os indivíduos”,334, obrigando, por certo, a reformulação de alguns mecanismos de interação entre as instâncias governamentais abrigadas no interior dos Estados. Em resumo, a autora informa que as transformações podem ser aferidas no tocante às seguintes matérias: ( $i$ ) questionamentos sobre democracia constitucional, na medida em que a produção de normas internacionais não se processa em atenção ao princípio da soberania popular, exercida por meio de representantes eleitos; (ii) aumento dos instrumentos ofertados pela Constituição para permitir que o Poder Executivo envolva o Estado no cenário internacional; (iii) ampliação do conjunto normativo cuja implementação caberá ao Judiciário, já que não mais somente atos normativos criados pelo Estado passam a ter execução no sistema jurídico interno; (iv) progressiva perda, pelo Parlamento, do papel de legislador, pois a função legislativa é cada vez mais moldada e substituída pelo Direito Internacional ${ }^{335}$.

Dessa forma, confirma-se que está em curso uma lenta refundação das bases de afirmação da soberania. A remodelação desse conceito passa a servir como justificativa para que cada Estado nacional, sem se desapegar dos valores e das tradições que lhes são caros, transforme a Constituição em ferramenta que, simultaneamente, viabiliza a abertura para as relações internacionais e fixe limites a esse movimento. É certificado, desse modo, o potencial do constitucionalismo para preparar condições de execução das medidas voltadas à realização da solidariedade interestatal - notadamente ações em prol da observância dos direitos humanos em suas múltiplas faces (em especial, proteção do indivíduo, assistência ao desenvolvimento econômico e social, preservação do meio ambiente, combate ao terrorismo, etc.) - indicando, assim, que o aprimoramento das relações exteriores não pode prescindir do alinhamento das Constituições em torno desse propósito $^{336}$.

\footnotetext{
${ }^{333}$ Cf. Antonio Remiro Brotons, La Accion Exterior, Ob. cit., pp. 94-95.

${ }^{334}$ L'Internationalisation des, Ob. cit., p. 641.

${ }^{335} \mathrm{Cf}$.Idem, Ibidem.

${ }^{336}$ Cf. PETER HÄBERLE, Estado Constitucional Cooperativo, Ob. cit., pp. 70-71.
} 
Diante dessas considerações, é crível defender que a ampliação das zonas de contato entre Direito Interno e Direito Internacional tem causado uma evolução institucional tanto dos órgãos do poder nacional quanto dos organismos internacionais. Esse dado é mais visível em Constituições elaboradas após 1945, as quais, lentamente, incorporaram as conquistas que a sociedade internacional logrou alcançar nesse período. Cumpre advertir que fenômeno em comento não significa que as Constituições devam sempre positivar, em seus textos, as mudanças operadas no espaço internacional, pois a adoção desse raciocínio importaria reduzir o Direito Constitucional a mero satélite das relações exteriores. Parece claro, todavia, que os estudiosos do Direito Constitucional, bem como os estudiosos do Direito das Gentes, devem orientar seus trabalhos cientes de que os institutos afirmados em um conjunto normativo decerto trarão impactos no outro, o que enaltece sobremaneira a relevante função dos entendimentos dialógicos entre esses dois segmentos do conhecimento jurídico, para o fortalecimento de ambos.

Interessa observar que a internacionalização das Constituições e as consequências dessa tendência nos arranjos que caracterizam o princípio da separação dos poderes não permitem que a normativa internacional, por si só, imponha alterações na maneira como cada sistema constitucional disciplina essa matéria. Ao contrário, é preciso esclarecer que a abertura do Direito Constitucional ao Direito das Gentes não torna anacrônico o entendimento "de que todos os atos da representação externa do Estado federal têm de ser exercidos em conformidade com as regras da Constituição, tanto na sua forma, como no seu conteúdo, sob pena de perder a sua validade, mesmo a geral e especialmente a necessária para a sua aplicação interna ${ }^{\text {"337 }}$. Conserva-se, pois, incólume todo o significado da advertência de que "as atribuições constitucionais dos Poderes Públicos, igualmente, não podem ser alteradas, por via contratual internacional. Como regra, pode-se dizer que onde há um preceito constitucional uma barreira se levanta à liberdade de contratar",338, apresentada por AURELIANO LEAL.

Frise-se, por derradeiro, que os atos de representação externa seguem subordinados aos preceitos das respectivas Constituições, cabendo apenas às normas constitucionais distribuir competências entre os órgãos internos a fim de que as mais variadas ações no terreno exterior sejam desenvolvidas ${ }^{339}$. O que ocorre nos últimos tempos é o surgimento

\footnotetext{
${ }^{337}$ Cláudio PaCheco, Novo Tratado das Constituições Brasileiras, Vol. 3, Brasília, Offset, 1992, p. 385.

${ }^{338}$ Teoria e Prática da Constituição Federal Brasileira - Primeira Parte: Da Organização Federal e do Poder Legislativo (Arts. 1 a 40), Rio de Janeiro, F. Briguiet e Cia, 1925, p. 629.

${ }^{339}$ Cf. Antonio La Pergola,Poder Exterior y, Ob. cit., p. 25.
} 
de novas modalidades de arquitetar as relações de controle recíproco entre os Poderes estatais, muitas vezes com o objetivo de dinamizar a inserção dos países em cenários caracterizados pela presença de instâncias internacionais que, a exemplo das funções típicas do Estado, também executam atividades em matérias legislativas, judiciárias e executivas. Como as atividades desempenhadas por esses órgãos internacionais geralmente precisam de complementação interna, tem-se que, atualmente, é impossível investigar o processo de entrelaçamento dos Estados Constitucionais com a sociedade internacional sem dedicar atenção à problemática da separação dos poderes.

\subsection{Poder Executivo e Relações Exteriores}

Em meio às reflexões que contribuíram para sedimentar as bases do constitucionalismo contemporâneo, JOHN LOCKE apontou a preocupação teórica de diferenciar a atuação do Poder encarregado da "execução das leis municipais da sociedade dentro de seus próprios limites sobre todos os que dela fazem parte" ${ }^{340}$ das ações realizadas pelo "Poder de guerra e paz, de firmar ligas e promover alianças e todas as transações com todas as pessoas e sociedades políticas externas" ${ }^{341}$. Sob essa perspectiva, o primeiro corresponderia ao Poder Executivo, enquanto o segundo ao Poder Federativo. Embora cuidassem de aspectos diversos da vida pública do Estado, dificilmente poderiam ser separados e confiados a pessoas diferentes, uma vez que a duplicidade na Chefia causaria grandes dificuldades para a governabilidade do país. O motivo que justificaria, então, a existência desses dois Poderes era o de que matérias referentes aos negócios exteriores deveriam sofrer menor controle do Poder Legislativo, porque o exercício das atribuições no campo internacional deveria ser acompanhado de um considerável grau de flexibilidade de movimentos e de liberdade decisória por parte da autoridade competente $^{342}$.

Com as variações que são próprias a cada uma das ordens nacionais, a concepção de LOCKE influenciou a estruturação de regimes constitucionais em que as competências internacionais são caracterizadas por "uma concentração de prerrogativas em torno do Executivo, pois só esse Poder reúne os requisitos necessários para imprimir dinâmica contínua à política externa, garantindo a segurança do Estado e preservando a sua

\footnotetext{
${ }^{340}$ Dois Tratados sobre o Governo, $2^{\mathrm{a}}$ ed., São Paulo, Martins Fontes, 2005, p. 516.

${ }^{341}$ Idem, Ibidem.

${ }^{342}$ Cf. Antonio Remiro Brotons, La Accion Exterior, Ob. cit., p. 14.
} 
existência",343. Vislumbra-se, desse modo, que "a atribuição para manter relações com Estados estrangeiros, em que o Presidente da República pode agir sem dependência de aprovação do Congresso Nacional, comporta uma larga margem de atos de representação, de cortesia, de entendimento, de participação, de discussão e de votação em órgãos internacionais permanentes e em Congressos ou Conferências, de estímulo a atividades culturais e até mesmo de contatos e visitas entre Chefes de Estado"344. Daí, o motivo por que cumpre ao titular do Poder Executivo desempenhar com primazia as ações exteriores, o que, como será exposto adiante, não exclui um controle realizado pelos demais Poderes.

Um aspecto sempre complicado na disciplina das competências exteriores dos Poderes nacionais são os limites constitucionais para o exercício dessa atribuição. Mesmo imprescindíveis, as modalidades de controle aventadas pelo constitucionalismo, deverão ser apreciadas com cautela, pois cerceamentos excessivos podem enfraquecer o Estado nacional como um todo, tornando praticamente impossível a defesa dos interesses nacionais diante de outros Estados e instâncias internacionais ${ }^{345}$. Ao se internacionalizarem, as Constituições passam a ter de lidar com novas e complicadas variantes, o que aumenta expressivamente as dificuldades de calibrar o já delicado mecanismo de freios e contrapesos entre os Poderes. Deve-se tomar cuidado, sobretudo, para não fomentar a hipertrofia do Poder Executivo, o qual tem recebido severas críticas por concentrar em demasia o exercício de funções que, ordinariamente, pertencem aos demais Poderes 346 .

Uma das formas possíveis de proceder - sem que ocorra o engessamento, nem a concessão de uma margem de liberdade muito ampla para o Chefe de Estado - é positivar, no texto constitucional, princípios que orientem o desenvolvimento das ações internacionais do país. Considerado o alto significado que esse tipo de comando normativo condensa, tem-se que suas funções ultrapassam a clássica ideia de proibir ou permitir

\footnotetext{
${ }^{343}$ AntÔNIO PaUlo CAChaPUZ De Medeiros, Atualização do Direito dos Tratados, in Desafios do Direito Internacional Contemporâneo, Antônio Paulo Cachapuz de Medeiros (org.), Brasília, Fundação Alexandre de Gusmão, 2007, pp. 154-155.

${ }^{344}$ ClÁUdio PACHECO, Novo Tratado das Constituições Brasileiras, Vol. 5, Brasília, Offset, 1992, p. 68.

${ }^{345}$ Cf. Antônio Paulo Cachapuz de Medeiros, Atualização do Direito dos Tratados, in Desafios do Direito Internacional Contemporâneo, Antônio Paulo Cachapuz de Medeiros (org.), Ob. cit., p. 156.

${ }^{346}$ Defende CARLos Ayres BRITTO que "não é difícil identificar e classificar um conjunto de normas constitucionais que elevam o Poder Executivo a uma posição de supremacia, em relação aos demais órgãos estruturais da União, particularmente o Poder Legislativo. Ou seja, há um tratamento jurídico nitidamente discriminatório, quando se cuida de outorgar competências aos dois Poderes eminentemente políticos do Estado - Executivo e Legislativo - com desvantagem para esse último" (Supremacia do Poder Executivo na União, na Partilha Constitucional de Competências, inDireito Constitucional: Organização dos Poderes da República (Coleção Doutrinas Essenciais, vol. 4), Clèmerson Merlin Clève e Luís Roberto Barroso (org.), Ob. cit., p. 451).
} 
condutas passíveis de execução, na medida em esses princípios se equivalem a diretrizes que objetivam dirigir ações de política externa por meio da fixação de metas a serem alcançadas com programas governamentais ${ }^{347}$. A implementação desses programas demanda a junção de uma série de atos estatais, cuja elaboração não fíca circunscrita apenas ao domínio presidencial, requerendo, pois, o efetivo envolvimento dos Poderes Legislativo e Judiciário.

No caso do Brasil, além dos vetores axiológicos estampados como princípios fundamentais no art. $4^{\circ}$ da Lei Maior, as competências presidenciais sobre o tema analisado estão previstas em diversos incisos do art. 84 (incisos VII, VIII, XIX, XX e $\mathrm{XXII})^{348}$. Entre esses incisos, destaca-se a redação empregada no inciso VII, que consagra uma cláusula genérica responsável por conceder razoável campo de discricionariedade para que o Chefe do Executivo desempenhe suas atribuições internacionais. Acerca do assunto, George Rodrigo Bandeira GaLindo analisa a norma apontada como "um daqueles dispositivos constitucionais que, embora redigidos economicamente, dão margem a uma gama amplíssima de atribuições. As escolhas (acertadas ou equivocadas) em matéria de política externa, tomadas pelo Poder Executivo, têm sua base reconhecida nessa competência aparentemente singela, mas com repercussões profundas para o Estado brasileiro: 'manter relações com Estados estrangeiros' e sua consequência, acreditar seus representantes diplomáticos" 349 .

É interessante sublinhar que, embora a literalidade da Constituição mencione somente a expressão "Estados estrangeiros", o mandamento em tela assegura ao Presidente

\footnotetext{
${ }^{347}$ Cf.Celso Lafer, A Internacionalização dos Direitos,Ob. cit., p. 19. Em complemento, observa GEORGE RODRIGO BANDEIRA GALINDO que "até antes da Constituição de 1988 havia quase nenhum limite explícito à condução das relações exteriores. A não ser por pequenas referências à solução pacífica de controvérsias, as escolhas nesse campo ficavam a cargo do Presidente, devendo este observar apenas os limites implícitos constitucionais. $\mathrm{O}$ art. $4^{\circ}$ da atual Constituição, pela primeira vez, estabelece que aquela competência oriunda da fórmula 'manter relações com Estados estrangeiros' encontra limites materiais claros. Assim, desde 1988, essa competência possui limites explícitos e implícitos, e, desse modo, deve-se compreender o art. 84, VII, não como uma carta branca, mas como um elemento para racionalizar a atividade do Estado (competência) à luz de normas acordadas pela comunidade política (Constituição)" (Art. 84, VII, in Comentários à Constituição do Brasil, J. J. Gomes Canotilho, Gilmar Ferreira Mendes, Ingo Wolfgang Sarlet, Lenio Streck e Léo Ferreira Leoncy (coord.), Ob. cit., p. 1239).

348 “Art. 84. Compete privativamente ao Presidente da República: [...] VII - manter relações com Estados estrangeiros e acreditar seus representantes diplomáticos; VIII - celebrar tratados, convenções e atos internacionais, sujeitos a referendo do Congresso Nacional; XIX - declarar guerra, no caso de agressão estrangeira, autorizado pelo Congresso Nacional ou referendado por ele, quando ocorrida no intervalo das sessões legislativas, e, nas mesmas condições, decretar, total ou parcialmente, a mobilização nacional; XX celebrar a paz, autorizado ou com o referendo do Congresso Nacional; [...] XXII - permitir, nos casos previstos em lei complementar, que forças estrangeiras transitem pelo território nacional ou nele permaneçam temporariamente".

${ }^{349}$ Art. 84, VII, in Comentários à Constituição do Brasil, J. J. Gomes Canotilho, Gilmar Ferreira Mendes, Ingo Wolfgang Sarlet, Lenio Streck e Léo Ferreira Leoncy (coord.), Ob. cit., p. 1239.
} 
da República competência para entabular relações com outros sujeitos internacionais, como as organizações internacionais, movimentos de libertação nacional e beligerantes ou insurgentes. As atribuições do Executivo no contexto das organizações internacionais assume, na atualidade, relevante papel para dinamizar as relações exteriores, pois esses organismos se transformaram em polos de produção normativa, fóruns de solução de controvérsias, e, ainda, centros de formação de alianças políticas. A ascensão dessas organizações, inelutavelmente, ressoa na forma com que as ordens constitucionais disciplinam as atribuições externas dos seus órgãos estatais, sobretudo porque novos instrumentos de interações entre os Estados acabam se afirmando externamente em ritmo muito mais rápido do que aquele em que as normas constitucionais costumam se renovar.

A política exterior obriga, muitas vezes, que Estados realizem reformas constitucionais ou que se valham de inovadoras interpretações de suas Constituições a fim de que possam superar visões estáticas sobre a criação de obrigações no âmbito do Direito das Gentes. Nesse rumo, enfatiza Antônio Paulo Cachapuz de Medeiros que o progresso das relações interestatais acelerou significativamente a produção de normas jurídicas, diversificando as fontes de criação das normas exteriores, o que, por conseguinte, leva à exclusão do controle parlamentar sobre muitas das normas internacionais que terão aplicação interna ${ }^{350}$. Podem ser citadas como exemplos dessa nova realidade algumas espécies normativas editadas por órgãos de integração regional, as quais, desde que autorizadas pelas Constituições nacionais, passam a ser exequíveis no interior dos Estados, sem que seja preciso obedecer a nenhuma formalidade de incorporação geralmente exigida para os tratados em geral.

Depreende-se que, caso os ordenamentos internos não se ajustem aos processos de produção da normativa internacional, duas situações extremas podem ser visualizadas: ou o Estado será alijado dos progressos que podem advir das relações exteriores, ou, no afã de se inserir ao máximo no universo do internacionalismo, o país terminará abraçando comportamentos incompatíveis com suas prescrições constitucionais. Ambas as hipóteses são igualmente indesejáveis porque inviabilizam uma relação de mútuo entendimento entre os sistemas normativos, importando em perdas tanto para o Direito Constitucional quanto para o Direito das Gentes. Sem dúvida, caberá ao Poder Executivo, responsável por conduzir as relações do Estado com o mundo externo, sensibilizar os demais Poderes

${ }^{350}$ Atualização do Direito dos Tratados, in Desafios do Direito Internacional Contemporâneo, Antônio Paulo Cachapuz de Medeiros (org.), Brasília, Fundação Alexandre de Gusmão, 2007, p. 143. 
constituídos para que, mediante a atuação concertada de todos eles, não ocorra dessas situações expostas.

$\mathrm{Na}$ verdade, o avanço do Direito Internacional causa, na esfera doméstica, uma valorização não apenas do papel a ser desempenhado pelo Poder Executivo. É certo que as iniciativas de contato com outros sujeitos internacionais dependem da vontade manifestada por esse Poder, mas tanto o Legislativo quanto o Judiciário têm suas áreas de ação engrandecidas. Ainda que várias espécies normativas cuja gênese ocorra no terreno do Direito das Gentes possam ser internalizadas sem o referendo do Congresso Nacional, caberá sempre ao Poder Judiciário zelar para que a aplicação doméstica dessas normas não implique violação da Constituição. Dessa maneira, a ausência de participação do Parlamento na formação dessas normas pode ser compensada por uma postura mais atuante do Judiciário, que terá aumentado o rol de atos normativos suscetíveis de figurar como objeto do controle de constitucionalidade ${ }^{351}$.

O fato de a Constituição admitir que determinadas normas internacionais possam ser cumpridas internamente sem o crivo do Legislativo não deve ser interpretado como uma autorização para que o Poder Executivo atue, no exercício das relações exteriores, de forma descompromissada com o ordenamento interno. Isso porque as obrigações jurídicas contraídas externamente e transpostas ao âmbito doméstico sempre poderão ser declaradas como incompatíveis com a Constituição, o que, em termos práticos, impossibilitará sua aplicação pelos órgãos nacionais. Essa situação, quando configurada, pode ser muito mais comprometedora ao país do que uma decisão do Legislativo que negue autorização para o Estado se vincular a determinado mandamento internacional. Ainda que a objeção do Parlamento possa ter impactos negativos na esfera da política externa, ela não constitui, sob a ótica do Direito das Gentes, ato ilícito.

Como é sabido, em matéria de responsabilidade internacional, nenhum Estado pode alegar, perante instâncias internacionais, questões internas - como, por exemplo, sentença proferida pelo Poder Judiciário nacional - para exonerar-se do dever de cumprir o que foi

\footnotetext{
${ }^{351}$ AtentaCRISTINA QUEIROZque essa orientação encontra exceções nas instituições regionais europeias em virtude do processo de integração supranacional vivenciado naquele continente. Sob esse prisma, anota a autora: "Mas quer o Direito Internacional quer o Direito da União Europeia tornam-se obrigatórios e vinculam diretamente o Poder Legislativo, Executivo e Judicial (internos) em virtude (ex vi) do Direito Constitucional. Deste modo, só excepcionalmente, tratando-se de um Direito regulador das relações entre os Estados e outros sujeitos de Direito Internacional (v. g., as organizações internacionais), o Direito Internacional teria capacidade para obrigar diretamente os cidadãos individualmente considerados. Não assim o Direito da União Europeia. A relação entre a Constituição e o Direito da União mostra-se, em consequência, muito mais complexa, necessitando de outros princípios complementares" (Direito Constitucional Internacional, Ob. cit., p. 75).
} 
estabelecido nas normas internacionais. Assim, se um tratado deixar de ser internalizado em virtude da discordância manifestada pelo Parlamento estatal, não haverá responsabilização internacional do Estado, pois o Legislativo atuou com amparo na soberania que é própria da autoridade estatal. Situação diversa é, sem dúvida, a impossibilidade de executar domesticamente norma internacional que foi objeto de declaração de inconstitucionalidade pelo Poder Judiciário do país. Nesta hipótese, como o mandamento exterior já concluiu suas etapas internacionais de criação, o Estado deverá obedecê-lo integralmente, sendo irrelevante, para o Direito das Gentes, eventuais impedimentos internos para tanto.

Nesse compasso, certifica-se que o Poder Executivo precisa atuar internacionalmente sempre em conformidade aos mandamentos constitucionais porque, caso pratique condutas que desviem dessa orientação, violará não apenas sua Constituição, mas também frustrará os esforços para que o Estado possa se inserir na sociedade internacional com segurança e prudência. Ainda que o Poder Executivo assim o faça, resta ainda outro impasse a ser discutido: a percepção de que, quanto mais normas internacionais são criadas, mais diminui a participação dos representantes do povo assentados nos Parlamentos nacionais no processo de criação do Direito em geral. Esse fenômeno, chamado de déficit democrático do Direito Internacional, tem proporcionado reflexões teóricas diversas sobre a participação dos Poderes estatais no processo de adensamento jurídico das relações internacionais. Em virtude da pertinência com o tema aqui apreciado, o déficit democrático é o assunto a ser enfrentado na sequência.

\subsubsection{O Déficit Democrático na Produção da Normativa Internacional}

A ampliação do campo de incidência da normativa internacional faz que os indivíduos tenham de obedecer a mandamentos que lhes são direcionados, sem que seus representantes - tradicionalmente influentes junto aos Parlamentos nacionais - participem do processo de elaboração desses comandos. Com o surgimento de novas fontes do Direito do Direito Internacional, advém o problema da legitimidade de muitos órgãos de normatização existentes. Em suma, o debate se refere à constatação de que, a despeito de tratados e outros atos internacionais conferirem direitos e imporem obrigações aos 
cidadãos, nem sempre seus representantes têm condições de participar efetivamente das etapas de elaboração desses mandamentos ${ }^{352}$.

Infere-se que as críticas colocadas a respeito do déficit de legitimidade na produção do Direito Internacional estão diretamente relacionadas aos processos decisórios em que o Poder Executivo atua isoladamente - o que, conforme a dinâmica das relações internacionais, constitui algo natural e tende a aumentar com a intensificação das relações exteriores $^{353}$. Essas hipóteses são verificadas em maior número nas experiências de integração regional, como é o caso da União Europeia e do Mercosul, e também de deliberações realizadas no âmbito das organizações internacionais, que, ao cuidar de temas especializados, emitem decisões com força obrigatória para os Estados-partes, nem sempre são submetidas ao crivo dos Legislativos nacionais. Cumpre esclarecer que o tratamento da questão no Direito brasileiro será objeto de análise específica no Capítulo 4 (Item 4.4), parte reservada a analisar as implicações decorrentes da execução interna de decisões e resoluções expedidas por organismos internacionais.

Corrobora a impressão inicialmente exposta ANN CAPLING, que informa que grande parte do debate envolvendo o déficit democrático está concentrada nas espécies normativas elaboradas por instituições associadas à governança econômica global, como o Fundo Monetário Internacional (FMI), o Banco Mundial e a Organização Mundial do Comércio (OMC). Embora os governos sejam os participantes das deliberações realizadas por essas instituições, inexistem mecanismos de responsabilização democrática na tomada de decisões, o que pode causar possíveis violações à soberania nacional e à autonomia política doméstica. Convém anotar que a problemática não se restringe às decisões provenientes de fóruns multilaterais. Abrange também aspectos do processo político de internalização de tratados e convenções, principalmente em países onde o poder de celebrar tratados é integralmente controlado pelo Executivo ${ }^{354}$.

As decisões de organismos internacionais multilaterais enfrentam maior resistência por parte daqueles que enxergam na falta de legitimidade um ponto prejudicial à imperatividade desse tipo de normativa. Nesse sentido, ROBERT A. DAHL se ocupa do estudo do processo de formalização das deliberações no âmbito dessas entidades e assevera

\footnotetext{
${ }^{352}$ Samantha Ribeiro Meyer-Pflug, A Internacionalização do Direito Constitucional Brasileiro, in Direito Constitucional Internacional dos Direitos Humanos, Alexandre Coutinho Pagliarini e Dimitri Dimoulis (org.), Ob. cit., pp. 277-278.

${ }^{353}$ Cf. HÉLÈnE TOURARD, L'Internationalisation des, Ob. cit., pp. 247-248.

${ }^{354}$ Can the Democratic Deficit in Treaty-Making be Overcome?: Parliament and the Australia-United Free Trade Agreement, in The Fluid State: International Law and National Legal Systems, Hilary Charlesworth, Madelaine Chiam, Devika Hovell e George Williams (ed.), Ob. cit., pp. 57-58.
} 
que, embora as decisões tomadas possam resultar em normas que atendem as expectativas dos Estados e até de suas populações, essa finalidade não é obtida em atenção aos postulados democráticos, porque os órgãos decisórios das referidas organizações são compostos, essencialmente, por burocratas indicados pelos respectivos governos, sem que os indivíduos atingidos possam interferir no que é decidido ${ }^{355}$. Independentemente da ausência de representantes do povo nos órgãos em questão, o autor adverte que não se devem rejeitar os benefícios advindos do aparecimento desses organismos, tendo em vista que eles já se mostram imprescindíveis para solucionar vários impasses que afetam a sociedade internacional ${ }^{356}$.

Ao debruçar-se sobre o funcionamento da União Europeia, cujos principais órgãos decisórios comunitários estão sediados na Bélgica, MiREILle DELMAS-MARTY reafirma a impressão descrita por ROBERT A. DAHL. Consoante a estudiosa, "mesmo que a União Europeia seja formada por países que são democráticos e que pretendem assim permanecer, o processo de decisão, essencialmente burocrático, dos especialistas de Bruxelas fornece um bom exemplo do déficit democrático engendrado pela transferência do poder de decisão que, nessa ocasião, não é mais das Assembleias Nacionais, mas de representantes governamentais $" 357$. Infere-se, assim, que o principal argumento que lastreia as objeções a respeito do déficit de legitimidade na produção de normas internacionais converge para os receios sobre o aumento do poder decisório de organismos intergovernamentais e supranacionais, sem que isso seja compensado com a criação de mecanismos que possibilitem a participação de representantes populares nessas entidades $^{358}$.

Acerca do tema, RAÚl GRANILLO OCAMPO pondera que a integração materializada no espaço europeu ainda não conseguiu superar o distanciamento físico entre as instituições comunitárias e o povo. A ausência de participação popular no processo decisório regional produz a sensação de que uma burocracia longínqua e distante dos sentimentos e das aspirações dos cidadãos governa as áreas mais sensíveis de políticas públicas aplicadas dentro das instituições erigidas no bloco regional ${ }^{359}$. Esse quadro acaba

\footnotetext{
${ }^{355}$ Cf. Can International Organizations be Democratic? A Skeptic's View, inDemocracy Edges, Ian Schapiro e Hacker-Cordón (org.), Cambridge, Cambridge University Press, 1999, p. 23.

${ }^{356} \mathrm{Cf}$.Idem, Ibidem.

${ }^{357}$ La Refondation des, Ob. cit., p. 19. Consultar também: JÜRGEN HABERMAS, Era das Transições, Ob. cit., p. 108.

${ }^{358}$ Cf. Alessandra Marchioni Pereira da Cunha, As Limitações da Democracia na Formação da União Europeia, Barueri, Manole, 2004, p, 129.

${ }^{359}$ Cf. Direito Internacional Público, Ob. cit., p. 134.
} 
não apenas dificultando a solidificação das instituições comunitárias de integração, mas também ameaçando as Constituições dos Estados, haja vista que, como sabido, são justamente estes documentos que servem como base para justificar todas as ações dos governos nacionais, inclusive em matéria de relações exteriores.

No fundo, é possível compreender o impasse gerado pela ideia de déficit democrático nas relações internacionais como um fenômeno que tem suas raízes em um processo de autorreferência do Estado, desencadeado pelo aprofundamento de suas interações com outros sujeitos internacionais. Na proporção em que os países aumentam seus contatos com o exterior - celebrando tratados, aceitando participar voluntariamente de organizações internacionais ou abrindo-se a processos de integração regional -, "os Estados nacionais aprendem a enxergar-se como membros de comunidades políticas maiores" ${ }^{, 60}$. Esse modo de conduzir as decisões de sua política externa já é, por si só, forte sinal indicativo de que o Estado está disposto a realinhar suas estruturas constitucionais, caso necessário, a fim de atingir os objetivos que estimulam o processo de internacionalização já colocado em prática ${ }^{361}$.

A expansão do Estado para além de suas fronteiras, entretanto, choca-se com a concepção de Estado Constitucional Democrático. Sob esse ponto de vista, o modelo estatal é definido como um conjunto de instrumentos que proporcionam "uma ordem desejada pelo povo e legitimada pela sua livre formação de opinião e de vontade, que permite aos que são endereçados pela justiça sentirem-se como os seus autores" ${ }^{\text {"362 }}$. Como o constitucionalismo encontra-se tradicionalmente apegado a essa concepção, as iniciativas dos Poderes estatais seriam, aparentemente, contrárias ao espírito das Constituições, quando ocasionassem a imposição de normas exteriores a órgãos públicos nacionais e a indivíduos, sem que estes pudessem - ainda que indiretamente - participar da formação dos mandamentos referidos.

\footnotetext{
${ }^{360}$ JÜRGEN HABERMAS, El Derecho Internacional, Ob. cit., p. 38.

${ }^{361}$ Corroboram essa visão, Gilmar Ferreira Mendes, InOCÊnCio Mártires Coelho e Paulo Gustavo GONET BRANCO, que atentam para o fato de que os "Estados Constitucionais não existem mais apenas para si mesmos, mas, também, como referência para outros Estados-membros de uma comunidade, em um modelo de cooperação capaz de permitir, ao mesmo tempo, a preservação de suas características nacionais, mas com vocação crescente para o intercâmbio no plano internacional. [...] A imagem da comunidade universal dos Estados constitucionais evidencia que o Estado Constitucional não mais terá suas referências apenas em si, mas nos seus semelhantes, que serão como espelhos a refletir imagens uns dos outros para a identificação de si próprios. A manifestação desse fenômeno ocorrerá por meio de princípios gerais, notadamente os que consagrarem direitos humanos universais (como aqueles de objetivos educacionais, paz mundial, proteção ao meio ambiente, amizade, cooperação e ajuda humanitária)" (Curso de Direito, Ob. cit., pp. 1164-1165).

362 JÜrgen HaBermas, A Constelação Pós-Nacional, Ob. cit., p. 83.
} 
Fica claro que, a menos que ocorra flexibilização no modo de entender a produção normativa, o déficit democrático poderá ser obstáculo intransponível, que, inclusive, dificultará a inserção de muitos Estados nas negociações e processos internacionais, notoriamente nos esquemas de integração regional. Não se trata, pois, de entender a questão como um embate entre o Direito Interno e o Direito Internacional a ser solucionado com a vitória de um sistema normativo sobre o outro. Como exposto no Capítulo 01 (Item 1.4.2), assiste-se a um progressivo entrelaçamento entre normas nacionais e internacionais, o que resulta na criação de mandamentos em ambos os ordenamentos que buscam proteger os mesmos bens jurídicos. Ao que tudo indica, o aumento da identidade material entre as prescrições normativas pode, de fato, ajudar a superar os embaraços causados pela falta de mecanismos de democratização do espaço internacional.

Acredita-se ainda que a interconexão entre Constituição e Direito das Gentes pode levar ao surgimento de instrumentos inovadores habilitados a conceder voz aos indivíduos em algumas instâncias internacionais. A criação de Parlamentos regionais na União Europeia e no Mercosul exemplificam essa percepção. Foi esse descompasso entre eficiência governamental e representatividade popular na condução dos interesses comuns que determinou o surgimento de um órgão parlamentar na Europa integrado por mandatários eleitos diretamente pela população dos Estados. Aclara-se, portanto, a ideia de que consolidar, ao menos no universo dos blocos regionais, os arranjos de integração demanda a inclusão do elemento democrático para compor as estruturas encarregadas de conduzir a vida comunitária.

Entendimento diverso, sem dúvida, pode conduzir a integração regional à estagnação e ao estranhamento entre as normas produzidas e os anseios da população vinculada à normativa criada. Averbe-se que a necessidade de órgãos internacionais dessa natureza é destacada nos contextos integracionistas porque os blocos regionais criados para fomentar, primeiramente, o tratamento conjunto de questões econômicas sempre ampliam suas pautas temáticas e, com isso, passam a emitir normas internacionais acerca dos temas mais diversos, como direitos humanos, cooperação judiciária, livre circulação de pessoas e de trabalhadores etc. Muito mais do que preencher o vazio democrático, a afirmação institucional dos Parlamentos regionais pode representar meio hábil para compensar temíveis quadros de paralisia do Poder Legislativo nacional diante da hipertrofia do Executivo, sobretudo se este passar a invocar suas atribuições e competências 
internacionais para fomentar a edição de normas jurídicas que se incorporam ao ordenamento doméstico automaticamente ${ }^{363}$.

Não obstante o assunto permaneça em aberto, aumenta a percepção de que a imbricação entre normas exteriores e Direito Interno exige reflexões sobre "como o Estado Constitucional (cooperativo) pode se desenvolver para além das formas já conhecidas de interdependência, através, em parte, de novos conteúdos, novos processos (por exemplo, opinião pública) e novos órgãos, como no campo das questões comerciais, para compensar a perda de competência do Parlamento" ${ }^{364}$. Esses temas, além de representarem significativos desafios a ser enfrentados pelo constitucionalismo do porvir, reafirmam a relevância das Constituições nesse ambiente de entrelaçamento de ordens jurídicas. Isso porque, sem a reformulação das Leis Fundamentais - sobretudo os textos mais antigos - e sem o aperfeiçoamento dos métodos hermenêuticos, é provável que ocorra a inação de ambos os compartimentos jurídicos em análise.

\subsection{O Papel do Poder Legislativo em Matéria de Relações Exteriores}

Apesar das preocupações em torno do déficit de legitimidade na elaboração de algumas normas internacionais, é preciso reconhecer que, no contexto interno, o Parlamento pode ser usado pelas Constituições para que os postulados democráticos sejam observados no desenrolar das ações exteriores. Com efeito, várias ordens constitucionais confiam ao Legislativo o exercício de um controle sobre as relações internacionais caracterizado pela atuação passiva e negativa, o que ocorre com avaliações a posteriori das iniciativas do Presidente da República sobre o tema ${ }^{365}$. A interferência do Parlamento funda-se, em grande medida, na ideia de que "para a nação que o aceitou, o tratado é uma verdadeira lei; obriga a todos, precisa ser integralmente cumprido. Logo é justo que o

\footnotetext{
${ }^{363}$ Essa situação indesejável é descrita por HÉlÈnE TOURARD no trecho que segue: “O papel do Parlamento está no centro de profundas mudanças no âmbito interno e internacional. O lugar preponderante que o Executivo detém na elaboração das normas internacionais pesa também sobre a função do Legislativo em termos da execução dessas normas. O Parlamento, na verdade, perde toda iniciativa, tanto em nível interno quanto internacional: em ambos os casos, ele se torna uma Câmara de registro da vontade do Executivo, e possui uma função meramente 'passiva' por assim dizer, no sentido em que concorda com o que os governos desenvolvem. Isso leva a uma inversão de funções entre o Poder Legislativo e o Poder Executivo em comparação a suas tarefas tradicionais respectivas" (L'Internationalisation des, Ob. cit., p. 141).

${ }^{364}$ PETER HÄBERLE, Estado Constitucional Cooperativo, Ob. cit., p. 17-18.

${ }^{365}$ Cf. Antônio Paulo Cachapuz de Medeiros, O Poder de Celebrar Tratados: Competência dos Poderes Constituídos para a Celebração de Tratados à Luz do Direito Internacional, do Direito Comparado e do Direito Constitucional Brasileiro, Porto Alegre, Sérgio Antonio Fabris Editor, 1995, pp. 171-173.
} 
homologuem os poderes competentes para legislar" ${ }^{366}$, como esclarece CARLOS MAXIMILIANO.

Muitas são as razões que justificam não concentrar, no Legislativo, competências para executar atos afeitos aos negócios internacionais, bem como para que este Poder não seja alçado à condição de representante do Estado soberano no plano externo. Prepondera a visão de que "a heterogeneidade e a instabilidade da composição das Câmaras, integradas por grande número de parlamentares; os períodos de recesso a que estão submetidas; o caráter público e nada discreto dos debates; a lentidão do processo decisório, entre outros aspectos, representam obstáculos muito sérios para que o Legislativo possa ter uma participação ativa na direção da política externa" ${ }^{\text {,367 }}$. A adequação dessa argumentação não invalidada, contudo, a importância de outras funções que o Parlamento pode desenvolver com vistas a contribuir com o fortalecimento do Direito Internacional e do próprio Estado nacional.

Conforme assevera Boris MiRKINE-GuETZÉVITCH, "não se pode compreender o verdadeiro significado jurídico das relações entre o Direito internacional e o Direito Constitucional, sem levar em conta os progressos do regime constitucional, as formas democráticas de governos, o reforço da competência do Poder Legislativo na conclusão dos tratados, o funcionamento do regime parlamentar. A democratização da vida interna conduziu à democratização do Direito Internacional" ${ }^{368}$. A clareza dessa conclusão, infelizmente, não se converteu em estudos jurídicos versando sobre a elaboração e o controle da política pelo Parlamento. São raras as obras que enfrentam a questão e parece que os pesquisadores se ocupam apenas com o problema de equacionar soberania com desenvolvimento das interdependências políticas e econômicas, esquecendo-se de que a ativa participação do Legislativo nas relações internacionais pode auxiliar a solucionar as dúvidas quanto à manutenção da soberania estatal ${ }^{369}$.

Anote-se que, até o século XVIII, a conclusão dos tratados internacionais foi sempre prerrogativa absoluta dos monarcas; por isso não existiam, naquele período, os problemas que foram surgindo com o progresso das instituições constitucionais. Como a vontade do príncipe era absoluta, não havia nenhum tratado inconstitucional, nem regra constitucional suscetível de incorrer em contradição com o Direito Internacional. A

\footnotetext{
${ }^{366}$ Comentários - Constituição Brasileira, Rio de Janeiro, Jacintho Ribeiro dos Santos, 1918, p. 359.

${ }^{367}$ Antônio Paulo Cachapuz de Medeiros, Atualização do Direito dos Tratados, in Desafios do Direito Internacional Contemporâneo, Antônio Paulo Cachapuz de Medeiros (org.), Ob. cit., p. 156.

${ }^{368}$ Cf. Derecho Constitucional Internacional, Ob. cit., p. 481.

${ }^{369}$ Cf.HÉLĖNE TOURARD, L'Internationalisation des, Ob. cit., p. 246.
} 
questão da validade interna de um tratado não era levantada, o príncipe podia sempre estabelecer a primazia do $\operatorname{tratado}^{370}$. Foi, portanto, o aprimoramento dos institutos do constitucionalismo voltados a concretizar os ideais democráticos nos Estados que possibilitou, em grande medida, que as relações exteriores também experimentassem ainda que de forma muito reduzida - técnicas de controle do poder político do Executivo por parte dos governados que se faziam representar nos Parlamentos.

$\mathrm{O}$ argumento de que "um tratado obriga o Estado, por conseguinte, obriga os cidadãos"371 foi impulsionado pela Revolução Francesa, o que acabou conferindo relevo à proposta de que a atividade de produção de normas internacionais, bem como toda a política exterior, sejam passíveis de apreciação pelo Legislativo ${ }^{372}$. Por constituírem documentos jurídicos habilitados a criar direitos e a impor obrigações aos cidadãos, os tratados internacionais não podem ser admitidos como meros atos que incorporam assuntos de interesse exclusivo dos governantes. Cuidam, sem dúvida, de tema que importa também aos governados, e, sob esse influxo, o Legislativo deve assumir uma clara função de contrapeso ao monopólio do Poder Executivo na condução dos negócios exteriores, sob pena de restar configurada incontornável violação ao princípio constitucional da separação de poderes ${ }^{373}$.

Sem dúvida, admitir a participação do Parlamento como etapa necessária para a conclusão de ajustes internacionais pelos Estados propicia ganhos para ambas as ordens jurídicas envolvidas ${ }^{374}$. Isso porque o Parlamento é o órgão estatal mais diretamente envolvido na execução interna dos tratados internacionais, pois o aumento dessas convenções exige que o Legislativo, mesmo depois de concordar com os atos externos formulados pelo Presidente da República, tenha de adotar várias outras medidas. Além de modificar a legislação interna existente no país com o objetivo de adaptá-la às obrigações

\footnotetext{
${ }^{370}$ Boris Mirkine-Guetzévitch, Derecho Constitucional Internacional, Ob. cit., pp. 226-227.

${ }^{371}$ Idem, p. 229.

${ }^{372}$ A respeito do início da participação do Parlamento no controle das ações internacionais do Estado, noticiaMARIA GARCIAque "a intervenção do Poder Legislativo, em si, surge no final do século XVIII por influências da Revolução Francesa e menção expressa da Constituição norte-americana de 1787, firmando-se em dois sistemas: o sistema norte-americano, pelo qual todos os tratados devem sofrer a sua intervenção, e o sistema belga, em que apenas alguns tratados são submetidos à apreciação legislativa" (Tratados Internacionais. Denúncia. Necessidade da Participação do Poder Legislativo. O Princípio Constitucional da Separação dos Poderes, in Cadernos de Direito Constitucional e Ciência Política, no 21, ano 5, out./dez. 1997, p. 93).

${ }^{373}$ Sobre a importância do controle político empreendido pelo Parlamento sobre as políticas públicas adotadas pelos governos, verMonica Herman Salem Caggiano(O Parlamento no Cenário Político do Século XXI, in Revista do Advogado, ano 23, n 76, nov. 2003, pp. 159-165).

${ }^{374}$ A Constituição Federal de 1988 consagra essa atribuição do Legislativo ao dispor, no art. 49, inciso I, que: "É da competência exclusiva do Congresso Nacional resolver definitivamente sobre tratados, acordos ou atos internacionais que acarretem encargos ou compromissos gravosos ao patrimônio nacional".
} 
internacionais subscritas pelo Estado, o Legislativo terá de elaborar novas regras que tornem possível implementar as obrigações internacionais assumidas ${ }^{375}$. Caso se mantenha inerte e não pratique as medidas referidas, certamente, a internacionalização fará, certamente, que o Parlamento sofra sensível redução no conjunto de suas competências, seja na função legislativa, seja no controle do Executivo ${ }^{376}$.

As tarefas do Legislativo nesse tema não ficam confinadas ao controle político exercido sobre o Poder Executivo e à concretização de novos direitos a partir da produção legislativa. JOANNA HARRINGTONvislumbra que o envolvimento parlamentar nas questões de índole internacional ajuda a contrabalancear o ativismo judicial, que, não raro, concede às partes direitos previstos em tratados internacionais pendentes de incorporação ao ordenamento doméstico. Interessa, nesse ponto, tomar nota de que a oposição do Parlamento à ratificação de determinada convenção internacional serve de alerta para o Poder Judiciário não avançar nesse sentido, já que evidenciada a recusa popular quanto ao direito que poderia vir a ser reconhecido por decisão judicial. Inversamente, cabe reconhecer que a aprovação parlamentar de um tratado atesta aos juízes que a aplicação das normas previstas nesse documento tende a não subverter os valores que informam a coesão do sistema jurídico nacional ${ }^{377}$.

Está certificado, por certo, que a "a adoção de um regime representativo e democrático requer que se faça efetivo o princípio da soberania popular no domínio da política externa, até o limite permitido pela natureza da sociedade internacional"378. Todavia, a intervenção parlamentar em matéria de relações exteriores não pode ficar restrita ao análise dos tratados internacionais. HÉLÈNE TOURARD proclama, de modo contundente, que as Constituições precisam incorporar instrumentos que permitam ao Parlamento verificar as ações internacionais tomadas pelo governo que não se apresentem sob a forma de convenções internacionais. Além da importância de controlar a atuação presidencial externa que não resulta na celebração de convenções internacionais, existe também a urgência de estimular o emprego dos meios ordinários de fiscalização governamental que os textos constitucionais conferem ao Legislativo, mas que, via de regra, são usados apenas para o acompanhamento e a responsabilização do Chefe do

\footnotetext{
${ }^{375}$ Cf.HÉLÈne TOURARD, L'Internationalisation des, Ob. cit., p. 117.

${ }^{376} \mathrm{Cf}$. Idem, p. 114.

${ }^{377}$ Cf.The Role for Parliaments in Treaty-Making, in The Fluid State: International Law and National Legal Systems, Hilary Charlesworth, Madelaine Chiam, Devika Hovell e George Williams (ed.), Ob. cit., p. 56.

${ }^{378}$ Antônio Paulo Cachapuz de Medeiros, O Poder de Celebrar Tratados: Competência dos Poderes Constituídos para a Celebração de Tratados à Luz do Direito Internacional, do Direito Comparado e do Direito Constitucional Brasileiro, Porto Alegre, Sérgio Antonio Fabris Editor, 1995, pp. 171.
} 
Executivo e demais agentes públicos envolvidos na consecução de programas governamentais desenvolvidos no campo estritamente doméstico ${ }^{379}$.

Esse entendimento acerca da necessidade de ampliar o emprego das ferramentas disponíveis ao Parlamento para controlar os atos governamentais praticados no exterior reafirma a ideia exposta por Celso D. DE Albuquerque Mello de que a "ativa participação do Poder Legislativo vai depender muito mais do preparo e maturidade deste do que propriamente do Poder Executivo" ${ }^{\$ 80}$. Assim, em rápida remissão ao texto da Constituição brasileira de 1988, encontram-se alguns institutos cuja utilização poderia perfeitamente ser direcionada ao campo das relações internacionais, como é o caso da convocação do Ministro das Relações Exteriores ou quaisquer outros agentes diplomáticos nacionais para prestar informações às Casas Legislativas ou suas Comissões $(\operatorname{art.~50})^{381} \mathrm{e}$, ainda, da atuação das Comissões Parlamentares de Inquérito (art. 58, $\left.\S 3^{\circ}\right)^{382}$. Outra maneira de fortalecer as competências do Poder Legislativo nesse setor seria por meio das Comissões de Relações Exteriores e de Defesa Nacional, partes permanentes da estrutura orgânica tanto da Câmara dos Deputados quanto do Senado Federal ${ }^{383}$. Com efeito, essas Comissões especializadas poderiam ampliar suas ações de controle e, assim, diminuir o vazio que se verifica da participação parlamentar no aprimoramento dos negócios exteriores.

\footnotetext{
${ }^{379}$ Cf.L'Internationalisation des, Ob. cit., pp. 196-197. No mesmo sentido: ANTONIO REMIRO BROTONS, La Accion Exterior,Ob. cit., pp. 81-82. Averbe-se que MONTESQUIEU preconiza ser a função fiscalizatória típica atividade do Parlamento, sob o argumento de que, "se num Estado livre, o Poder Legislativo não deve ter o direito de cercear o Poder Executivo, tem porém o direito, e deve possuir a faculdade, de examinar de que modo as leis que ele criou foram executadas" (O Espirito das Leis, Ob. cit., p. 198).

${ }^{380}$ A Revisão do, Ob. cit., p. 78.

381 “Art. 50. A Câmara dos Deputados e o Senado Federal, ou qualquer de suas Comissões, poderão convocar Ministro de Estado ou quaisquer titulares de órgãos diretamente subordinados à Presidência da República para prestarem, pessoalmente, informações sobre assunto previamente determinado, importando crime de responsabilidade a ausência sem justificação adequada".

382“"Art. 58. [...] § $3^{\circ}$ - As comissões parlamentares de inquérito, que terão poderes de investigação próprios das autoridades judiciais, além de outros previstos nos regimentos das respectivas Casas, serão criadas pela Câmara dos Deputados e pelo Senado Federal, em conjunto ou separadamente, mediante requerimento de um terço de seus membros, para a apuração de fato determinado e por prazo certo, sendo suas conclusões, se for o caso, encaminhadas ao Ministério Público, para que promova a responsabilidade civil ou criminal dos infratores".

${ }^{383}$ GABRIELA ZANCANER elenca uma série de atribuições das Comissões Parlamentares previstas nos respectivos Regimentos Internos que podem servir para o controle das atividades do Estado. Vale mencionar que poderiam servir ao propósito de fiscalizar aos atos exteriores as seguintes competências asseguradas aos órgãos parlamentares em comento: realização de audiências públicas; recebimento de petições, reclamações, representações ou queixas de qualquer pessoa; solicitação de depoimento de qualquer autoridade ou cidadão; estudar qualquer assunto compreendido no respectivo campo temático ou área de atividade, podendo promover, em seu âmbito, conferências, exposições, palestras ou seminários (Cf. As Competências do Poder Legislativo e as Comissões Parlamentares, São Paulo, Malheiros, 2009, pp. 101-109).
} 
É preciso, portanto, que o Direito Constitucional propicie meios de abandonar a letargia institucional que toma conta do Parlamento no tratamento de assuntos atinentes às relações exteriores ${ }^{384}$. Em um Estado que tem a democracia como a base para o funcionamento dos seus Poderes, o controle recíproco que caracteriza a principiologia da separação dos poderes deve ser aplicado como fator de otimização dos atos exteriores e das normas internacionais produzidos pelo país. Ainda que a dinâmica das interações com os demais sujeitos internacionais exija que a matéria figure como função tipicamente reservada ao Executivo, esse dado não é suficiente para justificar o fato de que "as tribunas parlamentares não têm se revelado instrumento apropriado para examinar em profundidade os temas das relações internacionais ou para conciliar interesses e visões conflitantes" ${ }^{\text {, }} 85$. Negar as parcelas de competência constitucional e de responsabilidade política que são próprias do Parlamento no contexto da abertura das Constituições ao Direito Internacional é um grave equívoco que pode, por si só, frustrar todos os demais esforços estatais realizados para atingir esse desiderato.

\subsubsection{Denúncia de Tratados e Participação do Congresso Nacional}

Prevista no art. 56 da Convenção de Viena sobre o Direito dos Tratados de $1969^{386}$ como causa de extinção dos tratados, a denúncia é um ato unilateral do Estado que manifesta sua intenção de deixar de fazer parte no acordo internacional. Não estabelece o Direito Internacional qual autoridade nacional deverá efetuar esse ato, motivo pelo qual é assente a compreensão de que "cabe ao ordenamento jurídico do Estado indicar o Poder responsável para tanto",387. Verifica-se, quanto a esse ponto, uma constância na história do Direito Constitucional brasileiro que aponta para o Presidente da República como o titular

\footnotetext{
${ }^{384}$ Nessa direção, HÉLÈNE TOURARD conclui que seria conveniente implementar, no plano internacional, a competência de controle que o Legislativo já desempenha internamente. Nesse sentido, aduz a autora que "as funções que os Parlamentos não podem mais cumprir no âmbito interno devem ser executadas por eles na seara internacional. Em vez de lamentar a perda de suas prerrogativas por causa do Direito Internacional, o Legislativo deveria considerar meios de reaver estas atribuições no processo de execução das normas internacionais" (L'Internationalisation des, Ob. cit., p. 142).

${ }^{385}$ Antônio Paulo Cachapuz de Medeiros, Atualização do Direito dos Tratados, in Desafios do Direito Internacional Contemporâneo, Antônio Paulo Cachapuz de Medeiros (org.), Ob. cit., p. 156.

386 “Art. 56. 1. Um tratado que não contém disposição relativa à sua extinção, e que não prevê denúncia ou retirada, não é suscetível de denúncia ou retirada, a não ser que: a)se estabeleça terem as partes tencionado admitir a possibilidade da denúncia ou retirada; ou b)um direito de denúncia ou retirada possa ser deduzido da natureza do tratado. 2. Uma parte deverá notificar, com pelo menos doze meses de antecedência, a sua intenção de denunciar ou de se retirar de um tratado, nos termos do parágrafo 1".

${ }^{387}$ MÁrcio Pereira Pinto Garcia, Comentários ao Artigo 56, in Direito dos Tratados: Comentários à Convenção de Viena sobre o Direito dos Tratados (1969), Aziz Tuffi Saliba (org.), Ob. cit., p. 485.
} 
da competência realizar a denúncia, tradição essa que se reflete na disposição encartada no art. 84, inciso VIII, da Lei Maior vigente.

Em defesa da competência privativa do Chefe do Executivo para formalizar o ato em análise, FRANCISCO REZEK afirma que, embora o sistema constitucional pátrio estabeleça que o Estado apenas poderá se vincular juridicamente a uma convenção internacional quando houver comunhão de vontades entre o Parlamento e o Presidente da República (ver Capítulo 4, Item 4.2.1), essa exigência não significa que essas duas vontades deverão entrar em concordância novamente para desonerar do dever de cumprir essa espécie normativa. Segundo o autor, "o ânimo negativo de um dos Poderes políticos em relação ao tratado há de determinar sua denúncia, visto que significa o desaparecimento de uma das bases em que se apoiava o consentimento do Estado"388. E, por assim ser, a realização da denúncia deverá ser feita somente pelo Executivo, pois este é Poder que tem a aptidão para executar atos no plano internacional em nome do Estado brasileiro.

Não obstante os argumentos histórico e sistêmico apresentados, convém assinalar que a questão da participação do Congresso Nacional tem inspirado inúmeras discussões do âmbito do Direito Interno brasileiro. Além de posições doutrinárias que militam em favor desse entendimento, tramita atualmente no Supremo Tribunal Federal a ADI n ${ }^{\circ} 1625$, ajuizada em 19/06/1997, pela Confederação Nacional dos Trabalhadores da Agricultura (CONTAG) e pela Central Única dos Trabalhadores (CUT), rebatendo a constitucionalidade do Decreto presidencial $n^{\circ} 2.100 / 1996$, que denunciou a Convenção $n^{\circ}$ 158 da Organização Internacional do Trabalho, após este tratado ter sido declarado formalmente inconstitucional pela decisão lavrada na ADI $\mathrm{n}^{\circ}$ 1480. A matéria segue inconclusa na jurisprudência do Supremo Tribunal Federal, porém é interessante apreciar alguns dos fundamentos arguidos pela doutrina brasileira para embasar o pleito de que o Parlamento não pode ser excluído da prática desse relevante ato internacional.

Citem-se, a título de exemplo, os comentários de PONTES DE MiRANDA à Constituição do Brasil de 1934, obra em que o tratadista desenvolve as seguintes considerações acerca da problemática: "Pode o Presidente da República, só, denunciar os tratados e convenções que já foram aprovados pelo Poder legislativo? Respondeu afirmativamente Clóvis Beviláqua (Jornal do Comércio, 9 de julho de 1926), mas sem razão. Entendia ele que o preceito constitucional não se referiu à denúncia. Não está certo: aprovar tratado ou convenção permitindo que o Poder Executivo o denuncie sem consulta,

${ }^{388}$ Direito Internacional Público: Curso Elementar, 14a ed., São Paulo, Saraiva, 2013, p. 150. 
nem aprovação, é subversivo dos princípios constitucionais. O Presidente da República pode apresentar projeto de denúncia, ou denunciar o tratado ou convenção ad referendum do Poder Legislativo. Se o Poder Judiciário declarar inconstitucional o tratado ou convenção, deve o Senado Federal suspender-lhe a execução (art. 91, IV) e o Presidente da República imediatamente denunciá-10"389.

$\mathrm{Na}$ mesma vertente, MARIA GARCIA enfatiza que a denúncia - assim como a ratificação do tratado - requer soma de vontades do Executivo e do Parlamento e "nada leva a entender o contrário na fala constitucional de celebração, com acréscimo atual da possibilidade de 'resolver definitivamente' sobre o assunto, nas hipóteses previstas"390. Registre, por oportuno, que exatamente esse foi o posicionamento adotado pelo Ministro MAURÍCIO CORRÊA ${ }^{391}$, relator da mencionada ADI nº 1625 , ação que, embora pendente de julgamento na Corte Constitucional brasileira, poderá mudar o modo pelo qual, tradicionalmente, a denúncia de convenção é conduzida pelo Estado nacional. Sem dúvida, caso prevaleça essa nova linha de compreensão, estarão confirmados os valores democráticos amalgamados no texto constitucional, ao mesmo tempo em que se ampliará o rol de atribuições do Parlamento no controle das relações exteriores.

Também abraça a ideia de engajamento do Congresso Nacional na terminação de tratados por meio de denúncia MÁrcio Pereira Pinto Garcia, que desenvolve interessante raciocínio sobre o caráter antidemocrático da atuação unilateral do Chefe do Executivo nessa seara. Expõe o estudioso que a decisão isolada do Presidente da República para extinguir convenções evidencia uma terrível contradição: “( $i)$ o Direito Internacional dos dias de hoje, com sua influência em todos os domínios da vida do Estado e do cidadão,

\footnotetext{
${ }^{389}$ Comentários à Constituição da República dos E. U. do Brasil, Tomo I, Artigos 1-103, Rio de Janeiro, Editora Guanabara, Waissman, Koogan, Ltda., 1936, p. 526. Informa-se que a alusão feita a CLóviS BELIVÁQUA diz respeito ao parecer emitido por esse jurista sobre a denúncia do Brasil ao tratado constitutivo da Liga das Nações, consulta na qual ficou gravada a opinião de que "o Poder Executivo celebra os tratados; quer a Constituição que o Congresso resolva sobre a sua conveniência, ou inconveniência, no momento da sua formação. Não exige que o Congresso se manifeste sobre a denúncia desses atos internacionais. Concluise desse silêncio que para a denúncia, a intervenção do Congresso é dispensável. E essa conclusão se corrobora, com a ponderação de que foi ao Poder Executivo que a Constituição entregou, privativamente, a mantença das relações com os Estados estrangeiros, sendo a intervenção do Congresso, na formação dos tratados, uma exceção ao princípio geral, a qual somente se aplica ao caso que especifica" (Parecer do Consultor Jurídico do Ministério das Relações Exteriores, Clóvis Beviláqua, sobre a Questão da Denúncia de Tratado (Caso da Retirada do Brasil da Liga das Nações), emitido no Rio de Janeiro, em 5 de julho de 1926, in Repertório da Prática Brasileira do Direito Internacional Público: Período 1919-1940, Antônio Augusto Cançado Trindade, $2^{\mathrm{a}}$ ed., Brasília, FUNAG, 2012, p. 127).

${ }^{390}$ Tratados Internacionais. Denúncia. Necessidade da Participação do Poder Legislativo. O Princípio Constitucional da Separação dos Poderes, in Cadernos de Direito Constitucional e Ciência Política, $\mathrm{n}^{\mathrm{o}} 21$, ano 5, out./dez. 1997, p. 96.Comunga de idêntica posição PINTO FERREIRA, Comentários à Constituição Brasileira - Vol. 2: Arts. 22 a 53, São Paulo, Saraiva, 1989, p. 548.

${ }^{391}$ Cf. STF, ADI no 1625-DF, Relator Min. MAURício CORRÊA, Informativo do STF $n^{o}$ 323, de 03/10/2003, documento disponível no endereço eletrônico $w w w . s t f . j u s . b r$.
} 
aponta para a necessidade democrática de participação do Poder Legislativo na formação da vontade estatal de pôr fim a um tratado, e (ii) o Chefe do Executivo, ao denunciar tratado sem anuência prévia do Congresso Nacional, age de modo inconstitucional visto estar legislando negativamente" ${ }^{392}$. Diante das normas inseridas pelo constituinte na Constituição de 1988 para orientar os órgãos nacionais no exercício das ações que possam impactar as relações exteriores do país, o regime de coparticipação na prática da denúncia parece ser, realmente, o entendimento que se coaduna com a interpretação contextualizada do texto constitucional vigente.

Cumpre elucidar que a intervenção do Parlamento como etapa obrigatória para a terminação dos tratados de que o Brasil seja parte não irá esgotar as atribuições do Poder Executivo nesse campo. Isso porque a exegese do art. 49, inciso I, da Lei Maior indica, nos termos da intelecção do Ministro JoAQuim Barbosa, que o Presidente da República continuará com a prerrogativa de decidir quais tratados deveriam ser denunciados e o momento mais conveniente para fazê-lo. Sob esse ponto de vista, o Congresso Nacional deve somente autorizar ou não a extinção da convenção, de forma que, uma vez negada a autorização, estará o Chefe do Executivo impedido de assim proceder; porém, na situação contrária, tem-se que a aquiescência congressual não obriga a denúncia, já que a decisão tomada no Legislativo é um ato meramente autorizativo ${ }^{393}$. A participação do Legislativo nesse processo, como evidenciado, não significa anular a competência presidencial para atuar com exclusividade na formalização da denúncia, tampouco prejudicará a inserção do Brasil na sociedade internacional, pois fará que o país apenas abandone os tratados quando certificada a impossibilidade de continuar a cumpri-los.

Ao final, resta concluir que a implementação dessa divisão de competências entre os Poderes Executivo e Legislativo para possibilitar a denúncia não está proibida na Lei Fundamental. O que existe na Constituição é unicamente um absoluto silêncio sobre a matéria. Ademais, a eventual consolidação desse entendimento, resultará, decerto, em ganhos tanto para a constância das relações internacionais - já que pode evitar decisões precipitadas e irrefletidas por parte do Presidente da República - quanto para o constitucionalismo pátrio - pois democratizará a forma de denunciar convenções. Esperase que o desfecho do julgamento da ADI $n^{\circ} 1625$ possa atestar que o advento da

\footnotetext{
${ }^{392}$ A Terminação de Tratado e o Poder Legislativo à Vista do Direito Internacional, do Direito Comparado e do Direito Constitucional Internacional Brasileiro, Rio de Janeiro, Renovar, 2011, p. 418.

${ }^{393}$ Cf. STF, ADI $n^{\circ}$ 1625-DF, Relator Min. MAURício CORRÊA, Voto do Min. JOAQUim BARBosA, Informativo do STF $n^{\circ}$ 549, de 01/06/2009, documento disponível no endereço eletrônico www.stf.jus.br.
} 
Constituição de 1988 e todos os elementos de internacionalização introduzidos por esse documento são fatores suficientes para que a denúncia de tratados não continue a ser orientada por procedimentos insculpidos em momento histórico em que o Estado buscava se fechar para as relações exteriores e, consequentemente, para o Direito Internacional.

\subsubsection{Parlamento do Mercosul e a Democratização (Possível) do Processo de Integração Regional}

A promoção da democracia no Mercosul é um assunto presente na agenda desse bloco desde os primeiros momentos de sua criação, denotando a profunda percepção por parte dos Estados envolvidos no processo regional de que não se pode dissociar integração econômica e respeito aos valores democráticos. Por certo, o primeiro grande marco normativo sobre a afirmação da democracia no bloco foi a celebração, em 1998, do Protocolo de Ushuaia sobre Compromisso Democrático no Mercosul, Bolívia e Chile, cujo texto estabeleceu que "a vigência das instituições democráticas é condição necessária para o gozo dos direitos de Estado membro ou associado do processo de integração do Cone Sul. Assim, toda ruptura da ordem democrática é considerada um obstáculo intransponível para a continuidade do processo de integração" ${ }^{394}$. A orientação de criar bases jurídicas para preservar as democracias nacionais não foi suficiente para responder ao ímpeto democrático verificado no interior dos países em tela. Clamava-se por participação popular também nos processos políticos de tomada de decisões no âmbito regional, e, em 2005, foi criado o Parlamento do Mercado Comum do Sul (Parlasul) para atender a essa finalidade.

Definido pelo Protocolo Constitutivo em 2005 - documento que foi internalizado pelo Brasil com o Decreto $n^{\circ}$ 6.105, de 30 de abril de 2007 -, o Parlamento do Mercosul constitui órgão singular de representação da população abrigada nos Estados-partes do bloco. Mesmo desprovido de competência legislativa autônoma, o Parlamento regional pode desempenhar várias atribuições relacionadas à cooperação interparlamentar entre os Estados, criando condições para que se harmonizem as legislações internas e para que se agilizem os processos domésticos de aprovação legislativa das normas internacionais criadas pelo Mercosul. O Parlamento pode, ainda, executar competência de fiscalização

\footnotetext{
${ }^{394}$ André De CARValho Ramos, Direitos Humanos na Integração, Ob. cit., p. 367. Anote-se que há dois outros documentos que também tratam do tema e que antecederam o Protocolo de Ushuaia: a Declaração Presidencial de Las Leñas, de 27 de junho de 1992, que explicitou a vontade política dos Estados em prol da plena vigência das instituições democráticas como condição indispensável para a existência e o desenvolvimento do Mercosul; e a Declaração Presidencial sobre Compromisso Democrático no Mercosul, de 25 de junho de 1996, elaborada na localidade de Potrero de Los Funes, Província de San Luis, Argentina (Cf. Idem, p. 258).
} 
sobre os órgãos decisórios e consultivos que compõem essa estrutura regional de integração $^{395}$.

Ressoa com clareza que o objetivo principal do Parlasul é o de privilegiar as dimensões social e política da integração iniciada em 1991, fornecendo ferramentas para contornar as críticas quanto ao déficit democrático das decisões de tomadas pelos órgãos do Mercosul, os quais são integrados por representantes dos governos nacionais, e não por representantes dos cidadãos atingidos pelos mandamentos criados (Item 3.2.1). O órgão parlamentar regional busca, pois, ampliar a legitimidade das decisões conjuntas adotadas no contexto do Mercosul e, ainda, responder aos reclamos de maior democratização do processo de integração desenvolvido na América do Sul ${ }^{396}$. Verifica-se que a institucionalização do Parlamento regional implicou alterações na forma de atuação dos Legislativos dos Estados-partes do bloco, o que, por óbvio, deve ser considerado como mais um sinal de abertura dos sistemas jurídicos internos ao Direito Internacional.

Talvez a mais significativa mudança nos respectivos sistemas constitucionais deflagrada pelo surgimento do Parlamento do Mercado Comum do Sul seja a necessidade de criar regimes internos habilitados a permitir a escolha dos representantes populares que, defendendo os interesses dos indivíduos, atuarão no Parlamento regional. Vale também mencionar outra interessante modificação advinda da afirmação institucional do órgão parlamentar do Mercosul: a obrigatoriedade de cada Estado-parte adotar procedimento preferencial de internalização da normativa criada em consonância com os pareceres consultivos emitidos pelo Parlasul ${ }^{397}$. Sem dúvida, ambas as alterações denotam alta margem de permeabilidade dos ordenamentos nacionais às regras criadas pelas instâncias

\footnotetext{
${ }^{395} \mathrm{O}$ art. $4^{\mathrm{o}}$ do Protocolo Constitutivo do Parlamento do Mercosul estabelece as competências desse órgão regional. Entre as atribuições encartadas nesse dispositivo, vale citar, a título ilustrativo, as seguintes: $(i)$ elaborar e publicar anualmente um relatório sobre a situação dos direitos humanos nos Estados Partes, levando em conta os princípios e as normas do Mercosul; (ii) elaborar e publicar anualmente um relatório sobre a situação dos direitos humanos nos Estados Partes, levando em conta os princípios e as normas do Mercosul; (iii) receber, ao final de cada semestre, a Presidência Pro Tempore do Mercosul, para que apresente um relatório sobre as atividades realizadas durante dito período; (iv) organizar reuniões públicas, sobre questões vinculadas ao desenvolvimento do processo de integração, com entidades da sociedade civil e os setores produtivos; (v) propor projetos de normas do Mercosul para consideração pelo Conselho do Mercado Comum, que deverá informar semestralmente sobre seu tratamento; (vi) elaborar estudos e anteprojetos de normas nacionais, orientados à harmonização das legislações nacionais dos Estados Partes, os quais serão comunicados aos Parlamentos nacionais com vistas a sua eventual consideração.

${ }^{396}$ Cf. Rodolfo R. Geneyro, El Parlamento ante la Vulnerabilidad del Mercosur, in La Encrucijada Política del Mercosur: Parlamentos y Nueva Institucionalidad, Gerardo Caetano e Rubén Perina (ed.), Montevideo, Centro Latinoamericano de Economía Humana (CLAEH) e Unidad para la Promoción de la Democracia (UPE), 2003, p. 205.

${ }^{397}$ Parlamento do Mercosul: Criação e Implementação de suas Funções, in Parlamentos: a Lei, a Prática e as Representações da Idade Média à Atualidade, Maria Helena da Cruz de Coelho e Maria Manuela Tavares Ribeiro (coord.), Lisboa, Assembleia da República, 2010, p. 21.
} 
do Mercosul, o que contribui destacadamente para inserir ainda mais os Legislativos nacionais no processo de internacionalização das Constituições.

Embora o Brasil ainda não tenha definido o sistema eleitoral a ser empregado para a escolha dos parlamentares que atuarão junto ao Parlamento regional representando a população brasileira ${ }^{398}$, o Congresso Nacional pátrio já editou regras específicas a fim de viabilizar a incorporação das normas do Mercosul elaboradas com o apoio do fórum parlamentar regional. Sobre o último ponto, informa MARIA ClaUdia DrumMOND que a obediência do comando consagrado no art. $4^{\mathrm{o}}, \mathrm{n}^{\mathrm{o}} 12$, do Protocolo Constitutivo do Parlamento do Mercosul ${ }^{399}$ é essencial para que o Parlamento intergovernamental possa contribuir efetivamente para aperfeiçoar os mecanismos de integração no Cone Sul ${ }^{400}$. Trata-se, com efeito, do denominado procedimento preferencial de aprovação nacional das normas oriundas do Mercosul, as quais foram elaboradas com a existência de consenso entre os órgãos decisórios do bloco e o Parlamento regional.

Cabe assinalar que, no caso brasileiro, a Resolução do Congresso Nacional $n^{0} 1$, de 2007, determina que as normas sujeitas ao referido procedimento preferencial serão apreciadas apenas pela representação nacional do Parlasul e pelos Plenários da Câmara dos Deputados e do Senado Federal $\left(\operatorname{art} .4^{\mathrm{o}}, \S 1^{\circ}\right)^{401}$. Isso garantirá maior rapidez ao processo

\footnotetext{
${ }^{398}$ As eleições diretas para a definição dos parlamentares do Parlamento do Mercosul estão previstas na terceira disposição transitória do Protocolo Constitutivo do Parlamento do Mercosul. Os Estados têm até o ano de 2014 para incluir em suas agendas eleitorais nacionais a realização de eleições por sufrágio direto, universal e secreto dos parlamentares regionais. O Paraguai foi o único país que, já em 2008, efetuou essas eleições. No Brasil, tramitam dois projetos de leis voltados a disciplinar o tema: o Projeto de Lei da Câmara $\mathrm{n}^{\circ} 5.279 / 2009$, proposto pelo deputado federal Carlos Zarattini (PT/SP) e o Projeto de Lei do Senado $\mathrm{n}^{\mathrm{o}}$ 126/2011, de autoria do senador Lindbergh Farias (PT/RJ). Ambos estão inconclusos até o momento.

399، Art. $4^{\circ}$ [... 12. Com o objetivo de acelerar os correspondentes procedimentos internos para a entrada em vigor das normas nos Estados Partes, o Parlamento elaborará pareceres sobre todos os projetos de normas do Mercosul que requeiram aprovação legislativa em um ou vários Estados-partes, em um prazo de noventa dias (90) a contar da data da consulta. Tais projetos deverão ser encaminhados ao Parlamento pelo órgão decisório do Mercosul, antes de sua aprovação. Se o projeto de norma do Mercosul for aprovado pelo órgão decisório, de acordo com os termos do parecer do Parlamento, a norma deverá ser enviada pelo Poder Executivo nacional ao seu respectivo Parlamento, dentro do prazo de quarenta e cinco (45) dias, contados a partir da sua aprovação. [...] Os Parlamentos nacionais, segundo os procedimentos internos correspondentes, deverão adotar as medidas necessárias para a instrumentalização ou criação de um procedimento preferencial para a consideração das normas do Mercosul que tenham sido adotadas de acordo com os termos do parecer do Parlamento mencionado no parágrafo anterior. O prazo máximo de duração do procedimento previsto no parágrafo precedente, não excederá cento oitenta (180) dias corridos, contados a partir do ingresso da norma no respectivo Parlamento nacional"..

${ }^{400}$ Parlamento do Mercosul: Criação e Implementação de suas Funções, in Parlamentos: a Lei, a Prática e as Representações da Idade Média à Atualidade, Maria Helena da Cruz de Coelho e Maria Manuela Tavares Ribeiro (coord.), Lisboa, Assembleia da República, 2010, p. 21.

401 "Art. $4^{\circ}$. No exame das matérias emanadas dos órgãos decisórios do Mercosul, a Representação Brasileira apreciará, em caráter preliminar, se a norma do Mercosul foi adotada de acordo com os termos do parecer do Parlamento do Mercosul, caso em que esta obedecerá a procedimento preferencial, nos termos do art. $4^{\circ}$, inciso 12, do Protocolo Constitutivo do Parlamento do Mercosul. $\S 1^{\circ}$ As normas sujeitas a procedimento
} 
de transposição das normas editadas no âmbito no Mercosul para o Direito Interno, tendo em vista que a dispensa da atuação das comissões parlamentares temáticas das duas Casas do Congresso Nacional no processo. Longe, portanto, de esvaziar as competências do Poder Legislativo nacional, a implementação desse procedimento especial pelo país retrata a tendência de aprofundamento dos arranjos jurídico-institucionais de integração, permitindo que, nos limites possíveis, ocorra a projeção da cidadania no espaço regional.

Diante do exposto, fica patente que compreender o funcionamento e a abrangência do Parlamento do Mercosul pressupõe o conhecimento das regras internas que cuidam da eleição dos parlamentares regionais e da adaptação das ordens jurídicas nacionais para o processamento preferencial de internalização da produção legislativa do bloco. Reflete-se, assim, que as Casas Legislativas dos Estados assumem novas funções no exercício do controle das atividades exteriores no plano da integração regional em curso ${ }^{402}$. A conclusão a que se chega, ao menos sob a perspectiva institucional, é no sentido de que o Parlasul não apenas introduz elementos concretos de legitimação democrática na tomada de decisões pelos órgãos do Mercosul, mas também desponta como fator de revigoramento das típicas funções legislativa e fiscalizatória, historicamente, assumidas pelo Legislativo dos Estados $^{403}$.

Confiar a um corpo de parlamentares, eleito por sufrágio direto e universal, competências para exercer, no terreno da integração regional, atribuições relacionadas a essas atividades potencializa a abertura dos Estados nacionais ao Direito das Gentes, condicionando o aperfeiçoamento das Constituições para que atendam às contingências do cenário internacional. No caso do Brasil, os pontos de contato entre as competências reservadas ao Legislativo pátrio e as atribuições do Parlamento regional certificam que a participação dos representantes do povo deve ultrapassar o mero referendo congressual dos tratados internacionais celebrados pelo Chefe do Executivo ${ }^{404}$. Justamente por ser uma obra inacabada, a erosão das fronteiras entre o externo e o interno clama que o

preferencial serão apreciadas apenas pela Representação Brasileira e pelos plenários da Câmara dos Deputados e do Senado Federal".

${ }^{402}$ Cf. Ricardo Victalino de Oliveira, Para Além do Referendo de Tratados, Convenções e Atos Internacionais: A Atuação do Legislativo Brasileiro Ante a Criação do Parlamento do Mercosul, in Revista Cientifica Virtual da ESA/OABSP, n 14, ano 5, out. 2013, p. 54.

${ }^{403}$ Cf. Mariela Morales Antoniazzi, La Cláusula Democrática y el Parlamento del Mercosur. Contextualización de su Alcance y Dimensionalidad, in Direitos Humanos, Democracia e Integração Jurídica na América do Sul, Armin von Bogdandy, Flavia Piovesan e Mariela Morales Antoniazzi(coord.), Rio da Janeiro, Lumen Juris, 2010, pp. 195-197.

${ }^{404}$ Cf. Ricardo Victalino De Oliveira, Para Além do, Ob. cit., p. 54. 
engajamento de todos os Poderes estatais não se desenvolva à margem das conquistas que a democracia e o constitucionalismo lograram sedimentar no interior dos Estados.

\subsection{Poder Judiciário e Aplicação do Direito Internacional}

A par da relevância que, atualmente, o Poder Legislativo adquire com o alargamento da pauta de negócios exteriores conduzidos pelos Estados nacionais, cabe apreciar ainda as responsabilidades destinadas ao Poder Judiciário na efetivação das normas resultantes da interação entre os vários sujeitos reconhecidos pelo Direito Internacional. Sobre a atuação do Judiciário nesse tema, preconiza MAURICIO IVÁN DEL TORo Huerta que "a análise da atividade jurisdicional deve se localizar em um contexto global marcado pela consecução de tendências simultâneas que situam o juiz nacional em uma posição singular sem precedentes tanto no âmbito nacional como internacional. Os juízes nacionais passam a ocupar condição intermediária entre a sociedade e o Estado que integram e entre este Estado e a sociedade internacional" ${ }^{405}$. A participação dos magistrados como garantidores do Direito das Gentes completa o regime de corresponsabilidade entre os Poderes estatais empregado pela engenharia constitucional na elaboração de sistemas jurídicos vertidos à internacionalização.

A experiência retrata que, quando o Parlamento não opta por implementar mediante edição de atos normativos correspondentes - tratados já ratificados pelo Estado, o foco das atenções em torno da efetivação dos direitos previstos nesses instrumentos desloca-se para o Judiciário. Observa-se que isso ocorre com mais frequência quando a ausência de normatização interna abrange convenções cujo conteúdo disciplina matéria afeita aos direitos humanos, possivelmente porque, nessa seara, os litigantes são os próprios indivíduos protegidos pela norma. A lenta mudança no modo de aplicar internamente mandamentos do Direito Internacional depende, sem dúvida, de sistemas constitucionais em que o Poder Judiciário goze de independência funcional e também externe consciência sobre a importância de promover a execução de normas que, mesmo não criadas exclusivamente pelos órgãos nacionais, visam a tutelar bens jurídicos que são igualmente protegidos pelo Direito Interno ${ }^{406}$.

\footnotetext{
${ }^{405}$ La Apertura Constitucional,Ob. cit.,pp. 328-329.

${ }^{406} \mathrm{Cf}$. WENDY LACEY, The Judicial Use of Unincorporated International Conventions in Administrative Law: Back-Doors, Platitudes and Window-Dressing, in The Fluid State: International Law and National Legal Systems, Hilary Charlesworth, Madelaine Chiam, Devika Hovell e George Williams (ed.), Ob. cit., p. 83.
} 
Percebe-se, dessa forma, que o fato de o conceito clássico de Constituição ser intimamente ligado ao Estado nacional, não significa "que, contemporaneamente, a interpretação constitucional também tenha que se limitar às fronteiras de cada país. $\mathrm{O}$ constitucionalismo - e a interpretação constitucional - não são apenas questões estritamente nacionais porque os problemas são internacionalmente comuns, e muitas vezes as realidades e as experiências jurídicas também o são. Nesse sentido, é possível afirmar que mesmo que não houvesse no mundo nenhum órgão (ou tribunal) supranacional, a integração, por meio do livre fluxo de ideias, poderia ser riquíssima e intensa" ${ }^{\text {407 }}$. Sob esse influxo, é possível inferir que a aplicação nos tribunais domésticos de mandamentos criados no plano interestatal constitui parâmetro seguro para aferir o grau de permeabilidade do ordenamento interno em relação ao Direito Internacional.

A disposição em cumprir normas exteriores não indica, entretanto, que o Judiciário tenha abandonado a Constituição como norma elementar do sistema jurídico nacional. Grifa Regina Maria Macedo Nery Ferrari que a orientação de que o texto constitucional "continua sendo o vértice do ordenamento jurídico e sede de determinação da estrutura da norma jurídica convencional" ${ }^{\text {408 }}$ mantém-se firme no presente cenário constitucional. Isso resulta na prevalência da Constituição quando esta é contrariada por tratados e demais atos internacionais, independentemente da possibilidade de responsabilização internacional do Estado que opte pela primazia de sua Lei Fundamental. O empenho dos juízes nacionais em efetivar o Direito Internacional é, antes, influência da axiologia consagrada nas próprias Constituições, cujos textos passam, gradualmente, a positivar normas que ampliam a percepção de que deve haver uma concordância substantiva entre os direitos protegidos por ambos os segmentos jurídicos.

Decerto, esse pluralismo jurídico - combinado com o interesse recíproco dos Estados e das instâncias internacionais em promover a aplicação de normas com cujos conteúdos se identificam - encoraja a adoção de técnicas e instrumentos que favoreçam a conciliação entre o Direito Interno e o Direito Internacional. A ampliação das hipóteses de entrelaçamento entre mandamentos jurídicos aumenta a convicção de que a supremacia da Constituição não é incompatível com outra realidade: o surgimento de centros extraestatais

\footnotetext{
${ }^{407}$ Virgíllo Afonso da Silva, Integração e Diálogo Constitucional na América do Sul, in Direitos Humanos, Democracia e Integração Jurídica na América do Sul, Armin von Bogdandy, Flavia Piovesan, e Mariela Morales Antoniazzi (coord.), Rio da Janeiro, Lumen Juris, 2010.p. 530.

${ }^{408}$ Critérios Científicos para a Solução dos Conflitos Aparentes Entre Tratados Internacionais e a Constituição Federal, in Revista dos Tribunais, vol. 855, ano 96, jan. 2007, p. 38.
} 
habilitados a criar normas oponíveis no território dos Estados ${ }^{409}$. Verifica-se, ainda, nesse panorama de interpenetração normativa, que a atuação coordenada de Cortes nacionais com Tribunais internacionais permite construir, de forma lenta, uma fertilização jurisprudencial crescente, que ajuda a incrementar a execução interna de comandos internacionais, especialmente na proteção dos direitos da pessoa humana ${ }^{410}$.

A preocupação de concatenar os sistemas jurídicos e a aplicação das respectivas normas reflete-se, inclusive, no controle de constitucionalidade de tratados e demais atos internacionais. Acerca desse assunto, ganha vigor a ideia de que o Estado nacional pode compatibilizar a máxima força normativa atribuída à Constituição com o dever de cumprir as normas internacionais, caso sejam instituídos mecanismos de controle de constitucionalidade preventivo jurisdicional das normas internacionais que necessitam de incorporação ao ordenamento interno. Esse sistema de defesa da ordem nacional diante das normas convencionais parece, de fato, contribuir para a inserção dos Estados nacionais nas relações jurídicas estabelecidas no exterior, pois evita os inconvenientes que decorrem da operacionalização do controle repressivo de constitucionalidade tendo por objeto atos normativos internacionais.

Consigna VICTOR BAZÁn que a introdução do controle de constitucionalidade préviodos tratados e convenções internacionais deveria ser uma etapa obrigatória da incorporação desse tipo de normativa pelos Estados, pois, assim, estaria prestigiada a segurança jurídica das relações exteriores e a supremacia constitucional ${ }^{411}$. Também evitaria perturbações decorrentes de ilícitos internacionais praticados pelo Estado ao não aplicar tratados que são internacionalmente vigentes, mas perderam a força jurídica no âmbito interno em razão da declaração de inconstitucionalidade. Essas ideias convergem para benefícios que podem ser sintetizados nos pontos que seguem: em caso de o instrumento internacional contrariar a Constituição, o controle a priori torna possível obstar a internalização do tratado; ou pode identificar incongruências parciais que resultarão em reservas no momento da ratificação da convenção; e, ainda, permite adotar soluções alternativas, como a hipótese de incorporar a norma exterior não como tratado,

\footnotetext{
${ }^{409}$ Cf. Nilsa Rojas-Hutinel, L' Articulation des Ordres Juridiques en Matière de Protection des Droits Fondamentaux et la Résurgence de la Suprématie de la Constitution, in Politeia, n ${ }^{\mathrm{o}}$ 22, dez. 2012, p. 282.

${ }^{410}$ Cf. Antônio Augusto CAnÇAdo Trindade, El Ejercicio de la Función Judicial Internacional: Memorias de la Corte Interamericana de Derechos Humanos, $2^{\circ}$ ed., Belo Horizonte, Del Rey, 2013, p. 215.

${ }^{411}$ Cf. Jurisdicción Constitucional, Control de Constitucionalidad de los Tratados y Convenios Internacionales, y Reforma de la Ley Fundamental, in Pensamiento Constitucional, vol. 9, $\mathrm{n}^{\circ}$ 9, 2003 , pp. 460.
} 
mas como emenda constitucional que reformaria a Constituição para viabilizar a vinculação do país à normativa externa ${ }^{412}$.

A proposta de investir no controle preventivo de constitucionalidade como engenho hábil para favorecer a aproximação entre Constituição e Direito das Gentes já encontrou adeptos no Brasil e, sem dúvida, confere relevo à posição do Poder Judiciário como parte responsável pelo êxito do projeto de expansão das relações exteriores estatuído na Constituição de 1988. Nessa direção, Gilmar Ferreira Mendes defende que a atual conjuntura internacional "impõe a necessidade de utilização de uma espécie de controle prévio, o qual poderia impedir ou desaconselhar a ratificação do tratado de maneira a oferecer ao Poder Executivo possibilidades de renegociação ou aceitação com reservas. Essa ideia, apesar de todos os óbices do sistema brasileiro, já apresenta os elementos suficientes para a sua exequibilidade. Uma vez que o Decreto Legislativo que aprova o instrumento internacional é passível de impugnação pela via da Ação Direta de Inconstitucionalidade (ADI), ou ainda, da Ação Declaratória de Constitucionalidade (ADC), esse controle de caráter preventivo é possível no Brasil"413.

Estimular as incursões do Judiciário nacional no universo do internacionalismo constitui medida indispensável para que se respeitem propriamente as Constituições estatais alinhadas ao fenômeno jurídico da internacionalização. Isso porque, ao consagrar a abertura ao exterior, o texto constitucional determina que sua observância apenas será completa se, em igual direção, os mandamentos internacionais conformes à Constituição também forem devidamente aplicados pelos órgãos domésticos incumbidos de desempenhar essa tarefa. Além desse dado, a resistência em executar, no espaço nacional, as normas oriundas do Direito das Gentes pode também ensejar a imposição de variadas sanções ao Estado transgressor por parte das instâncias judiciárias internacionais que se multiplicam presentemente. A relação dialógica entre essas cortes internacionais e os tribunais estatais constitui o objeto do próximo item deste trabalho.

\subsubsection{O Diálogo das Cortes e a Margem de Apreciação Nacional}

A aceitação da jurisdição de tribunais internacionais não significa o abandono da soberania pelo Estado. Ao contrário, atesta que a soberania estatal está preservada, porque a submissão a essas cortes é ato voluntário decidido pelo Estado. Ademais, ao reconhecer a

\footnotetext{
${ }^{412}$ Cf. Idem, pp. $460-461$.

${ }^{413}$ Controle Abstrato de Constitucionalidade: ADI, ADC e ADO: Comentários à Lei n. 9.868/99, São Paulo, Saraiva, 2012, pp. 153-154.
} 
autoridade dos tribunais internacionais, o Estado sela o compromisso de não mais realizar o chamado "judex in causa sua”,típico do Direito Internacional - em que o Estado é, concomitantemente, produtor, destinatário e intérprete de suas normas ${ }^{414}$. Como não há hierarquia entre os órgãos judiciários nacionais e internacionais, o reconhecimento da competência das instituições exteriores especializadas na aplicação do Direito das Gentes proporciona um ambiente que valoriza a posição do Judiciário interno, tendo em vista que, entre os dois tipos de tribunais, existe incindível relação de coordenação e complementariedade.

Sob esse prisma, é perceptível que, “à medida que as normas internacionais são integradas ao Direito Interno, os juízes nacionais tornam-se também guardiões do Direito Internacional (regional ou mundial)" ${ }^{\natural 15}$. Não é sem motivo, portanto, que se pode afirmar que a eficácia do Direito das Gentes repousa, amplamente, sobre os juízes nacionais ${ }^{416}$. Esse fato representa grande desafio aos tribunais internos, pois esses órgãos passam a lidar com uma realidade de aumento significativo no número de mandamentos passíveis de aplicação a casos concretos, cuja origem é internacional. Os juízes são forçados a se adaptarem à realidade descrita, sem que, no entanto, a estrutura organizacional das instâncias judiciárias domésticas tenha sido preparada para essa finalidade ${ }^{417}$. Avultam também tensões acerca da necessidade de, frente a normas externas de caráter universal, preservar valores e tradições históricas arraigadas no Estado nacional.

O caminho que desponta para vencer esse quadro de alta complexidade no exercício da função judicante é recorrer ao conceito de margem nacional de apreciação. Idealizada no espaço europeu, essa concepção permite que os magistrados nacionais considerem as diversidades, especialmente as culturais e religiosas, existentes mesmo em regiões razoavelmente homogêneas, no momento de proceder à execução dos comandos internacionais com alto grau de generalidade e abstração ${ }^{418}$. O cerne da tese da margem de

\footnotetext{
${ }^{414}$ Cf.André De CARvalho Ramos, A Interpretação Internacional dos Direitos Humanos: Choque ou Diálogo com o Supremo Tribunal Federal, in Novos Caminhos do Direito no Século XXI: Direito Internacional, Filosofia Jurídica e Política, Dogmática Jurídica e Direitos Fundamentais: Uma Homenagem a Celso Lafer, $2^{\mathrm{a}}$ ed., Luiz Olavo Baptista e Tercio Sampaio Ferraz Junior (coord.), Ob. cit., p. 314.

${ }^{415}$ Mireille Delmas-Marty, Le Relatif et,Ob. cit., p. 204.

${ }^{416}$ HÉLÈnE TOURARD, L'Internationalisation des, Ob. cit., p. 250.

${ }^{417}$ Idem, p. 297.

${ }^{418}$ Mireille Delmas-Marty, Études Juridiques Comparatives, Ob. cit., p. 34. Averbe-se, ainda, que a autora defende a noção de margem nacional de apreciação como "a chave principal do pluralismo ordenado. De um lado, ela explica a dinâmica centrífuga, a resistência nacional à integração; mas, por outro lado, não sendo a margem ilimitada, mas circunscrita por princípios comuns, ela impõe um limite, um limiar de compatibilidade que reconduz ao centro (dinâmica centrípeta). As oscilações, que traduzem ora as resistências dos direitos internos, ora os avanços do processo de harmonização, permitem, ao ajustar a
} 
apreciação está atrelado à "subsidiariedade da jurisdição internacional e prega que determinadas questões polêmicas relacionadas com as restrições a direitos protegidos devem ser discutidas e dirimidas pelas comunidades nacionais, não podendo o juiz internacional apreciá-las" ${ }^{419}$.

Nesse compasso, vale esclarecer um dado histórico sobre a doutrina da margem de apreciação nacional, surgida no continente europeu em consequência da aplicação de convenções de proteção dos direitos humanos pelos juízes nacionais. JAVIER GARCíA RoCA registra que esse conceito não está incluído de forma expressa entre os preceitos da Convenção Europeia de Direitos Humanos, de 1950, tampouco foi mencionado ou debatido nos trabalhos preparatórios do tratado referido. Surgiu como desdobramento natural à lógica da subsidiariedade ${ }^{420}$, inerente à proteção internacional na proteção dos direitos humanos. A origem do conceito é, portanto, incerta. Tem prevalecido a ideia de que a margem de apreciação nacional parece advir das técnicas da revisão judicial próprias dos Estados, em particular, do Conselho de Estado francês. Foi, contudo, a Corte Europeia de Direitos Humanos que acabou desenvolvendo o conceito com perfis próprios ${ }^{421}$.

A margem nacional de apreciação deve ser compreendida como um reduto ou critério de interpretação e de aplicação dos direitos humanos, atribuído ao Estado por parte das cortes internacionais. Sua existência é justificada pela ausência de consenso entre os diferentes Estados que figuram em convenções multilaterais como partes vinculadas ao tratado, o que impede, por conseguinte, que tribunais internacionais construam uma regra de interpretação unificada sobre a extensão normativa dos preceitos consignados nos $\operatorname{tratados}^{422}$. A importância desse conceito para o exercício da jurisdição internacional é

amplitude da margem aceitável, determinar um limiar de compatibilidade" (Le Pluralisme Ordonné, Ob. cit., p. 78).

${ }^{419}$ ANDRÉ De CARVAlho Ramos, Teoria Geral dos Direitos Humanos na Ordem Internacional, $3^{\mathrm{a}}$ ed., São Paulo, Saraiva, 2013, p. 104.

${ }^{420}$ Pontua MALCOLM N. SHAW que a ideia imanente à subsidiariedade da jurisdição internacional "permite que os Estados tentem resolver seus problemas internos de acordo com seus procedimentos constitucionais antes que sejam invocados os mecanismos internacionais aceitos, e é regra bem estabelecida no Direito Internacional. Entretanto, quando os remédios ou soluções internas inexistem, prolongam-se indevida e irrazoavelmente ou não têm grande probabilidade de resolver eficazmente a situação, não é necessário esperar para fazer apelo às medidas internacionais. [...] Todos os instrumentos internacionais e regionais de proteção aos direitos humanos contêm dispositivos que estipulam a necessidade de esgotar todos os recursos internos antes de pôr em ação os mecanismos internacionais" (Direito Internacional, Ob. cit., pp. 210-211).

${ }^{421}$ Cf.La Muy Discrecional Doctrina del Margen de Apreciación Nacional Según el Tribunal Europeo de Derechos Humanos: Soberanía e Integración, in Teoría y Realidad Constitucional, $\mathrm{n}^{\circ}$ 20, 2007, pp. 121-122. ${ }^{422} \mathrm{Cf}$. Francisco R. BARbosa Delgado, Os Limites à Doutrina da Margem Nacional de Apreciação no Tribunal Europeu e na Corte Interamericana de Direitos Humanos: Intervenção Judicial em Torno de Certos Direitos das Minorias Étnicas e Culturais, in Revista Direito do Estado, n. ${ }^{\circ}$ 26, jan./jun. 2011, pp. 109-100. 
muito grande, motivo pelo qual, hoje, não mais apenas os órgãos interestatais encarregados de zelar pelos direitos humanos o aplica.

Com efeito, informa MARCELO D. VARElla que a ideia de margem nacional de apreciação foi exportada para diferentes processos de internacionalização do Direito. Assim, o autor alude ao "conceito de 'níveis aceitáveis de risco' permitidos pela Organização Mundial do Comércio em matéria ambiental e sanitária e garante aos Estados a decisão do nível de risco que aceitam impor a sua própria população com o comércio (ou proibição do comércio) de um determinado produto" ${ }^{\text {"423 }}$, para exemplificar o emprego desse instituto jurídico em outras instâncias que não as cortes regionais de direitos humanos. Aclara-se, portanto, o quão relevante o desenvolvimento do conceito é para harmonizar a atuação dos órgãos judiciários nacionais e internacionais incumbidos de aplicar o mesmo Direito.

Ademais, a posição estratégica assumida pelos juízes nacionais no que diz respeito à abertura do Estado à ordem internacional é reforçada pelo crescente aparecimento de casos-problemas cuja solução interessa de igual maneira às diversas ordens envolvidas. Do ponto de vista do ordenamento estatal, o envolvimento dos tribunais constitucionais em assuntos pertinentes aos direitos humanos ou à delimitação do poder do Estado especialmente quando envolvem pretensões que ultrapassam o campo de validade específico do ordenamento interno - fortifica-lhes o caráter constitucional. No sentido inverso, é visível a tendência de incorporar matérias tipicamente constitucionais na pauta de decisões das cortes internacionais, órgãos que passam a levantar a pretensão de decidir com caráter vinculante e imediato para os agentes e cidadãos dos Estados, dispensando-se a intermediação das autoridades judiciárias nacionais para que sentenças exteriores adquiram força executória ${ }^{424}$.

São situações de dupla incidência de comandos normativos que certificam a importância de propostas como a do "diálogo entre as Cortes", exposta por ANDRÉ DE CARValho Ramos. Segundo essa concepção, o aumento das áreas de confluência entre o Direito Internacional e o Direito Interno demanda que tanto tribunais domésticos quanto cortes internacionais, aumentem a sintonia a fim de alcançar soluções que primem pela

\footnotetext{
${ }^{423}$ Internacionalização do Direito: Direito Internacional, Globalização e Complexidade, Tese de Livre Docência, Faculdade de Direito da USP, São Paulo, 2012, p. 420.

${ }^{424}$ Cf. MARCElo NeVES, Transconstitucionalismo, Ob. cit., pp. 132-133.
} 
implementação e uniformização da normativa afeita às relações internacionais ${ }^{425}$. Voltando-nos para a situação em que o Brasil se encontra, impende, nesse momento, que a jurisprudência do Supremo Tribunal Federal busque se conformar às decisões prolatadas pelas cortes internacionais. Essa tendência se fortaleceu depois da adesão do país a mecanismos internacionais de averiguação de cumprimento das normas de direitos humanos - a exemplo da Corte Interamericana de Direitos Humanos, cuja jurisdição foi formalmente reconhecida pelo Brasil em 1998.

Cumpre advertir que a formação de uma efetiva rede de diálogos entre órgãos judiciários internos e tribunais internacionais não significa, sob nenhuma ótica, a subordinação dos primeiros aos segundos ou vice-versa. O conceito de margem nacional de apreciação assegura que os Estados soberanos possam-se valer do respectivo Judiciário para, na ocasião da aplicação da normativa internacional, acomodar os mandamentos exteriores às realidades que vivenciam. Esse dado comprova que as cortes domésticas continuam independentes e, desde que respeitados parâmetros mínimos de proteção, podem emitir decisões que possibilitem conjugar o dever de respeitar as prescrições internacionais com as normas constitucionais. Compreensão contrária a esta, com certeza, inviabilizaria a decisão de os Estados (se não de todos, da maioria deles) reconhecerem a jurisdição das mencionadas instâncias internacionais.

Além da competência litigiosa, os tribunais internacionais contam, em geral, com a competência para emitir pareceres ou opiniões consultivas. É outro meio que se pode transformar no principal indutor da aproximação entre a jurisprudência interna dos Estados e a jurisprudência internacional. Mesmo não resultando em decisões com conteúdo obrigatório, o emprego dessa competência se mostra como ferramenta habilitada a orientar a atuação dos órgãos nacionais, antes mesmo que eventual aplicação inadequada do Direito Internacional ocorra ${ }^{426}$. Embora o Brasil possa também apresentar pedido de consultas à

${ }^{425}$ Cf. O Diálogo das Cortes: O Supremo Tribunal Federal e a Corte Interamericana de Direitos Humanos, in O STF e o Direito Internacional dos Direitos Humanos, Alberto do Amaral Júnior e Liliana Lyra Jubilut (org.), Ob. cit., pp. 849-850.

${ }^{426}$ Cf. FRANCISCO REZEK, Competência Consultiva dos Tribunais Internacionais: Uma Perspectiva para o Mercosul, in Estudos: Direito Público: Homenagem ao Ministro Carlos Mário da Silva Velloso, Ives Gandra Martins, Patrícia Rosset e Antonio Carlos Rodrigues do Amaral (coord.), São Paulo, Lex, 2012, p. 183. A importância dos pareceres consultivos emitidos pelos órgãos judiciários internacionais é ilustrada pelo trecho extraído da obra de ANDRÉ DE CARVALHO RAMOS: “As opiniões consultivas da Corte Interamericana de Direitos Humanos por certo não vinculam os Estados, mas fornecem preciosa fonte de informação sobre a visão do órgão responsável, justamente por interpretar as obrigações internacionais de direitos humanos dos Estados que ratificaram o Pacto de San José da Costa Rica. Nasce, como já escrevi anteriormente, o fenômeno da 'coisa julgada interpretada', que orienta os Estados e que deve ser acatada justamente para que se evite uma responsabilização futura.De fato, seria ilógico que o Brasil não cumprisse a orientação contida em uma opinião consultiva e logo depois fosse processado e condenado pela própria Corte Interamericana de 
Corte Internacional de Justiça e à Corte Interamericana de Direitos Humanos, é o mecanismo de consultas ao Tribunal Permanente de Revisão do Mercosul (TPR) que demonstra maior potencial de fomentar o diálogo entre as cortes.

Corrobora a impressão o fato de que, no caso dos dois primeiros tribunais internacionais citados, a legitimidade para apresentar pedido de consultas pertence a determinados órgãos da ONU ${ }^{427}$ ou aos Estados soberanos ${ }^{428}$ - sendo que, tradicionalmente, estes são representados pelos Chefes do Executivo. Já em relação ao Tribunal Permanente do Mercosul, a legitimidade foi concedida aos tribunais superiores dos Estados-partes do bloco (Decisão no 2/2007 do Grupo Mercado Comum) ${ }^{429}$. A propósito, a Emenda Regimental no 48/2012 alterou o Regimento Interno do Supremo Tribunal Federal brasileiro, com a finalidade de disciplinar o modo pelo qual as consultas do Poder Judiciário pátrio poderão ser apresentadas ao TPR. Ficou estabelecido que o juiz da causa ou qualquer uma das partes envolvidas podem solicitar pedido de opinião consultiva ao Tribunal do Mercosul sobre assunto afeito à integração regional (art. 354$\mathrm{I}^{430}$. O pedido será analisado, primeiramente, pelo Supremo Tribunal Federal do Brasil $(\text { art. 354-K })^{431}$, que, somente após um juízo de admissibilidade, poderá encaminhar a solicitação ao Tribunal do Mercosul (art. 354-L) ${ }^{432}$.

Direitos Humanos, no âmbito de sua jurisdição contenciosa" (O Diálogo das Cortes: O Supremo Tribunal Federal e a Corte Interamericana de Direitos Humanos, in O STF e o Direito Internacional dos Direitos Humanos, Alberto do Amaral Júnior e Liliana Lyra Jubilut (org.), Ob. cit., p. 825).

${ }^{427}$ Dispõe o art. 96 da Carta das Nações Unidas de 1945: "Art. 96. 1. A Assembleia Geral ou o Conselho de Segurança poderá solicitar parecer consultivo da Corte Internacional de Justiça, sobre qualquer questão de ordem jurídica.2. Outros órgãos das Nações Unidas e entidades especializadas, que forem em qualquer época devidamente autorizados pela Assembleia Geral, poderão também solicitar pareceres consultivos da Corte sobre questões jurídicas surgidas dentro da esfera de suas atividades".

${ }^{428} \mathrm{O}$ art. 64 da Convenção Americana de Direitos Humanos de 1969 prevê: "Art. 64. 1. Os Estados-membros da Organização poderão consultar a Corte sobre a interpretação desta Convenção ou de outros tratados concernentes à proteção dos direitos humanos nos Estados americanos. Também poderão consultá-la, no que lhes compete, os órgãos enumerados no capítulo X da Carta da Organização dos Estados Americanos, reformada pelo Protocolo de Buenos Aires".

429، Art. 1. O procedimento de solicitação de opiniões consultivas formuladas pelos Tribunais Superiores de Justiça dos Estados-partes obedecerá as regras estabelecidas neste Regulamento. Cada Tribunal Superior de Justiça dos Estados-partes, no âmbito de suas respectivas jurisdições, estabelecerão as regras internas de procedimento para a solicitação de opiniões consultivas a que se refere este Regulamento, verificando a adequação processual da solicitação".

430 “Art. 354-I. Têm legitimidade para requerer o encaminhamento de solicitação de opinião consultiva ao Tribunal Permanente de Revisão do Mercosul, o juiz da causa ou alguma das partes”.

431 “Art. 354-K. Ao receber a solicitação, o Presidente do Supremo Tribunal Federal iniciará o processo de colheita de votos dos demais Ministros pelo processo virtual ou, se entender conveniente, encaminhará cópias aos demais Ministros antes da sessão administrativa designada para deliberação sobre a presença dos requisitos de admissibilidade do pedido e sua pertinência processual".

432 “Art. 354-L. Uma vez preenchidos os requisitos de admissibilidade, a solicitação será encaminhada ao Tribunal Permanente de Revisão, com cópia para a Secretaria do Mercosul, e para as demais Cortes Supremas dos Estados Partes do Mercosul”. 
A emergência de cortes internacionais que reconhecem a competência do Judiciário doméstico para aplicar o Direito Internacional acabou intensificando a participação dos magistrados nacionais na efetivação de normas internacionais. Diante desse panorama de acentuada interconexão entre ordens normativas, aguarda-se que juízes de todos os níveis busquem meios de integrar-se uns aos outros, envidando esforços para que se protejam bens jurídicos interdependentes e indivisíveis, sem, contudo, anular a relevância de cada um dos ordenamentos entrelaçados ${ }^{433}$. Caso, ao contrário, as instâncias judiciárias interna e internacional se isolem, os projetos constitucionais de internacionalização do Direito dificilmente encontrarão condições para se concretizarem.

${ }^{433}$ Cf.Gustavo Zagrebelsky,Corti Costituzionali e Diritti Universali, in Rivista Trimestrale di Diritto Pubblico, $\mathrm{n}^{\mathrm{o}}$ 2, 2006, p. 310. 


\section{APLICAÇÃO DO DIREITO INTERNACIONAL NA ORDEM JURÍDICA BRASILEIRA}

"[...] todo Direito Internacional - geral ou comum, convencional e derivado de organizações internacionais e entidades afins - vigora ou tende a vigorar (com técnicas diversas) diretamente na ordem interna; e vigora mesmo que as Constituições não o digam".

JORGE MIRANDA 434

\subsection{Pluralidade Normativa e Entrelaçamento do Ordenamento Nacional com o Direito Internacional}

A dissolução do conceito de soberania ilimitada - que, no passado, foi a principal base tanto da ordem nacional quanto do sistema internacional - resultou no quadro atual, em que o Estado deixou de ser a única fonte de emanação do Direito vigente em seu território. Todo esse desenvolvimento implicou alterações no papel das Constituições, de forma que as normas constitucionais perderam o posto de referenciais jurídicos exclusivos da atuação dos Estados nacionais. A fragmentação do poder público obrigou-nos reformular a visão do Direito Constitucional em relação ao Direito Internacional, pois as normas internacionais passaram, em sua maioria, a ser elaboradas para que fossem aplicadas no interior dos Estados, incidindo, assim, sobre os agentes governamentais e os particulares confinados nos territórios nacionais.

O movimento a que se assiste, inegavelmente, contribui para o aperfeiçoamento do constitucionalismo, a ponto de ANTONIO ENRIQUE PÉREZ LUÑo expressar que "um dos traços informadores dos Estados constitucionais de Direito no presente é o fenômeno da 'supraestatalidade normativa'. Tal fenômeno supõe a adoção de valores, princípios ou regras jurídicas comuns no âmbito de ordenamentos diferentes, por efeito de certos atos de aceitação da estrutura normativa de determinadas organizações internacionais ou supranacionais, ou melhor, o reconhecimento implícito de valores ou normas jurídicas fora da área em que inicialmente foram promulgadas, a partir de sua vocação ou virtualidade global’435. Têm-se, dessa forma, mudanças na concepção tradicional de Constituição, o

\footnotetext{
${ }^{434}$ Direito Constitucional e, Ob. cit., p. 90.

${ }^{435}$ Perspectivas e Tendências atuais do Estado Constitucional, Porto Alegre, Livraria do Advogado, 2012, pp. 10-11. Ideia defendida também por CRISTINA QUEIROZ, que estatui que "quer na esfera do Direito Constitucional quer na esfera do Direito Internacional, a legitimidade significa, antes de mais, a necessidade de proteção de bens e interesses comuns, a proteção e manutenção da paz, da segurança e justiça comuns. E implica ainda aceitação e obediência a uma ordem dada" (Direito Constitucional Internacional, Ob. cit., pp. 34-35).
} 
que resvala no aparecimento do dever de o Direito Constitucional "compreender essa abertura e delimitá-la, pois as ordens constitucionais necessitam interagir com o externo sem perder sua identidade" 436 .

O processo de maior receptividade do Direito Internacional "não ocorreu contra a vontade dos Estados. Os direitos soberanos foram renunciados voluntariamente porque se esperava algo em troca: um aumento na capacidade de solucionar problemas em assuntos que não podiam mais ser manejados em nível nacional"437, na esteira do que observa DiETER GRIMM. Talvez tenha sido justamente essa notável disposição das instituições estatais em abrir-se ao Direito das Gentes que favoreceu elaborar a tese defendida de modo aguerrido pela maioria dos internacionalistas de que haveria uma superioridade hierárquica dos mandamentos exteriores diante das normas nacionais, em virtude da irrelevância jurídica destas quando opostas às prescrições internacionais.

Embora as inovações oriundas do incremento das relações exteriores tenham gerado muitas alterações no tratamento que as Constituições determinam ao Direito Internacional, inexistem argumentos jurídicos convincentes que provem como a convergência sistêmica entre o nacional e o externo seria, por si só, suficiente para assegurar a prevalência das normas internacionais. Ao revés, torna-se particularmente intrigante refletir sobre o posicionamento mencionado quando se toma nota de que "a vigência de um tratado no âmbito interno de um Estado depende, em geral, de um mecanismo constitucional de recepção" ${ }^{438}$. É matéria reservada ao Direito Constitucional definir não somente o processo de internalização das normas convencionais, mas ainda a posição hierárquico-normativa que deverá ser atribuída à normativa internacional integrada às ordens internas ${ }^{439}$.

A realidade prova que "as práticas domésticas (inclusive legislativas) repercutem no plano internacional, em termos de cumprimento ou descumprimento de obrigações assumidas pelos Estados, do mesmo modo que as normas de Direito Internacional Público, costumeiras ou convencionais, com intensidade e frequência cada vez maiores, incidem

\footnotetext{
${ }^{436}$ Marcos Augusto Maliska, Fundamentos da Constituição: Abertura, Cooperação, Integração, Curitiba, Juruá, 2013, pp. 15-16.

${ }^{437}$ The Achievement of Constitutionalism and Its Prospects in a Changed World, in The Twilight of Constitutionalism?, Petra Dobner e Martin Loughlin (Org.), Ob. cit., pp. 15-16.

${ }^{438}$ José LeVi Mello do Amaral JúNIOR, Os Tratados no Ordenamento Jurídico Brasileiro, in Direito \& Justiça, vol. 23, Ano 23, 2001, p. 175.

${ }^{439}$ Esclarece PONTES DE MIRANDA que "o Direito das Gentes nada tem com a ligação, ou uniformidade, entre as legislação interna e as formalidades de Direito Interno relativas aos tratados: são fatos que ficam aquém do campo interestatal, fatos interiores dos Estados" (Comentários à Constituição da República dos E. U. do Brasil - Tomo I: Artigos 1-103, Rio de Janeiro, Guanabara, 1937, pp. 576-577).
} 
nas relações jurídicas intraestatais" ${ }^{440}$. A interdependência entre os planos normativos e o papel da norma constitucional como mediadora das relações estabelecidas são evidenciados por MireILle Delmas-MARTY, ao enfatizar que os apelos doutrinários acerca da primazia da norma internacional sobre a norma interna podem até levar ao reconhecimento dessa diretriz nas Constituições, mas muito raramente a prevalência acaba sendo efetiva ${ }^{441}$. Avulta, pois, a importância de compreender o fenômeno do entrelaçamento entre ambos os conjuntos normativos mediante a adoção de uma perspectiva de complementariedade, que supere as pressupostas ideias de oposição entre as duas ordens jurídicas ${ }^{442}$.

No fundo, coloca-se ao constitucionalismo o desafio de encontrar um centro de equilíbrio para a difícil equação de manter a supremacia formal das Constituições, sem, todavia, fazer que esse princípio basilar do Direito Constitucional inviabilize o cumprimento das normas internacionais. $\mathrm{O}$ cruzamento de ordens normativas tem mostrado que a primazia da Constituição não tem sido um obstáculo na tarefa de implementar obrigações internacionais, uma vez que o respeito às prescrições exteriores figura, atualmente, como norma consagrada nos textos constitucionais ${ }^{443}$. Não obstante o fato de a confluência na proteção de idênticos interesses e bens jurídicos ter favorecido a aplicação interna dos comandos internacionais, permanece a problemática de como os ordenamentos nacionais enquadram as fontes do Direito das Gentes aplicáveis em seus territórios.

A necessidade de compatibilizar eventuais pontos de tensão decorrentes da conjugação das normativas interna e externa adquire maior expressividade nos contextos de integração regional. Como sublinha GIL CARLOS Rodríguez IGLESIAS, a existência de um órgão encarregado especificamente de assegurar o primado da Constituição pode fazer com que apareçam conflitos entre as normas responsáveis pelo funcionamento das estruturas jurídico-políticas comunitárias e as normas que resguardam os interesses de cada país. Daí por que a participação de um Estado em esquemas comunitários de integração

\footnotetext{
${ }^{440}$ Elival da Silva Ramos, Os Tratados sobre Direitos Humanos no Direito Constitucional Brasileiro PósEmenda Constitucional 45/04, in O STF e o Direito Internacional dos Direitos Humanos, Alberto do Amaral Júnior e Liliana Lyra Jubilut (org.), Ob. cit., p. 156.

${ }^{441}$ Cf. Le Pluralisme Ordonné, Ob. cit., p. 27.

${ }^{442}$ A respeito, EDUARDO ROZO ACUÑAconsidera que é possível "[...] concluir que os ordenamentos internos e internacional, os quais, por sua vez, são também plurais, reconhecem-se mutuamente como diferentes e originários, a fim de disciplinarem o funcionamento da vida real das sociedades e da comunidade internacional, partindo do recíproco reconhecimento de sua existência e da necessidade de recorrer também reciprocamente às suas respectivas normas" (Derecho Internacional y Derecho Interno en las Constituciones da America Latina, in Studi Urbinati: Rivista di Scienze Giuridiche, ano 75, 1997/1998, pp. 126-127).

${ }^{443}$ Cf. Nilsa RoJAS-Hutinel, L'Articulation des,Ob. cit., p. 272.
} 
exige, obrigatoriamente, fundamentos constitucionais explícitos ou implícitos aptos a possibilitar a atribuição, em prol de órgãos supranacionais, de parcela considerável das competências legislativas, executivas e judiciárias, antes desempenhadas somente pelos poderes constituídos dos Estados nacionais ${ }^{444}$.

Além das previsões encartadas nas Constituições, a atividade hermenêutica que se materializa no seio do controle de constitucionalidade pode servir como eficaz instrumento para a regulação constitucional do Direito originado das relações internacionais, de modo que interpretações adequadas do texto constitucional podem favorecer a obtenção de soluções para deficiências e vazios da Carta Fundamental ${ }^{445}$. Sob esse influxo, a abertura das Constituições ao exterior deve ser considerada um valor jurídico que serve como técnica para informar as soluções requeridas para o manuseio da normativa internacional pelas instituições nacionais. Nesse ponto, consoante pondera LAUTARO Ríos ÁlvarEZ, cabe lembrar que se identificam, ao menos, "três funções para os valores jurídicos: a) servem de clara orientação para definir o sentido e a finalidade das normas; b) proporcionam critérios adequados para interpretá-las; c) além disso, proporcionam elementos necessários para integrar lacunas ou vazios do ordenamento jurídico"446.

A cooperação internacional aponta que "os Estados constitucionais não existem mais apenas para si mesmos, mas, também, como referências para outros Estadosmembros de uma comunidade, em um modelo de cooperação capaz de permitir, ao mesmo tempo, a preservação de suas características nacionais, mas com vocação crescente para o intercâmbio no plano internacional" 447 . É compreensível que a axiologia que envolve a tendência de aceitar comandos normativos externos como peças na construção de uma ordem jurídica interna comprometida com a proteção dos mais diversos tipos de direitos não pode prescindir de maneiras adequadas de assegurar a observância, no contexto nacional, das normas exteriores. O Direito Constitucional, portanto, torna-se peça essencial para a afirmação da certeza de que "os sentimentos de solidariedade e de interdependência que animam os povos, o reconhecimento da existência da sociedade internacional, além de

\footnotetext{
${ }^{444}$ Cf. Tribunales Constitucionales y Derecho Comunitario, in Hacia un Nuevo Orden Internacional y Europeo: Estudios en Homenaje al Profesor don Manuel Diez de Velasco, Manuel Pérez González (Coord.), Madrid, Tecnos, 1993, pp. 1177-1178.

445 Cf. Miguel Angel Fernández GonzÁlez, Visión Prospectiva en Relación con la Regulación Constitucional de los Tratados Internacionales, in Revista Ius et Praxis, ano 9, $\mathrm{n}^{\mathrm{o}}$ 1, 2003, p. 511.

${ }^{446}$ El Fundamento Axiológico de las Relaciones Internacionales y de las Constituciones Modernas, in Anuario de Derecho Constitucional Latinoamericano, 2006, p. 1401.

${ }^{447}$ Gilmar Ferreira Mendes, Inocêncio Mártires Coelho e Paulo Gustavo Gonet Branco, Curso de Direito,Ob. cit., pp. 1164-1165.
} 
outros fatores, tornam indiscutível, na consciência jurídica universal, o respeito aos compromissos assumidos" ${ }^{448}$, seja interna ou externamente.

Ressaltados os postulados que norteiam a aproximação sistemática entre o nacional e o externo, cabe investigar de que modo essa tendência se manifesta no âmbito do Estado brasileiro. As investigações que serão apresentadas buscam, em síntese, analisar a forma pela qual o ordenamento pátrio recepciona as normas internacionais, o que permitirá visualizar, em termos concretos, o estágio da abertura da Constituição nacional ao Direito Internacional, bem como antever prováveis tendências nesse terreno. E, com fundamento em registros normativos, jurisprudenciais e doutrinários, as implicações relacionadas à aplicação interna dos tratados, costumes internacionais e decisões de organizações internacionais passam a ser o foco das atenções desta parte do trabalho ${ }^{449}$.

\subsection{Os Tratados no Direito Constitucional Brasileiro}

Por assumir uma feição marcantemente internacionalista, o Estado nacional deixa de ser mero produtor e aplicador autárquico do Direito Interno, para se tornar legítimo contratante e aplicador das normas internacionais. A soberania, do modo como é entendida no presente, passou a representar um atributo que não se materializa somente na prerrogativa de conceber o próprio ordenamento jurídico, mas também - e em níveis crescentes - dispõe-se como fator que induz a participação livre e independente do Estado na edificação da ordem normativa externa. A necessidade de existirem normas constitucionais que favoreçam a consecução desse processo atesta a relevância das reflexões que podem ser feitas acerca dos mecanismos atuais de integração do Direito Internacional Público ao Direito brasileiro ${ }^{450}$.

\footnotetext{
${ }^{448}$ MirTô FRAGA, O Conflito entre Tratado Internacional e Norma de Direito Interno: Estudo Analítico da Situação do Tratado na Ordem Jurídica Brasileira, Rio de Janeiro, Forense, 2001, p. 95.

${ }^{449}$ Pontue-se a observação de ANDRÉ DE CARVALHO RAMOS de que "as normas internacionais são oriundas de diversas fontes, como bem estabelece o art. 38 do Estatuto da Corte Internacional de Justiça. Não é possível, então reduzir a visão do Direito Constitucional sobre o Direito Internacional às normas previstas nos tratados tão somente. Devemos, ainda, analisar a relação do Direito brasileiro com as chamadas fontes extraconvencionais, com foco, no chamado costume internacional. Como a Constituição possui alguns artigos sobre tratados e nenhuma menção sequer a costume internacional, a posição do Supremo Tribunal Federal acabou sendo distinta para esses dois tipos de normas internacionais. Por isso, identificamos dois fenômenos ao longo dos anos na prática constitucional brasileira, a saber: o processo de formação e incorporação desses tratados ao direito brasileiro e o processo de impregnação do direito brasileiro pelas normas internacionais extraconvencionais" (Teoria Geral dos,Ob. cit., p. 255).

${ }^{450}$ Cf. Pedro B. A. DAllari, Constituição e Tratados, Ob. cit.,pp. 6-7.
} 
Um dado que não pode ser negligenciado na análise da interação entre convenções internacionais e Constituição estatal é que "o primado do Direito das Gentes sobre o Direito Nacional do Estado soberano é ainda hoje uma proposição doutrinária. Não há, em Direito Internacional positivo, norma assecuratória de tal primado" 451 . Acerca desse tema, Celso Ribeiro Bastos e Ives Gandra Martins informam que se observa um ponto comum entre todos os Estados integrantes da sociedade internacional, qual seja, o da supremacia formal da Constituição, inclusive diante das normas exteriores aplicáveis no âmbito interno. Já no que se refere aos atos infraconstitucionais, o mesmo não acontece, na medida em que existem países, como a França, a Grécia e o Peru, que consagram o primado do tratado, enquanto outros lhe garantem, em uma visão geral, apenas um tratamento paritário com as demais normas do ordenamento, a exemplo do caso dos Estados Unidos e do Brasil ${ }^{452}$.

E a fim de demarcar as principais implicações que derivam da inclusão dos tratados no sistema normativo brasileiro, passa-se ao estudo dos requisitos a serem obedecidos para que convenções internacionais adquiram executoriedade interna, bem como à definição do enquadramento hierárquico-normativo que as normas convencionais assumirão depois de incorporadas. A matéria assume lugar privilegiado em meio a contextos de internacionalização do Direito Constitucional, pois a tendência de admitir a relevância jurídica das normas exteriores acaba-se refletindo em alterações ou no texto constitucional ou na interpretação da Constituição que a flexibiliza, mas essa abertura não pode ocorrer com violação do núcleo essencial da Lei Fundamental ${ }^{453}$. Em suma, pretende-se contribuir para aclarar o complicado "equacionamento entre os mecanismos normativoconstitucionais pátrios que regulam a validade interna dos tratados em face do incremento do processo de inserção do Brasil na comunidade internacional” ${ }^{\text {"45, }}$, o que, embora seja de difícil solução, apresenta-se como ponto crucial para harmonizar a necessidade de preservar as conquistas do constitucionalismo com o progressivo adensamento jurídico do Direito das Gentes.

\footnotetext{
${ }^{451}$ FranCISCO REZEK, Direito Internacional Público, Ob. cit., pp. 126-127.

${ }^{452}$ Comentários à Constituição do Brasil (Promulgada em 5 de Outubro de 1988), Vol. 4 - tomo I: Arts. 44 a 69, São Paulo, Saraiva, 1995, p. 98.

${ }^{453}$ Cf. Samantha Ribeiro Meyer-Pflug, A Internacionalização do Direito Constitucional Brasileiro, in Direito Constitucional Internacional dos Direitos Humanos, Alexandre Coutinho Pagliarini eDimitri Dimoulis (org.), Ob. cit., p. 282.

${ }^{454}$ LuIZ EDSON FACHIN, Direito Internacional: Possibilidades e Limites da Harmonização entre Tratados Internacionais e a Constituição Federal: O Exemplo do Tratado de Itaipu, in Revista de Direito do Estado, Ano 1, no 4, out./dez. 2006, p. 313.
} 


\subsubsection{A Processualística de Internalização dos Tratados Internacionais}

Assevera José Levi Mello do Amaral JúnIOR que, “desde a Constituição do Império do Brasil, de 1824, o Direito pátrio pratica um mecanismo de incorporação da norma internacional em termos mais ou menos uniformes" ${ }^{455}$. Com efeito, no que tange às etapas internas de incorporação de convenções exteriores, a tradição constitucional nacional é sintetizada na ementa do paradigmático julgado proferido pelo Supremo Tribunal Federal em 2001, na ocasião do julgamento da ADI n ${ }^{\circ} 1480$. Assim pronunciou a Corte: "o exame da vigente Constituição Federal permite constatar que a execução dos tratados internacionais e a sua incorporação à ordem jurídica interna decorrem, no sistema adotado pelo Brasil, de um ato subjetivamente complexo, resultante da conjugação de duas vontades homogêneas: a do Congresso Nacional, que resolve definitivamente, mediante decreto legislativo, sobre tratados, acordos ou atos internacionais (CF, art. 49, I) e a do Presidente da República, que, além de poder celebrar esses atos de Direito Internacional (CF, art. 84, VIII), também dispõe - enquanto Chefe de Estado que é - da competência para promulgá-los mediante decreto" ${ }^{456}$.

\subsubsection{As Etapas Necessárias para Transpor ao Sistema Jurídico Brasileiro os Tratados em Geral}

Com a finalidade de apreciar as consequências jurídicas que acompanham o roteiro procedimental narrado, é conveniente estudar cada uma das etapas referidas em separado, o que será realizado a fim de identificar os principais aspectos constitucionais que lhes são inerentes. Em aspectos genéricos, antevê-se que a matéria comporta um processo complexo e solene de elaboração de tratados internacionais, perfazendo fases internacionais e internas, sendo que, em todas essas etapas, o Brasil encontra-se norteado por sua ordem constitucional ${ }^{457}$. Adverte-se, todavia que, apesar de o tema não ser uma

\footnotetext{
${ }^{455}$ Tratados e Convenções Internacionais sobre Direitos Humanos e o Pensamento de Celso Lafer, in Novos Caminhos do Direito no Século XXI: Direito Internacional, Filosofia Jurídica e Política, Dogmática Jurídica e Direitos Fundamentais: Uma Homenagem a Celso Lafer, $2^{\mathrm{a}}$ ed., Luiz Olavo Baptista e Tercio Sampaio Ferraz Junior (coord.), Ob. cit., p. 756. Cabe esclarecer que o art. 102, inciso VIII, da Constituição do Império estabelecia: "Art. 102. O Imperador é o Chefe do Poder Executivo, e o exercita pelos seus Ministros de Estado. São suas principais atribuições: [...] VIII. Fazer Tratados de Aliança ofensiva, e defensiva, de Subsídio, e Comércio, levando-os depois de concluídos ao conhecimento da Assembleia Geral, quando o interesse, e segurança do Estado permitirem. Se os Tratados concluídos em tempo de paz envolverem cessão, ou troca de Território do Império, ou de Possessões, a que o Império tenha direito, não serão ratificados, sem terem sido aprovados pela Assembleia Geral”.

${ }^{456}$ STF, ADI n ${ }^{\circ}$ 1.480-DF, Relator Ministro CELSO DE MELLO, Ementa, julgamento em 26/06/2001, publicação no DJ 08/08/2001, p. 3, decisão disponível no endereço eletrônico www.stf.jus.br.

${ }^{457}$ Cf. Patrícia Cobianchi Figueiredo,Os Tratados Internacionais de Direitos Humanos e o Controle de Constitucionalidade, São Paulo, LTr, 2011, p. 68.
} 
novidade para o constitucionalismo pátrio e ter a Constituição Federal vigente mantido uma diretriz há muito arraigada na cultura jurídica do país, a definição das exigências que integram o processo de internalização de tratados constitui tarefa complicada e que suscita inúmeras divergências, especialmente em sede doutrinária ${ }^{458}$.

A jurisprudência nacional e a doutrina majoritária convergem em explicar os atos necessários para o cumprimento interno dos tratados internacionais após a observância de quatro passos. O primeiro deles é comumente denominado de negociação entre as partes e assinatura do texto final: incumbe, em caráter privativo, ao Presidente da República, embora seja possível a nomeação de plenipotenciários pelo Chefe de Estado para que assinem tratados em seu nome ${ }^{459}$. Nessa fase, desenvolvem-se entendimentos bilaterais ou multilaterais entre os sujeitos do Direito Internacional contratantes, servindo à aposição da assinatura no texto acordado pelo Chefe do Executivo como marco que coloca fim às negociações e exterioriza o consentimento do Estado brasileiro, por ele representado ${ }^{460}$.

Interessa informar que a assinatura de uma convenção não pode ser considerada ato, por si só, habilitado a garantir vigências internacional e interna da norma convencional em formação. Será preciso cumprir as demais etapas para que se aperfeiçoem os processos responsáveis por conferir validade e existência ao tratado em ambos os sistemas jurídicos, sendo que o texto firmado não pode mais ser objeto de alteração, haja vista que comporta somente rejeição ou ratificação total ou parcial (instrumentalizada, no caso de vinculação a uma parte do tratado, mediante o emprego de reservas). No máximo, ao assinar um tratado, é imputável apenas uma obrigação externa ao Estado-signatário, qual seja, o dever de não frustrar o objeto e a finalidade da norma convencional antes da sua entrada em vigor, a teor

\footnotetext{
${ }^{458}$ ANTÔNIO PAUlo CACHAPUZ DE MEDEIROs ilustra esse quadro de pouca certeza entre os estudiosos do tema no excerto que segue: "Efetivamente, a Constituição de 1988 perdeu a oportunidade para disciplinar de forma moderna e clara a competência para celebrar tratados e ampliou ainda mais as divergências sobre o tema. Os comentários divulgados pelos doutrinadores, a propósito dos artigos 49, I e 84, VIII, demonstram que continuam existindo duas vertentes no pensamento jurídico brasileiro sobre a interpretação das normas constitucionais relativas à competência para celebrar tratados: 1 - a vertente doutrinária que se pronuncia pela compulsoriedade absoluta da deliberação do Legislativo para todos os acordos internacionais celebrados pelo Executivo; 2 - a vertente doutrinária que se pronuncia pela admissibilidade da celebração de certos acordos internacionais unicamente pelo Executivo, sem aprovação congressional" ( $O$ Poder de,Ob. cit., p. $383)$.

${ }^{459}$ Acerca dos plenipotenciários, sublinha EliVAL DA SILVA RAMOs que o disposto no art. 84, inciso VIII, da Constituição Federal de 1988, "não impede que o Presidente da República se faça representar, na assinatura ou ratificação de tratado, pelo Ministro das Relações Exteriores ou por outra autoridade do Poder Executivo federal, investida de plenos poderes, pois o que se pretendeu estabelecer no invocado dispositivo constitucional foi, simplesmente, que o Chefe de Estado é o responsável último pelo engajamento do Brasil em ajustes geradores de obrigações internacionais" (Os Tratados sobre Direitos Humanos no Direito Constitucional Brasileiro Pós-Emenda Constitucional 45/04, in O STF e o Direito Internacional dos Direitos Humanos, Alberto do Amaral Júnior e Liliana Lyra Jubilut (org.), Ob. cit., p. 154).

${ }^{460}$ Cf. Fernanda Dias MeneZes de Almeida, A Incorporação dos, Ob. cit., p. 51.
} 
do que preceitua o art. 18 da Convenção de Viena sobre o Direito dos Tratados de 1969, ratificada pelo Brasil em $2009^{461}$.

Vencido o primeiro passo, segue-se para a aprovação do Congresso Nacional, etapa iniciada com uma mensagem do Presidente da República ao Legislativo. O Parlamento delibera e decide, em regra, por maioria dos presentes, votando a Câmara dos Deputados e o Senado Federal separadamente. Aos parlamentares é proibido emendar ou alterar o texto da convenção, cabendo-lhes o papel de aprovar, com ou sem ressalvas, o documento recebido. A aquiescência congressual é, por fim, divulgada por publicação de um decreto legislativo autorizativo da ratificação do tratado ${ }^{462}$.

O comando do art. 49, inciso I, da Constituição da República deve ser tomado com cuidado, já que o texto constitucional é categórico ao fixar a competência exclusiva do Congresso para resolver definitivamente sobre tratados, acordos ou atos internacionais que acarretem encargos ou compromissos gravosos ao patrimônio nacional. Importa, nesse ponto, aclarar a extensão do significado da locução patrimônio nacional, tarefa um tanto quanto delicada, sobretudo quando se lembra que CELSO D. DE AlbuQUERQUE Mello lhe fazia referência como conceito "de conteúdo indefinível"463. Parece, entretanto, que a melhor razão está com JosÉ VICENTE LESSA, que registra que a função precípua do Parlamento não é a de velar pelo patrimônio nacional, mas sim a de legislar sobre todos os aspectos de interesse da nação, o que faz a capacidade legislativa ascender como critério nuclear para determinar os atos exteriores que devem ou não sofrer o crivo do Legislativo, permitindo, assim, contemplar convenções que trazem, além de ônus econômico, também obrigações estritamente jurídicas ao Estado brasileiro ${ }^{464}$.

\footnotetext{
461 “Art. 18. Um Estado é obrigado a abster-se da prática de atos que frustrariam o objeto e a finalidade de um tratado, quando: a) tiver assinado ou trocado instrumentos constitutivos do tratado, sob reserva de ratificação, aceitação ou aprovação, enquanto não tiver manifestado sua intenção de não se tornar parte no tratado; ou b) tiver expressado seu consentimento em obrigar-se pelo tratado no período que precede a entrada em vigor do tratado e com a condição de esta não ser indevidamente retardada".

${ }^{462}$ CARmen Tiburcio e Luís Roberto BARroso,Direito Constitucional Internacional, Ob. cit., p. 164.

${ }^{463} \mathrm{~A}$ Revisão do, Ob. cit., p. 83. Confirma a ausência de certeza quanto à amplitude desse dispositivo o ponto de vista sustentado por MANOEL GONÇALVES FERREIRA FILHO, que explica que "a redação inadequada, deste inciso não importa em excluir, como parece, a necessidade de aprovação por parte do Congresso Nacional de atos internacionais, celebrados pelo Presidente da República, como tratados e convenções, que não pesem diretamente sobre o patrimônio nacional. Cumpre lembrar que o art. 84, VIII (v. Infra), prevê tal aprovação, 'referendo' como diz" (Comentários à Constituição Brasileira de 1988, Volume 2, Arts. 44 a 103, São Paulo, Saraiva, 1992, p. 21).

${ }^{464}$ Anotações Sobre Atos Internacionais, in Desafios do Direito Internacional Contemporâneo, Antônio Paulo Cachapuz de Medeiros (org.), Ob. cit., pp. 415-417. Com base no posicionamento esposado, o estudioso defende que a submissão ao Congresso Nacional de "todos os atos internacionais para cuja aplicação no território nacional se requeira a aprovação de uma lei interna, seja criando uma nova norma ou estabelecendo a uma exceção legal à norma já existente, ou que requeiram medidas legais adicionais para sua implementação" (Idem, p. 415).
} 
O referendo congressual do texto outrora assinado, conforme assinala FERNANDA Dias Menezes de AlmeidA, “autoriza o Presidente da República a passar para a fase seguinte, a da ratificação do tratado. Autoriza, mas não o obriga, fique claro isso, pois a decisão de ratificar o acordo é só dele, Presidente, que poderá deixar de fazê-lo, se entender que é o caso, depois de melhor analisar a matéria”465. Essa conclusão apresenta inegável relevância para o desenrolar do treaty-making power; todavia, não pode ser inferida sem uma leitura atenta de todo o processo descrito, motivo pelo qual a doutrina critica a redação da norma constitucional em exame, sob o argumento de que "na verdade, resolver definitivamente quem o faz é o Poder Executivo porque a ratificação de um tratado é um ato discricionário dele" 466 .

A terceira fase, por seu turno, diz respeito à ratificação do tratado. Em essência, cuida de incumbência a ser desempenhada pelo Chefe do Poder Executivo no plano externo e ocorre somente quando o Brasil assina o texto original de uma convenção. Caso esta seja bilateral, ratifica-se pela via da troca de notas diplomáticas; se multilateral, pelo depósito do instrumento de ratificação perante a organização internacional que tenha patrocinado a elaboração do $\operatorname{acordo}^{467}$. No caso de adesão do Estado a uma convenção em que este não tenha participado das negociações e da assinatura, mas, independentemente disso, deseja tornar-se parte, essa manifestação volitiva terá os efeitos equivalentes ao da ratificação $^{468}$.

Percebe-se, nessa matéria, que a ratificação configura ato que apresenta sensível repercussão externa, porém é incapaz de determinar a aplicabilidade da norma internacional no plano interno. Como expressa o consentimento definitivo do Estado, a ratificação ocasiona (exceto se houver disposição diversa na própria convenção) o início da vigência internacional do acordo, ou seja, consubstancia-se em etapa que lhe confere exigibilidade externa, segundo os ditames do Direito das Gentes. Uma vez observadas as exigências necessárias para o cumprimento dessa etapa, o país passa a estar

\footnotetext{
${ }^{465}$ A Incorporação dos, Ob. cit.., p. 51. Explica MiRTÔ FrAGA que, todavia, "a manifestação do Congresso só é definitiva se concluir por negar aprovação ao texto, quando, então o Presidente da República estará impedido de concluir o acordo, ratificando-o" ( $O$ Conflito entre, Ob. cit., p. 57).

${ }^{466}$ Celso D. De Albuquerque Mello, O Direito Constitucional Internacional na Constituição de 1988, in Contexto Internacional, v.4, n.8, jul./dez. 1988, p. 14.

${ }^{467}$ Cf. CARMen Tiburcio e Luís Roberto BARroso,Direito Constitucional Internacional, Ob. cit., pp. 164165.

${ }^{468}$ Cf. Francisco RezeK, Direito dos Tratados, Rio de Janeiro, Forense, 1984, p. 425.
} 
internacionalmente obrigado a cumprir o tratado, somente dele se desvinculando mediante denúncia $^{469}$.

Ao final, já na quarta e última parte, tem-se a edição de decreto presidencial encarregado de introduzir efetivamente a norma convencional no ordenamento pátrio. Os contornos dessa fase estão assentados na jurisprudência do STF, que propaga que "o iter procedimental de incorporação dos tratados internacionais - superadas as fases prévias da celebração da convenção internacional, de sua aprovação congressional e da ratificação do Chefe de Estado - conclui-se com a expedição, pelo Presidente da República, de decreto, de cuja edição derivam três efeitos básicos que lhe são inerentes: a) a promulgação do tratado internacional; b) a publicação oficial de seu texto; e c) a executoriedade do ato internacional, que passa, então, e somente então, a vincular e a obrigar no plano do Direito Positivo Interno" ${ }^{470}$. Convém grifar que a imprescindibilidade do decreto de promulgação interna está em harmonia com uma prática há muito consagrada, embora não tenha sido expressamente prevista em nenhuma de nossas Constituições.

De origem controvertida, a exigência desse decreto presidencial para a ultimação da ritualística de incorporação dos tratados tem inspirado discussões a respeito de sua fundamentação. Acerca do tema, esclarece JOÃo GRANDINO RODAS que "seguindo a tradição portuguesa, o Brasil desde a Independência adotou a praxe de promulgar os tratados já ratificados, por meio de um decreto do Executivo. A Constituição de 1824 exigia a sanção imperial para a entrada em vigor, apenas para os decretos e resoluções da Assembleia Geral, silenciando relativamente aos tratados. Analogicamente, contudo, tal regra foi aplicada aos mesmos" ${ }^{471}$. Em abono, informa-se que o motivo do decreto presidencial, aqui analisado, decorre do fato de que este é "o ato mediante o qual o Chefe do Executivo exerce normalmente suas competências constitucionais, em matérias que não estejam sob a reserva de lei" ${ }^{472}$.

\subsubsection{A Problemática Doutrinária Sobre as Fases de Incorporação dos Tratados de Direitos Humanos}

Não obstante a doutrina majoritária e a Corte Constitucional do país apresentarem sintonia quanto à necessidade do decreto de promulgação das convenções a fim de que

\footnotetext{
${ }^{469}$ Cf. José CARlos de MAGAlHães, O Supremo Tribunal, Ob. cit., p. 67.

${ }^{470}$ STF, ADI n ${ }^{\circ}$ 1.480-DF, Rel. Min. CELSO DE MELlO, Ementa, julgamento 26/06/2001, publicação DJ 08/08/2001, p. 3, decisão disponível no endereço eletrônico www.stf.jus.br.

${ }^{471}$ A Publicidade dos Tratados Internacionais, São Paulo, Revista dos Tribunais, 1980, pp. 200-201.

${ }^{472}$ Fernanda Dias MeneZes de AlmeIdA, A Incorporação dos, Ob. cit., p. 51.
} 
seus textos sejam integrados à ordem jurídica nacional, existem correntes que discordam desse ponto, em especial entre os estudiosos dos direitos humanos. Assim é que Flávia PIOVESAN defende que a Constituição teria adotado um sistema jurídico misto, pois, para os tratados de direitos humanos, acolheria a sistemática da incorporação automática, enquanto, para os tratados tradicionais, continuaria existindo a obrigatoriedade de internalização via decreto presidencial. A tese que lastreia a proposta da autora é, em suma, a de que a previsão do art. $5^{\circ}, \S 1^{\circ}$, da Lei Maior ${ }^{473}$ teria atribuído aplicação imediata em benefício dos tratados de direitos humanos ratificados pelo Estado nacional, o que imporia a irradiação de seus efeitos na ordem jurídica externa e interna sem que fosse preciso, contudo, o decreto de execução ${ }^{474}$.

Em que pese os bem intencionados objetivos que acompanham a proposição exposta, é forçoso reconhecer que não há, no Direito Constitucional brasileiro, nenhuma previsão - nem mesmo implícita - que subtraia as convenções cujo conteúdo verse sobre direitos humanos das formalidades de incorporação estatuídas para os demais tratados celebrados pelo Estado nacional. Na verdade, a exegese do preceito constitucional plasmado no art. $5^{\circ}, \S 1^{\circ}$, da Constituição visa, na medida do possível, assegurar aplicação imediata das normas definidoras do direitos e das garantias fundamentais já integradas ao nosso ordenamento, o que, por óbvio, impede sua aplicação em relação a normas internacionais ainda não incluídas no sistema jurídico pátrio ${ }^{475}$. Carece de fundamentação, assim, a vertente que prega a aplicação direta dos tratados de direitos humanos no âmbito interno tão logo seus textos logrem ratificação exterior.

Outra iniciativa que busca enaltecer a proteção dos direitos humanos na ordem jurídica pátria é encabeçada por ANDRÉ RAMOS TAVARES, que vislumbra ter a Emenda Constitucional $n^{\circ} 45 / 2004$ (Reforma do Judiciário), ao incluir o $\S 3^{\circ}$ ao art. $5^{\circ}$ da Constituição, propiciado muito mais do que a elevação da hierarquia normativa de tratados de direitos humanos aprovados por procedimento específico ao patamar de emenda constitucional. Segundo o autor, a inovação teria impactado todo o iter procedimental para transpor essas convenções ao universo interno, ocasionando a presença do Presidente da República apenas na fase de celebração ${ }^{476}$. A ausência de participação do Chefe de Estado em quaisquer outras etapas decorre da ideia de que a promulgação interna desses tratados

\footnotetext{
473 “Art. $5^{\circ}[\ldots] \S 1^{\circ}$ - As normas definidoras dos direitos e garantias fundamentais têm aplicação imediata".

${ }^{474}$ Cf. Direitos Humanos e, 11 ed., São Paulo, Saraiva, 2010, pp. 91-94.

${ }^{475}$ Cf. Fernanda Dias Menezes de Almeida, A Incorporação dos, Ob. cit., p. 57.

${ }^{476}$ Cf. Reforma do Judiciário,Ob. cit., pp. 45-47.
} 
seguiria as normas da Constituição que tratam do processo legislativo das emendas constitucionais.

Estaria, dessa maneira, impedida qualquer interferência do Chefe do Executivo nos atos subsequentes à aprovação dos tratados em conformidade com as regras dispostas no art. $5^{\circ}, \S 3^{\circ}$, da Lei Maior, pois os projetos de emendas constitucionais, como sabido, não comportam sanção ou veto presidencial e são promulgados pelas Mesas das Casas Legislativas $^{477}$. Cabe, porém, considerar que as ideias esquadrinhadas parecem não encontrar amparo no seio da nossa Constituição. Acerca do assunto, ElivAL DA SILVA RAMOS adverte que o regime jurídico especial aplicável apenas aos pactos de direitos humanos, previsto na Emenda Constitucional $n^{\circ} 45 / 2004$, trouxe “inovações exclusivamente em matéria de celebração de tratados e de seu posicionamento hierárquico interno. Ou seja, o procedimento de incorporação dos tratados, inclusive daqueles versando sobre direitos humanos, não foi afetado pela Reforma do Judiciário. Portanto, a tese da incorporação automática dos tratados sobre direitos humanos, imediatamente após os atos de ratificação ou adesão, continua sendo inaceitável à luz do Direito Constitucional brasileiro em vigor" ${ }^{\prime 47}$.

A propósito, constata-se que, até o presente momento, há registro de um único acordo submetido ao processo instituído pelo constituinte de reforma: trata-se da Convenção sobre os Direitos das Pessoas com Deficiência e de seu Protocolo Facultativo, cuja assinatura aconteceu em Nova Iorque, em 30 de março de 2007. A internalização desse tratado ocorreu obedecendo os mesmos termos exigidos para que as demais convenções sejam transformadas em normas domésticas, tendo, dessa forma, o decreto legislativo $\mathrm{n}^{\mathrm{o}} 186 / 2008$ certificado sua aprovação pelo Congresso Nacional e o decreto presidencial $n^{\circ} 6.949 / 2009$ garantido a promulgação interna do seu texto. O significado desse fato para esclarecer as controvérsias instauradas pela doutrina é grande, motivo que fez José Levi MEllo do Amaral JúNIOR se convencer de que as eventuais dúvidas sobre

\footnotetext{
${ }^{477}$ MARCO ANTONIO CORRÊA MONTEIRO adota o mesmo entendimento, concluindo que "tudo o que decorrer da aprovação do decreto legislativo, que finaliza o procedimento de celebração dos tratados internacionais de direitos humanos, deverá 'ser equivalente às emendas constitucionais', inclusive o procedimento de incorporação e a posição hierárquica desses tratados internacionais de direitos humanos. Por força do art. 60, $\S 3^{\circ}$, da Constituição, 'a emenda à Constituição será promulgada pelas Mesas da Câmara dos Deputados e do Senado Federal, com o respectivo número de ordem'. O Presidente da República, assim, não participa da promulgação das emendas constitucionais. Assim deve ser também com os tratados internacionais de direitos humanos que, aprovados pelo procedimento previsto pelo art. $5^{\circ}, \S 3^{\circ}$, 'são equivalentes às emendas constitucionais"” (Tratados Internacionais de, Ob. cit., p, 134).

${ }^{478}$ Elival Da Silva Ramos, Os Tratados sobre Direitos Humanos no Direito Constitucional Brasileiro PósEmenda Constitucional 45/04, in O STF e o Direito Internacional dos Direitos Humanos, Alberto do Amaral Júnior e Liliana Lyra Jubilut (org.), Ob. cit., p. 172.
} 
o assunto aparentemente foram superadas depois da inclusão do pacto no ordenamento nacional, sem que fosse preciso, contudo, realizar mudanças na forma de transpor tratados para o plano doméstico ${ }^{479}$.

Os argumentos lançados pelos entusiastas da tese da executoriedade direta das convenções de direitos humanos que apresentam status de emendas constitucionais têm fulcro em interpretações elastecidas da norma especial introduzida pela Emenda Constitucional n 45/2004 para aprovação dessas convenções pelo Legislativo. Salvo juízo mais ajustado sobre a extensão do comando consignado no art. $5^{\circ}, \S 3^{\circ}$, da Lei Fundamental, é preciso ter bem definido que a aludida reforma constitucional não alterou as quatro etapas impostas como requisitos para internalizar tratados no país, mas unicamente uma dessas fases, qual seja, as regras que disciplinam a aprovação congressual da norma convencional. Atente-se que, em verdade, houve uma mudança pontual apenas no que respeita ao número de votações e ao quórum estipulados para o referendo dos aludidos tratados, fazendo que as regras que o Congresso Nacional adote para decidir autorizar a ratificação desses tratados sejam similares àquelas previstas pelo constituinte originário, no art. $60, \S 2^{\mathrm{o} 480}$, para a criação de emendas ao texto constitucional.

Inviável, por certo, endossar o entendimento de que todas as regras procedimentais acerca da edição de emendas constitucionais, que constam nos parágrafos e incisos do art. 60 da Constituição, também incidam sobre o processo diferenciado de votação, pelo Parlamento, de tratados cujo tema verse sobre direitos humanos ${ }^{481}$. Essa intelecção não somente contraria o comando definido no art. $5^{\circ}, \S 3^{\circ}$, do Pacto da República, como também carece de sintonia com a lógica que orienta o Direito Constitucional pátrio quanto ao modo de o Estado nacional se vincular às prescrições convencionais do Direito das Gentes. Ao participarem das etapas encarregadas de incluir, na ordem jurídica interna, todas as convenções, o Presidente da República e o Legislativo da União mantêm intactas

\footnotetext{
${ }^{479}$ Tratados e Convenções Internacionais sobre Direitos Humanos e o Pensamento de Celso Lafer, in Novos Caminhos do Direito no Século XXI: Direito Internacional, Filosofia Jurídica e Política, Dogmática Jurídica e Direitos Fundamentais: Uma Homenagem a Celso Lafer, $2^{\mathrm{a}}$ ed., Luiz Olavo Baptista e Tercio Sampaio Ferraz Junior (coord.), Ob. cit., p. 764.

480 “Art. $60[\ldots] \S 2^{\circ}$ - A proposta será discutida e votada em cada Casa do Congresso Nacional, em dois turnos, considerando-se aprovada se obtiver, em ambos, três quintos dos votos dos respectivos membros".

${ }^{481}$ Em idêntico caminho, explicita ELIVAL DA SILVA RAMOS que "a EC 45/04 não determinou ou permitiu que a aprovação dos tratados sobre direitos humanos passasse a ser feita por meio do procedimento legislativo das emendas constitucionais. $\mathrm{O}$ ato de aprovação era e continua sendo o decreto legislativo, com o adendo de que, uma vez alcançados três quintos dos votos dos parlamentares, em cada Casa do Congresso Nacional e em dois turnos de votação, assumirão aquelas convenções o status hierárquico das emendas constitucionais" (Os Tratados sobre Direitos Humanos no Direito Constitucional Brasileiro Pós-Emenda Constitucional 45/04, in O STF e o Direito Internacional dos Direitos Humanos, Alberto do Amaral Júnior e Liliana Lyra Jubilut (org.), Ob. cit., p. 173).
} 
suas atribuições constitucionais relacionadas ao tema, devendo, por conseguinte, exercer suas competências de forma a contribuir para o fortalecimento da normativa internacional voltada à proteção dos direitos da pessoa humana, sem, no entanto, deixar de zelar pela preservação dos valores constitucionais consagrados em nossa Lei Fundamental.

Um aparte merece ser feito para aclarar aspecto interessante ligado à sistemática de incorporação das normas internacionais que gozarão de paridade normativa em relação às emendas constitucionais. Trata-se de identificar quais autoridades poderão requerer a aplicação do regime especial de votação insculpido no art. $5^{\circ}, \S 3^{\circ}$, da Lei Fundamental, com o objetivo de garantir máxima estatura normativa às convenções de direitos humanos que venham a ser integradas à ordem jurídica doméstica. Como geralmente ocorre com o advento de inovações significativas no cenário jurídico, inexiste consenso a respeito da forma como deve ser aplicada concretamente a disposição constitucional referida.

Pode-se, nesse compasso, indicar duas diretrizes igualmente relevantes a respeito. A primeira linha de compreensão é promovida por FRANCISCO REZEK e ELIVAL DA SILVA RAMOS, tendo como ideia central a noção de que compete ao Parlamento decidir se empregará o sistema de duas votações, em ambas as Casas Legislativas, com quórum mínimo de três quintos dos respectivos membros ou se o tratado de direitos humanos será submetido ao processo análogo àquele de aprovação de lei ordinária ${ }^{482}$. A outra corrente é ilustrada por Hildebrando Accioly, G. E. do Nascimento e Silva e Paulo Borba CASElla e se apega ao ponto de vista de que, "desde a EC no 45 , há nova classe de tratados alçados a patamar constitucional, a critério do Poder Executivo, na medida em que a este cabe definir qual procedimento envia ao Congresso cada novo tratado, respeitados os

\footnotetext{
${ }^{482}$ Enfatiza FRANCISCO REZEK que "não é de crer que o Congresso vá doravante bifurcar a metodologia de aprovação dos tratados sobre direitos humanos. Pode haver dúvida preliminar sobre a questão de saber se determinado tratado configura realmente essa hipótese temática, mas se for tal o caso o Congresso seguramente adotará o rito previsto no terceiro parágrafo, de modo que, se aprovado, o tratado se qualifique para ter estatura constitucional desde sua promulgação - que pressupõe, como em qualquer outro caso, a ratificação brasileira e a entrada em vigor no plano internacional" (Direito Internacional Público, Ob. cit., pp. 139-140). Reafirma essa vertente Elival DA SiLVA RAMOS, no excerto no qual preleciona que, "ao receber mensagem da Presidência da República, noticiando a assinatura de tratado sobre direitos humanos, a Mesa da Câmara dos Deputados deverá dar início à tramitação do projeto de decreto legislativo de aprovação. Após a manifestação das Comissões temáticas pertinentes, será o projeto votado em plenário, cabendo à Presidência da Casa advertir para a necessidade da obtenção de $60 \%$ dos votos favoráveis dos Deputados para que ao tratado seja atribuída paridade hierárquica com as emendas constitucionais. Se a convenção for aprovada em primeira votação, mas apenas por maioria simples, sem o voto favorável de três quintos dos presentes, seguirá o projeto de decreto legislativo o procedimento-padrão, dispensado o segundo turno de votação na Câmara dos Deputados, e seguindo ao Senado Federal, onde será votado em turno único, dependendo do voto favorável da maioria simples dos Senadores para aprovação. Nesse caso, entretanto, o tratado sobre direitos humanos não gozará de equivalência hierárquica com as emendas à Constituição" $(O s$ Tratados sobre Direitos Humanos no Direito Constitucional Brasileiro Pós-Emenda Constitucional 45/04, in O STF e o Direito Internacional dos Direitos Humanos, Alberto do Amaral Júnior e Liliana Lyra Jubilut (org.), Ob. cit., pp. 173-174).
} 
requisitos de aprovação (quórum especial e votação em dois turnos)" ${ }^{\text {"483 }}$. Também é adepto deste segundo posicionamento José CARLOS Francisco, que defende que o início do processo de aprovação dos tratados de direitos humanos nos termos do art. $5^{\circ}$, $\S 3^{\circ}$, da Lei Maior depende de ato exclusivo do Chefe do Executivo ${ }^{484}$.

Embora a divergência retratada possa refletir indícios de diferentes concepções acerca das atribuições dos Poderes da República no tocante à condução da política externa nacional, sua relevância não ultrapassa as discussões acadêmicas. Isso porque, quando se confronta a questão com a principiologia imanente na Constituição Federal, em especial com o mandamento do art. $4^{\circ}$, inciso II, que instituiu a prevalência dos direitos humanos como vetor das relações internacionais do Estado brasileiro, fica evidenciado que todos os órgãos do Estado estão adstritos a cumprir o comando de primar pela observância desses direitos. Uma leitura conforme ao disposto no texto constitucional resulta na conclusão de que tanto o Chefe do Executivo quanto os Presidentes das Casas Legislativas podem pleitear a submissão de determinado tratado de direitos humanos ao rito de aprovação estabelecido pelo art. $5^{\circ}, \S 3^{\circ}$, da Lei Fundamental, pois, assim, estar-se-á aumentando a proteção dos direitos humanos no interior do país.

Aceitar que ambos os Poderes possam suscitar a internalização das convenções que cuidam dos direitos humanos de modo a terem hierarquia de emenda é, sem dúvida, um efetivo instrumento de partilha da responsabilidade de promoção do princípio da prevalência dos direitos humanos ${ }^{485}$. Essa ideia reforça a abertura internacional do Estado brasileiro, pois a permeabilidade do sistema jurídico interno ao Direito das Gentes demanda que o maior número possível de órgãos públicos constitucionalmente competentes participe ativamente na solução dos problemas internacionais, a exemplo da defesa dos direitos humanos ${ }^{486}$. Há que se registrar ainda, com base no escólio de CELSO

\footnotetext{
${ }^{483}$ Manual de Direito, Ob. cit., p. 222.

${ }^{484}$ Bloco do Constitucionalidade e Recepção dos Tratados Internacionais, in Reforma do Judiciário: Analisada e Comentada, André Ramos Tavares, Pedro Lenza e Pietro de Jesús Lora Alarcón (coord.), Ob. cit., p. 102.

${ }^{485}$ Corrobora a percepção aqui esposada INGO WOLFGANG SARLET, ao proclamar que "limitar a iniciativa das emendas dispondo sobre tratados em matéria de direitos humanos ao Presidente da República acabaria tornando unilateral a 'qualificação' de um tratado como sendo de direitos humanos, já que ao Congresso Nacional caberia apenas aprovar ou rejeitar o status privilegiado do tratado e não se pronunciar sobre sua qualidade como tratado de direitos humanos, prejudicando a desejável pluralidade deste processo de qualificação" (A Constituição Federal de 1988, os Tratados Internacionais de Direitos e o Assim Chamado Controle de Convencionalidade dos Atos Normativos Internos Analisada à Luz do Caso dos Direitos Sociais, Econômicos e Culturais, in Estudos Avançados de Direitos Humanos: Democracia e Integração Jurídica: Emergência de um Novo Direito Público, Amin von Bogdandy, Flavia Piovesan e Mariela Morales Antoniazzi (coord.), Rio de Janeiro, Elsevier, 2013, p. 789).

${ }^{486}$ Cf. J. J. Gomes Canotilho, Direito Constitucional e, Ob. cit., p. 369.
} 
LAFER, que as medidas instauradas pelo Estado brasileiro para observar as disposições encartadas no art. $4^{\circ}$ da Constituição Federal devem ser tomadas como ferramentas indispensáveis para viabilizar a complementariedade entre o Direito Internacional Público e o Direito Constitucional, além de indicarem a irradiação de conceitos elaborados no âmbito externo no plano nacional ${ }^{487}$.

Explicados os pontos de inflexão associados ao processo de incorporação dos tratados de direitos humanos, resta reafirmar que o movimento de deferência ao exterior pelo qual passa o constitucionalismo pátrio deve ser desenvolvido com atenção à força normativa da Constituição e evitando-se o risco de, sob o pretexto de premência de valores internacionalmente consagrados, desconsiderarem-se conquistas democráticas consagradas em nossa Constituição. De fato, um dos mais seguros indicativos da permeabilidade do Direito Interno são as convenções que passam a fazer parte da ordem jurídica doméstica, depois de cumpridos os requisitos constitucionais colocados pelos Estados nacionais e certificada a adequação material das normas exteriores diante das respectivas Constituições. Não é demais insistir, nessa senda, que a ampliação do Direito das Gentes deve considerar que cabe às Constituições disciplinar a acomodação da pluralidade de fontes normativas que se interconectam no ordenamento estatal, o que significa que a execução interna dos tratados, seja qual for a matéria que buscam disciplinar, não pode prescindir da compatibilidade dos mesmos com os valores apregoadas pelo Direito Constitucional contemporâneo.

\subsubsection{A Hierarquia Normativa dos Tratados Incorporados ao Ordenamento Jurídico} Pátrio

O ponto relativo à estatura hierárquica-normativa das convenções inseridas no Direito brasileiro rendeu inúmeras discussões doutrinárias e, durante aproximadamente duas décadas, deflagrou controvérsias na jurisprudência do Supremo Tribunal Federal. Muitas foram as causas da ausência de consenso, mas interessa indicar como fator preponderante o fato de que as Constituições nacionais sempre foram omissas a respeito da recepção dos tratados internacionais e dos seus efeitos no Direito Interno, sendo as convenções, no plano constitucional, analisadas quase exclusivamente sob a ótica da distribuição de competências entre os Poderes, o que fez as normas constitucionais se

${ }^{487}$ A Internacionalização dos, Ob. cit., p. 14. 
ocuparem com a disciplina do processo de celebração e aprovação dos tratados ${ }^{488}$. Em que pese a situação de permanente incerteza que reinou durante muito tempo, ao que tudo indica, a reforma constitucional provocada pela Emenda Constitucional $n^{0} 45 / 2004$, acrescida de posicionamentos firmados pela Corte Suprema, conseguiu êxito em estabelecer um regramento jurídico apto a sanar as dúvidas que rodeavam o tema.

Em uma perspectiva atrelada à evolução do entendimento predominante acerca do status atribuído aos tratados incorporados ao sistema jurídico pátrio, é indispensável apresentar três marcos decisivos. O primeiro ponto que influenciou a compreensão da matéria foi o julgamento do Recurso Extraordinário n ${ }^{\circ}$ 80.004, no ano de 1977, ocasião em que se instituiu a ideia de que as convenções internacionais ocupariam o mesmo patamar hierárquico das leis ordinárias federais. Em 2004, foi a vez da Emenda Constitucional $n^{\circ}$ 45 instituir o $\S 3^{\circ}$ ao art. $5^{\circ}$ da Lei Maior, que aumentou o chamado bloco de constitucionalidade brasileiro, ao conferir equivalência de emenda constitucional aos tratados de direitos humanos aprovados nas duas Casas do Congresso, em dois turnos de votação, mediante decisão de três quintos dos respectivos parlamentares. Por fim, em 2008, a decisão prolatada no Recurso Extraordinário $n^{\circ} 466.343$ fechou as discussões remanescentes, quando se reconheceu a condição de norma supralegal aos tratados de direitos humanos não aprovados nos termos especificados no art. $5^{\circ}, \S 3^{\circ}$, da Constituição. Em razão do expressivo significado de cada uma dessas referências ao constitucionalismo pátrio, convém apreciá-las em separado.

\subsubsection{O Recurso Extraordinário $n^{0}$ 80.004 e a Equiparação dos Tratados à Lei Ordinária Federal}

Antes de 1977, há poucos julgados que enfrentaram a matéria, porém os resultados aos quais chegaram são elucidativos do quão conturbado era o tratamento do problema. Nesse prisma, interessa lembrar que "uma das primeiras menções jurisprudenciais sobre a matéria é o voto vencido do Ministro Relator Philadelpho de Azevedo, num acórdão do STF de 1944, onde deixou clara a sua preferência pela supremacia do Direito Internacional, que não poderia ser revogado unilateralmente por um Estado através de sua legislação ordinária ${ }^{489}$. Foi, contudo, o acórdão confeccionado no julgamento do Recurso Extraordinário $\mathrm{n}^{\mathrm{o}} 80.004$ que reconheceu a equivalência de lei ordinária federal dos tratados transpostos ao sistema nacional, determinando, dessa forma, a orientação

${ }^{488}$ Cf. Pedro B. A. Dallari, Constituição e Tratados, Ob. cit.,pp. 45-46.

${ }^{489}$ CARMen Tiburcio e Luís Roberto BARroso,Direito Constitucional Internacional, Ob. cit., p. 181. 
jurisprudencial que, durante expressivo período de tempo, conseguiu apaziguar os ânimos e discussões em volta do assunto.

Adquiriu força, desde então, a ideia de que "a recepção do Direito Internacional no quadro do Direito Interno não significa que o Corpo Legislativo fique impedido de editar novas normas contrárias ao disposto nos tratados. O único efeito de recepção do Direito Internacional no quadro do Direito Interno é de dar força de lei às normas jurídicas assim incorporadas à legislação. Neste caso, os tratados valerão como lei e nesta qualidade serão aplicados pelos Tribunais, da mesma maneira, na mesma extensão e com a mesma obrigatoriedade próprias à aplicação do Direito Interno"490. Na prática, o Estado brasileiro acabou filiando-se à vertente de que "passando o tratado a integrar a legislação interna, depois de sua incorporação, encontra-se este em igualdade de condições às demais leis, e todas as incoerências que apresentar serão analisadas da mesma forma que aquelas surgidas em relação às demais leis"491.

Em um enfoque direcionado a identificar os aspectos constitucionais subjacentes à discussão travada na Corte Suprema no julgamento do Recurso Extraordinário no ${ }^{\circ 0.004}$, constata-se que a reiterada omissão, ao longo da história constitucional brasileira, no tocante ao enquadramento hierárquico das convenções internalizadas, serviu de embasamento para construir a compreensão em tela. Desse modo, porque inexistia norma na Constituição da época que estabelecesse restrições ao Poder Legislativo quanto à edição de leis internas contrárias aos tratados, entendeu-se que as concepções doutrinárias não bastavam para justificar o primado, na ordem positiva, das convenções frente a legislação pátria, de modo que contradições entre tratado anterior e lei interna posterior deveriam ser solucionadas em prol da aplicação desta ${ }^{492}$. Caberia, então, ao critério cronológico dedutível do caráter sistêmico do ordenamento jurídico ${ }^{493}$ - sanar eventuais antinomias entre as normas convencionais oriundas do Direito das Gentes e os atos normativos

\footnotetext{
${ }^{490} \mathrm{STF}, \mathrm{RE} \mathrm{n}^{\mathrm{o}}$ 80.004-SE, Rel. Min. Xavier de Albuquerque, Voto do Min. Cordeiro Guerra, julgamento 01/06/1977, publicação DJ 29/12/1977, pp. 50-51, decisão disponível no endereço eletrônico www.stf.jus.br.

${ }^{491}$ Hildebrando Accioly, G. E. do Nascimento e Silva e Paulo Borba Casella, Manual de Direito, Ob. cit., pp. 213-214.

${ }^{492}$ Cf. STF, RE no 80.004-SE, Rel. Min. XAVIER DE Albuquerque, Voto do Min. Rodrigues AlCKMin, julgamento 01/06/1977, publicação DJ 29/12/1977, pp. 84-85, decisão disponível no endereço eletrônico www.stf.jus.br.

${ }^{493}$ A respeito, sustenta NORBERTO BOBBIO que o critério cronológico, também referido pela fórmula lex posterior derogat priori, dimana de"uma regra geral no Direito em que a vontade posterior revoga a precedente, e que de dois atos de vontade da mesma pessoa vale o último no tempo" (Teoria do Ordenamento, Ob. cit., p. 94).
} 
internos, o que, não obstante pudesse causar responsabilidade internacional do Estado brasileiro, asseguraria a coesão da ordem jurídica nacional.

Ainda que a doutrina, em especial os internacionalistas, apresentasse reações ao entendimento firmado pelo Supremo Tribunal Federal acerca do status normativo de lei ordinária ostentado pelos tratados ${ }^{494}$, essa compreensão conseguiu, ao menos até o advento da Constituição de 1988, exterminar os impasses a respeito da aplicação interna das normas convencionais exteriores. A inauguração de uma nova ordem constitucional, inquestionavelmente envolvida com a efetivação dos direitos humanos e informada por preceitos normativos inéditos, reacendeu a discussão acerca da posição hierárquica dos tratados, mas, agora, foram as convenções de direitos humanos que ocuparam o centro das atenções. Em virtude de previsões - como aquelas que constam no art. $4^{\circ}$, inciso II, e no art. $5^{\circ}, \S 2^{\circ}$, da Lei Maior - que jamais tiveram correspondentes nas Cartas anteriores, a hermenêutica constitucional passou a demandar técnicas e esforços inovadores para que a interpretação de tais comandos fosse possível, o que provocou reflexos na forma de compreender a integração dos tratados referidos à ordem jurídica doméstica.

Nessa órbita, é certo que o princípio da prevalência dos direitos humanos, plasmado no texto constitucional vigente como norma encarregada de disciplinar as relações internacionais, interferiu na situação das convenções ligadas à proteção dessa categoria de direitos no seio do constitucionalismo pátrio. Isso porque, a partir do momento em que o Brasil se propõe a fundamentar suas ações exteriores nessa diretriz, não se pode olvidar que a conformação da soberania do Estado brasileiro fica submetida a regras jurídicas que devem adotar como parâmetro obrigatório a prevalência dos referidos direitos. Surge, pois, a necessidade de interpretar antigos conceitos do Direito Constitucional à luz desse comando principiológico, não somente porque, agora, ele goza de expresso reconhecimento na Constituição Federal, mas, sobretudo, porque está em sintonia com os valores que compõem a tônica do constitucionalismo contemporâneo ${ }^{495}$.

A chamada cláusula aberta dos direitos fundamentais, consignada no art. $5^{\circ}, \S 2^{\circ}$, da Constituição, tem igual relevância para o tratamento da posição hierárquica dos tratados de direitos humanos no âmbito da ordem jurídica brasileira. Esse preceito indica a

\footnotetext{
${ }^{494}$ Como exemplo do inconformismo doutrinário referido, pode-se citar as ponderações de JOSÉ CARLOS DE MAGALHÃES, o qual, mormente porque partilha da ideia comum entre os internacionalistas de primado do Direito Internacional ante o Direito Interno, registrou que "ao decidir que tratado revoga lei e que esta revoga tratado, mesmo não tendo sido denunciado, o STF faz incorrer a responsabilidade do Estado brasileiro perante a ordem internacional e os compromissos assumidos pelo país" (O Supremo Tribunal, Ob. cit., p. 67). ${ }^{495}$ Cf. Flávia PiOvesan, Direitos Humanos e, Ob. cit., p. 366.
} 
autorização do constituinte originário para que se aceitem direitos e garantias fundamentais que, a despeito de não estarem previstos no texto constitucional, figuram em convenções de que a República Federativa do Brasil seja parte. Embora o dispositivo em tela não faça nenhuma referência ao enquadramento hierárquico-normativo dos tratados mencionados, formou-se, em sede doutrinária, uma corrente de entendimento muito forte em defesa do reconhecimento da estatura constitucional de todos os pactos internacionais sobre a matéria $^{496}$.

O fato de o constituinte originário ter demonstrado receptividade com os avanços mais proeminentes em termos de reconhecimento e de garantia dos direitos do homem não significa, contudo, que toda e qualquer interpretação que procure expandir a abrangência desses direitos pode ser aceita sem nenhuma objeção. Com efeito, adverte FERNANDA DIAS MENEZES DE AlmeidA que "a generosidade exagerada que marca a Constituição nesta matéria chega a resvalar na demagogia, em certos pontos, com o risco de produzir mesmo uma maléfica banalização dos direitos fundamentais"497. Ao que tudo indica, na tentativa de proteger ao máximo os direitos humanos, o constituinte inovou nas disposições voltadas a privilegiá-los, o que acabou resultando em uma disciplina normativa não muito técnica e pormenorizada, notadamente no que diz respeito à matéria dos tratados internacionais. E isso fez surgir, na ordem constitucional pátria, uma série de problemas de difícil solução que, em vez de facilitar a aplicação dessas convenções, prejudicam-nas e, por conseguinte, trazem incertezas quanto ao modo de efetivar essa gama de direitos ${ }^{498}$.

\subsubsection{A Emenda Constitucional $n^{0}$ 45/2004 e a Possibilidade de Inclusão de Tratados de Direitos Humanos no Bloco de Constitucionalidade}

As intensas discussões doutrinárias e jurisprudenciais acerca da hierarquia normativa dos tratados de direitos humanos foram determinantes para que, em 2004, a Emenda Constitucional $n^{\circ} 45$ trouxesse previsão específica, reconhecendo a possibilidade

\footnotetext{
${ }^{496}$ Expressa essa linha de compreensão INGO WOLFGANG SARLET, cujo ponto de vista pode ser conhecido no trecho seguinte: "Na realidade, parece viável concluir que os direitos materialmente fundamentais oriundos das regras internacionais - embora não tenham sido formalmente consagrados no texto da Constituição - se aglutinam à Constituição material e, por esta razão, acabam tendo status equivalente. Caso contrário, a regra do art. $5^{\circ}, \S 2^{\circ}$, também neste ponto, teria o seu sentido parcialmente desvirtuado. Não fosse assim, virtualmente não haveria diferença (ao menos sob o aspecto da hierarquia das normas) entre qualquer outra regra de Direito Internacional incorporada ao Direito Nacional e os direitos fundamentais do homem consagrados nos textos internacionais" (A Eficácia dos, Ob. cit., pp. 123-124). Comungam do mesmo ideário: Flávia Piovesan, Direitos Humanos e, Ob. cit., pp. 53-58; Celso LAFER, A Internacionalização dos, Ob. cit., pp. 16-17.

${ }^{497}$ Fernanda Dias Menezes De Almeida, A Incorporação dos, Ob. cit., p. 58.

${ }^{498}$ Cf. Idem, ibidem.
} 
de parear com as emendas constitucionais as convenções sobre essa matéria que fossem submetidas a processo especial de votação no Congresso Nacional. Acrescentou-se, assim, o $\S 3^{\circ}$ ao art. $5^{\circ}$ da Constituição Federal, adotando-se requisitos formais - dois turnos de votação na Câmara dos Deputados e no Senado Federal, cada qual exigindo três quintos dos votos dos respectivos membros - como meio apropriado para fazer tratados de direitos humanos lograrem alcançar superioridade ante a legislação infraconstitucional. Essa mudança, por certo, torna compulsória a vinculação de todos os Poderes constituídos do Estado brasileiro aos comandos veiculados pelas convenções equivalentes às emendas, já que esses tratados passam a integrar o chamado bloco de constitucionalidade.

A inclusão no bloco de constitucionalidade transforma os tratados de direitos humanos em paradigma para o controle de constitucionalidade de leis e demais atos normativos, o que, por certo, paralisa a atividade do legislador nacional, que não mais pode editar leis que contrariem esses tratados. A relevância do bloco de constitucionalidade já tinha sido atestada pela jurisprudência do Supremo Tribunal Federal, em momento anterior à Emenda Constitucional n ${ }^{o}$ 45/2004, como comprova decisão preconizando que "a definição do significado de bloco de constitucionalidade - independentemente da abrangência material que se lhe reconheça - reveste-se de fundamental importância no processo de fiscalização normativa abstrata, pois a exata qualificação conceitual dessa categoria jurídica projeta-se como fator determinante do caráter constitucional, ou não, dos atos estatais contestados em face da Carta Política" ${ }^{\text {"499 }}$. Tem-se, de tal sorte, que, ao menos sob a perspectiva do Direito Constitucional, os tratados em questão receberam do constituinte derivado a maior deferência possível de ser atribuída a um ato normativo executável na ordem jurídica doméstica.

A autorização constitucional para que esses tratados adquiram equivalência de emendas à Constituição configura eficiente mecanismo de valorização dos direitos humanos criados, em um primeiro momento, no contexto das relações internacionais e que, depois disso, devem ser aplicados internamente ${ }^{500}$. Reforça-se, assim, o movimento de abertura do Estado Constitucional brasileiro ao mundo exterior, na medida em que, ao

\footnotetext{
${ }^{499}$ STF, ADI n ${ }^{\text {o }}$ 595-ES, Decisão Monocrática, Relator Min. CELSO DE MELLO, julgamento 18/02/2002, DJ 26/02/2002, decisão disponível no endereço eletrônico www.stf.jus.br.

${ }^{500}$ A reforma constitucional promovida pela Emenda Constitucional $n^{\circ} 45 / 2004$ conferiu concretude, no Brasil, ao queKEVIN FERDINAND NDJIMBA denomina da técnica de constitucionalização das normas de origem internacional - isto é, "a transformação das normas internacionais em normas constitucionais com o objetivo de lhes fornecer uma força jurídica superior" -, o que se transmuta em forte sinal da imprescindibilidade das Constituições nacionais na efetivação do Direito das Gentes, fortalecendo, assim, a percepção de que a expansão das normasexteriores não pode acontecer à margem do constitucionalismo (L'Internationalisation des, Ob. cit., p. 421).
} 
complementar o " $§ 2^{\circ}$ do art. $5^{\circ}$, que apenas reconhece direitos fundamentais de fonte extraconstitucional, mas não atribui a atos internacionais a força alteradora da Constituição" ${ }^{\text {,01 }}$, essa nova disposição amplia os instrumentos de proteção dos direitos da pessoa humana disponíveis no país. É inegável, portanto, que o novo preceito contribuiu, de modo objetivo, para esclarecer quais convenções de direitos humanos incorporadas ao ordenamento pátrio gozam, verdadeiramente, de hierarquia constitucional, o que enfraqueceu as proposições doutrinárias que militavam por uma abrangência mais larga de constitucionalização interna das normas internacionais.

Em que pese o avanço assistido, alguns estudiosos do Direito Internacional apresentaram objeções ao acerto do $\S 3^{\circ}$ do art. $5^{\circ}$, especialmente porque desejavam ver reconhecido o caráter constitucional de todos os tratados de promoção dos direitos humanos. Como elucida André De CARvalho Ramos, “a redação final aprovada do dispositivo foi recebida com pouco entusiasmo pelos defensores de direitos humanos, pelos seguintes motivos: 1) condicionou a hierarquia constitucional ao rito idêntico ao das emendas constitucionais, aumentando o quórum da aprovação congressual futura e estabelecendo dois turnos, tornando-a mais dificultosa; 2) sugeriu, ao usar a expressão 'que forem', a existência de dois tipos de tratados de direitos humanos no pós-Emenda: os aprovados pelo rito equivalente ao da emenda constitucional e os aprovados pelo rito comum (maioria simples); 3) nada mencionou quanto aos tratados anteriores à Emenda" ${ }^{, 502}$. Sem dúvida, essas críticas são importantes e devem ser objeto de reflexão porque contribuem para o contínuo aprimoramento do ordenamento jurídico, mas é preciso registrar que elas não servem para ofuscar a importância das alterações relatadas para a sistematização do quadro constitucional brasileiro.

Não é demais registrar que, na França, onde a teoria do bloco de constitucionalidade foi idealizada por LOUIS FAVOREAU ${ }^{503}$, os tratados internacionais não

\footnotetext{
${ }^{501}$ Senado Federal, Parecer n ${ }^{\mathrm{o}}$ 1.035/2002, Comissão de Constituição e Justiça e de Cidadania da Câmara dos Deputados, Relator Senador BERNARDO CABRAL, 30/10/2002, p. 3, texto disponível no endereço eletrônico www.senado.gov.br, acesso em 12/11/2013.

${ }^{502}$ Pluralidade das Ordens, Ob. cit., p. 49.

${ }^{503}$ Informa EDGAR CARPIO MARCOS que "a expressão 'bloco de constitucionalidade', de origem francesa, e desconhecida no Direito Constitucional de todo o século XIX e quase todo o XX, não é de cunho legislativo ou jurisprudencial, mas doutrinário. A opinião mais extensa é que ela se formou em meados da década dos anos 70, em virtude das ideias desenvolvidas por Louis Favoreau, que foi quem a utilizou em um trabalho dedicado a explicar a Decisão D-44, de 16 de Julho de 1971, emitida pelo Conselho Constitucional francês. [...] Nesse trabalho, Favoreau dava conta de uma decisão inovadora do Conselho Constitucional, mediante a qual declarou a inconstitucionalidade de uma lei, a qual, por sua vez, modificava uma disposição legislativa de 1901, que limitava o regulamentos das associações. Para declarar sua invalidade, o Conselho considerou que a lei questionada deveria ser analisada não apenas a partir da Constituição francesa de 1958, como também tomando como norma norteadora à Declaração Francesa dos Direitos do Homem e do Cidadão, de
} 
encontraram abertura para, somente mediante recursos de hermenêutica constitucional, serem considerados partes desse conjunto de mandamentos dotados de máxima hierarquia na ordem jurídica estatal. Cumpre consignar que "o Conselho Constitucional rechaçou, em decisão iniciada em 15 de janeiro de 1975, a possibilidade de controlar a conformidade das leis tomando como base tratados internacionais, quaisquer que estes fossem" ${ }^{\text {"504 }}$. E, diante desse contraponto com o Direito Constitucional francês, torna-se ainda mais evidente o descabimento de invocar o art. $5^{\circ}, \S 2^{\circ}$, da Magna Carta para justificar a posição constitucional de qualquer convenção de direitos humanos internalizada pelo Brasil, sobretudo ao se tomar nota de que, no ordenamento francês, quando o Conselho emitiu a decisão excluindo os tratados do bloco de constitucionalidade, estava em pleno vigor a norma do art. 55 da Constituição de 1958 - que estabelecia superioridade hierárquica em favor dos tratados ratificados por aquele país, mas que não serviu de fundamento para conceder-lhes status constitucional ${ }^{505}$.

Pontue-se, nessa senda, que a Emenda Constitucional $n^{\circ} 45 / 2004$ não foi responsável por inaugurar a noção de bloco de constitucionalidade brasileiro. Seu papel foi o de engrossar as normas habilitadas a integrá-lo, na medida em que franqueou aos tratados de direitos humanos aprovados em conformidade com os ditames do $\S 3^{\circ}$ do art. $5^{\circ}$ da Lei Maior a condição de parte do conteúdo inorgânico da Constituição de 1988, ou seja, passaram a figurar como normas dotadas de força de emenda sem, no entanto, estarem consolidados e sistematizados no diploma constitucional. Acerca do bloco de constitucionalidade pátrio, cumpre advertir que, além das convenções de direitos humanos alçadas ao patamar de emenda constitucional, compõem-no as normas do corpo permanente da Constituição Federal de 1988 e do Ato das Disposições Constitucionais Transitórias, bem como as normas das emendas constitucionais reformadoras e de revisão que não foram inseridas no texto da Lei Fundamental ou ADCT ${ }^{506}$.

A natureza nitidamente prospectiva do comando constitucional insculpido no art. $5^{\circ}, \S 3^{\circ}$, da Constituição necessita de ser sublinhada, haja vista a impossibilidade de se reconhecer, sem a submissão ao processo especial de referendo no Congresso Nacional, o

1789" (Bloque de Constitucionalidad y Proceso de Inconstitucionalidad de las Leyes, in Revista Iberoamericana de Derecho Procesal Constitucional, $\mathrm{n}^{\circ}$ 4, 2005, pp. 81-82).

${ }^{504}$ El Bloque de la Constitucionalidad, in Revista del Centro de Estudios Constitucionales, $\mathrm{n}^{\mathrm{o}}$ 5, pp. 55.

505 “Art. 55 da Constituição da V República da França de 1958. Os tratados ou acordos devidamente ratificados e aprovados terão, desde a sua publicação, autoridade superior à das leis, com ressalva, para cada acordo ou tratado, de sua aplicação pela outra parte".

${ }^{506}$ Cf.Ana Flávia Messa e José CARLos Francisco,Tratados Internacionais sobre Direitos Humanos e Poder Constituinte, in Direito Constitucional Internacional dos Direitos Humanos, Alexandre Coutinho Pagliarini e Dimitri Dimoulis (coord.), Ob. cit., p. 262. 
status constitucional dos tratados de direitos humanos internalizados antes de 2004. Não há, pois, no texto da Emenda Constitucional $n^{\circ} 45 / 2004$, nenhuma referência às convenções de direitos humanos aprovadas e integradas ao ordenamento brasileiro em período pretérito, o que levou ANNA CÂNDIDA DA CUNHA FERRAZ a defender que "a atribuição de qualificativos como: 'valor constitucional', 'hierarquia constitucional' ou 'equivalência constitucional' aos tratados e convenções internacionais de direitos humanos anteriores à $\mathrm{EC} \mathrm{n}{ }^{\circ} 45 / 2004$ é inviável, tanto sob o aspecto da teoria constitucional, como do ponto de vista lógico-jurídico e do processo legislativo constitucional" ${ }^{\text {507 }}$. Nesse particular, apresenta-se, ainda, como constitucionalmente adequada a tese de que "os tratados que já se encontravam em vigor anteriormente à promulgação da Emenda Constitucional n. 45/2004 conservam o status de que desfrutavam. Nada impede, todavia, que venham a ser submetidos à nova deliberação pelo Congresso Nacional, com observância das regras do $\S 3^{\circ}$ do art. $5^{\circ}$, hipótese em que sua eficácia seria levada à de emenda constitucional" ${ }^{" 508}$, esquadrinhada por Luís ROBERTO BARROSO.

Com base nas considerações acima expostas, fica difícil encontrar substrato constitucional para a teoria proposta por FLÁVIA PIOVESAN de que o advento do $\S 3^{\circ}$ do art. $5^{\circ}$ do Pacto Fundamental teria dado azo ao surgimento de duas categorias de tratados

\footnotetext{
${ }^{507}$ Os Tratados e as Convenções Internacionais de Direitos Humanos Anteriores à Emenda Constitucional $n$. 45/2004, in Revista Mestrado em Direito - Direitos Humanos Fundamentais, no 1, ano 7, jan./jun. 2007, p. 129.Certificam esse entendimento MARCO ANTONIO CORRÊA MONTEIRO, ao grifar que "existe um bloco de constitucionalidade na ordem jurídica brasileira, ao menos, desde 25 de agosto de 1992, com a promulgação da Emenda Constitucional $\mathrm{n}^{\circ}$ 2, que dispôs sobre o plebiscito previsto no art. $2^{\circ}$ do Ato das Disposições Constitucionais Transitórias sem alteração do texto constitucional" (Tratados Internacionais de, Ob. cit., p. 159); e JosÉ LEVI MELlo DO AMARAL JúNIOR, que, no ano de 2012, apresentou levantamento indicando as normas que apresentam hierarquia constitucional, ocasião em que destacou que "o sistema constitucional brasileiro já vai além da Constituição documental. A Constituição vigente possui 257 artigos. Porém, foi aprovada com um Ato das Disposições Constitucionais Transitórias (hoje com 97 artigos). Ademais, várias das 76 Emendas Constitucionais (aí incluídas as seis de Revisão) têm artigos autônomos, isto é, que veiculam normas comnível constitucional, mas que não foram incorporadas à Constituição documental. Postos de lado os artigos com cláusulas de revogação ou vigência, contam-se pelo menos 65 artigos constitucionais autônomos. Assim, o Direito pátrio possui algo em torno de 419 artigos em nível constitucional ecom forma documental.Com a promulgação da Convenção sobre os Direitos das Pessoascom Deficiência e seu Protocolo Facultativo, o bloco de constitucionalidadebrasileiro passa a ter, além daqueles 419 artigos, outros 68" (Tratados e Convenções Internacionais sobre Direitos Humanos e o Pensamento de Celso Lafer, in Novos Caminhos do Direito no Século XXI: Direito Internacional, Filosofia Jurídica e Política, Dogmática Jurídica e Direitos Fundamentais: Uma Homenagem a Celso Lafer, $2^{\mathrm{a}}$ ed., Luiz Olavo Baptista e Tercio Sampaio Ferraz Junior (coord.), Ob. cit., pp. 761-762).

${ }^{508}$ Interpretação e Aplicação da Constituição, $7^{\mathrm{a}}$ ed., São Paulo, Saraiva, 2009, p. 37. Engrossa ainda essa argumentação MONICA HeRMAN SALEM CAGGIANO, cujo posicionamento quanto à exegese do $\S 3^{\circ}$ do art. 5 da Constituição aponta para o fato de que "o constituinte outorgou um tratamento muito exato, específico e restritivo à questão. Conferiu o pedestal constitucional tão só àqueles tratados e convenções que cuidassem de direitos humanos e que atendessem às regras de aprovação legislativa estabelecida para as emendas constitucionais. Em se afigurando excepcional o dispositivo, restrito o seu campo interpretativo, porquanto ausente a flexibilidade necessária a exercícios de hermenêutica" (Emenda Constitucional $n^{\circ} 45 / 2004$, in Revista Brasileira de Direito Constitucional, $\mathrm{n}^{\circ}$ 5, jan./jun. 2005, p. 187).
} 
internacionais de proteção de direitos humanos: a) os materialmente constitucionais; e b) os material e formalmente constitucionais. Segundo a estudiosa, "todos os tratados internacionais de direitos humanos são materialmente constitucionais, por força do $\S 2^{\circ}$ do art. $5^{\circ}$. Para além de serem materialmente constitucionais, poderão, a partir do $\S 3^{\circ}$ do mesmo dispositivo, acrescer a qualidade de formalmente constitucionais, equiparando-se às emendas à Constituição, no âmbito formal" ${ }^{509}$. Essa diferenciação - vale insistir, que não encontra amparo constitucional de fácil intelecção -, caso adotada, acabaria com as querelas ligadas ao enquadramento hierárquico dos referidos tratados, já que apresenta repercussões práticas em dois outros campos específicos: no reconhecimento das convenções em foco como cláusulas pétreas e na proibição de denunciá-las.

Arrimada no argumento de que "ao se admitir a natureza constitucional de todos os tratados de direitos humanos, há que ressaltar que os direitos constantes nos tratados internacionais, como os demais direitos e garantias individuais consagrados pela Constituição, constituem cláusula pétrea e não podem ser abolidas por meio de emenda à Constituição, nos termos do art. $60, \S 4^{\circ,}, 510$, FLÁVIA PIOVESAN busca justificar a razão de ser das convenções que ela denomina de materialmente constitucionais. Apesar de perseguir objetivos nobres e inquestionavelmente positivos, percebe-se a incongruência dessa teoria em relação aos postulados que orientam a dogmática constitucional, em especial no que diz respeito à definição e à criação dos limites materiais ao poder de emenda da Constituição. A questão levantada aqui exige que se aclare o que são, para que servem e qual a gênese das cláusulas pétreas presentes na Lei Maior, como meio de possibilitar a realização de um juízo sobre o acerto ou o equívoco da proposta de transformar comandos oriundos do Direito Internacional em obstáculos permanentes ao poder de emenda do texto constitucional.

Como limites materiais ao poder reformador, as cláusulas pétreas impedem que o núcleo essencial da ordem constitucional seja abolido ou amesquinhado em decorrência da edição de atos reformadores. Dessa forma, as matérias que se revestem desse predicado como é o caso dos direitos fundamentais - não podem ser extirpadas da Constituição vigente, o que, por óbvio, não tolhe o legislador reformista de ampliar o catálogo de normas que abordem os temas petrificados. A questão que se coloca aqui, diante da ideia de estender o rótulo de cláusula pétrea aos tratados de direitos humanos, independentemente do procedimento de aprovação congressual que lhe foi imposto, é a de

\footnotetext{
${ }^{509}$ Direitos Humanos e, Ob. cit., p. 79.

${ }^{510}$ Idem, p. 80.
} 
saber se os novos direitos criados após a promulgação da Lei Suprema serão também considerados limites materiais ao poder de emenda.

Para sanar a dúvida levantada, recorre-se a GILMAR FERREIRA MENDES, INOCÊNCIO Mártires Coelho e Paulo Gustavo Gonet Branco, que, com lastro na teoria do poder constituinte, esclarecem que as cláusulas pétreas "se fundamentam na superioridade do poder constituinte originário sobre o de reforma. Por isso, aquele pode limitar o conteúdo das deliberações deste. Não faz sentido, porém, que o poder constituinte de reforma limitese a si próprio. Como ele é o mesmo agora ou no futuro, nada impedirá que o que hoje proibiu, amanhã permita. Enfim, não é cabível que o poder de reforma crie cláusulas pétreas. Apenas o poder constituinte originário pode fazê-10" ${ }^{\text {"511 }}$. Esse mesmo entendimento é exposto por Manoel Gonçalves Ferreira Filho, que assevera que "é inerente e própria à Constituição uma definição que se exprime nos pontos fundamentais que consagra sobre a ordem política. Em consequência, estes pontos fundamentais constituem o núcleo essencial da Constituição. Ora, o poder de reforma - poder de alterar a Constituição de acordo com a Constituição - não pode mudar esse núcleo, sob pena de estar fraudando a Constituição" ${ }^{\text {"512 }}$.

As reflexões acerca do alargamento dos direitos gravados como impossíveis de serem abolidos do sistema constitucional encontram nas observações feitas por RoDRIGO BRANDÃO interessantes argumentos que colaboram para a elucidação do problema. Grifa o autor que aceitar como cláusulas pétreas todos os direitos formalmente fundamentais, o que coincidiria com "as normas contidas no título II da Constituição (art. $5^{\circ}$ a 17 da Constituição), além dos direitos materialmente fundamentais previstos ao longo do texto, em tratados internacionais e decorrentes do regime e dos princípios constitucionais, consiste em exegese excessivamente ampliativa do âmbito de proteção do art. $60, \S 4^{\circ}, \mathrm{IV}$, da $\mathrm{CF} / 88$. Ter-se-á na hipótese fundado risco de implantar verdadeiro 'governo dos mortos sobre os vivos', vez que sujeitaria a geração atual a um amplíssimo rol de normas estatuídas pela geração constituinte, muitas delas de caráter substantivo e despedidas de uma especial dignidade normativa" ${ }^{, 513}$.

Certo é que compreender o tema cláusula pétrea exige foco centrado na teoria do poder constituinte, erigida há mais dois séculos no Direito Constitucional, sendo

\footnotetext{
${ }^{511}$ Curso de Direito, Ob. cit., 301-302.

${ }^{512}$ Significação e Alcance das Cláusulas Pétreas, in Revista de Direito Administrativo, vol. 202, out./dez. 1995, p. 14.

${ }^{513}$ Direitos Fundamentais, Democracia e Cláusulas Pétreas, Rio de Janeiro, Renovar, 2008, pp. 206-207.
} 
inapropriado substituir os dogmas inerentes a essa teoria pela necessidade de adaptar as Constituições de agora aos desafios impostos pela globalização e pela consolidação de órgãos internacionais de defesa dos direitos humanos. Não obstante o monopólio do constituinte originário no estabelecimento de cláusulas pétreas, identifica-se uma série de doutrinadores que, na contramão dos axiomas constitucionais, consideram que as convenções de direitos humanos, incluídas ou não no bloco de constitucionalidade, devem ser tratadas como autênticas barreiras ao poder de reforma. $\mathrm{O}$ assunto ainda não foi objeto de análise pela Corte Constitucional brasileira, mas tem angariado respeitáveis adeptos no meio acadêmico, a exemplo de MARIA GARCIA ${ }^{514}$, Ingo WOLFGANG SARLET ${ }^{515}$, Luiz Olavo Baptista $^{516}$, e Cláudia lima Marques e Valerio de Oliveira Mazzuoli ${ }^{517}$, propagadores da opinião de que todos os tratados voltados à proteção do homem devem ser petrificados; e CARMEn TiburCiO ${ }^{518}$, ERnesto Rey CANTOR ${ }^{519}$, e ANA Flávia MESSA e JosÉ CARLOS FRANCISCO ${ }^{520}$, que vislumbram como pétreas apenas as convenções equivalentes às emendas.

Situada a proposta de converter os tratados de direitos humanos (assim chamados de materialmente constitucionais) em matérias que jamais poderiam ser subtraídas do sistema constitucional brasileiro, resta apreciar ainda o invento de proibir a denúncia internacional desses mesmos tratados que, por força da previsão do art. $5^{\circ}, \S 3^{\circ}$, da Constituição de 1988, passam, no plano nacional, a ter paridade com as emendas constitucionais (e que seriam denominados de materialmente $e$ formalmente constitucionais). Os pregadores dessa ideia prendem-se à constatação de que tratados integrantes do bloco de constitucionalidade estariam fadados à permanência porque "os direitos neles enunciados receberam assento no texto constitucional, não apenas pela matéria que veiculam, mas pelo grau de legitimidade popular contemplado pelo especial e

\footnotetext{
${ }^{514}$ Cf. A Constituição e os Tratados - A Integração Constitucional dos Direitos Humanos, in Revista de Direito Constitucional e Internacional, ano 9, no 37, out./dez. 2001, p. 44.

${ }^{515}$ Cf. Os Direitos Fundamentais, Ob. cit., p. 193.

${ }^{516}$ Cf. A Aplicação das, Ob. cit., p. 34.

${ }^{517} \mathrm{Cf}$. O Consumidor-Depositário Infiel. Os Tratados de Direitos Humanos e o Necessário Diálogo das Fontes Nacionais e Internacionais, in Direito Internacional: Direito Internacional dos Direitos Humanos (Coleção Doutrinas Essenciais, vol. 3), Luiz Olavo Baptista e Valerio de Oliveira Mazzuoli (org.), Ob. cit., pp. 106-107.

${ }^{518}$ Cf. A EC n. 45 e Temas de Direito Internacional,in Reforma do Judiciário: Primeiros Ensaios Críticos Sobre a EC n. 45/2004, Teresa Arruda Alvim Wambier, Luiz Rodrigues Wambier, Luiz Manoel Gomes Junior e outros (coord.), Ob. cit., p. 126.

${ }^{519}$ Cf. El Bloque de Constitucionalidad. Aplicación de Tratados Internacionales de Derechos Humanos, in Estudios Constitucionales, ano 4, $\mathrm{n}^{\circ}$ 2, pp. 305-306.

${ }^{520}$ Cf. Tratados Internacionais sobre Direitos Humanos e Poder Constituinte, Alexandre Coutinho Pagliarini e Dimitri Dimoulis (coord.), Direito Constitucional Internacional dos Direitos Humanos, Ob. cit., p. 258.
} 
dificultoso processo de sua aprovação" ${ }^{, 521}$. Sob esse prisma, conclui FLÁVIA PIOVESAN que a estatura constitucional seria "como se o Estado houvesse renunciado a essa prerrogativa de denúncia, em virtude da 'constitucionalização formal' do tratado no âmbito jurídico interno" ${ }^{, 522}$.

Nos últimos tempos, assiste-se ao surgimento de posições doutrinárias que, no lugar de contribuir para pacificar as controvérsias relacionadas ao tratamento das normas convencionais exteriores integradas à ordem interna, têm difundido mais dúvidas sobre esse controvertido tema. Percebe-se que os estudiosos dos direitos humanos não hesitam em empregar a Constituição brasileira, em especial no que se refere à vedação de abolição de cláusulas pétreas, para sustentar que convenções que gozam de hierarquia constitucional “não podem ser objeto de denúncia do Presidente da República, por força do art. $60, \S 4^{\text {o }}$, da $C F^{, 523}$. Não bastasse a inadequação de emprestar caráter petrificado a atos normativos não elaborados pelo constituinte originário, essa orientação revela ainda outra debilidade conceitual: confunde $\mathrm{o}$ ato discricionário da denúncia de tratado, pautada na discricionariedade do Chefe de Estado, com a edição de emendas constitucionais, atividade incumbida ao constituinte derivado com as restrições determinadas pelo constituinte originário.

O que se pretende elucidar ao longo de toda a argumentação desenvolvida é que a decisão de conferir força normativa de emenda constitucional a tratados de direitos humanos internalizados não pode ser compreendida como a transformação dessas convenções em típicas emendas constitucionais. Esse equívoco não somente contraria o que dispõe o art. $5^{\circ}, \S 3^{\circ}$, da Constituição Federal, como também subverte os pontos mais elementares que disciplinam a teoria do poder constituinte. Se ficarem bem definidas as diferenças entre a promulgação de uma emenda constitucional e a incorporação de um tratado de direitos humanos com status de emenda, com certeza, os embaraços que se apresentam acerca da operacionalização do bloco de constitucionalidade serão facilmente solucionados, notadamente no que se refere à necessidade de decreto presidencial para a promulgação interna dos tratados em análise, à impossibilidade de considerá-los cláusulas pétreas e à viabilidade de o Estado, unilateral e discricionariamente, abandoná-los por meio de denúncia.

\footnotetext{
${ }^{521}$ Flávia PiOvesan, Direitos Humanos e, Ob. cit., p. 82.

${ }^{522}$ Idem, ibidem.

${ }^{523}$ CARMEn Tiburcio e Luís Roberto BARroso,Direito Constitucional Internacional, Ob. cit., p. 219.
} 
No que tange à pretensão de proibir a denúncia dos tratados equiparados às emendas, vale citar ainda MÁrcio PEREIRA PINTO GARCIA, que discorda do entendimento em formação porque não encontra na Constituição nenhuma regra que institua a obrigação de a República Federativa do Brasil figurar, para sempre, como parte nos pactos internacionais que tenha aderido voluntariamente. Informa também que a melhor técnica para a garantia da permanência do Estado em tratados não seria o silêncio do constituinte, mas "fazer como a Argentina, listar os tratados com estatura constitucional. Ela o fez mediante emenda de 1994, que introduziu o item 22 ao art. 75. O trabalho não é impossível [...]. E mais, o Congresso daquele país também estabeleceu hipótese de denúncia para eles. O quórum, para isso, é bastante elevado. Trata-se, pois, de uma quase impossibilidade. Evita-se, assim, o inconveniente - a que estamos sujeitos caso prevaleça entendimento ligado ao art. 60, $\S 4^{\circ}$, IV da nossa Constituição - de o tratado caducar no plano internacional e continuar operante na esfera interna" ${ }^{\natural 24}$.

Ao que parece realmente ser consonante com a dogmática constitucional é que a fórmula normativa que consta do $\S 3^{\circ}$ do art. $5^{\circ}$, ao ditar a faculdade de empregar método mais gravoso de incorporação de tratados que versam sobre direitos humanos, faz que convenções internacionais submetidas a essa sistemática funcionarem "como lei constitucional extravagante, ou seja, legislação de nível constitucional, mas não consolidada no corpo da Constituição documental (documento normativo denominado 'Constituição').[...] No nível superior, próprio às normas constitucionais, há uma consequência relevante. Normas que sejam aprovadas com nível constitucional (consolidadas ou não no texto constitucional documental) tornam-se parâmetro de

\footnotetext{
${ }^{524}$ A Terminação de Tratado, Ob. cit., pp. 414-415. Aderem a essa tese também LuIZ AlBERTO DAVID DE Araujo e Vidal Serrano Nunes Júnior, Curso de Direito Constitucional, $12^{\mathrm{a}}$ ed., São Paulo, Saraiva, 2008, p. 216. Em complemento, anote-se que o dispositivo da Constituição argentina mencionado preceitua: “Art. 75. Compete ao Congresso: [...] 22. Aprovar ou rejeitar os tratados celebrados com outras nações e organizações internacionais e concordatas com a Santa Sé . Os tratados e concordatas têm hierarquia superior às leis. A Declaração Americana dos Direitos e Deveres do Homem; a Declaração Universal dos Direitos Humanos; a Convenção Americana sobre Direitos Humanos; o PactoInternacional Econômicos, Sociais e Direitos Culturais; o Pacto Internacional sobre os Direitos Civis e Políticos e seu Protocolo Facultativo; a Convenção sobrea Prevenção e Punição do Crime de Genocídio; aConvenção Internacional sobre a Eliminação de todas Formas de Discriminação Racial; a Convenção sobre a Eliminação de todas as Formas de Discriminação contra a Mulher; a Convenção contra a Tortura e outros Tratamentos Cruéis, Desumanos ou Degradantes; a Convenção sobre os Direitos da Criança, emcondições da vigência, têm hierarquia constitucional, não revogarão nenhuma seção da primeiraParte da presente Constituição e devem ser entendidas como complementares aos direitos e garantias por ela reconhecido. Apenas poderão ser denunciadas, conforme o caso, pelo Poder Executivo nacional, com prévia aprovação por dois terços da totalidade dos membros de cada Câmara. Os demais tratados e convenções sobre direitos humanos, depois de aprovados pelo Congresso, requerem o voto de dois terços da totalidade dos membros da cada Câmara para gozarem de hierarquia constitucional".
} 
controle de constitucionalidade" ${ }^{, 525}$. Essa é, de fato, a única conclusão segura que pode ser depreendida da inovação aportada pela Emenda Constitucional nº 45/2004.

E, antes que essa conclusão seja carimbada como reacionária e contra o progresso jurídico da ordem interna, convidam-se aqueles que venham a dela discordar a refletirem sobre a necessidade de prudência na incorporação de tratados de direitos humanos, sobretudo diante da verificação de que a doutrina nacional tem apresentado ideias que nem sempre encontram guarida na literalidade ou no espírito da Lei Fundamental da República. Como adverte Elival DA SiLva RAMOS, atente-se que ativismo exacerbado em prol desses direitos, quando dissociado do respeito à dinâmica da representação política e ao princípio da legalidade, resulta em práticas voluntaristas e antidemocráticas camufladas no discurso de generosidade na defesa da pessoa humana para ultrajar normas constitucionais igualmente importantes para a manutenção das conquistas proporcionadas pelo constitucionalismo $^{526}$. O zelo redobrado quanto ao modo de incorporar essas convenções é o expediente mais efetivo para evitar situações em que as incertezas de ser parte de um tratado de direitos humanos sejam tantas e tão preocupantes a ponto de desestimular o Estado a assim proceder, fazendo que as autoridades nacionais prefiram editar (somente ou na maior parte das vezes) legislação infraconstitucional para reconhecer direitos básicos da pessoa.

\subsubsection{O Recurso Extraordinário $n^{0} 466.343$ e a Afirmação da Supralegalidade Inerente aos Tratados Protetivos dos Direitos Humanos em Geral}

A Emenda Constitucional $n^{\circ} 45 / 2004$, que introduziu o $\S 3^{\circ}$ do art. $5^{\circ}$ da Constituição Federal, "estimulou a revisão da jurisprudência do STF sobre os tratados internacionais de direitos humanos. Assim, vários Ministros do STF adotaram novos padrões hermenêuticos sobre o estatuto interno dos tratados de direitos humanos, formando recente maioria e modificando a visão tradicional de outrora, que os via apenas como equivalentes à lei ordinária federal, sujeitos à suspensão de eficácia caso surgisse lei

\footnotetext{
${ }^{525}$ José LeVi Mello do Amaral JúNIOR, Tratados e Convenções Internacionais sobre Direitos Humanos e o Pensamento de Celso Lafer, in Novos Caminhos do Direito no Século XXI: Direito Internacional, Filosofia Jurídica e Política, Dogmática Jurídica e Direitos Fundamentais: Uma Homenagem a Celso Lafer, $2^{\mathrm{a}}$ ed., Luiz Olavo Baptista e Tercio Sampaio Ferraz Junior (coord.), Ob. cit., p. 761.

526 Cf. Os Tratados sobre Direitos Humanos no Direito Constitucional Brasileiro Pós-Emenda Constitucional 45/04, in O STF e o Direito Internacional dos Direitos Humanos, Alberto do Amaral Júnior e Liliana Lyra Jubilut (org.), Ob. cit., p. 188.
} 
posterior em sentido contrário" ${ }^{, 527}$. Coube, assim, à jurisprudência da Corte Constitucional brasileira reconhecer, em 2008, na ocasião do julgamento do Recurso Extraordinário $\mathrm{n}^{\mathrm{o}}$ 466.343, o caráter supralegal dos tratados de direitos humanos já incorporados ao ordenamento pátrio ou que seriam internalizados em momento posterior sem, no entanto, observar o processo de votação nas duas Casas congressuais, em dois turnos, cada qual com a aprovação de, no mínimo, três quintos dos respectivos parlamentares ${ }^{528}$.

Como - ao menos, pelo ponto de vista teleológico - os tratados sobre direitos humanos não poderiam afrontar a supremacia da Constituição, pois primam pela proteção da mesma variedade de direitos preservados pelas normas constitucionais, deveriam ter "lugar especial reservado no ordenamento jurídico. Equipará-los à legislação ordinária seria subestimar o seu valor especial no contexto do sistema de proteção dos direitos da pessoa humana" ${ }^{529}$. Dessa forma, o status supralegal determina que, mesmo enquadradas como atos infraconstitucionais, as convenções de salvaguarda do ser humano assumem posição hierárquica de destaque na disposição do ordenamento, isto é, passam a ocupar nível intermediário entre o bloco de constitucionalidade e os documentos normativos que gozam de legalidade ordinária, o que, em termos práticos, assegura que não sejam descumpridas internamente, caso apresentem incompatibilidade com lei nacional mais específica ou mais recente.

A supralegalidade dos tratados de direitos humanos, por ter sido afirmada no exercício da atividade jurisdicional, constitui prova de que o Supremo Tribunal Federal está alinhado à tendência do constitucionalismo contemporâneo de prestigiar as normas internacionais destinadas à proteção da pessoa. Como se depreende sem maiores esforços do cenário atual, o adensamento das relações interestatais, traduzidas em um emaranhado crescente de normas internacionais, requer que as Constituições sejam ferramentas que viabilizem a concretização da eficácia dos mandamentos exteriores. Essa necessidade não

\footnotetext{
${ }^{527}$ André De CARVAlho RAmos, O Diálogo das Cortes: O Supremo Tribunal Federal e a Corte Interamericana de Direitos Humanos, in OSTF e o Direito Internacional dos Direitos Humanos, Alberto do Amaral Júnior e Liliana Lyra Jubilut (org.), Ob. cit., p. 849.

${ }^{528}$ CHRISTINE OLIVEIRA PETER DA SILVA anota que a decisão em questão traduz-se em "julgamento histórico, cuja discussão não coube em apenas um processo, sendo necessário três deles (RE 349.703, RE 466.343 e HC 87.585) para que a questão pudesse ser enfrentada em sua plenitude. O julgamento do RE 466.343 foi o mais relevante, seguindo-se do julgamento do RE 349.703 e do HC 87.585. Este último foi de importância crucial para a afirmação de posição da Suprema Corte brasileira acerca do status jurídico dos tratados internacionais no ordenamento jurídico pátrio" (A Histórica Decisão do Supremo Tribunal Federal sobre a Possibilidade de Prisão Civil do Depositário Infiel: Considerações sobre o RE 466.343, in Jurisprudência do STF nos 20 Anos da Constituição, Gilmar Ferreira Mendes, Paulo Gustavo Gonet Branco e André Rufino do Vale (org.), São Paulo, Saraiva, 2010, p. 85).

${ }^{529} \mathrm{STF}, \mathrm{RE} \mathrm{n}^{\mathrm{o}}$ 466.343-SP, Rel. Min. Cezar Peluso, Voto do Min. Gilmar Mendes, julgamento 03/12/2008, publicação DJ 04/06/2009, p. 20, decisão disponível no endereço eletrônico www.stf.jus.br.
} 
significa, obviamente, que a normativa internacional tenha de assumir a condição de norma supraconstitucional, já que o ideal é conceber abordagens que, sem desprezar os valores nacionais que identificam cada Estado soberano, aproximem o Direito Constitucional do Direito das Gentes.

Mais do que resolver um debate que se arrastou ao longo dos vinte primeiros anos de vigência da Constituição de 1988, envolvendo a aplicabilidade do Pacto de San José da Costa Rica como forma de impedir a prisão civil por dívidas nos casos de depositários infiéis, o Recurso Extraordinário $\mathrm{n}^{\mathrm{o}} 466.343$ desencadeou a revisão do entendimento seguido estritamente pela Suprema Corte brasileira, desde o final da década de 1970, quanto à equivalência dos tratados às leis ordinárias federais, mesmo aqueles ligados à promoção dos direitos humanos. Esse acórdão, ao afirmar a superioridade hierárquica da Convenção Americana de Direitos Humanos de 1969 (Pacto de San José) - cujo art. $7^{\circ}, \mathrm{n}^{\mathbf{o}}$ $7^{\circ}{ }^{530}$ proibia a modalidade de prisão civil em comento -, tornou a legislação infraconstitucional encarregada de estabelecer as hipóteses de prisão civil do depositário infiel impossível de ser aplicada. Para além do Pacto de San José, o caráter supralegal passou a ser um atributo dos demais tratados sobre direitos humanos, determinando que quaisquer atos normativos internos inseridos no plano infraconstitucional que sejam conflitantes com aqueles tenham sua eficácia paralisada ${ }^{531}$.

Vale ressaltar, pois, que o julgamento de 2008 significou um importante marco para orientar a produção normativa no país. Como enfatizam LUIZ GUILHERME MARINONI, Daniel Mitidiero e Ingo Wolfgang SARLEt, desde então, assentou-se "que a legislação infraconstitucional, para produzir efeitos, não deve apenas estar em consonância com a Constituição Federal, mas também com os tratados internacionais dos direitos humanos. Nesta perspectiva, existem dois parâmetros de controle e dois programas de validação do direito ordinário. Além da Constituição, o direito supralegal está a condicionar e a controlar a validade da lei",532. O mérito dessa nova forma de entender os tratados de direitos humanos é inquestionável, pois acaba com o inconveniente da tese da legalidade

\footnotetext{
530 “Art. $7^{\circ}$ do Pacto de San José da Costa Rica. [...] 7. Ninguém deve ser detido por dívidas. Este princípio não limita os mandados de autoridade judiciária competente expedidos em virtude de inadimplemento de obrigação alimentar".

${ }^{531}$ Essa diretriz pode ser verificada no voto proferido pelo Ministro GILMAR MENDES no acórdão lavrado no julgamento do Recurso Extraordinário $\mathrm{n}^{\circ}$ 466.343, na parte em que assevera que "diante do inequívoco caráter especial dos tratados internacionais que cuidam da proteção dos direitos humanos, não é difícil entender que a sua internalização no ordenamento jurídico, por meio do procedimento de ratificação previsto na Constituição, tem o condão de paralisar a eficácia jurídica de toda e qualquer disciplina normativa infraconstitucional com ela conflitante" (STF, RE n ${ }^{\circ}$ 466.343-SP, Rel. Min. CEZAR PELUSO, julgamento 03/12/2008, publicação DJ 04/06/2009, p. 26, decisão disponível no endereço eletrônico www.stf.jus.br).

${ }^{532}$ Curso de Direito Constitucional, São Paulo, Revista dos Tribunais, 2012, p. 1186.
} 
ordinária, a qual permitia ao Estado brasileiro descumprir esses acordos internacionais internamente, e incorrer, por isso, em ilícito internacional perante as instâncias imbuídas de promover a responsabilidade internacional por violação das normas exteriores.

A mudança na jurisprudência do Supremo Tribunal Federal retratada, juntamente com a anterior reforma da Constituição pela Emenda Constitucional $n^{\circ} 45 / 2004$, foram recebidas e apreciadas de modos diferentes pelos acadêmicos nacionais. Há quem, como Virgílio Afonso da Silva, entendeu-a como prova de que existe uma acentuada separação entre o nível internacional e o nível constitucional, porque o reconhecimento da supralegalidade dos tratados internacionais de direitos humanos teria sido causada "não por uma aceitação maior da interação entre o Direito Constitucional e o Direito Internacional, mas pura e simplesmente em razão de uma mudança no texto constitucional, por meio da EC 45/2004" ${ }^{, 533}$. De outra banda, VALERIO DE OLIVEIRA MAZZUOLI enxergou nesse fato a consolidação de uma inovadora maneira de controlar a validade dos atos legais no Brasil, a qual denominou de controle de convencionalidade, advertindo que "os juízes e tribunais nacionais estão obrigados a controlar ex officio a convencionalidade das leis, invalidando as normas domésticas incompatíveis com os tratados de direitos humanos em vigor no Estado" ${ }^{, 534}$.

Quanto à primeira ponderação, referente à pouca disposição do Direito Constitucional pátrio em dialogar com o Direito das Gentes, salvo melhor juízo, a argumentação que dominou as manifestações dos magistrados da Corte Constitucional no julgamento do Recurso Extraordinário n $n^{\circ} 466.343$ indica o contrário. Nesse particular, cabe consignar que houve registros externando a sensibilidade dos julgadores no tocante à tendência do constitucionalismo mundial de prestigiar as normas de proteção da pessoa, bem como a imprescindibilidade de adequar-se a ordem constitucional a essa salutar vertente. Outro aspecto ressaltado foi a preocupação com a efetividade dos direitos humanos, nos planos interno e internacional, além da menção à evolução do regime de responsabilidade dos Estados transgressores dos direitos humanos, instituído pela Organização dos Estados Americanos (OEA) com a criação da Convenção Americana

\footnotetext{
${ }^{533}$ Integração e Diálogo Constitucional na América do Sul, in Direitos Humanos, Democracia e Integração Jurídica na América do Sul, Armin von Bogdandy, Flavia Piovesan, e Mariela Morales Antoniazzi (coord.), Ob. cit., p. 528.

${ }^{534} O$ Controle Jurisdicional da Convencionalidade das Leis, $2^{\mathrm{a}}$ ed., São Paulo, Revista dos Tribunais, 2011, p. 168.
} 
sobre Direitos Humanos no final dos anos 60, encontrando na Corte Interamericana de Direitos Humanos o principal garantidor ${ }^{535}$.

A teoria do controle de convencionalidade, por seu turno, embora seja sedutora aos olhos daqueles que se dedicam ao Direito Internacional, não agrega significativas novidades ao constitucionalismo brasileiro, a não ser o aumento das normas que podem ocupar o posto de parâmetro para o controle de constitucionalidade. Na linha do que expõe MAZzUOLI, esse controle consistiria em adotar os tratados internacionais de direitos humanos integrados ao bloco de constitucionalidade em virtude da aplicação do art. $5^{\circ}, \S$ $3^{\circ}$, da Constituição como fundamento de validade de leis e demais atos normativos infraconstitucionais, podendo ser aferida a compatibilidade destes em face daqueles tanto na via concentrada quanto na via difusa. Em complemento, defende-se que os tratados de direitos humanos supralegais ocupariam somente o papel de paradigma do controle de convencionalidade difuso, ou seja, o controle que deve ser suscitado, perante qualquer juízo ou órgão jurisdicional, pelas partes envolvidas em casos concretos em que se vislumbra conflito normativo em convenções supralegais e leis nacionais ${ }^{536}$.

A par dessas considerações, fica claro que a primeira forma de concretização do controle de convencionalidade em nada se diferencia da hipótese de realizar o controle de constitucionalidade adotando-se tratados equivalentes às emendas para fundamentar a inconstitucionalidade dos atos normativos hierarquicamente inferiores. Quanto ao outro modo de exercê-lo, isto é, decidindo-se, sempre em casos concretos, pelos tratados supralegais em detrimento da legislação ordinária que os contrarie, tem-se no caso evidente aplicação do princípio da hierarquia como recurso de solução de antinomias, o que já é praticado desde sempre pelos juízes nacionais. As conclusões a que se chega recebem o aval dos constitucionalistas que, ao tratarem do controle de constitucionalidade, sem maiores cerimônias e nenhum desvio teórico a respeito do já complexo quadro que envolve essa matéria, aceitam pacificamente os tratados de direitos humanos aprovados nos termos especificados pelo art. $5^{\circ}, \S 3^{\circ}$, da Constituição como paradigma desse controle ${ }^{537}$. Não

${ }^{535}$ Cf. STF, RE $n^{\circ}$ 466.343-SP, Rel. Min. Cezar Peluso, Voto do Min. Gilmar Mendes, julgamento 03/12/2008, publicação DJ 04/06/2009, pp. 17-26, decisão disponível no endereço eletrônico www.stf.jus.br.

${ }^{536} \mathrm{Cf}$. O Controle Jurisdicional,Ob. cit., p. 168.

${ }^{537}$ Cf. Gilmar Ferreira Mendes, Controle Abstrato de,Ob. cit., pp. 158-159, Elival Da Silva Ramos, Os Tratados sobre Direitos Humanos no Direito Constitucional Brasileiro Pós-Emenda Constitucional 45/04, in O STF e o Direito Internacional dos Direitos Humanos, Alberto do Amaral Júnior e Liliana Lyra Jubilut (org.), Ob. cit., p. 178; JoSÉ LEVI MELlo DO AMARAL JÚNIOR, Tratados e Convenções Internacionais sobre Direitos Humanos e o Pensamento de Celso Lafer, in Novos Caminhos do Direito no Século XXI: Direito Internacional, Filosofia Jurídica e Política, Dogmática Jurídica e Direitos Fundamentais: Uma Homenagem a Celso Lafer, $2^{\mathrm{a}}$ ed., Luiz Olavo Baptista e Tercio Sampaio Ferraz Junior (coord.), Ob. cit., p. 761; Luís 
destoa dessa percepção a jurisprudência do Supremo Tribunal Federal, que, quando resolveu antinomia entre lei brasileira e tratado supralegal, acabou não reconhecendo vício de nulidade da legislação interna, tendo decidido apenas ter ocorrido a mera revogação $\operatorname{desta}^{538}$.

Igual impressão é externada por GonZALO Aguilar CAVALlo no excerto em que o autor grifa que o controle de convencionalidade "tende a confundir-se com o controle de constitucionalidade das normas porque no debate acerca desse tipo de controle judicial surge a discussão sobre a hierarquia normativa dos tratados internacionais, principalmente dos tratados de direitos humanos. Como mencionado anteriormente, nos últimos anos, em toda a América Latina, é crescente a atribuição de hierarquia constitucional às convenções de direitos humanos. Justamente em virtude desse fato, os direitos humanos ou os tratados que os prevejam, por apresentarem estatura constitucional, proporcionam a confusão ou a aproximação do aludido controle de convencionalidade com o controle de constitucionalidade. Por essa razão, estendem-se as categorias próprias deste último controle, tais como o controle concentrado e o difuso, também ao controle de convencionalidade ${ }^{, 539}$.

Aparentemente não se encontram, assim, razões suficientemente fortes para justificar a realização de alterações textuais na Constituição com o objetivo de aperfeiçoála para que se desenvolva aquilo que vem sendo denominado pela doutrina de controle de convencionalidade. Esse enfoque indica ser precipitada a sugestão de reforma do art. 102 da Lei Maior vigente feita por Leonardo Martins e Thiago Oliveira Moreira, a fim de que esse dispositivo passe a contar com a redação de que "compete ao STF a guarda da Constituição e dos tratados internacionais de direitos humanos, cabendo-lhe processar e julgar, originariamente: a) a ação direta de inconstitucionalidade ou inconvencionalidade de lei ou ato normativo federal ou estadual e a ação declaratória de constitucionalidade ou

RoBerto BARroso, Interpretação e, Ob. cit., p. 37; ANA FlÁvia Messa e José CARlos FRANCISCO,Tratados Internacionais sobre Direitos Humanos e Poder Constituinte, in Direito Constitucional Internacional dos Direitos Humanos,Alexandre Coutinho Pagliarini e Dimitri Dimoulis (coord.), Ob. cit., p. 263; Lenio Luiz Streck, Jurisdição Constitucional e Decisão Jurídica, $3^{\mathrm{a}}$ ed., São Paulo, Revista dos Tribunais, 2013, pp. 826-827; e MARCO ANTONIO CORRÊA MONTEIRO, Tratados Internacionais de, Ob. cit., p. 158.

${ }^{538}$ A respeito, pronunciou-se a Corte: "A subscrição pelo Brasil do Pacto de São José da Costa Rica, limitando a prisão civil por dívida ao descumprimento inescusável de prestação alimentícia, implicou a derrogação das normas estritamente legais referentes à prisão do depositário infiel" (STF, HC n ${ }^{0}$ 87.585-TO, Rel. Min. MARCo AurÉLIO, Ementa, julgamento 03/12/2008, publicação DJ 25/06/2009, decisão disponível no endereço eletrônico www.stf.jus.br).

${ }^{539}$ ¿Quién es el Guardián de la Convención Americana sobre Derechos Humanos?, in Revista de Derechos Fundamentales, ${ }^{\circ}$ 6, pp. 34-35. 
convencionalidade de lei ou ato normativo federal" ${ }^{140}$. Ainda que eventuais reformas nesse sentido possam servir para reafirmar a abertura do Estado Constitucional brasileiro ao Direito Internacional, acredita-se que existem métodos mais eficientes para promover esse desiderato, sendo o principal deles o incremento da atuação consciente dos três Poderes da República no exercício das múltiplas atribuições que cada um deles possui, em especial no que concerne às competências relacionadas com o tema relações exteriores ${ }^{541}$.

Averbe-se que mesmo VAlerio de Oliveira Mazzuoli, provavelmente o mais ativo propagador da teoria do controle de convencionalidade no país, não aventa a hipótese de alteração formal dos preceitos constitucionais para que as convenções internacionais de direitos humanos sejam tomadas como paradigma de controle vertical de validade em face da legislação ordinária. Realça o estudioso que “a partir da EC 45/2004, é necessário entender que a expressão 'guarda da Constituição', utilizada pelo art. 102, I, alberga, além do texto da Constituição propriamente dito, também as normas constitucionais por equiparação. Assim, ainda que a Constituição silencie a respeito de determinado direito, mas estando o direito previsto em tratado de direitos humanos constitucionalizado pelo rito do art. $5^{\circ}, \S 3^{\circ}$, passa a caber, no STF, o controle concentrado de constitucionalidade (v.g., uma ação direta de inconstitucionalidade) para compatibilizar a norma infraconstitucional com os preceitos do tratado constitucionalizado" ${ }^{, 542}$.

Cabe esclarecer, por último, que o controle de convencionalidade não pode ser desprezado como mecanismo de proteção dos direitos do homem. Isso porque embora, sob a perspectiva do Direito Interno, esse controle seja confundido com o controle de constitucionalidade e com o respeito ao princípio da hierarquia dos atos normativos do

\footnotetext{
${ }^{540}$ Controle de Convencionalidade de Atos do Poder Público - Concorrência ou Hierarquia em Face do Controle de Constitucionalidade?, in Direito Constitucional Internacional dos Direitos Humanos, Alexandre Coutinho Pagliarini e Dimitri Dimoulis (coord.), Ob. cit., p. 308. Segundo os referidos autores, as propostas de reforma da Constituição para permitir o exercício do controle de convencionalidade abrangem também: "o necessário reconhecimento da produção de efeitos erga omnes e vinculantes das decisões proferidas pelo STF em sede das ações declaratórias de inconvencionalidade e de convencionalidade, a alteração do caput artigo 103 da CF para que os legitimados para proporem ação direta de constitucionalidade sejam-no também para a ação de inconvencionalidade, bem como a declaração da inconvencionalidade por omissão de medida para tornar efetiva norma prevista em tratados internacionais de direitos humanos incorporados pelo rito especial do $\S 3^{\circ}$ do artigo $5^{\circ}$ da CF. Ter-se-ia, dessa forma, uma Ação Direta de Inconvencionalidade, uma Ação Declaratória de Convencionalidade, bem como uma Ação Declaratória de Inconvencionalidade por Omissão" (Idem, ibidem).

${ }^{541}$ Lembre-se, aqui, do escólio de KONRAD HESSE de que "um ótimo desenvolvimento da força normativa da Constituição depende não apenas do seu conteúdo, mas também da sua práxis. De todos os partícipes da vida constitucional, exige-se partilhar aquela concepção anteriormente por mim denominada vontade da Constituição" (A Força Normativa da Constituição, Porto Alegre, Sergio Antonio Fabris Editor, 1991, p. 21). 542 Teoria Geral do Controle de Convencionalidade no Direito Brasileiro, in Direitos Humanos, Democracia e Integração Jurídica: Emergência de um Novo Direito Público, Armin von Bogdandy, Flávia Piovesan e Mariela Morales Antoniazzi (coord.),Rio de Janeiro, Elsevier, 2013, p. 772.
} 
ordenamento, no Direito Internacional, o desenvolvimento dessa concepção ocasionou mudanças altamente significativas em prol da defesa desses direitos. Com efeito, ERNESTO REY CANTOR, depois de analisar a jurisprudência da Corte Interamericana de Direitos Humanos, identificou que esse Tribunal fundou o controle de convencionalidade, em sede internacional, ao definir que toda norma jurídica interna é suscetível submissão ao exame de compatibilidade com os tratados de direitos humanos, independentemente de sua hierarquia e também de a questão ter sido definitivamente resolvida, pois a existência de coisa julgada nacional não impede que a Corte exerça sua competência para reconhecer a incompatibilidade da lei e, consequentemente, a existência de violações aos direitos humanos $^{543}$.

Sob esse prisma, destaca-se o acerto de AndRÉ DE CARVAlHo RAMOS, autor que apregoa que "o verdadeiro controle de convencionalidade, em última análise, é internacional, por isso também denominado de controle de convencionalidade autêntico ou definitivo" ${ }^{\text {544 }}$.Dessa forma, os órgãos jurisdicionais que têm a incumbência de velar pelo Direito das Gentes - especialmente os direitos humanos - exigem que os atos nacionais sejam conformes às prescrições internacionais, sendo irrelevante o fato de as leis estatais apresentarem congruência com a Constituição e de o Estado se pautar nos valores democráticos. Isso acontece porque "a razão de ser do Direito Internacional dos Direitos Humanos é justamente oferecer uma garantia subsidiária e mínima aos indivíduos, em especial às minorias" ${ }^{, 545}$, o que é feito mediante a constatação de que os Estados que infringirem as obrigações assumidas no plano externo deverão ser responsabilizados pelo ilícito configurado.

\subsection{A Aplicação do Costume Internacional no Ordenamento Jurídico Interno}

Diversamente do que acontece no Direito Interno, onde o costume tem aplicabilidade reduzida, figurando, na maior parte dos casos, como meio de integração do

\footnotetext{
${ }^{543} \mathrm{Cf}$. Controles de Convencionalidad de las Leyes, in La Ciencia del Derecho Procesal Constitucional. Estudios en Homenaje a Héctor Fix-Zamudio en sus Cincuenta Años como Investigador del Derecho - Tomo $I X$ - Derechos Humanos y Tribunales Internacionales, Eduardo Ferrer Mac-Gregor e Arturo Zaldívar Lelo de Larrea (coord.), México, Universidad Nacional Autónoma de México, Instituto de Investigaciones Jurídicas, 2008, pp. 241-242.

${ }^{544}$ Teoria Geral dos, Ob. cit., p. 283.

${ }^{545}$ Idem, Responsabilidade Internacional do, Ob. cit., p. 56.
} 
ordenamento jurídico diante da verificação de lacunas ${ }^{546}$, no Direito Internacional, as normas consuetudinárias desempenham destacado papel, já que são admitidas como fontes formais desse conjunto de normas, responsáveis pela criação de direitos e deveres perfeitamente oponíveis aos sujeitos internacionais. Acerca das funções das normas costumeiras em cada uma das ordens normativas estudadas, MALCOLM N. SHAW anota que a razão de o costume ocupar posição de prestígio no terreno do Direito das Gentes deve-se "à natureza do sistema internacional, ao qual faltam órgãos centralizados de governo",547. Complementa AlBerto AmARAl JúNiOR asseverando que "no plano externo, não só o costume está na origem do Direito Internacional, como também durante longo tempo as normas consuetudinárias eram o principal modo de regular o comportamento dos governos" $" 548$.

As transformações sentidas na atualidade pelas relações interestatais, notadamente o aumento expressivo do número de tratados internacionais, não abalam a importância do costume como fonte normativa do Direito Internacional, pois esse movimento de codificação está longe de abarcar todos os comandos normativos exteriores. Além disso, em inúmeros campos do internacionalismo, as normas consuetudinárias apresentam-se como satisfatórias, dispensando, assim, reprodução por escrito ${ }^{549}$. Justifica também a relevância jurídica do costume a ilação de que, pela ótica do Direito Internacional, "não há desnível hierárquico entre normas costumeiras e normas convencionais. Um tratado é idôneo para derrogar, entre as partes celebrantes, certa norma costumeira. De igual modo, pode o costume derrogar a norma expressa em tratado" $" 550$.

A irrefutável natureza normativa do costume para o Direito Internacional faz surgir questionamentos ligados à forma de como proceder para aplicar internamente esse tipo de norma exterior ${ }^{551}$. A elucidação requer, de início, que se tenha como certa a impossibilidade de, no que tange à forma de incorporação aos ordenamentos domésticos,

\footnotetext{
${ }^{546}$ A função reservada ao costume no sistema normativo interno pode ser depreendida do disposto no art. $4^{\circ}$ da Lei de Introdução às Normas do Direito Brasileiro (Decreto-lei n 4.657/1942), que dispõe: “Art. 4". Quando a lei for omissa, o juiz decidirá o caso de acordo com a analogia, os costumes e os princípios gerais de direito".

${ }^{547}$ Direito Internacional, Ob. cit., p. 58.

${ }^{548}$ Curso de Direito, Ob. cit., p. 131.

${ }^{549}$ Cf. Hildebrando Accioly, G. E. do Nascimento e Silva e Paulo Borba Casella, Manual de Direito, Ob. cit., pp. 129-130.

${ }^{550}$ FrANCISCO REZEK, Direito Internacional Público, p. 161.

${ }^{551}$ É pertinente assinalar que existe alusão ao costume como fonte de emanação do Direito Internacional no art. 38, $\mathrm{n}^{\circ} 1, b$, do Estatuto da Corte de Justiça Internacional (CIJ), cujo texto estatui que: "Artigo 38. 1. A Corte, cuja função é decidir de acordo com o Direito Internacional as controvérsias que lhe forem submetidas, aplicará: [...] b) o costume internacional, como prova de uma prática geral aceita como sendo o direito".
} 
equiparar normas consuetudinárias com normas convencionais. Isso porque, de acordo com MirTô FrAGA, "relativamente ao Direito Internacional costumeiro, pode-se ver na regra international law is part of the law of the land uma norma comum a todos os Estados civilizados, ainda quando não esteja expressa na Constituição. Quanto ao convencional, as soluções variam. A adoção pode ser automática ou não; a superioridade do tratado sobre a lei pode ser expressa, sendo verdadeira, também, a posição oposta; pode-se, ainda, nada estabelecer, competindo, nesse caso, aos Tribunais a tarefa de determinar qual delas deva ser aplicada" ${ }^{552}$.

Coloca-se, então, a seguinte pergunta: "o que ocorre nos Estados cujas Constituições são silentes a respeito da integração ao Direito Interno do Direito Internacional consuetudinário? A resposta é afirmativa no sentido de que a recepção do Direito Internacional costumeiro pela ordem interna é automática” ${ }^{, 553}$. Assim, a integração das normas internacionais consuetudinárias à ordem nacional independe de manifestação formal do Estado, pois há a pressuposição de que o respectivo Estado tenha consentido para a formação do costume, em virtude de não ter expressado objeção em relação ao mandamento não escrito. Esses esclarecimentos interessam para a compreensão da problemática no âmbito do Direito brasileiro, pois nosso sistema constitucional não prevê nenhum dispositivo que cuide da introdução, da posição hierárquica e da aplicação das normas consuetudinárias oriundas do Direito das Gentes ${ }^{554}$.

\footnotetext{
${ }^{552}$ MirTô Fraga, $O$ Conflito entre, Ob. cit., p. 27.Corroboram esse entendimento NGUYEN QUOC DINH, Patricl Daillier e Alain Pellet, Direito Internacional Público, Ob. cit., p. 351; André De CARVAlHO Ramos, Teoria Geral dos, Ob. cit., pp. 273-276; Vicente MarotTa Rangel, Os Conflitos entre, Ob. cit., pp. 38-39; LOUIS HeNKIn,Foreign Affairs and, Ob. cit., p. 221; e ANTONIO CASSESE, L'Apertura degli, Ob. cit., pp. 56-57.

${ }^{553}$ Marco Gerardo Monroy CABra, El Derecho Internacional como Fuente del Derecho Constitucional, in Anuario Colombiano de Derecho Internacional, $\mathrm{n}^{\mathrm{o}}$ 1, ano 1, p. 116. Sobre a formação do costume internacional, consultarALEXANDRE COUTINHO PAGLIARINI, em especial na parte em que se pontua que "ao contrário do que ocorre nos tratados, o costume não se assenta sobre a base material de um suporte físico. Entretanto, não poderá a norma costumeira passar a viger no território de um dado Estado soberano se este, expressamente, não consente com a vigência do dispositivo consuetudinário internacional. Vigerá o costume, contudo, se o Estado não se expressar contrariamente e se o costume estiver sedimentado em seus atos" (Reflexões sobre o Costume, como Norma Internacional Imaterializada, e sobre o Tratado, como Norma Internacional Assentada em Suporte Físico, in Revista de Direito Constitucional e Internacional, $\mathrm{n}^{\circ} 49$, ano 12, out./dez. 2004, p. 321).

${ }^{554} \mathrm{~A}$ ausência de regramento na Lei Maior em relação às normas consuetudinárias oriundas do Direito das Gentes é ressaltada por SAUlo José CASAli BAHIA, que anota ter a Assembleia Nacional Constituinte de 1987-1988 deixado de lado o assunto. Consoante destaca o autor, o anteprojeto da Subcomissão da Nacionalidade, da Soberania e das Relações Exteriores "apenas dizia que o 'Direito Internacional faz parte do Direito Interno'. Apesar de implicitamente introduzir na ordem interna o Direito costumeiro internacional, pecava a proposta por não conferir-lhe significação hierárquica (o que poder ser conseguido com a dicção de que o Direito Internacional - aí incluídos os costumes - preponderaria na ordem interna). O anteprojeto da Subcomissão apenas referiu-se aos 'tratados e compromissos internacionais')" (Tratados Internacionais no Direito Brasileiro, Rio de Janeiro, Forense, 2000, pp. 105-106).
} 
Não é demais esclarecer que quadro diverso ao cenário erigido no Brasil é identificado no Direito Constitucional alemão, tendo em vista que o art. 25 da Lei Fundamental de Bonn de $1949^{555}$ proclama que as regras gerais do Direito Internacional isto é, o Direito Internacional consuetudinário de validade universal e os princípios gerais do Direito das Gentes - fazem parte do ordenamento jurídico federal e têm primazia ante a legislação ordinária. Com base nessa prescrição, vislumbra-se que “o Direito Internacional costumeiro encontra, no respectivo alcance e conteúdo vigentes em cada caso, imediata abertura constitucional no ordenamento jurídico germânico, além de possuir prevalência em relação ao Direito Interno alemão, mesmo que tal primazia não alcance as normas constitucionais" ${ }^{556}$. O referido dispositivo assume, portanto, função que ultrapassa a preocupação do constituinte daquele país em resolver prováveis antinomias entre normas internas e internacionais, uma vez que aponta KONRAD HESSE que ele assume contornos de "uma garantia na qual se manifesta claramente a 'amabilidade para o Direito Internacional Público’ da Lei Fundamental" ${ }^{557}$.

Ao mirar novamente as atenções para a ordem jurídica pátria, encontra-se a precisa advertência de ANTENOR MADRUGA lembrando que a "afirmação de que 'a norma internacional não dispõe, por autoridade própria, de exequibilidade e de operatividade imediatas no âmbito interno' deve ser lida com cautela, pois não se dirige a toda e qualquer norma internacional, mas apenas à norma derivada de fonte normativa convencional" De fato, a jurisprudência do Supremo Tribunal Federal tem determinado a execução de normas consuetudinárias cuja gênese ocorreu no contexto do Direito das Gentes sem, no entanto, a necessidade de submetê-las a processos internos de incorporação. A condução dos julgamentos referentes ao tema da imunidade de jurisdição de Estado estrangeiro no país prova isso, pois, desde 1989, quando houve a apreciação da Ação Cível no 9.696, a Corte Constitucional mantém-se firme no entendimento de que "essa imunidade não está prevista nos textos de Viena, não está prevista em nenhuma forma escrita de Direito

\footnotetext{
555 “Art. 25 da Constituição da República Federal Alemã de 1949. As regras gerais do Direito Internacional Público são parte integrante do Direito federal. Sobrepõem-se às leis e constituem fonte direta de direitos e obrigações para os habitantes do território federal".

${ }^{556}$ Christian HillgRUBER, La Integración del,Ob. cit., p. 123.

${ }^{557}$ Elementos de Direito Constitucional da República Federal da Alemanha, Porto Alegre, Sergio Antonio Fabris Editor, 1998., p. 94.

${ }^{558}$ Constituição Brasileira de, Ob. cit., pp. 135-136.
} 
Internacional Público. Ela resulta, entretanto, de uma antiga e sólida regra costumeira do Direito das Gentes" $" 559$.

Há que se concluir, com embasamento nos argumentos expostos, pela inviabilidade de exigir que os costumes internacionais tenham a sua eficácia e aplicabilidade domésticas dependentes de etapas de internalização análogas àquelas que se impõem às convenções internacionais. Desse modo, é inequívoco que "basear a análise da eficácia imediata de normas internacionais na peculiaridade do procedimento de incorporação dos tratados empobrece o já inócuo debate sobre monismo e dualismo e, pior, torna míope a visão dos juízes em relação ao Direito Internacional" ${ }^{560}$. O Direito Internacional de origem consuetudinária, ao contrário do convencional, não reclama nenhum processo formal de incorporação para ser executável no Brasil, o que não quer dizer, todavia, que a aplicação das normas internacionais costumeiras são isentas do dever de guardar compatibilidade vertical com os preceitos sacramentados na Lei Fundamental do país.

Nessa direção, Manoel GonçAlves Ferreira Filho ensina que “o Direito internacional costumeiro - pois em relação às normas de tratados é evidente o caráter contratual - só prevalece sobre o Direito Interno, quando a Constituição do Estado o aceita e na medida em que o aceita" ${ }^{, 561}$. Em outras palavras, importa admitir que a ausência de forma escrita não prejudica o controle da compatibilidade vertical das normas internacionais consuetudinárias tomando-se a Lei Fundamental nacional como paradigma. Embora não possa ser objeto de ações judiciais típicas do controle abstrato, o costume internacional submete-se ao controle concreto ou difuso de constitucionalidade, haja vista que o juiz nacional pode negar a aplicação de mandamento consuetudinário no plano interno sempre que verificar que há dissonância em relação aos preceitos constitucionais.

Apresentem-se, por oportuno, as considerações tecidas por CARLOS BLANCO DE MORAIS no tocante à aplicação do costume internacional no interior do Estado português, o

\footnotetext{
${ }^{559}$ STF, ACi n ${ }^{\circ}$ 9.696-SP, Rel. Min. Sydney SANCheS, Voto do Min. FranCisCo RezeK, julgamento 31/05/1989, publicação DJ 12/10/1990, p 11, decisão disponível no endereço eletrônico www.stf.jus.br. Acrescente-se que, em 16/02/2102, o Tribunal Superior do Trabalho também reconheceu a natureza consuetudinária da imunidade soberana dos Estados estrangeiros, ao consolidar sua posição quanto à diferença desta em relação à imunidade jurisdicional das organizações internacionais mediante a edição, pela Subseção I da Seção Especializada em Dissídios Individuais do Tribunal Superior do Trabalho, da Orientação Jurisprudencial $\mathrm{n}^{\circ} 416$, que conta com a seguinte redação: "OJ 416. As organizações ou organismos internacionais gozam de imunidade absoluta de jurisdição quando amparados por norma internacional incorporada ao ordenamento jurídico brasileiro, não se lhes aplicando a regra do Direito Consuetudinário relativa à natureza dos atos praticados. Excepcionalmente, prevalecerá a jurisdição brasileira na hipótese de renúncia expressa à cláusula de imunidade jurisdicional”.

${ }^{560}$ AnTENOR MADruga, Constituição Brasileira de, Ob. cit., p. 136.

${ }^{561}$ Manoel Gonçalves Ferreira Filho, O Futuro do Estado, in Revista da Escola Paulista da Magistratura, $\mathrm{n}^{\circ}$ 4, nov./jun. 1998, p. 94.
} 
que, em que pese a cautela que sempre deve acompanhar o estudo do Direito Comparado, podem ser aproveitas para entender a realidade brasileira, dada a similitude contextual que se observa entre os dois ordenamentos constitucionais. Sobre o tema, esquadrinha que "as normas de Direito consuetudinário aplicam-se diretamente na ordem interna portuguesa nos termos do $\mathrm{n}^{\circ} 1$ do art. $8 .^{\circ}$ da CRP, encontrando-se, como tal, sujeitas à fiscalização da sua constitucionalidade. [...] O fato é que também se torna perfeitamente concebível, por exemplo, que uma regra consuetudinária geral, em matéria de comunicações no ciberespaço, sirva de parâmetro comportamental a normas da Administração Pública emitidas ao abrigo de uma habilitação legal chocando-se com normas constitucionais em matéria de privacidade e proteção de dados pessoais. A ocorrer essa hipótese, julga-se ser perfeitamente possível sindicar, não só, a constitucionalidade da norma administrativa, mas também o costume geral que padronizou o seu conteúdo" ${ }^{, 562}$.

E acrescenta o autor lusitano que, quanto à existência de formas próprias de fiscalização do costume, embora seja inviável controlar esse tipo de norma internacional preventivamente (porque não há etapas internas de aprovação legislativa e de promulgação presidencial), a ausência de previsão no texto constitucional não pode impedi-la, pois é certo que "os processos de fiscalização sucessiva, concreta e abstrata, se dirigem a normas vigentes no ordenamento, sem especificar quais, figurando implicitamente o costume geral de entre as mesmas" ${ }^{, 563}$. Depreende-se, portanto, que o dever das autoridades nacionais aplicarem, no contexto doméstico, as normas costumeiras internacionais demanda a adoção de práticas e de procedimentos que perpassem as questões atinentes à execução interna dessa espécie normativa, uma vez que se faz necessário implementar também engenhos habilitados a permitir guardar a Constituição. O complicado trabalho de identificar os preceitos consuetudinários vigentes do Direito das Gentes não pode ser causa do rechaço a esse tipo de norma pelas autoridades nacionais, porque, se isso ocorrer, o Estado Constitucional estará atestando que promove uma incompleta e deficitária abertura ao internacionalismo.

Em virtude da notável importância que o costume internacional tem para a disciplina das relações internacionais, é inquestionável a relevância de as autoridades nacionais observá-lo, porém de modo a não fragmentar a coesão e a sistematicidade do

\footnotetext{
${ }^{562}$ Justiça Constitucional - Tomo I - Garantia da Constituição e Controlo da Constitucionalidade, $2^{\mathrm{a}}$ ed., Coimbra, Coimbra Editora, 2006, pp. 487-488. A propósito, esclarece-se que o preceito constitucional da Constituição portuguesa estabelece: "Art. 8. 1. As normas e os princípios de Direito Internacional geral ou comum fazem parte integrante do direito português".

${ }^{563}$ Idem, p. 488.
} 
ordenamento jurídico interno ${ }^{564}$. Ainda que exista forte discussão acerca do enquadramento do Direito Internacional consuetudinário no âmbito nacional, o ponto de vista prevalente é o de que essa normativa tem o status análogo ao ocupado pelas leis federais, sendo autoexecutável e vinculando, por conseguinte, os tribunais pátrios, apesar da ausência de autorização do Congresso Nacional para tanto ${ }^{565}$. O compromisso dos juízes nacionais no cumprimento dos preceitos internacionais que se revestem da natureza costumeira figura, pois, como uma das maiores contribuições que o Poder Judiciário pode prestar ao Direito das Gentes e à tendência de abertura do Estado para o internacionalismo.

Os desafios que acompanham a marcha rumo à maior aproximação dos sistemas normativos nacional e exterior demandam, por certo, que o Poder Judiciário dos Estados nacionais não ignore a normatividade dos comandos consuetudinários do Direito Internacional. No caso brasileiro, é imperioso admitir que o costume internacional corresponde a um conjunto de normas passíveis de aplicabilidade direta no plano interno, razão pela qual as normas costumeiras do Direito das Gentes se agregam automaticamente ao ordenamento jurídico e passam a obrigar particulares e autoridades públicas, independentemente de qualquer requisito específico. Embora não apresente forma escrita e prescinda de qualquer etapa de internalização, isso não significa, contudo, que as normas consuetudinárias sejam imunes aos instrumentos do controle de constitucionalidade, os quais, pelo que se pode perceber, serão operacionalizados apenas pela via incidental ou concreta, tendo em vista a impossibilidade de analisar-se em tese ou abstratamente a adequação do costume exterior em relação à Lei Maior.

\subsection{A Execução Interna das Decisões e Resoluções Emanadas das Organizações Internacionais}

A atual configuração da sociedade internacional tem como peças-chaves as organizações internacionais que, juntamente com os Estados soberanos, ocupam os

\footnotetext{
${ }^{564}$ GonZalo Aguilar CAVAllo aduz que a influência do Direito Internacional consuetudinário é vital e vai se incrementando também no âmbito da regulação nacional e internacional dos direitos do homem, uma vez que permite fazer que os Estados que não participam de tratados internacionais sobre a matéria sejam obrigados a seguir os preceitos protetivos dos direitos humanos, em razão de uma norma consuetudinária, norma que pode ter, inclusive, nível de norma de jus cogens. Diane dessa constatação, arremata o estudioso que "aí está a importância do reconhecimento, concedido pela Corte Suprema do Chile em diversas oportunidades, da incorporação automática da norma consuetudinária internacional, a qual é uma fonte jurídica riquíssima em matéria de Direito Internacional dos Direitos Humanos" (La Internacionalización del,Ob. cit., p. 237).

${ }^{565}$ Curtis A. Bradley e Jack L. Goldsmith, Foreign Relations Law: Cases and Materials, $33^{\mathrm{a}}$ ed., New York, Aspen Publishers, 2009, pp. 585-586.
} 
principais lugares na produção do plexo de comandos normativos do Direito Internacional $^{566}$. Na realidade, consoante observa CRISTINA QUEIROZ, a ascensão dessas organizações contribuiu de modo muito marcante para a erosão do tradicional conceito de soberania estatal, pois os Estados nacionais acabaram privados de certas prerrogativas soberanas em decorrência de terem atribuídos novos direitos e poderes às organizações internacionais $^{567}$. A consolidação da subjetividade jurídica desses novos integrantes do concerto internacional impõe a necessidade de empreender reformulações nas clássicas abordagens relacionadas ao Direito das Gentes e à sua consequente interação com os ordenamentos internos, sobretudo porque as organizações internacionais passaram a exercer competência normativa própria, a qual ainda não foi totalmente definida e, por conta disso, rende uma série de incertezas ${ }^{568}$.

Nesse compasso, RiCARDo SEITENFUs sentencia que "as OIs são os principais vetores de um processo que torna as relações internacionais cada vez mais jurídicas e menos políticas. Não se trata de solucionar todos os conflitos, mas colocá-los sob o controle das OIs ${ }{ }^{569}$. Desse modo, é natural que a atividade normativa desempenhada por essas organizações resulte no surgimento de comandos exteriores impossíveis de serem compreendidos apenas por meio do emprego dos conhecimentos e recursos forjados em um contexto anterior, quando as organizações internacionais não gozavam da relevância que apresentam hoje. Não é sem razão que há quem entenda serem os atos emanados das organizações internacionais as normas jurídicas responsáveis por acelerar as substanciais mudanças de paradigma enfrentadas na contemporaneidade pelas relações exteriores,

\footnotetext{
${ }^{566}$ ANTÔNIO AUGUSTO CANÇADO TRINDADE expõe, em linhas gerais, os impactos sentidos em decorrência do quadro narrado nos termos que seguem: "as organizações internacionais, de índole e características as mais diversas, têm efetivamente modificado a estrutura do Direito Internacional: puseram fim ao monopólio estatal da personalidade jurídica internacional e dos privilégios e imunidades, expandiram a capacidade de celebrar tratados, alteraram as regras da sua própria composição, passaram a participar em procedimentos judiciais internacionais e ampliaram consideravelmente as vias da cooperação internacional e da integração regional e sub-regional. Este fenômeno, que já era notado nas décadas de sessenta e setenta, pode ser hoje adequadamente apreciado, em perspectiva histórica, no âmbito do Direito das Organizações Internacionais"(Direito das Organizações, Ob. cit., p. 537).

${ }^{567}$ Cf. CRISTINA QUEIROZ, Direito Constitucional Internacional, Ob. cit., p. 24.

${ }^{568}$ A respeito, ALBERTO AMARAL JÚNIORpreconiza que "a competência normativa externa das organizações internacionais consiste na atividade destinada a impor direitos e obrigações aos Estados-membros e, em situações limitadas, aos Estados não membros. Os atos pelos quais se expressa são conhecidos sob a denominação de resoluções, recomendações e atos preparatórios de tratados e outros instrumentos internacionais. A terminologia empregada é bastante imprecisa, exigindo, por isso, a análise específica dos atos em causa para que se possa indicar a extensão dos seus efeitos. A jurisprudência internacional tem, a propósito, papel decisivo na ampliação do grau de certeza nessa matéria" (Curso de Direito, Ob. cit., pp. 190191).

${ }^{569}$ Manual das Organizações,Ob. cit., p. 361.
} 
sendo certo que "a exata configuração de sua extensão e de sua aplicação como fonte de Direito Internacional ainda tem de ser consolidadas" ${ }^{, 570}$.

Apesar de não figurarem expressamente no art. 38 do Estatuto da Corte Internacional de Justiça (CIJ), "as resoluções das organizações internacionais constituem a mais nova fonte do DI"571. De fato, o curto espaço de tempo de institucionalização das organizações internacionais na teia das relações exteriores e a forma com que essas decisões colegiadas são criadas acabam contribuindo para acentuar as controvérsias sobre a juridicidade das resoluções oriundas dos organismos intergovernamentais. Ainda que existam inúmeras discussões margeando a natureza jurídica e os efeitos das mencionadas resoluções, tem-se como dado já incontestável que esses atos se destacam no presente como fatores de desenvolvimento de standards de comportamento internacional, além de auxiliarem nos processos de conformação do Direito Internacional costumeiro, de cristalização dos princípios gerais do internacionalismo e de definição de novas convenções ${ }^{572}$.

A natureza normativa dessas deliberações inegavelmente pode alcançar o Direito Interno, em especial o ordenamento jurídico dos Estados-partes da organização internacional que cria a resolução vinculante. Quando isso acontece, surgem dificuldades variadas para assegurar o cumprimento dessas decisões por parte da atuação dos agentes estatais imbuídos da competência de aplicar, em cada um dos sistemas internos, esses comandos normativos, principalmente porque são raras as Constituições que, a exemplo da Constituição da Holanda ${ }^{573}$, contêm disposições consagrando a força obrigatória das decisões das organizações internacionais e a superioridade destas sobre a legislação nacional. A complexidade da questão é retratada no excerto da obra de NGUYEN QUOC Dinh, PATRICK DAILLIER e ALAIN PELLET, em que é assinalado que "os tribunais nacionais mostram-se embaraçados quando lhes é solicitado que apliquem decisões de organizações internacionais. À sua jurisprudência falta coerência. Com bastante frequência os tribunais internos evitarão pronunciar-se diretamente sobre o valor jurídico destes atos: sem negar

\footnotetext{
${ }^{570}$ Hildebrando Accioly, G. E. Do Nascimento e Silva e Paulo Borba Casella, Manual de Direito, Ob. cit., p. 180.

${ }^{571}$ Celso D. De Albuquerque Mello, Curso de Direito Internacional Público, vol. 1, Ob. cit., p. 290.

${ }^{572} \mathrm{Cf}$. Antônio Augusto Cançado Trindade, Direito das Organizações, Ob. cit., p. 30.

573 “Art. 93 da Constituição da Holanda de 1983. As previsões de tratados e de resoluções de organizações internacionais, que são obrigatórias para todas as pessoas em virtude do seu conteúdo, tornam-se obrigatórias depois de terem sido publicadas" e "Art. 94 da Constituição da Holanda de 1983. As normas legais em vigor no Reino não serão aplicáveis, caso essa aplicação estiver em conflito com as disposições dos tratados obrigatórios para todas as pessoas ou das resoluções de organizações internacionais".
} 
abertamente o seu alcance obrigatório, eles encontrarão subterfúgios processuais para não terem de os tomar em consideração" 574 .

Fixada a relevância jurídica das resoluções elaboradas pelas organizações internacionais para o Direito das Gentes - o que, é importante ressaltar, tem aumentado visivelmente a cada dia -, cumpre analisar, agora, de que forma o Estado brasileiro as tem adotado, bem como as implicações jurídico-constitucionais ligadas à execução, no ambiente doméstico, dessas decisões. Nessa órbita, ressalta Sufyan el Droubi que "o Brasil tem incorporado ao Direito Interno as resoluções obrigatórias do Conselho através de decreto presidencial, fundado no art. 84 , IV, da CF/88. Não ocorre a participação do Congresso, nem mesmo tópica, no processo de incorporação" ${ }^{\text {575 }}$. Essa prática vem sendo reproduzida ainda com base na ideia de que o poder normativo das organizações internacionais tem o amparo nos respectivos tratados constitutivos desses organismos, os quais já obtiveram a aquiescência do Congresso Nacional e do Chefe do Executivo em momento anterior e têm, em seus textos, preceitos que autorizam a edição dessas resoluções por parte dos organismos que criam $^{576}$.

Em que pese o reiterado emprego do decreto presidencial como única exigência colocada para incorporar à ordem jurídica pátria os atos normativos expedidos pelas organizações intergovernamentais, esse fato não impede que se apresentem reflexões sobre os prováveis impactos dessa prática ao Direito Constitucional nacional. Para tanto, serão adotadas duas linhas de abordagem. A primeira, concentrada na apreciação crítica do emprego do art. 84, inciso IV, do Pacto Fundamental da República ${ }^{577}$, apreciará se é realmente possível defender que se trata de situação em que se busca assegurar a fiel execução de normas jurídicas já existentes. O outro foco de análise, por seu turno, relaciona-se aos reflexos que a exigência de intermediação dos Poderes da República na adoção dessas resoluções pode causar no processo de internalização da Constituição brasileira.

A promulgação de decisões das organizações internacionais, como as da OEA ou da ONU, mediante decreto presidencial fundado no poder regulamentar, que é próprio do Chefe do Executivo, requer análise cautelosa. Nos termos consignados por CELSO D. DE

\footnotetext{
${ }^{574}$ Direito Internacional Público, Ob. cit., p. 384.

${ }^{575}$ As Resoluções Obrigatórias do Conselho de Segurança da ONU e sua Introdução no Direito Brasileiro, in Revista de Direito Constitucional e Internacional, no 60, ano 15, jul./set. 2007, pp. 341-342.

${ }^{576}$ Cf.Guido Fernando Silva SoARES, Curso de Direito, Ob. cit., pp. 118-119.

577، Art. 84. Compete privativamente ao Presidente da República: [...] IV - sancionar, promulgar e fazer publicar as leis, bem como expedir decretos e regulamentos para sua fiel execução".
} 
Albuquerque Mello, "o texto constitucional fala em 'sancionar, promulgar e fazer publicar as leis, bem como expedir decretos e regulamentos para sua fiel execução'. É interessante mencionar que não foi prevista expressamente a execução de resoluções de organizações internacionais. E mais, dizer que elas são fundadas em seus tratados constitutivos que foram aprovados pelo Poder Legislativo também não resolve a questão, porque os tratados não são leis, quando muito pode-se dizer que produzem 'efeito de lei' ${ }^{, 9578 .}$

Com base na orientação mais precisa no tocante à delimitação do espaço a ser ocupado pelo poder regulamentar, é assente que o art. 84, inciso IV, da Lei Maior não autoriza o Presidente da República a criar, modificar ou extinguir direitos e obrigações por meio de decretos voltados a viabilizar a execução de leis. Isso porque "o regulamento não pode ampliar os poderes jurídicos constantes da lei" ${ }^{579}$, já que a função regulamentar não pode contrariar ou extrapolar o conteúdo agasalhado na lei objeto de detalhamento. Anotese, a propósito, que a jurisprudência do Supremo Tribunal Federal mantém o sólido posicionamento de que "eventual extravasamento, pelo ato regulamentar, dos limites a que materialmente deve estar adstrito poderá configurar insubordinação executiva aos comandos da lei" ${ }^{580}$, o que causará, consequentemente, a invalidade do ato expedido.

É interessante registrar ainda que, embora o sentido da expressão 'lei' no art. 84, IV, da Constituição corresponda "a qualquer ato constitucional ou primário (fundado diretamente na Constituição, como lei complementar, lei ordinária, medias provisórias, leis delegadas, decretos legislativos e outros atos normativos)" ${ }^{\text {"581 }}$, não se apresenta adequado incluir nesse conjunto as resoluções derivadas das deliberações promovidas pelas organizações intergovernamentais. Deve-se lembrar que os atos dos organismos internacionais executados internamente representam hoje fontes de normas internacionais cujo conteúdo muitas vezes inova na ordem jurídica externa e, por conseguinte, nos ordenamentos nacionais onde são aplicados. Não se trata tipicamente de atos que especificam conteúdos já previstos no tratado constitutivo da organização que o elabora,

\footnotetext{
${ }^{578}$ Curso de Direito Internacional Público, vol. 1, Ob. cit., p. 114.

${ }^{579}$ Oswaldo Aranha BandeIra de Mello, Principios Gerais de Direito Administrativo - vol I: Introdução, $3^{\mathrm{a}}$ ed., São Paulo, Malheiros, 2007, p. 377.

${ }^{580}$ STF, ADI n ${ }^{\circ}$ 996-MC-DF, Relator Min. CELSO DE MELlo, Ementa, julgamento 11/03/1994, publicação DJ 06/05/1994, p. 1, decisão disponível no endereço eletrônico www.stf.jus.br.

${ }^{581}$ José Carlos Francisco, Art. 84, IV, in Comentários à Constituição do Brasil, J. J. Gomes Canotilho, Gilmar Ferreira Mendes, Ingo Wolfgang Sarlet, Lenio Streck e Léo Ferreira Leoncy (coord.), Ob. cit., p. 1224.
} 
mas de mandamento que, valendo-se da estrutura orgânica criada por esta convenção, é criado mediante deliberação dos Estados-partes desse organismo.

Assim, quando se verifica a introdução no sistema jurídico brasileiro de normas internacionais decorrentes de resoluções dos organismos internacionais, sem a participação do Congresso Nacional, evidencia-se a inobservância ao disposto no art. 49, inciso I, da Carta Constitucional de 1988. A construção teórica de que essas decisões internacionais demandariam unicamente decreto do Presidente da República para serem exequíveis no âmbito doméstico não pode subsistir, pois a exegese do texto constitucional que vem prevalecendo indica que a atual Constituição - "ao estabelecer de maneira sistemática, pela primeira vez na história constitucional, princípios que regem as relações exteriores do Brasil (art. $4^{\circ}$ ) -, teria reforçado o papel do Parlamento em matéria de política exterior"582. Além disso, cabe lembrar que a participação do Parlamento nesse particular constitui eficiente mecanismo para contornar os impasses apresentados no Capítulo 3 (Item 3.2.1) acerca do déficit de legitimidade na produção de normas internacionais pelos organismos intergovernamentais e supranacionais.

Impedir que o Congresso manifeste seu consentimento em relação às resoluções produzidas pelas organizações internacionais retrata uma diretriz que, aparentemente, não mais se sustenta diante do quadro constitucional inaugurado com o advento da Constituição em 1988. E não somente porque a transposição para a ordem nacional dessas resoluções não configura exercício de função regulamentar do Presidente da República é que o Parlamento deve participar desse processo, a participação do Legislativo precisa ocorrer sobretudo porque a prática presentemente operada viola o disposto no art. 49, inciso I, da Lei Maior ${ }^{583}$. Acrescente-se, nesse particular, que o desenvolvimento da matéria no cenário internacional retrata que "as matérias veiculadas nas resoluções podem atrair grandes responsabilidades não apenas ao país (como, por exemplo, no caso de

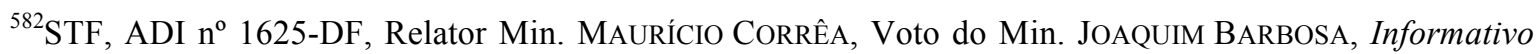
do $S T F n^{\circ} 549$, de 01/06/2009, documento disponível no endereço eletrônico www.stf.jus.br.

${ }^{583}$ Confirma esse ponto de vista OTÁvio AUGUSTO DRUMMOND CANÇADOTRINDADE, ao estatuir que: "Apesar de a Constituição brasileira não mencionar expressamente, em seus artigos 49, I, e 84, VIII, o termo decisões de organizações internacionais, entendemos que o processo de inserção desses atos no Direito brasileiro está implicitamente previsto nos referidos dispositivos constitucionais. Ambos os incisos referemse a atos internacionais, categoria em que evidentemente se enquadram os atos unilaterais - ou decisões - de organizações internacionais" (A Incorporação das Normas do Mercosul ao Direito Brasileiro e a Segurança Jurídica Regional, in Novas Perspectivas do Direito Internacional Contemporâneo, Carlos Alberto Menezes Direito, Antônio Augusto Cançado Trindade e Antônio Celso Alves Pereira (coord.), Ob. cit., p. 248).
} 
sanções econômicas impostas a parceiros comerciais próximos), como aos particulares (perda de bens em negociação com países ou pessoas sob sanção econômica)"584.

Apesar da escassa literatura acerca do assunto, MARIA J. ROCA informa que "a vinculação da Alemanha por meio de resoluções das organizações internacionais está legitimada pela aprovação do Parlamento federal da entrada da República em ditas organizações. Na medida em que se mostre necessária a transformação, em Direito nacional, das resoluções, tal transformação está submetida ao controle parlamentar"585. Esse registro pode servir de parâmetro seguro para ajudar a compreender as implicações que decorrem do segundo aspecto que merece ser apreciado: a necessidade de encontrar um ponto de equilíbrio entre a preservação das Constituições (e das prerrogativas e competências atribuídas por este documento aos Poderes do Estado que ele organiza) ante o crescente papel desempenhado pelas organizações internacionais, que é sucedido pelo incremento do número de normas internacionais delas emanados.

Conforme pontua SufYAN EL Droubi, o problema relativo à forma de introdução no Direito brasileiro de atos internacionais se resolve a partir da observância das normas constitucionais atinentes ao tema, o que, no país, acaba sendo muito complicado porque “não há normas na Constituição que sejam completas, claras e harmônicas o bastante para compreender e regular a forma de introdução, no sistema pátrio, das diversas classes de normas internacionais" $" 586$. A ausência de prescrições normativas na Lei Fundamental não pode, entretanto, impedir que o Estado brasileiro se integre ao fenômeno da proliferação das organizações intergovernamentais, haja vista que entendimento diverso impediria que o Brasil obtivesse os benefícios que a cooperação interestatal, desenvolvida no seio dessas

\footnotetext{
${ }^{584}$ Sufyan EL Droubi, As Resoluções Obrigatórias do,Ob. cit., pp. 347-348. Como exemplos de decisões de organizações internacionais que alteraram situações jurídicas no interior do Estado brasileiro e que não foram objeto de apreciação pelo Congresso Nacional, destaquem-se "as sanções impostas pelo Conselho de Segurança da ONU à África do Sul em decorrência do regime do apartheid foram internalizadas pelo Decreto n. 91.524 (DOU de 13.9.1985), que determinou, em seu art. $1^{\circ}$, o seguinte: 'ficam proibidas quaisquer atividades que caracterizem intercâmbio cultural, artístico ou desportivo com a África do Sul'. No ano de 2002, o Decreto n. 4.525 (DOU de 18.12.2002), incorporando a Resolução n. 1.446 do Conselho de Segurança, determinou, em seu art. $1^{\circ}$ : 'fica proibida a importação direta e indireta de diamantes em estado bruto originários de Serra Leoa'. No mesmo sentido, o Decreto n. 5.451 (DOU de 2.6.2005), sobre embargo de armas a entidades não-governamentais e indivíduos operando na região de Darfur, no Sudão, e o Decreto n. 5.548 (DOU de 23.9.2005), sobre embargo de armas a todo o território da República Democrática do Congo, proibição de viagens e congelamento de fundos, ativos financeiros e recursos econômicos de pessoas e entidades" (OtÁvio Augusto Drummond CANÇAdo TRIndade,A Incorporação das Normas do Mercosul ao Direito Brasileiro e a Segurança Jurídica Regional, in Novas Perspectivas do Direito Internacional Contemporâneo, Carlos Alberto Menezes Direito, Antônio Augusto Cançado Trindade e Antônio Celso Alves Pereira (coord.), Ob. cit., p. 249).

${ }^{585}$ El Control Parlamentario y Constitucional del Poder Exterior: Estudio Comparado del Estado Actual de la Cuestión en el Derecho Alemán y Español, in Revista Española de Derecho Constitucional, $\mathrm{n}^{\circ}$ 56, ano 19, p. 122.

${ }^{586}$ As Resoluções Obrigatórias do Conselho,Ob. cit., p. 343.
} 
instituições, pode oferecer no enfrentamento dos complexos desafios colocados pela globalização. Deve a Constituição, por certo, “compreender as novas formas de vinculação do Estado que decorrem de sua participação nas organizações internacionais" ${ }^{\text {"587, }}$, sem que isso signifique a aceitação da ideia de que, ao aderir voluntariamente, a uma dessas organizações, tenha o Estado soberano concedido todos os poderes para que a organização se sobreponha ao próprio Estado por meio das normas jurídicas que venha a expedir.

Por derradeiro, interessa sublinhar que a afirmação da proposta de participação do Congresso Nacional no controle das resoluções normativas geradas pelas organizações internacionais pode ser decisiva para favorecer a permanência do país nesse concerto internacional. Diferentemente do que a primeira impressão pode sugerir, a inclusão do Legislativo no processo de internalização dessa categoria de norma exterior não prejudicará o cumprimento das mesmas no contexto nacional. Ainda que a deliberação do Congresso alargue o tempo para que o Brasil passe a obedecer a essas decisões, os ganhos advindos da adoção dessa prática certamente compensarão, porquanto permite evitar situações em que a impossibilidade de resguardar os interesses nacionais afetados pelos referidos atos determine que o Parlamento não encontre outra saída a não ser exigir que o Estado brasileiro abandone a organização internacional.

${ }^{587}$ Helene TOURARD, L'Internationalisation des, Ob. cit., p. 110. 


\section{FEDERALISMO E RELAÇÕES INTERNACIONAIS: A ATUAÇÃO EXTERIOR DOS ENTES FEDERADOS}

“[...] uma Federação nunca está pronta e acabada, evoluindo sempre para adaptar-se às exigências de novos tempos".

FERNANDa Dias MENEZES DE AlmeidA ${ }^{588}$

\subsection{O Protagonismo dos Entes Federados em Matéria de Relacionamentos com o} Mundo Exterior

Ao traçar as características principais do Direito Constitucional estadunidense, BRUCE ACKERMAN proclamou que "a Constituição é mais do que uma ideia. Trata-se de uma prática constitucional evolutiva, constituída por gerações de norte-americanos, conforme esses se mobilizaram, discutiram e solucionaram suas controvérsias com relação à identidade e ao destino da nação" ${ }^{, 589}$. Longe de ser uma particularidade encontrada apenas no constitucionalismo enraizado nos Estados Unidos, esse entendimento é aplicável a todos os povos que buscaram na Constituição, considerada em sua acepção moderna, uma ferramenta confiável para assegurar a convivência dentro de parâmetros ajustados de liberdades públicas e de organização política. E, em um contexto de rápidas e drásticas alterações nos quadros constitucionais em virtude de forças originadas fora das fronteiras estatais, é perfeitamente compreensível o advento de inovadoras formas de promover a permeabilidade do Direito Constitucional em relação ao Direito Internacional, mesmo que seja em terrenos jurídicos que antes não despertavam nenhuma atenção no tocante à matéria, como é o caso da estruturação e do funcionamento das Federações.

Como se procurou esclarecer nos capítulos anteriores, a abertura dos Estados Constitucionais ao Direito Internacional é uma inclinação sentida no constitucionalismo que, por excelência, comprova a percepção de ACKERMAN. A interação experimentada com o mundo exterior "não pode ser descrita definitivamente ou até mesmo 'catalogada': isso iria contrariar sua abertura e a espontaneidade das formas isoladas de cooperação. Intensidade e grau, matérias, processos e instrumentos de cooperação ocupam uma

\footnotetext{
${ }^{588}$ A Federação a Serviço da Democracia e do Estado de Direito, in Direito Constitucional, Estado de Direito e Democracia: Homenagem ao Prof. Manoel Gonçalves Ferreira Filho, Carlos Bastide Horbach, Fernando Dias Menezes de Almeida, José Levi Mello do Amaral Júnior e Roger Stiefelmann Leal (coord.), Ob. cit., p. 228.

${ }^{589}$ Nós, o Povo Soberano: Fundamentos do Direito Constitucional, Belo Horizonte, Del Rey, 2006, p. 47.
} 
considerável amplitude de variação" ${ }^{, 590}$. Esse dado explica, assim, o por que existem Estados que já estão visivelmente adiantados e trazem previsões diversas em suas Constituições acerca da temática ao mesmo tempo que é possível identificar outros países (especialmente aqueles influenciados historicamente pela concepção clássica de soberania) que permanecem voltados para si, demonstrando pouca ou nenhuma disposição para se ocupar com os assuntos correlatos às relações internacionais.

No que respeita à configuração das Constituições e à realização de atos internacionais, cabe memorar que a globalização determinou a superação da secular concepção de que o governo central seria único habilitado a exercer ações no cenário exterior. A atual conjuntura indica um processo de desagregação ou fragmentação da autoridade nacional em prol do aumento exponencial da atuação de diferentes grupos e organizações, alterando significativamente os processos de tomada de decisões políticas e jurídicas $^{591}$. Por força da imersão do Estado em um conjunto mais vasto de redes de interações - que passa a congregar, além de organismos do governo nacional, organizações não governamentais e outros atores internacionais de natureza pública ou privada -, surgem experiências concretas e bem-sucedidas de participação dos entes subnacionais no tratamento de matérias cujo conteúdo transborda as respectivas fronteiras.

Contemporaneamente, tem-se que "é irrefutável a crescente ampliação das relações multilaterais e de integração entre países, derivadas da multiplicação dos interesses, valores e direitos que caracterizam as relações diplomáticas e governamentais, de cooperação, de comércio e de intercâmbio técnico-científico, dentre muitas outras" ${ }^{, 592}$. O quadro narrado desencadeia profundas reconstruções na organização do poder estatal, fato que enaltece o papel a ser desempenhado pela forma federativa de Estado na obtenção de instrumentos que permitam acomodar as novas necessidades e contingências que desafiam a governabilidade dos Estados. O federalismo deve portar-se como regime que, mais do que um concerto coerente de partes autônomas que viabiliza a unidade dentro da diversidade, propicia infinitas oportunidades para experimentos voltados a solucionar descompassos graves e inéditos, impossíveis de serem vencidos pelo emprego de técnicas e esquemas jurídicos que triunfaram no passado ${ }^{593}$.

\footnotetext{
${ }^{590}$ Peter HÄBerle, Estado Constitucional Cooperativo, Ob. cit., p. 15.

${ }^{591}$ Cf. CRISTINA QueIROZ, Direito Constitucional Internacional, Ob. cit., p. 31.

${ }^{592}$ LuIZ EDSON FACHIN, Direito Internacional: Possibilidades, Ob. cit., p. 306.

${ }^{593}$ Cf. PAUl SCHIFF BERMAN, Federalism and International Law Through the Lens of Legal Pluralism, in Missouri Law Review, vol. 73, 2008, pp. 1149-1150. Idêntico posicionamento é apresentado por ELISABETH ZOLLER, segundo a qual o governo federal é, por sua essência, incompleto, o que justifica o fato de sempre
} 
As causas que impulsionam a atividade exterior de partes autônomas são tão variadas e complexas quanto aquelas que condicionam a imbricação das Constituições e do Direito das Gentes, não havendo dúvidas, todavia, de que a ação dos governos locais nessa seara é um destacado fator que contribui para induzir a convergência entre os sistemas normativos interno e internacional. Com efeito, existe uma série de razões endógenas ligadas ao desenvolvimento político e econômico das próprias regiões que, ao se combinarem com elementos internacionais, contribuem para o fortalecimento do movimento em análise e transformam radicalmente os tradicionais esquemas de repartição de competências e encargos entre poder central e poderes subnacionais ${ }^{594}$. A proliferação dos pontos de contato entre o nacional e o exterior passa a ser notada como via de acesso na promoção de parcerias diversas que materializam complementariedades externas em inúmeros níveis, incluindo a formação de consciência, por parte de regiões e municipalidades, de que o alcance de seus interesses vai um tanto além de seus entornos imediatos $^{595}$.

Diante dos novos paradigmas que se apresentam, erra quem supõe que a atuação exterior das unidades subnacionais causaria impactos negativos às conquistas logradas pelo constitucionalismo. Na verdade, essas relações induzem justamente ao oposto: enaltecem a importância das normas constitucionais no processo de reformulação do Estado para situálo no processo de mundialização, haja vista que as capacidades internacionais "dos Estados federados são determinadas pelo Direito Constitucional federal e só são garantidas por processos internos" ${ }^{, 596}$. Compete, portanto, aos arranjos federativos consagrados nos textos constitucionais fixarem a amplitude das práticas internacionais a serem empreendidas por todas as instâncias de governo, pois, se inexistir adequada organização políticoadministrativa doméstica, será impossível que unidades regionais exerçam externamente sua autonomia ${ }^{597}$.

Assiste-se, no presente, a um crescente engajamento das unidades federadas na arena internacional, de tal sorte que é inevitável a pertinência de novas abordagens a

haver espaço para que os entes subnacionais desempenhem diversificadas operações jurídicas, inclusive na esfera internacional (Cf. Aspects Internationaux du, Ob. cit., p. 119).

${ }^{594}$ Cf. Michael Keating, Regions and International Affairs: Motives, Opportunities and Strategies, in Action: The Foreign Relations of Subnational Governments, Francisco Aldecoa e Michael Keating (org.), Londres e Portland, Frank Cass, 1999, p. 1.

${ }^{595}$ Cf. José Vicente da Silva Lessa, Paradiplomacia no Brasil e no Mundo: O Poder de Celebrar Tratados dos Governos Não Centrais, Viçosa, Editora UFV, 2007, p. 23.

${ }^{596}$ NguYen QuOc Dinh, PATrick DAILliER e AlAin PELlet,Direito Internacional Público, Ob. cit., p. 437.

${ }^{597}$ Cf. Malcolm N. SHAw, Direito Internacional, Ob. cit., p. 166-167. Ver também: HANS J. MichELMANN, Conclusion, in Foreign Relations in Federal Countries (A Global Dialogue on Federalism, vol. V), Hans Michelmann (ed.), Montreal \& Kingston, McGill-Queen's University Press, 2009, pp. 331-332. 
respeito do regime federativo com vistas a compatibilizá-lo com os reclamos surgidos nos últimos tempos. A Federação, idealizada no século XVIII nos Estados Unidos, por óbvio, também foi influenciada pelas tendências de internacionalização das Constituições e de advento da pluralidade normativa com a globalização, de maneira que as alterações decorrentes desse quadro determinaram ao federalismo rumos impensáveis à época em que os fundadores da teoria que embasa o núcleo dessa forma de Estado desenvolveram seus trabalhos. Deve-se, portanto, avançar sobre a construção de AlEXANDER HAMILTON, JAMES JAY e JOHN JAY, que, com base no argumento de que "nenhum Estado [federado] poderá participar de qualquer tratado, aliança ou confederação" ${ }^{\text {"598, }}$, pregava os poderes exclusivos do governo central para manter relações internacionais.

Embora permaneça firme a convicção de que a soberania pertence unicamente ao Estado federal - o que lhe assegura exclusividade no exercício de tarefas relacionadas aos pontos nucleares de sua política externa, política de segurança e de defesa e, ainda, política fiscal e monetária ${ }^{599}$-, as partes federadas têm manifestado forte interesse em operar no plano externo, sem que tenham de receber a chancela do governo central ${ }^{600}$. A atuação dos entes em matéria internacional pode ser verificada, por exemplo, na celebração de acordos de cooperação na busca de potencializar, em benefício das próprias unidades regionais, o desenvolvimento econômico e comercial, a captação de investimentos estrangeiros, além da atração das exportações e de agentes econômicos que contribuam para aprimorar a ciência e tecnologia ${ }^{601}$. Mesmo não sendo o momento mais adequado para discutir a natureza jurídica desses acordos, um dado já se coloca como indiscutível: a necessidade de admitir governos não centrais como figuras habilitadas a se envolverem, dentro de determinadas condições, no universo das relações exteriores - ainda que seus relacionamentos não se enquadrem nos padrões difundidos pelo Direito Internacional clássico $^{602}$.

\footnotetext{
${ }^{598}$ O Federalista, Brasília, Universidade de Brasília, 1984, p. 371.

${ }^{599}$ Cf. Luigi VAnnicelli, Neofederalismo Unitario e Pluralismo Interconfessionale (Profili Giuridici Comparati), Roma, Editrice Universitaria di Roma - La Goliardica, 1994, p. 72.

${ }^{600}$ Cf. TAtiana LACERda Prazeres, Por uma Atuação Constitucionalmente Viável das Unidades Federadas Brasileiras Ante os Processos de Integração Regional, in A Dimensão Subnacional e as Relações Internacionais, Tullo Vigevani, Luiz Eduardo Wanderley, Maria Inês Barreto, Marcelo Passini Mariano (org.), São Paulo, EDUC e Editora UNESP, 2004, pp. 284-285.

${ }^{601}$ Cf. STÉPhane PAQuin, Paradiplomatie Identitaire et Diplomatie en Belgique Fédérale: Le Cas de la Frandre, in Canadian Journal of Political Science, vol. 36, 2003, pp. 621-622.

${ }^{602}$ Consoante Monica Herman Salem Caggiano, "o sistema federativo ou soluções políticas de índole federativa vem conquistando adeptos em todas as partes, afigurando-se, na atualidade, uma das mais requisitadas opções na definição do modelo de organização estatal desejado, exatamente na expectativa de que, operando por via de um governo difuso, o federalismo viria autorizar as comunidades periféricas (as unidades componentes de um sistema federativo) a determinar, em razoável extensão, os seus objetivos e os
} 
As ideias dominantes outrora sobre a definição de quais autoridades poderiam ter voz no equacionamento dos entendimentos voltados a compatibilizar os interesses nacionais e internacionais ficam cada vez menos sustentáveis. Quanto mais os entes locais aumentam sua participação na criação e evolução de mecanismos que multiplicam as possibilidades de ações governamentais no terreno das interações internacionais, menos plausível fica a proposta de que unicamente o governo central estaria habilitado a desenvolver incursões nesse âmbito. A aferição de uma crescente pluralidade de vetores de negociações exteriores ocasiona o surgimento de instrumentos de composição dos interesses federativos também no tocante às relações internacionais, impondo que se considere a superação definitiva da noção de que tais relacionamentos devem restringir-se a esquemas verticalizados de poder, cujo monopólio da execução pertenceria a agentes oficiais do governo central ${ }^{603}$.

Nesse prisma, observa HÉLÈnE TOURARD que a literatura especializada em Direito pouco tem se ocupado de estudar a cooperação internacional realizada pelas unidades que integram os Estados compostos, mas a amplitude dessas práticas na atualidade justifica seu enfrentamento com objetivo de determinar a extensão das implicações jurídicas que decorrem desse fenômeno ${ }^{604}$. Endossa a constatação o fato de que a visão da diplomacia como atividade desempenhada exclusivamente sob o manto da soberania, mediante o envio de representantes diplomáticos, não passa de um discurso institucionalizado, já que não é a única via de aproximação dos governos que se pratica no contexto internacional ${ }^{605}$. Tornase premente, dessa forma, que a arquitetura federativa considere a viabilidade do uso de diversificadas possibilidades de coordenação horizontal na execução da política exterior, pois, conforme sublinha RoBERT B. AHDIEH, a realidade, por si só, desmente a doutrina de que, em tal campo, "somente 'uma voz' - a da autoridade nacional - deve ser audível"606.

meios pelos quais esses serão perseguidos e atingidos" (Explorando o Federalismo. O Que é Federalismo?, Revista Direito Mackenzie, ano 1, $\mathrm{n}^{\circ}$ 2, 2000, pp. 31-32).

${ }^{603}$ Cf. JosÉ ViCEnTE DA SILVA LeSSA, Paradiplomacia no Brasil, Ob. cit., p. 17.

${ }^{604}$ Cf. L'Internationalisation des, Ob. cit., p. 85.

${ }^{605}$ Cf. NoÉ Connago, Diplomacy and Paradiplomacy in the Redefinition of International Security Dimensions of Conflict and Co-operation, in Paradiplomacy in Action: The Foreign Relations of Subnational Governments, Francisco Aldecoa e Michael Keating (org.), Ob. cit., p. 40.

${ }^{606}$ Asuntos Exteriores, Derecho Internacional y el Nuevo Federalismo: Lecciones Derivadas de la Coordenación, in Teoria y Realidad Constitucional, nº 24, 2009, p. 146. 


\subsubsection{A Ascensão do Conceito de Paradiplomacia e de Figuras Afins}

As concepções tradicionais registram que as partes de Estados federais costumam ter participação indireta na estipulação de tratados internacionais mediante o referendo de tais atos por órgãos do Poder Legislativo integrados por representantes das unidades subnacionais. Mas, segundo defende Antonio REMIRO BROTONS, essa participação, certamente útil, mostra-se insuficiente para garantir que todos os interesses regionais sejam atendidos quando o assunto versa sobre as relações exteriores realizadas pelo governo central. É certo que a aprovação legislativa de convenções internacionais celebradas pelo Estado soberano permite aferir as expectativas e necessidades dos entes autônomos (cantões, regiões ou entes federados) tomados em seu conjunto; entretanto, não constitui engenho apto para revelar adequadamente quais são os interesses internacionais que podem existir somente para o governo de uma dessas unidades, considerada em seu particular ${ }^{607}$.

Outro instrumento que proporciona a participação indireta dos entes na condução da política externa de um Estado Federal são os grupos de pressão, os quais costumam ser integrados por agentes dos governos não centrais e por suas respectivas equipes e buscam influenciar a tomada de decisões da União ${ }^{608}$. A extensão do lobby feito pelos grupos aludidos pode ser prejudicial ao pacto federativo, na medida em que sempre há o risco de determinados grupos obterem do governo central ações que apenas lhes sejam favoráveis, o que compromete estruturalmente a unidade federativa. Caso venha a alcançar patamares extremados, a atividade de grupos de pressão passa a causar preocupações, motivo pelo qual parece ser equivocada a opção política de fomentar a atuação desses grupos como forma de assegurar a introdução na pauta do governo central de qualquer assunto que seja relevante para as partes autônomas ${ }^{609}$.

${ }^{607}$ La Accion Exterior, Ob. cit., pp. 247-248. M. ANTONIA ARIAS MARTíNEZfortalece essa impressão, quando analisa o quadro constitucional da Espanha - que, embora seja um Estado regional, permite conhecer um impasse enfrentado também por várias Federações -, e pronuncia-se no sentido de que "o problema é que o Senado espanhol, tal qual está configurado atualmente na Constituição, não é uma autêntica Câmara de representação territorial, e, portanto, não é, hoje, o caminho adequado para a participação das Comunidades Autônomas na política exterior" (Comunidades Autónomas y Relaciones Internacionales. Un Estudio de Jurisprudencia Constitucional, in Autonomies, n 21, dez. 1996,p. 364).

${ }^{608}$ Cf. IVO DuCHACEK, Perforated Sovereignties: Towards a Typology in New Actors in International Relations, in Federalism and International Relations, Hans J. Michelmann e Panayotis Soldatos (org.), Oxford, Claredon Press, 1990, p. 9.

${ }^{609}$ No tocante às atividades dos grupos de pressão, PABLO LUCAS VERDÚ adverte: “Os grupos mais poderosos arrancam dos poderes públicos as decisões que lhes convêm, em detrimento dos demais e em franco prejuízo da generalidade. As escandalosas pressões sobre os poderes públicos burlam o procedimento democrático e as afirmações constitucionais sobre a liberdade e igualdade de todos, cidadãos e grupos ante a lei. A atuação dos grupos de pressão é odiosa porque, diferentemente dos partidos políticos, utilizam procedimentos tortuosos, oblíquos, corruptos, sem nenhum compromisso com a responsabilidade política. Exercem um poder invisivel muito difícil, praticamente impossível de controlar" (Principios de Ciencia 
Equívocos e ineficiências das autoridades centrais na condução de relações exteriores, bem como a emergência de demandas postas pelas partes federadas, ocasionaram alterações substanciais na condução dos envolvimentos internacionais pelo aparato governamental. Em razão de, por exemplo, burocratização excessiva, de ausência de perícia, de recursos limitados e do distanciamento do poder nacional, as unidades autônomas tentam, por meio de mandatários investidos do poder de negociar internacionalmente em nome próprio, remediar situações desfavoráveis e propiciar ganhos da forma que lhes sejam diretamente benéficos ${ }^{610}$. Assim é que os entes subnacionais se envolvem crescentemente na prestação de auxílio aos serviços executados pela diplomacia convencional ou, em algumas hipóteses, até substituindo as tarefas confiadas aos agentes do Estado nacional, que deveriam representar o todo - o que, em tese, não excluiria os interesses das partes.

A presença da temática internacional nas agendas de governos não centrais representa, em última análise, uma resposta do federalismo à globalização, seja porque há inegável perda da capacidade do poder central atuar satisfatoriamente como promotor do desenvolvimento regional, seja porque ocorre a proliferação de redes de contato entre as regiões - mesmo aquelas pertencentes a nações diversas - nos domínios econômico, político, social e jurídico ${ }^{611}$. Cumpre acrescentar que, como consequência do ofuscamento da "linha de demarcação entre os negócios exteriores e as preocupações de interesse exclusivamente nacional, o problema do controle dos negócios estrangeiros fica mais agudo na maior parte das Federações, a ponto de suas implicações para a repartição de competências passarem a ser notáveis" ${ }^{\prime 612}$. A complexidade das inúmeras ligações políticas concernentes à inserção do Estado na órbita internacional impôs alterações e condicionamentos na organização estatal, porquanto reduziu as margens de manobra do

Politica, Volume III: Estado Contemporaneo y Fuerzas Politicas (Partidos Políticos, Corrientes Intrapartidistas, Asociaciones, Clubs Políticos, Grupos de Presión, Propaganda Política), Editorial Tecnos, Madrid, 1969, p. 140).

${ }^{610} \mathrm{Cf}$. PANAYOTIS Soldatos, An Explanatory Framework for the Study of Federal States as Foreign-Policy Actors, in Federalism and International Relations, Hans J. Michelmann e Panayotis Soldatos (org.), Ob. cit., p. 35 .

${ }^{611}$ Cf. MARIA InÊs BARRETo e MARCElo PASSINI MARIANo, Questão Subnacional e Integração Regional: o caso do Mercosul, in A Dimensão Subnacional e as Relações Internacionais, Tullo Vigevani, Luiz Eduardo Wanderley, Maria Inês Barreto, Marcelo Passini Mariano (org.), Ob. cit., pp. 22-23.

${ }^{612}$ Renaud Dehousse, Fédéralisme et Relations Internationales: Una Réflexion Comparative, Bruxelas, Bruylant, 1991, p. 79. 
governo nacional e, concomitantemente, permitiu que fossem dinamizadas e estimuladas as operações promovidas pelas unidades federadas nesse campo ${ }^{613}$.

Evidenciada uma série de iniciativas regionais sobre o entrelaçamento entre as partes autônomas de Estados compostos distintos, vale fixar as possíveis terminologias empregadas para identificar esse fenômeno a fim de que se possa entendê-lo para, quando preciso for, orientar seu desenvolvimento em harmonia com os postulados da Federação e do Direito Internacional. De pronto, sublinhe-se que a expressão relações diplomáticas é inapropriada para designar o movimento em foco, uma vez que o art. $2^{\circ}$ da Convenção de Viena sobre Relações Diplomáticas de 1961 prescreve que estas relações apenas poderão ser estabelecidas entre Estados soberanos que apresentem consentimento recíproco ${ }^{614}$. As atividades externas dos governos não centrais precisam se compatibilizar com os escopos que buscam alcançar e as limitações que dimanam da personalidade jurídica de Direito Público Interno dos entes federados - o que, sem dúvida, torna impossível enquadrá-las dentro da área de incidência das normas regentes da diplomacia estatal.

O conceito de paradiplomacia, idealizado na década de 1980, é tido como pertinente para explicar as relações formadas entre as partes regionais e unidades congêneres em outras Federações mediante ajustes exteriores ${ }^{615}$. Por ser uma espécie específica de relações internacionais, a paradiplomacia“deve ser compreendida como uma prática renovada que permite uma releitura do próprio modelo estatal, voltada para suprir a ausência de maior integração entre o poder central e o poder local"616. Mais do que responder às demandas advindas da globalização, o exercício dessa modalidade de interação atesta que o regime federativo dispõe de ferramentas que o habilitam para funcionar em uma contextura em que intensos pontos de contatos com o ambiente externo forçam o enredamento de todas as instâncias governamentais.

\footnotetext{
${ }^{613}$ Cf. Miryam Colacrai e Graciela Zubelzú, Las Vinculaciones Externas y la Capacidad de Gestión Internacional Desplegadas por las Provincias Argentinas en la Última Década. Una Lectura Desde las Relaciones Internacionales, in A Dimensão Subnacional e as Relações Internacionais, Tullo Vigevani, Luiz Eduardo Wanderley, Maria Inês Barreto, Marcelo Passini Mariano (org.), Ob. cit., p. 316.

614 “Art. $2^{\circ}$. O estabelecimento de relações diplomáticas entre Estados e o envio de Missões diplomáticas permanentes efetua-se por consentimento mútuo". Confirmam esse mandamento G. E. DO NASCIMENTO E Silva, Paulo Borba Casella e Olavo de Oliveira Bittencourt Neto, ao aduzirem que "o direito do Estado de manter relações diplomáticas com os demais Estados é denominado na doutrina de direito de legação, sendo considerado um dos direitos fundamentais dos Estados" (Direito Internacional Diplomático: Convenção de Viena Sobre Relações Diplomáticas na Teoria e na Prática, $4^{\mathrm{a}}$ ed., São Paulo, Saraiva, 2012, p. 147).

${ }^{615}$ Cf. IÑAKi AguiRre, Making Sense of Paradiplomacy? An Intertextual Enquiry About a Concept in Search of a Definition, in Paradiplomacy in Action: The Foreign Relations of Subnational Governments, Francisco Aldecoa e Michael Keating (org.), Ob. cit., pp. 185-186.

${ }^{616}$ Álvaro Chagas Castelo Branco, Paradiplomacia \& Entes Não-Centrais no Cenário Internacional, Curitiba, Juruá, 2008, p. 62.
} 
Os mecanismos paradiplomáticosmaterializam-se na "atividade de política externa de uma unidade federada, que decorre do surgimento de uma sociedade industrial avançada e envolve uma ampla gama de conceitos", consoante define PANAYOTIS SOLDATOS ${ }^{617}$. Em uma escala ampliada, a atuação dos entes territoriais para domínios que transbordam a cooperação intergovernamental formada dentro do próprio do Estado federal indica a conveniência de abandonar a visão monolítica da ação exterior do Estado soberano para fortalecer uma concepção aberta e plural das relações internacionais. Urge, nesse compasso, diferenciar as práticas internacionais resultantes da política externa da autoridade nacional - e que, por isso, vinculam o Estado enquanto sujeito de Direito Internacional - daquelas outras que apenas têm repercussão internacional, sem, no entanto, importar manifestação da soberania ${ }^{618}$.

O desenrolar das ações paradiplomáticas aclara que o ingresso direto e indireto de governos subnacionais na área das relações exteriores varia sobremaneira em forma, intensidade, frequência e finalidade. A destacada multiplicidade de ajustes que podem surgir para conformar os interesses autonômicos no âmbito da cooperação com o exterior justifica a percepção de IVO DUCHACEK quanto à existência de, no mínimo, três categorias dessas relações, quais sejam, a paradiplomacia regional transfronteiriça, os contratos transregionais (ou macrorregionais) paradiplomáticos e a paradiplomacia global. A esse mapeamento da extensão geopolítica, adiciona-se a constatação de que os acordos intergovernamentais no plano internacional perseguem predominantemente objetivos econômicos e técnicos, sendo que apenas em situações excepcionais (como acontece com os anseios separatistas de determinadas unidades), os interesses políticos acabam sendo relevantes para o assunto ${ }^{619}$.

Em virtude da ausência de relevância dos motivos de índole política para incitar os entendimentos internacionais entre governos não centrais, a doutrina é ciosa em distinguir os significados de paradiplomacia e de protodiplomacia. Enquanto este termo designa os esforços exteriores de representantes dos governos regionais que desejam obter seu

\footnotetext{
${ }^{617}$ An Explanatory Framework for the Study of Federal States as Foreign-Policy Actors, in Federalism and International Relations, Hans J. Michelmann e Panayotis Soldatos (org.), Ob. cit., p. 35. Acerca do assunto, TUllo VigeVANI considera que "a obra de Panayotis Soldatos parece ter sido pioneira na formulação de um novo marco teórico" (Federalismo e Relações Internacionais: Marco Jurídico e Institucional. Algumas experiências, in O Século 21 no Brasil e no Mundo, Maria Izabel Valladão de Carvalho e Maria Helena de Castro Santos (org.) Bauru, EDUSC, 2006, p. 239).

${ }^{618}$ Cf. Francisco Fernández Segado, El Estado y las Comunidades Autónomas ante las Relaciones Internacionales en la Constitución Española de 1978, in Anales de la Academia Nacional de Derecho y Ciencias Sociales de Córdoba, Tomo XXXII, 1993, pp. 30-31.

${ }^{619} \mathrm{Cf}$. Perforated Soveregnities: Towards a Typology in New Actors in International Relations, in Federalism and International Relations, Hans J. Michelmann e Panayotis Soldatos (org.), Ob. cit., pp. 15-16.
} 
reconhecimento definitivo como Estado soberano, a paradiplomacia alude ao somatório de atos e acordos responsáveis por adaptar, em grande parcela, a forma federativa ao mundo globalizado, onde as Constituições experimentam os reflexos da abertura do Estado a uma variedade de conexões com o externo ${ }^{620}$. As escassas ações ligadas à protodiplomacia não costumam receber atenção dos estudiosos porque o movimento que procura promover não se coaduna com a lógica responsável por solidificar os alicerces do Estado federal.

As iniciativas protodiplomáticas trariam consigo mensagens visivelmente separatistas, implicando utilizar, na prática, as relações econômicas, sociais e culturais firmadas pelo ente subnacional com outras nações para fortalecer esse desiderato. Como ocorreu, no passado, com Quebec, as autoridades regionais superiores tentaram empregar as respectivas missões comerciais e culturais no exterior para preparar o terreno internacional para uma futura secessão, o que certamente ajudaria no processo de reconhecimento da soberania desejada por parcela dos quebequenses ${ }^{621}$. E porque as Constituições contemporâneas têm proibido que as unidades federadas exerçam o direito unilateral de secessão ${ }^{622}$, fica patente que a protodiplomacia está fadada ao desaparecimento e tende a ser um conceito importante tão somente para fins de referências históricas.

Ao voltar-se, outra vez, o foco para as experiências paradiplomáticas compatíveis com as diretrizes que fundam os sistemas federativos, mostra-se interessante consignar que, em termos genéricos, a ação externa dos governos subnacionais pode ser denominada de cooperação internacional descentralizada. Ademais, MARINANA ANDRADE E BARROS informa que, especificamente no Brasil, determinados setores, sobretudo os órgãos

${ }^{620}$ Cf. Louis BalthaZAr, The Quebec Experience: Sucesso or Failure?, in Paradiplomacy in Action: The Foreign Relations of Subnational Governments, Francisco Aldecoa e Michael Keating (org.), Ob. cit., p. 162.

${ }^{621}$ Cf. Ivo DuchaCeK,Perforated Soveregnities: Towards a Typology in New Actors in International Relations, in Federalism and International Relations, Hans J. Michelmann e Panayotis Soldatos (org.), Ob. cit., p. 27.

${ }^{622}$ Esclarece RONALD L. WATTS que "poucas Federações têm incluído em suas Constituições o reconhecimento do direito unilateral de secessão ou previsões explícitas de um processo formal de separação. $\mathrm{Na}$ verdade, a Constituição da antiga União Soviética foi a única que fez referência a um direito unilateral de secessão. Geralmente, três motivos são apresentados para justificar a ausência da aceitação do direito unilateral de retirada nos textos constitucionais das Federações. Primeiro, o temor de que tal direito enfraqueceria todo o sistema, colocando uma arma de coerção política nas mãos dos governos das unidades constituintes. Em segundo lugar, a possibilidade de secessão pode introduzir um elemento de incerteza e falta de confiança no futuro, prejudicando seriamente os esforços para construir o desenvolvimento econômico da nacional e regional. Por último, os teóricos argumentam que fragilizaria o princípio basilar da coordenação entre os níveis de governo da Federação, pois, se um governo regional, atuando sozinho, poderia decidir unilateralmente deixar o conjunto, bem como o poder central resolver expulsar um determinado ente federado, então, poder-se-ia cogitar da existência de um subordinação entre os níveis governamentais" (Comparing Federal Systems, 2 ${ }^{\mathrm{a}}$ ed., Montrel e Kingston, McGill-Queen's University Press, 1999, pp. 107108). 
atrelados ao governo federal, utilizam das expressões política externa federativa ou diplomacia federativa para se referir às atividades, aqui, apreciadas ${ }^{623}$. Em complemento, é antevista a potencialidade da criação de arranjos denominados de microdiplomacia regional, que buscam concretizar uma série de atividades idealizadas por um grupo de entes autônomos com o propósito de aumentar a repercussão de suas ações no cenário exterior, conseguindo-se, de tal sorte, benefícios que a atuação individualizada de cada uma das partes jamais seria capaz de trazer-lhes ${ }^{624}$.

A inclusão de novos atores e interesses no campo das relações exteriores, o que pode ocorrer mediante consultas e outras formas de cooperação entre os segmentos domésticos que desejam acessar o sistema internacional, leva à conclusão de que, conforme expressão cunhada por BRIAN HockING, há a prática de uma diplomacia de múltiplas camadas ${ }^{625}$. Corrobora essa assertiva o exemplo extraído do sistema constitucional da República Federal Alemã (art. 32, nº 2, da Lei Fundamental de Bonn ${ }^{626}$ ), que contempla uma cláusula de consulta ou audiência de um ou vários Länder, caso a Federação esteja em vias de concluir tratados internacionais que repercutam na situação particular das mencionadas partes autônomas ${ }^{627}$. Assim, pode-se entender que a cooperação internacional descentralizada exprime, em sua essência, parte de um processo estrutural muito mais amplo e que extravasa a adaptação do regime federativo aos ditames da globalização: constitui uma importante peça no processo de democratização da atividade exterior do próprio Estado e do Direito Internacional ${ }^{628}$.

Independentemente da terminologia empregada para aludir às iniciativas regionais no segmento das relações internacionais, resta perceptível que as práticas observadas nessa seara refletem a impressão de que os assuntos exteriores têm permitido que os entes autônomos possam defender suas prioridades políticas regionais fazendo uso de instrumentos inovadores. Vê-se que "as instituições, normas e o Direito Internacional, mais do que atuarem como um controle ou obstáculo, oferecem um ponto de encontro, um ponto em comum para que as autoridades subnacionais promovam seus interesses" ${ }^{629}$,

\footnotetext{
${ }^{623}$ Cf. A Atuação Internacional dos Governos Subnacionais, Belo Horizonte, Del Rey, 2010, p. 6.

${ }^{624}$ Cf. RenAud Dehousse, Fédéralisme et Relations, Ob. cit., p. 240.

${ }^{625}$ Cf. Managing Foreign Relations in Federal States: Linking Central and Non-Central International Interests, in Foreign Relations and Federal States, Brian Hocking (ed), Londres e Nova Iorque, Leicester University Press, 1993, p. 68.

626 “Art. 32 [...] 2. Antes da assinatura de um tratado que afete as condições especiais de um Estado federal, este deverá ser consultado com a devida antecedência".

${ }^{627}$ FrANCISCO FERNÁNDEZ SEGADO, El Estado y, Ob. cit., p. 61.

${ }^{628}$ Cf. Marinana Andrade e BARros, A Atuação Internacional, Ob. cit., p. 137.

${ }^{629}$ Robert B. AHDIEH, Asuntos Exteriores, Ob. cit., pp. 132-133.
} 
especialmente porque viabilizam aos entes apoio externo em temas muitas vezes ignorados pelo poder central. O juízo de que "a paradiplomacia, em vez de ser um processo de conflito, denota um processo de racionalização, mediante o qual governos federais aceitam ou até acolhem a função internacional das unidades federadas como complemento (coordenado, conjunto ou monitorado) para os esforços internacionais" ${ }^{\prime 630}$ indica, portanto, ser a direção para a qual as iniciativas implementadas convergem.

Ante o exposto, há que se reconhecer que a orientação de que a competência de atuar externamente estaria reservada apenas ao poder central reflete um equívoco básico de perspectiva: a crença de que as relações internacionais manteriam a substância do passado, e, por conseguinte, ainda estariam restritas aos contatos diplomáticos interestatais. $\mathrm{O}$ avanço da participação das unidades autônomas em assuntos pertencentes ao repertório das relações externas representa um inquestionável sinal do protagonismo dos governos federados em áreas jamais imaginadas pelos idealizadores da teoria federalista ${ }^{631}$. Saber que as partes federadas atuam - em nome próprio ou conjuntamente com o Estado nacional - na execução de programas e encargos internacionais requer que se investigue os contornos jurídicos passíveis de serem atribuídos aos atos e acordos resultantes dessas ações. E é justamente isso que será feito a partir desse ponto.

\footnotetext{
${ }^{630}$ PANAyOtis Soldatos, An Explanatory Framework for the Study of Federal States as Foreign-Policy Actors, in Federalism and International Relations, Hans J. Michelmann e Panayotis Soldatos (org.), Ob. cit., p. 49.

${ }^{631}$ RICHARD B. BILDER, depois de mais de dois séculos da promulgação da Constituição estadunidense, revisitou o tema da participação de Estados federados e cidades no cenário internacional, oportunidade em que se convenceu da relevância de repensar o federalismo sob o prisma das interferências da política externa. Com o fito de justificar sua intelecção, o autor destaca: "Em 1789, os Estados Unidos eram um país recémnascido, a sua identidade internacional era frágil e incerta, e, além disso, havia a real e ameaçadora possibilidade de cada ente tentar estabelecer relações interestatais com governos estrangeiros. Ocorre que, em 1989, a República é muito diferente de outrora, o princípio da ampla supremacia federal sobre as relações internacionais está firmemente estabelecido e as nações estrangeiras estão convencidas de que somente o governo federal fala em nome da Federação. Acrescente-se, ainda, que a agenda da política externa inclui de modo crescente questões de comércio, mercado de trabalho, meio ambiente, direitos humanos, intercâmbio cultural e várias questões ligadas à vida particular dos cidadãos americanos. Talvez, no contexto do 'novo federalismo', exista, agora, espaço para uma atitude mais tolerante, flexível e cooperativa no que concerne ao envolvimento estadual e municipal nesses temas, o que, certamente, incentivaria os cidadãos comuns, por meio da ação dos governos mais próximos a eles, a participar com mais intensidade na formação e na concretização de políticas externas que afetam profundamente suas vidas" (The Role of States and Cities in Foreign Relations, in The American Journal of International Law, vol. 83, 1989, p. 831).
} 


\subsection{Natureza Jurídica dos Atos e Acordos Decorrentes das Ações Externas das} Unidades Autônomas

A ideia esposada por LOUIS HENKIN de que "o poder presidencial de 'elaborar tratados' não tem nenhum correspondente em assuntos domésticos" ${ }^{\text {} 632}$ merece reparos porque o constitucionalismo hoje é obrigado a disciplinar meios de atuação exterior cuja amplitude e peças estatais envolvidas ultrapassam a competência do Chefe de Estado para celebrar convenções internacionais. Ganha evidência que os modelos tradicionais de compreensão da política externa encontram-se submetidos a um complexo processo de desagregação e reconstrução, e, por isso, exige-se da engenharia constitucional adaptações no aparato governamental para que os diferentes níveis do poder possam se adaptar às pressões que, cada vez mais, atenuam os limites entre o nacional e o internacional ${ }^{633}$. Como a globalização aumentou a interdependência global, os Estados foram forçados a cooperarem, até mesmo, mediante a conexão internacional dos governos subnacionais com outras autoridades políticas não centrais, o que exprime ser maturação do federalismo um tópico cujo interesse deixou de ser adstrito ao campo interno.

Novas abordagens são transpostas para o universo das ações governamentais em áreas que, anteriormente, eram ignoradas pelos representantes dos entes federados, como é o caso das relações exteriores. Diante do panorama descrito, o desempenho dos referidos entes na celebração de arranjos de natureza internacional contribui para compatibilizar, de um lado, os desafios aportados pela erosão das linhas divisórias entre o interno e o externo e, de outro, a necessidade de resguardar a prerrogativa de autogoverno assegurada às partes autônomas. Como anota Francisco FERnÁndez SEgAdo, embora os governos subnacionais não possam ocupar o espaço que sempre coube à diplomacia tradicional, "parece oportuno reivindicar a conveniência de buscar-se instrumentos que favoreçam uma comunicação mais fluente entre o Estado e as Comunidades Autônomas com vistas a uma adoção de decisões mais realistas e que assegurem o cumprimento correto das obrigações assumidas" $" 634$.

Cabe assinalar que, em Federações que esboçam tendências mais acentuadas de projeção internacional das competências de suas unidades, existem técnicas de controle e de coordenação voltadas a garantir a harmonização dos interesses das partes com os

\footnotetext{
${ }^{632}$ Foreign Affairs and, Ob. cit., p. 6.

${ }^{633}$ Cf. BRIAn Hocking, Patrolling the "Frontier": Globalization, Localization and the "Actorness" of NonCentral Goverments, in Paradiplomacy in Action: The Foreign Relations of Subnational Governments, Francisco Aldecoa e Michael Keating (org.), Ob. cit., pp. 17-18.

${ }^{634}$ El Estado y, Ob. cit., p. 60.
} 
interesses gerais do conjunto ${ }^{635}$. Do contrário, ter-se-ia nas relações exteriores um perigoso caminho para a quebra da unidade política imprescindível para o bom funcionamento do regime federativo ${ }^{636}$. Depreende-se, nessa toada, que o desenvolvimento da chamada paradiplomacia pressupõe acurada estruturação interna de um sistema federativo, porque, se já é notadamente difícil assegurar eficiência e liberdade na execução das prerrogativas inerentes à autonomia no plano nacional, muito mais complicado é proporcionar que isso aconteça no espaço internacional.

Em uma dimensão mais alargada, é factível reconhecer a existência de um estágio considerável de organização político-administrativa descentralizada mesmo em Estados federais que, a despeito de não franquearem capacidades exteriores aos respectivos entes, confiam aos governos subnacionais o cumprimento das prescrições normativas criadas por intermédio do poder central. Esclarece ANTONIO DE LA PERgOLA que, nos casos em que os Estados-membros ou regiões executam tratados internacionais, em virtude das competências internas de que são detentores, os órgãos nacionais precisam posicionar-se como uma peculiar instância de vigilância ou de controle para remediar as hipóteses em que os entes autônomos tenham deixado de cumprir suas atribuições adequadamente ${ }^{637}$. O cuidado permanente do governo nacional é compreensível porque "a província federada, embora tenha aquilo que chamamos de personalidade jurídica de Direito Público Interno, é inidônea para figurar numa relação internacional: o ilícito que tenha causado será de responsabilidade da soberania a que se subordina"638.

Depois da balizar os aspectos preponderantes que informam o lançamento das unidades federadas no contexto internacional, convém perquirir sobre o elemento mais marcante das relações exteriores realizadas por esses atores- que, na opinião de RENAUD

${ }^{635}$ Cf. Luis Alberto Pomed SÁnchez, La Proyeccion Exterior de las Comunidades Autonomas Ante el Tribunal Constitucional, in Revista de Administración Pública, no 123, set./dez. 1990, p. 219.

${ }^{636}$ Nesse ponto, com fundamento na obra de JOSÉ ALFREDO DE OLIVEIRA BARACHO, vale assinalar que a estrutura do Estado federal deve guardar alguns aspectos nucleares, sob pena de desfiguração do regime federativo dentre eles constam: o equilíbrio da pluralidade com a unidade; a manutenção da unidade do Estado, para que a descentralização não leve à dissolução da comunidade jurídica; o estabelecimento de relações decorrentes da distribuição de competências, o que pode ser feito mediante participação dos entes federados na formação da decisão dos órgãos centrais e pela coordenação das relações intergovernamentais (Teoria Geral do Federalismo, Belo Horizonte, FUMARC/UCMG, 1982, p. 24).

${ }^{637}$ Cf. Poder Exterior y, Ob. cit., p. 26. Ver também DiRCÊO TORRECILlas RAmos, A Federalização das Novas Comunidades: A Questão da Soberania, Rio de Janeiro, Forense, 2004, p. 59.

${ }^{638}$ Francisco ReZEK, Direito Internacional Público, Ob. cit., p. 323. Aderem a esse posicionamentoCARMEN TiBURCIO e Luís RoBerto BARRoso, que averbam: "Trata-se de conhecimento convencional, de longa data estabelecido no Direito Internacional, que o ato de uma subdivisão política pode implicar a responsabilidade internacional do Estado. A matéria já foi objeto de pronunciamento da Corte Internacional de Justiça e, mais recentemente, foi codificada no art. $4^{\circ}$ do Projeto de Artigos sobre Responsabilidade dos Estados por Atos Internacionais Ilícitos elaborado pela Comissão de Direito Internacional das Nações Unidas" (Direito Constitucional Internacional, Ob. cit., pp. 142-143). 
DEHOUSSE,é precisamente "a diversidade de formas que elas podem assumir" demonstrar a magnitude das interações entabuladas pelos governos autônomos na seara internacional, emprega-se a catalogação apresentada por IVO DUCHACEK, para quem seis fórmulas sintetizam as experiências de maior envergadura até o momento. São elas: $(i)$ criação de escritórios permanentes em capitais ou centros estrangeiros de comércio e de indústria; (ii) viagens ao exterior, bastante promovidas e divulgadas, realizadas por líderes dos referidos governos; (iii) missões profissionais, de curto prazo e para averiguação de fatos, com o objetivo de colher dados e informações para subsidiar ações políticas futuras; (iv) exposições de comércio, serviços e de investimento que exibem know-how tecnológico e industrial dos entes que as promovem; $(v)$ criação de zonas de comércio internacional entre partes alocadas em Estados diversos; (vi) envio de representantes e participação nos trabalhos de conferências e de organizações internacionais ${ }^{640}$.

A comprovação de que os modelos de ações paradiplomáticas já construídos são variados e não uniformes não pode ser tomada como reflexo de descoordenação e fragilidade institucional dessas práticas porque, ao contrário, isso desponta como consequência natural da autonomia assegurada pelo federalismo aos respectivos governos não centrais. Com propriedade, FERnANDA DiAs MENEZES DE AlmeIDA registra que a conformação estrutural do regime federativo é, em essência, um benéfico incentivo à criatividade, na medida em que viabiliza a elaboração de incontáveis arranjos políticoinstitucionais para que seja possível atender as diferentes realidades em que essa forma de Estado é implantada ${ }^{641}$. Infere-se, pois, que a multiplicidade de mecanismos que servem os governos regionais no tocante às relações internacionais indica, seguramente, que tal

\footnotetext{
${ }^{639}$ Fédéralisme et Relations, Ob. cit., p. 238. O estudioso delineia as inúmeras áreas de manifestação da paradiplomacia no excerto que segue: “As mais conhecidas são, naturalmente, os acordos e entendimentos calcados no modelo de tratados concluídos entre os Estados, ou as redes de representação exterior muito desenvolvidas de que dispõem províncias como Ontário ou Quebec, as quais contam, cada uma, com mais de vinte representações no estrangeiro. Isso, porém, trata-se apenas da parte mais visível de um conjunto bem mais vasto. Trocas de informação, consultas, missões de estudos, visitas destinadas à pesquisa de mercados ou ao desenvolvimento de relações comerciais com parceiros estrangeiros, incentivos à exportação: a lista de ações de caráter internacional que as autoridades regionais podem concretizar é longa. Algumas têm somente um caráter ocasional; outras são, ao contrário, parte integrante de um complexo de relações mais institucionalizadas. Uma grande parte dessas interações implica apenas troca de informações; entretanto, outra parcela tem como finalidade estabelecer projetos comuns, que são, por vezes, apresentados em forma de comunicado ou declaração conjunta, quando não chegam a ser, até mesmo, objeto de compromissos mais solenes. Cabe, também, mencionar a existência, simultaneamente às relações bilaterais, de diversos tipos de relações multilaterais" (Idem, pp. 238-239).

${ }^{640}$ Cf. Perforated Soveregnities: Towards a Typology in New Actors in International Relations, in Federalism and International Relations, Hans J. Michelmann e Panayotis Soldatos (org.), Ob. cit., pp. 14-15.

${ }^{641}$ Cf. Considerações Sobre o Rumo do Federalismo nos Estados Unidos e no Brasil, in Revista de InformaçãoLegislativa, Brasília, ano 24, n 96, out./dez. 1987, p. 58.
} 
impulso não se opõe aos postulados mais elementares que conferem vigor às Federações do mundo.

Há que se convir que a grande variedade de atividades que expressam o engajamento exterior das unidades subnacionais torna inviável a análise pormenorizada de cada uma delas, porque isso desviaria por completo as atenções para outros domínios que não a contribuição dos entes federados para dinamizar a abertura do Estado constitucional brasileiro. Em todo caso, em um enfoque estritamente jurídico, é possível empreender um estudo que pontue as características gerais dos atos e contratos criados em tal âmbito, o que facilitará o entendimento das implicações decorrentes dessas manifestações da autonomia federativa $^{642}$. Como se verificará, as ações paradiplomáticas favorecem a criação de ajustes intergovernamentais dotados de nítido caráter bifronte, uma vez que os documentos celebrados para orientar as interações em questão comportam apreciação tanto sob a ótica do Direito das Gentes quanto sob o prisma do Direito Interno.

\subsubsection{Atos e Acordos Paradiplomáticos e Direito Internacional}

De pronto, é preciso esclarecer que os acordos firmados entre unidades federadas não podem ser considerados tratados internacionais, o que, na prática, significa que os referidos entendimentos não geram normas internacionais de natureza convencional, mesmo quando corporificados em textos escritos confeccionados pelos legítimos representantes dos governos subnacionais. Conforme grifa FrANCISCO REZEK, em todo tratado, as partes necessariamente devem ser pessoas jurídicas de Direito Internacional Público, o que compreende os Estados soberanos, organizações internacionais e outros sujeitos reconhecidos pelo Direito das Gentes ${ }^{643}$. São desprovidos dessa personalidade jurídica internacional - e, assim, carecem da capacidade de figurar como pactuantes em convenções internacionais - as empresas privadas e os entes federados ${ }^{644}$.

Nessa direção, o art. $2^{\circ}$ da Convenção de Viena sobre o Direito dos Tratados de 1969 prevê que a definição de tratado remete a um acordo internacional concluído por

\footnotetext{
${ }^{642}$ A relevância de apreciar as práticas paradiplomáticas à luz dos seus aspectos jurídicos é certificada por JosÉ BLANES SALA, que registra que o tema tem sido visto "mais como um fenômeno político do que um objeto de análise jurídica" (Introdução - O Município: De Ator a Sujeito das Relações Internacionais, in $O$ Município e as Relações Internacionais: Aspectos Jurídicos, José Blanes Sala (org.), São Paulo, EDUC, 2009, p. 15).

${ }^{643}$ Direito Internacional Público, Ob. cit., p. 42.

${ }^{644}$ Sobre a ausência de personalidade jurídica de Direito Público Externo das empresas privadas e dos entes federados, consultar, respectivamente, IAN BROWnlie, Princípios de Direito, Ob. cit., p. 80; e HILDEBRANDO Accioly, G. E. do Nascimento e Silva e Paulo Borba CaSella, Manual de Direito, Ob. cit., p. 244.
} 
escrito entre Estados e regido pelo Direito Internacional ${ }^{645}$. O Direito das Gentes, ao eleger a forma escrita e a necessidade de Estados soberanos serem partes contratantes como requisitos de caracterização de suas convenções, manifestou incontroversa opção por elementos extrínsecos e de fácil caracterização como fatores habilitados a delimitar quais acordos internacionais podem ensejar a criação de normas convencionais ${ }^{646}$. Conclui-se, desse modo, que "numa Federação, por serem autônomos todos os seus integrantes, não são eles sujeitos de Direito Internacional Público habilitados a celebrar tratados. Só detém essa qualidade o Estado federal, por quem falará o representante constitucionalmente capaz" 647 .

Acerca da capacidade externa das unidades federadas serem partes em tratados, MaLCOLM N. SHAW menciona que o projeto que originou o texto definitivo da Convenção de Viena sobre o Direito dos Tratados de 1969 “dispunha que 'os Estados-membros de uma União podem ter a capacidade de celebrar tratados, se tal capacidade for contemplada pela constituição federal e permanecer dentro dos limites ali estabelecidos', mas essa ideia foi rejeitada" ${ }^{\prime 48}$. Caso vingasse tal disposição, ter-se-ia inquestionável afronta aos axiomas da Constituição nacional como mecanismo competente para discriminar as competências das partes federadas e do monopólio do Estado soberano para atuar no plano internacional $^{649}$. Colocadas em outros termos, as razões que justificaram a recusa do comando apontado refletem o receio de que tratados celebrados pelos entes autônomos impactassem negativamente na interpretação dos textos constitucionais, bem como a preocupação de impedir possíveis intervenções de Estados estrangeiros em assuntos tipicamente internos dos Estados federais ${ }^{650}$.

Definida, assim, a amplitude jurídica das relações exteriores e certificado que as unidades federadas não possuem o treaty making power, avista-se que a autonomia garante que os governos regionais e locais realizem ações externas, desde que isso não implique exercício do ius contrahendi e se busque atender propostas governamentais inseridas no

\footnotetext{
645 “Art. $2^{\circ}[\ldots]$ 1. Para os fins da presente Convenção: a) 'tratado' significa um acordo internacional concluído por escrito entre Estados e regido pelo Direito Internacional, quer conste de um instrumento único, quer de dois ou mais instrumentos conexos, qualquer que seja sua denominação específica".

${ }^{646}$ Cf. José Augusto Fontoura, Direito dos Tratados: Comentários à Convenção de Viena sobre o Direito dos Tratados (1969), Aziz Tuffi Saliba (org.), Belo Horizonte, Arraes, 2011, p. 12

${ }^{647}$ Fernanda Dias MENEZES DE AlmeIDA, A Incorporação dos, Ob. cit., p. 49.

${ }^{648}$ Direito Internacional, Ob. cit., p. 164.

${ }^{649}$ Cf. Alberto do Amaral JúNIOR, Curso de Direito Internacional, Ob. cit., p. 178.

${ }^{650}$ Cf. Malcolm N. SHaw,Direito Internacional, Ob. cit., p. 164.
} 
raio de competências de cada uma das partes envolvidas ${ }^{651}$. A projeção internacional dessas unidades alcança, por certo, aquelas atividades que guardam estrita compatibilidade com as matérias que lhes são constitucionalmente destinadas, motivo pelo qual "a prática da cooperação transfronteiriça mostra que os acordos de cooperação são, na maioria das vezes, considerados como ações de Direito Interno, às quais se aplica o Direito Público Interno de uma das coletividades envolvidas" ${ }^{\prime 652}$. Mesmo diante de quadros específicos, em que o texto constitucional, expressamente, concede competência para as partes federadas celebrarem tratados, não se tem exceção à regra de que os aludidos entes estão impedidos de participarem, em nome próprio, das interações internacionais tradicionais.

A propósito, explica HÉlÈne TOURARD que as Constituições da Alemanha e da Suíça, apesar de permitirem que unidades federadas desempenhem atos apropriados para a criação de verdadeiras convenções internacionais, trazem bem fixados dois limites para o exercício dessa atribuição. A primeira das restrições concerne ao aspecto material e circunscreve o campo de ação internacional dos Länder $^{653}$ e Cantões ${ }^{654}$ aos temas que integram suas respectivas competências legislativas e materiais; já a segunda limitação é de índole formal e consiste na obrigatoriedade de que haja submissão à aprovação federal de todos os acordos firmados pelas entidades federadas ${ }^{655}$. Registre-se que a Constituição dos Estados Unidos de $1787^{656}$ consagra semelhante dispositivo e, ainda, no contexto da

${ }^{651}$ Cf. M. Antonia Arias MartíneZ, Comunidades Autónomas y, Ob. cit.,p. 371. Reforça esse ponto de vista o excerto retirado da obra de NGUYen Quoc Dinh, PATRICK DAILliER e Alain Pellet: "O chefe do Estado federal representa todos os Estados-membros nas relações internacionais; o Ministro dos Negócios Estrangeiros é um órgão do Estado federal; os agentes diplomáticos e consulares são nomeados pelas autoridades federais e atuam em nome do conjunto dos Estados federados; a responsabilidade internacional em virtude dos comportamentos dos Estados membros é suportada pelo Estado federal; finalmente o Estado federado não é beneficiário da imunidade de jurisdição perante os tribunais estrangeiros" (Direito Internacional Público, Ob. cit., pp. 436-437).

${ }^{652}$ HÉLÈne TOURARD, L'Internationalisation des, Ob. cit., p. 88.

653 “Art. 32 da Constituição da República Federal Alemã de 1949. [...] 3. No âmbito da sua competência legislativa e com a aprovação do Governo federal, os Estados poderão firmar tratados com Estados estrangeiros".

654 “Art. 56 da Constituição Federal da Confederação Suíça de 1999. [...] 1. Um Cantão pode concluir tratados com Estados estrangeiros sobre matérias que se encontram dentro do seu âmbito de competência. 2. Tais tratados não devem entrar em conflito com a lei ou os interesses da Confederação, ou com o direito de todos os outros Cantões. O Cantão deve consultar a Confederação antes de concluir um tratado".

${ }^{655} \mathrm{Cf}$.L'Internationalisation des, Ob. cit., p. 158. Consultar ainda KONRAD HESSE, Elementos de Direito, Ob. cit., p. 204; Peter Pernathaler, Lo Stato Federale Differenziato, Bolonha, Il Mulino, 1998, pp. 90-91; Daniel ThÜrer e Malcolm Maclaren, Swiss Confederation, in Foreign Relations in Federal Countries (A Global Dialogue on Federalism,vol. V), Hans Michelmann (ed.), Ob. cit., pp. 283-287; GREG CRAVEN, Federal Constitutions and External Relations, in Foreing Relations and Federal States, Brian Hocking (ed.), Londres e Nova Iorque, Leicester University Press, 1993, pp. 12-13; e LuZIUS WILDHABER, Switzerland, in Federalism and International Relations, Hans J. Michelmann e Panayotis Soldatos (org.), Ob. cit., pp. 252253.

656 “Artigo $1^{\circ}$ da Constituição dos Estados Unidos da América de 1787. [...] Seção 10, 3. Nenhum Estado poderá, sem o consentimento do Congresso, lançar qualquer direito de tonelagem, manter em tempo de paz 
América Latina, a Constituição argentina de $1995^{657}$ é pródiga ao reproduzir parecida prescrição constitucional em benefício de suas províncias.

Interessa advertir que as referidas autorizações constitucionais, encarregadas de disciplinar a participação das partes federadas no processo de criação de tratados internacionais, evidenciam uma manifesta e muito significativa atuação do poder central em tal assunto. Extrai-se dos exemplos narrados acima que é da Federação o poder de autorizar os governos subnacionais a negociar convenções cujo conteúdo deve versar sobre temas incluídos na lista de suas competências constitucionais; e, além disso, o governo federal pode sempre rejeitar as propostas de tratados definidas pelos entes regionais e locais - o que, por conseguinte, equivale à não adoção da norma internacional convencional pelo Estado federal. Os mecanismos de controle, voltados a resguardar o interesse do conjunto federativo e a evitar desvios em relação à política exterior traçada pela Federação, ao demandarem a intervenção do poder central no processo descrito, transformam as convenções celebradas por um ente federado específico em norma internacional vinculante para o Estado nacional como um todo.

Não se pode confundir os condicionantes que incidem na pretensão das unidades federadas de atuarem ativamente no campo dos tratados e convenções internacionais com as ações que são deflagradas pelos governos não centrais com a finalidade de formalizar convênios externos com outros entes autônomos. Ainda que não possam, enquanto pessoa jurídica, assumir a condição de parte nas relações exteriores orientadas pelo Direito Internacional não é proibido, todavia, que entes federados direcionem esforços tendentes “à prática de atos ou à celebração de contratos de natureza privada com entidades estrangeiras, para o que não é necessária essa espécie de personalidade jurídica qualificada" ${ }^{958}$. Como será exposto no próximo tópico, na ocasião em que os acordos e atos negociais internacionais estabelecidos entre governos subnacionais serão analisados

exércitos ou navios de guerra, concluir tratados ou alianças, quer com outro Estado, quer com potências estrangeiras, ou entrar em guerra, a menos que seja invadido ou esteja em perigo tão iminente que não admita demora". Ao analisar o citado mandamento constitucional, FABIEN GÉLINAS pondera que "o efeito do consentimento do Congresso é o de transformar um pacto interestadual em uma lei dos Estados Unidos, com a consequente supremacia legislativa sobre as leis estaduais e jurisdição em relação às Cortes federais" (The Constitution of Agreement: A Brief Look at Sub-Federal Cross-Border Cooperation, in Michigan State Law Review, ${ }^{\circ}$ 5, 2006, p. 1181).

657 “Artigo 125 da Constituição da Nação Argentina de 1995. As Províncias podem celebrar tratados parciais para fins de administração da justiça, dos interesses econômicos e obras de utilidade pública, com o conhecimento do Congresso Federal, e promover a sua indústria, a imigração, a construção de ferrovias e canais navegáveis, a colonização das terras provinciais, a introdução e estabelecimento de novas indústrias, a importação de capital estrangeiro e de exploração seus rios, por meio de leis que protegem esses fins, e com seus próprios recursos".

${ }^{658}$ CARMEN TIBURCIO e Luís Roberto BARroso,Direito Constitucional Internacional, Ob. cit., p. 129. 
sob as lentes do Direito Interno, restará claro que a maior parcela de documentos resultantes das interações paradiplomáticas assumem a forma de convênios administrativos.

Considerados, em uma acepção genérica, acordos informais, os ajustes que unem entidades autônomas localizadas em Federações distintas, ainda que não sejam aptos a originar normas internacionais convencionais, têm, obviamente, alguma relevância jurídica para o Direito das Gentes. Impõe-se, dessa feita, indicar como tais documentos usualmente chamados de acordos, memorandos de entendimentos, protocolos de intenções - são tipificados pelo sistema jurídico internacional, a fim de identificar quais efeitos podem deles ser retirados. Sem dúvida, a informalidade que acompanha as atividades federativas direcionadas ao exterior constitui aspecto sobressalente na aferição da exigibilidade jurídica ou não do teor inscrito nesses compromissos governamentais ${ }^{659}$.

Sob essa perspectiva, talvez a mais proeminente característica das relações em destaque seja o acentuado traço de personalismo que acompanha os acordos formalizados, consoante sublinhado por José ViCENTE DA SILVA. Com efeito, esse fator acaba repercutindo decisivamente na etapa de execução do conteúdo consignado nos documentos concluídos pela paradiplomacia, uma vez que a inexistência de obrigação jurídica de cumprir o que fora aventado faz sua implementação depender de modo exclusivo do empenho pessoal das lideranças envolvidas ${ }^{660}$. Na esteira do que é ressaltado por HANs J. MichelmanN, os acordos em comento assumem, para o Direito Internacional, a natureza de autênticos gentlemen's agreement, responsáveis por favorecer a conjugação de iniciativas governamentais entre entes autônomos acerca de matérias diversificadas, a exemplo do turismo, investimentos, cultura e preservação de florestas transfronteiriças ${ }^{661}$.

Mostra-se oportuno apresentar, nesse ponto, a distinção entre tratado internacional e gentlemen's agreement, pois importantes consequências jurídicas decorrem do correto enquadramento de um acordo internacional em uma ou em outra dessas espécies. Cabe anotar que "o gentlemen's agreement não é um tratado pela razão elementar de que os contratantes não são pessoas jurídicas de Direito Internacional, não são Estados. São pessoas humanas, investidas em cargos de mando, e hábeis para assumir externamente -

${ }^{659}$ Cf. TAtiana Lacerda Prazeres, Por uma Atuação Constitucionalmente Viável das Unidades Federadas Brasileiras Ante os Processos de Integração Regional, in A Dimensão Subnacional e as Relações Internacionais, Tullo Vigevani, Luiz Eduardo Wanderley, Maria Inês Barreto, Marcelo Passini Mariano (org.), Ob. cit., pp. 302-303.

${ }^{660}$ Cf. Paradiplomacia no Brasil, Ob. cit., p. 127.

${ }^{661}$ Cf. Conclusion, in Foreign Relations in Federal Countries (A Global Dialogue on Federalism, vol. V), Hans Michelmann (ed.), Ob. cit., p. 338-339. 
sobretudo em matéria prospectiva - compromissos de pura índole moral, cuja vitalidade não ultrapassará aquele momento em que uma dessas pessoas deixe a função governativa" ${ }^{662}$. São, assim, os compromissos intergovernamentais exteriores acordos de cavalheiros, cuja carga de juridicidade e vínculo estabelecido não os fazem semelhantes aos tratados, em especial porque carecem de obrigatoriedade internacional.

O fato de terem natureza jurídica diversa daquela dos tratados não significa, entretanto, que os acordos federativos internacionais sejam absolutamente irrelevantes para o Direito Internacional. Deve-se lembrar que o estágio atual das relações internacionais indica "que as formas de manifestação de cooperação são múltiplas. Elas alcançam desde formas 'frouxas' (por exemplo 'relações coordenadas') até formas 'mais densas': da concepção e da realização cooperativa de 'tarefas comunitárias' em processos e instituições comuns ou da fundação de composições supranacionais, etc. Várias formas de cooperação se encontram ainda na forma evidentemente imprecisa da soft law ou nas suas pré-formas não vinculantes" ${ }^{\prime 63}$. De tal sorte, como assinala JOHN KINCAID, para os padrões do ordenamento internacional, os ajustes externos formalizados entre entes autônomos representam concretas manifestações da denominada soft law ou direito suave ${ }^{664}$.

No que tange à definição do soft law, SALEM HiKMAT NASSER informa que sua emergência está diretamente ligada com a participação de outros atores nas relações exteriores que não os Estados soberanos. Como observou o autor, o termo soft law "tem, atualmente, seu sentido expandido para abarcar aquelas atividades e contatos internacionais que são praticados por indivíduos, empresas, organizações não governamentais e outros, atividades e contratos esses que servem a variados propósitos, e que independem dos Estados ou, ao menos, não se dão no âmbito das relações interestatais" estrutural, reflete mais um elemento decorrente da globalização, tendo em conta que seu

\footnotetext{
${ }^{662}$ Francisco ReZeK, Direito Internacional Público, Ob. cit., p. 43. Consultar também AlBerto DO Amaral Júnior, Curso de Direito Internacional, Ob. cit., p. 178; Celso D. De AlbuQuerque Mello, Curso de Direito Internacional Público, vol. 1, Ob. cit., p. 193; e Marcelo D. VARELlA, Direito Internacional Público, $4^{\mathrm{a}}$ ed., São Paulo, Saraiva, 2012, pp. 44-45.

${ }^{663}$ PETER HÄBERLE, Estado Constitucional Cooperativo, Ob. cit., pp. 13-14.

${ }^{664}$ Cf.Constituent Diplomacy in Federal Polities and the Nation-State: Conflict and Cooperation, in Federalism and International Relations, Hans J. Michelmann e Panayotis Soldatos (org.), Ob. cit., p. 71.

${ }^{665}$ Fontes e Normas do Direito Internacional: Um Estudo sobre a Soft Law, $2^{\mathrm{a}}$ ed., São Paulo, Atlas, 2006, pp. 114-115.
} 
aparecimento "não afeta o Direito, mas, ao contrário, torna-o mais complexo, multiplicando-lhe as fontes"

No fundo, da comparação entre hard law e soft law, conclui-se que o direito suave desenvolveu-se porque a hard law - cujos exemplos são os tratados formais e os acordos vinculantes aos Estados soberanos - é tida como rígida demais e, portanto, inadequada para atender as necessidades advindas das novas circunstâncias que requerem disciplina do Direito Internacional. Negociações longas são, com frequência, exigidas para obter a hard law e, por vezes, conflitos políticos e posturas inflexíveis dos governos nacionais dificultam a conclusão de normas internacionais rígidas, o que eleva a oportunidade de emprego, no âmbito das relações exteriores, de instrumentos mais flexíveis e dinâmicos, como é daqueles considerados soft law ${ }^{667}$. Ainda que lhe falte exigibilidade internacional, o Direito das Gentes não pode simplesmente ignorar o conjunto destes atos e acordos, porque, sem dúvida, o direito suave "é significativo para assinalar a evolução e a fixação de diretrizes, que poderão a certa altura ser convertidas em normas legalmente obrigatórias. Tais diretrizes são importantes e influentes, mas, por si, não constituem normas jurídicas"

A ideia subjacente à admissão generalizada da soft law - qual seja, o sentimento de que os esquemas tradicionais de produção da norma internacional estão incapacitados de responder a todos os segmentos que exigem hoje normatização ${ }^{669}$ - encontra pontos de intersecção nas causas que contribuíram para o surgimento das ações federativas transfronteiriças. O recente desenvolvimento da paradiplomacia, somado à proibição de entes federados figurarem como partes vinculadas em tratados internacionais, é forte sinal de que, em vez de tentar regular os acordos subnacionais com outros governos estrangeiros, pela via da hard law, deve-se explorar as possibilidades ofertadas pelas regras que formam a soft law ${ }^{670}$. Nessa direção é que se destaca a intensa participação de atores

\footnotetext{
${ }^{666}$ PAOlO SPADA, Regole e Giurisdizioni in Concorrenza: Il Crepusculo dela Soveranità, Editorale Scientifica, 2009, pp. 12-13.

${ }^{667}$ Cf. JOHN KINCAID, Constituent Diplomacy in Federal Polities and the Nation-State: Conflict and Cooperation, in Federalism and International Relations, Hans J. Michelmann e Panayotis Soldatos (org.), Ob. cit., p. 71. A fim de ilustrar os documentos internacionais que podem ser considerados parte do direito suave, GUIDO FERNANDO SILVA SOARES pontua que "as denominações das normas que integram a soft law têm variado: non binding agreements, gentlemen's agreements, códigos de conduta, memorandos, declaração conjunta, declaração de princípios, ata final e até mesmo apelações mais comumente reservadas aos tratados internacionais, como: acordos e protocolos" (Curso de Direito, Ob. cit., p. 138).

${ }^{668}$ MalCOLM N. SHAW, Direito Internacional, Ob. cit., p. 93.

${ }^{669}$ Cf. GuIdo Fernando Silva SoARES, Curso de Direito, Ob. cit., p. 137.

${ }^{670} \mathrm{Cf}$. JOHN KINCAID, Constituent Diplomacy in Federal Polities and the Nation-State: Conflict and Cooperation, in Federalism and International Relations, Hans J. Michelmann e Panayotis Soldatos (org.), Ob. cit., pp. 71-72.
} 
desprovidos de personalidade jurídica internacional na produção do direito suave, pois restam a eles apenas a soft law para que possam promover seus variados interesses mediante relações jurídicas que tomam forma para além de suas fronteiras ${ }^{671}$.

Depois de exposto o cenário que favoreceu o aumento sem precedentes da atuação externa das unidades federadas, cumpre arrematar que os documentos jurídicos resultantes das interações exteriores entre unidades autônomas têm importância secundária para o Direito Internacional. Em virtude de não configurarem autênticas convenções internacionais orientadas pelo Direito das Gentes, bastante restrito se apresenta o campo de interesse dos internacionalistas na matéria, de forma que as maiores contribuições para a compreensão do fenômeno jurídico em questão deve ser prestada pelo Direito Interno - em especial pela doutrina administrativista, encarregada de estudar os ajustes consensuais entre entidades públicas que buscam alcançar interesses comuns. Os gentlemen's agreement derivados da convergência de interesses entre autoridades subnacionais engajadas em relações internacionais tendem a instituir benefícios recíprocos para os entes contratantes, mas, porque pertencem à categoria da soft law, nada pode o Direito Internacional fazer para assegurar seu efetivo cumprimento.

Tentativas de aplicar os institutos e as regras convencionais do Direito Internacional para explicar a elaboração e a execução dos atos e acordos paradiplomáticos retratam métodos inapropriados de entender o que, de fato, acontece. Essas ações pouco (na verdade, quase nada) dependem dos dogmas reproduzidos por esse ramo da ciência jurídica, dado que os textos e registros jurídicos produzidos não são aptos a gerar normas internacionais exigíveis. Ao que tudo indica, os principais estudiosos nacionais sobre o tema perfilham uma abordagem que parte de uma premissa incorreta: a suposição de que a inserção das unidades autônomas no plano internacional "vem sendo levada a cabo sob uma aparente ilegalidade, haja vista a falta de previsão normativa para tanto, o que gera uma inegável insegurança jurídica"672.

A ausência de expressiva normativa internacional acerca das matérias afeitas à paradiplomacia não pode, sob nenhum ângulo, ser interpretada como falta de respaldo jurídico para o desenvolvimento dessas relações intergovernamentais. Isso, ao contrário,

${ }^{671}$ Cf. Gregory C. Shaffer e Mark A. Pollack, Hard vs. Soft Law: Alternatives, Complements, and Antagonists in International Governance, in Minnesota Law Review, vol. 94, p. 790.

${ }^{672}$ Cf. Álvaro Chagas Castelo Branco, Paradiplomacia \& Entes, Ob. cit., p. 119; José ViCEnTE DA Silva LeSSA, Paradiplomacia no Brasil, Ob. cit., p. 150; José Flávio Sombra SARAIVA, Federalismo e Relações Internacionais do Brasil, in Relações Internacionais do Brasil: Temas e Agendas, vol. 2, Henrique Altemani de Oliveira e Antônio Carlos Lessa (org.), Ob. cit., pp. 447-448; e MARINANA ANDRADE E BARROS, A Atuação Internacional, Ob. cit., p. 87. 
ressoa como consequência lógica da natureza dos entendimentos formalizados, os quais dependem de normas jurídicas pertencentes aos ordenamentos nacionais dos Estados envolvidos. A análise do funcionamento das relações federativas transfronteiriças, à luz das regras e institutos do Direito Interno, ajuda a esclarecer que as teorias levantadas por muitos acadêmicos, embora pareçam ser um espinhoso problema, na prática, não passam de um fenômeno menos surpreendente do que a empolgação inicial que o novo e pouco explorado, geralmente, faz parecer ser.

\subsubsection{Atos e Acordos Paradiplomáticos e Direito Interno}

Entre as muitas variantes que devem ser ordenadas pela Constituição que organiza política e administrativamente o Estado federal, o tópico das relações externas é uma pauta de difícil definição. Existe uma dificuldade intrínseca à tarefa de distribuir, nos diversos níveis governamentais, poder político para que os entes possam atuar externamente, uma vez que é preciso assegurar ao poder central domínio suficiente para executar uma política externa que congregue todo o conjunto federativo sem, todavia, proibir que as partes federadas persigam seus próprios interesses no ambiente internacional ${ }^{673}$. Cabe, assim, encontrar no rol de competências constitucionais o fundamento precípuo que orientará as ações desempenhadas pelas unidades subnacionais, seja em assuntos cuja natureza esteja visivelmente ligada à acomodação interna dos interesses regional e local, seja em matérias que explicitem a atuação exterior dos mencionados entes autônomos.

Como é dedutível, a cooperação transfronteiriça tem suas principais bases de justificação no Direito Interno. Não é, portanto, sem motivos que o Direito Internacional sempre indica os ordenamentos nacionais como as fontes adequadas para definir as capacidades internacionais que, eventualmente, pertençam às partes federadas. Nesse compasso, tem-se observado que, em Federações onde as atividades governamentais não centrais também incluem o desenvolvimento de interações internacionais, "a liberdade de auto-organização tem servido de base jurídica para a criação de ministérios e de agências especializadas em questões internacionais, assim como tem permitido o estabelecimento de redes de representações externas" ${ }^{\prime 674}$. São estabelecidas inúmeras conexões, vinculando, de um lado, entes federados pertencentes a uma Federação específica, a, de outro lado, unidades governamentais alocadas em outro Estado soberano (entes federados, regiões

${ }^{673}$ Cf. Greg Craven, Federal Constitutions and External Relations, in Foreing Relations and Federal States, Brian Hocking (ed.), Ob. cit., p. 11.

${ }^{674}$ RenAud DeHOUSSE, Fédéralisme et Relations, Ob. cit., p. 240. 
autônomas, regiões administrativas). Também é possível que essas relações envolvam governos subnacionais de um Estado tanto com poder central de outros Estados soberanos quanto com organismos internacionais ${ }^{675}$.

As experiências de paradiplomacia, embora tenham impactos pouco abrangentes para o Direito das Gentes, implica consequências significativas para o exercício das competências administrativas ou materiais de inúmeros governos federados. Isso porque, cada vez mais, os programas estatais precisam ser idealizados em atenção ao fenômeno do adensamento de redes de interdependência, que caracteriza a globalização multidimensional e impõe mudanças na forma de optar, escolher e decidir quais ações governamentais implementar ${ }^{676}$. Diante desse quadro, “insere-se a paradiplomacia como uma das alternativas que permitem uma releitura do Estado, objetivando promover melhor interação entre a esfera de poder central e o regional/local, bem como uma maior efetivação das políticas sociais" $"$.

E porque os ajustes externos entre governos federados não podem criar tratados internacionais é que estes devem ser entendidos como convênios internacionais, celebrados em conformidade com as regras do Direito Administrativo editadas, individualmente, pelas Federações envolvidas. Trata-se de uma avença firmada por entidades políticas que buscam alcançar escopos comuns mediante práticas cooperativas que se desenrolam no plano exterior, vinculando unidades autônomas convenentes inseridas em Estados federais diversos e que somam esforços para concretizar suas respectivas competências federativas. Em uma outra perspectiva, vê-se que a conclusão desses acordos desemboca no processo da internacionalização da Administração Pública, descrito por EBERHARD SCHMIDTABMANN a partir da realização de atos típicos de gestão pública por autoridades governamentais de um país em espaços que ultrapassam suas fronteiras nacionais, fato que

\footnotetext{
${ }^{675}$ FRANCISCO REZEK menciona exemplo de ajuste entre unidade federada e organização internacional, como comprova o trecho que segue: "O Diário Oficial de 11 de junho de 1970 estampou o texto integral de um 'contrato de empréstimo' entre o Banco Interamericano de Desenvolvimento e o Estado de Minas Gerais, celebrado em 26 de maio daquele mesmo ano. O Banco em questão é uma organização internacional regional, de índole financeira, dotada de indiscutida personalidade jurídica no plano do Direito das Gentes" (Direito Internacional Público, Ob. cit., p. 279).

${ }^{676} \mathrm{Cf}$. Marcelo Fernandes Oliveira e Caroline Klaus Luvizotto, Cooperação Técnica Internacional: Aportes Teóricos, in Revista Brasileira de Politica Internacional, $\mathrm{n}^{\circ}$ 54, 2011, p. 8.

${ }^{677}$ LuCiana Santos Pontes De Miranda, A Capacidade do Estado-membro da Federação Celebrar Tratados Internacionais, in Revista da ESMAFE - Escola de Magistratura Federal da $5^{a}$ Região, no 14, 2007, p. 175.
} 
indica fortalecimento da ideia de que o princípio da territorialidade do Direito Administrativo vai deixando, aos poucos, de ser um valor absoluto ${ }^{678}$.

A infinidade de acordos possíveis entrelaçando governos subnacionais, apesar de não se afirmarem como normas positivas internacionais, claramente envolve assuntos de política estatal e, por essa razão, "não podem ser facilmente equiparados a um contrato comum sobre questão estritamente comercial" ${ }^{679}$. Parece, de fato, que os acordos corporificam uma paradigmática espécie de ajuste voltada a potencializar a tendência de construção de um Direito das relações administrativas internacionais, o qual persegue dois objetivos predominantes: a proteção dos direitos individuais frente a Administração; e o fornecimento de procedimentos e mecanismos que viabilizam o eficaz cumprimento das funções públicas ${ }^{680}$. Esses acordos são, pois, resultado das contingências ditadas pela globalização e de mudanças nos sistemas administrativos estatais, principalmente nas áreas em que os interesses comuns se viram afetados pela proximidade dos problemas econômicos, sociais, ambientais e culturais dos países ${ }^{681}$.

Pressente-se que a maior aposta do Direito Administrativo Internacional são os mecanismos de cooperação vertical e horizontal para vencer os desafios advindos do entrecruzamento de ordens jurídicas, uma vez que tanto o Direito Interno quanto o Direito Internacional devem trabalhar em sintonia para atender os complexos reclamos da contemporaneidade. Nessa empreitada, o Direito Constitucional ocupa posição imprescindível porque ao Direito Administrativo - inclusive, em sua feição internacionalista - incumbe "dar organização complementar ao Estado constituído, para essas atuações, perquirindo juridicamente os diferentes modos em que se apresenta sua organização" 682 . Dito em outras palavras, "o Direito Administrativo consistiria em meios de desenvolvimento, desdobramento, concretização, transformação em ato, dos princípios e instituições do Direito Constitucional" ${ }^{\prime 683}$.

A abertura do Direito Constitucional às interações exteriores enredadas nas suas mais diversas modalidades figura como substrato para que o Direito Administrativo possa igualmente se adaptar ao panorama descrito. Sob tal influxo, conclui-se que os acordos

\footnotetext{
${ }^{678}$ Cf. La Ciencia del Derecho Administrativo Ante el Reto de la Internacionalización de las Relaciones Administrativas, in Revista de Administración Pública, n 171, set./dez. 2006, p. 9.

${ }^{679}$ FABIEN GÉLINAS, The Constitution of, Ob. cit., p. 1189.

${ }^{680}$ Cf. EBERHARD SCHMIDT-ABMANn,La Ciencia del, Ob. cit., p. 9.

${ }^{681}$ Cf. Maria de Jesus Rodrigues Araújo Helimann, Globalização e o Novo Direito Administrativo, Curitiba, Juruá, 2010, pp. 277-278.

${ }^{682}$ Oswaldo Aranha BandeIra de Mello, Princípios Gerais de, Ob. cit., p. 73.

${ }^{683}$ J. H. MeIRELles TeIXEIRA, Curso de Direito, Ob. cit., p. 15.
} 
transfronteiriços preconizam um modelo de cooperação administrativa mais participativo, em que se reconhecem governos autônomos como parceiros importantes das tradicionais relações Estado-Estado ${ }^{684}$. Assinalada a amplitude interna das atividades paradiplomáticas, coloca-se como necessário investigar um aspecto que FABIEN GÉLINAS adverte permanecer em grande parte indefinido: o estatuto jurídico dos contratos, acordos, termos de parceiras e instrumentos análogos instituídos entre as unidades autônomas, com base nas respectivas normas internas ${ }^{685}$.

Sedimentados os traços jurídicos ofertados pelo Direito das Gentes a respeito dos ajustes federativos de cooperação internacional (considerados, consoante desenvolvido acima, espécies que integram a soft law), cumpre entendê-los sob o pálio do Direito Interno. Rechaça-se, aprioristicamente, a opinião de José VICENTE DA SILVA LESSA no sentido de que, "além da sua informalidade e da resultante ausência de juridicidade, alguns dos atos examinados revelam certas carências que não poderiam admitir em atos de pleno direito" ${ }^{686}$. Essa conclusão retrata patente equívoco, na medida em que se opõe ao postulado da legalidade administrativa, o qual é "aceito universalmente, e é uma consequência do sistema de legislação escrita e da própria natureza da função administrativa" ${ }^{687}$.

Por certo, ainda que os acordos paradiplomáticos sejam incapazes de perfazer atos que se incorporam aos ordenamentos nacionais com status de lei ou outro ato normativo, eles não podem ser confeccionados ao arrepio da legislação vigente em cada Estado federal. Verifica-se que esses ajustes encontram no Direito Administrativo embasamentos adequados, o que lhes confere a forma de autênticos convênios administrativos elaborados para terem eficácia para além dos territórios que abrigam as partes convenentes. Fixada a categoria jurídica das referidas avenças, é interessante apresentar os aspectos gerais que orientam o estabelecimento dos convênios entre governos a fim de contribuir para a delimitação dos reflexos jurídicos que lhes podem ser atribuídos.

Saber que os acordos internacionais entre entes federados representam convênios administrativos não encerra as discussões a respeito do significado que possuem para Direito Interno, haja vista que o Direito Administrativo pátrio não tem esse tema como

${ }^{684}$ Cf. Marcelo Fernandes Oliveira e Caroline Klaus Luvizotto, Cooperação Técnica Internacional, Ob. cit., p. 19.

${ }^{685}$ The Constitution of, Ob. cit., p. 1190.

${ }^{686}$ Paradiplomacia no Brasil, Ob. cit., p. 126.

${ }^{687}$ Miguel Seabra Fagundes, O Controle dos Atos Administrativos pelo Poder Judiciário, $8^{\mathrm{a}}$ ed., Rio de Janeiro, Forense, 2010, p. 115. 
pacificado - e, averbe-se, agregar a ele elementos de internacionalização tende a complicar ainda mais sua compreensão. No que é atinente às controvérsias que cercam os ajustes intergovernamentais em questão, THIAGO MARRARA aduz que, “em primeiro lugar, não há posicionamentos claros, nem na doutrina, nem na jurisprudência, sobre quais sejam os elementos essenciais do convênio administrativo. Não existe sequer unanimidade sobre a natureza jurídica desse instrumento, quer como espécie de contrato administrativo, quer como outra espécie qualquer de ato jurídico. Em segundo lugar, por consequência dessa indefinição conceitual resultam dificuldades para se desenhar o regime jurídico estrutural que os rege, impossibilitando a compreensão dos limites de aplicabilidade de regras e princípios de licitação e contratos administrativos sobre eles" ${ }^{, 688}$.

Nessa órbita, não obstante haver forte divergência quanto à natureza jurídica dos convênios administrativos ${ }^{689}$, é notável serem hoje uma ferramenta vital para governos autônomos concretizarem suas tarefas constitucionais, em especial serviços públicos que requerem articulação de esforços entre diferentes setores. A internacionalização do Direito Interno transforma os convênios transfronteiriços em solução viável para contornar impasses administrativos, bem como para induzir práticas governamentais adequadas ao interesse público, que incidem no contexto de mais de uma Federação, sem, no entanto, justificarem a formação de tratados internacionais. A autorização para celebrar os convênios é um claro desdobramento da autonomia desfrutada pelas unidades federadas, isto é, a "capacidade de autodeterminação dentro do círculo de competências traçado pelo poder soberano, que lhes garante auto-organização, autogoverno, aulolegislação e autoadministração, exercitáveis sem subordinação hierárquica dos Poderes estaduais aos Poderes da União" ${ }^{690}$.

\footnotetext{
${ }^{688}$ Identificação de Convênios Administrativos no Direito Brasileiro, in Revista da Faculdade de Direito da USP, vol. 100, jan./dez. 2005, pp. 551-552.

${ }^{689}$ Entre outros, posicionam-se pelo caráter contratual dos convênios administrativos: FERNANDO DIAS Menezes de AlmeidA, Contrato Administrativo, Quartier Latin, São Paulo, 2012, p. 243; OdeTE MedAUAR, Convênios e Consórcios Administrativos, in Boletim de Direito Administrativo, $\mathrm{n}^{\circ}$ 8, 1995 pp. 456-457; Celso Antônio Bandeira de Mello, Curso de Direito Administrativo, 30 a ed., São Paulo, Malheiros, 2013, pp. 679-682; MARÇAL Justen FILHO, Comentários à Lei de Licitação e Contratos Administrativos, $10^{\mathrm{a}}$ ed., São Paulo, Dialética, 2004, p. 641; Thiago Marrara, Identificação de Convênios, Ob. cit., pp. 559565; Gustavo Alexandre Magalhães, Convênios Administrativos: Aspectos Polêmicos e Análise Crítica de seu Regime Jurídico, São Paulo, Atlas, 2012, pp. 169-198. Em oposição, defendem que esses ajustes não podem ser tomados como tipos de contratos: MARIA SYlvia ZANElla Di PIETRO, Direito Administrativo, $26^{\mathrm{a}}$ ed., São Paulo, Atlas, 2013, pp. 349-350; Edmir NeTto De Araújo, Curso de Direito Administrativo, $3^{\text {a }}$ ed., São Paulo, Saraiva, 2007, pp. 690-691; José dos SAntos CARVAlho Filho, Manual de Direito Administrativo, $26^{\mathrm{a}}$ ed., São Paulo, Atlas, 2013, pp. 224-225.

${ }^{690}$ Fernanda Dias Menezes de Almeida, Competências na Constituição de 1988, 6 a ed., São Paulo, Atlas, 2013, p. 11.
} 
Com o propósito de mapear as implicações jurídico-administrativas decorrentes das relações paradiplomáticas, interessa explicar que "não existe no ordenamento jurídico, nem mesmo implicitamente, vedação para que qualquer pessoa jurídica, de Direito Público ou Privado, celebre convênio administrativo. Vale dizer que não há limitações para a celebração em razão da natureza jurídica dos partícipes. Por isso, seria possível a celebração de convênio entre: [...] entes públicos nacionais e estrangeiros"691. É factível, com base nos paradigmas do Direito Administrativo, destacar que o que caracteriza os ajustes é a aferição de "uma mútua colaboração, que pode assumir várias formas, como repasse de verbas, uso de equipamentos, de recursos humanos e materiais, de imóveis, de know-how e outros; por isso mesmo, no convênio não se cogita de preço ou remuneração, que constitui cláusula inerente aos contratos" ${ }^{\prime 692}$.

Outra constatação que fortalece o entendimento de que os acordos externos federativos são convênios administrativos é a ausência de vinculação contratual que os caracteriza. Na linha do que enfatiza EDMIR NETTO DE ARAÚJO, todos os partícipes dessa espécie de ajuste são alocados "na mesma posição de igualdade, sem a preponderância característica dos contratos administrativos, pois a execução e operacionalidade de convênios fundamenta-se basicamente na confiança recíproca e na cooperação, colaboração e permanência voluntárias dos partícipes, enquanto desejam essa permanência" ${ }^{693}$. A voluntariedade na execução do que fora convencionado também é um traço marcante dos atos federativos de cooperação internacional, o que enaltece sobremaneira a incidência da disciplina administrativista para explicá-los.

Embora alguns acreditem que a inexistência de vinculação obrigacional faz dos convênios intergovernamentais exteriores uma realidade perturbadora, essa visão não retrata a real substância dos mesmos. A anunciada "ausência de garantia de continuidade na execução dos acordos, mormente quando a unidade federada passa para o governo de adversários políticos" ${ }^{\prime 694}$ não desfigura a relevância que os convênios possuem para a implementação de ações governamentais concertadas, tampouco é um sintoma de ilegalidade ou extrapolação de competências por parte dos entes não centrais. Esses

\footnotetext{
${ }^{691}$ Thiago Marrara, Identificação de Convênios, Ob. cit., p. 557. Fernando Dias MeneZes De AlmeidA, em contraposição, preconiza que "o convênio é, no Brasil, no mais das vezes, instrumento para a criação de situação subjetiva - ainda que envolvendo interesses convergentes - e, nesse aspecto, merece receber o mesmo tratamento jurídico do contrato (no sentido estrito que lhe dá tradicionalmente a doutrina) (Contrato Administrativo, Ob. cit., p. 243).

${ }^{692}$ Maria Sylvia Zanella Di Pietro, Direito Administrativo, 26 a ed., São Paulo, Atlas, 2013, p. 350.

${ }^{693}$ Curso de Direito Administrativo, $3^{\mathrm{a}}$ ed., São Paulo, Saraiva, 2007, pp. 690-691.

${ }^{694}$ Cf. José VICENTE DA Silva LeSSA, Paradiplomacia no Brasil, Ob. cit., p. 127.
} 
acordos encarnam, na verdade, manifestações de uma consciência despertada pela complexidade dos problemas transnacionais colocados aos governos autônomos, que passam a compreender os potenciais benefícios da assunção voluntária de deveres com o mundo externo quando se buscam saídas combinadas para desafios comuns.

A falta de compreensão do fenômeno e a inaptidão para guiar as relações paradiplomáticas atestam que o Direito Internacional não é o ramo da ciência jurídica mais indicado para instituir uma efetiva normativa acerca da matéria. Por ser uma consequência - sentida no âmbito subnacional de governo - da aceleração do processo de interdependência entre as nações, a paradiplomacia demanda atenção e aperfeiçoamento por meio de trabalhos a serem desenvolvidos com mais propriedade pelos estudiosos do Direito Público Interno. Essa conclusão não significa, entretanto, que devem ser excluídas as contribuições que sempre podem ser ofertadas pelos internacionalistas, em especial quando se recorda do fato de que as Constituições nacionais têm progressivamente indicado um movimento de abertura aos ditames e institutos típicos do Direito das Gentes.

Os ajustes externos firmados entre entes federados são mais uma evidência do quadro colocado por CARLO AMIRANTE, no qual a globalização e o avanço das relações internacionais convidam os "constitucionalistas a olharem para o futuro não só com realismo e frieza, mas também com a disposição de quem tem um papel não marginal a desempenhar" ${ }^{\circ 95}$. Certamente é hora de superar construções lastreadas no ideário do século XVIII, quando os alicerces do federalismo foram fincados, para que se vislumbre uma dimensão das relações internacionais que, ao lado da política externa nacional e em conformidade com suas diretrizes, é desenvolvida pelas unidades autônomas na consecução das competências constitucionais que lhes atribuem capacidade para solucionar problemas governamentais, inclusive quando há o transbordamento da fronteira do Estado federal. A menos que, por comodidade e conformismo, se permaneça preso aos conceitos tradicionais sobre a organização do Estado, o regime federativo precisa acomodar essa necessidade, sob pena de prejudicar o autogoverno em alguns setores da vida pública.

Uma última observação a ser feita consubstancia-se na impressão de que, caso os cultores do Direito Internacional não se tivessem distanciado do Direito Interno, provavelmente já teriam percebido que não há nada de inquietante nos convênios administrativos transfronteiriços. Sem dúvida, as normas internas apresentavam importância para as relações internacionais desde muito antes de os entes federados

${ }^{695}$ Uniões Supranacionais e Reorganização Constitucional do Estado, São Leopoldo, Editora Unisinos, 2003, p. 55. 
iniciarem contatos permanentes com o exterior. Mas o florescimento da cooperação técnica internacional entre unidades autônomas aumentou demasiadamente a relevância dos ordenamentos nacionais para o tratamento de temas antes integrantes apenas da agenda internacional. A paradiplomacia deve, portanto, ser agregada como mais um dos fatores que certificam a incongruência da ideia propagada pela maioria dos internacionalistas de que o Direito Interno pouco ou nada tem a ver com o desenvolvimento das interações internacionais.

\subsection{Federação Brasileira e Relações Externas Empreendidas pelos Entes Federados}

Nota-se atualmente uma tendência generalizada à reivindicação de competências externas pelas entidades federadas, o que, não raro, vem acompanhado de uma extrapolação do âmbito característico da cooperação descentralizada em direção à extensão da autonomia interna para os confins do Direito Internacional. Embora essa tendência possa ser perfeitamente explicada pela crescente interpenetração das ordens jurídicas nacional e externa, não se pode admiti-la como algo impossível de ser objeto de regramento pelo Direito Constitucional, principalmente quando se recorda que as Constituições adotam o princípio básico de confiar ao poder central o monopólio da condução das relações exteriores ${ }^{696}$. Tomada essa advertência como norte, cabe analisar de que forma os entes não centrais da Federação brasileira têm conduzido suas ações em matérias que vão além do plano estritamente interno, o que, por óbvio, vai exigir que se apreciem os dispositivos consagrados na Constituição Federal, nas Constituições Estaduais e em leis editadas pelos diversos entes federados, com o objetivo de identificar os mandamentos que servem de esteio para orientar as práticas externas que, hoje, são agregadas como mecanismos de governo por parte das unidades federadas.

\subsubsection{A Competência para Manter Relações com Estados Estrangeiros, Participar de Organizações Internacionais e Figurar como Parte em Tratados Internacionais}

O exercício de qualquer ação internacional em que haja a incidência das normas de Direito Internacional Público deve ocorrer com referência ao comando constitucional estatuído pelo art. 21, inciso I, da Lei Maior ${ }^{697}$. A abrangência desse dispositivo confirma

\footnotetext{
${ }^{696}$ Cf. HÉLÈnE TOURARD, L'Internationalisation des, Ob. cit., p. 157.

697 “Art. 21. Compete à União: I - manter relações com Estados estrangeiros e participar de organizações internacionais".
} 
que, no Estado federal brasileiro, a política externa figura entre as atribuições remetidas com exclusividade ao governo central, uma vez que houve a fixação da competência para a União atuar internacionalmente como legítima representante da República Federativa do Brasil. É relevante asseverar que a União, enquanto ente federado nacional, não pode adquirir, em nome próprio, direitos e obrigações validamente oponíveis no terreno do Direito das Gentes, uma vez que, como explica Fernanda Dias Menezes de Almeida, é tradição consagrada na teoria federalista "conferir à União, como representante do Estado federal soberano, a competência de manter relações com Estados estrangeiros da mesma estatura"698.

Merece registro, nesse ponto, a jurisprudência do Supremo Tribunal Federal que, no julgamento do Recurso Extraordinário no 229.096-0/RS, fixou seu entendimento acerca do assunto. Da manifestação do Ministro CELSO DE MELlo extrai-se que, no universo das relações exteriores, é de suma importância apartar os papéis desempenhados por duas pessoas jurídicas diferentes: a União, ente autônomo e pessoa jurídica de Direito Público Interno que - agindo como poder central - tem função meramente representativa; e a República Federativa do Brasil, verdadeiro Estado soberano, dotado de personalidade jurídica externa, mas cuja manifestação de vontade é instrumentalizada pela União. Nessa direção, fica incontroverso que é o "Estado federal brasileiro, que ostenta, este sim, a qualidade de sujeito de Direito Internacional Público e que constitui, no plano de nossa organização política, a expressão mesma de uma comunidade jurídica global, investida do poder de gerar uma ordem normativa de dimensão nacional e total, essencialmente diversa, em autoridade, eficácia e aplicabilidade, daquela que se consubstancia nas leis e atos de caráter simplesmente federal”, ${ }^{\circ 99}$.

Os reflexos advindos dessa distinção são significativos quando convertidos em ações práticas, sobretudo porque delimitar a função representativa exercida pela União no desempenho das relações exteriores permite compreender como o exercício da

\footnotetext{
${ }^{698}$ Art. 21, I, in Comentários à Constituição do Brasil, J. J. Gomes Canotilho, Gilmar Ferreira Mendes, Ingo Wolfgang Sarlet, Lenio Streck e Léo Ferreira Leoncy (coord.), Ob. cit., p. 726. Ver ainda Jõ̃o BARBALHO UCHOA CAVALCANTI que averba: "Aos Estados é visto que não poderia caber semelhante poder de fazer tratados, quer porque não têm, separadamente personalidade internacional, quer pelos óbvios e múltiplos inconvenientes que dali resultariam, em prejuízo deles e da União. Basta considerar que tratados haveria vantajosos para os que os realizassem e nocivos a outros Estados. Por outro lado, mal segura ficaria a União quanto à sua fé, seu crédito e paz, dependentes assim das veleidades dos Estados, das dificuldades internas, bem como das complicações internacionais dai promanadas" (Constituição Federal, 1891: Comentada, ed. fac-similar, Brasília, Senado Federal, Conselho Editorial, 2002, p. 111).

${ }^{699}$ STF, Recurso Extraordinário n ${ }^{\circ}$ 229.096-0-RS (voto do Ministro CELSO DE MELLO), Relator Ministro ILMAR GALVÃO, Relator para Acórdão Ministra CÁRMEN LÚCIA, julgamento em 16/08/2007, publicação no DJ 11/04/2008, p. 985, decisão disponível no endereço eletrônico www.stf.jus.br.
} 
competência prevista no art. 21, inciso I, do Pacto Fundamental não prejudica a convivência amistosa entre todos os níveis governamentais da Federação. Como assinalado anteriormente, em virtude de as unidades federadas serem autônomas - como prevê o art. 18, caput, da Constituição Federal ${ }^{700}$-, tem-se, como regra geral, a proibição de um ente imiscuir-se no exercício das competências constitucionalmente asseguradas a outro. Esse vetor serve de fundamento para reconhecer a existência do princípio da paridade entre as unidades políticas, conforme transparece em comandos incluídos no texto constitucional com a finalidade de assegurar o exercício, dentro de parâmetros harmoniosos, das respectivas competências federativas, a exemplo do preceito do art. 151, inciso III, da Lei Maior $^{701}$, paradigmática norma que evita conflitos federativos em matéria de isenções tributárias.

É justamente a ideia de igualdade entre os entes federados que impede a União de editar leis federais que disciplinem temas designados pela Constituição como pertencentes à pauta de competências legislativas privativas dos Estados-membros ou dos Municípios. Não obstante estar vedada a elaboração de normas federais impondo obrigações jurídicas às demais unidades integrantes do concerto federativo quando a matéria legislada for de competência dos demais entes, o Supremo Tribunal Federal entendeu que tratados e convenções internacionais estão autorizados a instituir situações de sujeição aos Estadosmembros, aos Municípios e ao Distrito Federal. Essa linha de intelecção somente é viável porque os tratados, diferentemente das leis federais, embora celebrados pela União, vinculam a República Federativa do Brasil, pessoa jurídica que é titular do monopólio da soberania e da personalidade internacional.

As convenções regidas pelo Direito das Gentes podem criar obrigações a todos os entes federados, ainda que os governos subnacionais não tenham nenhuma participação direta no processo de formulação das normas convencionais ${ }^{702}$. Na órbita do constitucionalismo brasileiro, cumpre asseverar que seria inconstitucional qualquer disposição prevista em Constituições estaduais ou em Leis Orgânicas dos Municípios e do Distrito Federal estipulando competências para que os correspondentes entes praticassem

\footnotetext{
700 “Art. 18. A organização político-administrativa da República Federativa do Brasil compreende a União, os Estados, o Distrito Federal e os Municípios, todos autônomos, nos termos desta Constituição".

701 "Art. 151. É vedado à União: [...] III - instituir isenções de tributos da competência dos Estados, do Distrito Federal ou dos Municípios".

${ }^{702}$ Em igual sentido, o art. 29 da Convenção de Viena sobre o Direito dos Tratados de 1969 enfatiza que "a não ser que uma intenção diferente se evidencie do tratado, ou seja estabelecida de outra forma, um tratado obriga cada uma das partes em relação a todo o seu território".
} 
atos exteriores com o objetivo de tornarem-se partes de tratados internacionais ${ }^{703}$. Dessa forma, não existe margem para evocar-se o princípio da simetria federativa como fundamentação de eventuais iniciativas dos governos não centrais que desejam celebrar pactos típicos do Direito Internacional.

Reafirma essa linha de compreensão JosÉ SOUTO MAIOR BORGES, ao ponderar que “a União é uma pessoa jurídica de Direito Público Interno. Por isso o exercício de sua competência, no Direito Interno, pode ser contrastado com o da competência estadual e municipal, dado que são ordens jurídicas parciais, como visto. Daí a proibição de instituir a União isenções de impostos estaduais e municipais. Não se deve confundir a República Federativa do Brasil com uma entidade que a integra - a União, que não é sujeito de Direito Internacional. Muito menos os Estados-membros e Municípios. Nenhum desses é em si mesmo dotado de personalidade internacional. Constitui, porém, equívoco elementar transportar os critérios constitucionais de repartição de competências para o plano das relações interestatais. Essas reclamam paradigma diverso de análise. Nesse campo, como já o fizera dantes com as leis nacionais, a CF dá à União competência para vincular o Estado brasileiro em nome dela e também dos Estados-membros e Municípios"704.

A inaptidão dos Estados, dos Municípios e do Distrito Federal para adquirir direitos e obrigações no âmbito do Direito Internacional impede, pois, que lhes sejam imputadas as consequências imediatas do descumprimento de normas externas que incidem sobre a Federação, ainda que o ilícito internacional se tenha instaurado em decorrência de postura tomada unicamente pelos governos subnacionais. Nessa circunstância, deve o poder central tentar persuadir a unidade componente a corrigir a violação perpetrada, haja vista que as instâncias e organismos internacionais, quando provocados para apurar o ocorrido, poderão impor medidas somente aos sujeitos de Direito das Gentes ${ }^{705}$. A ação ou omissão de uma unidade política compromete, portanto, todo o Estado federal, fazendo que este responda

\footnotetext{
${ }^{703}$ Lembre-se que a conformação jurídico-constitucional do poder que edita as Constituições Estaduais indica que ele, "sendo um poder derivado do poder constituinte originário, não se trata de um poder soberano, no sentido de poder dotado de capacidade de autodeterminação plena. O poder constituinte dos Estadosmembros é, isto sim, expressão da autonomia desses entes, estando submetido a limitações, impostas heteronomamente, ao conteúdo das deliberações e à forma como serão tomadas" (GILMAR FERREIRA Mendes, inocêncio Mártires Coelho e Paulo Gustavo Gonet Branco, Curso de Direito, Ob. cit., p. 943).

${ }^{704}$ Isenções em Tratados Internacionais de Impostos dos Estados-membros e Municípios, in Direito Tributário: Estudos em Homenagem a Geraldo Ataliba, vol. 1, Celso Antônio Bandeira de Mello (org.), São Paulo, Malheiros, 1997, pp. 176-177.

${ }^{705}$ Cf. Malcolm N. SHAW, Direito Internacional, Ob. cit., p. 167.
} 
pelos ilícitos internacionais ${ }^{706}$ - hipótese que, a propósito, conta com específica previsão no art. 28 do Pacto de San José da Costa Rica ${ }^{707}$, sob o signo de cláusula federal.

A arquitetura federativa brasileira priva, como se esclareceu, os entes políticos de assumirem a condição de sujeitos do Direito das Gentes, não apenas em razão de carecerem de personalidade jurídica apropriada para tanto, mas sobretudo porque a Constituição destinou expressamente à União competência para, em nome do conjunto estatal, vincular a República Federativa do Brasil à normativa internacional. Em compensação, têm os entes autônomos outras possibilidades de atuarem no plano externo, o que tem sido feito em atenção às diretrizes preconizadas pela paradiplomacia. Por força do avanço desse movimento, avulta a importância de arrolar os fundamentos jurídicos que lastreiam os atos e acordos externos conduzidos pelos governos não centrais.

\subsubsection{A Competência para Celebrar Convênios Administrativos Internacionais}

Como o texto constitucional outorgou à União a faculdade de relacionar-se com outros Estados soberanos, automaticamente, essa competência não poderá ser exercida pelos demais entes federados. Essa constatação não significa, contudo, que as unidades federadas estão impedidas de estabelecer vínculos de Direito com pessoas estrangeiras, tanto particulares quanto governamentais ${ }^{708}$. Por certo, poderão valer-se das competências federativas que lhes foram concedidas a fim de, sem realizar incursões no contexto do Direito Internacional Público, firmar ajustes e acordos variados que, em termos gerais, revestir-se-ão da natureza jurídica de convênios administrativos transfronteirços, incapazes

\footnotetext{
${ }^{706}$ Cf. CARMen Tiburcio e Luís Roberto Barroso,Direito Constitucional Internacional, Ob. cit., pp. 156157. Sobre esse ponto, André De CARvalho Ramos explica que “o Estado Federal é, de acordo com o Direito Internacional, uno e passível de responsabilização internacional, mesmo quando o fato internacionalmente ilícito é da atribuição interna de um Estado-membro da Federação. Assim, a Federação responde pela conduta de seus entes internos. Esse entendimento é parte integrante do direito dos Tratados e do Direito Internacional costumeiro. A ausência de 'competência federal' é matéria de Direito Interno e não de Direito Internacional. O Estado Federal responde pelo fato internacionalmente ilícito da mesma maneira que responde por atos ou omissões efetuadas por seu agente, mesmo quando este age em cumprimento estrito do Direito Interno. Alegar obediência ao Direito Interno (por exemplo, o governo federal afirma não poder 'invadir' esfera de atribuição de outro ente federado) não é aceito como excludente da responsabilidade internacional do Estado (O Diálogo das Cortes: O Supremo Tribunal Federal e a Corte Interamericana de Direitos Humanos, in O STF e o Direito Internacional dos Direitos Humanos, Alberto do Amaral Júnior e Liliana Lyra Jubilut (org.), Ob. cit., p. 842).

707 "Artigo 28. 1. Quando se tratar de um Estado-parte constituído como Estado federal, o governo nacional do aludido Estado-parte cumprirá todas as disposições da presente Convenção, relacionadas com as matérias sobre as quais exerce competência legislativa e judicial. 2. No tocante às disposições relativas às matérias que correspondem à competência das entidades componentes da federação, o governo nacional deve tomar imediatamente as medidas pertinentes, em conformidade com sua Constituição e com suas leis, a fim de que as autoridades competentes das referidas entidades possam adotar as disposições cabíveis para o cumprimento desta Convenção".

${ }^{708}$ Cf. Celso Ribeiro Bastos, Curso de Direito, Ob. cit., pp. 443-444.
} 
de gerar a responsabilização internacional do Estado federal, porque disciplinados pelo Direito Administrativo elaborado, soberanamente, em cada uma das Federações envolvidas.

Embora a Constituição brasileira de 1988 não contenha expressa disposição que autorize os entes subnacionais a concluir acordos de cooperação técnica com outros governos estrangeiros, é importante encontrar em nosso sistema constitucional suporte que ateste a juridicidade dos convênios internacionais estabelecidos entre as unidades não centrais inseridas em países diferentes. Nesse mister, as regras sobre a partilha das competências federativas esclarecem que não existe proibição que impeça os entes de desenvolver ações exteriores com o objetivo de promover seus legítimos interesses nos segmentos da política, economia, cultura, entre outros temas. E, sob esse prisma, vale antecipar que identificar as capacidades internacionais de que as unidades são detentoras requer precisa delimitação das competências que esses entes possuem internamente, já que, ao atuar para além de suas fronteiras, as partes subnacionais estão, por meio da conjugação de esforços, ampliando o raio territorial no qual suas capacidades federativas acabam sendo projetadas.

Existem, pois, fundamentos em nossa ordem constitucional que conferem competências para que Estados, Municípios e o Distrito Federal realizem contatos políticos e, se for o caso, formalizem ajustes internacionais, sob a égide das denominadas relações paradiplomáticas. Grife-se que o fato de o art. 52, inciso V, da Constituição ${ }^{709}$ ser o único preceito normativo que, de modo explícito, reconhece capacidade internacional para os entes federados desempenharem atividades externas, ainda que circunscritas ao campo das operações financeiras, não representa obstáculo para que outros acordos exteriores sejam entabulados pelas partes autônomas da Federação brasileira. Assim, consoante se extrai da análise do complexo sistema de repartição de competências consignado no texto constitucional, é necessário interpretar os dispositivos relacionados à matéria à luz do princípio da unidade da Constituição ${ }^{710}$ a fim de que se consiga obter o devido equacionamento desse assunto realmente delicado.

\footnotetext{
709 “Art. 52. Compete privativamente ao Senado Federal: [...] V - autorizar operações externas de natureza financeira, de interesse da União, dos Estados, do Distrito Federal, dos Territórios e dos Municípios".

${ }^{710}$ J. J. GOMES CANOTILHO enuncia que "o princípio da unidade da Constituição ganha relevo autônomo como princípio interpretativo quando com ele se quer significar que a Constituição deve ser interpretada de forma a evitar contradições (antinomias, antagonismos) entre as suas normas. Como 'ponto de orientação', 'guia de discussão' e 'fator hermenêutico de decisão', o princípio da unidade obriga o intérprete a considerar a Constituição na sua globalidade e a procurar harmonizar os espaços de tensão existentes entre as normas constitucionais a concretizar (ex.: princípio do Estado de Direito e princípio democrático, princípio unitário e
} 
Nesse compasso, observa-se que a Comissão de Constituição e Justiça e de Cidadania da Câmara dos Deputados (CCJC), ao apreciar o Projeto de Emenda Constitucional (PEC) no 475, apresentado em 2005, que intentava acrescentar um novo parágrafo ao art. 23 da Lei Maior com vistas a permitir que os entes federados pudessem promover atos e celebrar acordos ou convênios com entes subnacionais estrangeiros, emitiu parecer conclusivo pela inadmissibilidade da proposta. Segundo o teor da manifestação lavrada pelo órgão, "nada há no texto constitucional que impeça Estados, Distrito Federal e Municípios de celebrar atos internacionais (com pessoas físicas ou jurídicas, públicas ou privadas, contratos, acordos ou convênios, etc...). A liberdade de celebrar atos é decorrente da autonomia declarada no artigo 18 da Constituição da República e explicitada em outros artigos, como o 30. Sua liberdade é ampla e submissível a apenas dois limites: a) em casos onde o legislador constituinte deliberou restringi-la (vide artigo 52, inciso V); b) o próprio conjunto de competências atribuídas aos entes estatais pela Constituição da República"711.

Ante a rejeição da proposta de reforma da Lei Fundamental, impende encontrar, no próprio texto constitucional, amparo que justifique os ajustes internacionais que já são uma realidade para as partes do Estado federal pátrio. Ganha relevância, nesse ponto, relembrar que aos Estados-membros são asseguradas as competências remanescentes ou residuais, isto é, "tudo aquilo o que não se incluir entre as competências enumeradas ou implícitas da União ou dos Municípios, nem incidir no campo das vedações constitucionais que limitam a atuação das entidades federadas" ${ }^{, 712}$. Com relação aos Municípios, por seu turno, importa preconizar que "o conceito-chave utilizado pela Constituição para definir a área de atuação do Município é o do interesse local. Cairá, pois, na competência municipal tudo aquilo que for de seu interesse local. É evidente que não se trata de um interesse exclusivo, visto que qualquer matéria que afete uma dada comuna findará de qualquer maneira, mais ou menos direta, por repercutir nos interesses da comunidade nacional”,713.

princípio da autonomia regional e local). Daí que o intérprete deva sempre considerar as normas constitucionais não como normas isoladas e dispersas, mas sim como preceitos integrados num sistema interno unitário de normas e princípios" (Direito Constitucional e, Ob. cit., pp. 1224-1225). Ver também Virgílio Afonso DA Silva, Interpretação Constitucional e Sincretismo Metodológico, in Interpretação Constitucional, Virgílio Afonso da Silva (org.), São Paulo, Malheiros, 2007, pp. 121-127.

${ }^{711}$ Câmara dos Deputados, Parecer sobre o Projeto de Emenda à Constituição no 475/2002, Comissão de Constituição e Justiça e de Cidadania da Câmara dos Deputados, Relator Deputado NEY LoPES, 18/04/2006, p. 2, texto disponível no endereço eletrônico www.camara.gov.br , acesso em 20/11/2013.

${ }_{712}$ Cf. Fernanda Dias MeneZes de AlmeIdA, Competências na Constituição, Ob. cit., p. 103.

${ }^{713}$ Celso Ribeiro Bastos, Curso de Direito, Ob. cit., pp. 450-451. Auxilia na compreensão da cláusula constitucional do "interesse local" ALEXANDRE DE MORAES, que aponta que "apesar de difícil conceituação, interesse local refere-se aos interesses que disserem respeito mais diretamente às necessidades imediatas dos 
Certificado o esquema genérico plasmado na Constituição para orientar o exercício das competências federativas estaduais, é preciso aportar como as competências remanescentes dos Estados-membros são visualizadas sob a perspectiva das práticas paradiplomáticas. É forçoso admitir, nessa senda, que os Estados-membros estão aptos a atuar no âmbito das relações com o mundo exterior, desde que as ações desenvolvidas sejam pertinentes com a promoção dos interesses que integram suas respectivas competências constitucionais materiais e financeiras. $\mathrm{O}$ engajamento externo dos governos estaduais pode, assim, materializar-se em acordos transfronteiriços, embora as avenças que venham a ser aperfeiçoadas jamais serão consideradas tratados internacionais.

Nessa órbita, por estarem reservadas aos Estados-membros as competências que não lhes são vedadas pela Constituição Federal (art. $\left.25, \S 1^{0}\right)^{714}$, vislumbra-se nítido fundamento para que os entes autônomos aqui mencionados desenvolvam variados relacionamentos no campo externo, haja vista que somente a celebração de tratados e a representação da República Federativa nas organizações internacionais configuram competências que cabem, com exclusividade, à União. Em outras palavras, significa que as competências remanescentes que o texto constitucional destina aos Estados federados podem ser exercidas mediante cooperação intergovernamental com unidades federadas congêneres pertencentes a outros Estados federais, o que será enquadrado sob a forma de convênios administrativos internacionais. Não é sem razão, portanto, que algumas Constituições estaduais trazem expressas disposições acerca da matéria em apreço ${ }^{715}$.

Quanto às atividades internacionais concluídas pelos Municípios, vale registrar que essa entidade federada está habilitada a atuar sempre que verificada a existência de

Municípios, mesmo que acabem gerando reflexos no interesse regional (Estados) ou geral (União)" (Constituição do Brasil Interpretada e Legislação Constitucional, 9a ed., São Paulo, Atlas, 2013, p. 740).

714 "Art. 25. [...] $\S 1^{\circ}$ - São reservadas aos Estados as competências que não lhes sejam vedadas por esta Constituição".

${ }^{715}$ Cite-se, a título ilustrativo, o art. 90, inciso XVIII, da Constituição do Estado de Minas Gerais (“Art. 90 Compete privativamente ao Governador do Estado: [...] XVIII - contrair empréstimo externo ou interno e fazer operação ou acordo externo de qualquer natureza, após autorização da Assembleia Legislativa, observados os parâmetros de endividamento regulados em lei, dentro dos princípios da Constituição da República"); o art. 5, inciso VIII, da Constituição do Estado de Goiás (“Art. $5^{\circ}$ - Compete ao Estado: [...] VIII - firmar acordos e convênios com a União e demais unidades federadas, com os Municípios e com instituições nacionais e internacionais, para fins de cooperação econômica, cultural, artística, científica e tecnológica"); o art. 105, inciso XVII, da Constituição do Estado da Bahia ("Art. 105 - Compete privativamente ao Governador do Estado: [...] XVII - contrair empréstimos externos ou internos e fazer operações ou acordos externos de qualquer natureza, após autorização da Assembleia Legislativa, observada a Constituição Federal"). Averbe-se que a Constituição do Estado de São Paulo, mesmo não trazendo norma que reconheça explicitamente a capacidade de a respectiva unidade federada figurar como parte em convênios ou acordos internacionais, tem no art. 47, inciso I, fundamento que justifica as relações paradiplomáticas do governo estadual (“Art. 47 - Compete privativamente ao Governador, além de outras atribuições previstas nesta Constituição: I - representar o Estado nas suas relações jurídicas, políticas e administrativas"). 
predominante interesse local. Desse modo, o mandamento previsto no art. 30, inciso I, da Lei Magna ${ }^{716}$, franqueia aos governos municipais desempenhar suas capacidades federativas para atender as demandas que interessam diretamente ao localismo, o que, por óbvio, pode, em situações específicas, exigir a adoção de mecanismos de cooperação técnica internacional. É oportuno concluir que o constituinte originário gravou em benefício dos Municípios uma série de competências implícitas, as quais devem ser reconhecidas sempre que o interesse local assim o exigir ${ }^{717}$.

Inexiste, pois, taxatividade acerca das competências político-administrativas das unidades municipais, de forma que esses entes estão autorizados a participarem de acordos e demais ações exteriores sempre imbuídos do compromisso de atender os reclamos derivados dos interesses que dimanam de cada localidade. A admissibilidade da paradiplomacia municipal faz perceber que essa atividade vem "aumentando gradativamente desde os anos 1980, porém uma política externa federativa, que implica ações concertadas de unidades locais para alcançar alguma inserção internacional, é registrada apenas a partir dos anos 1990, em algumas grandes cidades do país. Não obstante a característica do atual ordenamento jurídico brasileiro, as cidades brasileiras participam do movimento de projeção nas relações internacionais, porém com grande assimetria de atuação"

Como não há um modo padronizado de os Municípios lançarem-se no terreno das ações internacionais ${ }^{719} \mathrm{e}$, em geral, as participações nesse setor requerem investimentos governamentais vultosos, cabe alertar que a paradiplomacia local pode, com certeza, aprofundar ainda mais as crônicas desigualdades entre as referidas entidades autônomas.

716 “Art. 30. Compete aos Municípios: I - legislar sobre assuntos de interesse local”

${ }^{717}$ Cf. Gilmar Ferreira Mendes, Inocêncio Mártires Coelho e Paulo Gustavo Gonet Branco, Curso de Direito, Ob. cit., p. 959.

${ }^{718}$ Maria Clotilde Meirelles RiBeiro, Globalização e Novos Atores: A Paradiplomacia das Cidades Brasileiras, Salvador, EDUFBA, 2009, p. 70.

${ }^{719}$ Como exemplos dessa ampla possibilidade de cada Município conduzir suas ações internacionais da maneira que lhe seja mais conveniente, interessa aludir às previsões que constam no art. 108, inciso XIV, da Lei Orgânica do Município de Belo Horizonte (“Art. 108 - Compete privativamente ao Prefeito Municipal: [...] XIV - contrair empréstimo, externo ou interno, e fazer operação ou acordo externo de qualquer natureza, mediante prévia autorização da Câmara, observados os parâmetros de endividamento regulados em lei, dentro dos princípios da Constituição da República"); e no art. $4^{\circ}$ da Lei Orgânica do Município de São Paulo (“Art. $4^{\circ}$ - O Município, respeitados os princípios fixados no art. $4^{\circ}$ da Constituição da República, manterá relações internacionais, através de convênios e outras formas de cooperação"). No caso desta última unidade política, vale registrar que, desde 2001, existe um Secretaria Municipal de Relações Internacionais (SMRI), criada pela Lei Municipal $n^{\circ} 283 / 2001$, órgão público que, quando instalado, "representou uma inovação política e jurídica, pois, até então, nenhuma Prefeitura brasileira contava com tal organização" (JOSÉ BLANES Sala e Clara Maria Faria SAntos, O Fundamento Jurídico para a Ação Internacional do Município de São Paulo,in O Município e as Relações Internacionais: Aspectos Jurídicos, José Blanes Sala (org.), Ob. cit., p. 147). 
Daí por que parece ser interessante idealizar instrumentos para induzir o progressivo engajamento desses entes em negociações internacionais, já que não é crível esperar que todos os Municípios brasileiros tenham condições e recursos técnicos suficientes para, impulsionados por sua própria iniciativa, passar a fazer parte de negociações internacionais, as quais, muitas vezes, podem ser essenciais para a solução de problemas governamentais vivenciados em seus respectivos territórios. Seja como for, o movimento paradiplomático indica um amadurecimento da noção de autonomia política local, uma vez que permite aos Municípios exercer suas prerrogativas federativas mesmo em áreas que extravasam o território nacional, quando necessário para o atendimento dos interesses da localidade.

Anote-se, ainda, que o fato de comumente os governos subnacionais empregarem a figura do convênio administrativo para concretizar seus entendimentos no campo da cooperação técnica internacional torna relevante considerar também o preceito constitucional do art. 23, parágrafo único, da Lei Maior de $1988^{720}$ como fundamento dos ajustes firmados para vincular unidades autônomas brasileiras e entidades equivalentes de outros Estados soberanos. Nesse particular, José DOS SANTOS CARVALHO FILHO ensina que “não há qualquer vedação constitucional para tais ajustes; ao contrário, o sistema adotado conduz normalmente a esse desiderato, emanando de várias de suas disposições o sentido de se volverem as entidades federativas a objetivos comuns" ${ }^{\text {721 }}$. Com efeito, mesmo não havendo menção aos convênios internacionais no comando constitucional destacado, é razoável empregá-lo como parâmetro hermenêutico para auxiliar a formar a convicção de que a ordem constitucional brasileira não rechaça as ações paradiplomáticas que suas unidades autônomas venham a desenvolver.

Em abono à percepção de que os ajustes paradiplomáticos devem adotar a forma de convênio administrativo transfronteiriço, cabe considerar, ainda, o preceito estampado no

\footnotetext{
720 “Art. 23. [...] Parágrafo único. Leis complementares fixarão normas para a cooperação entre a União e os Estados, o Distrito Federal e os Municípios, tendo em vista o equilíbrio do desenvolvimento e do bem-estar em âmbito nacional".

${ }^{721}$ Manual de Direito, Ob. cit., p. 226. Corrobora essa ideia GuSTAVO AlEXANDRE MAGAlHãES, ao defender que "não há dúvidas, pois, que o parágrafo único do art. 23 consiste em norma constitucional de eficácia contida, nos termos da classificação proposta por José Afonso da Silva, que poderá apresentar condicionantes ao direito dos entes federativos de celebrarem convênios. Se não forem editadas as referidas leis complementares, as pessoas políticas devem observar apenas as limitações constitucionais e as normas gerais estabelecidas pela União com base no art. 24 e 241. A partir da edição de leis complementares, os entes federativos terão que observar os limites também ali previstos" (Convênios Administrativos: Aspectos, Ob. cit., pp. 37-38).
} 
art. 241 da Lei Fundamental da República ${ }^{722}$, cuja redação foi determinada pela Emenda Constitucional $n^{\circ} 19 / 1998$. Esse comando deve ser interpretado como mais um aspecto que reforça a abertura do federalismo brasileiro às relações exteriores, especialmente no campo das competências materiais, cuja execução demanda a soma de esforços entre unidades políticas - contemplando, também, governos subnacionais localizados no interior de outros países. O exercício compartilhado das referidas competências dependerá de acordos intergovernamentais, devendo o legislador estabelecer, no ato normativo que regulamentará os consórcios e convênios, instrumentos adequados para que o desenvolvimento da paradiplomacia não extrapole os limites constitucionais e internacionais impostos aos entes federados que promovem ações exteriores.

Apontados os fundamentos jurídicos que sustentam as atividades internacionais concretizadas pelas partes autônomas do Estado federal pátrio, parece equivocada a observação de JosÉ FlÁVIO SOMBRA SARAIVA sobre o tema. Consoante entende esse autor, na cena das relações federativas internacionais, "o primeiro e mais claro registro que já se pode fazer da atuação dos agentes externos dos governos subnacionais brasileiros é que eles estão, de facto, ainda que não de jure, atuando de forma crescente na busca de 'autonomia relativa",723. As competências constitucionais estaduais remanescentes e as competências municipais implícitas para o atendimento do interesse local atestam que a partilha de poderes entre as peças do conjunto federativo não privou as mencionadas entidades das capacidades de negociar e firmar compromissos exteriores.

Em verdade, tendo em vista que os convênios internacionais em foco representam emanações diretas das autonomias estadual e municipal, não há que se aguardar a edição de atos legislativos por parte da União para disciplinar o modo pelo qual devem ocorrer as interações paradiplomáticas dos Estados, Municípios e Distrito Federal ${ }^{724}$. Isso porque, à exceção dos acordos de índole financeira, os demais entendimentos e ações internacionais encetados pelos governos autônomos dentro da amplitude competencial que lhes foi

\footnotetext{
722 “Art. 241. A União, os Estados, o Distrito Federal e os Municípios disciplinarão por meio de lei os consórcios públicos e os convênios de cooperação entre os entes federados, autorizando a gestão associada de serviços públicos, bem como a transferência total ou parcial de encargos, serviços, pessoal e bens essenciais à continuidade dos serviços transferidos".

${ }^{723}$ Federalismo e Relações Internacionais do Brasil, in Relações Internacionais do Brasil: Temas e Agendas, vol. 2, Henrique Altemani de Oliveira e Antônio Carlos Lessa (org.), Ob. cit., pp. 447-448.

${ }^{724}$ Salvo melhor juízo, "a criação de um marco legal para a atividade paradiplomática que possa definir norteamentos para esta atuação", como proposto por MARIA ClOTILDE MEIRELLES RIBEIRO (Globalização e, Ob. cit., p. 185), não constitui uma medida imprescindível para garantir o êxito das ações dos governos não centrais no contexto internacional, já que existem fundamentos constitucionais que bastam para esse desiderato, o que não exclui, obviamente, a viabilidade de incrementar essa atividade mediante edição de atos normativos pelos entes federados, no exercício da capacidade de autolegislação que cada um deles possui.
} 
determinada pela Constituição não exigem sequer aquiescência do Senado Federal. Ademais, cumpre advertir que eventual legislação federal sobre a matéria muito provavelmente poderia incorrer em vício material de inconstitucionalidade em razão de interferência indevida e comprometimento da autonomia federativa assegurada constitucionalmente aos Estados e Municípios (e, nos termos do art. 32, § $1^{\mathrm{o}}$, da $\mathrm{CF} / 88^{725}$, também ao Distrito Federal).

Feitas essas considerações, cabe reafirmar que - a não ser que Estados, Municípios e Distrito Federal desejem ingressar no universo próprio do Direito Internacional Público é equivocado alardear que a atuação paradiplomática vem sendo realizada no país em situação de precariedade, porque the faltaria base jurídica adequada. $O$ sistema constitucional inaugurado em 1988 tem, de fato, elementos suficientemente coesos para não somente permitir, mas também potencializar, as relações políticas e de cooperação estabelecidas entre unidades integrantes de diferentes Estados compostos. No Brasil, apresenta-se inviável ainda cogitar um modelo único a ser seguido pelos governos periféricos na prática da denominada paradiplomacia, já que esta - por refletir a autonomia federativa das unidades autônomas - é desenvolvida em atenção aos interesses e estruturas de poder próprios dos diferentes entes ${ }^{726}$.

Tem-se, portanto, como consequência inegável da autonomia proporcionada pelo regime federativo, a comprovação de que as experiências já adotadas pelos Estados e Municípios brasileiros para permitir as relações com o exterior denotam uma expressiva diversidade de arranjos institucionais. De tal sorte, a fim de fomentar acordos negociais corporificados entre governos subnacionais, foram idealizados Escritórios Exteriores de Representação, Secretarias, Subsecretarias, Assessorias, Coordenadorias ou órgãos integrantes de pastas voltadas ao comércio exterior ou internacional ${ }^{727}$, o que depende da

\footnotetext{
725 “Art. 32. [...]§ $1^{\text {o }}$ - Ao Distrito Federal são atribuídas as competências legislativas reservadas aos Estados e Municípios".

${ }^{726}$ Cf. RiCARDo ViCtAlino De Oliveira, Federalismo e Relações Internacionais: A Atuação Externa dos Entes Federados, inO Federalista Atual: Teoria do Federalismo, Dircêo Torrecillas Ramos (org.), Belo Horizonte, Arraes Editores, 2013, pp. 152-153.

${ }^{727}$ Cf. Álvaro Chagas Castelo Branco, Paradiplomacia \& Entes, Ob. cit., pp. 90-91. Nessa direção, TAtiana LACERDA PRAZERES entende ser adequada a proposta do Ministério das Relações Exteriores do Brasil que conta, na atualidade, com uma Assessoria Especial para Assuntos Federativos e Parlamentares, instituída inicialmente em 1997 e reformulada pelo Decreto $n^{\circ} 4.759$, de 21 de junho de 2003, cuja função primordial é intermediar as relações entre poder central e poderes subnacionais, especialmente por meio da contemplação dos interesses das unidades federadas no processo de concepção da política exterior nacional e do acompanhamento e assessoria das iniciativas paradiplomáticas conduzidas pelos governos subnacionais (Por uma Atuação Constitucionalmente Viável das Unidades Federadas Brasileiras Ante os Processos de Integração Regional, in A Dimensão Subnacional e as Relações Internacionais, Tullo Vigevani, Luiz Eduardo Wanderley, Maria Inês Barreto, Marcelo Passini Mariano (org.), Ob. cit., pp. 300-301).
} 
forma com que cada unidade decidiu encaminhar a matéria. A multiplicidade de mecanismos utilizados pelos governos na atuação externa é, sem dúvida, o principal indicativo de que tal impulso não se mostra incompatível com a essência da Federação, já que se harmoniza com o postulado de preservar a principal vantagem que acompanha o federalismo: permitir a unidade do conjunto, sem, no entanto, negar a diversidade que dimana das suas partes.

\subsubsection{A Competência para Realizar Operações Externas de Natureza Financeira}

Ao lado dos convênios administrativos que instrumentalizam infinitos arranjos de cooperação técnica internacional entre entes autônomos, a ordem constitucional brasileira ainda permite que União, Estados, Distrito Federal, Municípios e Territórios realizem operações externas de natureza financeira, exigindo, para esse propósito, aquiescência prévia do Senado Federal (art. 52, inciso V). Embora seja uma medida que contemple, além dos entes federados, os Territórios ${ }^{728}$ - que são desprovidos de autonomia -, trata-se de modalidade específica de atuação exterior dos governos não centrais. Como se pode perceber facilmente, a matéria é restrita a contratos sobre transferência de numerário e há uma regra procedimental a ser cumprida para sua validade no âmbito interno. Sublinhe-se que a intervenção da Casa Legislativa não transforma os contratos e acordos financeiros celebrados pelos entes federados e Territórios em tratados regidos pelo Direito das Gentes, restando infirmada, portanto, a ideia de que, com essa competência, "a personalidade internacional deles não está completamente desaparecida"729.

Acerca do enquadramento jurídico desses acordos, explica VALERIO DE OLIVEIRA MAzzUOLI que “[...] não é demais lembrar que tais acordos concluídos com credores privados têm natureza jurídica de 'contratos administrativos internacionais', também conhecidos por State contracts ou 'contratos com o Estado', regidos pelo Direito Interno de uma das partes - normalmente o Direito Nacional dos credores, que sempre exigem, nas suas negociações com o Estado, a submissão deste à jurisdição de suas respectivas sedes"730. Cumpre frisar, assim, que "o art. 52, inciso V, da Constituição tem abrangência para quaisquer operações externas de natureza financeira de interesse da União, dos

\footnotetext{
${ }^{728}$ A doutrina registra a necessidade de submeter ao crivo da Câmara Alta operações financeiras externas empreendidas também pelas entidades que integram a Administração Indireta. Sobre esse entendimento, consultar: MANOel GonÇAlves FerReira Filho, Comentários à Constituição Brasileira de 1988, vol. 1, Ob. cit., p. 313; e Antônio Paulo CachapuZ De Medeiros, O Poder de, Ob. cit., p. 398.

${ }^{729}$ Celso D. De Albuquerque Mello, Curso de Direito Internacional Público, vol. 1, Ob. cit., p. 349.

${ }^{730}$ Art. 52, V, inComentários à Constituição do Brasil, J. J. Gomes Canotilho, Gilmar Ferreira Mendes, Ingo Wolfgang Sarlet, Lenio Streck e Léo Ferreira Leoncy (coord.), Ob. cit., p. 1055.
} 
Estados, do Distrito Federal, dos Territórios e dos Municípios, quer seja a operação realizada com credores privados (bancos etc.) ou com instituições de natureza pública (como o FMI, o Banco Mundial etc.)" ${ }^{, 731}$.

As conclusões que podem ser depreendidas da exegese do disposto no art. 52, inciso $\mathrm{V}$, do documento constitucional em vigor iniciam-se pela nota de que esse tipo de exigência não representa inovação do constituinte de 1988. A Constituição do Brasil de 1967 apresentava mandamento análogo, quando preceituava no inciso IV do seu art. 42 que, dentre as competências do Senado Federal, figurava a autorização de empréstimos, operações ou acordos externos, de qualquer natureza, de interesse dos Estados, do Distrito Federal e dos Municípios, ouvido o Poder Executivo da União. Essa referência à Constituição anterior é de todo interessante, haja vista que permite verificar que, antes de 1988, toda a sorte de ajuste externo celebrado pelos entes periféricos deveria lograr aprovação da Câmara Alta, independentemente de ostentarem ou não significação financeira $^{732}$.

Acrescente-se também o registro de José Flávio SOMBRA SARAIVA e JosÉ NELSON Bessa MaIA de que "a primeira Constituição Republicana (promulgada em 24.02.1891) garantiu aos governos dos Estados o controle da então principal fonte de arrecadação tributária - o imposto de exportação - e o direito de manipular seus tributos, de criar outros não concorrentes com a União, de recorrer à dívida pública e aos empréstimos externos, bem como atuar em qualquer área de seu interesse, respeitados os poderes expressos da União" ${ }^{, 733}$. A competência constitucional concedida aos Estados-membros na República Velha referente às operações financeiras externas resultou em um quadro no qual, segundo os estudiosos citados, "o conceito moderno de paradiplomacia pode ser empregado para explicar o processo precoce dos governos estaduais brasileiros na busca de

\footnotetext{
${ }^{731}$ Idem, p. 1054.

${ }^{732}$ Cf. Manoel Gonçalves Ferreira Filho, Comentários à Constituição de Brasileira, $6^{\mathrm{a}}$ ed., São Paulo, Saraiva, 1986, p. 231. Convém registrar que,em seus comentários à Constituição de 1967, PONTES DE MIRANDA escreveu que "a atitude do legislador constituinte, a propósito do art. 42, IV, foi radical: não só se referiu a empréstimos externos, mas sim a negócios jurídicos externos, a atos jurídicos stricto sensu externos, ou a atos-fatos jurídicos externos, de jeito que precisam de autorização quaisquer operações externas. Mais: quaisquer acordos externos. Os Estados-membros, o Distrito Federal e os Municípios precisam, em todos os casos, de autorização do Senado Federal" (Comentários à Constituição de 1967, Ob. cit., p. 87).

${ }^{733}$ Federalismo no Brasil da República Velha, 1890-1930: Um Caso Precoce de ParadiplomaciaFinanceira, in Revista Brasileira de Estudos Constitucionais, $\mathrm{n}^{\circ}$ 19, ano 5, jul./set. 2011, p. 112. A propósito, sublinhe-se que o art. 65, § 2 , da Constituição Federal do Brasil de 1891 prescrevia: “Art. 65. É facultado aos Estados: [...] 2. Em geral, todo e qualquer poder, ou direito que lhes não for negado por cláusula expressa ou implicitamente contida nas cláusulas expressas da Constituição". Por isso, na exegese desse dispositivo, JOÃO BARBALHO UCHOA CAVALCANTI afirma que a diretriz a ser observada era a de que "a União nada pode fora da Constituição, - os Estados só não podem o que for contra a Constituição" (Constituição Federal, 1891, Ob. cit., p. 274).
} 
captar recursos externos para cobrir suas necessidades de financiamento. A forte descentralização federativa que caracterizou o sistema político brasileiro nos primórdios do regime republicano permitiu não só o livre acesso dos Estados aos créditos internacionais, como ensejou um descontrole continuado que acabou por gerar uma crise de endividamento e exaustão do crédito externo"734.

Não se pode deixar de relembrar também que, no contexto da Primeira República, o federalismo brasileiro adquiriu contornos muito singulares no que tange à delimitação do conceito de autonomia política de seus entes. Naquele período, “a posição dos Estados federados no seio da Federação nem sempre foi devidamente determinada, permitindo a história constitucional o aparecimento de verdadeiras aberrações, como as derivadas da profunda estreiteza doutrinária dos teóricos que se deparam com o problema da formação dos Estados-membros, criados a partir das Províncias do Império. Vários deles declaram-se soberanos (Bahia, Piauí, São Paulo), outros autônomos e soberanos ou autônomos e independentes (Espírito Santo e Goiás), outros livres e autônomos (Alagoas e Sergipe), e outros, ainda, aludindo à soberania do povo ou à soberania do Estado (Minas Gerais e Rio de Janeiro) ${ }^{, 735}$. Por óbvio, em que pesem as imprecisões advindas do contexto narrado, a indefinição sobre o âmbito de ação das unidades federadas precisa ser computada como mais um dos fatores que potencializaram as ações exteriores desempenhadas pelos governos regionais no período compreendido entre 1891 a 1930.

Esses dados históricos são bastante elucidativos, uma vez que fornecem subsídios para que se visualize, ao menos no campo do nosso constitucionalismo, a tendência de reconhecer que as unidades federadas já podiam realizar ações internacionais antes do advento da atual Constituição, sendo certo que nunca os acordos firmados no exercício dessa competência configuraram tratados ou convenções internacionais. A análise do texto da Constituição de 1967 também indica que, como todos os ajustes internacionais dependiam de autorização do Senado Federal para que fossem celebrados, o Direito pátrio já reconhecia competências federativas que se projetavam para o mundo exterior antes do movimento instaurado pela doutrina especializada na década de 1980, e que fícou conhecido como paradiplomacia. O que se pretende, com essa constatação, é estancar quaisquer questionamentos quanto à legitimidade constitucional dos acordos internacionais

\footnotetext{
${ }^{734}$ Idem, p. 132.

${ }^{735}$ SaUlo José CASAli BAhIA, Tratados Internacionais, Ob. cit., pp. 25-26. Interessa mencionar que PAULO BONAVIDES informa que, no período em questão, o Ceará chegou a organizar Secretarias encarregadas de organizar negócios da Guerra e das Relações Exteriores (Reflexões: Política e Direito, 2ª ed., Rio de Janeiro, Forense, 1978, p. 82).
} 
firmados pelos entes autônomos da Federação brasileira com o objetivo de viabilizar a execução das respectivas competências em contextos onde a cooperação internacional trará sensíveis benefícios em matéria de governabilidade.

Por último, é preciso esclarecer que a redação estampada no art. 52, inciso V, do Pacto Fundamental em vigor, não pode dar ensejo a interpretações restritivas sobre o fenômeno político-jurídico das interações internacionais entre entes federados. A decisão consignada no texto do dispositivo apontado, consistente na previsão de que a competência do Senado Federal está circunscrita à apreciação das operações externas de caráter financeiro, não pode, sob nenhum ponto de vista, ser tomada como fator impeditivo para que as unidades federadas realizem convênios administrativos internacionais. A intenção do constituinte foi outorgar ao Senado o poder de fiscalizar - e também impedir - que os governos autônomos efetuassem operações externas financeiras capazes de comprometer a funcionalidade da Federação ${ }^{736}$, não fechar as portas das unidades federativas para o processo de internacionalização das Constituições, o que, caso acontecesse, colocaria o federalismo brasileiro na contramão do movimento de abertura dos Estados nacionais em prol das práticas, relações e normas internacionais.

\footnotetext{
${ }^{736}$ Confirma essa percepção ANTÔNIO PAULO CACHAPUZ DE MEDEIROS, ao considerar que "o artigo 52 deixa bem sublinhado o controle do Senado sobre as operações financeiras externa, prescrevendo que também compete à Câmara Alta, privativamente: dispor sobre limites globais e condições para as operações de crédito externo e interno da União, do Estado, do Distrito Federal e dos Municípios, de suas autarquias e demais entidades controladas pelo Poder Público Federal (artigo 52, VII); e dispor sobre limites e condições para a concessão de garantia da União em operações de crédito externo e interno (artigo 52, VIII)" (O Poder de, Ob. cit., p. 398).
} 


\section{CONCLUSÃO}

O progressivo desenvolvimento das relações entre os Estados, o alargamento da proteção jurídica conferida a temas igualmente sensíveis ao Direito Interno e ao Direito Internacional, além do aparecimento de sujeitos internacionais que desenvolvem suas ações, concomitantemente, nos contextos nacional e exterior, têm conduzido à expressiva intensificação dos pontos de contatos entre Direito Constitucional e Direito das Gentes. Por óbvio, hoje, essa interação entre ordens jurídicas suplanta em muito as primeiras concepções apresentadas a partir do século XVIII acerca do tratamento que as Constituições deveriam conferir aos atos normativos cuja gênese estava atrelada ao universo das relações exteriores. Assiste-se, no presente, a um processo sem precedentes na história do constitucionalismo, por meio do qual a maioria dos sistemas jurídicos nacionais se abre em prol de um diálogo permanente com as normas que, embora aplicáveis no âmbito interno dos Estados, são criadas nos domínios do Direito Internacional.

Percebe-se, pois, como consequência desse fenômeno, que as Constituições embora continuem a ser o ato normativo responsável por configurar os aspectos elementares da organização dos Estados - têm-se vertido à tendência de reservar significativo espaço nos seus textos para disciplinar como os órgãos nacionais deverão portar-se diante do adensamento jurídico do Direito Internacional. Além disso, o fato de muitas normas internacionais estabelecerem prescrições voltadas a proteger bens jurídicos que também encontram no Direito Constitucional efetivos instrumentos de tutela parece indicar que essas duas ordens jurídicas não podem ser tratadas como sistemas divergentes em que haveria a prevalência de um sobre o outro. A verificação dessa complementariedade recíproca determina que cada um deles tenha relevância jurídica perante o outro, de modo que o Direito das Gentes não poderá alcançar patamares mais apurados de desenvolvimento se ignorar o Direito Constitucional e vice-versa.

Além disso, as imposições decorrentes da globalização, notadamente o surgimento de problemas altamente complexos cuja solução requer o esforço combinado das nações, exigem a reformulação do conceito tradicional de soberania. A vetusta ideia ancorada na lógica do Estado insulado dentro do seu território - porque, nesse espaço, nenhuma outra força poderia interferir - não mais subsiste. Da maneira como se mostra atualmente, o reconhecimento de limites ao exercício das prerrogativas do Estado pode ser admitido sem 
que, em razão disso, deva-se proceder à negação da ideia de soberania. Os esforços da sociedade internacional em criar um arcabouço normativo que consiga evitar eventos que coloquem em perigo a manutenção da paz mundial, bem como a consolidação dos direitos fundamentais como verdadeiros limites à arbitrariedade do Estado podem ser tomados como fortes indicativos de balizas para a compreensão da atual conformação desse conceito.

Ao que tudo indica, parece ser impossível defender, nos dias correntes, que a essência da legitimidade do poder ínsito ao Estado continue a calcar-se apenas na ideia de criação de uma ordem jurídica consonante à vontade do povo abrigado dentro das suas fronteiras. Um novo panorama passa a condicionar a construção dos Estados Constitucionais e a interferir no exercício das competências definidas para as instituições que os integram: o imperativo de que a soberania deve também encontrar no Direito Internacional regras para justificar sua existência e para orientar seu exercício. Esse dado apresenta-se com acentuada envergadura quando observado o estágio no qual se encontram as relações internacionais, cuja dinâmica foi profundamente reformulada com o surgimento das organizações internacionais ao longo do século XX e com a emergência dos direitos humanos como tema marcantemente presente na agenda internacional. Isso contribuiu para que o Direito das Gentes deixasse de ser um conjunto de normas jurídicas encarregado de viabilizar a coexistência pacífica dos Estados para se tornar um fator de promoção da cooperação entre os povos, com vistas a permitir o progresso da humanidade.

A convergência de todos esses fatores impulsou os Estados nacionais a, voluntariamente, se alinharem a novos valores jurídicos difundidos na seara internacional e a comporem estruturas regionais de integração, a exemplo do Mercosul e da União Europeia. A fim de potencializar a observância pelas instituições nacionais da axiologia sedimentada no contexto exterior e para que fosse possível a inserção dos países nos blocos regionais, as Constituições passaram a prever normas que refletiam não somente disposição para que os Estados aumentassem as experiências de cooperação internacional, mas ainda normas que retratavam a inclusão no texto constitucional de comandos que se desenvolveram, em primeiro lugar, no campo das relações exteriores. Esse movimento foi, assim, responsável pela instauração da chamada internacionalização do Direito Constitucional, cuja principal característica é a patente abertura da Constituição ao Direito das Gentes. 
Por óbvio, a ordem constitucional brasileira não ficou à margem desse processo de abertura ao exterior. O texto constitucional vigente traz normas jurídicas que permitem inferir de que modo o nosso constitucionalismo, sem renegar seus valores fundantes e que foram consolidados ao longo da história das instituições político-constitucionais do país, cuidou de fixar parâmetros seguros para que o ordenamento nacional pudesse, progressivamente, admitir a aplicação de comandos normativos internacionais, sem, contudo, esvaziar a força normativa da Constituição. São justamente essas normas abrigadas na Lei Maior que permitem compreender as características que orientam o processo de abertura do Estado Constitucional brasileiro ao Direito Internacional que, a partir de agora, serão referidas brevemente, a título de sinopse conclusiva.

A expressa consagração de princípios constitucionais que regem as relações internacionais no art. $4^{\circ}$ da Constituição Federal, além de ter confirmado a tradição de primar pela solução pacífica de controvérsias e de promover a paz que o Estado brasileiro cuidou de construir ao longo de suas sucessivas Constituições, agregou novos valores muito significativos para a matéria. Por certo, foi o princípio da prevalência dos direitos humanos - um ineditismo advindo com a ordem constitucional vigente - que permitiu ao Brasil se engajar em alguns arranjos internacionais comprometidos com a promoção dessa matéria, como, por exemplo, o reconhecimento da jurisdição de órgãos internacionais judiciários. Agregue-se, ainda, que a norma principiológica constante no parágrafo único do dispositivo em comento serviu de esteio para que o país pudesse participar ativamente, desde o início da década de 1990, da criação e do consequente desenvolvimento do Mercosul, organização internacional que tem por fito fomentar a integração econômica entre os países do Cone Sul.

Além do constituinte originário, o poder de reforma constitucional também contribuiu para que o Brasil pudesse aperfeiçoar seu sistema jurídico nacional em relação a alguns pontos em que o Direito Interno apresenta flagrante interconexão com o Direito Internacional. Nesse sentido, em 2004, a Emenda Constitucional n ${ }^{\circ} 45$ trouxe contribuições relevantes para a internacionalização da Constituição brasileira, o que atesta a sintonia do constituinte derivado reformador com a axiologia que informou as opções feitas pelo constituinte originário durante os trabalhos da Assembleia Nacional Constituinte de 19871988 no tocante à matéria. A referida emenda editou normas que inauguraram: $(i)$ a possibilidade de determinados tratados de direitos humanos, uma vez aprovados em dois turnos de votação, nas duas Casas do Congresso Nacional, com quorum de três quintos dos 
respectivos membros, tornarem-se equivalentes às emendas constitucionais (art. $5^{\circ}, \S 3^{\circ}$ ); (ii) a submissão do Estado brasileiro à jurisdição de Tribunal Penal Internacional a cuja criação tenha aderido (art. $5^{\circ}, \S 4^{\circ}$ ); e (iii) o deslocamento de competência para julgamento de processos em trâmite na Justiça estadual para a Justiça federal, com base em pedido formulado pelo Procurador-Geral da República perante o Superior Tribunal de Justiça, se existir fundado receio de que a inércia das autoridades estaduais ocasione grave violação de tratados internacionais de direitos humanos (art. 109, § $5^{\circ}$ ).

O comprometimento constitucional do Estado brasileiro com a observância da normativa internacional importou, como consequência natural, maior permeabilidade do ordenamento pátrio ao Direito das Gentes. Esse dado reflete-se na ampliação das competências dos Poderes do Estado para desempenhar tarefas relacionadas às relações exteriores e também na visível arquitetura de um regime de corresponsabilidade entre Executivo, Legislativo e Judiciário voltada a permitir que cada um desses Poderes possa, mediante o exercício de atribuições próprias, contribuir para a efetivação do projeto do constituinte de internacionalizar, nos termos definidos no próprio texto constitucional, o Estado brasileiro. Fica, dessa forma, aclarado que o fato de o Executivo ser, por excelência, o Poder que conduz as interações do Estado brasileiro com os demais sujeitos do Direito Internacional não significa que os demais Poderes não devem ocupar um papel de coadjuvantes nesse campo.

Cabe ao Legislativo aumentar sua participação de fiscalização das ações exteriores dirigidas pelo Presidente da República, o que deve ser feito, principalmente, com base no emprego de instrumentos constitucionais já usados comumente para o controle das decisões políticas internas. Ademais, o surgimento do Parlamento do Mercosul indica que, ao menos no espaço regional, as populações dos países envolvidos nesse processo integracionista poderão fazer-se representar nesse órgão regional que, mesmo despido de competência legislativa, pode realizar importantes intervenções na formação de atos normativos, tanto no âmbito dos órgãos decisórios do Mercosul, quanto nos processos de incorporação pelos Estados da normativa criada. Sem dúvida, o Parlamento regional do Mercosul fortalece o bloco, enaltece o papel dos Legislativos nacionais em questões que envolvem a formação de normas internacionais referentes à integração e ainda permite que os postulados democráticos - que devem ser tão caros às Constituições nacionais - sejam adaptados para que órgãos internacionais, antes dominados apenas por burocratas que não 
são escolhidos pelos cidadãos, passem a contar, em alguma medida, com representatividade popular.

O Poder Judiciário, por seu turno, também ocupa posição fulcral no processo de abertura da Constituição ao mundo externo. Isso porque são os juízes nacionais os principais agentes que asseguram, diante da aplicação das normas em casos concretos, a execução interna dos comandos jurídicos internacionais, ao mesmo tempo em que zelam pela autoridade da Constituição. Avulta, portanto, a percepção de que esse Poder mostra-se apto a contribuir destacadamente para compatibilizar o Direito Interno e o Direito das Gentes, o que pode ser feito, sobretudo, por meio do estabelecimento de um profícuo diálogo entre as cortes nacionais e os tribunais internacionais, já que ambas as instâncias, no fundo, são encarregadas de aplicar o mesmo comando normativo. Esse entendimento entre órgãos judiciários pode ainda fortalecer a percepção de que alguns aspectos da norma exterior devem ser aferidos apenas pelos Estados nacionais, os quais procurarão adaptar a normativa internacional aos seus valores culturais e sociais e às suas tradições históricas.

A necessidade de obedecer aos preceitos constitucionais sobre a incorporação das normas internacionais nos ordenamentos internos prova, de modo inequívoco, que as relações exteriores não podem prescindir das Constituições para organizar o sistema estatal no qual os tratados, costumes e demais espécies normativas criados sob a égide do Direito Internacional serão executados. Observa-se, sob esse prisma, que cada Estado mantém sua prerrogativa para estabelecer a necessidade ou não de processos domésticos de internalização dos comandos normativos internacionais. No caso do Brasil, verifica-se que a jurisprudência do Supremo Tribunal Federal já assentou os aspectos mais proeminentes sobre a transposição de tratados ao ordenamento do país, reconhecendo, inclusive, a possibilidade de submeter os decretos de promulgação interna das convenções internacionais ao controle de constitucionalidade. Não se encontra, contudo, número expressivo de decisões quanto à definição do modo de cumprir, no plano doméstico, os costumes internacionais e as decisões provenientes de organizações internacionais.

No que respeita aos tratados e convenções de direitos humanos, vale ressaltar que, desde o advento da Emenda Constitucional no 45/2004, é possível internalizá-los com status de emenda constitucional, hipótese que permite incluir essa categoria de norma internacional no bloco de constitucionalidade pátrio. Com isso, as referidas convenções passam a ser tomadas como paradigma para a realização do controle de constitucionalidade das leis e demais atos normativos internos, o que, inquestionavelmente, se apresenta como 
um notável avanço para a proteção dos direitos humanos no país. Para que adquiram status de emenda, é necessário aprovar os tratados de direitos humanos conforme o procedimento estatuído pelo art. $5^{\circ}, \S 3^{\circ}$, da Lei Maior, decisão que, segundo se depreende de interpretação sistemática da Constituição, pode partir tanto do Chefe do Executivo quanto dos Presidentes de cada uma das Casas do Congresso Nacional. Ainda sobre esse tipo de tratado, cabe pontuar que carece de fundamentação constitucional a posição doutrinária que defende a impossibilidade de denunciá-los, sob o argumento de que, uma vez integrados ao ordenamento brasileiro com estatura de emenda, tornar-se-iam cláusulas pétreas, haja vista que a previsão de cláusulas pétreas é prerrogativa exclusiva do poder constituinte originário.

Vencidos os pontos relativos à importância do princípio da separação de poderes e ao modo de incorporar e executar as normas internacionais na ordem jurídica interna, resta esclarecer quais impactos do processo de internacionalização da Constituição de 1988 também podem ser verificados no terreno da organização político-administrativa do Estado brasileiro. A engenharia empregada pelo federalismo pátrio, embora atribua personalidade jurídica de Direito Internacional Público apenas à República Federativa do Brasil - que é o verdadeiro Estado soberano e, portanto, única legitimada a figurar como parte na celebração de tratados internacionais -, não impede que as unidades autônomas empreendam relações exteriores. Diante das contingências afloradas juntamente com o fenômeno da globalização, ganha espaço o conceito de paradiplomacia, que permite aos governos subnacionais realizar inúmeros atos e ajustes de cooperação transfronteiriça.

Rechaçar a importância dos acordos externos sobre temas variados firmados pelas unidades federadas consiste em erro comum e que deve ser evitado. Embora seja certo que os referidos compromissos não se apresentam como instrumentos habilitados à criação de normas internacionais vinculantes, devem ser compreendidos como mecanismos negociados que favorecem a execução de atribuições administrativas e financeiras ligadas ao universo governamental subnacional, já que resultam do exercício conjugado de competências federativas materiais. Os acordos construídos entre governos não centrais de duas ou mais Federações não se confundem, portanto, com os tratados internacionais e se mostram, a cada dia, mais necessários para que as competências federativas possam ser projetadas para além do território nacional.

Ao final, uma conclusão desponta como síntese do processo de abertura das Constituições contemporâneas ao internacionalismo: a certeza de que a internacionalização 
do Direito Constitucional não implica, sob nenhum ponto de vista, a negação do papel da Constituição como documento normativo fundante dos ordenamentos jurídicos internos. Ao se internacionalizarem, as Constituições não perdem seu valor normativo porque passam a figurar como o principal mecanismo que viabiliza a inclusão do Estado no seio da sociedade internacional e a execução, no plano doméstico, dos compromissos e das normas criadas externamente. Essa permeabilidade descrita não acarreta a perda da identidade e dos valores nacionais, haja vista que continua a ser dos textos constitucionais a prerrogativa de fixar os limites do processo de aceitação da normativa internacional no âmbito interno.

Assinale-se, ainda, que a efetiva abertura de um Estado Constitucional às relações exteriores apenas é possível em países que demonstram considerável maturidade de suas instituições político-constitucionais. Isso porque os órgãos estatais terão de demonstrar aptidão para respeitar não apenas as normas jurídicas que o próprio Estado criar, mas também comandos normativos oriundos do sistema internacional. E, ao analisar as normas consagradas na Constituição Federal de 1988 sobre a temática, é possível certificar que o Brasil se encontra no rol de Estados que demonstram essa maturidade institucional, a qual se converte, sob o ponto de vista de nossa história constitucional, em promessa de estabilidade e de duração da Lei Fundamental vigente. 


\section{BIBLIOGRAFIA}

ACCIOLY, Hildebrando; SILVA, G. E. do Nascimento e; CASELLA, Paulo Borba, Manual de Direito Internacional Público, 17ª ed., São Paulo, Saraiva, 2009.

ACKERMAN, Bruce, Nós, o Povo Soberano: Fundamentos do Direito Constitucional, Belo Horizonte, Del Rey, 2006.

ACUÑA, Eduardo Rozo, Derecho Internacional y Derecho Interno en las Constituciones da America Latina, in Studi Urbinati: Rivista di Scienze Giuridiche, ano 75, 1997/1998, pp. 121-212.

AHDIEH, Robert B., Asuntos Exteriores, Derecho Internacional y el Nuevo Federalismo: Lecciones Derivadas de la Coordenación, in Teoria y Realidad Constitucional, $\mathrm{n}^{\circ}$ 24, 2009, pp. 109-172.

ALARCÓN, Pietro de Jesús Lora, Constituição, Relações Internacionais e Prevalência dos Direitos Humanos, in Revista de Direito Constitucional e Internacional, $\mathrm{n}^{\mathrm{o}}$ 57, ano 14, out./dez. 2006, pp. 331-332.

ALCALÁ, Humberto Nogueira, Los Límites del Poder Constituyente y el Control de Constitucionalidad de las Reformas Constitucionales en Chile, in Estudios Constitucionales, ano 4, nº 2, 2006, pp. 435-455.

ALDECOA, Francisco; KEATING, Michael (org.), Paradiplomacy in Action: The Foreign Relations of Subnational Governments, Londres e Portland, Frank Cass, 1999.

ALMEIDA, Fernanda Dias Menezes de, A Incorporação dos Tratados Internacionais ao Ordenamento Jurídico Brasileiro. Análise do Tema à luz do Direito Constitucional, in Revista do Advogado, ano 23, no 73, nov. 2003, pp. 48-58.

,Competências na Constituição de 1988, 6ª ed., São Paulo, Atlas,

2013.

, Considerações Sobre o Rumo do Federalismo nos Estados Unidos e no Brasil, in Revista de Informação Legislativa, Brasília, ano 24, n 96, out./dez. 1987, pp. 57-64.

ALMEIDA, Fernando Dias Menezes de, Contrato Administrativo, São Paulo, Quartier Latin, 2012.

ALMEIDA, João Daniel Lima de, História do Brasil, Brasília, FUNAG, 2013.

ALMEIDA, Paulo Roberto de, As Relações Internacionais na Ordem Constitucional, in Revista de Informação Legislativa, n 101, ano 26, jan./mar. 1989, pp. 47-70. 
, Relações Exteriores e Constituição, in Revista de Informação Legislativa, $\mathrm{n}^{\circ}$ 94, ano 24, abr./jun. 1987, pp. 109-120.

ALTEMANI, Henrique de Oliveira e LESSA, Antônio Carlos (org.), Relações Internacionais do Brasil: Temas e Agendas, Vol. 2, São Paulo, Saraiva, 2006.

ÁLVAREZ, Lautaro Ríos, El Fundamento Axiológico de las Relaciones Internacionales y de las Constituciones Modernas, in Anuario de Derecho Constitucional Latinoamericano, 2006, pp. 1371-1403.

AMARAL JÚNIOR, Alberto do, Curso de Direito Internacional Público, $4^{\mathrm{a}}$ ed., São Paulo, Atlas, 2013.

AMARAL JÚNIOR, José Levi Mello do, Os Tratados no Ordenamento Jurídico Brasileiro, in Direito \& Justiça, vol. 23, Ano 23, 2001, pp. 175-199.

AMIRANTE, Carlo, Uniões Supranacionais e Reorganização Constitucional do Estado, São Leopoldo, Editora Unisinos, 2003.

ANZILOTTI, Dionisio, Cours de Droit International, Paris, Panthéon-Assas, 1999.

ARAÚJO, Edmir Netto de, Curso de Direito Administrativo, $3^{\mathrm{a}}$ ed., São Paulo, Saraiva, 2007.

ARAUJO, Luiz Alberto David; NUNES JÚNIOR, Vidal Serrano, Curso de Direito Constitucional, 12a ed., São Paulo, Saraiva, 2008.

ARNAIZ, Alejandro Saiz, La Apertura Constitucional al Derecho Internacional y Europeu de los Derechos Humanos. El Artículo 10.2 de la Constitución Española, Madrid, Consejo General del Poder Judicial, 1999.

BAHIA, Saulo José Casali, Tratados Internacionais no Direito Brasileiro, Rio de Janeiro, Forense, 2000.

BAPTISTA, Luiz Olavo, A Aplicação das Normas do Mercosul no Brasil, in Revista de Direito do Mercosul, $\mathrm{n}^{\circ}$ 5, ano 2, 1998, pp. 28-42.

BAPTISTA, Luiz Olavo; FERRAZ JUNIOR, Tercio Sampaio (coord.), Novos Caminhos do Direito no Século XXI: Direito Internacional, Filosofia Jurídica e Politica, Dogmática Jurídica e Direitos Fundamentais: Uma Homenagem a Celso Lafer, $2^{\mathrm{a}}$ ed., Curitiba, Juruá, 2013.

BAPTISTA, Luiz Olavo; MAZZUOLI, Valerio de Oliveira (org.), Direito Internacional: Direito Internacional dos Direitos Humanos (Coleção Doutrinas Essenciais, vol. 3), São Paulo, Revista dos Tribunais, 2012. 
Direito Internacional: Direito Internacional Econômico (Coleção Doutrinas Essenciais, vol. 2), São Paulo, Revista dos Tribunais, 2012.

,Direito Internacional: Teoria Geral (Coleção Doutrinas Essenciais, vol. 1), São Paulo, Revista dos Tribunais, 2012.

BARACHO, José Alfredo de Oliveira, Teoria Geral do Federalismo, Belo Horizonte, FUMARC/UCMG, 1982.

BARROS, Marinana Andrade e, A Atuação Internacional dos Governos Subnacionais, Belo Horizonte, Del Rey, 2010.

BARROS, Sérgio Resende de; ZILVETI, Fernando Aurelio, Direito Constitucional: Estudos em Homenagem a Manoel Gonçalves Ferreira Filho, São Paulo, Dialética, 1999.

BARROSO, Luís Roberto, Interpretação e Aplicação da Constituição, $7^{\mathrm{a}}$ ed., São Paulo, Saraiva, 2009.

O Controle de Constitucionalidade no Direito Brasileiro, $6^{\mathrm{a}}$ ed., São Paulo, Saraiva, 2012.

BASTOS, Celso Ribeiro, Curso de Direito Constitucional, 22a ed., São Paulo, Malheiros, 2010.

, Das Grandezas da Integração Internacional às Misérias do Nosso Nacionalismo, in Cadernos de Direito Constitucional e Ciência Política, ano 1, no 3, abr./jun. 1993, pp. 239-240.

BASTOS, Celso Ribeiro; MARTINS, Ives Gandra, Comentários à Constituição do Brasil (Promulgada em 5 de Outubro de 1988), Vol. 4 - tomo I: Arts. 44 a 69, São Paulo, Saraiva, 1995.

, Comentários à Constituição do Brasil (Promulgada em 5 de Outubro de 1988), vol. 1: Pré-Constitucionalismo. O Estado. Constituição. Arts. $1^{o}$ ao $4^{\circ}$, São Paulo, Saraiva, 1988.

BAZÁN, Victor, Jurisdicción Constitucional, Control de Constitucionalidad de los Tratados y Convenios Internacionales, y Reforma de la Ley Fundamental, in Pensamiento Constitucional, vol. 9, nº 9, 2003, pp. 413-462.

BERMAN, Paul Schiff, Federalism and International Law Through the Lens of Legal Pluralism,in Missouri Law Review, vol. 73, 2008, pp. 1149-1184.

BIGLIATI, Francesco Giuseppe, Diritto Internazionale e Diritto Costituzionale, vol. I - Lo Stato e la Societá Internazionale, Torino, Fratelli Bocca, 1904. 
BILDER, Richard B., The Role of States and Cities in Foreign Relations, in The American Journal of International Law, vol. 83, 1989, pp. 821-831.

BINENBOJM, Gustavo, Monismo e Dualismo no Brasil: Uma Dicotomia Afinal Irrelevante, in Revista Forense, vol. 350, abr./jun. 2000, pp. 39-48.

BOBBIO, Norberto, Da Estrutura à Função: Novos Estudos de Teoria do Direito, Barueri, Manole, 2007. , Teoria do Ordenamento Jurídico, 2ª ed., São Paulo, Edipro, 2014.

BODIN, Jean, Os Seis Livros da República: Livro Primeiro, São Paulo, Ícone, 2011.

BOGDANDY, Armin von; PIOVESAN, Flavia; ANTONIAZZI, Mariela Morales (coord.), Direitos Humanos, Democracia e Integração Jurídica na América do Sul, Rio da Janeiro, Lumen Juris, 2010.

, Direitos Humanos, Democracia e Integração Jurídica: Emergência de um Novo Direito Público, Rio de Janeiro, Elsevier, 2013.

BONAVIDES, Paulo, Ciência Política, 10ª ed., São Paulo, Malheiros, 2003.

,Curso de Direito Constitucional, 25ª ed., São Paulo, Malheiros, 2010.

1978.

, Reflexões: Política e Direito, $2^{\mathrm{a}}$ ed., Rio de Janeiro, Forense,

BONAVIDES, Paulo; MIRANDA, Jorge; AGRA, Walber de Moura (coord.), Comentários à Constituição de 1988, Rio de Janeiro, Forense, 2009.

BONIFÁCIO, Artur Cortez, O Direito Constitucional Internacional e a Proteção dos Direitos Fundamentais, São Paulo, Método, 2008.

BORGES, José Souto Maior, Curso de Direito Comunitário, $2^{\mathrm{a}}$ ed., São Paulo, Saraiva, 2009.

BOUSTANI-BEAUVINON, Yasmine el, Externalisation ou Circulation $d u$ Droit Constitutionnel?, in Politeia, $\mathrm{n}^{\circ}$ 22, dez. 2012, pp. 497-507.

BRADLEY, Curtis A.; GOLDSMITH, Jack L., Foreign Relations Law: Cases and Materials, $3^{\mathrm{a}}$ ed., New York, Aspen Publishers, 2009.

BRANCO, Álvaro Chagas Castelo, Paradiplomacia \& Entes Não-Centrais no Cenário Internacional, Curitiba, Juruá, 2008. 
BRANDÃO, Rodrigo, Direitos Fundamentais, Democracia e Cláusulas Pétreas, Rio de Janeiro, Renovar, 2008.

BRANT, Leonardo Nemer Caldeira (coord.), O Brasil e os Novos Desafios do Direito Internacional, Rio de Janeiro, Forense, 2004.

BROTONS, Antonio Remiro, La Accion Exterior del Estado, Madrid, Editorial Tecnos, 1984.

BROWNLIE, Ian, Princípios de Direito Internacional Público, Lisboa, Fundação Calouste Gulbenkian, 1997.

BUENO, José Antônio Pimenta, Direito Público Brasileiro e Análise da Constituição do Império (Coleção Formadores de Opinião), São Paulo, Editora 34, 2002.

BURGUESS, Michael, Comparative Federalism: Theory and Pratice, Londres, Routledge, 2006.

CABRA, Marco Gerardo Monroy, El Derecho Internacional como Fuente del Derecho Constitucional, in Anuario Colombiano de Derecho Internacional, $\mathrm{n}^{\mathrm{o}}$ 1, ano 1, pp. 107-138.

CAETANO, Gerardo; PERINA, Rubén (ed.), La Encrucijada Política del Mercosur: Parlamentos y Nueva Institucionalidad, Montevideo, Centro Latinoamericano de Economía Humana (CLAEH) e Unidad para la Promoción de la Democracia (UPE), 2003.

CAGGIANO, Monica Herman Salem, Explorando o Federalismo. O Que é Federalismo?, in Revista Direito Mackenzie, ano 1, nº 2, 2000, pp. 31-44.

, Emenda Constitucional $n^{\circ} 45 / 2004$, in Revista Brasileira de Direito Constitucional, $\mathrm{n}^{\mathrm{o}}$ 5, jan./jun. 2005, pp. 185-204.

, O Parlamento no Cenário Político do Século XXI, in Revista do Advogado, ano 23, n 76 , nov. 2003, pp. 146-166.

CALLEJÓN, Francisco Balaguer, As Relações entre o Tribunal de Justiça da UE e os Tribunais Constitucionais Nacionais dos Estados-membros, in Direitos Fundamentais e Justiça, no 13, out./dez. 2010, pp. 13-36.

CALOGERAS, João Padiá, Formação Histórica do Brasil, Rio de Janeiro, Pimenta de Mello \& C., 1930.

CANOTILHO, J. J. Gomes, "Brancosos" e Interconstitucionalidade: Itinerários dos Discursos sobre a Historicidade Constitucional, $2^{\mathrm{a}}$ ed., Coimbra, 2008. 
Almedina, 2003.

Direito Constitucional e Teoria da Constituição, $7^{\mathrm{a}}$ ed., Coimbra,

CANOTILHO, J. J. Gomes; MENDES, Gilmar Ferreira; SARLET, Ingo Wolfgang; STRECK, Lenio Luiz; LEONCY, Léo Ferreira (coord.); Comentários à Constituição do Brasil, São Paulo, Saraiva e Almedina, 2013.

CANTOR, Ernesto Rey, El Bloque de Constitucionalidad. Aplicación de Tratados Internacionales de Derechos Humanos, in Estudios Constitucionales, ano 4, $\mathrm{n}^{\mathrm{o}}$ 2, pp. 299-334.

CARO, Ernesto J. Rey, Los Tratados Internacionales en el Ordenamiento Juridíco Argentino. Consideraciones sobre la Reforma Constitucional, in Anuario Argentino de Derecho Internacional, Vol. VI, 1994-1995, pp. 209-238.

CARVAlHO FILHO, José dos Santos, Manual de Direito Administrativo, $26^{\mathrm{a}}$ ed., São Paulo, Atlas, 2013.

CARVALHO, Maria Izabel Valladão de; SANTOS, Maria Helena de Castro (org.), $O$ Século 21 no Brasil e no Mundo, Bauru, EDUSC, 2006.

CASELLA, Paulo Borba, Tratado de Versalhes na História do Direito Internacional, São Paulo, Quartier Latin, 2007.

CASSEB, Paulo Adib, Processo Legislativo: Atuação das Comissões Permanentes e Temporárias, São Paulo, Revista dos Tribunais, 2008.

CASSESE, Antonio, International Law, 2a ed., New York, Oxford, 2005.

, L'Apertura degli Ordinamenti Statali all'Ordinamento della Comunità Internazionale, Editoriale Scientifica, 2009.

CAVALCANTI, João Barbalho Uchoa, Constituição Federal, 1891: Comentada, ed. facsimilar, Brasília, Senado Federal, Conselho Editorial, 2002.

CAVALlO, Gonzalo Aguilar, ¿Quién es el Guardián de la Convención Americana sobre Derechos Humanos?, in Revista de Derechos Fundamentales, no 6, pp.17-49.

, La Internacionalización del Derecho Constitucional, in Estudos Constitucionais, $\mathrm{n}^{\circ}$ 1, ano 5, 2007, pp. 223-281.

CAZETTA, Ubiratan, Direitos Humanos e Federalismo: O Incidente de Deslocamento de Competência, São Paulo, Atlas, 2009.

CHARLESWORTH, Hilary; CHIAM, Madelaine; HOVELL, Devika; WILLIAMS, George (ed.), The Fluid State: International Law and National Legal Systems, Sydney, The Federation Press, 2005. 
CHOUDHRY, Sujit (ed.), The Migration of Constitutional Ideas, Cambridge, Cambridge University Press, 2006.

CLÈVE, Clèmerson Merlin, Direito Constitucional, Novos Paradigmas, Constituição Global e Processos de Integração, in Revista da Academia Brasileira de Direito Constitucional, $\mathrm{n}^{\circ}$ 5, 2004, pp. 223-237.

CLÈVE, Clèmerson Merlin; BARROSO, Luís Roberto (org.), Direito Constitucional: Organização dos Poderes da República (Coleção Doutrinas Essenciais, vol. 4), São Paulo, Revista dos Tribunais, 2011.

,Direito Constitucional: Teoria Geral do Estado (Coleção Doutrinas Essenciais, vol. 2), São Paulo, Revista dos Tribunais, 2011.

COELHO, Maria Helena da Cruz de; RIBEIRO, Maria Manuela Tavares (coord.), Parlamentos: a Lei, a Prática e as Representações da Idade Média à Atualidade, Lisboa, Assembleia da República, 2010.

COMPARATO, Fábio Konder, A Afirmação Histórica dos Direitos Humanos, $8^{\mathrm{a}}$ ed., São Paulo, Saraiva, 2013.

COUTO, Estêvão Ferreira, A Relação entre o Interno e o Internacional: Concepções Cambiantes de Soberania, Doutrina e Jurisprudência dos Tribunais Superiores no Brasil, Rio de Janeiro, Renovar, 2003.

CUNHA, Alessandra Marchioni Pereira da, As Limitações da Democracia na Formação da União Europeia, Barueri, Manole, 2004.

CUNHA, Joaquim da Silva e PEREIRA, Maria da Assunção do Vale, Manual de Direito Internacional Público, 2ª ed., Coimbra, Almedina, 2004.

DAllari, Dalmo de Abreu, A Constituição na Vida dos Povos: Da Idade Média ao Século XXI, $2^{\text {a }}$ ed., São Paulo, Saraiva, 2013.

Saraiva, 2009.

, Elementos de Teoria Geral do Estado, $28^{\mathrm{a}}$ ed., São Paulo,

DALlARI, Pedro B. A., Constituição e Relações Exteriores, São Paulo, Saraiva, 1994.

,Constituição e Tratados Internacionais, São Paulo, Saraiva, 2003.

DEHOUSSE, Renaud, Fédéralisme et Relations Internationales: Una Réflexion Comparative, Bruxelas, Bruylant, 1991.

DELGADO, Francisco R. Barbosa, Os Limites à Doutrina da Margem Nacional de Apreciação no Tribunal Europeu e na Corte Interamericana de Direitos Humanos: 
Intervenção Judicial em Torno de Certos Direitos das Minorias Étnicas e Culturais, in Revista Direito do Estado, n. ${ }^{\circ}$ 26, jan./jun. 2011, pp. 107-135.

DELMAS-MARTY, Mireille, Études Juridiques Comparatives et Internalisation du Droit (Leçons Inaugurales du Collège de France), Paris, Collège de France/Fayard, 2003.

, La Refondation des Pouvoirs: Les Forces Imaginantes du Droit (III), Paris, Éditions du Seuil, 2007.

, Le Pluralisme Ordonné: Les Forces Imaginantes du Droit (II), Paris, Éditions du Seuil, 2006.

Le Relatif et l'Universal: Les Forces Imaginantes du Droit (I), Paris, Éditons du Seuil, 2004.

, Por um Direito Comum, São Paulo, Martins Fontes, 2004.

,Vers Une Communauté de Valeurs?: Les Forces Imaginantes du Droit (IV), Paris, Éditons du Seuil, 2011.

DI PIETRO, Maria Sylvia Zanella, Direito Administrativo, 26ª ed., São Paulo, Atlas, 2013.

DIAZ, Elias, Estado de Derecho y Sociedad Democratica, Madrid, Cuadernos para el Dialogo, 1966.

DINH, Nguyem Quoc; DAILLIER, Patrick; PELLET, Alain, Direito Internacional Público, $2^{\mathrm{a}}$ ed., Lisboa, Fundação Calouste Gulbenkian, 2003.

DIPPEL, Horst, História do Constitucionalismo Moderno, Lisboa, Fundação Calouste Gulbernkian, 2007.

DIREITO, Carlos Alberto Menezes; TRINDADE, Antônio Augusto Cançado; PEREIRA, Antônio Celso Alves (coord.), Novas Perspectivas do Direito Internacional Contemporâneo: Estudos em Homenagem ao Professor Celso D. de Albuquerque Mello, Rio de Janeiro, Renovar, 2008.

DOBNER, Petra; LOUGHLIN, Martin (Org.), The Twilight of Constitutionalism?, Oxford, Oxford University Press, 2010.

DÓRIA, A. de Sampaio, Direito Constitucional: Curso e Comentários à Constituição, tomo I, $3^{\text {a }}$ ed., São Paulo, Companhia Editora Nacional, 1953.

DROUBI, Sufyan el, As Resoluções Obrigatórias do Conselho de Segurança da ONU e sua Introdução no Direito Brasileiro, in Revista de Direito Constitucional e Internacional, $\mathrm{n}^{\mathrm{o}}$ 60, ano 15, jul./set. 2007, pp. 317-360. 
DUFFY, Helen, National Constitutional Compatibility and the International Criminal Court, in Duke Journal of Comparative \& International Law, vol. 11, 2000, pp. 5-38.

ESPADA, Cesáreo Gutiérrez, Derecho Internacional Publico, Editorial Trotta, Madrid, 1995.

ESPADA, Cesáreo Gutiérrez; HORTAL, María José Cervell, El Derecho Internacional en la Encrucijada, Madrid, Editorial Trotta, 2008.

ESPALTER, Mario Falcão, Ensayo sobre la Influencia del Derecho Internacional en el Derecho Constitucional: Historia y Doctrina, Montevideo, Peña \& Cia, 1938.

FACHIN, Luiz Edson, Direito Internacional: Possibilidades e Limites da Harmonização entre Tratados Internacionais e a Constituição Federal: O Exemplo do Tratado de Itaipu, in Revista de Direito do Estado, Ano 1, no 4, out./dez. 2006, pp. 305-317.

FAGUNDES, Miguel Seabra, O Controle dos Atos Administrativos pelo Poder Judiciário, $8^{\mathrm{a}}$ ed., Rio de Janeiro, Forense, 2010.

FAVOREAU, Louis, El Bloque de la Constitucionalidad, in Revista del Centro de Estudios Constitucionales, $\mathrm{n}^{\mathrm{o}}$ 5, pp. 45-68.

FERRAJOLI, Luigi, A Soberania no Mundo Contemporâneo: Nascimento e Crise do Estado Nacional, 2a ed., São Paulo, Martins Fontes, 2007.

, Pasado y Futuro del Estado de Derecho, in Revista Internacional de Filosofía Política, $\mathrm{n}^{\mathrm{o}}$ 17, 2001, pp. 31-45.

FERRARI, Regina Maria Macedo Nery, Critérios Científicos para a Solução dos Conflitos Aparentes Entre Tratados Internacionais e a Constituição Federal, in Revista dos Tribunais, vol. 855, ano 96, jan. 2007, pp. 30-45.

FERRAZ, Anna Cândida da Cunha, O Município e os Direitos Fundamentais: Uma Análise das Competências Constitucionais do Município em Matéria de Direitos Fundamentais, in Revista Mestrado em Direito, ano 6, no 2, jul./dez. 2006, pp. 139176.

, Os Tratados e as Convenções Internacionais de Direitos Humanos Anteriores à Emenda Constitucional n. 45/2004, in Revista Mestrado em Direito - Direitos Humanos Fundamentais, no 1, ano 7, jan./jun. 2007, pp. 117-132.

FERREIRA FILHO, Manoel Gonçalves, A Estrutura do Estado. A Auto-Organização dos Estados e Municípios e seus Limites. A Repartição de Competências, in Revista da Indústria, ano 1, nº 1, jan./mar. 1992, pp. 84-99.

Saraiva, 2003. , Aspectos do Direito Constitucional Contemporâneo, São Paulo, 
, Comentários à Constituição Brasileira de 1988, Vol. 1, 2 $2^{\mathrm{a}}$ ed., São Paulo, Saraiva, 1997.

, Comentários à Constituição Brasileira de 1988, Vol. 2, Arts. 44 a 103, São Paulo, Saraiva, 1992.

, Comentários à Constituição Brasileira, $6^{\mathrm{a}}$ ed., São Paulo, Saraiva, 1986.

, Constitucionalismo e Direito Natural: Uma Relação Inelidivel, in Revista Brasileira de Direito Constitucional, $\mathrm{n}^{\mathrm{o}}$ 6, jul./dez. 2005, pp. 642-653.

2009.

, Estado de Direito e Constituição, $4^{\mathrm{a}}$ ed., Saraiva, São Paulo,

, O Estado Federal Brasileiro à Luz da Constituição de 1988, in Revista da Faculdade de Direito da USP, vol. 86, 1991, pp. 116-129.

, O Estado no Limiar do Novo Século, in Revista de Direito Administrativo, vol. 217, jul./set. 199, pp. 81-90.

, O Futuro do Estado, in Revista da Escola Paulista da Magistratura, $\mathrm{n}^{\circ}$ 4, nov./jun. 1998, pp. 91-98.

, Princípios Fundamentais do Direito Constitucional: O Estado da Questão no Início do Século XXI, em Face do Direito Comparado e, Particularmente, do Direito Positivo Brasileiro, $2^{\mathrm{a}}$ ed., São Paulo, Saraiva, 2010.

, Significação e Alcance das Cláusulas Pétreas, in Revista de Direito Administrativo, vol. 202, out./dez. 1995, pp. 11-17.

FERREIRA, Pinto, Comentários à Constituição Brasileira - Vol. 1: Arts. $1^{\circ}$ ao 21, São Paulo, Saraiva, 1989.

Paulo, Saraiva, 1989.

,Comentários à Constituição Brasileira - Vol. 2: Arts. 22 a 53, São , Princípios Gerais do Direito Constitucional Moderno, tomo I, $2^{\mathrm{a}}$ ed., José Konfino, Rio de Janeiro, 1951.

FERREIRA, Waldemar Martins, História do Direito Constitucional Brasileiro, São Paulo, Max Limonad, 1954.

FIGUEIREDO, Patrícia Cobianchi, Os Tratados Internacionais de Direitos Humanos e o Controle de Constitucionalidade, São Paulo, LTr, 2011. 
FONTOURA, Jorge, O Avanço Constitucional Argentino e o Brasil, in Revista da Faculdade de Direito da UFPR, vol. 34, ano 32, 2000, pp. 45-50.

FORMENTO, Augusto; DELPIAZZO, José Miguel, Primer Reconocimiento Jurisprudencial del Bloque de Constitucionalidad: Concepto, Importancia, Efectos Jurídicos y Perspectivas, in Revista de Derecho de la Universidad de Montevideo, ano $9, \mathrm{n}^{\mathrm{o}} 18,2010$, pp. 101-113.

FRAGA, Mirtô, $O$ Conflito entre Tratado Internacional e Norma de Direito Interno: Estudo Analítico da Situação do Tratado na Ordem Jurídica Brasileira, Rio de Janeiro, Forense, 2001.

FRANCA FILHO, Marcílio Toscano, O Silêncio Eloquente: Omissão do Legislador e Responsabilidade do Estado na Comunidae Europeia e no Mercosul, Coimbra, Almedina, 2008.

FRANÇA, Vladimir da Rocha; ELALI, André; BONIFÁCIO, Artur Cortez (coord.), Novas Tendências do Direito Constitucional: Em Homenagem ao Professor Paulo Lopo Saraiva, Curitiba, Juruá, 2012.

FRANCO, Afonso Arinos de Melo, Curso de Direito Constitucional Brasileiro, Vol. I: Teoria Geral, Rio de Janeiro, Forense, 1958.

Direito Constitucional: Teoria da Constituição; As Constituições do Brasil, Rio de Janeiro, Forense, 1976.

GAMBINO, Silvio, Tendances du Constitutionnalisme Contemporain en France et en Europe, in Politeia, no 22, dez. 2012, pp. 509-539.

GARCÉS, Clicerio Coello, El Estado Democrático Postnacional: Dimensiones Actuales del Principio de Soberanía y Ciudadanía, Valencia, Tirant lo Blanch, 2013.

GARCÍA-PELAYO, Manuel, As Transformações do Estado Constitucional Contemporâneo, Rio de Janeiro, Forense, 2009.

GARCÍA, Hernán Alejandro Olano, El Bloque de Constitucionalidad en Colombia, in Estudios Constitucionales: Revista del Centro de Estudios Constitucionales, Ano 3, $\mathrm{n}^{\mathrm{o}} .1,2005$, pp. 231-242.

GARCIA, Márcio Pereira Pinto, A Terminação de Tratado e o Poder Legislativo à Vista do Direito Internacional, do Direito Comparado e do Direito Constitucional Internacional Brasileiro, Rio de Janeiro, Renovar, 2011.

GARCIA, Maria, A Autodeterminação dos Povos e a Defesa da Paz. O "Princípio da Insegurança" (Rancière) e o Constitucionalismo Internacional, in Revista de Direito Constitucional e Internacional, $\mathrm{n}^{\mathrm{o}}$ 58, ano 15, jan./mar. 2007, pp. 306-313. 
A Constituição e os Tratados - A Integração Constitucional dos Direitos Humanos, in Revista de Direito Constitucional e Internacional, ano 9, $\mathrm{n}^{\circ} 37$, out./dez. 2001, pp. 38-44.

, A Integração dos Estados - O Brasil no Mercosul: Implicações e Abrangências na Ordem Interna e Internacional, in Revista de Direito Constitucional e Internacional, $\mathrm{n}^{\mathrm{o}} 35$, ano 9, abr./jun. 2001, pp. 16-23.

, Fundamentalidade e Direitos Fundamentais: $O \xi 2^{\circ}$ do Art. $5^{\circ} d a$ CF/1988. Direitos Humanos e Garantias Fundamentais, in Revista de Direito Constitucional e Internacional, $\mathrm{n}^{\mathrm{o}}$ 67, ano 17, abr./jun. 2009, pp. 244-257.

, Limites da Ciência: A Dignidade da Pessoa Humana: A Ética da Responsabilidade, São Paulo, Revista dos Tribunais, 2004.

, O Efeito Prismático dos Direitos Humanos: A Expressão Circular do Homem Vitruviano e os Direitos Humanos das Vítimas, in Revista Mestrado em Direito, $\mathrm{n}^{\mathrm{o}}$ 1, ano 8, jan./ jun. 2008, pp. 255-266.

, Tratados Internacionais. Denúncia. Necessidade da Participação do Poder Legislativo. O Princípio Constitucional da Separação dos Poderes, in Cadernos de Direito Constitucional e Ciência Política, $\mathrm{n}^{\circ}$ 21, ano 5, out./dez. 1997, pp. 92-97.

GARCIA, Maria; GAMBA, Juliane Caravieri Martins; MONTAL, Zélia Maria Cardoso (coord.), Direito Constitucional Internacional: O Direito da Coexistência e da Paz, Curitiba, Juruá, 2012.

GÉLARD, Patrice, As Transformações do Direito Constitucional na Sociedade Contemporânea, in Revista da Faculdade de Direito das Faculdades Metropolitanas Unidas, ${ }^{\mathrm{o}}$ 15, ano 10, jan./jun. 1996, pp. 35-45.

GÉLINAS, Fabien, The Constitution of Agreement: A Brief Look at Sub-Federal CrossBorder Cooperation, in Michigan State Law Review, n 5, 2006, pp.1179-1191.

GIDDENS, Anthony, As Consequências da Modernidade, São Paulo, Editora UNESP, 1991.

GOLDSMITH, Jack; LEVINSON, Daryl, Law for States: International Law, Constitutional Law, Public Law, in Harvad Law Review, vol. 122, n 7, mai. 2009, pp. 1791-1865.

GOMES, Eduardo Biacchi; REIS, Tarcísio Hardman (coord.), O Direito Constitucional Internacional Após a Emenda 45/2004 e os Direitos Fundamentais, São Paulo, Lex, 2007. 
GONZÁLEZ, Manuel Pérez (coord.), Hacia un Nuevo Orden Internacional y Europeo: Estudios en Homenaje al Profesor don Manuel Díez de Velasco, Madrid, Tecnos, 1993.

GONZÁLEZ, Miguel Angel Fernández, Visión Prospectiva en Relación con la Regulación Constitucional de los Tratados Internacionales, in Revista Ius et Praxis, ano 9, $\mathrm{n}^{\mathrm{o}} 1$, 2003, pp. 485-511.

GOUREVITCH, Peter Alexis, Squaring the Circle: The Domestic Sources of International Cooperation, in Internationl Organization, vol. 50, 1996, pp. 349-373.

GRAU, Carmen Innerarity, Democracia e Integración Política. ¿Cómo Afectan los Procesos de Integración a la Representación Política?, in Reis: Revista Española de Investigaciones Sociológicas, $\mathrm{n}^{\circ}$ 91, 2000, p. 39-58.

GRIMM, Dieter, Integration by Constitution, in International Journal of Constitutional Law, 2005, vol. 3, 2005, pp.193-208.

GUIMARÃES, Samuel Pinheiro (org.), Alca e Mercosul: Riscos e Oportunidades para o Brasil, Brasília, IPRI e FUNAG, 1999.

HÄBERLE, Peter, Direito Constitucional Comum Europeu, in Revista de Estudo Políticos, $\mathrm{n}^{\mathrm{o}} 79$, jan./mar. 1993, pp. 7-46.

,El Estado Constitucional, México, Universidad Nacional Autonóma de México, 2003.

, Estado Constitucional Cooperativo, Rio de Janeiro, Renovar, 2007.

, Liberdad, Igualdad, Fraternidad. 1789 como Historia, Actualidad y Futuro del Estado Constitucional, Madrid, Editorial Trotta, 1998.

, Pluralismo y Constitución: Estudios de Teoría Constitucional de la Sociedade Abierta, Madrid, Tecnos, 2008.

HABERMAS, Jürgen, A Constelação Pós-Nacional: Ensaios Políticos, São Paulo, Littera Mundi, 2001.

, El Derecho Internacional en la Transición Hacia un Escenario Posnacional, Barcelona e Buenos Aires, Centro de Cultura Contemporánea de Barcelona e Katz Editores, 2008.

, Era das Transições, Rio de Janeiro, Tempo Brasileiro, 2003.

HAMILTON, Alexander; MADISON, James e JAY, John, O Federalista, Brasília, Universidade de Brasília, 1984. 
HEILMANN, Maria de Jesus Rodrigues Araújo, Globalização e o Novo Direito Administrativo, Curitiba, Juruá, 2010.

HENKIN, Louis, Foreign Affaris and the Constitution, Nova Iorque e Londres, W. W. Norton \& Company, 2007.

HERRERA, Miguel Ángel García Herrera (org.), El Constitucionalismo em la Crisis del Estado Social, Bilbao, Servicio Editorial de la Universidad del Pais Vasco, 1997.

HESSE, Konrad, A Força Normativa da Constituição, Porto Alegre, Sergio Antonio Fabris Editor, 1991.

, Elementos de Direito Constitucional da República Federal da Alemanha, Porto Alegre, Sergio Antonio Fabris Editor, 1998.

, Temas Fundamentais do Direito Constitucional: Textos Selecionados e Traduzidos por Carlos dos Santos Almeida, Gilmar Ferreira Mendes e Inocêncio Mártires Coelho, São Paulo, Saraiva, 2009.

HILlGRUBER, Christian, La Integración del Derecho Internacional y del Derecho de la Unión Europea en el Ordenamiento Constitucional Alemán, in Revista de Derecho Constitucional Europeo, nº 1, jan./jun. 2004, pp. 115-138.

HOCKING, Brian (ed.), Foreign Relations and Federal States, Londres e Nova Iorque, Leicester University Press, 1993.

HORBACH, Carlos Bastide; ALMEIDA, Fernando Dias Menezes de; AMARAL JÚNIOR, José Levi do; LEAL, Roger Stiefelmann (coord.), Democracia: Homenagem ao Prof. Manoel Gonçalves Ferreira Filho, São Paulo, Quartier Latin, 2011.

HUERTA, Mauricio Iván del Toro, La Apertura Constitucional al Derecho Internacional de los Derechos Humanos en la Era de la Mundialización y sus Consecuencias en la Práctica Judicial, in Boletín Mexicano de Derecho Comparado, $\mathrm{n}^{\mathrm{o}} 112$, ano 38, 2005, pp. 325-363.

IANNI, Octavio, A Sociedade Global, 11ª ed., Rio de Janeiro, Civilização Brasileira, 2003.

JACQUES, Paulino, A Constituição Explicada, $3^{\text {a }}$ ed., Rio de Janeiro, Forense, 1970.

JANKOV, Fernanda Florentino Fernandez, Direito Internacional Penal: Mecanismo de Implementação do Tribunal Penal Internacional, São Paulo, Saraiva, 2009.

JULIOS-CAMPUZANO, Alfonso de, Constitucionalismo em Tempos de Globalização, Porto Alegre, Livraria do Advogado, 2009. 
JUSTEN FILHO, Marçal, Comentários à Lei de Licitações e Contratos Administrativos, $10^{\mathrm{a}}$ ed., São Paulo, Dialética, 2004.

KANT, Immanuel, A Paz Perpétua: Um Projeto Filosófico, Covilhã, Universidade da Beira Interior, 2008.

KELSEN, Hans, La Paz por Medio del Derecho, Madrid, Editorial Trotta, 2008.

KRISCH, Nico, Beyond Constitutionalism: The Pluralism Structure of Posnational Law, Oxford, Oxford University Press, 2010.

LA PERGOLA, Antonio, Poder Exterior y Estado de Derecho: El Constitucionalista Ante el Derecho Internacional, Salamanca, Ediciones Universidad Salamanca, 1987.

LAFER, Celso, A Internacionalização dos Direitos Humanos: Constituição, Racismo e Relações Internacionais, Barueri, Manole, 2005.

, A Reconstrução dos Direitos Humanos: Um Diálogo com o Pensamento de Hannah Arendt, São Paulo, Companhia das Letras, 1988.

LEAL, Aureliano, Teoria e Prática da Constituição Federal Brasileira - Primeira Parte: Da Organização Federal e do Poder Legislativo (Arts. 1 a 40), Rio de Janeiro, F. Briguiet e Cia, 1925.

LESSA, José Vincente da Silva, Paradiplomacia no Brasil e no Mundo: O Poder de Celebrar Tratados dos Governos Não Centrais, Viçosa, Editora UFV, 2007.

LEWANDOWSKI, Enrique Ricardo, Globalização, Regionalização e Soberania, São Paulo, Juarez de Oliveira, 2004.

LIMA, Janice de Carvalho, O Direito Internacional e o Poder Legislativo na Condução da Politica Externa, in Revista de Informação Legislativa, ano 42, $\mathrm{n}^{\mathrm{0}} 166$, abr./jun. 2005, pp. 165-179.

LOCKE, John, Dois Tratados sobre o Governo, 2a ed., São Paulo, Martins Fontes, 2005.

LUÑO, Antonio Enrique Pérez, Derechos Humanos, Estado de Derecho y Constitución, $10^{\mathrm{a}}$ ed., Madrid, Tecnos, 2010.

, Perspectivas e Tendências Atuais do Estado Constitucional, Porto Alegre, Livraria do Advogado, 2012.

, Dogmática de los Derechos Fundamentales y Transformaciones del Sistema Constitucional, in Teoria y Realidade Constitucional, $\mathrm{n}^{\mathbf{0}}$ 20, 2007, pp. 495-511. 
MAC-GREGOR, Eduardo Ferrer; LARREA, Arturo Zaldívar Lelo de (coord.), La Ciencia del Derecho Procesal Constitucional. Estudios en Homenaje a Héctor Fix-Zamudio en sus Cincuenta Años como Investigador del Derecho - Tomo IX - Derechos Humanos y Tribunales Internacionales, México, Universidad Nacional Autónoma de México, Instituto de Investigaciones Jurídicas, 2008.

MADRUGA, Antenor, Constituição Brasileira de 1988: Monista ou Dualista?, in Revista de Informação Legislativa, ano 45, n 179, jul./set. 2008, pp. 135-140.

MAGAlHÃES, Gustavo Alexandre, Convênios Administrativos: Aspectos Polêmicos e Análise Crítica de seu Regime Jurídico, São Paulo, Atlas, 2012.

MAGALHÃES, José Carlos de, O Supremo Tribunal Federal e o Direito Internacional: uma Análise Crítica, Porto Alegre, Livraria do Advogado, 2000.

MAIA, Maurilio Casas, A Cooperação Solidária e a Desigualdade Compensadora como Mandamento Constitucional Brasileiro e Imperativo do Direito Internacional do Desenvolvimento, in Revista de Direito Constitucional e Internacional, ano 20, vol. 79, abr./jun. 2012, pp. 329-348.

MALBERG, R. Carré de, Teoría General del Estado, 2a ed., México, Facultad de Derecho/UNAM e Fondo de Cultura Económica, 2001.

MALISKA, Marcos Augusto, Estado e Século XXI: A Integração Supranacional sob a Ótica do Direito Constitucional, Rio de Janeiro, Renovar, 2006.

, Fundamentos da Constituição: Abertura, Cooperação, Integração, Curitiba, Juruá, 2013.

MALUF, Sahid, Teoria Geral do Estado, 29a ed., São Paulo, Saraiva, 2009.

MARCHI, Eduardo Cesar Silveira Vitta, Guia de Metodologia Jurídica, Lecce, Del Grifo, 2001.

MARCOS, Edgar Carpio, Bloque de Constitucionalidad y Proceso de Inconstitucionalidad de las Leyes, in Revista Iberoamericana de Derecho Procesal Constitucional, $\mathrm{n}^{\mathrm{o}} 4$, 2005, pp. 79-114.

MARRARA, Thiago, Identificação de Convênios Administrativos no Direito Brasileiro, in Revista da Faculdade de Direito da USP, v. 100, 2005, pp. 551-570.

MARTÍNEZ, M. Antonia Arias, Comunidades Autónomas y Relaciones Internacionales. Un Estudio de Jurisprudencia Constitucional, in Autonomies, no 21, dez. 1996, pp. 359-387. 
MARTINS, Ives Gandra; REZEK, Francisco (coord.), Constituição Federal: Avanços, Contribuições e Modificações no Processo Democrático Brasileiro, São Paulo, Revista dos Tribunais e Centro de Extensão Universitária (CEU), 2008.

MARTINS, Ives Gandra; ROSSET, Patrícia; AMARAL, Antonio Carlos Rodrigues do (coord.), Estudos: Direito Público: Homenagem ao Ministro Carlos Mário da Silva Velloso, São Paulo, Lex, 2012.

MATIAS, Eduardo Felipe Pérez, A Humanidade e suas Fronteiras: Do Estado Soberano à Sociedade Global, São Paulo, Paz e Terra, 2005.

MAXIMILIANO, Carlos, Comentários - Constituição Brasileira, Rio de Janeiro, Jacintho Ribeiro dos Santos, 1918.

Janeiro, 2009.

, Hermenêutica e Aplicação do Direito, $19^{\mathrm{a}}$ ed., Forense, Rio de

MAZZUOLI, Valerio de Oliveira, Curso de Direito Internacional Público, $7^{\mathrm{a}}$ ed., São Paulo, Revista dos Tribunais, 2013.

,O Controle Jurisdicional da Convencionalidade das Leis, $2^{\mathrm{a}}$ ed., São Paulo, Revista dos Tribunais, 2011.

MEDAUAR, Odete, Convênios e Consórcios Administrativos, in Boletim de Direito Administrativo, $\mathrm{n}^{\circ}$ 8, 1995, pp. 451-461.

MEDEIROS, Antônio Paulo Cachapuz de (org.), Desafios do Direito Internacional Contemporâneo, Brasília, Fundação Alexandre de Gusmão, 2007.

, O Poder de Celebrar Tratados: Competência dos Poderes Constituídos para a Celebração de Tratados à Luz do Direito Internacional, do Direito Comparado e do Direito Constitucional Brasileiro, Porto Alegre, Sérgio Antonio Fabris Editor, 1995.

MELLO, Celso Antônio Bandeira de (org.), Direito Tributário: Estudos em Homenagem a Geraldo Ataliba, vol. 1, São Paulo, Malheiros, 1997.

2013. , Curso de Direito Administrativo, 30ª ed., São Paulo, Malheiros,

MELLO, Celso D. de Albuquerque, A Revisão do Direito Internacional na Constituição de 1988, in Revista de Ciências Sociais, Rio de Janeiro, v. 1, n.1, 1995, pp. 75-89.

Janeiro, Renovar, 1997.

Curso de Direito Internacional Público, vol. 1 e 2, $11^{\mathrm{a}}$ ed., Rio de 
Janeiro, Renovar, 1994.

, Direito Constitucional Internacional: Uma Introdução, Rio de , O Direito Constitucional Internacional na Constituição de 1988, in Contexto Internacional, vol. 4, no 8, jul./dez. 1988, pp. 9-21.

MELLO, Oswaldo Aranha Bandeira de, Princípios Gerais de Direito Administrativo - vol. I: Introdução, $3^{\text {a }}$ ed., São Paulo, Malheiros, 2007.

MENDES, Gilmar Ferreira, Controle Abstrato de Constitucionalidade: ADI, ADC e ADO: Comentários à Lei n. 9.868/99, São Paulo, Saraiva, 2012.

MENDES, Gilmar Ferreira; BRANCO, Paulo Gustavo Gonet; VALE, André Rufino do (org.), A Jurisprudência do STF nos 20 Anos da Constituição, São Paulo, Saraiva, 2010 .

MENDES, Gilmar Ferreira; COELHO, Inocêncio Mártires; BRANCO, Paulo Gustavo Gonet, Curso de Direito Constitucional, $5^{\text {a }}$ ed., São Paulo, Saraiva, 2010.

MICELI, Vincento, Lo Stato e La Nazione nei Rapporti fra il Diritto Costituzionale e il Diritto Internazionale, Firenze, Cellini, 1890.

MICHELMANN, Hans (ed.), Foreign Relations in Federal Countries (A Global Dialogue on Federalism, vol. V), Montreal \& Kingston, McGill-Queen's University Press, 2009.

MICHELMANN, Hans J.; SOLDATOS, Panayotis (org.), Federalism and International Relations, Oxford, Clarendon Press, 1990.

MIRANDA, Jorge, Curso de Direito Internacional Público, $4^{\mathrm{a}}$ ed., Princípia, Cascais, 2009.

, Democracia e Constituição para lá do Estado, in Revista da Faculdade de Direito da Universidade de Lisboa, vol. 51, no 1 e 2, pp. 33-46.

, Direito Constitucional e Direito Internacional, in Revista do Advogado, ano 23, no 73, nov. 2003, pp. 89-93.

, Manual de Direito Constitucional - Tomo II: Constituição, $6^{\mathrm{a}}$ ed., Coimbra, Coimbra Editora, 2007.

MIRANDA, Luciana Santos Pontes de, A Capacidade do Estado-membro da Federação Celebrar Tratados Internacionais, in Revista da ESMAFE - Escola de Magistratura Federal da $5^{a}$ Região, n 14, 2007, pp. 165-193.

MIRANDA, Pontes de, Comentários à Constituição da República dos E. U. do Brasil, Tomo I: Artigos 1-103, Rio de Janeiro, Guanarabara, 1937. 
,Comentários à Constituição da República dos E. U. do Brasil, Tomo I, Artigos 1-103, Rio de Janeiro, Editora Guanabara, Waissman, Koogan, Ltda., 1936.

, Comentários à Constituição de 1967, Tomo III (Arts. 32-117), 2a ed., São Paulo, Revista dos Tribunais, 1970.

MIRKINE-GUETZÉVITCH, B., Derecho Constitucional Internacional, Madrid, Editorial Reus, s. a..

MONTEIRO, Marco Antônio Corrêa, Tratados Internacionais de Direitos Humanos e Direito Interno, São Paulo, Saraiva, 2011.

MONTESQUIEU, Charles de Secondat, Do Espírito das Leis: Vol. 1, Rio de Janeiro, Nova Fronteira, 2012.

MORAES, Alexandre, Constituição do Brasil Interpretada e Legislação Constitucional, 9a ed., São Paulo, Atlas, 2013.

, Federação Brasileira - Necessidade de Fortalecimento das Competências dos Estados-Membros, in Revista de Direito Administrativo, $\mathrm{n}^{\mathrm{o}} 251$, mai./ago. 2009, pp. 11-27.

MORAES, Guilherme Peña de, Readequação Constitucional do Estado Moderno: Transformações do Conceito de Estado no Direito Constitucional do Limiar do Século XXI, Rio de Janeiro, Lumen Juris, 2006.

MORAIS, Carlos Blanco de, Justiça Constitucional - Tomo I - Garantia da Constituição e Controlo da Constitucionalidade, $2^{\mathrm{a}}$ ed., Coimbra, Coimbra Editora, 2006.

MOREIRA, Eduardo, Cláusulas Pétreas Expandidas, in Revista Forense, vol. 412, ano 106, nov./dez. 2010, pp. 49-61.

MOURA, Lenice S. Moreira de (org.), O Novo Constitucionalismo na Era Pós-Positivista: Homenagem a Paulo Bonavides, São Paulo, Saraiva, 2009.

MÜLLER, Luís T. Díaz (coord.), Globalización y Derechos Humanos, Universidad Nacional Autónoma de México, México, 2003.

NASSER, Salem Hikmat, Fontes e Normas do Direito Internacional: Um Estudo sobre a Soft Law, $2^{\mathrm{a}}$ ed., São Paulo, Atlas, 2006.

, Jus Cogens: Ainda Esse Desconhecido, in Revista Direito FGV, vol. 1, n 2 , jun./dez. 2005, pp. 161-178. 
NDJIMBA, Kevin Ferdinand, L'Internationalisation des Constitutions et la Revalorisation du Droit Constitutionnel des Etats, in Politeia, $\mathrm{n}^{\circ}$ 22, dez. 2012, pp. 409-428.

NEVES, Marcelo, Transconstitucionalismo, São Paulo, Martins Fontes, 2009.

OCAMPO, Raúl Granillo, Direito Internacional Público da Integração, Rio de Janeiro, Elsevier, 2009.

OLIVEIRA, Henrique Altemani de; LESSA, Antônio Carlos (org.), Relações Internacionais do Brasil: Temas e Agendas, vol. 2, São Paulo, Saraiva, 2006.

OLIVEIRA, Marcelo Fernandes; LUVIZOTTO, Caroline Klaus, Cooperação Técnica Internacional: Aportes Teóricos, in Revista Brasileira de Política Internacional, $\mathrm{n}^{\mathrm{o}}$ 54, 2011, pp. 5-21.

OLIVEIRA, Ricardo Victalino de, Para Além do Referendo de Tratados, Convenções e Atos Internacionais: A Atuação do Legislativo Brasileiro Ante a Criação do Parlamento do Mercosul, in Revista Científica Virtual da ESA/OABSP, n 14 , ano 5, out. 2013, pp. 48-55.

PACHECO, Cláudio, Novo Tratado das Constituições Brasileiras, Vol. 3 e 5, Brasília, Offset, 1992.

PAGLIARINI, Alexandre Coutinho, Constituição e Direito Internacional: Cedências Possiveis no Brasil e no Mundo Globalizado, Rio de Janeiro, Forense, 2004.

, Reflexões sobre o Costume, como Norma Internacional Imaterializada, e sobre o Tratado, como Norma Internacional Assentada em Suporte Físico, in Revista de Direito Constitucional e Internacional, $\mathrm{n}^{\mathrm{o}} 49$, ano 12, out./dez. 2004, pp. 321-332.

PAGLIARINI, Alexandre Coutinho; DIMOULIS, Dimitri (coord.), Direito Constitucional Internacional dos Direitos Humanos, Belo Horizonte, Fórum, 2012.

PAQUIN, Stéphane, Paradiplomatie Identitaire et Diplomatie en Belgique Fédérale: Le Cas de la Frandre, in Canadian Journal of Political Science, vol. 36, 2003, pp. 621642.

PAULSEN, Michael Stokes, The Constitutional Power to Interpret International Law, in The Yale Law Journal, vol. 118, 2009, pp. 1762-1842.

PAUPERIO, A. Machado, O Conceito Polêmico de Soberania, $2^{\mathrm{a}}$ ed., Rio de Janeiro, Forense, 1958.

PEDROSO, Fernando Gentil Gizzi de Almeida; RIBEIRO, Roberto Victor Pereira (org.), Questões Relevantes do Direito Penal e Processual Penal, Porto Alegre, Lex Magister, 2012. 
PELLEGRINO, Carlos Roberto, Estrutura Normativa das Relações Internacionais, Rio de Janeiro, Forense, 2008.

PERNATHALER, Peter, Lo Stato Federale Differenziato, Bolonha, Il Mulino, 1998.

PERRONE-MOISÉS, Cláudia, Antecedentes Históricos do Estabelecimento do Tribunal Penal Internacional, in Revista da Faculdade de Direito da USP, vol. 98, 2003, pp. 573-579.

,O Princípio da Complementariedade no Estatuto do Tribunal Penal Internacional e a Soberania Contemporânea, in Revista de Politica Externa, vol. 8, no 4, mar./mai. 2000, pp. 3-11.

PETERS, Anne; AZNAR, Mariano J. e GUTIÉRREZ, Ignacio (ed.), La Constitucionalización de la Comunidade Internacional, Valencia, Tirant lo Blanch, 2010.

PIMENTEL JÚNIOR, Paulo Gomes (coord.), Direito Constitucional em Evolução: Perspectivas, Curitiba, Juruá, 2006.

PIOVESAN, Flávia, Direitos Humanos e Justiça Internacional, $3^{\text {a }}$ ed., São Paulo, Saraiva, 2012. ed., São Paulo, Saraiva, 2010.

, Direitos Humanos e o Direito Constitucional Internacional, $11^{\mathrm{a}}$

PIZZORUSSO, Alessandro, La Produzione Normativa in Tempi di Globalizzazione, Torino, G. Giappicheli Editore, 2008.

QUEIROZ, Cristina, Direito Constitucional Internacional, Coimbra, Coimbra Editora, 2011.

RAMÍREZ, Manuel Becerra e MARÍN, Nuria González (coord.), Estado de Derecho Internacional, México, Universidad Nacional Autónoma de México, 2012.

RAMOS, André de Carvalho, A Integração Regional e a Constituição: Vinte Anos Depois, in Revista de Informação Legislativa, n 179, ano 45, jul./set. 2008, pp. 317-331.

, A Responsabilidade Internacional do Estado por Violação de Direitos Humanos, in Revista CEJ, n $\mathrm{n}^{\mathrm{O}}$ 29, abr./jun. 2005, pp. 53-63.

, Direitos Humanos em Juizo: Comentários aso Casos Contenciosos e Consultivos da Corte Interamericana de Direitos Humanos e Estudo da Implementação Dessas Decisões no Direito Brasileiro, São Paulo, Max Limonad, 2001. 
, Direitos Humanos na Integração Econômica: Análise Comparativa da Proteção de Direitos Humanos e Conflitos Jurisdicionais na União Europeia e Mercosul, Rio de Janeiro, Renovar, 2008.

, Pluralidade das Ordens Jurídicas: A Relação do Direito Brasileiro com o Direito Internacional, Curitiba, Juruá, 2012.

Saraiva, 2013.

, Processo Internacional de Direitos Humanos, $3^{\mathrm{a}}$ ed., São Paulo,

, Responsabilidade Internacional por Violação de Direitos Humanos: seus Elementos, a Reparação Devida e Sanções Possíveis: Teoria e Prática do Direito Internacional, Rio de Janeiro, Renovar, 2004.

ed., São Paulo, Saraiva, 2013.

, Teoria Geral dos Direitos Humanos na Ordem Internacional, $3^{\mathrm{a}}$

RAMOS, Dircêo Torrecillas (org.), O Federalista Atual: Teoria do Federalismo, Belo Horizonte, Arraes Editores, 2013.

, A Federalização das Novas Comunidades: A Questão da Soberania, Rio de Janeiro, Forense, 2004.

RAMOS, Elival da Silva, A Proteção aos Direitos Adquiridos no Direito Constitucional Brasileiro, São Paulo, Saraiva, 2003.

RANGEL, Vicente Marotta, Os Conflitos entre o Direito Interno e os Tratados Internacionais, in Ciências Econômicas e Sociais, vol. 3, jul. 1968, pp. 25-67.

REALE, Miguel, Teoria Tridimensional do Direito, 2a ed., São Paulo, Saraiva, 1979.

REIS, Luciano Elias, Convênio Administrativo: Instrumento Jurídico Eficiente para o Fomento e Desenvolvimento do Estado, Curitiba, Juruá, 2013.

REVERBEL, Carlos Eduardo Dieder, O Federalismo numa Visão Tridimensional do Direito, Porto Alegre, Livraria do Advogado, 2012.

REZEK, Francisco, Direito dos Tratados, Rio de Janeiro, Forense, 1984. Paulo, Saraiva, 2013.

Direito Internacional Público: Curso Elementar, $14^{\mathrm{a}}$ ed., São

RIBEIRO, Maria Clotilde Meirelles, Globalização e Novos Atores: A Paradiplomacia das Cidades Brasileiras, Salvador, EDUFBA, 2009.

ROCA, Javier García, La Interpretación Constitucional de una Declaración Internacional, el Convenio Europeo de Derechos Humanos, y Bases para una Globalización de los 
Derechos, in Revista Iberoamericana de Derecho Procesal Constitucional, $\mathrm{n}^{\circ} 5$, 2006, pp. 139-182.

,La Muy Discrecional Doctrina del Margen de Apreciación Nacional Según el Tribunal Europeo de Derechos Humanos: Soberanía e Integración, in Teoría y Realidad Constitucional, nº 20, 2007, pp. 117-143.

ROCA, Maria J., El Control Parlamentario y Constitucional del Poder Exterior: Estudio Comparado del Estado Actual de la Cuestión en el Derecho Alemán y Español, in Revista Española de Derecho Constitucional, n 56, ano 19, mai./ago. 1999, pp. 105133.

ROCHA, Cármen Lúcia Antunes, Constituição, Soberania e Mercosul, in Revista de Informação Legislativa, no 139, ano 35, jul./set. 1998, pp. 283-304.

, O Constitucionalismo Contemporâneo e a Instrumentalização para a Eficácia dos Direitos Fundamentais, in Revista de Direito Público, $\mathrm{n}^{\circ} 16$, 1996, pp. 39-58.

RODAS, João Grandino, A Publicidade dos Tratados Internacionais, São Paulo, Revista dos Tribunais, 1980.

ROJAS-HUTINEL, Nilsa, L' Articulation des Ordres Juridiques en Matière de Protection des Droits Fondamentaux et la Résurgence de la Suprématie de la Constitution, in Politeia, n $^{\circ}$ 22, dez. 2012, pp. 259-282.

ROMANO, Santi, Princípios de Direito Constitucional Comparado, São Paulo, Revista dos Tribunais, 1977.

RUFFİA, Paolo Biscaretti di, Transformaciones Constitucionales en Occidente, en la URSS y en los Estados Socialistas del Este Europeo, México, Fondo de Cultura Económica, 1996.

SALA, José Blanes (org.), O Município e as Relações Internacionais: Aspectos Jurídicos, São Paulo, EDUC, 2009.

SAliBA, Aziz Tuffi (org.), Direito dos Tratados: Comentários à Convenção de Viena sobre o Direito dos Tratados (1969), Belo Horizonte, Arraes, 2011.

SÁNCHEZ, Luis Alberto Pomed, La Proyeccion Exterior de las Comunidades Autonomas Ante el Tribunal Constitucional, in Revista de Administración Pública, $\mathrm{n}^{\mathrm{o}}$ 123, set./dez. 1990, pp. 211-258.

SÁNCHEZ, Miguel Azpitarte, La Función de la Constitución en el Contexto Contemporáneo, in Revista de Derecho Constitucional Europeo, no 12, pp. 171-189. 
SARAIVA, José Flávio Sombra; MAIA, José Nelson Bessa, Federalismo no Brasil da República Velha, 1890-1930: Um Caso Precoce de Paradiplomacia Financeira, in Revista Brasileira de Estudos Constitucionais, no 19, ano 5, jul./set. 2011, pp. 103142.

SARLET, Ingo Wolfgang, A Eficácia dos Direitos Fundamentais: Uma Teoria Geral dos Direitos Fundamentais na Perspectiva Constitucional, $11^{\mathrm{a}}$ ed., Porto Alegre, Livraria do Advogado, 2012.

, Os Direitos Fundamentais, a Reforma do Judiciário e os Tratados Internacionais de Direitos Humanos Notas em Torno dos $\S \S 2^{\circ}$ e $3^{\circ}$ do art. $5^{\circ}$ da Constituição de 1988, in Revista da AJURIS, n 102, ano 32, pp. 177-208.

SARLET, Ingo Wolfgang; FURIAN, Leonardo; e FENSTERSEIFER, A Reforma (ou Deforma?) do Judiciário e a Assim Denominada "Federalização" dos Crimes Contra os Direitos Humanos: Proteção ou Violação de Princípios e Direitos Fundamentais, in Revista Eletrônica de Direito Público, $\mathrm{n}^{\circ}$ 4, jan./fev. 2006, pp. 1-57.

SARLET, Ingo Wolfgang; MARINONI, Luiz Guilherme; MITIDIERO, Daniel, Curso de Direito Constitucional, São Paulo, Revista dos Tribunais, 2012.

SARMENTO, Daniel, Constituição e Globalização: A Crise dos Paradigmas do Direito Constitucional, in Revista de Direito Administrativo, vol. 215, jan./mar. 1999, pp. 19-34.

Direitos Sociais e Globalização: Limites Éticos-Jurídicos ao Realinhamento Constitucional, in Revista de Direito Administrativo, vol. 223, jan./mar. 2001, pp. 153-168.

SCHAPIRO, Ian; HACKER-CORDÓN, Cassiano (org.), Democracy Edges, Cambridge, Cambridge University Press, 1999.

SCHMIDT-ABMANN, Eberhard, La Ciencia del Derecho Administrativo Ante el Reto de la Internacionalización de las Relaciones Administrativas, in Revista de Administración Pública, $\mathrm{n}^{\circ}$ 171, set./dez. 2006, pp. 7-34.

SEGADO, Francisco Fernández (ed.), The Spanish Constitution in the European Constitutional Context, Madrid, Dykinson Editorial, 2003.

, El Estado y las Comunidades Autónomas ante las Relaciones Internacionales en la Constitución Española de 1978, in Anales de la Academia Nacional de Derecho y Ciencias Sociales de Córdoba, Tomo XXXII, 1993, pp. 2789.

SEITENFUS, Ricardo, Manual das Organizações Internacionais, $5^{\mathrm{a}}$ ed., Porto Alegre, Livraria do Advogado, 2008. 
SHAFFER, Gregory C.; POLLACK, Mark A., Hard vs. Soft Law: Alternatives, Complements, and Antagonists in International Governance, in Minnesota Law Review, vol. 94, pp. 706-799.

SHAW, Malcolm N., Direito Internacional, São Paulo, Martins Fontes, 2010.

SILVA, G. E. do Nascimento; CASELLA, Paulo Borba e BITTENCOURT NETO, Olavo de Oliveira, Direito Internacional Diplomático: Convenção de Viena Sobre Relações Diplomáticas na Teoria e na Prática, 4a ed., São Paulo, Saraiva, 2012.

SILVA, José Afonso da, Aplicabilidade das Normas Constitucionais, $7^{\mathrm{a}}$ ed., São Paulo, Malheiros, 2007.

Malheiros, 2009.

, Curso de Direito Constitucional Positivo, $32^{\mathrm{a}}$ ed., São Paulo,

SILVA, Virgílio Afonso (org.), Interpretação Constitucional, São Paulo, Malheiros, 2007.

SLUITER, Göran, The Surrender of War Criminals to the International Criminal Court, in Loyola of Los Angeles International and Comparative Law Review, vol. 25, 2003, pp. 605-651.

SOARES, Guido Fernando Silva, Curso de Direito Internacional Público - vol. 1, São Paulo, Atlas, 2002.

SPADA, Paolo, Regole e Giurisdizioni in Concorrenza: Il Crepusculo dela Soveranità, Editorale Scientifica, 2009.

SPIRO, Peter J., Foreign Relations Federalism, in University of Colorado Law Review, $\mathrm{n}^{\mathrm{o}}$ 70, 1999, pp. 1223-1275.

STRECK, Lenio Luiz, Jurisdição Constitucional e Decisão Jurídica, $3^{\mathrm{a}}$ ed., São Paulo, Revista dos Tribunais, 2013.

SUNDFELD, Carlos Ari, Fundamentos de Direito Público, $5^{\mathrm{a}}$ ed., São Paulo, Malheiros, 2012.

TAQUARY, Eneida Orbage de Brito, Tribunal Penal Internacional \& A Emenda Constitucional 45/04 (Sistema Normativo Brasileiro), Curitiba, Juruá, 2011.

TARR, G. Alan, Explaining Sub-national Constitutional Space, in Penn State Law Review, vol. 115, pp. 1133-1149.

TAVARES, André Ramos, Reforma do Judiciário no Brasil Pós-88: (Des)estruturando a Justiça: Comentários Completos à EC n. 45/04, São Paulo, Saraiva, 2005. 
TAVARES, André Ramos; LENZA, Pedro; ALARCÓN, Pietro de Jesús Lora, Reforma do Judiciário: Analisada e Comentada, São Paulo, Método, 2005.

TAVARES, André Ramos; MENDES, Gilmar Ferreira; MARTINS, Ives Gandra da Silva, Lições de Direito Constitucional em Homenagem ao Jurista Celso Bastos, São Paulo, Saraiva, 2005.

TAVARES, Raúl Cervini Juarez, Princípios de Cooperação Judicial Penal Internacional no Protocolo do Mercosul, São Paulo, Revista dos Tribunais, 2000.

TEIXEIRA, J. H. Meirelles, Curso de Direito Constitucional, Rio de Janeiro, Forense Universitária, 1991.

TIBURCIO, Carmen, Temas de Direito Internacional, Rio de Janeiro, Renovar, 2006.

TIBURCIO, Carmen; BARROSO, Luís Roberto, Direito Constitucional Internacional, Rio de Janeiro, Renovar, 2013.

TOCQUEVILLE, Alexis de, A Democracia na América - Livro I: Leis e Costumes de Certas Leis e Certos Costumes Politicos que Foram Naturalmente Sugeridos aos Americanos por seu Estado Social Democrático, 2a ed., São Paulo, Martins Fontes, 2005.

TOURARD, Hélène, L'Internationalisation des Constitutions Nationales, Paris, Librairie Générale de Droit et de Jurisprudence, 2000.

TRIEPEL, Henrich, Droit International et Droit Interne, Paris e Oxford, A. Pédone e Oxford, 1920.

TRINDADE, Antônio Augusto Cançado, Direito das Organizações Internacionais, $4^{\mathrm{a}}$ ed., Belo Horizonte, Del Rey, 2009.

, El Ejercicio de la Función Judicial Internacional: Memorias de la Corte Interamericana de Derechos Humanos, $2^{\mathrm{a}}$ ed., Belo Horizonte, 2013.

,Repertório da Prática Brasileira do Direito Internacional Público: Período 1919-1940, 2ª ed., Brasília, FUNAG, 2012.

TRINDADE, Otávio Augusto Drummond Cançado, A Carta das Nações Unidas: Uma Leitura Constitucional, Belo Horizonte, Del Rey, 2012.

VALADÉS, Diego (org.), Conversas Acadêmicas com Peter Häberle, São Paulo, Saraiva, 2009.

VANNICELLI, Luigi, Neofederalismo Unitario e Pluralismo Interconfessionale (Profili Giuridici Comparati), Roma, Editrice Universitaria di Roma - La Goliardica, 1994. 
VARELLA, Marcelo D., Direito Internacional Público, 4ª ed., São Paulo, Saraiva, 2012.

Internacionalização do Direito: Direito Internacional, Globalização e Complexidade, Tese de Livre Docência, Faculdade de Direito da USP, São Paulo, 2012.

VENTURA, Deisy, As Assimetrias entre o Mercosul e a União Europeia: Os Desafios de uma Associação Inter-Regional, Barueri, Manole, 2003.

VERDROSS, Alfred, Derecho International Publico, 5ª ed., Madrid, Aguilar, 1969.

VERDÚ, Pablo Lucas, O Sentimento Constitucional: Aproximação ao Estudo do Sentir Constitucional como Modo de Integração Política, Rio de Janeiro, Forense, 2004.

Principios de Ciencia Politica, Volume III: Estado Contemporaneo y Fuerzas Politicas (Partidos Politicos, Corrientes Intrapartidistas, Asociaciones, Clubs Políticos, Grupos de Presión, Propaganda Política), Editorial Tecnos, Madrid, 1969.

VERGOTTINI, Giuseppe, Garantía de la Identidad de los Ordenamientos Estatales y Límites de la Globalización, in Teoria y Realidad Constitucional, $\mathrm{n}^{\mathrm{o}}$ 18, 2006, pp. 131-145.

VIGEVANI, Tullo; WANDERLEY, Luiz Eduardo; BARRETO, Maria Inês; MARIANO, Marcelo Passini (org.), A Dimensão Subnacional e as Relações Internacionais, São Paulo, EDUC e Editora UNESP, 2004.

WALKER, Neil (org.), Sovereignty in Transition: Essays in European Law, Portland, Hart Publishing, 2003.

WALT, Steven, Why Jurisprudence Doesn't Matter for Customary International Law, in William \& Mary Law Review, vol. 54, pp. 1024-1055.

WAMBIER, Teresa Arruda Alvim; WAMBIER, Luiz Rodrigues, GOMES JUNIOR, Luiz Manoel e outros (coord.), A Reforma do Judiciário: Primeiras Reflexões sobre a Emenda Constitucional n. 45/2004, São Paulo, Revista dos Tribunais, 2005.

WATTS, Ronald L., Comparing Federal Systems, $2^{\mathrm{a}}$ ed., Montrel e Kingston, McGillQueen's University Press, 1999.

ZAGREBELSKY, Gustavo, Corti Costituzionali e Diritti Universali, in Rivista Trimestrale di Diritto Pubblico, no 2, 2006, pp. 297-312.

Trotta, 2011.

,El Derecho Dúctil. Lei, Derechos, Justicia, Madrid, Editorial 
ZANCANER, Gabriela, As Competências do Poder Legislativo e as Comissões Parlamentares, São Paulo, Malheiros, 2009.

ZIPPELIUS, Reinhold, Introdução ao Estudo do Direito, Belo Horizonte, Del Rey, 2006.

ZOLLER, Elisabeth, Aspects Internationaux du Droit Constitutionnel: Contribution à la Théorie de la Fédération d'Etats, in Recueil des Cours, n² 294, 2003, pp. 39-166. 


\section{RESUMO}

O progressivo desenvolvimento das relações internacionais, acompanhado dos múltiplos reflexos da globalização, em especial do aparecimento de novos sujeitos que atuam, concomitantemente, nos âmbitos interno e externo, resultou na intensificação dos pontos de contatos entre Direito Constitucional e Direito Internacional. Esse cenário faz que, cada vez mais, as fronteiras entre o nacional e o exterior tornem-se rarefeitas, impondo significativas transformações em conceitos tradicionais consagrados pelo tempo. Assim, as Constituições nacionais abrem-se para o Direito das Gentes e as normas internacionais - antes encarregadas de apenas possibilitar a coexistência entre soberanias ampliam seu campo de incidência na medida em que passam a disciplinar temas que eram objeto de estudo somente do constitucionalismo.

É exatamente esse acentuado entrelaçamento entre as ordens jurídicas que inspirou a elaboração desta tese, cujo escopo principal é o de contribuir para que se conheça, ainda que de modo incompleto, os reflexos sentidos no Direito Constitucional brasileiro em decorrência do processo de internacionalização das Constituições. Apesar da ambivalência inerente à problemática tratada, na compreensão desse complexo quadro, primou-se por um enfoque centrado na perspectiva do Direito Constitucional. Essa opção demandou, pois, análises que evidenciassem como o constitucionalismo pátrio - sem perder sua identidade e preservando suas conquistas - tem enfrentado o desafio de assegurar a execução interna de uma infinidade de mandamentos provenientes do exterior.

As conclusões obtidas apontam para a importância de cultivar um permanente diálogo entre Constituição e Direito Internacional como instrumento para que essa crescente interconexão resulte em aperfeiçoamento de ambas as ordens jurídicas. Do ponto de vista do Direito Constitucional, cabe antecipar que a aproximação sistêmica em questão já permite vislumbrar a revitalização do funcionamento do mecanismo de freios e contrapesos derivado do princípio da separação de poderes, a valorização dos mandamentos exteriores por parte das autoridades nacionais responsáveis por aplicá-los e, ainda, o fortalecimento da autonomia federativa em matéria de interações com o mundo externo. Embora os resultados finais desse processo sejam incertos, acredita-se que ele não acabará com o papel das Constituições para os Estados nacionais porque, se isso acontecer, toda a dinâmica dos relacionamentos estudados restará severamente comprometida. 


\section{PALAVRAS-CHAVE}

Constituição, Direito Internacional, Internacionalização, Abertura, Diálogo, Separação dos Poderes, Federalismo. 


\begin{abstract}
The progressive development of international relations, followed by the multiple reflexes of globalization - especially the emergence of new subjects that act simultaneously in the internal and external spheres - has resulted in the intensification of the intersections between Constitutional law and International law. Such a scenario makes the boundaries between national and international increasingly rarefied, imposing significant changes in traditional concepts consecrated by time. Therefore, national Constitutions open up to the Ius Gentium and the international rules - originally in charge of merely enabling the coexistence of sovereignties - expanding their scope as they shall regulate topics that were formerly approached only by constitutionalism.

It is precisely this strong entwinement of legal systems that has inspired the development of this thesis, whose main aim is to contribute for the knowing, albeit incomplete, of the reflexes felt in the Brazilian Constitutional law as a result of the internationalization process of Constitutions. Despite the ambivalence inherent to the problem approached, we have chosen to focus on the Constitutional law perspective in the understanding of this complex scenario. Such an option has demanded, thus, analyses that would evidence how national constitutionalism - without losing its identity and by preserving its achievements - has faced the challenge of ensuring the internal implementation of a plethora of external commands.

The conclusions drawn highlight the importance of cultivating a constant dialogue between Constitution and International law as a means for this increasing interconnection to result in improvement for both legal systems. From the point of view of Constitutional law, we should anticipate that the systemic approximation at issue provides insight into the revitalization of the functioning of the checks and balances mechanism deriving from the principle of separation of powers, the valuing of external commands by the national authorities in charge of their enforcement, and also the strengthening of federal autonomy in terms of interaction with the external world. Even though the final results of this process are still uncertain, we believe that it will not end the role of the Constitutions for the national States, because, if that happens, the whole dynamics of the relationships studied will ultimately be severely compromised.
\end{abstract}




\section{KEYWORDS}

Constitution, International law, Internationalization, Openness, Dialogue, Separation of Powers, Federalism. 


\section{RIASSUNTO}

Il progressivo sviluppo dei rapporti internazionali aggiunto ai multipli riflessi della globalizzazione, specialmente quello che riguarda il sorgimento di nuovi soggetti i quali, correlatamente, attuano negli ambiti interno ed esterno, ha risultato nel aumento dei punti di contatto tra il Diritto Costituzionale ed il Diritto Internazionale. Questo scenario permette che i confini tra la nozione di nazionale o estero diventino gradatamente più sottili e, dunque, si impongono significative trasformazioni nei concetti tradizionali che il tempo ha consacrato. Così, le Costituzioni nazionali si aprono per al Ius Gentium e alle norme internazionali - una volta incaricate soltanto di possibilitare la coesistenza tra le sovranità - ed ingrandiscono il loro spazio di incidenza, giacché passano a disciplinare su temi che eramo oggetto di studio soltanto del costituzionalismo.

L'ispirazione per scrivere questa tesi - il cui scopo principale è quello di contribuire per che si conosca qualcos'altro circa i riflessi specchiati nel Diritto Costituzionale brasiliano, in decorrenza del processo di internazionalizzazione delle Costituzioni - è dovuta al'accentuato legame tra le ordine giuridiche. Nonostante l'ambivalenza implicita alla questione in studio, addirittura si concepisce questo complesso quadro sotto la prospettiva del Diritto Costituzionale. Tale scelta ha, dunque, domandato delle analisi che evidenziassero come il costituzionalismo brasiliano ha fronteggiato senza perdite per la sua identità e preservando le sue conquiste - la sfida di garantire l'esecuzione interna di un'infinità di nuovi mandamenti inviati dall'estero.

Le conclusioni ottenute puntano verso l'importanza di coltivarsi un permanente dialogo tra Costituzione e Diritto Internazionale come strumento per via del quale questo crescente rapporto intra di loro raggiunga un livello più perfezionato per ambedue le ordine giuridiche. Dal punto di vista del Diritto Costituzionale si deve anticipare che il ravvicinamento sistemico in questione già permette degli sguardi alla rivitalizzazione del meccanismo di freni e contropesi deviato dal principio della separazione fra i poteri; la visura della valorizzazione dei mandamenti esteri per conto delle autorità nazionali investite di potere per applicarle e, in più si vede il rinforzamento della autonomia federale nel riguardo delle interazioni con il mondo estero. Malgrado i risultati finali di questo processo siano alcunché di incerti, si crede che, tutto complesso, non si esaurirà il ruolo delle Costituzioni per gli Stati nazionali perché, in questo caso, l'intera dinamica dei rapporti qui stabiliti sarà gravemente compromessa. 


\section{PAROLE CHIAVI}

Costituzione, Diritto Internazionale, Globalizzazione, Apertura, Dialogo, Separazione fra i Poteri, Federalismo. 